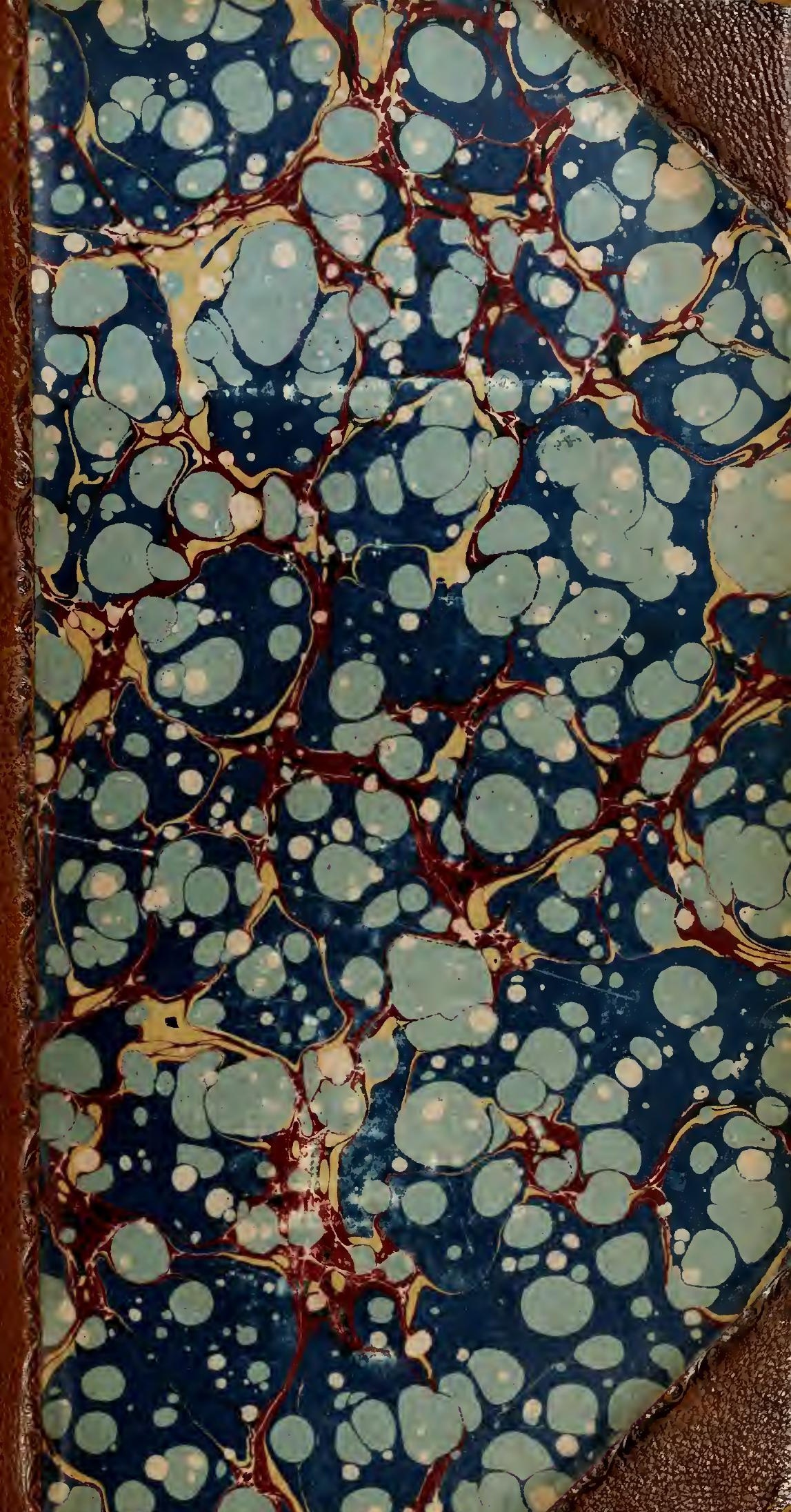




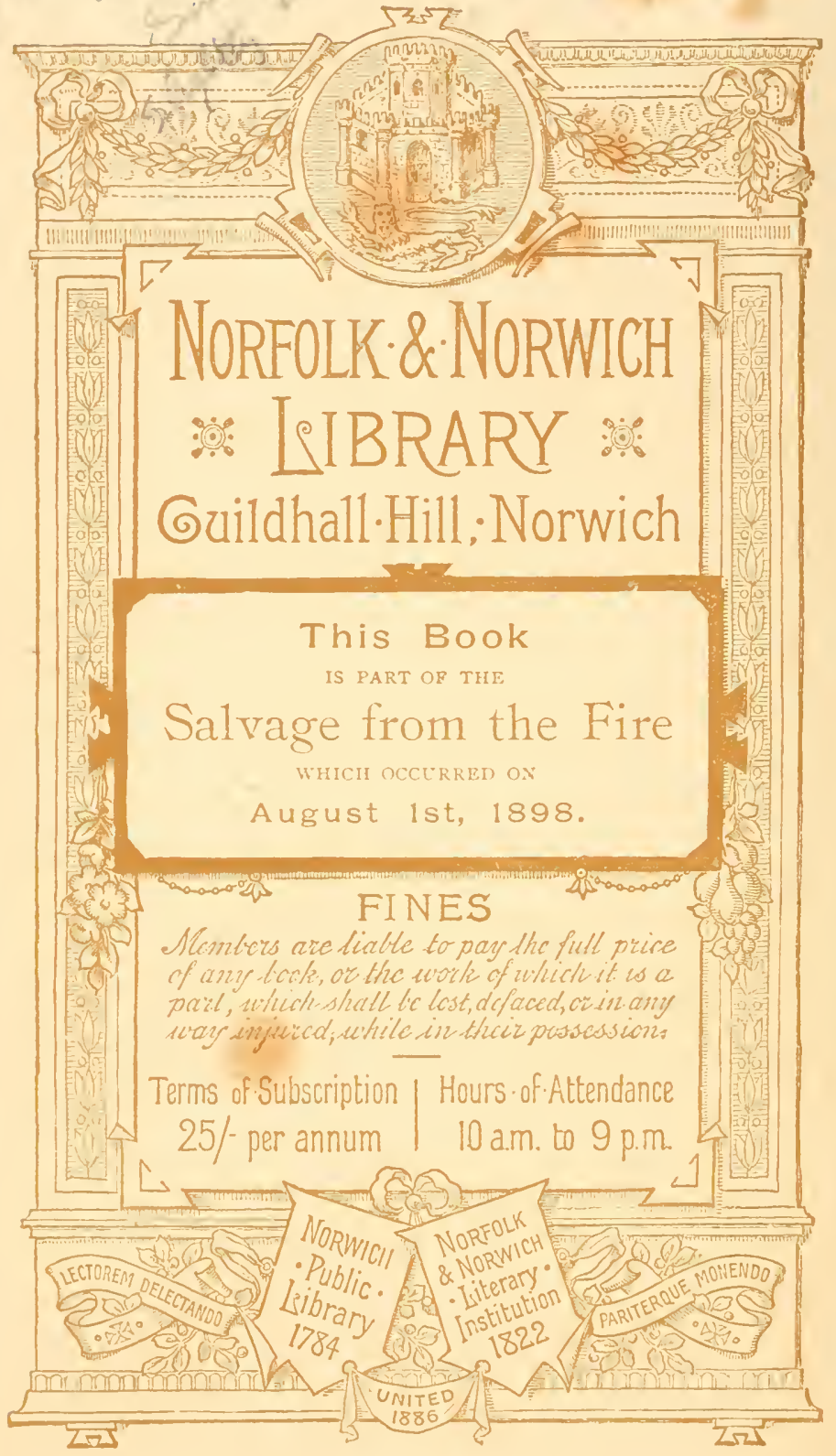






BRITISH ZOOPHYTES. 
"Antequam progrediar, non ab re fortasse fuerit ohjectioni alicui quæ in me moveri potest occurrere. Non deerit scilicet qui me vanæe curiositatis arguat, quòd res adeo viles et abjectas, mullius in vita usûs, indagaverim, iisque describendis tantum temporis et operæ impenderim._C Cui respondeo, Quod De1 opera sunt in quibus contemplandis memet exerceo : quod Divinæ Artis et Potentix effecta, quibus exquirendis subsecivas horas addico: quod lLLE me in hunc mundum introduxerit, tam inexplicabili $r \in r u m$ varietate instructum et ornatum ; quod oculis, quos mihi contulit, ea videnda, animo consideranda objecerit. In DEI ergo contumeliam redundat, quod hæc, quæ eum creâsse negare non andes, supervacanea et inutilia esse affirmes._Dices, Majora et magis necessaria studia sunt, quæ totum hominem requirumt. Respondeo, Majoribus istis me majorem curam impendere, interim tamen minora læe et leviora non opus est ut prorsus negligam: Utrique penso sufficio ; utrique temporis abunde suppetit, modò id prndenter dispensem, modò caveam ne qua ejus pars omnino vacua priterlabatur. Vitam (ut rectè Seneca) non accepimus brevem sed fecimus, nec inopes ejus, sed prodigi sumus. Deinde Medici etiam severiores aliquam temporis portionem recreationibus deputant. Hisce ego studiis et inquisitionibus memet recreo et oblecto. Quod alii venationibus, aucupiis, confabulationibus, lusibus insumunt, illud ego " Toophytis" indagandis, colendis, contemplandis impendo. Recreat et refocillat animum, quamvis laboriosum sit, illum quocumque oblectatur." Raıus. 


\section{H I S'TOR Y}

OF THE

\section{BRITISH ZOOPHYTES.}

B Y

\section{GEORGE JOHNSTON, M. D. Edin.}

FHLLW OF THE ROYAL COLLEGE OF SURGEONS, AND EXTRAORDINARY MEMBER OF THE ROYAL, MEDICAL SOCIETY OF EDINBURGH.

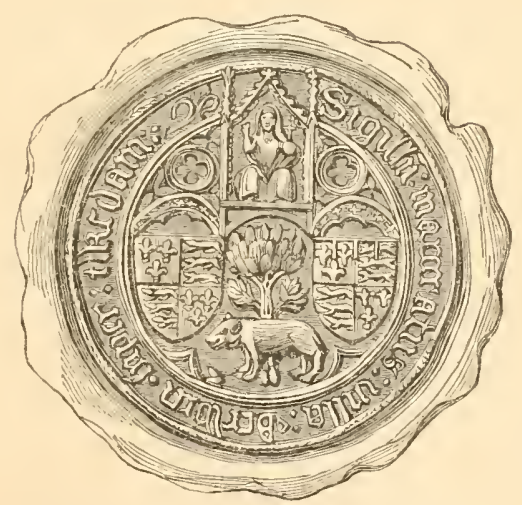

ARMS OF THF TOWN OF BERWICK-UPON-TWEED.

W. H. LIZARS, EDINBURGH :

S. HIGHLEY, 32, FLEET STREET, LONDON ; AND

IV. CURRY, JUN. \& CO., DUBLIN.

MDCCCXXXVII.

1838 


$$
4+3
$$



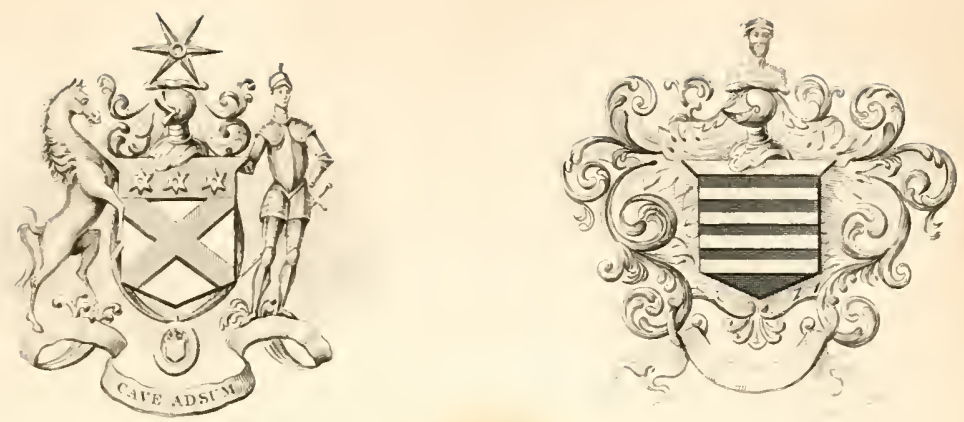

\section{$(1,1$,}

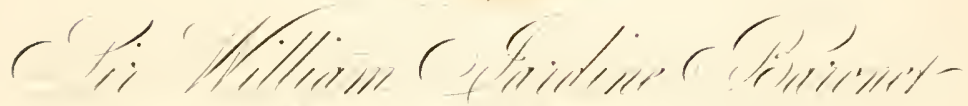

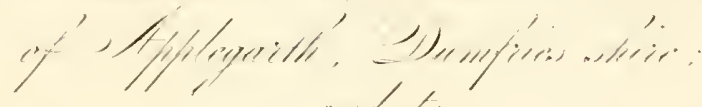
and II.

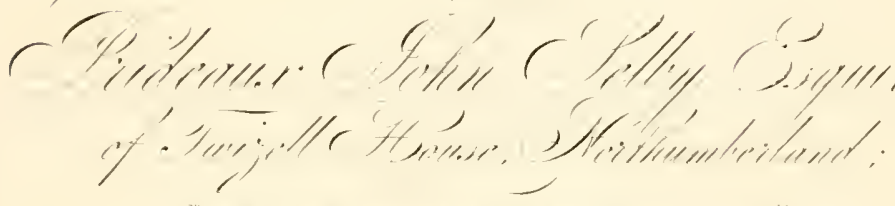
"pribibus sturlis et anope derinetis"

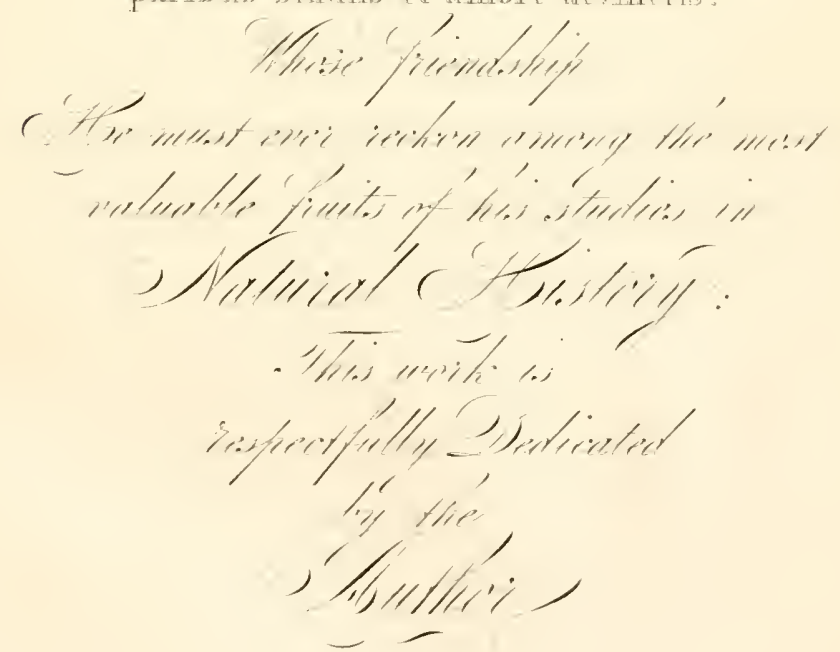





\section{PREFACE.}

" Iltum nee spiro, nee spero."

Since the publication of Ellis's Essay on Corallines in the year 1755, no separate work has appeared in illustration of our native Zoophytes. In the meantime, and more especially within these few last years, a much more accurate knowledge of their structure has been attained, and many species have been added to the list; and it has been my object to give here an account of these discoveries, to connect them with what had been previously made known, and to combine the whole under a system more in harmony with the anatomy of the objects than has hitherto been done. If I have succeeded in bringing within a convenient volume, the materials that at present lie scattered through many expensive and miscellaneous ones, some of them too of difficult acquisition, I may, perhaps, claim the merit of having conferred no inconsiderable benefit on the student, even should his future studies convince him that I have not forwarded or enriched this particular branch of natural history by any novelties. Originality indeed has been less my aim than fulness and accuracy of compilation; but I have endeavoured to qualify myself for this apparently humble task by many personal researchesandobservations on the species that are found in my own neighbourhood, uniler the conviction that a compiler will rarely snceed in giving a correct idea or representation of the objects 
under investigation without a direct acquaintance with them. It is indeerl desirable that the author of a work of this kind shonld have examined all the species, and in various distant localities, that he may justly eharacterize them, and estimate the extent of their variations; nor was the circumstance of the comparative 1 mmoveableness to which a medical practitioner is doomed unconsidered as a bar to my own competency, but the love of the subject prevailed, especially when friends were readily found to contribute to the removal of the difficulty. To them I have in this place to render my grateful acknowledgements. To Mr Bean of Scarborough, Dr Coldstream of Leith, J. V. Thompson, Esq. Inspector of Hospitals, for some time resident in Cork, and the Rev. David Landsborough of Stevenston in Ayrshire, I stand indebted for numerous specimens; and similar communications of less extent have been sent me in a friendly manner by John Edward Gray, Esq. of the British Museum; Mr Robert Embleton, surgeon in Embleton; Messrs Alder and Bowman of Newcastle; Mr Teale of Leeds : J. Hogg, Esq. of Norton; and Messrs Macgillivray and P. W. Maclagan of Edinburgh. One other name must not be forgotten, for, besides a friendly interest in the book, and his revision of it during its progress through the press, I have had the kind assistance of the Rev. Thomas Riddell, of Trinity College, Cambridge, whenever the assistance of a classical scholar was required.

I am not certain that any apology will be deemed necessary for the notes and quotations which have been introduced with considerable liberality, for the tastes of the naturalist have ever seemed to me akin to those of the antiquary; and this has always been a favourite mode of illustration with the latter. It is one that chimes in with my own humour, and the indulgence of it seemed at least harmless on the present occasion. Many of these notes are devoted to notices of the individuals who, so far as I could leam, were the first to notice the species of 
zoophyte to which their names are respectively athixed,-follow ing immediately the specific character. This has been a plcasing inquiry, Snit with the beauty-real or fancied-of the objects of his study, a curiosity is uaturally awakened to liscover the name and degree of the person who had first deemed it worthy of his examination and participated in our pleasure, for we conclude assuredly that he who had taken the trouble to record the name and treasure up the object, was one of like mind, and imbued with much of the same affections and dispositions as ourselves. Some of them were found to be men of renown,others in whom I felt a deeper sympathy, are now forgotten, their name and their labours swallowed up in the ligher and more enduring reputation of those whom they were honoured to assist and delighted to serve. The genuine naturalist will not censure this "fond attempt" to restore the faint traces of men who had sought the best occupation of a leisure hour in congenial pursuits and studies; but rather will with me lament the obscurity and shortuess of their " simple annals."

" Paullum sepultæ distat inertiæ

"Celata virtus. Non ego te meis

"Chartis inornatum silebo,

"Totve tuos patiar labores

" Impune_____carpere lividas

"Obliviones. *_Hor. Carm. iv. 9.

It was gratifying to remark that most of my pretlecessors in this field of inquiry were members of the medical profession. How largely natural science, in all its branches, has been indebted for its progress to this body is too notorious to be insisted

* The first stanza in Shenstone's "School-mistress" may serve as a translation of this passage :

"Ah me! full sorely is my heart forlorn,

To think how modest worth neglecter lies.

\section{let me try}

To sound the praise of merit, ere it dies,

Such as I oft have chanced to espy,

Lost in the dreary shades of dull obscurity.' 
on; but it has been less noticed that the men who thus oeenpied themselves in acquiring and forwarding a knowledge which many may deem purely ornamental, were the same individuals who were most engaged in the active discharge of the duties of their profession, and the most instrumental, to its advance. Boerhaave, Cullen, Hunter, Darwin and Jenner are very memorable instances of this fact, which is illustrated with lesser brilliancy in Lister, Sloane, Mead, Fothergill, Lettson, Sims, Maton, in Withering of Birmingham, in Percival and Hull of Manchester, in Pulteney of Dorset, Stokes of Chesterfield, and numerous others whose names will occur to every one conversant with the history of medicine. This is only what on reflection might have been anticipated, for that very activity of mind and perspicacity which originated and mpheld their sagacity and success as practitioners, was sure to carry them far in whatever side-path the natural bent of their taste led them for the occupation and entertainment of the leisure hours which the busiest must have or may create. Idleness has no leisure. Were it necessary I might safely shetter myself under the cover of these exemplars, in the contemplation of whose lives I have often nurtured my love to my profession,_and hence, perhaps, an ambition to follow them even at a far distance;-but there never was a time when it was necessary to vindicate to any but the ignorant the erratic excursions of medical men into the fields of science and literature, for assuredly the rank which the profession as a body has taken and holds in public estimation depends for its patent, in part at least, on the scientific and liteary character of its professors; and by continuing to support that character they will best secure it from the vulgarity of a common mercature, or the selfishness of a renal quackery.

Zoophytes present to the physiologist the simplest independent strnctures compatible with the existence of animal life, ruabling hisu to examine some of its phenomena in isolation and fiee from the obsenrity which greater complexity of anato- 
my entails : the means of their propagation and increase are the first of a series of facts on which a theory of generation must rise; the existence of vibratile cilia on the surfaces of membranes, which has since been shewn to be so general and influential among animals, was first discovered in their study; and in them is first detected the traces of a circulation carried on independently of a heart and ressels. The close adhesion of life to a low organization, - its marvellous capacity of redintegration; the organic junction of hundreds and thousands of individuals in one body, the possibility of which fiction had scarcely ventured to paint in its vagaries, have all in this class their most remarkable illustrations._- On the geologist zoophytology has peculiar claims. Its subjects are apparently the first of animals which were called into existence, and from that high date to this time, they have played a part in the earth's mutations, from chaos to the present well ordered scene, greater perhaps than any other class of beings. Separating from the waters of the ocean the calcareous matter held in solution, they reduce it to a solid state; constructing therewith their varied jolypidoms or corals which, by their continual growth, their coalescences, their enormous numbers and extent, first roughen the smooth basin of the sea, raise up reefs and ridges that obstruct the hitherto open course of navigation, and become ultimately the foundation of islets and islands that remain the "monumental relics" of the puny race. As now the process and change goes on in tropical seas, - so operated it, in the preadamic times, over the waters of the globe, for it is principally from the debris of polypous excretions that the extensive beds and quarries of chalk and limestone which are found in every region of the globe take their original.*_-But it is to the zoologist that I exclusively address myself in this work, and however considerations like the above may enhance the importance of the subject in the estimation of others, they sway him little, and lie apart from his 
more immediate objects. He finds his pleasure in the contemplation of their novel forms, in the examination of those characters which distinguish them as species, in the quest of their mutual affinities, their relations and analogies with other beings, the order in which Creative Wisdom may seem to have called them into existence, their habits, economy and uses;-and in all these things he is ever watchful to find a " moral compliment" that the pursuit to which his taste and constitution of mind has led him may be neither uninfluential nor virtueless on his heart.

The plates and wood-cuts which illustrate the volume are, with few exceptions, original,--engraved from drawings made for it by Mrs Johnston, who is herself the engraver of fourteen of them. The naturalist who may have attempted similar illustrations will appreciate the labour, perseverance and skill which has been hestowed upon them, and will not harshly censure any errors of detail which a minute criticism may discover. As I could not have undertaken this history without her assistance, I may crave, from any one who shall find a merit in it, the ascription of that merit to my colleague.

BERWICK-UPON-TWEED,

August $15,1838$. 


\section{CON'TEN'TS.}

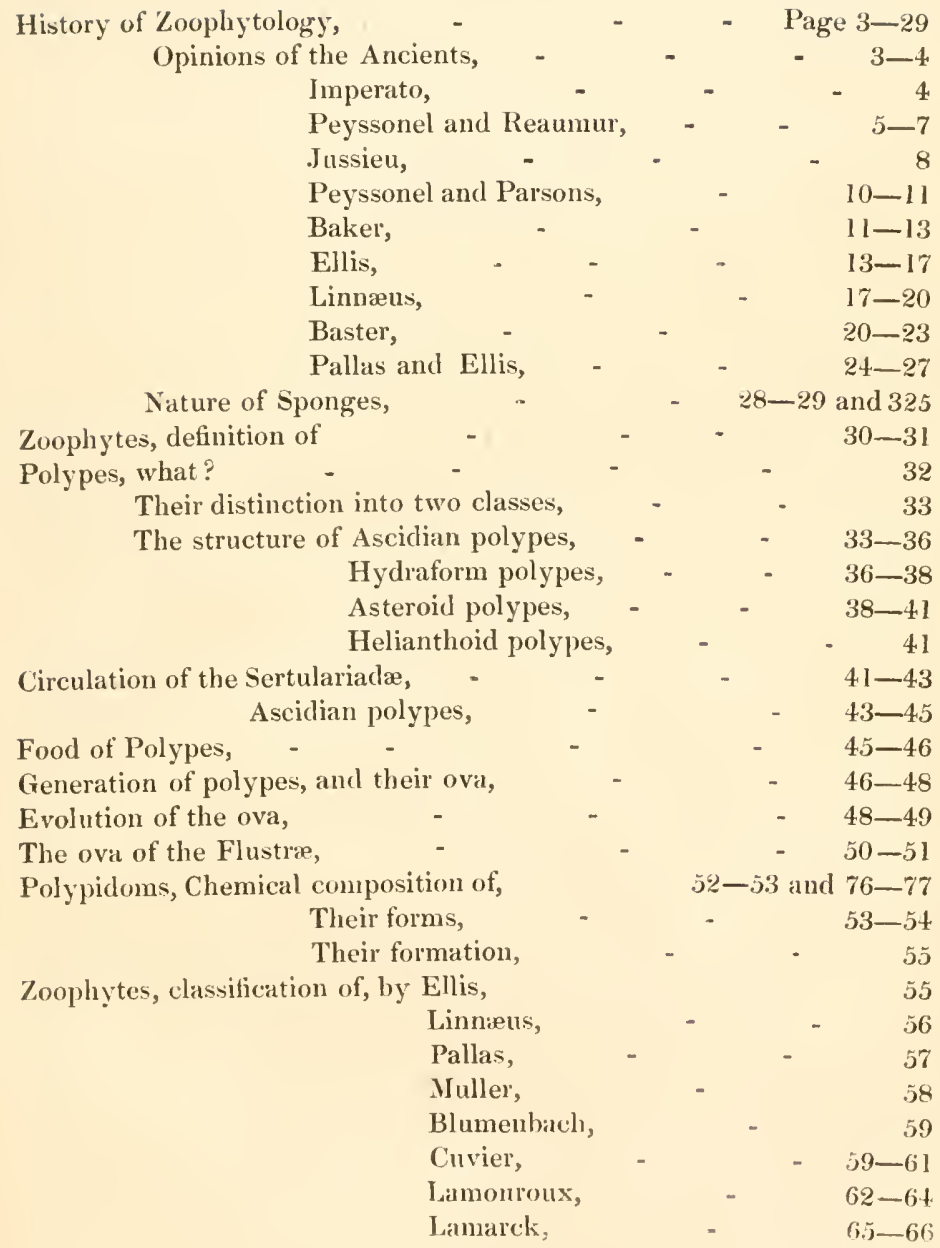




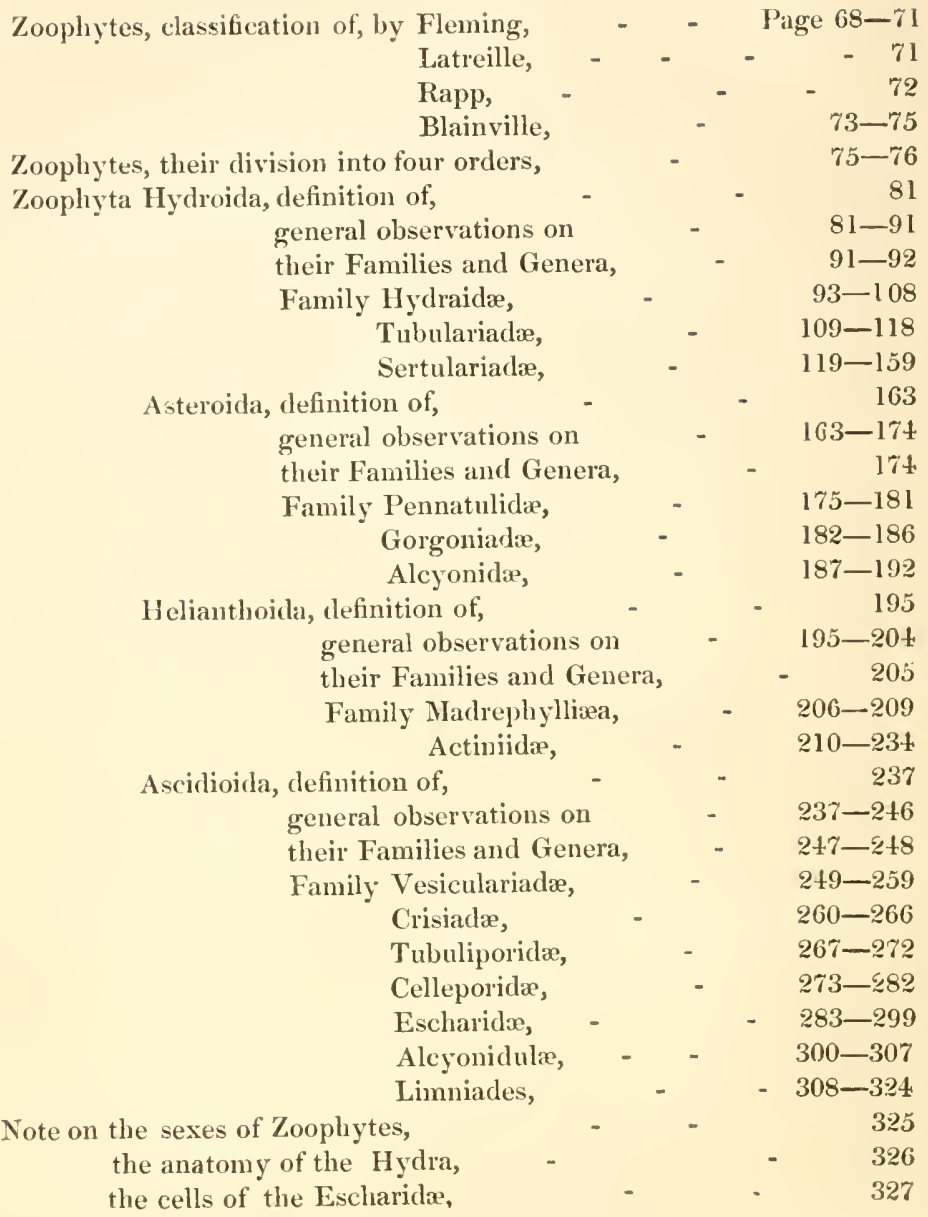




\section{BRITISH ZOOPHYTES.}

\section{PART I.}

'The History of Zoophytology; and on the Śtructure, Physiology, and Classification of Zoopiryes.

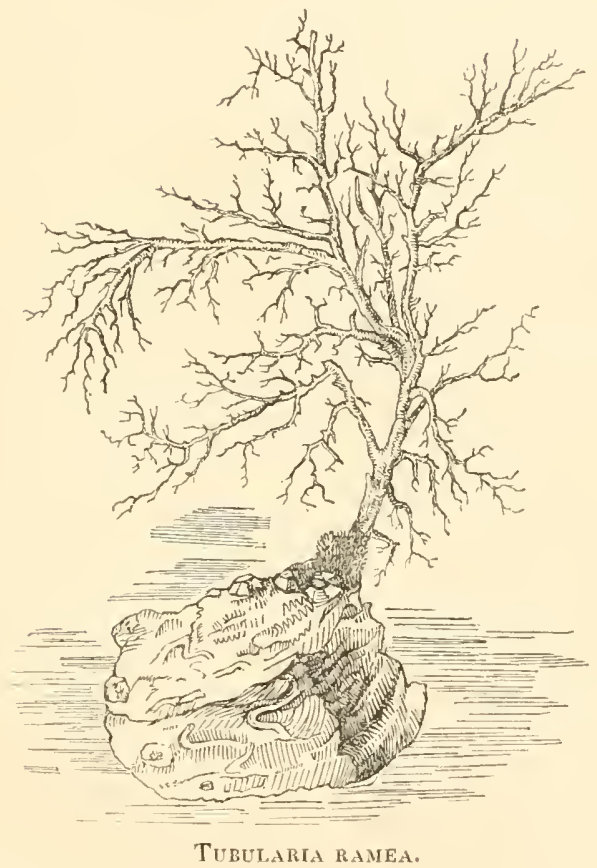

" In nova fert animus mutatas dicere formas

"Corpora."-Orid, Metamorph. i. 
"Ipse manus haustâ victrices abluit undâ Anguiferumque caput durâ ne lædat arenti, Mollit humum foliis, natasque sub requore virgas Sternit, et imponit Phorcynidos ora Medusæ. Virga recens, bibulâque etiamıum viva medullâ Vim rapuit monstri, tactuque induruit hujus, Percepitque novum ramis et fronde rigorem. At pelagi nymplax factum mirabile tentant Pluribus in virgis, et idem contingere gaudent : Seminaque ex illis iterant jactata per undas. Nunc quoque curaliis eadem natura remansit, Duritiem tacto capiant ut ab aëre, quodque Vimen in requore erat, fiat super aequora saxum."

Ovid. Metam. iv. 


\section{BRITISH ZOOPHYTES.}

\section{CHAPTER I. \\ History of Zoophytology.}

THe natural productions about to occupy our attention, have been denominated Zoophytes because, according to some pliysiologists, they partake of the nature both of vegetables and animals, and connect the two kingdoms of organized matter; or because, as others define the term, having the outward semblance of sea-plants, they are yet in reality the formations of little animals or polypes that nestle in the cells or tubes of the zonphyte, to which they are organically and indissolubly conmected.

Little more than a century lias elapsed since the first discoveries were made, on which these opinions are founded. Previously to that time zoophytes were considered the undoubted subjects of the regetable kingdom, naturalists being obviously led to this allocation of them by their arborescent appearances, in which it were vain to trace any likeness to any common animal forms, - and by their permanent fixedness to the objects from which they grow, for zooplyytes are attached by means of a disk or tubular fibres much in the same way that marine plants are, while the capability of moving at will from place to place was deemed to be the principal character of distinction between the two classes of animated beings. The zoologist claimed none of them, if we except the Actinize or animal-flowers, for his province and study, but left them without dispute to botanical writers; and if any of these, in reference to a very few zoophytes of the least arborescent character, hazarded a whispered conjecture that they were wrongly classed, it died away in the ut- 
terance, and raised no echo to awaken further inquiry. The only opposition to the botanical theory came from the mineralogist, who some of them questioned the vegetability of such of these productions as were of a hard and stony nature, contending they were rather rocks or stones formed by the sediment and agglutination of a submarine general compost of calcareous and argillaceotis materials, moulded into the figures of trees and mosses by the motion of the waves, by crystallization, by the incrustation of real fuci, or by some imagined vegetative power in brute matter. But although not more-perliaps less repugnant to the outward sense than the opposite hypothesis, yet the mineral theory seems at no time to have obtained very general favour or credit; and accordingly we find that, in the works of Tournefort and Ray, * the leading naturalists of the age immediately antecedent to the discoveries which led to the modern doctrines, the zoophytes, whether calcareous and hard, or horuy and flexible, were arranged and described among sea-weeds and mosses without any misgivings concerning the propriety of doing so.

Ferrante Imperato, an apothecary in Naples, was the first naturalist, according to M. De Blainville, distinetly to publish, as the result of his proper observations, the animality of corals and madrepores, $\uparrow$ and he is said to have accompanied the de-

* In his "Wisdom of God in the Creation," Ray has, however, reckoned the Lithophyta among " inanimate mixed bodies." Of these, he says, " some have a kind of vegetation and resemblance of plants, as corals, pori, and fungites, which grow upon the rocks like shrubs."-p. 83, duod. Lond. 1826. His opinions on this point were probably unsettled; and certainly many naturalists believed that Ovid only expressed the simple fact when he wrote-

"Sic et curalium, quo primum contigit auras
"Tempore durescit; mollis fuit herba sub undis."

Metam. lib. xv.

$\dagger$ Man. d'Actinol. p. 14.-Lamouroux on the contrary places Imperato on the same Jevel with Gesner, Boccone, and Shaw-none of whom had any distinct notion of the animality of any zoophytes, and had no doubt of the vegetable natıre of almost all of them. "Les observations de ces hommes célébres, an lieu d'éclairer les naturalistes sur cette branche intéressante de la science, embrouillaient encore plus son étude."-Lam. Cor. Flex. Introd. p. xiv. My coly of Imperato's work is of the edition printed at Venice in 1672 , folio. It is written entirely in Italian, and, being ignorant of that language, I can give no opinion of the value of its letter-press. The only copper..plate is a very curious one representing the interior of Imperato's museum, which appears to have been a rery elegant and copious collection of curiosities, a servant pointing with a 
scriptions of the species which fell under his notice with illustrative figures of considerable accuracy. His " Historia Naturale," of which De Blainville assuredly speaks in very exaggerating terms when he represents it as one of the most important works in the history of zoophytology, was printed at Naples in 1599 ; but although reprinted some years afterwards (1672), the book, and the knowledge it contained, had sunk into such complete oblivion, that when Peyssopnel, in the year $1 \% 27$, communicated the same discovery to the Academy of Sciences in Paris, it was received by the members of that learned body in a manner which is sufficient to convince us that it was entirely new to them, and exposed the author to the obloquy and censure which are the usual portions of an original discoverer.

Some time previously to the publication of Peyssonnel's discovery, those who maintained that the stony zoophytes were plants had received a strong corroboration of their opinion from the researches of Count Marsigli, who, having detected the existence of polypes in coral and madrepore, had, under the influence of the fishionable theory, described them as being literally their blossoms or flowers.* Peyssonnel, therefore, had to contend not only against the prejudices of the vulgar based on appearances which spoke direct to the outward sense, but against the actual observations of a naturalist of acknowledged merit; and the observations of Peyssonnel, although numerous and unequivocal, were yet mixed up with so much that was fanciful or erroneous, that it is not wonderful his opinion was received with coldness and suspicion. Reaumur, to whom Peyssonnel's communication was intrusted, even concealed the name of the

rod and directing the attention of two wondering visitors to the more remarkable of them, while a third leans against it cabinet, and surreys,

$$
\text { " Its many singularities." }
$$

The book contains besides many wood-cuts of a miscellaneous kind, very tolerably engraved for the age. The Zoophytes figured belong chiefly to the Lithophyta, with some Sponges and Alcyonia. The opinions of Rumphius seem to have been as explicitly stated as those of Imperato, but they effected nothing. Pall. Eleneh. 14, and 275.

* "Ce fut une découverte qui lit grand bruit dans le monde natualiste, que celle des theurs du corail." Reaumur._Marsigli's work was published in 1711. His name is sometimes written Mursilli._For an accuunt of his works see Ilaller, Bib. Bot. i. 630 . 
author when he laid it before the Academy, with the benevolent intention doubtless of shielding him from the scor'u and ridicule that might possibly be the lot of one who had ventured to contradict the observations of an Italian Count, and to oppose the established belief; * and he immediately afterwards read, before the same academicians, an essay of his own, in which he opposed the theory of Peyssonnel with numerous objections, and attempted to explain the growth of coral in accordance to the armitted principles of regetable physiology. $\uparrow$

The memoir in which Peyssonnel originally proposed his doctrine does not appear to have been published: the only account I have seen of it is contained in the essay of Reaumur just alluded to. He maintained that what Marsigli had described as the blossoms of coral, were true animals or insects analogous to the Actinix or sca-anemonies; that the coral was secreted in a fluid form by the inluabitant Actinix, and became afterwards fixed, hard, and changed into stone; and that all other stony sea-plants, and even sponges, are the work of different insects, particular to each species of these marne bodies, which labour uniformly according to their nature, and as the Supreme Being has ordered and determined. Reaumur remarks, that these opinions were not entirely the offspring of fancy : it wonld have been more candid and just had he said they were simply the convictions of a practical naturalist, who had long and patiently studied the productions in question, in their native sites on the coasts of France and of Barbary. Peyssonnel had seen the polypes of coral and of the madrepores; he recognized their resemblance to the naked animal flowers; he had witnessed their motions, - the extension of their tentacula, and the contraction and opening of the oral aperture; he ascertained, that, unlike flowers, they were to be found the same at all seasons;

* "L'estime que j'ai pour M. l’eyssonnel ure fit même éviter de la nonmer pour l'auteur d'un sentiment qui ne powvoit manquer de parôitre trop hasardé." - Reaunur.

$\dagger$ Observations sur la formation du corail, et des autres productions appellées Plantes pierreuses. Par M. de Reaumur._" Il prend pour une Plante l'ecorce grossiere et seusible du corail, tres-distinete de ce que nous appellons corail, et de phus une autre ecorce beaucoup plus fine, et que les yeux ne distinguent point de la vaye substance coralline qu'elle revêt; et tout le reste du corail, presque toute lit substance coralline n'est qu’une pierre sans organisation."- - Hist. de l'Arad. Loy. des Sc. I727. 1. 51. and more particulaly his ow memoir in the s:une vol. p. 380 . 
that their corruption exhaled the odour; their chemical analysis discovered the constituent principles of animal matters; and that the stony part of them exhibited no trace of vegetable organization: and opinions deduced from such data, abstracting his analogical reasoning of no value and little applicability, might have been sufficient to have attracted at least some attention had his opponent been less influential, or his own reputation and rank somewhat greater. *

The name and doctrine of Pevssonel lay in this manner unknown and neglected, until the remarkable experiments of Abraham Trembley, in 1741, on the reproductive powers of the fresh-water polypes, + and more especially his discovery of the Plumatella, itself a plant-like animal production, while they extorted the wonder and admiration of every one engager in the study of natural science, were the means of recalling to the recollection of Reaumur the views of Peyssonnel; and he now became forward in promoting such inquiries as seemed likely to confirm and extend them. He himself appears to have repeated the experiments of 'Trembley, and had an opportunity of observing the habits of the Plumatella; and, as he remarks, since the number of species of animals which are covered by the waters of the sea is much greater than that of the fresh waters, so it seemed natural to presume that not only would polypes be found in the ocean, but in greater numbers and variety than in ponds, rivers or rivulets. To ascertain the validity of this conjecture, and to settle if possible the discrepancy between the observations of Marsigli and Peyssonnel, his friends Bernard

* Peyssonnel is remembered solely by this discovery. " M. Peyssonnel, disposed from his youth to the study of natural history, after having qualified himself for the practice of medicine, applied himself with great diligence to that science, to which his inclination so strongly prompted lim, and being a native of, and residing at Marseilles, he had the opportunity of examining the curiosities of the sea, which the fishermen, more especially those who search for coral, furnished him with."-Phil. Trans. He was subsequently appointed Physician-Botanist to "His Nost Christian Majesty" in the island of Guadalupe, and had an opportunity of prosecuting his researches on the coast of Barbary. He is the author of two or three communications in the Phil. Trans, of which the most interesting is " An account of a visitation of the Leprous persons, in the isle of Guadalupe" in the volume for the year 1757.

+ In the Fhil. Trans. for $17+2$, the reader will find a full account of this discovery. 
de Jussieu and Guettard * proceeded, in the antumns of 1741 and 1742, to different parts of the coasts of France with the view of examining their zoophytical productions; and both were soon satisfied of the truth of the animal theory. Bernard de Jussieu in particular shewed that it was equally applicable to many zoophytes which Peyssonnel had not examined, and whose amimality had not yet been suspected, viz. the flexible and delicate Sertularix, the Flustra, and the Alcyonium or Lobularia, the latter of which seems to have excited much astonishment by the protrusion of its thousands of polypes of a size large enough to be seen and examined at ease with the naked eye. +

The memoir which Jussieu presented to the Academy of Sciences in Paris is short, but characterized by great distinctness and precision in the detail of his observations, and illustrated with excellent figures; - his aim being evidently not to entrap our blind assent by a declamatory display of the new wonders opened up in science, but to prove his conclusion to be the true one in the eye of reason and sobriety. He limits his descriptions and remarks to four species, viz. Alcyonium digitatum, Tubularia indivisa, Flustra foliacea, and Cellepora pumicosa, which seem to have been selected as examples of the more remarkable tribes, for it is evident that he had examined manymore, but hisobservations on them were reserved for another memoir which, I believe, was never written. $\neq-$ Reaumur's ad-

* Lamouroux speaks highly of the labours of this naturalist, whose attention seems to have been chiefly directed to fossil polypidoms and to sponges. - Corall. Flex. Introd. p. xvii. See also Hall. Bib. Bot. ii. 341.

† Examen de quelques productions marines qui ont été mises au nombre des Plantes, et qui sont l'ouvrage d'une sorte d'Insectes de mer. Par. M. Bernarl de Jussien. 14th Nov. 1742. Published in 1745. - See Hall. Bib. Bot. ii. 281.

‡ That Jussieu had ascertained the animality of the Sertulariadie is, I think, indisputable from the following passage. "ll s'en presentoit ensuite quantité de celles qu'on appelle Corallines, les unes pierreuses dans lesquelles je ne remarquai rien, et les autres dont les tiges et les branches, et ce qui passoit pour feuilles, etoient d'une apparence membraneuse, dans lesquelles je decouvris que ce qu'on y prenoit pour feuilles disposées alternativement, on dans un sens opposé, n'etoit autre chose que de petits tuyaux contenant chacun un petit insecte." —Mém. de l'Acad. Roy. des Sc. an. 1742. p. 292.-Reaumur is still more explicit. : "Après avoir observé dans l'eau même de la mer plusieurs espèces de ces productions si bien conformées à la manière des plantes, il vit sortir des bouts de toutes leurs branches et de tous leurs nouds, ou de toutes leurs articulations, de petits animanx qui, comme les polypes à panache d'eau douce, se domoient tautôt plus, tantôt moins de mouvement, qui comme ceux-ci s'épanouissoient eu 
vocacy of the new dloctrine was in a more popular style, but not the less excellent. He gave a short exposition of the ascertained facts,-reviewed with the clearness of an eye-witness the discoreries of 'Trembley,-pointed out their relations to the ex. periments of Jussieu and Guettard, and low they mutually lent and borrowed strength,-palliated and explained away his former opposition to Peyssomnel,-and declared his complete faith in the animality of Zoophytes, and his conviction that a numerous list of productions hitherto unexamined would be found to be of the same nature. "All that we have saic," he thus concludes, "of the polypes of the sea, is merely a sort of advertisement which, however, cannot fail to produce the effect which we promise ourselves from it: it will direct undoubtedly the curiosity of naturalists who reside by the sea to insects so worthy of being better known. They will seek ont the different species; they will delight to describe to us the varieties presented in their forms never but remarkable; they will study the figure and disposition of the cells of the varions species, their manner of growth and reproduction and wherewithal they are nourished; they will in short, place in a clear light every thing that has reference to the different polypidoms and their formation, so that a department of natural history, so interesting, so new, and as yet only sketched in outline, may be rendered as perfect as it merits to be." *

The appeal, eloquent as it was and from one having great inlluence, was however made in vain; for whether from the inveteracy of habit and our fondness of opinions long cherished, or from the fewness of the published observations whence the general conclusion was drawn, it seems certain that the new doc-

rertains temps, et qui dans d'autres rentroient en entier dans leur petite cellule, hors de laquelle leur partie postérieure ne se trouvoit jamais. Enfin, il (B. de Jussieu) reconnut que plusieurs espèces de ces corps, dont chacun avoit l'extérieur d'une très-belle plaute, n'étoient que des assemblages d'un nombre prodigieux de cellules de polypes; en un mot, que plusieurs de ces productions de la mer, que tous les botanistes que les ont déerites ont prisespour des plautes et ont fait représenter comme telles avec eomplaisance, n'étoient que des polypiers."-Preface, Vol. vi. p. 71, 72. See also Amoenitates Arademicæ, Vol. i. p. 185, for an enumeration of the species of Sertularia, \&c., which Jussieu hrat examined, and considered to be auimal productions. His account, however, of the animal of the Sertularix is altogether erroneous.

* Mémoires pour servir ì l'histoire des Insectes, Tome sixième, Paris, 1742. Quarto. Preface, from p. 68 to p. 80. 
trines were everywhere received with doubts and suspicion, and beyond the immediate sphere of the Parisian acadeny, excited apparently so little interest, that no one was induced to enier into a practical examination of them. Douati indeed shortly after gave a minute and accurate description of the coral and its polypes, and a somewhat less detailed one of the madrepores, but his phraseology being botanical and his opinions unformed,* his researches were of little immediate service to the cause of the zoologists, and perhaps rather tended to smpport the erroneous hypothesis which they were combating. $\dagger$

Peyssonnel was still living, and it was impossible that this dis. cussion should not interest him. Accordingly we find that in 1751, he transmitted to the Royal Socicty of London a manuscript treatise on coral and other marine productions, $\ddagger$ of which Dr Watson has given a review in the $47 \mathrm{th}$ volume of its Transactions, published in 1753. The treatise was sent to the English society, because " that in France some lovers of natural history do attribute and even appropriate to themselves his labours and his discoveries, of which they have had the communication;"a charge probably directed against Reaumu, but which the conduct of that illustrious man, so far as appears, did not warrant. The treatise contains upwards of 400 quarto pages, and is the

* Shortly after this, bowever, he made other observations which convinced him of the animality of coral. He says_- " 1 am now of opinion, that coral is nothing else than a real animal, which has a rery great number of heads. I consider the polypes of coral as the heads of the animal. This animal has a bone ramified in the shape of a shrub. This bone is coverel with a kind of flesh, which is the flesh of the animal. My observations have discovered to me several analogies between the amimals of kinds approaching to this. There are, for in. stance, Keratophyta, which do not differ from coral, except in the bone, or part that forms the prop of the animal. In the coral it is testaceous, and in the Keratophyta it is horny."-Phil. Trans. (1757) abridg. xi. p. 83.

+ New Discoveries relating to the History of Coral, by Dr Vitaliano Donati. Translated from the French, by Tho. Stack, M. D. F. R. S. (Fel. 7, 1750.)Plil. Trans. Vol. xlvii. p. 95. IJaller characterizes the original as " nobile opus, ex proprio labere natum."-Bib. Bot. ii. 400.

f Traité du corail, contenant les nouvelles decouvertes, qu'on a fait sur le corail, les pores, madrepores, scharras, litophitons, éponges, et autres corps et productions, que la mer fournit, pour servir ì lhistoire naturelle de la mer. By the Sieur de Peyssomel, M. D. Correspondent of the Royal Actumy of Sciences of Paris, of that of Montpelier, and of that of Belles Lettres at Marseilles. This treatise was nerer pmblisherl. 
result of the observations of above thirty year's, but we find in it no facts in support of his theory additional to those already mentioned, for the greater portion of it is occupied with many details on the medical uses and other applications of coral which have no relation to the question at issue. It seems at first to have excited considerable attention among the members of the Royal Society, but Peyssonnel's endeavours were doomed ever to be unfortunate, for whatever favour his theory was likely to receive here was nipt in the bud by the opposition of Dr Parsons, a naturalist of considerable eminence, and an active member of the society. The analysis of Peyssonnel's treatise was read in May 1752, and in June of the same year, Dr Parsons read his answer, * which savours much of the supercilious dog. matism of a sceptical philosophy. He does not pretend that he had tested the doctrine of Peyssonnel by any experiments or observations, nor does he question his veracity, but he chose to consider the animals observed by Peyssonnel in the coral and madrepores as merely accidental settlers which had nothing to do with their growth,-occupants of mansions prepared for them by more active entities, - there being no "seeming power, proportion, and stability" in the polypes to render them capable of performing such works as they were thought to have done. "And indeed it would seem to me," says the learned doctor, "much more difficult to conceive, that so fine an arrangement of parts, such masses as these bodies consist of, and such regular ramifications in some, and such well-contrived organs to serve for vegetation in others, shonld be the operations of little, poor, helpless, jelly-like animals, rather than the work of more sure vegetation, which carries on the growth of the tallest and largest trees with the same natural ease and influence, as the minutest plant."

The mineral theory also found at this period its latest advocate. Henry Baker, during his numerous microscopical enquiries, had become familiar with the beautiful and regular "vegetations" which many salts and earths assume in their crystal-

* A Letter from James Parsons, M. D. F. R. S. to the Rev. Mr Birch, Secr. R. S. concerning the Formation of Corals, Corallines, \&c. For an account of Dr Parson's writings see Hall. Bib. Bot. ii. 340 ; and there is a short biographical notice of him in Plil. Trans, abridg. viii, 692. 
lizations from a fluid state, and, seeing nothing more uniform or beautiful in the stony corals and corallines, he was naturally led to give an easy assent to that doctrine which taught that these were all the result of similar depositions. The new opinions might be true or not when restricted to the pliant horny corallines, (though he inclined to believe in their vegetable origin,) but it was unnecessary to call in the agency of animalcules to explain the formation of the hard stony kinds, which indeed seemed beyond the power of an almost gelatinous animalcule to excrete and laborate. Nor would he believe these to be seaplants, but rather of a mineral nature and origin. "The rocks in the sea on which these corals are produced," he says, "are undoubtedly replete with mineral salts, some whereof near their surface, being dissolved by the sea-water, must consequently saturate with their saline particles the water round them to a small distance, where blending with the stony matter with which seawater always abounds, little masses will be constituted here and there and affixed to the rocks. Such adliering masses may be termed roots : which roots attracting the saline and stony particles, accorling to certain laws in nature, may produce branched or other figures, and increase gradually by an apposition of particles; becoming thicker near the bottom where the saline matter is more abounding, but tapering or diminishing toward the extremities, where the mineral salts must be fewer, in proportion to their distance from the rock whence they originally proceed. And the different proportions of mineral saline particles, of the stony or other matter wherewith they are blended, and of marine salt, which must have a consicherable share in such formations, may occasion all the variety we see. Nor does it seem more difficult to imagine that the radiated, starry, or cellular figures along the sides of these corals, or at the extremities of their branches, may derive their production from salts incorporated with stony matter, than that the curious delineations and appearances of minute shrubs and mosses on slates, stones, \&c. are owing to the shootings of salts intermixt with mineral particles: and yet these are generally allowed to be the work of mineral steams or exhalations; by which must, I think, be meant the finest particles of some metal or mineral incorposrated with and brought into action by a volatile penetrating 
acid, which carrying them along with it in to the fissures at least, if not into the solid substance of such stones or slates, there determines them to shoot into these elegant branchings; after the same manner, and frequently in the same figures, as the particles of meresury, copper, \&c. are disposed and brought together by the salts in aqua fortis."*

But the progress of truth, although it may be delayed by opposition, cannot be permanently arrested. The converts to the new doctrines were indeed few, but much had been done to fircilitate their future reception, for the slumber of prejudice har been broken, the hold of the ancient opinions on the affections had been loosened, and men no longer startled into scepticism when they heard of animals that in their productions mimicked the most beautiful and delicate regetable forms. $f$ The mind of naturalists was thus in some measure prepared for the change on the very eve of being effected by the labours and assiduity of a member of that very society which had lately listened, with apparent approbation, to the reveries of Dr Parsons.

John Ellis-the name of the individual alluded to-was a merchant in London, who devoted his leisure to the study of natural history, in which he attained so considerable knowlerge as to gain easy access to the Royal Society, and the acquaintance and correspondence of the most celebrated naturalists of his time. He seems to have attached himself more particularly to the economical department of botany, and seized every opportunity to introduce foreign plants to our gardens, especially such as were remarkable from furnishing any material employed in the arts and manufactures; and he was equally solicitous to acquire and diffuse accurate information relative to any natural productions which might be rendered subservient to the necessities or comforts of mankind. He was fond also of amusing himself in making imitations of landscapes by the cllrious and skilful disposition of delicate sea-weed and corallines

* Employment for the Microscope, p. 218-20. Lond. 1753.

+ "For it is not because an opinion is true, that others will therefore adopt it. It must at the same time be congrnous with our other impressions, and admit of being dovetailed into them, or it will be rejected, for it is judged of by its conformity to the previons acquisitions, and is disliked and condemned if incompatible with them."-Turner, Sac. Hist. of the World, Vol. ii. p. 19. 
on paper: and it was this amusement that directed his enquiries into the nature of the latter, for, attracted by their beauty and neatness, he was induced to examine them minutely with the microscope, by the aid of which he immediately perceived "that they differed not less from each other, in respect to their form, than they did in regard to their texture; and that, in many of them, this texture was such, as seemed to indicate their being more of an animal, than vegetable nature." These "suspicions," as he modestly terms them, were communicated to the Royal Society in June 1752; and, encouraged by some of the members, he prosecuted this enquiry with such ardour, and care, and sagacity, that in August of the same year, he had fully convinced himself "that these apparent plants were ramified animals, in their proper skins or cases, not locomotive, but fixed to shells of oysters, mussels, \&c. and to Fucus's."*

Ellis, however, was not forward to publish his discovery : he waited further opportunities to confirm the accuracy of his first observations, and to institute other experiments to remove whatever appeared hostile to the doctrine, which at length he fully explained to the members of the Royal Society in a paper read before them in June 1754: and it was made more generally known in the following year by the publication of his "Essay towards a natural history of the Corallines, and other marine preductions of the like kind, commonly found on the coasts of Great Britain and Ireland;"-a work so complete and accurate that it remains an unscarred monument of his well-earned re-

* See the Iutroduction to his Essay on the Corallines of Great Britain. It is from this work, and from the valuable "Selection of the Correspondence of Limnæus, and other naturalists, from the original nannseripts, by Sir James Edward Sinith," 2 vols. 8 vo. Lond, 1821, that 1 derive iny account of Ellis's opinions. Sir J. E. Smith commences bis memoir by saying-_ John Ellis, F. R.S., illustrious for his discoeery and complete demonstration of the animal nature of Corals and Corallines, was a mative of lreland." We have seen that he has no claim to this discovery, though be himself seems to have thought so, and never makes mention of his predecessors in the sume field. A Professor Buttner at Gottingen, who had been in Eingland, and become acquainted with Ellis, who calls him an " excellent botanist," utuhesitatingly claimed Ellis's discoveries for his own, but a more bare-faced literary theft has not been recorded, and its detection has renderesl the name of the German Professor infumous, - Lin. Corresp. Vol. i. p. 170 and $179,-$ For a list of Ellis's writings the reader may consult Ha1l. Bil. Bot ii. 433, and the Introd. to Soland. Zoopln, p. viii. 
putation as a philosophical inquirer, and is even to this day the principal source of our knowledge in this department of natural history. In sereral essays presented subsequently to the Royal Society, and published in their Transactions, he continued to illustrate and extend his opinions, and defended them so successfully against his opponents, that they soon came to be very generally adopted.

There was nothing unformed nor mystical in Ellis's opinion. Certain marine productions which, under the names of Lithophyta and Keratophyta, had been arranged among vegetables, and were still very generally beliered to be so, he maintained and proved with a most satisfactory fulness of evidence, to be entirely of an animal nature - the tenements and products of animals similar in many respects to the naked fresh-water polype. By examining them, in a living state, through an ordinary microscope, he saw these polypes in the denticles or cells of the zoophyte ; he witnessed them display their tentacula for the capture of their prey,-their varied actions and sensibility to ex. ternal impressions, - and their mode of propagation; he saw further that the little creatures were organically connected with the cells and could not remove from them, and that although each cell was appropriated to a single individual, yet was this united "by a tender thready line to the fleshy part that occupies the middle of the whole coralline," and in this manner connected with all the individuals of that coraline. The conclusion was irresistible-the presumed plant was the skin or corering of a sort of miniature hydra, - a conclusion which Ellis strengthened by an examination of the covering separately, which, he said, was as much an animal structure as the nails or horns of beasts, or the shell of the tortoise, for it differs from "6 sea-plants in texture, as well as hardness, and likewise in their chemical productions. For sea-plants, properly so callerl, such as the Alga, Fuci, \&c. afford in distillation little or no traces of a volatile salt: whereas all the corallines afford a considerable quantity ; and in burning yield a smell somewhat resembling that of burnt horn, and other animal substances; which of itself is a proof that this class of bodies, though it has the vegetable form, yet is not entirely of a regetable nature." *

- Dr Good is in error when he states that the anmoniacal smell from burnt 
Ellis taught no novel doctrine, but he gave it fixidity and currency; and he moreover applied it to those very zoophytes which possessed the regetable appearance in the most perfection, many of which he was the first to notice, and which he illustrated with a series of figures of unequalled accuracy. $* \mathrm{He}$ rarely went beyond the mere statement of the facts witnessed, or what seemed an unavoidable inference from them; but, perhaps, he deserted his usual caution when, from analogy principally, he asserted that the articulated calcareous corallines ( $\mathrm{Co}$ rallina, Lin.) and sponges, of a very different structure from coral, madrepore, or the horny corallines, were also like them, manifestly the places of abode of different species of polypes. In the former (Corallina) he had indeed detected some slender fibres which, it was presumed, might be parts of polypes, but this observation he was never able to confirm, and it was rather because of the porous structure of the corallines, than from any thing else, that he inferred the existence of polypes in them,a structure which he had examined with minute accuracy, and shown to be essentially different from any known vegetable tissue,-and, secondly, because of their chemical ccnstituents, of which he procured an accurate analysis to be made.-With regard to the Sponges, Ellis, as Peyssonnel had previously done, supposed at first that the regular holes observable in dry specimens, strongly indicated their being once filled with animals; but when after repeated examinations of recent sponge, he could detect none, this conjecture was abandoned, and so thoroughly

zoophytes was the principal fact for placing them in the animal kingdom. - Book of Nature, i. 175 and 210.

* As mentioned above, Bernard de Jussieu knew that the Sertulariadæ-tlıe zoophytes bere alluded to-were animal productions, but no detailed account of his observations seems ever to have been published. Trembley had made the same discovery. Dr Watson, in his account of Peyssonnel's treatise in 1752, tells us that Mr Trembley shewed him, "at the late excellent Duke of Richmond's" the small white polypes of the Corallina minus ramosa alterna vice denticulata of Ray, "exactly in form resembling the frest-water polype, but infinitely less." "When the water was still, these arimals eame forth, and moved their claws in search of their prey in various directions; but, upon the least motion of the glass, they instantly disappeared." P. 463._Limnæus, however, in reference to the observations made previons to Ellis, says they arc "iuchoatæ, non ad plenum confectæ, et desiderentur adhuc quam plurima, quic dics forte revelabit."-Amoen. Aead. Vol. j. p. 186. 
was he afterwards satistied of the non-existence of animaleules, that he combated the opinion of those who maintained the contrary, pointing out where the error lay in mistaking small insects which had crept into the sponge in search of food or shelter for the real inhabitants and fabricators of the zoophyte. Yet not the less was Ellis convinced of its animality ; - its chemical constituents and its structure were to him conclusive proofs of this fact, particularly when added to the signs of irritability he saw them exhibit when in a fresh state. "I am persuaded," he writes to Linnæus, "the fibre intertextce of sponges are only the tendons that enclose a gelatimous substance, which is the flesh of the sponge. Mr Solander and I have seen the holes or sphincters in some of our sponges taken out of the sea, open and slut while they were kept in sea-water; but discovered no animal like a polype, as in the Alcyonium manus mortui." And again - " I attended last summer in pursuit of the animals in sponges, but believe me there are none: but the whole is an animal, and the water passes in a stream through the holes, to and fro, in each papilla." **

When Ellis published these discoveries, which form in fact an epoch in the history of natural science, + Limnæus was in the

* Lin. Corresp. Vol. i. p. 161 and p. 163. In a subsequent letter Ellis explains limself more fully. "I am now looking into the nature of sponges, and thimk by lissecting and comparing them with what 1 have seen recent, and with the $A l c y-$ onium manus mortua, that 1 can plainly see how they grow ; without trusting to Peyssonell's account of them, which is printed in our Philosophical Transactions, wherein he pretends to tell you, that he takes the animal out of them, that forms them; and that he put it into them, and it crept about through the meander's of the sponge. This kind of insect, which harbours in sponges, I have seen; but sponges have no such animals to give them life, and to form them. Their mouths are open tubes all over their surfaces, not furnished, like the tubes of the Alcyonium manus mortua, with polype-like mouths or suckers. With their mouths they draw in and send out the water; they can contract and dilate them at will, and the Count Marsigli has (though he thought them plants) confirmed me in my opinion, that this is their manner of feeding. If you observe what he bas wrote on sponges in his Histoire de la Mer, and the observations he has made on the Systole and Diastole of these holes in Sponges, during the time they are full of water, you will be of my opinion. Take a lobe of the officinal sponge, and cut it through perpendicularly and horizontally, and you will observe how near the disposition of the tubes are to the figure I lave given of the sections of the Alcyonium manus mortua in my plate of the Sea-Pens." - Lin. Corresp. Vol. i. p. 79-80.

† The Royal Society adjudged to Ellis the Copley merlal, "as the most 
zenith of his reputation,-the "t prince of naturalists," as his followers loved to style him,-from whose decision on all disputed points in natural history, there was scarcely an admissible appeal. And Linnæus almost merited this distinction, for he was a man not only of superior capacity and acquirements, of great sagacity, reacly apprehension, and fruitful fancy, but he was also of a candid and liberal disposition; and the ingenious labours of Ellis received from him great and merited commendation. He had previously, in the belief that lime was never formed but by animals, placed the Lithophyta in the animal kingdom; and he now adopted the opinions of Ellis so far as to include in it the horny and flexible polypidoms also, but at the same time he broached the conjecture, for it deserves no higher praise, that these were really intermediate between the animal and vegetable kingdoms, so that it could not be said they properly belong to either. The animalcules of the Lithophyta, like the testaceous tribes, he said, fabricated their own calcareous polypilom, forming the whole mass into tubes, each ending on the surface in pores or cells, where alone the animal seems to dwell; ; but the polypes of the proper Zoopliyta, so far from constructing their plant-like polypidons, were, on the contrary, the productions or efflorescences of it, $f$ just as the flowers do not make the herb or tree but are the results of the vegetative life proceeding to perfection. Polypes, according to this fancy, bore the same relation to their polypidom that flowers do to the trunk and branches of the tree; both grew by vege-

public mark that the Conncil ean give of their bigh sense of the great aceession which natural knowledge has received from your most ingenious and aeeurate investigations." The medal was delivered to him, Nor. 30, 1768, by Sir John Pringle, the President._-Soland. Zooph. Introd. p. xi. See also Swainson's "Discourse on the Sturly of Nat. History," p. 5ิ8-9.

* Lithophyta_" animalia mollusca, composita. Coralliun caleareum, fixum, quod insedifiearmnt animalia affixa."-Syst. 1270 .

† Zoophyta_" arimali: composita, efllorescentia. Stirps vegetans, metamorphosi transiens in florens Animal." - Syst. 1287. "Zoophyta non sunt, uti Lithophyta, anctores suie testae; sed Testa ipsorum; sunt enim eorpora (uti flores) imprimis generationis organa, adjectis nomulis oris motusque instrumentis, ut motum, quem extrinseens non habent, a se ipsis obtineant." - . Syst. Nat. edit. 10. 799. When Berkenhont translates the first of these definitions" stems vegetating and changing into animals;" Synop. i. 15, he eertainly departs, if not from the letter, yet from the meaning of Linneus. 
tation, but while the one evolved from the extremities blossoms which shrunk not under external irritations and were therefore properly flowers, - the other put forth flowers which, because they exhibited every sign of animality, were therefore with reason considered animals. "Zoophyta," he writes to Ellis, "are con-. structed very differently, living by a mere regetable life, and are increased every year under their bark, like trees, as appears from the annual rings in a section of the trunk of a Gorgonia. They are therefore regetables, with flowers like small animals, which you have most beautifully delineated. All submarine plants are nourished by pores, not by roots, as we learn from Fuci. As zoophytes are, many of them, covered with a stony coat, the Creator has been pleased that they should receive nourishment by their naked flowers. He has therefore furnished each with a pore, which we call a mouth. All living beings enjoy some motion. The zoophytes mostly live in the perfectly undisturbed abyss of the ocean. They cannot therefore partake of that motion, which trees and herbs receive from the agitation of the air. Hence the Creator has granted them a nervous system, that they may spontaneously move at pleasure. Their lower part becomes hardened and dead, like the solid wood of a tree. The surface, under the bark, is every year furnished with a new living layer, as in the vegetable kingdom. 'Thus they grow and increase; and may even be truly called vegetables, as having flower's, producing capsules, \&c. Yet as they are endowed with sensation, and voluntary motion, they must be called, as they are, animals ; for animals differ from plants merely in having a sentient nervous system, with voluntary motion; nor are there any other limits between the two. Those therefore who esteem these animalcules to be distinet from their stalk, in my opinion, founded on observation, deceive and are deceived." **

There was something in this hypothesis peculiarly captivating to an imaginative mind, and few poets liave possessed a richer fancy than Limnæus. He seems to have ever fondly cherished the opinion, for in his curious Diary, in which he has enumerated with much complacency all his works and merits, it is mentioned as one of his principal recommendations to the respect 
of posterity. "Liunc," he says, "decider that they (zoophytes) were between regetalbles and animals: regetables with re. spect to their stem; and animals with respect to their florescence. This iclea is still entertained."* Before we notice the manner of its reception by Ellis, we may take a short review of the writings of some other of the opponents of the latter naturalist.

Eliis had indeed effected a revolution in the opinions of scientific men, but there were some even of considerable reputation who either wavered between the old and new, or continued to hold the notions of their fathers, $\uparrow$ which, however, very few ventured to maintain publicly. Of these the only one who merits our particular notice is Dr Job Baster of Zurichsee in Zealand, who seems to have been rery imperfectly qualified for the task he had undertaken. At first he boldly asserted the vegetability of all zoophytes, attempted to prove that the Sertularix were really articulated Conferva, and that the little animals observed on them were merely parasites, which had as little to do with the formation of the object they rested on, as the maggots in a mushroom had to do with its moonlight growth. These the results of his actual observation were set forth in a tone of arrogance calculated to wound the fcelings and good fame of Ellis, nor is this conduct to be wondered at, for ignorance is usually as unfeeling as she is proverbially confident in her assertions, and the Dutch naturalist was truly very ignorant of all relating to the subject he attempted to elucidate. Unskilled in marine botany he actually mistook the objects of the enquiry, and instead of Sertularix set himself to examine true Conferva, -a fact which the drawings illustrative of his paper demonstrate. His further experiments made him fully aware of this ridiculous error; and having become better acquainted with his subject,

* Pulteney's General view of the Writings of Linnæus, by Dr Maton, p. 560 . Lond. 180 j.

+ Count Ginamni was one of these, and had the hardihood to question the accuracy of the observations of even Jussieu.-How far he was competent to obserre himself will be made apparent to the zoophytologist by the following extract : - Loco polyporum Bernudi de Jussieu, papillas septem glandulis consitas reperit, et mucum putat esse, quem vocant cornua : ex papillis rero pressis aqua, deinde lase puliulat, eiedemane ad corticem inscparabili nexu adhærent." - Hall. Bih. Bot. ii, 444 . 
he appears to have been puzzled what to make of zoophytes; they were certainly not sea-weeds, - and it were too humiliating to adopt a once rejected theory, - when happily the Systema Natura came to his aid, and he instantly adopted with zeal the vegeto-animal fancy, because, he says, it illustraterl in a wonderful manner other things which were previously obscure and incomprehensible, and because it was in perfect keeping with the doctrine which taught that animated beings were a series of links constituting one long chain that could not be broken without violation to the continuity of organization,-the different species being so closely connected on this side and that, that neither sense nor imagination can detect the line which separates one from the other. It must be allowed that in Baster the doctrine of Linneus has found its best adrocate. He tells us that in zoophytes there are too many signs of a perfect vegetation to permit us to believe that they can owe their origin to animalcules so minute as to require a microscope to see them, and the great simplicity of whose organization altogether unfits them for perfecting such works: and as from the law of continuity indieated above it was reasonable to presume the existence of beings in which the distinctions between animals and plants should meet and amalgamate, so by a comparison of their lefinitions it may be made obvious that these distinctions disappear in zoophytes. A plant is an organized body without sense or spontaneous motion, adhering by means of a root to some foreign substance whence it derives the material of its life and increase : an animal, on the contrary, is an organized body endowed with sensation and perception, which can, of its own free will, make certain movements peculiar to itself. Like the plant, zoophytes grow fixed by a root; and yet at the same time they are animals, for they show when touched that they feel by some motion, and when they perceive food proper for them they seize and devour it by the action of certain members.

Having in this manner commended the theory to our favour, and shown its reasonableness and consonance to nature, Baster gocs on to explain the manner in which he conceives his experiments prove that the Sertulariadie or flexible corallines grow. The ova or seeds of these zoophytes, he asserts, pullulate from the body of the mother in the likeness of tender articulations 
or new branches, which fall off on maturity, and adhere to any stone, shell, or other hard body, by which they are protected until the young are excluded. Now the outer coat of this egg or seed is of a regetable nature, and it throws out from the sides in the manner of other seeds, certain little roots by means of which it remains permanently attached; but the internal part of the egg or seed is animal, and growing simultaneously with its vegetable covering, it is clispersed through all the ramifications and occupies their hollow interior, being developed into polypes in the lateral denticles and extreme cells. Such was the deduction he came to from observations macte on the growth more especially of the Sertularia abietina, which he had kept alive for nearly four months in a vessel of sea water. When a new part was formed, there first emerged from the stem a minute tubular joint, which rose to four, five, or even eight lines in height: after some days some lesser buds, regularly disposed in an alternate manner, were seen on the sides of this branch, which in the course of four or six days grew into cells contain. ing perfect polypes. Hence it is obvious to Baster that the stem of this and similar zooplyytes grows in thickness and length as plants do, and that the medullary pith is animal, which it is not wonderful should assume a dendroidal form, when we see zinc and quicksilver do the same by the mere force of affinity. Trembley had already pronounced the cells of the fresh-water zoophytes (Plumatella) to be not the work of the polypes, but rather compartments in which they concealed a part of their body; and this fact, added to those already given, makes it certain that the animalcules of the Sertulariadæe are entirely passive, and have no more to do with their polypidoms than the Hower has with the increase and growth of the herb.*

There is some ambiguity in Baster's statement of his opinions, for it is not very obvious whether he believed the new formed branchlets to be themselves the eggs or seeds, or whether they only contained the eggs; but be this as it may, it appears scarcely doubtful that he knew nothing of the true ova and their curious ovaries. The phenomena observed in the production of new parts are correctly stated, but nothing but wilful prejudice

* Phil. Trams. Vol. lii. p. loE-118...For Baster's works sce Hall. Bib. Bot. i. 468 . 
could blind lim to the fallacy of the consequent reasoning. The analogy attempted to be drawn between the eggs of zooplytes and the seeds of plants has no existence, for every tyro knows well that the coat or skin of a seed in no instance ever pushes forth radica! fibres, or ever exhibits any sign of vegetation; -it is a dead part which is cast off or corrupts, and exerts no further infuence on vegetation than as a protection to the cotyledons and embryo which it invests, so that if it is true that the coat of the ova of zoophytes is the source of their regetative part, as Baster says, that coat must be of a very different nature from the skin of seeds. It would have been better to have compared the oviform bodies of the zoophyte with the buds of the tree, and he might have disported with this fancy to some effect, for there are many analogical resemblances, and the inapplicability of the illustration is not so very plain. Still it is inapplicable, for buds grow from the absorption of water and inorganic matter which is diffused and assimilated by means of a certain determinate organization, while the covering of zoophytes receives no increase except through the medium of its polypes;-it has no sap-ressels, no spiral tubes, no cellular parenchyma, no absorbent roots, no pores and spiracles on the surface, so that all its material must be derived from an internal source; and to say that a body vegetates when the nutriment is received and assimilated in a different manner, and by a different structure from what it is in plants, and is productive in its assimilation of opposite principles, is to use terms in so vague a sense as would be intolerable in any science.

Neither the authority of Limneus, nor the imperfect experiments of Baster, had any effect on Ellis, who steadily opposed this vegeto-animal doctrine, and whose superior knowledge made it easy for him to detect and point out the erroneousness of the observations on which it principally rested. In reference to the opinion itself he wrote to Linnæus, _ " artful people may puzzle the vulgar, and tell us that the more hairy a man is, and the longer his nails grow, he is more of a vegetable than a man who shaves his hair or cuts his nails; * that frogs bud like trees,

* Bohadsch in answer to those who believed that the Pennatulæ were plants uscs the same argument.-De Anim. Nar. p. 123. This author, who wrote in 1761 , was a strenuous advocate for the ummixed animality of zoophytes. 
when they are tadpoles; and caterpillars blossom into butterflies. These are pretty rhapsodies for a Bonnet. Though there are different manners of growth in the different parts of the same animal, which the world has long been acquainted with, why should we endeavour to confound the ideas of regetable and animal substances, in the minds of the people that we would willingly instruct in these matters?"* And in a subsequent letter he repeats, "I cannot, reconcile myself to vegetating animals : the introduction of the doctrine of this mixed kind of life will only confuse our ideas of nature. We have not proof sufficient to determine it; and I am arerse to hypotheses." +

PALLAS, who published at this period an admirable history of zoophytes, $\ddagger$ was also the adrocate of the Linnæan doctrine, but he adduced no other facts than those furnished by Baster in its aid, - setting, however, in bolder relief, the argument derived from its accordance with the hypothesis of a continuous series in the structure of organized beings, which, it was for long a point of orthodoxy to believe, formed a chain " in linked sweetness long drawn out," graduating insensibly from man to the monad, - as Bonnet maintained ; or branching off into lesser series after the manner of a tree, - a simile suggested by Pallas himself as more correctly representing the "S System of Nature." $\$$ He also adopted the opinion of Baster, who in this respect continued in opposition to Linnæus, that the true corallines (Corallina) were entirely of a vegetable nature, and his arguments on this head may be summed up as follows: In external appearance and structure a few corallines resemble some fuci, and many of them are like conferva; they differ from other zoophytes in chemical composition, for, on being burned, they emit the smell of vegetable matter, neither do they contain a volatile salt or animal oil; the pores observable in their calcareous portion are too small to be the habitations of po-

Lin. Comesp. Vol. i. p. 226.

$\uparrow$ ibid. p. 260.

$f$ "Princeps in hac classe opus."- Hall. 13ib. But. ii, 566

\$ "Didicimus in Zoophytis, sir jure vorandis, vegetabilem naturan cmu animali ita misceri, ut vere aneeps et dubia passim sit." \&e. Elenc Zoopl. Pref. vii. The Introduction to the work is healed. "De zoophytorum intermedia nutura ef inventione." llis jileas of the Natural system are given in an interesting pissige at ]3. 23-1, which is 100 long for quotation in this place. 
lypes, and similar pores can be detected on fuci; no polypes nor any visible token of life could be discovered by Jussieu in any coralline, a species of which, moreover, a Mr Meese had fount growing upon a heath in Friesland; and lastly, the fructification of corallines is very similar to that of fuci and confervae.

Were these the deductions of correct observation and experiment they would unquestionably have been conclusive, but some of them were already known to be contrary to the fact, and the others were weakened with doubts and uncertainties. Ellis, conscious of his superior knowledge both of marine botany and zoophytology, put forth an answer to this attack which is remarkable for clear arrangement, and for candid and honourable bearing to his opponent, who had scarcely deserved this at his hand. * Having shewn that the presumed coralline which Pallas had compared to a fucus or sea-weed, was in fact a fucus, Ellis proceeded to prove how widely different every coralline was in structure and texture from any confervæ; and that the former, contrary to Pallas's assertion, not only gave out when burned "an offensive smell like that of burnt bones or hair," but afforded also on careful analysis both volatile alkali and empyreumatic oil. + " Dr Pallas," Ellis continues, "proceeds to prove that corallines cannot be animals, as the pores of their calcareous substances are too minute for any polypes to harbour in. These words of the Doctor's seem to imply, as if the coralline substances were only habitations for detached polypes, and not part of the animals themselves. How this affair stands, I hope to have clearly demonstrated long before this, for I have plainly seen, and endeavoured to shew mankind, that the softer and harder parts of zoophytes are so closely connected with one

- It appears from the Lin. Corresp. Vol. i. p. 186, that Pallas had written disrespectfully of Ellis. In his Elell. Zoophytorum the latter, lowever, is profusely complimented :- " Ellisium subtilitate atque acumine observationum omnes super eminentem,"-Pref. p. x.-is praise enough surely, but its sincerity might be questionable.

+ 'This character, as Lamouroux remarks, is insufficient, seeing that the inajor part of marine plants give out, in burning, odours and products analogous to those of animals.-Cor. Flex. p. 12. It is now well known that chemistry afforrls us, in its minute analyses, no test between animal and vegetalle matter.-Sce Prout's Bridgewater Treat. p. 415, and more particularly 'Tiedemann's Comp. Phy'siolo. gy, p. 48, \&c. 
another, that they cannot separately exist, and therefore have not hesitated to call them constituent parts of the same body, and that the polype-like suckers are so many mouths belonging thereto.

"Now, for the smallness of the pores, which the Doctor has mentioned here (among the Corallines) to be a contradiction to animal life ; he certainly has forgot one circumstance, when he introduces the Corallium pumilum album, (Essay Cor. t. 27.f. c.) or his Millepora calcarea (Pall. Elench. p. 265, ) as an animal, which is, that he there says, it has absolutely no pores at all.

"As there can be no doubt, but every part of what is called Coralline is necessary to make out such an animal, or being, it will be very difficult, if not almost impossible, to determine the proportion there ought to be between softer and harder parts; and therefore it cannot be thought unreasonable to say, that in some of this tribe the stony parts are by much the greater part of the whole, especially as Doctor Pallas's objection can be only against the crust, or lapidescent part, as the inside of many of them is far from being hard, being exactly like a Sertularia, so that I do not know if it would not be a good definition to one well âcquainted with that tribe to say, a Coralline is a Sertularia, corered with a stony or calcareous crust; if the mouths should happen to be very small, their number may make up that deficiency. We see in the greatest number of corallines their surface full of holes; we saw the same in Escharas and Milleporas thirty years ago; since that time magnifying glasses have been improved, so as to shew us, that they are all orifices for polype-like suckers; why should not we now admit that glasses may be still more improved, so as even to make us able to see what may be the intention and nse of these minute orifices, which according to all rules of reasoning, we must suppose to approach in nature to them they are most alike. From this extreme minuteriess then of the pores of these Milleporæ, confessed to be zoophytes, as well as those of Corallina officinalis as before mentioned, it is no great matter of surprise, that Doctor Jussieu could not perceive any animal life in the corallines, nor Doctor Schlosser in the Millepora calcarea. As these experiments ought to be attencled with many convenient coinciding circumstances that do not often happen to persons who only go to the 
sea side, perhaps for a few days or hours, so that it is unreasonable to conclude, because they have been unsuccessful, that more accurate observers may not be more fortunate at another time."-Having thus disposed of an argument which he could not distinctly answer, Ellis goes on to notice the fact of the coralline which had been found on Bergummer heath in Friesland, and which the vagueness of the manner in which the discovery was announced permitted or warranted him to ascribe to accident; and he then concludes his admirable essay with a faithful and minute account of the fructification of the conferva, and proves to a demonstration that when Baster and Pallas attributed a similar fructification to corallines, they had very erroneous ideas of the subject.*

The discussion rested here, and zoophytes, including the sponges and corallines, have been ever since enumerated among the subjects of the animal kingdom, although some, among whom Spallanzani may be particularized, continued in the belief that the corallines and the sponges were regetables. But naturalists continue to be divided in opinion relative to the nature of acknowledged zoophytes, for many, of whom Bory de St Vincent may be considered the chief, $\uparrow$ still speak of them as intermediate beings partaking of a twofold nature; while others, under the leading of Lamarek, defend their claims to pure animality. No new docirine has been promulgated; neither indeed have the old been defended or attacked by any other facts or arguments than those already referred to, and with these before me I cannot hesitate to give my assent to the opinion of Ellis. No one denies that the polypes considered abstractedly from their polypidoms are really animals; - their quick and varied movements, - their great irri-

- Phil. Trans. Vol. lvii. p. 404, \&c.-Pallas appears to have been convinced by this cssay that the Corallines were animal; and he acknowledged that in reference to the land species he had been imposed on._Lin. Corresp. i. 227, and 568. Yet it should be remembered that Captains Vancouver and Flinders observed on the shores of New Holland, at considerable heights above the level of the sea, arborescent calcareous productions which they considered to be corals. Peron says they are either corals or vegetables incrusted with calcareous matter; and Dr Clarke Abel has proved that they are the latter._Edin. Phil. Journ. ii. 198.

† Encyclop. Method. ii, 647.-Cuvier in an early work gave countenance to this opinion, but in his Regne Animal, iii, 2:20, Paris, 18:30, it is repuliated. 
tability, - the existence of a mouth and stomach, - the nature of their food, its digestion, and the eromition of the indigestible remains are incontestible proofs of this;-and it seems improbable, to say no more, that this animal should be fitted round with a case that grew independent of it and from a difierent cause. And the case itself has no analogy, as Ellis shewed very clearly, either to bark or to wood: it possesses the structure of neither of them, nor is it formed in the same manner by the addition of concentric layers, nor does it contribute to the formation of new parts, but, like the shell of testaceous mollusca, it is extravascular, and when once formerl suffers no other change than what external injuries or time may operate. If possible its coincidences with the skin of cellular plants are even fewer: the one is a living part which has very important functions to perform in relation to the plant itself and to the atmosphere or circumfluent medium in which it lives; the other exhibits no action characteristic of life, and is nothing more than a conchensed albuminous or calcareous sheath, appropriated solely to support or protection.*

But although I agree with the advocates of the animality of zoophytes in general, I cannot go the length of Ellis in considering it proved that sponges and corallines belong to the same class. Ellis, we have seen, knew that no polypes were to be found in sponge, and their existence in the pores of corallines was inferred merely from the structure of these and their chemical composition. They have been examined by subsequent naturalists fully competent to the task, and under the most favourable circumstances, - in particular by Cavolini and Schweigger, - and the result has been a conviction that these productions are truly apolypous. Now this fact, in my opinion, determines the point, for if they are not the productions of polypes, the zoologist who retains them in his province must contend that they are individually animals, an opinion to which I cannot assent, see-

* I do not enter into the question whether the Conferva are real animals or not, because, whatever eonclusion we might adopt, they would not come within our definition of a zoophyte or polype, siuce they assuredly have neither mouth, tentacula, nor stomach. Nor need I discuss the propriety of instituting, with 'Treviranus, a fourth kinglom of animated nature, eomposed of the zoopliytes and aquatic eryptogamial, as my olject and plan is only to describe what have been almost universally considered zoophytes. 
ing that they have no animal structure or individual organs, and exhibit no one function usually supposed to be characteristic of that kingdom. Like regetables they are permanently fixed,like vegetables they are non-irritable, - their movements, like those of vegetables, are extrinsical and involuntary, - their nutriment is elaborated in no appropriated digestive sac-and like cryptogamous vegetables or alga they usually grow and ramify in forms determined by local circumstances, and if they present some peculiarities in the mode of the imbibition of their food and in their secretions, yet even in these they evince a nearer affinity to plants than to any animal whatever. 


\section{CHAPTER II.}

\section{On the Structure and Functions of the Polypes} ABSTIACTEDLY CONSIDERED.

ON the continent the term zoophyte has of late been used in a very extensive sense, so as to include every animal which exhibits a circular disposition of parts radiating from a common centre, and many also in which this character is little or not at all obvious. In this country the word has never been so employed excepting in translations from a foreign language: no English writer ever thinks of ealling an intestinal worm, or a sea-jelly, or a star-fish, or eren the infusory animalcules, a zoophyte; but he applies the name to no other creatures than those which in their form, or most remarkable eharacters, recall the appearance of a vegetable or its leading properties. In this restricted sense I also use it in this work, or rather with a still narrower circumscription, having assigned what appear to be sufficient reasons for removing the corallines and sponges from the category, and restoring them to the regetable kingdom, to which the earlier naturalists beliered they had a rightful claim. The definition of a zoophyte is thus considerably simplified, but there remains sufficient variety and discrepancy in the constituents of the order to render that definition in some degree vague and incongruous. The fact is-the classification of molluscous, and radiated, and acritous animals requires to be recast: the limits between them have not been determined with undisputed precision, and it seems probable that there are in each class some tribes which will pass from one to the other as discovery proceeds. It has been recently proposed* to remore a large pro-

\footnotetext{
* Thompson's Zoological Researches and Illustrations, p. 92.
} 
portion of zoophytes hitherto considered legitimate subjects of their order to the mollusea, which, about the year 1815, * had received a considerable accession to its numbers from the same source; but so far from acknowledging the propriety of the proposed translation, I incline to agree with Lamarckt, that it would be better to separate again the colonized zoophytes from the mollusca, and form with them, and with such zoophytes as have an analogous organization, a distinct class, to occupy the wide interval between the molluscan and radiated types, allied to the former by the non-symmetrical figure of the body, and to the latter by the circularity of the oral members. It is, however, unnecessary to enter here upon this discussion, for my intention is to describe what are usually reckoned zoophytes, without having regard to the naturalness of the group considered as a whole, and with this view I adopt the class as it was long ago established by Solander and Ellis, excepting only the corallines and sponges, which will form the subject of separate monographs. The following definition may serve to characterize the class:

Animals avertebrate, inarticulate, soft, irritable and contractile, without a vascular or separate respiratory or nervous system : mouth superior, central, circular, edentulous, surrounded by tubular or more commonly by filiform tentacula : alimentary canal variable, -nhere there is an intestine the anus opens near the mouth: asexual; gemmiparous: aquatic.-The indiriduals (Polypes) of a few families are separatc and perfect in themselves, but the greater number of zoophytes are compound beings, viz. each zoophyte consists of an indefinite number of individuals or polypes organically connected and placed in a calcareous, horny or membranous case or cells, forming, by their aggregation, corals or plant-like Polypidoms.

In this definition there are two parts which require our particular attention - the Polype whose presence is essential, and the Polypidom, $f$ which is the house or support of the polype,

* Savigny's Memoires sur les Animaux sans Vertebrès. Seconde Partic. Paris, 1816,8 ro.

† Hist. Nat. des Anim. s. Vert. iii. S2—87.

‡ I borrow this term from the translator of Lamouroux's work on Corallines. The Rer. Mr Kirby, in his Bridgewater Treatise, uses the word Polypary to express the same thing. Both of them are translations of Polypier, a word inrented by Reaumur, and now in general use among the French 1laturalists. 
and which, though commonly present, is yet not necessary to the existence of a zoophyte. To the structure and functions of the former I limit myself in this chapter; and should the reader find the outline given in relation to some of the families too slight and sketchy, I may advertise him that he will find it filled up with greater detail in the observations which it is intended to prefix to each separate order.

The description usually given of the structure and functions of polypes in general has been derived principally from an examination of the Hydra-a naked species which inhabits ponds and ditches. A polype is thus represented as being a somewhat globular or cylindrical body of small size, of a homogeneous gelatinous consistence, and very contractile, in the centre of which there is excavated a cavity for the reception and digestion of its food. The aperture to this cavity is placed on the upper disk of the body, and is encircled by one or two series of filaments or tentacula which are used to capture the necessary prey, and bring it within reach of the lips; while the opposite end serves the purpose of a sucker to fix the creature to its site, or being prolonged like a thread down the hollow sheath, to connect it with its fellow-polypes of the same polypidom, which by this means become compound animals, "the whole of whose parts are animated by onc common principle of life and growth." There are no organs of sense, no limbs appropriate to locomotion, no circulating vessels, no nerves, nor lungs, nor gills, no chylopoetick riscera, nor intestine, for there is "but one conduit both for purgation of their excrements, and reception of their sustenance;" and when to these negations there is to be added the want of generative organs, a being of simpler organization than the polype can scarcely be conceived; and, perluaps, it is actually the simplest, for the infusory animalcules which lad been placed underneath them in the scale of organization, are now known to possess a much more complex structure.

Such is the idea of a polype we obtain from the writings of Ellis, and the description of its general structure given by Lamarck, after an interval of serenty years, is identically the

* Anim. s. Vert. ii. 10. Bose, Vers, ii. 216.-Lamouroux in 1810 and 1812 had indeed asserted that the polypes with polypidoms could not, in relation to their structure, be compared with the fresh-water bydra, but that they approxi- 
same. Some few species, classed by the predecessors of the latter among zoophytes, had in the meantime been ascertained to be differently constructed, and furnished with less simplicity, but being in consequence removed into a different eategory, they were not allowed to disturb the received opinions on polype anatomy. Still more recent discoveries have shewn, however, that these are very erroneous, and that the animals of even our native polypidoms form at least two classes distinguished by a very remarkable dissimilarity of organization. By the one they are allied to the tunicated and acephalons mollusca, more especially to the compound families of the former, and hence may be denominated Ascidian polypes; by the other they form a link of the chain or circle which associates the radiated animals, and, assuming the hydra for their representative, we shall call them Hydraform polypes.

'The ascidian polypes never occur in a separate and naked form, but are always placed within the cells of a polypidom of a calcareous, membranous, or tibro-gelatinous consistence. 'The form of the cells in many genera, as Eschara, Flustra and Cellepora, suggests a belief that their tenants, although arranged in a close and determinate manner, are each separate from thei: neighbours ant complete in themselves,-an opinion that is held by some of our best naturalists; but the observations of Dujardin on some allied fossil polypidoms, render it very probable that there are pores of communication between the cells; while those made by Professor Grant seem to have proved that the polypes of the Flustra are connected together by a living axis, and are hence truly compound beings. Since the Vesiculifera also, which are admitted to be composites, belong unquestionably to this remarkable form of animated entities, it is safer,

mated nearer than was believer to the mollusca, of which they might at some future time be considered a family. The opinion certainly rested on few and hasty observations, and no anatomical details were given in its support. See his Edit. of Soland. Zoophyt. pref. p. vii. For example, he not only recognizes a relationship between Lobularia and Actinia, but he tells us that the polypes of the Flustrie, Cellarice and Sertulariæe are similar to those of Lobularia! Coral. Flex. p. 332. Such loose observations as these are, lhave no influence on the progress of discovery. The observations of Savigny were evidently more specific and correct; but I am not aware that the details have been yet pullisher.

- See his Mem. sur les Anim. s. Vert. ii. p. 65.

* Blainville's Actinologie, p. 675. 
for the present, to consider all the ascidian as compound polypes.* 'There is nevertheless a remarkable difference between them and the hydraform tribes in their mode of composition. In the latter the polypes are simply developements of the common central theshy mass, identical with it in structure and texture; in the former each individual is a distinct organism, and the inedium which binds them together, whether rascular or ligamentou, has its own peculiar character. The one we may compare to a chain of which all the links are welded, - the other to a necklace where the beads are strumg together by a percurrent thread. To express this distinction we shall call the hydraform compound polypes, and the ascidian aggregated polypes.

The body of the ascidian polypes is lengthened, somewhat cylindrical or at times bulgerl at the base, and when at rest lies, in the form of a syphon, doubled up upon itFig. 2. self in the cell, (Fig. 2, †) to which it is connected by a tendon at the bottom, and by the duplicature of a thin membrane round the aperture, so that it is impossible it should ever voluntarily leave the cell to swim at large, as Baster and others have maintained. 'The head or upper end is surrounded by a single row of tentacula, (Fig. 3, a, ) which are solid, filiform and non-contractile, for the animal can only shorten them, excepting to a slight extent, by rolling them up in a spiral

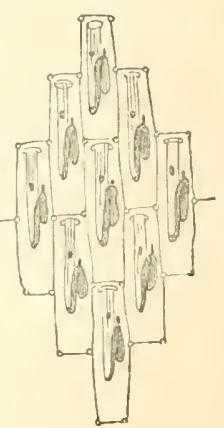
manner: they are apparently smooth, but with a ligh magnifier it is ascertained that they are clothed with numerous fine cilia, + which are in ceaseless motion, and are supposed

* "The polypi are most intimately and inseparably conrected witl the axis by three parts of their hody, and are only digestive sacs or mouths developed by the axis, as in all other zoophytes, for the nourishment of the general mass. By the axis of a zoophyte, 1 understand every part of the body excepting the polypi, whether of a calcarcous, homy, or flesy nature. The exact mathematical arrangement and forms of the cells of Flustre is incompatible with their existence as separate and independent beings, but is quite analogous to what we are accustomed to obserse in Cellarix, Sertularix, Plumularia, and many other wellknown compound animaln."-Grant in Ldin. New lhil. Jonm. iii. 116. See also Bhaimville, Man. d'Actinologie, 1. 99.

t The figure, for which $I$ atm indeited to my friend Mr William Scott, represents the polypes of Flustra membranarea in a state of retraction.

For a history of this discovery, written with greut learning and impartiality, 
to perform the office of breathing organs by keeping up a constant current of water along their surfices, which sets in towards the mouth in an invaliable dircction; Fiig. 3. and from the incessunt revolution of particles within the mouth and the gullet, observed by Professor Grant, this organ seems to be also ciliated internally. The more especial use of the tentacula is to arrest the prey which chance floats within their reach and conduct it to the mouth, - a simple aperture placed in the centre of the tentacular circle, and which is armless, having in no instance either jaws or teeth. It is the entrance into a long membranous gullet $(b$,$) of jerfect transparency, and$

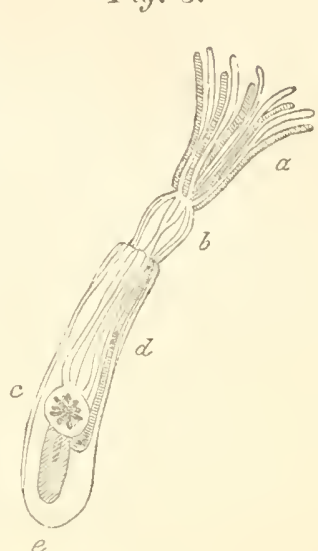
which can be traced through its equally transparent envelope, to its termination in a somewhat globular and comparatively large organ placed near the curvature of the bods, and rendereul opaque partly by the greater thickuess and fleshiness of its structure, but perhaps more so by the nature of its contents. This is the stomach $(c$,$) and from the side of it there proceeds$ a narrow intestine $(d$,$) which follows a straight upward course$ along the side of the gullet, and opens at the aperture of the cell by a separate orifice, from which the undigested remains of the food are ejected. There is another organ of a roundisi figure appended to the bend of the intestine, which is supposed by some to be an ovarium $\left(e_{2}\right)$ but it seems not unnecessary to remark, that this appropriation of it to the generative function has perhaps no better proof than what is derived from a similarity of position between it and the supposed ovarium of the compound mollusca. It is, I presune, the organ which Blainville says he is willing to believe performs the functions of the liver, * an opinion in which I am disposed to concur.

see Dr Sharpey's article "Cilia" in the Cyclopædia of Anatomy and Physiology, Vol. i. p. 609.

- Manuel d'Actinologie, p. 22 .- In the Actinix, Blainville adds, it is almost eertain that there is no Liver; nor in the Hydraform polypes; but in the Pennatulæ " disséqués vivans ou très-frais, ou remarque, daus les parois memes du corps de l'estomac, des rangée's d'organes en forme de petites taclıc: jaumâtres. 
No trace of a nervous or vascular system of any kind has been detected, nor is there any organ of sense, but the polypes are notwithstanding very sensible of exterual impressions. * When left undisturbed in a glass of fresh sea water, they push their tentacula beyond the mouth of the cell by straightening the bo$\mathrm{dy}$; and then expanding them in the form of a funnel or bell, they will often remain quiet and apparently immoveable for a long time, presenting a very pretty and most interesting object to an observer of "the ninims of nature." If, however, the water is agitated they withdraw on the instant, probably by the aid of the posterior ligament or muscle ; - the hincler part of the body is pushed aside up the cell, the whole is sunk deeper, and by this means the tentacula, gathered into a close column, are brought within the cell, the aperture of which is shut by the same series of actions. The polypes of the same polypidom often protrude their thousand heads at the same time, or in quick but irregular succession, and retire simultaneously or nearly so, but at other times I have often witnessed a few only to venture on the display of their glories, the rest remaining concealed; and if, when many are expanded, one is singled out and touched with a sharp instrument, it alone feels the injury and retires, with. out any others being conscious of the danger, or of the hurt inflicted on their mate.

Of the anatomy of the hydraform polypes a sketch has already been given in the beginning of this chapter. They differ from the ascidian in their figure, which is somewhat globular or cylindrical and straight; in the position of the body, which is vertical; in the homogeneity of their composition, which is a semitransparent glairy gelatine, full of microscopic coloured granules; $\dagger$ and very remarkably, in being contractile at every

que je regarde comme analognes au foie."-Fig. 2 represents the polype of Vesicularia imbricata highly magnified. It is copied from Thompson's Zool. 111. Memoir v. pl. i. fig. 4.

* "But as we pereeive, in these animals, phenomeua which take place by the medium of nerves in animals of a more elevated order, that is to say, sensi. bility and voluntary motion, it is not inprobable that in them the nerrous substance is mixed with their gelatinous or mucous mass, without being demonstrable as a particular tissue."-Tiedemann's Comp. Plips. p. 61.

+ Trembley having ascertained that the colour of the polype resides in these gramules, and that it varies will the quality of their food, of which the mutritive part or chyme passes first into the grantules of the stomachal cavity and then 
point, so that they can change the figure of their bodies from a globe to a cylinder, or clistort it with strictures, and can shorten and extend the tentacula at will, sometimes to an extent which is astonishing, although nothing like muscular tissue can be detected in their structure. ${ }^{*}$ When therefore they have occasion to conceal themsclves within their cells, they are not necessitated, like the ascidian, to bend the body in order to obtain sufficient space for the tentacula, but they shorten the body and the tentacula at the same time, eausing the one to assume a more globular form, and the oflier to dwindle down to mere knobs or Fïg. 4.

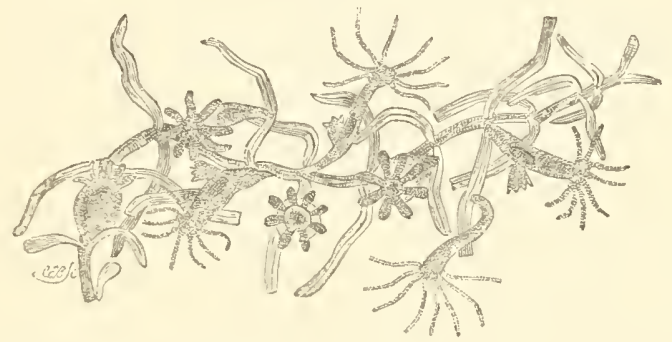

papillae (Fig. 4.) + The tentacula, even when fully extended,

gradually into those placed more towards the surface, infers that they are a kind of glands or ratber vesicles, which have the power of sucking in and again transpiring the nutritive fluid.- Hist. des Polypes, p. 132. Lamarck adopts this opinion, Anim. s. Vert. ii. 9, which is probably correct, but it ought to be remembered that it is somewhat hypothetical. Consult in relation to this subject Roget's Bridgewater Treatise, Vol. ii. p. 77-8, Carus's Comp. Anat. Eng. Trans. Tol. i. p. 2.5, §. 23 ; and the reader will find Edwards' and Dutrochet's opinions on the nature of the elementary corpuscles in Bostock's Elementary System of Physiology, Vol. iii. p. 348 et seq. Tiedemann sums up our aciual knowledge in the following sentence.- " In animals of a simple structure, polypi, entozoa, and some others, in which no vascular system for the morement of the humours has litherto been discovered, the nutritions assimilated liquid passes directly into the parenchyma of the body, with which it enters into combination."--Comp. Physiology, p. 35.

* Trembley, Mem. pour l'hist. des Polypes, p. 25. Carus' Comp. Anat. i. p. 43. -Mr Lister, however, says that "in the substance of the necks of the polypi (of Sertularia pumila,) transverse lines were visible, bearing a resemblance to those characteristic of voluntary muscles in the higher animals;" but we may doubt whether they are truly muscular, for this accurate observer shortly after acknowledyes, that "nothing like muscular contraction was seen in the pulp of this (Plumularia setacea,) or any other species."-l'lil. Trans. 1334, pp. $371-372.2$.

$\dagger$ The figures represent Hydra viridis in rarious attitudes and states. 
have not the same appearance, - they taper a little, and are ronghened with minute warts generally arranged in an imperfeetly verticiliate fulion; and in their evolution they are less regularly campanulate, one or more being usually in action and moring from the outline of the circle. The stomach is not a di-tinct salc, but a simple carity towards the centre of the body, "neither figured nor limited by particular membranes," and from which the indigestible remains of the food are ejected at the same aperture by which it had entered, for the aperture in the base of the stomach or inte-tine seems to be appropriated to other offices. And in reference to its relation with the polypidom there is this difference, the hydraform polype is not connected with the cell by any membrane or ligament, but rather sits free within its miniature cup, retained there only by the gelatinous living pedicle which is prolonged from its base down the sheath, and binds all the polypes of the polypidom in one sympathizing fumily.

But this description is applicable only to the Hydra itself, and to those compound species which tenant the cups of the plant-like polypidoms embraced in the order Zoophyta hydroida. The polypes of the Asteroid zoophytes, although evidently modelled on the same type, have made considerable advances towards complexity of organization, and their relation to the polypidom is entirely altered. Hitherto the polypidom has been, what its name imports, a cell for retreat in danger, and in ordinary an extravascular insensible sheath to protect the contained animal from the rude contact of the circumfluent element; but now we find it occupving an internal position, and instead of a covering it has become a sort of prop or skeleton to a fleshy crust in which the polypes are immersed. In the Alcyonium this interior support is scarcely to be recognized in some calcareous spicula seattered through the central mass, but in Pennatula it forms a bone stretched like a vertebral column from one extremity to the other, and in Gorgonia it is ramified into branches after the manner of a tree. It is this axis, under whatever shape it appears, which is the true analogne of the polypidom of the ascidian and hydraform polypes, although the name certainly has nosuitableness here, for the polypes not only cannot nestle in that which is uncellular, but they have no immediate 
connection with it. 'They, as already mentioned, are found lodged in a sort of cell (Fig. 5. a.) excavated in a sareoid crust, which constitutes the main bulk of the polypiferous mass, and which, in fact, is nothing more than a modification of the bases and outer skin of the polypes hardened by a deposition of calcareous granules and spicula, and made more coriaceous in texture, to bear with impunity"the contact and ruffling of

Fig. 5.

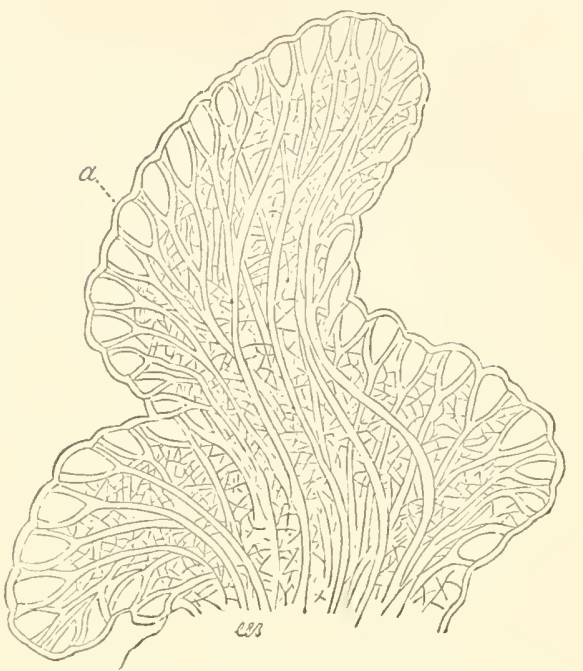
the water.* This crust is accordingly a living irritable structure, permeated by tubes prolonged from the polypes and by capillary canals, for the conveyance of water and nutriment to every part.

The connection between the crust and the polypes is therefore of the most intimate kind, and if for conveniency the latter arc separately described, the reader should erer remember, that this separation is a forced and artificial one. An asteroid polype mass is known by the orifices of the cells forming on the surface a mark more or less resembling a star, as commonly represented in maps-bence the name of the order: when the polype is

* "Lorsqu'on observe les Alcyons dans leur état naturel, la ligne de démarcation entre ces deux parties parâit bien tranch ée, et on pourait au premier abord, croire ces petits animaux logés dans des cellules au pourtour de l'ourerture desquelles ils athereraient; mais quand on elève à l'aide d'um acide étendu d'eau, le dépôt calcaiıe dont la lase du polype est environée, on voit qu'il y a entre ces parties continuite organique, et que la cellule polypifere n'est autre chose que la portion inferieure du corps du polype qui, en se contractant, rentre e luimême, comme nous l'avons deji v'u pour les Alcyonides. Le polypier commun n'est en effet autre chose quie la résultat de l'aggrégation intime de la portion basilaire des polypes." Miluc-Edwards in Ann. des Sc. Nit. iv. 336. an 1835. The student may compare this with Lamonroux's description of the Gorgonid. Corallina, p. 198. 
protruded from this cell the body has a cylindrical figure, its upper disk surrounded by eight short pectinated hollow tentacula, in the centre of which the mouth is situated, leading into a distinct stomach, which is as it were suspended in the centre, and sustained there by eight thin membranous septa, which, stretched between the outer surface of the stomach and the inner surface of the external tunic, divide the intervening space into eight equal compartments. The base of the stomach is perforated like the mouth, and from the margin of the aperture depend eight white tortuous filaments, which hang, either loose or connected to a continuation of the membranous septa, in a wide abdominal carity, immediately underneath the stomach. This cavity is again continuous with a tube which penetrates the common mass, communicating freely by anastomoses with the tubes of other polypes, and with a fine net-work of capillary vessels, formed in the spaces between them, by means of small apertures in their walls. (Fig. 5.**) In this manner there is effected a very free communication between the individuals of each common mass, so much so, that the water swallowed by any one polype of it rapidly permeates the whole. + By tracing the course of the fluid we may obtain a clearer view of the organization. The water then enters the mouth, and passes through the cylindrical gullet and stomach into the abdominal cavity; thence part of it, flowing through the canals formed by the septa stretched between the stomach and outer tunic, passes into the tentacula with whose cavity the canals are continuons, and by means of small apertures in the sides of the lollow tentacula, the water penetrates and unfolds the cilia, with which these tentacula are fringed. By the distension from the water thus introduced, the body of the polype and its tentacula are forced beyond the surface, and every organ fully displayed. Another portion of the water in the abdominal cavity passes into the tube continuous with it, fills it and the others in connection with it, and by neans of holes in their parietes finds access into the intermediate capillary net-work, so that the whole mass is permeated with the fluid, and all and every

* A longitudinal section of Alcyonium digitatum.

$\uparrow$ MiInc-Edward has proved this by a decisive experiment.-Ann. des Se. Nat. iv. 328, and :3:39, an. IS3.). 
portion distended to a bulk which may be more than double of that which it had previous to the introduction of the fluid, and which it resumes when, from the application of irritants, the polypes contract themselves, and by their contractions force out all the imbibed water.-The tortuous filaments suspended from the base of the stomach have been generally taken for ovaries, but the observations of Dr Grant and M. Elwards seem to have disproved this opinion. The latter of these eninent naturalists belieres them to be analogous to the biliary canals of insects. *

The affinity in structure between the asteroid zoophytes and those which we name helianthoid, from their resemblance to some compound flowers, is erident, although in the latter there is a still further recession from the simplicity of polype anatony. We find in them a mucous coat covering the surface,-beneath it a layer of transverse submuscular fibres, while the body is supported by numerous strong cartilaginous lamella arranged in longitudinal parallelism. Each of the lamellæ is attached inferiorly to the circular layer which constitutes the base of the animal, and divides into three fascicles, - one which goes to the stomach and to the rim of the oral aperture, -another to the roots of the tentacula, - and the third is prolonged to the outer labial border, where it is bent back to form its free margin. $†$ The stomach has its distinet and proper parietes; there are special organs for the developement of the reproductive gemmæ; and even some traces, as is asserted, of a nervous system; while the numerous tentacula are perforated like canals, in order that the water of respiration may be introduced into the interior, and the nutritive fluids more thoroughly influenced by its oxygen.

It has been mentioned already that there is no proper eirculation-no movement of a fluid analogous to blood in appropriate ressels-in any zoophyte, but in many of the hydroida it has been discovered that there is a continuous and uniform current of a fluid, containing granular bodies which have themselves a rotatory motion, within the tubular portions of the horny polypidom. Cavolini first detected this sort of circulation, which

* Am. des Sc. Nat. iv. 331 ; an. 1835.

+ Blainville, Man. d'Artinologie, p. 68 . 
is very similar to what has been observed in the Chara and other plauss. in the Sertularia; and recently Mr Lister has confirmed this discovery, and ascertained the existence of the same phenomenon in almost all the genera of the order. 'I he result of his curious obserrations is thus summed up by Dr Roget. "In a specimen of the Tubularia indivisa, when magnified one hundred times, a current of paticles was seen within the tubular stem of the polype, strikingly resembling, in the steadiness and continuity of its stream, the vegetable circulation in the Chara. Its general course was parallel to the slightly spiral lines of irregular spots on the surface of the tube, ascending on the one sicle, and clescending on the other; each of the opposite currents occupsing one-half of the circumference of the cylindric cavity. At the knots, or contracted parts of the tube, slight eddies were noticed in the currents; and at each end of the tube the particles were seen to turn round, and pass over to the other side. In various species of Sertularix, the stream does not flow in the same constant direction; but, after a time, its velocity is retarded, and it then either stops, or exhibits irregular eldies, previous to its return in an opposite course; and so on alternately, like the ebb and flow of the tide. If the currents be designedly obstructed in any part of the stem, those in the branches go on without intermption, and independently of the rest. The most remarkable circumstance attending these streams of fluid is, that they appear to traverse the cavity of the stomach itself, flowing from the axis of the stem into that organ, and returning into the stem, without any visible cause determining these movements." *

The power which sets in motion and maintains this current is yet undiscovered. Professor Grant asserts that it depends on the action of minute vibratile cilia, - "the conmon agents of all analogous movements in the lowest tribe of animals," + but no direct observation has confirmed this explanation, which, it will be observed, is founded on analogy only, and it has this in opposition - that the non-existence of cilia in the external organs of the zoophytes in question has been distinctly proved.

* Bridgew. Treat. Vol. ii. p. 233. Sce also Tiedemanu's Coinp. Plysiol. p. 150, Ent. Nag. Vol. iii. p. 174: and Grant's Outlines of Comp. Anat. p. $4: 39-30$.

$\dagger$ ()ublines of Comp. Muat. [3. 4:30. 
As to the purpose of the circulation in the animal's economy, it appears, from the experiments of Mr Lister, "to be the great agent in alsoreption, and to perform a proninent part in the obscure processes of growth; and its flow into the stomach of the polypi seems to incicate that in the very simple structure of this family it acts also as a solvent of the food.-The particles carriel by it," continues Mr Lister, "present an analogy to those of the blood in the higher animals on one side, and of the sap of regetables on the other. Some of them appear to be derived from the digested food, and others from the melting down of parts absorbed; but it wonld be highly interesting to ascertain distinctly how they are produced, and what is the office they perform, as well as the true character of their remarkable activity and seeming'y spontaneous motions; for the hypothesis of their individual vitality is too startling to be adopted without good eridence."**

This sort of circulation is not to be confounded with those aqueous currents which flow over the surfaces of the external organs of the ascidian polypes. $†$ - It has been already stated

* phil. Trans. 1834, p. 377.

+ Dr Grant repeatedly asserts that the tentacula of the hydraform polypes are also ciliated, and I woukl not have dared to controvert this statement, although my own observations had long ago satisfied ne of its incorrectness, had it not been at variance with the observations of others who have especially directed their attention to the subject. Raspail states that lie was not able to discover anything antogous to cilia on the tentacula of the Hydra, (Org. Chem. p. 293;) and Dr Sharpey says, that in the form of polype " which exists in most true species of Sertularia, Campanularia, and Plumularia, and in allied genera, the tentacula or arms are destitute of cilia, and incapable of giving an impulsion to the water."-Cyclopedia of Auat, and Physiology, Vol. i. p. 611. The observations of Mr Lister are equally decisive. Phil. Trans. 18.34, p. 377.

lianpail maintains that there are really 110 cilia, but that the appearance of them is occasioned by currents of fluid aspired or drawn to and within the body, and expired or driven from it, and these currents are said to be produced by the difference of temperature between the fluid in the botly and exterior to it. "A happy conjecture led me to consider these vibratory cilia as being merely streams of a substance either inspired or expired, but at any rate of a different density, and consequently of a different refractive power from the surrounding medium." P. 293._" The cilia of a respiratory organ are, then, the effect of a difference of density between the water expired, and that in which the ani. mal swius. Now there is no difficulty in admitting that, since caloric is disengaged in the respiration of animals of a superior order, it may also be disengaged, although, if we may so speak, in a microscopic proportion, during the act of 
that innumerable cilia or miniature lamella clothe the surfaces of their tentacula, and by their rapid vibrations drive a constant equable stream of water along one side, which returns along the other in an opposite direction : and by this means the purposes of respiration are effected, and the nutrient fluid fitted for assimilation with the body. The cilia, to adopt the language of Professor Girant, "are disposed and mored in such a manner as that the streams which they produce in the surrounding water are driven along the one side of the tentaculum from the mouth of the polypus, and on the other side of the tentaculum always towards the mouth of the polypus. And we never find that direction of their motion reversed, or that direction of the currents changed, by which their respiration is effected and their food obtained. They are vibratile on the arms of most of the lower zoophytes, as sertulariæe, plumulariæe, serialaria, cellariæ, flustræ, alcyonia, which keep their arms stiflly out in a regular campanulate form, while the currents flow to their mouth. When we watch the sides of the tentacula of these animals with attention, and by the aid of powerful glasses, we see the extreme rapidity of the movements, and the remarkable regularity of the form, disposition, and motions, of those singular vibratile bodies. From the number of them, exceeding sometimes 400,000,000 in a single animal, it is not probable that their extraorlinary movements are the result of any spontancous efforts of the animal, or are accompanied with any kind of perception or consciousness in these animals, which have never been found to present a single nerve in their bodies. The independent nature of the motion of those minute respiratory organs is observed when we cut off the tentacula altogether; and observe, that

expiration in the Infusoria and the Molluscre. The difference, then, between the density of the water expired and that of the surrounding water, proceeds from a difference of temperature." P. 297.-Raspail has defended this explanation of the phenomena at great length in the Mem. ole la Soc. d'Hist. Nat. de Paris, Tome iv. p. 131-142.-Dr Mnyer also denies the existence of cilia, and concludes that the motion is produced by a peculiar substance named by him " vibratory matter," which adheres to the surfaces on which the phenomenon show itself. Brit. and Foreign Med. Rev. Vol. iii. p. 467. The explanation of Raspant, and the foolish hypothesis of Mayer, are completely disproved by the observations of Professor Graut on the Beroe; (Trans. Zool. Soc. $i$. 1. 11.) and of Dr Sharpey on numerous animals. E Edin. New Phil. Journ. July: 183.5. 
they still continue the rapid vibration of their cilia; and though severed from the polypus, the tentacula continue to more forward through the water; the serered tentaculum of a flustra is seen to swim through the water like a worm. The number of those organs varies much; they are eight in Serialaria lendigera, and in Plumularia falcata, fourteen in Cellaria avicularia, twenty. two in Flustra carbasea. The effect of those motions of the cilia again is obviously to change the stratum of water constantly in contact with the most delicate fleshy parts of those zoophytes, with the highly organized soft irritable fleshy polypi. 'Thus they aerate the cellular texture of their body, at the same time that they bring the animalcules - their ordinary food-within the grasp of the tentacula." *

All polypes-ascidian and hydraform-subsist on animal matter, feeding upon it either in a living state, or dissolved and suspended in the circumfluent medium. 'The Hydræ and smaller species seize on worms and animalcules brought accidentally within reach, or carried into the vortex formed by the play of the tentacular cilia : $\nmid$ the larger kinds (Helianthoida) swallow small crabs and shelled mollusca, rejecting the shells after having sucked out the soft contents. The food, in the Hydroida, is dissolved and necessarily made chylous in the stomach, and directly absorbed from it; but in the ascidian it is probable that the process of chylification is not completed until the food has passed into the intestine. In the higher animals the chyle is mixed with the blood and exposed to the influence of atmospherical air before it is fitted for assimilation and growth; and though bloodless, this air is no less necessary to the growth and existence of polypes, which soon languish and die in vessels of un-

* Lect. Comp. Auat. in the Lancet, 1834, Vol. ii. p. 959._- "All the cilia appear to commence and to cease their motions at the same moment. The constancy with which they continue would seem to exclude the possibility of their being the result of volition; and they are, therefore, more probably determined by some unknown physical cause, dependent, however, on the life of the animal.' Roget, Bridgew. Treat. i. 173.

$\dagger$ " Il seroi: cependant possible de croire que ces animanx pourroient aussi bien se nourrir d'animalcules que les Hydres; mais Cavolini dit positivement que, quoiqu’il ait souvent observé des polypes de gorgones, de millépores dans des eaux remplies d'animalcules, il ne les a jamais vus essayer ì en saisir avec leur tentacules." Blainville, Man. d'Aptinol. p. 97. Rasyail nevertheless proves that they feed on them.-Mem. Soc. Hist. Nat. iv. p. 88 . 
renewed water. Hence the current within the tubes of some polypidoms which has been noticed: it is the morement of the nutrient fluirl which has found its way from the alimentary sac to the surface of the body, where it is subjected to that agent which alone can fit it for the purposes of life.

Among'st zoophytes there is no distinction of sexes, but every individual appears to be capable of producing reprociuctive buds or gemmules, or even eggs.* For the production of these, there is, in the opinion of some good observers, a peculiar organ or ovarium in all the ascidian tribes, and it is certain that their eggs are al. ways generated within the polype cell. There are appropriate productive organs also in the Helianthoida and Asteroida, in the former situated between the ligamentons clissepiments which radiate from the mouth to the base, between the stomach and the skin; and in some of the latter attached to the membranous dissepiments in the abdominal cavity, while in others the gemmules appear to sprout from every part of the abdominal carity, and of the tube continuons with it. On the contrary, there is no local generative organ in any Hydroida-all are "full of reproductive life :" in the Hydra germs, similar in all respects to the substance of the body, sprout indiscriminately from every part of the surface; in the Tubulariadre they pullulate from underneath the tentacula where they may frequently be observed in clusters, and, in both of these famllies, the gems are naked or uncovered. But in the extensive family which embraces the Sertularia and all its subgenera, the gemmules, attached in general to a central placenta, (which is but a continu-

* "These corpuscles differ from true ova and seeds, which are ripened by fecundation, inasmuch as the substance of which the new being is formed is not, as ova and seeds are, enclosed in a special envelope, which is separated from them at the moment of the developement of the germ, and inasmuch as the formation of the new individual is owing to the entire substance of the reproductive corpuscle."-Tiedemamn's Comp. Phy. 42._" ln the present slate of our knowledge, however," as Dr Allen Thomson well remarks, "the distinetion between an ovmm and a sporule (or genmule) must be admitted to be somewhat arbitrary."-Cyclop. of Aliat. and Phys. ii. 434.

In reference to the asexual character of Zonphytes it seems proper to mention in this note, that Spix and M. Delle Cluaje consider the Artinia to be bisexous or hermapluroditical, (BBlainv. Actinol. p. 79) ; and Raspail las liuted that a similar doubleness may be the property of the Alcyonella._-Mem. sup. cit. p. 112. Nothing has yet heen advanced to give these opinions a probable aspect. 
ation of the fleshy central part of the stem, are enclosed in vesicles of the same texture als the polypitom itself, and neither proceed from, nor have any immediate connection with, the proper hody of the polype, being evolutions from the pith or fleshy axis which connects the polypes together, and binds the various heads into one whole.-Snch is a brief summary of the farcts ascertained on this head, but it behoves me to mention that it is, to a certain extent, at variance with the opinions of Professor Grant. He maintains from his numerous observations on a great variety of zoophytes, that the gemmules by which these animals propagate are highly organized portions of the gelatinous substance of the parent, formed " in almost every known zoophyte," and not merely in the Hydrazoa, as we have limited it, "by the common comnecting substance of the animal, and not by the polypi, which appear to be only the mouths or organs of digention. In Plumularix, Sertularix, Campanularia, horny Cellarie, Antemnularie, the ova are formed in vesicles which originate from the centre of the stem. In Flustra, calcareous Cellariae, and some others, the ora are formed in the cells, but exterior to the bodies of the polypi, which disappear before the ova arrive at maturity. In the Lobularix, Gorgoniæ, Spongiae, Clione, \&c. the ora are formed and matured in the common fleshy substance of the body before they advance to be discharged through the polypi, or the fecal orifices." *

The gemmules exhibit considerable variety in colour, - they are milk-white, yellow, red, pink or green, but sometimes the colour is not fully developed until near maturity. In all the ascidian polypes they are globular or have a tendency to that form, and appear to preserve it until after their discharge from the body; but in the Hydroida this is not the case, for although spherical in their earlier stages, "their shape alters on approaching maturity; it elongates, becomes elliptical, next prismatic, and at length each corpusculum issues as a perfect animal from the orifice of the resicle," and exhibits in figure and in motion much resemblance to the little leech-like Planarix. (Fig. 6.†)

* Edin. Journ. of Scienre, No. 14.

+ The figures represent the gemmules of Plumularia pluma. For the drawing 1 am indebted to my friend Dr Coldstream of Leith. 
The gemmules are all clothed with vibratile Fig. 6. cilia similar to those of the tentacula of the parents. Sometime previous to their discharge from the polypidom they are observed to be in a constant rotatory motion, by
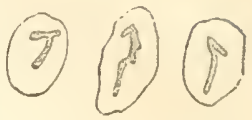
which their birth seems to be facilitated; and now at liberty in the water they move and swim about as if they were guided by volition and sense, whirling at the same time on their own axis.* This freedom to move whither they list may continue for several hours, or even for two or three days, before a proper site for their permanent stay and future growth is found, when they begin to shoot up rapidly into those beautiful forms particular to each species, as the Supreme Being has ordered and determined. The transformation of the ova, says Di Grant, "from their moving, irritable, and free condition of animalcules, to that of fixed and almost inert zoophytes, exhibits a new metamorphosis in the animal kingdom, not less remarkible than that of many reptiles from their first aquatic condition, or that of insects from their larva state." One purpose of this mobility in the ova is obvious; - it is a means ordained for their diffusion, for the parents being fixed immoveably to one spot, the reproductive germs would have dropt and sprung up at their roots, had they not, by some such mechanism as we have described, been carried to a distance, and spread over the bosom of the deep.

The evolution of the gemmules, subsequent to their fixation, has been minutely traced by Professor Grant and Sir J. G. Dalyell. When the bud falls from the crested head of Tubularia indivisa, slight prominences, enlarged at the tips, pullulate from the under surface, and the " nascent animal" elevating itself on these rudiments of the tentacula, as on so many feet, enjoys the faculty of locomotion. "Apparently selecting a site, it reverses

* In reference to those of Flustra carbasea-and the observation appears to be very generally applieable-Dr Grant snys_c they are very irritable, and are frequently observed to contract the cireular margin of their broad extrenity, and to stop suddenly in their course when swimming; they swim with a gentle glid. ing motion, often appear stationary, revolving rapidly round their long axis, with their broad end uppermost, and they bound straight forward, or in eircles, without any other apparent chject, than to keep themselves afloat till they find themselves in a farourable situation for fixing and assuming the perfect state."- Edin. New Phil. Journ. iii. 117. 
itself to the natural position with the tentacula upwards, and is then rooted permanently by a prominenee, which is the incipient stalk, originating from the under part of the head. Gradual elongation of the stalk, afterwards continues to mase the head, and the formation of the zoophyte is perfected."*-So the worm-like embryo of the vesiculiferous Hydroida, a few days after its exclusion from the vesicle, becomes stationary and contracts into a circular or spherical spot which always retains its original colour. It is transparent and soft, but in a short time some opaque fleshy spots are visible within it, and are separated by a thin homogeneous transparent substance, which is to form the future polypidom. "As yet it is exceedingly minute, soft, and gelatinous; but in the progress of its growth, the soft, thin, homogeneous substance of the exterior becomes more dense, embracing the first formed parts of the fleshy substance, indeed all parts, and the whole jelly, with its thin covering, and continues to advance and to radiate. Then we observe a stem beginning to rise from the centre of these radii of roots, which are, in fact, the first formed parts that the little round gemmule shoots out. So that the gemmule is become, not a polypus but a ront. It begins then to rise from the centre of the roots, and at length to divide; so it will at length form on its branches a cell, at the bottom of which cell will gradually be developed a polypus." + In the Flustra and other ascidian zoophytes the process is very similar, but in these, instead of the rootlets and little embryo stalk, a cell is the part first formed, in which a polype quickly and almost coetaneously developes itself; and this original cell and polypus is as large, as perfect, as fit for every purpose to which it is destined as any of those which are in rapid succession evolved from its sides and apex, for age adds only to the number of individuals in the polypidom, and nothing to their perfection.

* Dalyell in Edin. New Phil. Journ, xrii. 412.

+ Grant, in the Lancet, 1854, Vol. i. p. 229.

\section{Additional Notes.}

\section{Raspail', Description of the Structure of Polypes.}

"I have pointed out that the polypus is nothing but the continuation of its case, which becomes bony or cartilaginous in the lower part, in proportion as the upper part is developed. Consequently its tube, or rather its involucrum, 
instead of being a shapeless transudation from its body, is formed by successive additions of epidermoid membranes applied over each other in proportion as they are successively ossified. I have pointed out also that these polypi are merely microscopic fixed Cephalopodes, having, like the large species of this genus, a bag whicb is contained within the tube, an excrementitial funnel, ovaries, an intestinal canal with similar curvatures, and a head with all its aecessories equally corresponding; so that, if the Sepia, for example, instead of having the dorsal part of its large bag ossified, had undergone the same change over the whole external circumference of this organ, and if its base had been fastened by an adhesive substance to a rock, it woukd have been exactly a gigantic polypus." - New System of Org. Chem. p. 281-2._Obs. The species on which Raspail made these curious observations are not mentioned in the work from which the extract is taken: they are applicable only to the ascidian polypes, and were indeed derived from the Alcyonella stagnorum, as we learn from his Memoir on this species in the fourth vol. of "Mém. Soc. Hist. Nat. de Paris."

\section{Dr Grant's Account of the Ora of the Flustro.}

"Although the ova of Flustræ have been often observed, no onc appears to have hitherto examined either their mode of formation within the cells, or their mode of developement after expulsion, so as to determine the real nature of these globular bodies, and the erroneous conjectures of naturalists respecting them have greatly perplexed the history of this genus. The ova of the $F$. carbasea make their first appearance as a small yellow point, a little below the aperture of the cell, and behind the body of the polypus; they are unconnected with the polypus, and appear to be produced by the posterior wall of the cell, in the same manner as the axis, or common connecting substance of the polypi, produces then in other zoophytes. In this rudimentary state, they are found in the same cells with the healthy polypi, but, before they arrive at maturity, the polypi of such cclls perish, anl disappear, leaving the entire cavity for the developement of the ovum. There is never more than one orum in a cell, and it occupies about a third of the cavity, when full grown and ready to escape. When first visible, it has a round or slightly oblong and regular form; when mature, it is ovate with the small end next the aperture of the cell. The ova do not appear in ail the cells at one time, nor is there any discerrible order as to the particular cells which produce ova, or the part of the branch which rontains them. Cells containing ova are found alike on every part of the branches, from the base to within two or three rows from the apex, occupicd only by young polypi. Sometimes we find half a dozen or a dozen of contiguous cells all containing ova, sometimes two or three only; and often stech cells occur singly, at short and irregular distances from each other. We find the ova in all stuges of maturity on the same branch at the same time; and we seidom observe a specimen of the $F$. carbasea, during tlie montlis of February, March, and April, which does not contain numerous ova. The ova have a lively yellow colour; and when they occur abundantly on a specimen or a part of a lranch, they cause it to exhilhit the same lively bue, which is very different from the dull spotted brown appearance which the branches present at other seasons. Cells are often observed on different parts of the branches, containing neither polypi nor ova; but the fewress of these, and the great number of cells still containing only polypi at the season of generation, render it probable that polypi are reginerated in the 
cmpty cells after the escape of the ova. In the empty cells from which the ova bave escaped, we frequently observe a few remains of the former polypus, lying at the place where the lody of the polypus bifurcated, and where the prineipal connection seems to exist between the polypus and the axis ; we likewise perceive numerous monades and other animalcules busily employed in consuming the remains of the dead polypus. The ovum, even before arriving at maturity, exhibits very obvious sigus of irritability; frequently contracting different parts of its surface, and shrinking backward in its cell; the cilia on its surface are likewise observed in rapid motion within the cell, as in the ciliated ova of other zoophytes. The mature ova are often found with their small end projecting from the opening of the cells, and their final escape is aided by the incessant vibrations of the cilia covering their surface, by the ova contracting themselves in their lateral direction, by the waves agitating the branches of the flustra, and by the same incomprehensible laws which regulate the formation and growth of the ova, and the whole economy of this zoophyte."-Edin. New. Phil. Jourt. iii. 116-7.

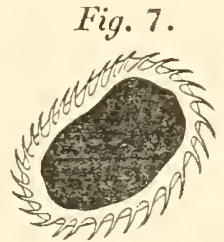

FGg of ALCYONIDICM HIRSUTCM. 


\section{CHAPTER III.}

\section{The Classifications of Zoophytes.}

THE existence of a polypidom is not, as has been already mentioned, essential to a polype; nor does it exercise, when present, that great influence over the organization of its architects and tenants which might have been anticipated. Thus the animal of the matreporous Caryophyllwa does not essentially differ from the naked Actinia; and the gelatinous Hydra is a true representative of the tenant of the sheathed Sertulariada and Tubularia. No ascidian polype, however, is ever found detached, and without a polypidom; and it is the same with all our mative Astroida, but, perhaps, the chistered animal-flower (Actinia sociata, Ellis, Zoanthus, ('uv.) of the Caribbran sea, might take its place in this tribe with greater propriety than in any other.

In reference to their composition, Polypidoms may be divided into 1. the stony or calcareous, 2. the membrano-calcareous, and 3. the horny and flexible; but the line which separates these divisions is often as uncertain and debateable as that which is traced between the sister kingdoms. All are composed of the same materials, viz. lime, and a gelatimous or membranaceous substance; and their peculiar characters depend on the different proportions in which the materials are mixed. The calcareous, which are hard and inflexible, and, when dry, assume a white colour, consist principally of carbonate of lime, with a small quantity of the phosphate of the same earth, and the gelatinous matter which cements them into one coherent mass, is in sparing proportion: that proportion is so greatly increased in the polypidoms of the second section, that when the earthy in gredients have been removed by the action of diluted acids, the structure retains its original form, and is, in fact, reduced to the 
condition of the polypidoms of the third section, which contain no lime, or very little of it, but are formed of a condensed gelatinous membrane, which resmbles horn in every essential property.**

'I hese dirersities in their chemical composition appear to be of little value, either in a physiological or systematical point of vicw, for in every order of polypiferous zoophytes, we find calcareous and horuy polypidoms. A curious species of Actinia secretes a horny basis, the first rudiment of a madrepore $; \dagger$ but all other madrepores are calcareous: the axis of the Astroida is sometimes of lime, sometimes of horm, and sometimes of membrane: the polypidoms of the Hydroida are Hexible and horny without perhaps any exception; but there is no hesitation in asserting, that the ascidian tribes fabricate productions, some of which are referabie to every class that the chemist could devise.

The reader who is not already familiar with the outward forms of our native polypidoms, will most easily obtain a correct idea of them, by examining the figures which illustrate this work. The very few and insignificant madrepores, or helianthoid polypidoms, which inhabit the British shores, form either short cylinders or reversed cones, having the apex cupped and starred with lamellæ, which radiate from the depressed centre to the circunference. In the major part of the Astroida, or corticiferous polypidoms, there is a central calcareous or horny axis, which may be compared to the wood of a tree, and which is formed by the successive deposition of layer over layer: this is coated or barked round with a living irritable flesh or jelly, thickened with calcareous matter, which has usually crystallized in the form of spicula. The cells of the polypes are excavated in this soft bark, on the surface of which they open by an aperture, which is always cut into eight rays disposed in a starred fashion, and corresponding to the number of the polype's tentacula; and this aperture can be opened and shut at the pleasure of the inmates. In Aleyonium, although an asteroid, there is no solid axis, but

* See Additional Note.

† It has been doubted whether this horny base is formed by the Actinia, but I quite agree with Dr Coldstream, that " it is secreted by its base, and that it is as much part of the animal, in fact its skeleton, as are the calcareous axes of Caryophyllæa, Fungia, \&c., between which and the true Actinia, it seems to form a well-marked link."-See the Edin. New Phil. Journ. ix. p. 238. 
there is an evident tendency to its formation; the materials lie scattered in the form of spicula in the soft gelatinous centre; and in the Cydonium these spicula have become so numerous, that they impart considerabie rigidity to the whole mass.

The polypidoms of the Iydraform and Ascidian zoophytes are more diversified in their figures and more decidedly arborescent. The latter are formed by an aggregation of distinct cells, united in general after the fashion of the quincunx and spread out into leaves or layers or compressed branches; or the cells being placed upon each other in pairs, or even in a single line, they form neat confervoid tufts ; or lying immersed without any very traceable pattern, the masses resulting from their union are amorphous, or at least inconstant and irregular. The horny material of the Hydra tribe is always formed into tubular sheaths encasing the living flesh, jointed at intervals, sometimes of the same calibre throughout, but more commonly dilated at intervals into vases or cups, or cells, in which the proper body of the polype is placed. The manner in which the sheath or tube is divicled and branched, is limited in diversity only by the number of the species, which are among the most delicate and interesting of all polypidoms, and pre-eminently imitative of vegetable forms. These forms are of course altogether independent of their aninıated tenants,-these " have been specifically appointed by Him to do what they have done, and are still effectuating. They are mere instrumentalities at His command. They know nothing of the results they cause, nor mean to perform any of them, nor could of themselves co-operate with each other, nor produce any systematical arrangement, or regulated or orderly effects. It is their Master and Maker who organizes, governs, and guides them to those movements and operations which they perform, and from all others; so that by His directing will they are made to do what we see them effect, and that only because He restrains and averts them from all else."*

The formation of polypidoms has been the subject of considerable discussion. "The opinion of Ellis, as we have already seen, was, that they are the result solely of a transudation, or excretion of the constiuent matters from the body of the polypes, and this opinion has been maintained recently by Lamarck,

- Turner's Sac. Hist of the World, Vol. ii. p. 71. 
and some other naturalists. It rests on the assumption that the polypidom is extrarascular and inorganic, so that after its first solidification, it suffers no alteration in form and quality, beyond what is evidently effected by the operation of chemical and mechanical causes: the changes resulting trom its increase in size, are not from the activity and pulsion of any inherent principle, but from the super-imposition of additional layers, or from the additions of new cells, or from the prolongation of the tubes, which additions are all coetaneous with the growth and multiplication of the polypes, and the results of new secretions. Linnæus, Pallas and Baster opposed Ellis, and believed in a vegetative principle, inlerent in the polypidom itself, so that its growth was in some measure independent of the living tenant; and various arguments have been brought forward by Bory de St Vincent, * which appear to him to demonstrate the truth of this doctrine. We may act, however, not unreasonably in withholding our assent, for with such a feeble and errant point was the argument handled that few felt its force, and the discussion has continued even to this day in an unsettled state. It seems probable in fact that neither theory will explain the growth of all polypidons; and as the peculiarities which distinguish these are considerable and would render a general description involved and obscure, I shall reserve the explanation of their mode of increase for a section in the preface to each separate order. Enough has in the meantime been said to show how unimportant the polypidom must be as a primary character in a natural classification of zoopluytes, and yet, until very recently, no other basis was looked for or deemed available, and hence the artificialness of the proposed "Systems" which, as a matter of history, we now venture to leview.

\section{The Classifications of Zoophytes.}

The main object of Ellis being to prove the animality of zoophytes, he deemed a new classification of them unnecessary, and, as it was sufficient for his purpose, he followed very closely that which had been proposed by Ray in his Synopsis of British Plants. + In successive chapters he treats of the vesiculated corallines (Sertulariada), the tubular corallines ('Tubularia), of the cel-

* Encyclop. Method. art. Zoophyte.

$\dagger$ Syn. Meth. Stirpiun Brit. Edit. 3. L,ond. 1724. 
liferous (Cellariadx), and of the articulated corallines (Corallina), of Keratoplyyta, of the Eschara, of the English corals, of sponges, of the Alcyonium, and of tubular corals, under which head he describes several of the more common tubicolous worms, which are found on our coast, and which have no relationship whatever to the other subjects of his treatise. Looking back on this arrangement from our present vantage ground, it appears disorderly and very defective, but when we reflect how mperfect the knowledge of species was at that period, and how crude the notions were on the nature and use of systems, we may find much to commend in it. Some of the chapters indeed contain a mixture of very dissimilar things, but others may be justly considered as so many natural genera or families, which subsequent naturalists had merely to subdivide and name.

Linnaus-in every sense the first of systematists - published the tenth edition of his Systema Natura in 1758. In it the avertebrate animals are arranged in two classes, Insecta and Vermes, - and of the latter zoophytes, with the exception of Actinia which is placed amongst the mollusca, form the last two orders which he named Lithophyta and Zoophyta. That we may appreciate the nature and value of the changes proposed subsequently to lis time, it will be necessary to give the definitions of his orders and genera.

I. "LITHOPHYTA Mollusca composita, hasin solidam ædificantia.

TUвipora Corcllium tubis cylindricis.

Miliepora Corallium tubis obconicis teretibus.

Madrepora Corallium tubis stellatis."

II. "ZOOPHYTA Plantæ vegetantes floribus animatis.

Is ss Stirps radicata, lapidea, nuda, geniculis corneis.

Gorgonia Stipps radicata, cornea, crustata, continua.

Alcyonium Stirps stuposa, corticata, continua.

Tubularia Stirps fistulosa, tunicata, subgeniculata.

Eschara Stivps papyracea, nuda, porosa.

Corallixs Stirps fibrosa, crustata, articulata: articulis multifloris.

Sertularia stirps fibrosa, nuda, articulata: articulis mifloris. Hyora Stimps suloralicata, gelatinosa, apice florifera.

Pennatula Stimps lihera, pennata, basi ore instructil. 


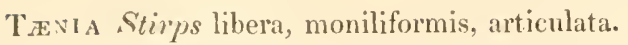

Vouvox Stirps lilera, globosa, sobole nidulante." *

The precision of the definitions in this arrangement, and the manner in which they are contrasted, is highy characteristic of its author, but into many of the genera species are introduced, which are not conformable to the definitions; and some of these, Pennatula and Hydra, for example, are grossly erroneous. The theoretical character of the second order, and of some of its genera, might also be objected to in a matter-of-fact work; but it is an easy task for the student of the present ra to point out defects in the method of the master who had to plan the way, and who suceeded in making it level and easy to his followers.

Pallas, in 1766, embraced the Lithophyta and Zoophyta in one order, for which he adopted the latter denomination, for he very properly believed that the Linnaan distinctions served only to " divide the things that are in nature join'd." He separated some spurious species of Hydra and formed them into the genus Brachionus, which, though a good genus, is a duubtful member of the order of zoophytes. His genus Antipathes, serered from Gorgonia, is well defined; and with equal propriety he restored the celliferous corallines of Ellis, which Limnæus had mixed with the Sertularia, to a separate generic rank-Cellularia. The claims of Truia, Volvox, and Corallina to a place amongst zoophytes were disallowed, although he has described the species in an appendix, for he knew that Tænia properly belonged to the intestinal worms, and Volvox to the infusorial animalcules; and he believed that Corallina was altogether of a vegetable nature.

In the twelfth edition of the "Systema," published in 1767 , Linnaus inade no material improvements on his first system, but the errors relative to the Hydra and Pennatula are corrected, and the definitions in general are abridged and rendered less theoretical. To the Lithophyta he added the genus Cellepora" corallium cellulis cavis ;"- -and he followed EHlis and Pallas in now introducing the Sponges into his second order. In this we also find, for the first time, the genus Vorticella, which is near-ly synonymous with the Brachiomes of Pallas; the Flustra, which 
is the same as Eschara of his preceding edition; the Furia, which is an apocryphal animal; and the Chaos, which is an infusory animalcule. Were we to analyze the genera we should find, in almost every one of them, species which properly belong to a different class of animals, or whose characters are at variance with those assigned to the genus: but many of these misplacements were the almost necessary consequences of the then state of knowledge relative to the beings in question.

Solander, in arranging the materials of Ellis, followed the system of Pallas, but he introduced and placed the Actiniæ at the head of the order; he entirely rejected all the intestinal worms and infusory animalcules; and be amended the definitions of the genera by carefully avoiding all theoretical phraseology. He used the term "Zoophyta" exactly in the same sense, and with the same latitude, that it is used in the present work.*

The method of Miiller cannot be considered as any improvement on those of his predecessors, but there is an attempt after novelty in it. He places the Actinia and the Hydra among the Mollusca, an order full of heterogeneous things, embracing the cuttle-fish, snails and star-fish; and in the same order we find the beautiful Lucernaria, one of the discoveries of this industrious and excellent naturalist. The proper zoophytes he denominates Cellularia, which are defined to be compound animals, enclosed in cells, and propagating by means of buds. The genera are classed and defined as follows:

\section{* Calcarea.}

Articulata, tenera,

Caleared.

Articulata, lapidea,

Tubulosa, aggregata vel solitaria,

Foraminulosa,

Lamelloso-stellata,

Pertusa poris,

.

** Subcornea.

Tubulosa, tentaculis simplicilus, . Tubulosa, lenteculis cristatis,
Corallana. Isis.

Tubipora.

Cellepora.

MADREPORA.

MileEPoRA.

Fistularia.

Tubularia.

- The Natural History of many curious and uncommon Zoophytes, by the late John Ellis, systematically arranged and desrrihed by the late Daniel Solander. l.ond. 1786. 4 to. 
Ramosa, nuda, tentaculis manifestis, Ramosid, incrustata, tent. inconspicuis,

$$
\text { ***** Fungosit. }
$$

()siculum polypiferum, Suberosa, poly pis stellatis, Stuposa, osculis hiantibus, Osculis atomiteris,
Sertularia.

Gorgonia.

Pennatula.

Alcyonium.

Spongia.

Clavari.I. *

The last genus is a sort of mushroom which Miiller was led to arrange among zooplytes from having witnessect the apparent spontaneous movements of its sporules; but no one has followed him in this, alıhough, it may be remarked, that some recent authors have no better reasons for their proposal to remove a large proportion of the aquatic alga to the animal kingdom.

Blumenbach adopted the Linnæan class Vermes, and he also retained the Actiniæ in the order Mollusca, but the proper zoophytes were differently arranged, and the alteration was unquestionably for the worse. The " polypes and other zoophytes inhabiting coral branches and similar structures" formed the order Corallia; and his Zoophyta included only the "naked plant-like animals withont any habitations; also the animalculæ of infusions!" The genera were the same, or nearly the same, as the Linnæan, and followed one another apparently as their names had risen in random series to his memory. $\dagger$

About the beginning of the present century Civier first of all pointed out the advantages of having our systematical arrangements in harmony with anatomical structure, -of making the one an index to the other, - of classifying animals not according to one or two exterual characters which might really have little or no influence upon their anatomy and habits, but according to their agreement in those great systems by which the life, growth, and propagation of creatures are upheld and carrierl on. When, however, he began to arrange the animal kingdom accordingly, the knowledge of the organization of Zoophytes was too imperfect to permit him to follow out his principles in this depart-

* Zoologie Danicre Prodromus, p. xxxi. Havn. 1776.

$\dagger$ Elements of Natural History, p. 269 and 274. Lond. 1825. 
ment, and even his latest systematical attempt exhibits many derelictions of them. Having, at the suggestion of Pallas, established a section of arertebrated animals for the reception of such as exhibited in the disposition of their organs a radiated appearance, to the whole of which he applied the term Zoophytes, he subdivided it into five classes, of which the last but one embraced the subjects of the present treatise. 'I'hey were named Polypes because, from the tentacula encircling their mouth, they somewhat resembled the cuttle-fish called Polypus by the ancients; and they were defined to be little gelatinous animals the mouth of which, encircled with the tentacula, lead into a stomach sometimes simple and sometimes furnished with intestines in the form of vessels. It is in this class that we fond those inumerable compound animals, with a fixed and solid stem, which were so long regarcled as marine plants. The following is a synopsis of Cuvier's method, as it appears in the last edition of the "Règue Animal."*

\section{Les Polypes.}

Ord. I. P. Charnus.

Les Actinies. (Actinia, Lin.)

Actinia.

Zoanthus. Cur. (nov. gen.)

Les Lncernaires.

Lucernaria.

Ord. II. P. gelatineux.

Hydra.

Corine.

Cristatella. Cuv. (nov. gen.)

Vorticella.

Pedicellaria.

Ord. III. P. A POLYPIERS.

Fam. i. Les Polypes à tuyaux.

Tulipora.

Tubularia.

Sertularia.

Fam. ii. Polypes à cellules.

Cellularia. 
Flustra.

Cellepora.

Tubulipora.

Corallina.

Fam. iii. Les Polypes corticaux.

Tribe 1. Des Ceratophytes.

Antipathes. .

Gorgonia.

Tribe 2. Les Lithophytes.

Isis.

Madrepora.

Millepora.

Tiribe 3. Polypes Nageurs.

Pennatula. Subgenera-Pennatula, Cuv. Virgularia, Lam. Scirpearia, Cur. Pavonaria, Cur. Renilla, Lam. Veretillum, Cuv. Ombellularia, Cuv.

Tribe 4. Alcyons.

Alcyonium.

Spongia.

In the definitions there is throughout a certain degree of vagueness, or at least the absence of that finicalness, which is so pleasing to the practical systematist; and in the value of the characters chosen to separate the orders and families there is great inequality. Hydra and Corine, for example, are more nearly allied to Tubularia and Sertularia, than the latter are to the Ceratophytes, yet these are placed in one and the same, and the Hydra in a separate order. Had the Ceratophytes been elevated to the rank of an order, and the Madrepora been removed to the Polypes charnus, the system would have been improved, and no very obvious alliances broken. In the subordinate parts of the system there are many misplacements of the subgenera, as the genera of his contemporaries were named, of which we may instance the Campanularia which is placed under Tubularia of Linnæus, to which, however, it has certainly much less affinity than to the Sertularia, where it had always hitherto been assigned.

In 1810, Lamouroux of Caen presented to the Academy of Sciences of Paris a new classification of the flexible polypidoms; and it would appear that Lamarck was engaged at the same time 
in similar labours; but, proceeding on different principles, they arrived at very different results. The anatomy of the workers or polypes was, according to Lamouroux, so imperfectly ascertained, and from their situation as well as from their minuteness, so little within attainment, that it seemed hopeless to procure materials for a classification from that source, and he confined his attention solely to the polypidoms, on whose composition he founded his primary divisions. Lamarck, although he also confined his examination to the polypidoms, took higher ground: he maintained that as these were secreted by the polypes and formed on and by them, a sameness in the structure of the one necessarily implied a sameness in the structure of the other; that in fact we might as safely infer a sameness of structure or dissimilarity from the various configurations of the polype-cells and coral, as we could from an actual inspection of the animated tenants themselves. The experience of a few years has shown either that Lamarck's examination of the coral was hasty, or that his principle was erroneous, for his arrangement is far from being in harmony with a physiological one, and, although greatly superior to Lamouroux's, yet is not the less artificial; there being even in some of his genera, species whose polypes are widely at variance with each other. I do not mean to trace the systems of either of these authors through their various changes, from their first promulgation to their perfection; * an outline of them in their latest state is sufficient for our purpose.

\section{System of Lamouroux.}

(1821.)

Division 1.

POLYPIDOMS FLEXIBLE, OR NOT ENTIRELY STONY. Section 1 .

Polypiers celluliferes. - Polypes in non-irritable cellules.

Ord. I. Celléporées.-Tubulipore. Cellépore.

Ord. II. Flustrées. - Berenice. Phéruse. Elzerine. Flustre. Electre.

- Blainville has given a bistory of all the proposed classifications in chronological series in his Manuel d'Actinologie, which the reader may consult with advantage.

+ The primary sections of this systematist may have been borrowed from $J$. F. Roques de Maumont._-See Blainr. Man. d'Actinol. p. 23. 
Ord. 111. Cellariées.-Cellarie. Cabérée. Canda. Acanarchis Crisiè. Menipée. Loricaire. Eucratée. Alecto. Lafæe. Hippothoé. Aétée.

Ord. IV. Sertularićes.-Pasythée. Amathie. Nemertesie. Aglaophenie. Dynamēue. Sertulaire. Idie. Entalophore. Clytie. Laomédée. Thoée. Salacie. Cymodocée. Amphitöite.

Ord. V. Tubularićes.--Tibiane. Näis. Tubulaire. Cornulaire. Telesto. Liagore. Neomeris.

\section{Section II.}

Polypiers Calciferes. - A calcareous substance mixed with the animal matter or covering it, apparent in all its states.

Ord. VI. Acetabulariées.-A cetabulaire. Polyphyse.

Ord. VII. Corallinées.-Galaxaure. Nesée. Janie. Coralline. Cymopolie. Amphiroé. Halimede. Udotée.

\section{Section III.}

Polvpiers Corticiferes. - Composed of two substances, an exterior and enveloping, named the bark or crust; the other, called the axis, placed in the centre and sustaining the first.

Ord. VIII. Spongiées.-Ephydatie. Eponge.

Ord. IX. Gorgoniées. - Anadyomène. Antipathe. Gorgone. Plexaure. Eunicée. Municée. Primnoe. Corail.

Ord. X. Isidées.-Mélitée. Mopsée. Isis.

\section{Division II.}

\section{POLYPIDOMS ENTIRELY STONY AND INFIEXIBLE.}

\section{Section I.}

Polyiers foramines.-Cells small, perforated, almost tubular, without internal plates.

Ord. XI. Escharées.-Adeone. Eschare. Rétépore. Discopore. Diastopore. Obalie. Celleporaire.

Ord. XII. Milléporées.-Ovulite. Reteporite. Lunulite. Orbulite. Ocellaire. Melobésie. Eudée. Alveolite. Distichopore. Hornere. Krusensterne. Tilesie. Théonée. Chrysaore. Millepore. Terebellaire. Spiropore. Idmonée.

\section{Section II.}

Polypiers lamelliferes. - Stony, the cells in the form of lamellated stars, or waved furrows gar'nished with lamellæ. 
Ord. XIII. Caryophyllaires.-('aryophyllie. Turbinolopse. 'Turhinolie. Cyclolite. Fongie.

Ord. XIV. Meandrinées - Pavone. $\Lambda$ psendesie. Agarice. Meandrine. Monticulaire.

Ord. XV. Astrées.-Echinopore. Explanaire. Astrée.

Ord. XVI. Malréporées.-Porite. Seriatopore. Pocillopore. Madrepore. Oculine. Styline. Sarcinule.

Section III.

Polypiers tubulés.-Stony, formed of distinct and parallel tubes. Ord. XVII. Tubiporées.-Catenipore. Favosite. Eunomie. 'Tubipore.

\section{Division III.}

POLYPIDOMS CARNOSE, MORE OR LESS IRRITABLE AND WITHOUT A CENTRAL AXIS.

Ord. XVIII. Alcyonées.-Alcyon. Lohulane. Anmothée. Xenia. Anthelie. Alcyonidée. Alcyonelle. Hallirhoe.

Ord. XIX. Polyclinées-Distome. Sigilline. Synoique. Aplide. Polycline. Didemne. Encelie. Botrylle.

Ord. XX. Actinaires.-Chenendopore. Hypalime. Lymnorée. Pelagie. Montlivaltie. Isaure. Iérée.

Remark on this system seems almost unnecessary. The student will deem it too complex with all its sections and subsections; and the experienced naturalist will at once eschew it as only tending to embroil, and confuse and nullify all the knowledge which has been acquired on the structure and physiology of the remarkable creatures which are here so elaborately misarranged. Animals which the adminable anatomical researches of Savigny had proved, by the consent of all, to belong to a different category, are here forcibly degraded to their Linnaan rank, and stand in juxtaposition with true zoophytes on the one hand, and doubtful ones on the other; and, perhaps to make room for these pretenders, some rightful claimants, as Hydra and Pennatula, are altogether excluded: some genera so nearly allied that their distinction may be questioned, for example, Flustra and Eschara, stand in difierent divisions at wide distances; while others, which have not one cliaracter of importance to connect, and every thing to dissever them, are placed 
almost in juxtaposition, as the Sponges and the Gorgonix. The merits of Lamouroux have always appeared to me to have been much overrated: it is a very easy matter, by arbitrarily fixing on this or that character, to set in order any given number of objects in any pattem we may choose, and Lamouroux had no higher notion of the character of a systematist than this, and acted accordingly. It is very true that he named and distinguished many genera, but who, on critically examining these genera, will deny that he proceeded without caution and without judgment,-determined apparently to make as many as could be made that his successors might be spared the unprofitable task of coining and inventing names!*

\section{System of Lamarck. (1816.)}

\section{Class POLYPI.}

\section{Order I. P. ciliati.}

Polypes without tentacula, but having near the mouth, or at its orifice, vibratile ciliæ or ciliated and rotatory organs which agitate or whirl the water.

I. Section.-Vibratiles.-Rattulus, Trichocerca, Vaginicola.

II. Section.-Rotrferes.-Folliculina, Brachionus, Furcularia, Urceolaria, Vorticella, Tubicolaria.

\section{Order II. P. DENUdATI.}

Polypes with tentacula, without an envelope or polypidom, and fixed either permanently or spontaneously.

$$
\text { Hydra_Coryne-Pedicellaria-Zoantha. }
$$

\section{Order III. P. vaginati.}

Polypes with tentacula, invariably fixed in an inorganic polypidom which envelopes them ; and forming, in general, compound animals.

* Polypidoms of homogeneous composition.

I. Section. Polypiers fluviatiles.- Difflugia, Cristatella, Spongilla, Alcyonella.

* Blainville in criticising Lamouroux's latest work, says_- "Nous nous bornerons à dire que Lamouroux a encore considerablement augmenté le nombre des genres, surtout parmiles polypiers pierreux, pour y placer un grand nombre de corps organisés fossiles, trouvés dans le calcaire à polypiers de Caen, et que malheureusement la plupart de ces geures sont mal caractérisés, ce dont je me suis assuré directement sur les objets mèmes qui ont servi à ses observations." Man. d'Actinol. p. 54. 
II. Section. Polypiers raciniforaies. * Polypidoms naked, not varnished nor encrusted on the exterior. (1) Cells terminal -Plumatella, Tubularia, Cornularia, Campanularia. (2) Cells lateral-Sertularia, Antennularia, Plmmularia, Serialaria. - *** Polypidoms varnished or slightly crusted on the exterior. Liriozoa, Cellaria, Anguinaria, Dichotomaria, Tibiana, Acetabulum, Polyphysa.

III. Section. Polypiers a reseau.-Flustra, Tubulipora, Discopora, Cellepora, Eschara, Adeona, Retepora, Alveolites, Ocellaria, Dactylopora.

IV. Section. Polypiers foramnes._Ornlites, Lunulites, Orunlites, Distichopora, Millepora, Favosites, Catenipora, Tubipora.

V. Section. Polypiers ranelliferes. - * Star's telminal-Stylina, Sarcinnla, Caryophyllia, Turhinolia, Cyclolites, Fungia. * Star's lateral or spreal over the surface-Pavonia, Agaricia, Meandrina, Monticularia, Echinopora, Explanaria, Astrea, Porites, Pocillopora, Madrepora, Seriatopora, Ocu. lina.

VI. Section. Polypiers corticiferes.-Corallinm, Melitra, Isis, Antipathes, Gorgonia, Corallina.

ViI. Section. Polypiers empates. - Penicillus, Flabellaria, Spongia, Tethia, Geodia, Alcyonimm.

\section{Order IV. P. TUBIFERI.}

Polypes united on a common fleshy living body, eithex simple or lobed or branched, and attached by its base : no external polypidom; no solid interual axis; the surface loaled with numerons tubiform little cylinders, rarely entirely retractile. Mouth terminal ; tentacula 8 , pectinated; no anus; 8 longitudinal semi-partitions unlerneath the stomach; 8 iritestines of two kinds ; 6 groups of gemmæ resembling as many oraries.

Anthelia, Xenia, Ammothea, Lobularia.

\section{Order T. P. NATANTES.}

Polypes united on a common free elongated fleshy and organic bo:ly, enveloping a cartilagimous almost bony and sometimes stony inorganic axis. Tentacula set in a radiating manner round the mouth of each polype.

Veretillum, Funiculina, Pematula, Renilla, Virgularia, Encrinus, ¿mbellularia. 
In the outline this system is not very materially different from that of Cuvier, the deviations being sometimes for the better and sometimes for the worse. If the Polypi ciliati are to be numbered amongst proper zoophytes it is for the better to have them placed in a separate order; but Zoantha is badly associated with the Hydra, Coryne and the spurious Pedicellaria. The Polypi vaginati, considered as an order, is a most heterogeneous collection; and the manner in which it is subdivided into sections, although in general excellent and worthy of commendation, is yet far from unexceptionable; and these exceptions are very obvious in the first, sixth and seventh sections, in which apolypous, or it may be regetable productions, are mingled with real zoophytes. The characters which divide the Polypi tubiferi from the natantes are not of sufficient importance to be considered ordinal, (it would have been preferable to have made them families in one order); and the location of the Encrinus in the latter is the result of a most unlucky conjecture.* As a systematist, however, Lamarck has few equals, and probably, with the exception of Linnæus, not a superior : there is no vagueness nor ambiguity about him, - all is clear, well arranged and ordered, and his characters, which are usually well chosen, are defined in expressive words and in a felicitous manner. These advantages have given his System great currency, and though the favour shewn to it has somewhat abated, it still holds its place, and is in frequent use, with those who are engaged in arranging local catalogues and museums.

Dr Fleming is the only British naturalist who has attempted

* According to Lamarck Nature could not have done otherwise than she has done, and we are repeatedly assured that his System is a naked exposition of her necessitated steps in calling organized beings into existence! After announcing with an almost ludicrous degree of confidence and complacency, that this fictitious Power can only complicate animal organizations in successive gradation, he adds,_- " La connaissance de cette vérité me suffit ; je reconmais le véritable rang des polypes, comme celui des infusoires ; j'aperçois les rapports qui les lient les uns aux autres, ainsi que ceux qui lient les familles entr'elles; enfin, je conçois les limites que la nature n'a pu franchir dans la composition de l'organization de ces animaux, d'après celles que je découvre dans ceux des classes supérieures. Je puis donc dire positivement, à l'égard des polypes, comme à celui de bien d'autres, ce que la nature r'a pas pu faire." Anim. s. Vert. ii. 8._What a humiliating commentary and lesson have the discoveries of a few short years afforded on this passage! 
an original classification of Zoophytes, and although no one, from his previous studies and important discoveries relative to their structure and functions, ever came better prepared for the task, yet the system he framed is assuredly not superior to those of his predecessors. The Actiniæ and Lucernaria were collocated with the Radiata acalepha or sea-jellies, and the Zoophyta divided into four orders as follow:

\section{Carnosa.}

Polypi connected with a fleshy substance.

Keeping this definition in view, who would have expected to find Sponges and Corallines and Madrepores under this order? and yet they are there in defiance of the definition. The following is a synopsis of this order-

I. Free; marine; moving by the contraction orexpansion of the fleshy part; form symmetrical; axis of the body supported by a bone contained in a sac.

Pennatula.

Virgularia.

II. Fixed or stationary.

A. Polypiferous matter covering a solid axis.

a. Axis with stellular dises.-LaMeldiferde.

b. Stellular discs terminal.

Sarcinula.

Lithostrotion.

Caryophyllea.

Turbinolia.

Cyclotites.

$b b$. Stellnlar discs aggregated.

Explanaria.

Astrea.

Porites.

Pocillopore.

a $u$. Axis destitute of cellular discs.

$b$. Axis corneous and flexible; polypiferous basis cretaceous ; the axis with spines.

$c$. Polypi developed.-Gorgoniadr.

Gorgonia.

Primnoa.

c c. Polypi not developed.-Corallinade.

Jania.

- History of British Animals, Edin. 1828. 8ro. 
Corallina.

Halimeda.

$b$ b. Axis stony.

Isis.

B. Polypiferous basis destitute of a continuous solid axis. a. Poly pi developed.

$b$. Polypi with 8 tentacula; the base fibrous.

Lobularia.

Cydonium.

Cliona.

$b$ b. Polypi with tentacula exceeding 8 in number; basis nearly uniform.

Alcyonium.

Cristatella.

a a. Polypi not developed.-SPONGIA Dz.

Tethya,

Halichondria.

Spongia.

Grantia.

\section{Cellulifera.}

Polypi lodged in Calcareous cells imperforate at the BASE.

A. Substance rigid, stony.

1. Cells in the form of minute pores, imbedded.-MILLEPORADE.

Millepora.

II. Cells tubular, and produced beyond the surface.-TU. BIPORAD在.

Tubipora.

Favosites.

Tubulipora.

Discopora.

Filipora.

Terebellaria.

III. Cells utricular, adjacent, or superimposed.- Esch ARAD正.

Eschara.

Retepora.

Cellepora.

Berenicea. 
Hippothoa.

Alecto.

A A. Substance flexible.Fustrade.

Farcimia.

Flustra.

III. ThECATA.

Polypi surRounded BY a MeMBranaceous TUBE, COVERING

THE SUBDIVISIONS OF THEIR COMPOUND BODY.

A. Sheath slightly calcareous; cells single, or in rows.

I. Sheath slightly calcareous, cells enlarged, in rows, united or single.-CELL A RIADE.

a. Cells united.

b. Cells with the orifices opening on the upper surface. Cellularia.

Tricellaria.

Crisia.

b b. Cells in pairs, attached by the back, the orifices with opposite aspects.

Notamia.

a a. Cells single.

Eucratia.

Anguinaria.

A A. Sheath membranaceous, cells enlarged externally and lateral. -SFRTULARIADE.

I. Base of the cells broad, coalescing with the stem.

a. Cells on opposite sides of the stem.

Sertularia.

Dynamena.

Thuiaria.

« $\iota$. Cells unilateral.

Antennularia.

Plumularia.

Serialaria.

II. Base of the cells narrow, or pedunculated.

Campanularia.

Valkeria.

Cymolocia.

AAA. Sheath membranaceous; the cells are the simple extremities of the branches.-TUBULARIADI.

Tubulalia.

Plimatella. 
IV. NUDA.

lolypi naked, the moUth With marginal tentacula. Coryna.

Hydra.

Latreille's method may next be noticed. He, following Lamarck, divides the animal kingdom into three prinary sections, the last of which is denominated ACEPHALA, which, with various other classes, includes all the Zoophyta. The Actinia and Lucernaria constitute a distinct class-Helianthoila-which is placed between the sea-stars (Echinodermata), and sea-jellies, (Acaleplia), being superior to the latter and to zoophytes by their organization, in which Spix had detected a nerrous system. The Polypes follow the sea-jellies, and are subdivided thus:

\section{Order I. Brachiostoma.}

Mouth encireled with tentacula, of ten retractile.

Family I. Catamides. Pennatula, Virgularia, \&e.

II. Alcronea. Lobularia, Alcyonium, \&c.

III. Alveolaria. This family is portioned into tribes.

1. Lamellifera - the P. lamellifères of Lamarck.

2. Forctminosa-the P. foraminés of Lamarck.

3. Corticiferc-the P. corticifères of Lamarck, with the genera Penicillus and Flabellaria.

4. Reticularia-the P. à résean of Lamarck.

5. I aginiformic - the P. vaginiformes of Lamarck.

6. Spongites-the sea and fluviatile sponges.

IV. Limnopolypi. 1. Tentacula retractile; a sheathPlumatella, Cristatella, Difflugia. 2. Tentacula non-retractile; no sheath - Pedicellaria, Coryne, Hydra.

\section{Orcler II. Trichostoma.}

No tentacula at the mouth, which are replaced by rotatory organs or cilice.

Family I. Cancriformic-Brachionus, Follicularia, Tubicolaria. II. Cempanulate-Vorticella, Urceolaria, Furcularia. III. Caudata-Vaginicola, Tricocercus, Ratulus.

Not having access to the original works, I pass over in silence the methods of Oken, Schweigger, and Van der Hören, the 
more willingly that they are but modifications, to no material extent, of one or other of those which preceded them, are in no respect preferable, and evolve no new prineiple, for surely the assumption on Oken's part that the orders, families, and genera in this class, as in the animal kingdom generally, are regulated by a law which throws them into quaternary sections — the number 4 exereising throughout a paramount influence - searcely leserves this praise. It is different with the attempt of Rapp, Professor of Anatomy at Tubingen, who in 1829 published a small work in German on the natural history of the Actinix. He proposed to divide the zoophytes, understanding the term in the same restrieted sense that I do, into two great orders, the Exoaria and Endoaria, - the former producing their ova or reproductive gemmules from the exterior, while in the latter " the ova are produced in the interior of the body, and are either conveyed outwards by means of oviducts which open by separate orifices, or they are discharged by the mouth." The distinction here first pointed out is a very important one, but in common with all single characters is of itself insufficient, and if rigorously adhered to leads to artificial and unnatural combinations. The Exoaria for example has all its members well and distinetly affined, embracing only three families, 1 . the Hydre; 2. Corynea, consisting of the genera Sertularia, Tubularia and Coryne; and 3. Millepora, limiting probably this de.nomination to $M$. truncata. The ENDoARIA embraces a wider range-the Alcyonea equivalent to the Polypes tubiferes of Lamarek; the Tupipora; the Corallia ineluding the genera Corallium, Gorgonia, Isis and Antipathes; the Pematula; Zoanthes; and Madrepores with the subdivisions which have been introduced by Lamarek. * So far the order labours under little error, or is perhaps unexeeptionable, but its definition would entitle us to place in it also the Escharida, the Cellepores, and Lymnopolypi, which are all very alien to the families which Rapp seems to have had too exelusively under his view.

The only other classification I shall notice is Blainville's, the most elaborate of any; and this author, as it appears to me, is the first who allowed the anatomy of the Polypes, abstractedly

- See Edin. Journ. of Geogr. and Nat. Science, ii. p. 406, and Blauv. Man. d'Actinol. p. 5 \%. 
considered, to have its due influence on our systems. Notwithstanding, however, Blainville's unquestionable merits, his very defective acquaintance with species will ever prevent him becoming a first-rate systematist: he may sketch the outline, the details he cannot supply, and his attempt has exposed him to numerous errors: he is too fond of generalizations where his facts are few and specifical; he wants the necessary neatness and brevity of definition, and he evinces everywhere such a total disregard to the old nomenclature that his system is not likely to become popular, or to be generally adopted. Many of his alterations are excellent, and must meet the approval of all, for surely no one will henceforth reinstate the apolypous sponges and regetating corallines, which he has so properly separated, to a rank amongst proper polypes; and his removal of the Madrepores from the compound hydracolous polypidoms to a level with the Actinia seems to be equally judicious, and beyond future cavil.

\section{System of H. M. D. De Blainville. (1834.)}

\section{Class-ZOANTHA.}

Body regular, resembling a flower, more or less elongated, free or fixed, very contractile, furnished with an intestinal canal without distinct parietes, and with a single large terminal aperture encircled with multiform tentacula, always hollow, and in communication with the musculo-cavernous parenchyma of the skin.

The class is divided into three families :

The Soft-Actiniadæ. Lucernaria, Actinia, \&c.

The Coriaceous-Zoanthus.

The Calcareous-divided into 1. the Madrephyllica, in which are the genera Turbinolia and Caryophyllæa: and 2. the Madrepores.

\section{Class-POLYPIARIA.}

Animals like the Hydra, viz. in general slender, furnished with a single series of filiform and not numerous tentacula, naked or contained in multiform cells (but never lamelliferous), clustered so as to form a polypidom very variable in shape and structure.

Sub-Class I. P. Solıda.-Containing the families Millepores, of which there is no British genus amongst recent zoophytes; and Tubuliporea which contains 'Tubulipora only. 
Sub-Class II. P. Membranacea-in which are the three families -1. P. operculifera, of which the British genera are Es. chara, Retepora, Cellepora, Berenicea, Discopora, and Membranipora ; 2. P. celluriae contains Flustra, Cellaria, Tricellaria, Acamarchis, Bicellaria, Crisia, Gemicellaria, Unicellaria, Catenicella; 3. Sertularicce-arrangedthus :-

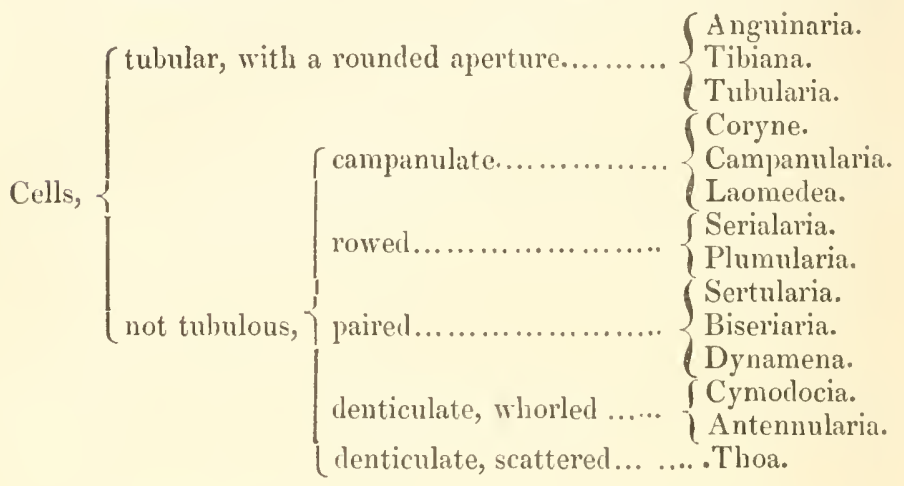

Sub-Class III. P. DuBia_Cristatella, Plumatella, Alcyonella. Sub-Class IV. P. NudA-Hydra.

\section{Class-ZOOPHYTARIA.}

Body rather large and somewhat variable in shape, furnished with a single circle of pinnated tentacula of determinate number; the ovaries internal.

Family 1. Tubiporea-divided into two sections, (1.) envelope fleshy--with the genera Cuscutaria, which is the same as Valkeria of Fleming, Telesto, Cornularia, and Clavularia, of which last three we have no native species: (2.) envelope calcareous-Tubipora.

Family 2. Corallia-Corallium, Isis, Gorgonia, Eunicea, Primnoa, Antipathes, \&c.

Family 3. Pennatularia-represented by Pennatula of Lin. with the various genera into which it has been portioned.

Family 4. Alcyonaria-Lobularia, Alcyoninm, Cydonium, Pulmonellum, Cliona.

$$
\text { Type II. }
$$

AMORPHOZOA.

Bodies organized, animal, shapeless or withont a determinate form, 
pierced with oscula and numerons pores, but without mouths or distinct individual animals, always adherent, and composed of a fibro-gelatinous substance, intermixed or not with calcareous or siliceous spicula, with internal buds or gemmules not localized. This embraces the sponges only, divided into the following generaAlcyonellum, Spongia, Calcispongia, Halispongia, Spongilla, Geodia, Cæloptychium, Siphonia, Myrmecium, Scyphia, Eudea, Hallirhoa, Hippelimus, Cnenimidium, Lymnorea, Chenendopora, Tragos, Manon, Jerea, Tethium.

\section{PSEUDOZOA.}

Organized bodies not animal but vegetahle.

\section{Class I. Calciphyte.}

Family 1. Corallince-Corallina, Jauia, and Flabellaria are British genera.

Family 2. Fucoidec-of which there are no native examples.

When some years since I planned this history of our native zoophytes these were all the classifications that the books accessible to me furnished for my purpose, but their imperfections and incongruities had been made so apparent in the progress of discovery, that I was induced to devise that one for my guidance which is here adopted. This method, drawn up without any foreknowledge of it, is in its main features similar to that proposed by Audouin and Milne-Edwards; $*$ and from this coincidence I feel the more assured that it will be found in closer harmony with the structure of the animals than any of its predecessors, and not less difficult in its practical applications. It is then proposed to divide the British zoophytes in the first place into the following sub-classes and orders, whose families and genera will be found characterized under their respective heads.

\section{Sub.Class I. RADIATED ZOOPHYTES.}

Body contractile in every part, symmetrical; mouth and anus one; gemmiparous and oviparous.

Order I. Hrdroida. Polypes compound, rarely single and naked,

* Recherches pour servir à l'Histoire Nat. du Littoral de la France, Vol. i. p. 73-6,-Ann. des Sciences Nat. Part. Zool. vi. 15, 16; and Lam. Anim. s. Vert. ii. 104. 2de edit. Paris, 1836. 
the mouth encircled with roughish filiform tentacula; stomach without proper parietes; intestine 0 ; anus 0 ; reproductive gemmules pulhulating from the body and naked, or contained in external vesicles. Polypidcms horny, fistular, more or less phytoidal, fixed, external. Marine, excepting Hydra, which is lacustrine.

Order II. Asterorda. Polypes compound, the mouth encircled with 8 fringed tentacula; stomach membranous, with dependant vasculiform appendages; intestine 0 ; anus 0 ; reprodnctive gemmules produced interiorly. Polype-mass variable in form, free or permanently attached, carnose, generally strengthened with a horny or calcareous axis enveloped with the gelatinous or creto-gelatinous crust in which the polype-cells are immersed, and which open on the surface in a starred fashion with eight rays. Marine.

Order III. Heliantuoida. Polypes single, free or permanently attached, fleshy, naked or encrusted with a calcareous Polypidom, the upper surface of which is crossed with radiating lamellæ; mouth encircled with tubulous tentacula; stomach membranous, plaited; intestine 0 ; anus 0 ; oviparous, the ovaries internal. Marine.

\section{Sub-Class II. MOLLUSCAN ZOOPHYTES.}

Rody non-contractile, and non-symmetrical; mouth and anus separate; gemmiparous and oviparous.

Order IV. Ascidioida. Polypes aggregate, the mouth encircled with filiform ciliated retractile tentacula; a distinct stomach, with a curved intestine terminating in an anus near the mouth; ova internal. Polypidoms very variable,-either horny, fistular and confervoid, or calcareous, membranous, or fibro-gelatinous, formed of cells connected and arranged in a determinate and usually quincuncial manner. Marine and lacustrine.

\section{Additional Note.}

The only extensive series of experiments we have on the composition of Polypidoms are those of Mr Hatchett, published in the Philosophical Transactions for 1800 , and the subsequent progress of zoological and chemical science requires a new investigation of the subject. The general results of Mr Hatchett's experiments are, "that the Madrepores and Millepores are formed of a gelatinous or membranaceous substance, hardened by carbonate of lime, the difference consisting ouly in the mode in which these materials are combined: that in the Tubipora, Flustra and Corallina, some phosphate of lime is mixed with the carbonate of lime: that in the Isis the basis is a regularly organized membranaceous, cartilaginous and horny substance, hardened by carbonate of lime, one species only (the lsis ochracea) yielding also a small proportion of phosphate of lime. That the hardening substance of the Gorgonia nobilis is likewise the carbonate of lime, with a small portion of phosphate; but that the matter forming the membranaceous basis consists of two parts, the interior being 
gelatinous, and the external a complete membrane, so formed as to cover the stem in the manner of a sheath or tube. That the other Gorgonia consist of a horny stem coated by a membrane, which is hardened by carbonate of lime. That the sponges are of a nature similar to the horny stems of the Gorgonia, and only differ from these and from each other by the quality of texture. And lastly, that the Alcyonia are likewise composed of a soft thexible membranaceous substanee, very similar to the cortical part of some of the Gorgoniæ; and in like manner slightly hardened by carbonate, mixed with a small portion of phosphate of lime.

"From this mass of evidence we collect, in general, that the varieties of bone, shell, coral, and the numerous tribe of Zoophytes with which the last are connected, only differ in composition by the nature and quantity of the hardening or ossifying principle, and by the state of the substance with which this principle is mixed or commeted; the gluten, or jelly, which cements the particles of carbonate or phosphate of lime, and the membrane, cartilage, or horny substance which serves as a basis, appearing to be only modifications of the same substance, which progressively graduates from a viscid liquid, or gluten, into a gelatinous substance, which again, by increased inspissation, and by the more or less perfect degrees of organic arrangement, forms the varieties of membrane, cartilage, and horn, which, it seems, form the peculiar differences of the several species." Abst. Phil. Trans. i. 25-26. There is a very full analysis of Hatchett's paper in Thomson's Syst. of Chem. v. p. 559, et seq. The paper itself will be found in Phil. Trans. abridg. xviii. p. 706 .

Raspail has ascertained that a large proportion of iron enters into the composition of the Alcyonella, which he thinks may be derived from the habitat, the zoophyte developing itself upon ferruginous rocks. The iron bolds the same position in the polypidom, that the carbonate of lime does in the Oculinæ, or the crystals of silex in the sponges. Its great proportional quantity may be estimated from the following experiment._- Un fragment sec du Polypier faisait dévier de trois degrés la nouvelle aiguille aimantée, construite par notre collêgue, M. Saigey, quoique ce fragment ne présentât à l'aiguille qu'une surface d'un centimètre environ. Cette déviation paraîtra énorme si l'on veut se rappeler que l'Alcyonelle est une substance spongieuse extraordinairement légère; ajoutes à l'importance de ce résultat que le fer paraît y exister à l'état de trioxide, puisqu' avant comme après l'incinération, la substance est également rougeâtre, et qu'en conséquence son influence sur l'aiguille aimantée serait infiniment faible, si le fer existait en faible quantité dans son tissu lâche et spongieux."-Mem. de la Soc. d'Hist. Nat. iv. p. 119.

"Non tamen, post tot ac tantos scriptores, pigebit meam quibusdam locis posuisse sententiam. Neque enim me cujusquam sectæ, velut quâdam sup€rstitione imbutus, addixi :-_ _ _ _ sicut ipse plurium in unum confero inventa, ubicumque ingenio non erit locus, curæ testimonium meruisse contentus."Quintilian. iii. i. 



\section{BRITISH ZOOPHYTES.}

\section{PART II.}

ZoOpIITA Hydroida.

Fig. 8.

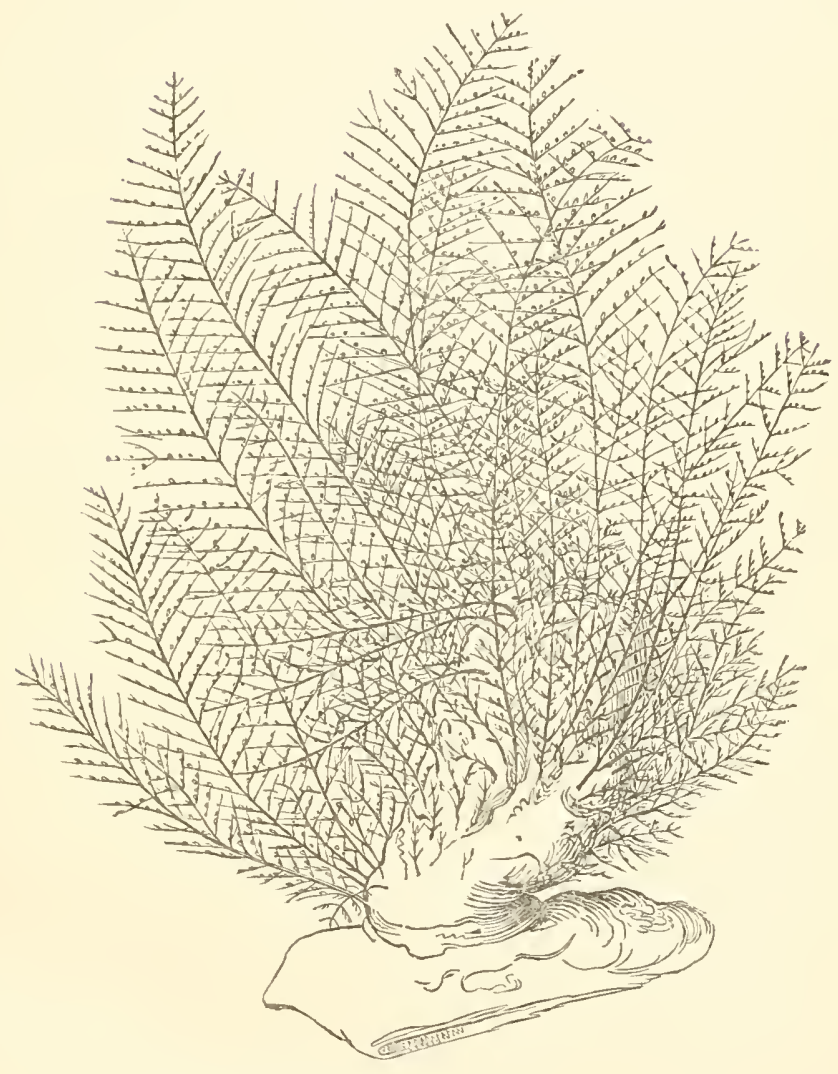

Pltiularia Catilarina.

"Involved in sea-wrack, here you find a race,

"Which seience doubting, knows not where to place;

"On shell or stone is dropp'd the embryo seed,

"Ant quickly regetates a vital breed."-Crubbe. 
"Interpone tuis interdum gaudia curis,

"Ut possis animo quemvis sufferre laborem."

Catullus.

"Early habits have made me prefer the entertainment resulting from the exposition of the beauties of Nature, and the delight to be derived from examining the works of the Creator, in which infinite wisdom and intelligence are displayed, to all other amusements."-Sir Everard Home.

"The works of the Lond are great, and sought out of all them that have pleasure therein."-Psalmist.

"And many disappointments could not cure

" This born obliquity, or break the lure

"Which this strong passion spread."

H. Taylor.

"Whate'er you study, in whate'er you sweat,

"Indulge your taste

"He chooses best, whose labour entertains

" His vacant fancy most."

Armstrong. 


\section{ZOOPHYTA BRITANNICA.}

\section{ORDER I.}

\section{Z. HYDROIDA.}

\section{Character.}

Polypes compound, rarely single and naked, the mouth encircled with roughish filiform tentacula; stomach without proper parietes; intestine 0 ; anus 0 ; reproductive gemmules pullulating from the body und naked, or contained in external vesicles.Polypidoms horny, fistular, more or less phytoidal, fixed, external.

\section{Observations.}

"6 As for your pretty little seed-cups or vases, they are a sweet confirmation of the pleasure Nature seems to take in superadding an elegance of form to most of her works, wherever you find them. How poor and bungling are all the imitations of art? When I have the pleasure of seeing you next, we will sit down, nay kneel down if you will, and admire these things." Thus did Hogarth-our great moral painter-write to Ellis in evident reference to the zoophytes of the present order; and he must indeed be more than ordinarily dull and insensate who can examine then without catching some of the enthusiasm of the artist. They excel all other zoophytical productions in delicacy and the graceful arrangement of their forms, some borrowing the character of the prettiest marine plants, others assuming the semblance of the ostrich-plumie, while the variety and elegance exhibited in the figures and sculpture of their miniature cups and chalices is only limited by the number of their species.

The Hydroida vary from a few lines to upwards of a foot in 
height. They are all, with the exception of the hydra or freshwater polype, marine productions, and are found attached to rocks, shells, sea-weed, other corallines, and to various shell-fish. Many of them appear to be indiscriminate in their choice of the object, but others again make a decided preference. Thus Thuiaria thuja prefers the valves of old shells, Thoa helicina is more partial to the larger univalves, Antennularia antennina grows on rocks, Campanularia genieulata delights to cover the broad frond of the tangle with a fairy forest peopled with its myriads of busy polypes, while the Sertularia pumila rather loves the more common and coarser wracks. The choice may in part be dependent on their habits, for such as are destined to live in shallow water, or on a shore exposed by the reflux of every tide, are in general vegetable parasites; while the species which spring up in the deep seas must select between rocks, corallines or shells, the depths at which they are found being too great for the vegetation of sea-weed.*

The polypidoms are confervoid and more or less divided, the ramifications being disposed in a variety of elegant plant-like forms. The stem and branches are alike in texture, slender, horny, fistular, and almost always jointed at short and regular intervals, the joint being a mere break in the contimuity of the sheath without any character of a proper hinge, and evidently formed by regular periodical interruptions in the growth of the polypidoms. Along their sides, or at the extremities, we find the denticles or cup-like cells of the polypes arranged in a determinate order, either sessile or elevated on a stalk, (Fig. 9, a.) Though of the same substance, the cell is something more than a simple expansion of the stem or branch, for near its base there is a distinct partition or diaphragm on which the body of the polype rests, with a plain or tubulous perforation in the centre, through which the connection between the individual polype and

" Lamouroux says,_- We fiud some polypidoms placed always on the southel's slopes of rocks and never on that towards the east, west, or north. Others, on the contrary, grow only on these exposures, and never on the south. Sometimes their position is varied according to latitude, and the shores inclined towards the south, in temperate or cold countries, produce the same species as the northern exposures in equatorial regions; in general their branches appear directed towards the main sea."- Corall. Flex. Introd. p. L. 
the common medullary pulp is retained, (Fig. 9, b.) * Besides the cells there are found, at certain seasons, a larger sort of vesicles, readily distinguished from the others by their size and the irregularity of their distribution. - The more robust tribes grow erect, and, beng Hexible and elastic, yield readily to the waves and currents; but some of the very delicate species avoid a shock for which they are unequal by creeping along the surface.

Fig. 9.

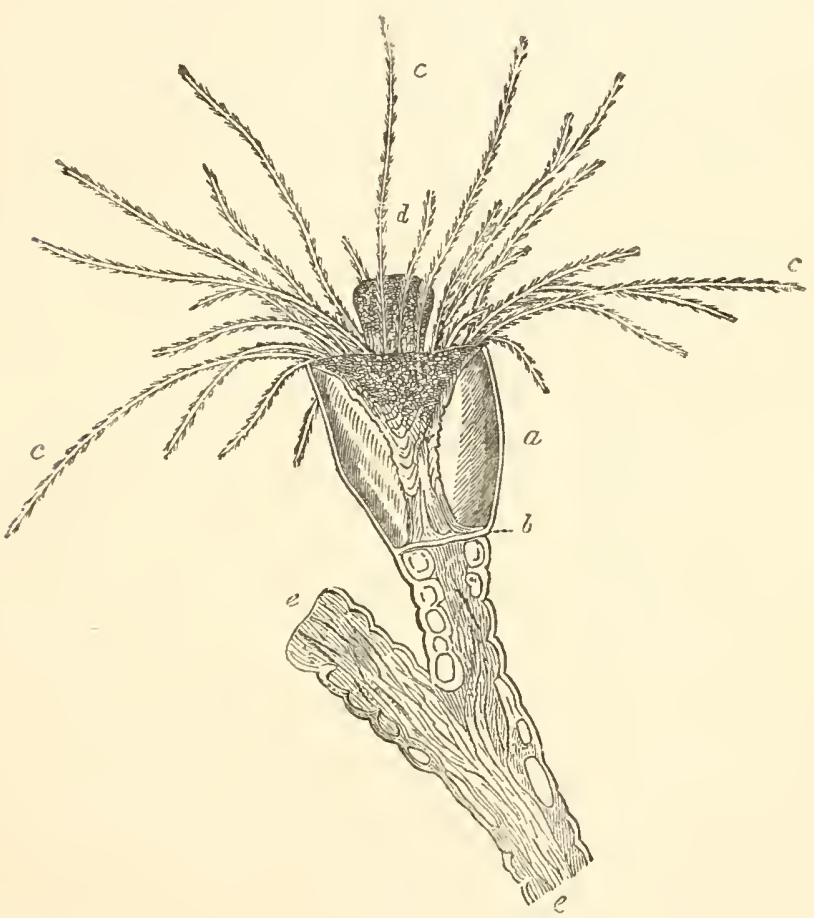

The polypidoms, when dried, are for the most part of a yellowish or horn colour. "When they are immersed in water, they recover the same form they appeared in when fresh in the sea; and soon become filled with the liquid. This gives them a semitransparent amber colour, and makes them very elastic." $†$ Their material appear's to be analogous to horn or condensed

- Lister, in Phil. Trans. 1831, p. 371.

$\uparrow$ Ellis, English Corallines, p. 3. 
albumen, which is moulded into a homogeneous investing sheath, for the protection of the semifluid pulpous body. It seems to be in fact a sort of hardened epidermis, at first in contact and partial adhesion with the living interior pulp, from which it is subsequently detached, in the natural progress of its consolidation, by a process of shrirelling in the soft matter, and by the motions aud efforts of the polypes themselves.* Link says that the experiments he has made on the Plumularia falcata and the Sertularia cupressina have led him to adopt the opinion of Carolini and Schweigger, that this sheath is vascular and organized, for, under a very powerful maguifier, he has seen coloured ressels ramified in the stem and branches of these polypidoms. He is also certain that their stems are often increased with age by concentric layers, and that the calcareons matter is deposited in true cells.t These observations are intended to support the theory of the independent growth of the polypidom from innate living motions or a vegetative principle, but notwithstanding Link's high authority, I would caution the student against a too hasty reception of the facts. They are at variance with the experiments of Ellis, Grant and Blainville; nor does Dr Fleming nor $\mathrm{Mr}$ Lister appear ever to have noticed traces of vascularity in these objects during their microscopical inquiries; and I have in vain sought for the existence of ressels in some transparent species, as Sertularia rosacea and Campanularia gelatinosa, where it seemed likely they would most easily be detected. Dr Fleming, from observations of a different kind, as $e . g$. the conversion of cells into resicles and of these into branches, or even of the polypes themselves into branches, in the Plumularia bullata and Campanularia gelatinosa, has come to the conclusion that the polypidom is, in its mode of growth, analogous to bone, " a circumstance on which its apparent regetating power depends"+; but since I suspect the accuracy of the alleged observations, and cannot, on reflection, perceive where the analogy between these horny sheaths and bone lies, I am necessitated

* See Lister's Observations in Phil. Trans. 1834, p. 374; and Lam. Anim. s. Vert. ii. 119. 2de edit. Milne-Edwards also tells us that there is a canal ciown the centre of the soft pulp in which the circulation is carried on. Is not this a transcendentul piece of anatomy?

† Ann. des Seiences Nat. Part. Bot. Vol. ii. p. 321.

\# Memoirs of the Wernerian Soc. Vol. v. p. 303-6. 
to believe the polypidom to be extravascular and inorganic-the result of an exudation from the interior pulp, and lependent. on this for its form and growth, however varied this may be. In the reproductive gemmule there are two substances, viz. the pulp and the thin cuticle or membrane, the latter of which is the germ of the future arborescent or cellular polypidom : by the growth of the pulp the membrane is distended and moulded into a cell, or pushed upwards in the form of a shoot, in which, after a time, the pulp is arrested in its growth longitudinally, swells out, and is developed into an animated polype, furnished with tentacula, a mouth, and digestive organs. Bursting the cell at the point which becomes the future aperture, it there displays its organs, and begins the capture of its prey, for, unlike higher organisms, the polype is at this the period of its birth as large and as perfect as it ever is at any subsequent period, the walls of the cell having become indurated and unyielding, and setting a limit to any further increase in bulk. The growth being thus hindered in that direction, the pulp, incessantly increased by new supplies of nutriment from the polype, is constrained and forced into its original direction, so that the extremities of the tube, which have remained soft and pliant, are pushed onwards, the downward shoot becoming a root-like fibre, and the upper continuing the polypidom, and swelling out as before, at stated intervals, into cells for the new developement of other polypes.— The polypidom then, however like unto certain vegetables in appearance, has, as Ellis said, nothing vegetable about it, but is entirely an animal production, and excreted by the animated pulp which fills its whole interior. Ellis and his followers are only so far wrong, that they have attributed to the polypes themselves what is actually due to the pulp. The latter is that from which the polypidom is exuded; for, indeed, the cell always precedes the existence of the polypus which is developed within it; while the polypidom begins to be developed from the gelatinous substance of the reproductive gemmules before any polypes are formed, and it continues to be developed and extended by the fleshy mass of the zoophyte, whether polypes are dereloped in the cells or not. "There is but one life, and one plan of derelopement, in the whole mass; and this depends uot on the polypi, which are but secondary and ofteu 
deciduous parts, but on the general fleshy substance of the body."**

The polypes are placed in the cells within which, with the exception of the Tubulariæ, they can hide themselves entirely when danger threatens. When at rest and in their native sites, they expand their tentacula and push them far beyond the rim of their cups, in readiness to arrest any small worm or crustaceous insect which may float within their circle.

"Utque sub requoribus deprensum polypus hostem

"Continet, ex omni dimissis parte Hagellis."

Ovid. Met. vi. 366.

These tentacula are always simple but roughish, (Fig. $9 c$,) and in the centre of the disk round which they are arranged we perceive the oral aperture $(d$,$) leading to a stomachical cavity without$ intestine or other chylopoetick viscus. The body is somewhat globular, soft and irritable; and it is prolonged posteriorly down the stalk or tube to be united with the central pulp which fills the branches and stem, $(e$,$) so that in this manner all the po-$ lypes of the same polypidom are connected together by a living thread, and constitute a family whose objects and interests are identical, and whose workings are all regulated by one harnonious instinct.

"Unconscious, not unworthy, instruments,

By which a hand invisible was rearing

A new creation in the secret deep."

Or if, with Linnæus and Cuvier, we suppose that the "whole composure makes one animal," this may be described as a sort of hydra divided, after the manner of a tree, into many or innumerable branches, from each of which pullulate one or more armed heads to capture and digest the prey that is to serve for the nutriment of their common trunk.

The reproductive gemmules of Tubularia and Coryne are generated in the interior and extrucled near the base of the tentacula; but in all the other genera they are produced in external vesicles, which were therefore appropriately named by Ellis the matrices or ovaries, and which we have already mentioned as being larger than the cells and irregular in their distribution. They are produced at certain seasons only, most conmonly in spring, and fall off after the maturity and discharge of their con-

* Grant's Outlines of Comp. Anatomy, p. 14. 
tents. * The number of the gemmules in each vesicle, and their. shape, varies in every species. In the vesicle they are comected to a central placentular column, though there are some exceptions to this, and when mature they escape outwards by a disruption or fall of the lid which closes the top, being extruded in succession and, in some cases at least, after intervals of some hours. It appear's to be deducible from some figures of Ellis, $\dagger$ rather than from his expressions, $\ddagger$ which are equivocal, that the ovules are sometimes developed into perfect polypi before their expulsion from the matrix, but the fact, though not incredible, needs confirmation, and it is certain that their birth in the oviform condition is the general rule. At this period they are clothed with cilia, as Ellis has figured them, $§$ and as Professor Grant first distinctly brought into view; and by means of the rapid vibrations of these minute organs they are carried to and fro through the water for some time, varying from a few hours to two or three days, until, having at length in due course settled on a proper site, they throw out, in the manner of a vegetable seed, a root-like fibre to fix themselves, and then push up a shoot as a commencement to the future polypidom. |f Polype-cells and polypes are rapidly evolved on the sides of this shoot, and nourishment being now re-

"So that Hedwig's axiom, adopted by MI. Virey, " that the reproductive organs of animals are contimuous with the life of the individual, while the reproductive organs of perennial plants, when their functions have been performed, are thrown off, and replaced in the succeeding season by others,"-must be received with some limitations. - See Tiedemann's Comp. Physiology, p. 76.

† Corall. pl. v. fig. A. $\mp$ Corall. Introd. p. $x$.

\$ Corall. pl. xxxviii. fig. B.

II $\mathrm{Mr}$ Lister has minutely described the ova of Campanularia gelatinosa. "The ova were roundish, and consisted of two portions; the outer and more transparent, that might be called the white, inclosing an inner bag filled with particles in fluid like those in the currents of the stem, and connected with them by the cord. The current and agitation were seen in the inuer bags only, and the flow into and from them alternately along the cord was strongly marked." As they approach maturity " the ova became more opaque, which lid the changes that might be taking place within them. The number in a full ovary was about seven." When mature they emerged from the cell "in suecession at an arerage interval of six hours. The protrusion took about a quarter of an hour, and was commonly preceded by a transparent projection, like tom membrane, before the end of the ovary, and a few active particles in the water." -Phil. Tralls. I834, [1. 375 . 
ceived from an external source, and circulating through the whole animal, there is not merely an upward growth, but creeping tubes, "full of the same living medullary substance with the rest of the body," are projected from the base along the surface of the object of fixture. "These tubes not only secure it from the motion of the waves, but likewise from these rise other young animals or corallines, which growing up like the former, with their proper heads or organs to procure food, send out other adhering tubes from below, with a further increase of these many-headed branched animals; so that in a short time a whole grove of vesicular corallines is formed, as we find them on oysters, and other shell-fish, when we drag for them in deep water." *

There are many facts which prove that the growth of these polypidoms is very rapid, but not more so than might be anticipated when it is remembered how vast is the number of polype architects; and no sooner is a new branch extended than it becomes almost simultaneously a support of new workers which, with " toil unwearyable," add incessantly to the materials of increase. Their duration is various: some have only a summer's existence, as Campanularia geniculata; many are probably annual, and the epiphyllous kinds cannot at most prolong their term beyond that of the weed on which they grow : but such as attach themselves to rocks are probably less perishable, for their size and consistency seem to indicate a greater age : it is thus with the Tubularixe and some of the compound Sertulariadx.

But the life of the polypes considered abstractedly is probably in no instance coetaneous with the duration of the polypidom, for the lower parts of this become, after a time, empty of pulp and lifeless, and lose the cells inhabited by the polypes,

- Ellis and Solander's Zoophytes, p. 33.

"New buds and bulbs the living filore shoots

"On lengthening branches, and protruding roots;

"Or on the father's side from bursting glands

" The adhering young its nascent form expands;

" In branching lines the parent-truik adorns,

"And parts ere long like plumage, hairs, or loons.

Darwin's Temple of Nature, Canto in: 
which, in an old specimen, are to be found in a state of activity only near the summit, or on the new shoots. The Thuiaria thuja affords a remarkable example of this fact; the branches which carry the polypes dropping off in regular succession as younger ones are successively formed, so that the polypidom retains, throughout its whole growth, the appearance of a bottlebrush, the naked stem and the branched top being kept in every stage in a due proportion to each other. Sertularia argentea, Plumularia falcata, \&c. are subjected to the same law,- the primary polypiferons shoots being deciduous, so that in them also the stalk becomes bare, while the upper parts are graced with a luxuriant ramification loaded with tiny architects. But in our eagerness to generalize, let us not forget that there are some species, as Sertularia pumila, abietina, \&c., in which this process of successive denudation is not observable,-perhaps, however, because of their form, which is not of a kind to be altered by it, and hence unnoticeable, or because the duration of the whole is too fugitive to permit the law to produce a visible effect.

There are facts which appear to prove that the life of the individual polypes is even more transitory than their own cells; that like a blossom they bud and blow and fall off or are absorbed, when another sprouts up from the medullary pulp to occupy the very cell of its predecessor, and in its turn to give way and be replaced by another. When speaking of flexible corallines I amouroux says, "Some there are that are entirely covered with polypi through the summer and autumn, but they perish with the cold of winter: no sooner, however, has the sun resumed his revivifying influence than new animals are developed, and fresh branches are produced upon the old ones." Of the Tubularia indivisa, Sir John G. Dalyell tells us that " the head is deciduous, falling in general soon after recovery from the sea. It is regenerated at intervals of from ten days to several weeks, but with the number of external organs successively diminishing, though the stem is always elongated. It seems to rise within this tubular stem from below, and to be dependent on the presence of the internal tenacions matter with which the tube is ac- 
cupied. A head springs from the remaining stem, cut over very near the root; and a redundance of heads may be obtained from artificial sections, apparently beyond the ordinary provisions of nature. Thus twenty-two heads were produced through the course of 550 days, from three sections of a single stem." * The observations of Mr Harvey on the same, or a very nearly allied, species of zoophyte confirm the experiments of Sir J. G. Dalyell, so far as these have reference to the deciduousness of the polypes and their regeneration; + and it seems to me not altogether unwarrantable to infer a like temporary existence and revival in those of the Sertulariadæ from a reflection on the experiments of Mr Lister,-incomplete certainly, but which prove that under certain circumstances their polypes disappear by a process of internal absorption, ${ }_{+}^{+}$and under convenient circumstances would probably have been renovated, as I have witnessed this result in similar experiments. On Saturday, May 28th 1837, a specimen of Campanularia gelatinosa was procured from the shore, and after having ascertained that the polypes were active and entire, it was placed in a saucer of sea-water. Here it remained undisturbed until Monday afternoon, when all the polypes had disappeared. Some cells were empty or nearly so, others were half-filled with the wasted body of the polype, which had lost, however, every vestige of the tentacula. The water had become putrid, and the specimen was therefore removed to another vessel with pure water, and again set aside. On examining it on the Thursday,

* Edin. New Phil. Journ. xvii. p. 415.

$\dagger$ "The most singular circumstance attending the growth of this animal, and which I discovered entirely by accident, remains to be mentioned. After I had kept the clusters in a large bowl for two days, I observed the animals to droop and look unliealthy. On the third day the heads were all thrown off, and lying on the bottom of the vessel; all the pink colouring matter was deposited in the form of a cloud, and when it bad stood quietly for twe days, it beeame a very fine powder. Thinking that the tubes were dead I was going to throw them away, but I happened to be iuder the necessity of quitting home for two days, and on my return 1 found a thin transpirent film being protruded from the top) of every tube: I then changed the water every day, and in three days time every tube had a small body reproduced upon it. The only difference that I can disrover in the structure of the young from the old heads, consists in the new ones wanting the small red papilla, and in the absence of all colour in the animal." - Proceed. Zool. Soc. No. 41, p. 55.

4 Phil. Traus. 1834, p. 374, 376 . 
(June 1st) the cells were evidently filling again, although no tentacula were visibly protruded, but on the afternoon of Friday (June 2d) every cell had its polype complete, and displayed in the greatest perfection. Had these singular facts been known to Linnaeus, how eagerly and effectively would he have impressed them into the support of his favourite theory! Like the flowers of the field the heads or "flores" of these polypidoms expand their petaloid arms, which after a time fall like blighted blossoms off a tree;-they do become "old in their youth," and rendered hebetous and unfit for duty or ornament by age or accident, the common trunk throws them off, and supplies its wants by ever-young and vigorous growths. The phenomena are of those which justly challenge admiration and excuse a sober scepticism, so alien are they to all we are accustomed to observe in more familiar organisms; but besides that faithful observation renders the facts undeniable, a reflection on the history of the Hydra might almost have led us to anticipate such events in the life of these zoophytes. "Verily for mine owne part, the more I looke into Nature's workes, the sooner am I induced to beleeve of her even those things that seem incredible."

I arrange the British species of this order under the following families and genera :

\section{Family I. HYDRAID蚱。}

Polypes gemmiparous, the young pullulating from the body of the parent.

1. Hydra. Polypes naked, single, locomotive.

Family II. TUBULARIADÆ.

Polypes gemmiparous, the gemmules naked, pullulating from the buses of the tentacula.

* No Polypidom.

2. Coryne. Polypes naked, the tentacula filiform.

3. Hermia. Polypes tunicated, the tentacula with glandular tips.

A distinct polypidom.

4. Tubularia. Polypes not retractile within cells : Polypidoms fistular, simple or branched. 
Family III. SERTULARIADA.

Polypes gemmiparous, the gemmules enclosed in externat onarim persistent vesicles scattered on the polypidom.

* Polype-cells sessile.

5. THоA. Cells indistinct, tubular or campanulate, alternate.

6. Sertularia. Cells biserial, vasiform, short, erect, the apertures everted.

7. 'Thuiaria. Cells biserial, tubular-conical, imbedded, the apertures looking forward.

8. Plumularia, Cells uniserial ; the branchlets plumose or pectinate.

9. Antennularia. Cells uniserial; the branchlets whorled. ** Polype-cells on ringed stalks.

10. Laomedea. Cells from a thickened joint of the stem, alternate, campanulate.

11. Campanularia. Cells continuous with the stem, irregular or whorled, campanulate.

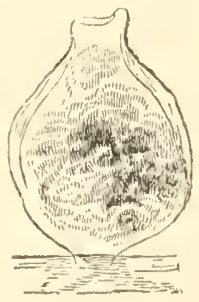


Fig. 11.

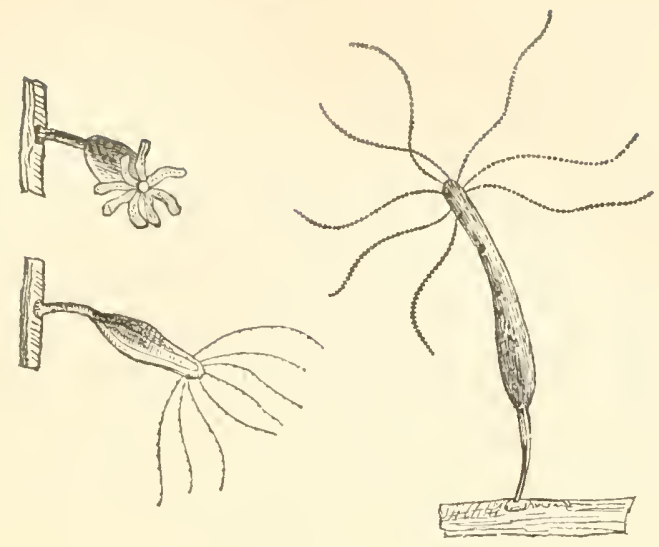

\section{Z OOPHYTA HY DROIDA.}

\section{FAMILY I. HYDRAIDÆ.}

1. Hydra, ${ }^{*}$ Linnæus.

Character.-Polypes locomotive, single, naked, gelatinous, sub-cylindrical, but very contractile and mutable in form, the mouth encircled with a single series of granulous filiform tentacula.

I. H. virIDIs, grass-green ; body cylindrical or insensibly narrowed downwards; tentacula 6-10, shorter than the body.

Woodcut, No. 4, page 37.

Polypes verds, Trembley, Mem. 29, pl. 1, fig. 1; pl. 3, fig. 1-10.Fresh-water Polypus, Trembley, in Phil. Trans. Abridg. riii. 623. Folkes, in ibid. 676. pl. 17, and pl. 18, fig. 1-3._- Hydra viridis. Lin. Fann. Suec. 367, No. 1283. Lin. Syst. 1320. Mull. Verm. I. ii. 13. Zool. Dan. prod. 230, No. 2783. Berk. Syn. i. 221. Ure's Rutherg. 232. Turt. Gmel. iv. 691. Turt. Br. Fam. 218. Lam. Anim. s. Vert. ii. 60. Stew. Elem. ii. 452. pl. 12, fig. 4, 5. Blumenbach's Man. 275. pl. l. fig. 10. Bose, Vers ii. 274. Stark, Flem. ii. 443. Wooduard in Mag. Nat. Hist. iii. 349, fig. 89. Roget, Bridgew. Treat. i. 162, fig. 59, and 176-8, fig. 73-76. Adams on the Microscope, 399, pl. 21, fig. 5.

*" $\Upsilon \delta_{\rho} \alpha$-properly " a water serpent," but the name has been appropriated to the monster of Lake Lerna, fabled to have 50 or 100 heads, of which no sooner was one of them cut off, than two sprouted ont in its place. From this property Limmens was obrionsly led to apply the name to the animalcules in question. 
Carus, Comp. Anat. tab. 1. fig. 1.__..H. viridissima, Pall. Elench. 31. Third sort of Polype, Baker, Polyp. 19 c. fig._L_Le Polype vert, Cuv. Reg. Anim. iii. 295.—L'Hydre verte, Blainv. Actinol. 494. pl. 85 , fig. 1 .

Hab. Ponds and still waters, common thronghont England, and the south of Scotland. In almost all the parishes in the vicinity of Glasgow, Ure.

The polypes of this species differ from the following, " not only in colour, but likewise in their arms, which were much shorter in proportion to their bodies, capable of but little extension, and narrower at the root than the extremity, which is contrary to the other species. Their arms were so short, they could not clasp round a very small and slender worm, but seemed only to pinch it fast, till they could master and devour it, which they did with as much greediness as any. I imagined these polypes owed their green colour to some particular food, such as weeds, \&c. and that they would lose it upon being kept to worms; but I find myself mistaken, for they retain their greenness after some months as well as ever, and are now grown of a moderate size, extending sometimes three quarters of an inch; their arms are also lengthened very much to what they were, and are of a lighter green than the body, their number eight, nine, or ten. The tail is very little slenderer than the body, but more spread at the end than the tails of other kinds."-Baker.

Pallas says that the offspring are produced from every part of the body, while Blainville thinks he has remarked that they shoot always from the same place, "au point de jonction de la partie creuse et de celle qui ne l'est pas." Blainville is candid enongh, however, to inform us that Professor Van der Höven had made some observations adverse to his opinion; ${ }^{*}$ and our own are certainly in accordance with those of Pallas and of the Professor of Leyden.

Trembley is careful to tell us that he discovered this species in June 1740 , nor can we smile at the particularity of the record when we remember that the discovery is the foundation of his immortal fame. $\uparrow$ It was first observed in England in the spring of 1743 by a $\mathrm{Mr}$ Du Cane of Essex. It appear's to be a hardy animal. I have kept it for more than twelvemonths in a small vial of water unchanged during the whole of that time, and it remained lively, and bred freely, feeding on the minute Entomostraca confined with it, and which propa-

- Bulletin des Sc. Nat. xvi. 337.

† "Trembley (Abraham), de Genéve, ne en 1710, mort en 1784; immortel par le découverte de la reproduction du polype."-Cuvier, Reg. Animal. iii. 422. - Blumenbach also informs us that his obscrvations on this polype first led him to his ingenions investigations on the Nisus formativus. 
gating much more abundantly, furnisherl a good supply of what was evidently a farourite food.

2. H. vulgaris, orange-brown or sometimes oil-green; body cylindrical ; tentacula 7-12, as long or longer than the body.

\section{Plate I.}

Polypes de la seconde espéce, Tremb. Mem. pl. 1, fig. 2, 5 ; pl. 2. fig. 2 ; pl. 6. fig. 2 and 8 ; pl. 8. fig. $1-7$; pl. 10. fig. $1-7$; pl. $11,12,13$. figs. omn. partly ropied in Adams, Micros, 399, pl. 21. fig. 6.—-Hydra vulgaris, Pall. Eleuch. 30. Ellis in Phil. Trans. Ivii. 430. Ellis and Soland. Zooph. 9.—H. grisea, Lin. Syst. 1320. Mull. Zool. Dan. Prod. 230, No. 2784. Verm. i. ii. 14. U're's Rutherg. 233. Berk. Syn. i. 222. Turt. Gmel. iv. 692. Turt. Brit. Faun. 218. Blumenb. Man. 295. Stew. Elem. ii. 452. Lam. Anim. s. Vert. ii.60. Bose, Vers ii. 275. Stark, Elem. ii. 443. Templeton in Mag. Nat. Hist. ix. 418.-H. brunnea, Templeton, loc. cit. 417. fig. 56._- First sort of Polype, Baker, Polyp. 17. c. fig._L_Hydre commune, Blainv. Actinol. 495 .

Hab. Weedy ponds and slowly running waters Probably common in all parts of the kingdom.

On comparing the descriptions of the authors quoted above, I am led to conclude that this species is either subject to much variety, or that two species have been confounded together, and given rise to a discrepancy which seems otherwise irreconcileable. My own experience inclines me to the latter supposition, but since I have had no opportunities of making observations on specimens from different and distant localities, I deem it more prudent to indicate what appear to be two species as only varieties of the vulgaris, until the point can be settled by more leisured naturalists.

Var. a. aurantia, light reddish-brown or orange-coloured; tentacula not longer than the body. Fig. 2.

Var. b. grisea, light olive-green; tentacula paler and longer than the body. Fig. 1.

The first is by much the commoner, and does not exceed the II. viridis in size, which it resembles also in its habits and form. It is always of an orange, brown, or red colour, the intensity of the tint depending on the nature of the food, on the state of the creature's repletion, becoming even blood-red when fed upon the small crimson worms and larvæ which usually abound in its haunts.* The ten-

* "I have found a bright red Hydra rather abundant on Putney Heath, near London. It does not much differ, except in colour, from the green one." $J$. E. Gray in lit. May 6, 1833._-See Trembley's Mem. p. 47, and 128. 
tacula in all my specimens have never exceeded the length of the body, are usually seven or eight in number, and taper to the point insensibly. Every part of the body is generative of young, which may frequently be seen hanging from the parent at the same time in different stages of their growth. Baker's figure represents this variety very well.

The second is a larger animal and comparatively rare, less sensible to external impressions, and of a more gracile form. Its colour is a dilute olive-green with paler tentacula, which are considerably longer than the body, and hang like silken threads in the water, waving to and fro without assuming that regular circular disposition which they commonly do in the $H$. viridis. I lave not observed more than one young at a time, pnllulating from near the middle of the body, and after this has attained a certain growth, the polype has the appearance of being dichotomously divided.

Dr Fleming's Hydra vulgaris, Brit. Anim. 553, embraces this and the preceding, as well as the following species, which are considered the mere variations of one protean original ;-

" Facies nor omnibus una,

Nec diversa tamen :"-

but the conviction of their permanent distinctness has been forced upon me by a long continuous observation of individuals in a state of confinement. Had, however, personal observation been wanting, the same conclusion would have been willingly adopted on the paramount authorities of Trembley and Baker, who had very carefully studied these creatures; and Pallas speaks very decidedly to the same purport. "Species Hydræ a Linnæo* pro varietatibus habitas, a Ræselio primum bene determinatas adoptavi, cum de trium priorum constantia, propria me experientia certissimum reddiderit."-Elench.29.

3. H. FUSCA, brown or griseous; inferior half of the body suddenly attenuated; tentacula several times longer than the body. Vignette, No. 11, page 93.

Polypes à long bras, Tremb. Mem. pl. 1. fig. 3, 4,6; pl. 2. fig. 1, 3, 4; pl. 3 , fig. 11 ; pl. 5, fig. $1-4$; pl. 6 , fig. $3-7,9,10$; pl. 8 . fig. 8 , 11 ; pl. 9 . copied in Adams, Micros. 399, pl. 21, fig. 7, 8 ; pl. 23, A. B ; pl. 24, A. B. fig. omnes. Cuv. Reg. Anim. iii. 295.__ Long armed fresh-water Polype, Ellis, Corall. xvi. pl. 28. fig. C. (the tentacula shortened for the conveniency of introducing them within the size of the plate.) __ Second sort of I'olyje, Baker, Polyp. 18. c. fig.-Hydra oligactis, Pall. Elencb. 29._-H. fusca, Lin. Syst. 1320. Ellis and Solund. Zooph. 9. Berk.

* In the 10th edit. of Syst. Nat. p. 816, under the name of Iydra Polypus. 
Syn. i, 221. Turt. Gmel. iv. 991. Blumenb. Man, 275. Turt. Brit. Faun. 218. Stew. Elem. ii. 452. L,am. Anim. s. Vert. ii. 60. Bosc, Vers, ii. 275.—L'H. brune, Blainv. Actinol. 495.

Hab. Still waters in England, rare. In a pond at Hackney, $\mathbf{M r}$. John Ellicot.**

"The tails of these are long, sleniler, and transparent, and when placed before the microscope, a long straight gut nay plainly be distinguished passing from the body-part or stomach to an opening at the end thereof. These are rather lighter coloured than the former, (II. vulgaris,) and have seldom more than six or eight arms, but those capable of great extension."-Baker.

Baker reckoned that his English exemplars were of a sort different from those he had received from M. Trembley, but the only ap. parent difference lies in the greater shortness of the tentacula of the former, and this is a character liable to considerable variation, and insufficient of itself for specific distinction. The species has been beautifully illustrated in Trembley's "Mémoires," by the pencil and graver of the celebrated Lyonet, for it is an interesting fact that all the figures, and nost of the plates, which adorn the admirable book just mentioned, were drawn and etched by the anthor of the "Traité anatomique de la chenille du saule," $\dagger$ and are indeed among the very earliest specimens of his extraordinary attainments in these arts.

It may be worth while to call attention to the remarkable resemblance of the Hydra fusca to the Cucullanus cirratus of Muller, Zool. Dan. tab. 38, fig. 1-7, which is an intestinal worm!

4. H. verRucosa, pale cinereous; body pedunculate, campaniform; tentacula longer than the body.

Hydra verrucosa, Templeton, in Mag. Nat. Hist. ix. 418, fig. 57.

Hab. Still waters. "In the pond at Cranmore (near Belfast,) Sept. 1812," J. Templeton, Esq.

"Of a pale cinereous hue, with six verrucated tentacula, of moderate length, and nearly equal thickness."__ "This species, when at rest, assumes more of a campanulate form than any other species of the genus, except lntea and the following. The warts are not uniformly diffused, as in pallens; nor do the tentacula diminish much in size towards the tips." $-T$ empleton.

* Elected F. R. S. Oct. 26, 1738; and the author of several papers on subjects in Natural Philosophy, published in the Phil. Trans. between the years 1745 and 1750. He was a watchmaker, and died in 1772 .

+ " Ouvrage qui est à la fois le chef-d'œurre de l'anatomie et celui de la gravure."-Curior. 


\section{* Marine species.}

5. H.? LITTORALis, "white; head large; about 10 extremely short teutacula encircling the base."-Robert Jameson. *

Hydra lutea? Jamesm, in Wern. Mem. i. 565-H. lutea, Flem. Brit. Anim. 554.-H. corynaria, Templeton, in Mag. Nat. Hist. ix. 419, fig. 58. Hab. Sea shore, adhering to Fuci. Frith of Forth, Professor Jumeson. "Found adhering to Fucus vesiculosus, at White House Point, Belfast Lough, Oct. 1810," J. Templeton, Esq.

'The fignre represents a branched animal with enlarged clavate heals encircled round the truncate apex, with tentacula rather shorter than the diameter.-To justify the change I have made in the name, it is only necessary to mention that nothing can be more certain than that this species is not identical either with the Hydra lutea or corynaria of Bosc.

\section{OBservations.}

Leeuwenhoek $\nmid$ discovered the Hydra in 1703, and the uncommon way its young are produced, and an anonymons correspondent of the Royal Society made the same discovery in England about the same time, but it excited no particular notice until Trembley made known its wonderful properties, about the year 1744. These were so contrary to all former experience, and so repugnant to every established notion of animal life, that the scientific world were amazed; and while the more cantious among naturalists set themselves to verify what it was difficult to believe, there were many who looked upon the alleged facts as impossible fancies. The discoveries of Trembley were, however, speedily confirmed; and we are now so familiar with the outlines of the history of the fresh-water polype, and its marvellous reproductive powers, that we can scarcely appreciate the vividness of the sensation felt when it was all novel and strange; when the leading men of our learned societies were daily experimenting on these poor worms, and transmitting them to one another from distant countries, lyy careful posts, and as most precions gifts; and when even ambassador's interested themselves in sending early intelligence of the engrossing theme to their respective courts.

* The name affixed to the specific character is that of the person who, so far as I have been able to ascertain the point, added the species to the British Famna.-Mr Jameson is the present Regius Professor of Natural History in the University of Edinburgh.

+ "Antonius v. Leeuwenhoek, civis Delphensis, peritus vitrorum politor, curiosus, et ad paradoxas opiniones pronus." Haller, Bib. Bot. i. 583. He Was boln 1632 ; elected F. R. S. January 1680 ; and died in 1723. 
The Hydræ are found in fresh and, perhaps, also in salt waters, but the former species only have been examined with care, and are the objects of the following remarks. They prefer slowly running or almost still water, and fasten to the leaves and stalks of submerged plants by their base, which seems to act as a sucker. The body is exceedingly contractile, and lience liable to many changes of form: when contracted it is like a tubercle, a minute top or button, and when extended it becomes a narrow cylinder, being ten or twelve times longer at one time than at another, the tentacula suffering changes in their length and diameter equal to those of the body. "It can lengthen out or shorten its arms, withont extending or contracting its body ; and can do the same by the body, without altering the length of its arms : both, however, are usually moved together, at the same time and in the same direction."-The whole creature is apparently homo. geneons, composed of minute pellucid grains cohering by means of a transparent jelly, for even with a high magnifier no defined organization of ressels and fibres can be detected. On the point opposite the base, and in the centre of the tentacula, we observe an aperture or mouth which leads into a wider cavity excavated as it were in the midst of the jelly,* and from which a narrow canal is continued down to the sucker. When contracted, and also when fully extended, the body appears smooth and even, but " in its middle degree of extension," the sides seem to be minutely crenulated, an effect probably of a wrinkling of the surface, although from this appearance Baker has concluded that the Hydra is annulose, or made up of a number of rings capable of being folded together or evolved, and hence, in some measure, its extraordinary ability of extending and contracting its parts. $\dagger$ That this view of the Hydra's structure is erroneous, Trembley has proved ; $\ddagger$ and the explanation it afforded of the animal's contractility was obviously unsatisfactory, for it was never pretended that

* Pallas denies this. "Ab alimento recepto cavatce, inquam, haud enim Hydræe corpus naturaliter intestini instar cavum erediderim. Totum solidum et medullare, pro admoto alimento, ceræ instar, digitum admittentis, cavari concipio parenchyma et alimentis insinuatis sese circumfundere. Qui alias per longitudinem dissecta Hydra, illico qualibet portione deglutire, et caro clauso alimenta condere posset? quod tamen obselvare rarum non est." Elench. Zooph. 27, 28. - For a view of the Hydra's stomach see Tremb. Mem. pl. 4, fig. 7, copied by Roget in his Bridgew. Treat. ii. 74, fig. 241.

+ "The outward coat is white like the arms, and made up of minute annuli or ringlets, that donble in the midst, and can, occasionally, be folded close to gether, in the manner of a paper lanthorn."-Hist. of the Polype, 25.

† Mem. 27. 
such an antatomy could be detected in the tentacula, which, however, are equally or more contractile. These organs encircle the mouth and raliate in a star-like fashion, but they seem to originate a little under the lip, for the mouth is often protruded like a kind of small snont: they are cylindrical, linear or very slightly tapered, hollow and roughened, at short and regular intervals, with whorls of tubercles which, under the microscope, form a very beautiful and interesting ohject; and I have thought, when viewing them, that every lit. the tubercle might be a cup or sucker similar to those which garnish the arms of the cuttle-fish.* Trembley has shewn us that this is a deception, and that there is really no exactness in the comparison. $t$ The tentacula are amazingly extensible, from a line or less to ore or, as in H. fusca, to more than eight inches; and " another extraordinary circumstance is, that a polype can extend an arm in any part of its whole length, without doing so thronghout, and can swell or lessen its diameter, either at the root, at the extremity, in the middle, or where it pleases : which occasions a great variety of appearances, making it sometimes terminate with a sharp point, and at other times lilunt, knobbed, and thickest at the end, in the figure of a bohbin." We naturally enquire how this wonderful extension is made,by what power a part withont muscularity is drawn out until it exceeds by twenty or even by forty times the original length? The dissections of Trembley have proved beyond any doubt that the body is a hollow cylinder or bowel, and that the tentacula are tubular and have a free communication with its carity ; and in this structure, combined with the loose granular composition of the animal, we find an answer to the question. Water flows, let us say by suction, into the stomach throngh the oral aperture, whence it is forced by the vis a tergo, or drawn hy capillary attraction, into the canals of the tentacula, and its current outwards is sufficient to push before it the soft yielding material of which they are composed, until at last the resistance of the living parts suffices to arrest the tiny flood, or the

* Pallas has the same suggestion. Elench. 26. See also Roget's Bridgew. Treat. i. 182.- Baker says that "two or three pretty long hairs" issue from each of the papillie or tubercles, p. 36 ; and Trembley has figured a short hair issuing from some of the $14 \mathrm{~cm} .62, \mathrm{pl} .5$, fig. 3 . This appearance of hairs is, I presume, produced by the glutinous secretion from them being drawn out into fine lines and drying on the glass. The tentacula probably adhere to foreign bodies principully by means of a mucous exeretion, and being as it were engrained into the microscopic interstices of the body to which they areapplied.Tremb. Mem. 46.

+ Mem. 108.

† Ibid. 123-5; and 263 . 
tube has become too fine in its bore for the admission of water attenuated to its smallest possible stream,- - how inconceivably slender may indeed be imagined, but there is no thread fine enough to equal it, seeing that the tentacula of Hydra fusca in tension can be compared to nothing grosser than the scarce visible filament of the gossamer's web.

The Hydra, though usually found attached, can nevertheless move from place to place, which it loes either by gliding with imperceptible slowness on the lase, or loy stretching out the body and tentacula to the utmost, fixing the latter, and then contracting the body towards the point of fixture, loosening at the same time its hold with the hase; and by reversing these actions it can retrograde. Its ordinary position seems to be pendant or nearly horizontal, hanging from some floating weed or leaf, or stretching from its sides. In a glass of water the creature will crawl up the sides of the vessel to the surface, and hang from it, sometimes with the base, and sometimes with the tentacula rlownwards; and again it will lay itself along horizontally.* Its locomotion is always very slow, and the disposition of the zoophyte is evidently sedentary; but the contractions and mutations of the body itself are sufficiently vivacions, while in seizing and mastering its prey it is surprisingly nimble; seizing a worm, to use the comparison of Baker, "with as much eagerness as a cat catches a monse." It is dull and does not expand freely in the dark, but enjoys light, and hence undoubtedly the reason why we generally find the Hydra near the surface and in shallow water.

The Hydræ are very voracions, feeding only on living animals, t but

* "The position in which they appear to take most delight, is that of remaining suspended from the surface of the water by means of the foot alone: and this they effect in the following manner. When the flat surface of the foot is exposed for a sliort time to the air, above the surface of the water, it becomes dry, and in this state exerts a repulsive action on the liquid, so that when drag ged below the level of the surface, by the weight of the body, it still remains uncovered, and occupies the bottom of a cup-shaped hollow in the fluid, thereby receiving a degree of buoyancy, sufficient to suspend it at the surface. The principle is the same as that by which a dry needle is supported on water, in the boat-like hollow which is formed by the cohesive force of the liquid, if care be taken to lay the needle down very gently on the surface. If, while the Hydra is floating in this manner, suspended by the extremity of the foot, a drop of water be marle to fall upon that part, so as to wet it, this hydrostatic power will be destroyed, and the animal will immediately sink to the bottom." - Rogret. Bridgw. Tr. i. 179. This passage is nearly a literal translation fron Trembley's Hist. des Polypes, p. 37-8.

$\dagger$ In confinement however, Trembley fonnd that they might be fed on minred fish, beef, muton, or veal.-11/ 104. 
when necessary they can sustain a fast of many weeks without other loss than what a paler colour may indicate. Small larvæ, worms, and entomostracous insects seem to be the favourite food, and to entrap these they expand the tentacula to the utmost and spread them in every direction, moving them gently in the water to increase their chances, and when a worm, \&c. touches any part of them it is immediately seized, canied to the mouth by these flexible and contractile organs, and forced into the stomach. "'Tis a fine entertainment," says Baker, "to behold the dexterity of a polype in the mastering" its prey, and observe with what art it evades and overcomes the superior strength or agility thereof. Many times by way of experiment, I have put a large worm to the very extremity of a single arm, which has instantly fastened on it with its little invisible claspers. Then it has afforded me inexpressible pleasure to see the polype poising and balancing the worm with no less seeming caution and judgment than a skilful angler shows when he perceives a heavy fish at the end of a single hair-line, and fears it should break away. Contracting the arm that holds it, by very slow degrees, he brings it within the reach of his other arms, which eagerly clasping round it, and the danger of losing it being over, all the former cantion and gentleness is laid aside, and it is pulled to the polype's mouth with a surprising violence."* Sometimes it happens that two polypes will seize upon the same worm, when a struggle for the prey ensues, in which the strongest gains of course the victory; or each polype begins quietly to swallow his portion, and continues to gulp down his half until the months of the pair near and come at length into actual contact. The rest which now ensues appears to prove that they are sensible of their untoward position, from which they are frequently liberated by the opportune break of the worm, when each obtains his share, but should the prey prove too tough, woe! to the unready! The more resolute dilates the month to the requisite extent, and deliberately swallows his opponent, sometimes partially, so as, however, to conpel the discharge of the bait, while at other times the entire polype is engulperl But a polype is no fitting food to a polype, and his capacity of endurance saves him from this living tomb, for after a time, when the worm is sucked out of him, the sufferer is disgorged with no other loss than his dinner. This fact is the more remarkable when it is contrasted with the fate which awaits the worms on which they feed. No sooner are these laid hold upon than they evince every symptom of painful suffering, but their violent contortions are

* Ulist. of the Polype, 65. Also Roget's Bridgw. Treat ii. 76

+ Trembley, Hem. 112. 
momentary and a certain death suddenly follows their cupture. How this effect is prodnced is mere matter of conjecture. Worms, in ordinary circumstances, are most tenacious of life even under severe wounds, and hence one is inclined to suppose that there must be something eminently poisonous in the Hydra's grasp, as it is impos. sible to believe, with Baker, that this soft toothless creature can bite and inject a venom into the wound it gives. "I have sometimes," says Baker, "forced a worm from a polype the instant it has been litten, (at the expence of breaking off the polype's arms,) and have always observed it to lie very soon afterwards, without one single instance of recovery." To the Entomostraca, however, its touch is not equally fatal, for I have repeatedly seen Cyprides and Daphnixe entangled in the tentacula and arrested for some considerable time, escape even from the very lips of the month, and swim about afterwards unharmed; perhaps their shell may protect them from the poisonous excretion.-The grosser parts of the food, after some hour's digestion, are again ejected by the month; lut, as alrealy mentioned, the stomach is furnished with what, in one sense, may be calles an intestine to which, according to Trembley and Baker, there is an outlet in the centre of the base, and the latter asserts that he has, "sever"al times, seen the dung of the polype in little round pellets lischarged at this outlet or anus." +

* Hist. of the Polype, 33-comp. with 67-8._- " That insignificant and inactive insect called the fresh water polypus, of all poisonous animals, seems to possess the most powerful and active venom. Small water-worms, which the polypus is only able to attack, are so tenacious of life, that they may be cut to pieces without their seeming to receive any material injury, or to suffer much pain from the incisions. But the poison of the polypus instantly extingnishes every principle of life and motion. What is singular, the mouth or lips of the polypus have no sooner toucher this worm than it expires. No wound, however, is to be perceived in the dead animal. By experiments made with the best microscopes, it has been found, that the polypus is neither provided with teeth, nor any other instrumert that could pierce the skin." Smellie's Phil. of Nat. History, ii. 462.- The fact that fishes cannot be made to swallow Hydre, seems to prove the presence of some irritating quality in the latter.- See Trembley, Mem. 137.

$\dagger$ Lib. s. cit. 27. - He adds, - " Nuch the greater and grosser part of what the polype eats, is most certainly thrown ont again by the mouth, after lying a proper time to become digested in the stomach: and, for a good while, I imagined there was no other evacuation; but am now convinced, that the finer part, $i_{11}$ small quantity, is carried downwards through the tail, and passed off that way: $I$ believe however there is also another pupose to which this passage serves, and that is, to convey a mucus or slimy matter to the end of the tail, for its more ready adhesion to sticks, stalks, or other bodies." 
But the Hydra is principally celebrated on account of its manner of propagation. It is of course like zoophytes in general, asexual; and every individual possesses the faculty of continuing and multiplying its race, principally, however, by the process of subdivision. During the summer season, a small tubercle rises on the surface, which lengthening and enlarging every hour, in a day or two de. velopes in irregular succession, or in snccessive pairs,* a series of tentacula, and becomes in all respects, excepting size, similar to its parent. It remains attacher for some time, and grows and feeds, and contracts and expands after the fashion of this parent, until it is at length thrown off by a sort of sloughing or exfoliation. These buds sprout, in the common species, from every part of the surface of the body, but not from the tentacula; and very often two, three or four young may be seen depending at one time from the sides of the fruitful mother, in different stages of growth, every one playing its part independent of the others:

"_-_where some are in the bud,

" some green, and rip'ning some, while others fall."

They are evolved with rapidity in warm weather especially, one no sooner dropping off than another begins to germinate; " and what is most extraordinary, the young ones themselves often breed others, and those others sometimes push out a third or fourth generation before the first fall off from the original parent."-Trembley found in one experiment that an indivirhal of $\mathrm{H}$. grisea produced forty-five young in two months; the average number per month in summer was twenty, but as each of these began to produce four or five days after its separation, the whole produce of a month was prodigious. $\uparrow$

"No sooner is a young one furnished with arms, than it seizes and devours worms with all possible eagerness; nor is it an unusual thing to behold the young one and the old one struggling for, and gorging different ends of the same worm together. Before the arms come out, and even sometime afterwards, a communication continues between the bodies of the old and young, as appears beyond dispute by the swelling of either when the other is fed. $\ddagger$ But a little before the young one separates, when its tail-end begins to look white, trans. parent, and slender, the passage between them, I believe, is closed. And when the young one comes away, there remains not the least

* Baker's Hist. 3j.

† Mem. pour l'Hist. des Polypes, 174-5. Also Baker, lib. s. cit. 53-4.

\# By some clever dissertions, Trembley demonstrated the reality of this comnunication. $11 \mathrm{~cm}, 16 \mathrm{l}-2$. 
mark where it had been protruded." - " After a young polype once gets all its arms, it alters indeed in size, but neither appears to shift its skin, or undergo any of the changes most other insects do."

Instead of buds or little protuberances, the body sometimes pushes forth single tentacula scattered irregularly over it, and these tentacula can be metamorphosed into perfect polypes, the base swelling out to become the body, which, again soon shoots out additional tentacula to the requisite number $! \dagger$

This is a mode of generation which the term viviparous does not correctly embrace, unless we give to that word a signification so extensive as to include all generations which are not oviparous: It is an example of equivocal, or what some foreigu physiologists denominate, the generation by the individualisation of a tissue previously or already organised, $\downarrow$ - and seems to be the usual way of propagation among the Hydre during the summer months. But in antumn the Hydra generates internal oviform gemımnles which, extruded from the body, lie during the winter in a quiescent state, and are stimulated to evolution not until the return of spring and its genial weather. Few observations have heen made on these apparent ova, so that their structure, their source, their manner of escape from the body, and their condition during winter are scarcely known. Trembley describes them as little spherical excrescences, of a white or yellow colour, attached to the body by a very short pedicle. He never saw more than three on the same polype. After some time they became separate, and fell to the bottom of the glass of water in which the creatures were kept, where they came to nothing, excepting one only which was presumed to have evolved into a polype, for although his experiment renlers this conclusion probahle, it was still rather an inference than an actual observation, so much so, that Trembley continued to entertain doubts of their nature. Jussieu, it seems, conceived that each little excrescence was a vesicle filled with ova of

- Baker, lib. s. cit. 50.

$\dagger$ Baker ut cit. 110-11: 121-3.

† La génération n'est pas pour cela spontanée; une génération spontanće doit être la production d'un être organisé de toutes pièces, lorsque des élémens inorganiques se réuniront pour produire un animal, une plante. Cette génération est impossible, et n'a jamais lieu. Une génération équivoque est celle où des tissus organisés préalablement par un être déjì pourvu de vie, s'individualisent, e'est-a-dire se séparent de la masse commune et participent encore, après cette séparation, de l'état dynamique de la masse, c'est-à-dire de sa vie, mais, à son propre profit. C'est ainsi qu'un tissu produit un Eritozoaire. C'est de la vie continuée."-Ch. Morren in Ann. des Sc. Nat. an. 1836, Vol. vi. p. 90. Part. Zool. 
microscopic minuteness, but there is no foundation for any such hy. pothesis. *

These are the modes in which the Hydra naturally multiplies its kind, but it can be increased, as already hintel, by artificial sections of the body, in the same manuer that a peremial plant can he hy slips and shoots. If the body is halved in any direction, each half in a short time grows up a perfect Hyilra; if it is cut into four or eight, or even minced into forty pieces, $†$ each continues alive, anil de. velopes a new animal, which is itself capable of being multiplied in the same extraordinary manner. If the section is made lengthways, so as to divide the borly into two or more slips "connected merely by the tail, they are speedily resoldered, like some heroes of fairy tale, into one perfect whole; or if the pieces are kept asunder, each will become a polype, and thus we may have two or several polypes witl only one tail between them; but if the sections be made in the contrary lirection - from the tail towarls the tentacnla-you proluce a monster with two or more bodies and one head. If the tentacula,-the organs by which they take their prey, and on which their existence might seem to depend,-are cut away, they are reproduced, and the lopt off parts remain not long without a new body: if only two or three tentacula are embraced in the section, the result is the same; and a single tentaculum will serve for the evolntion of a complete creature. $\ddagger$ When a piece is cut out of the body the wound speedily beals, and, as if excited by the stimulus of the knife, young polypes sprout from the wound more abundantly, and in preference to unscarred parts; when a polype is introduced by the tail into another's body, the two unite and form one individual; and when a heal is lopt

* Trembley, Mem. 196-7.

† "J'ai ouvert sur ma main un Polype, je l'ai étendu, et j'ai conpé en tout sens la peau simple qu'il formoit, je l'ai rednit en petits morceanx, je l'ni en quelque maniére haché. Ces petits morceaux de peau, tant ceux qui aroient des bras, que ceux qui n'en avoient point, sont devenns des Polypes parfaits."Trembley, Mem. 248. Romé de Lisle attempted to lessen the remarkableness and singularity of this fact by supposing that the 1Hydra was a colony of minute animaleules beld together in a moveable polypidom, represented by the this outer cuticle, and of course that this eutting and division only set free a number of independent entire beings. The hypothesis is a bold one, but has nothing in the way of observation to support it. See Blainv. Actinol. p. 563.

From the experiments of Trembley; (Mem. 235, ) of a correspondent of Baker's and of Baker himself, it would seem that a tentaculum eamot produre a new hody umless a part of the head or body is removed with it (1list. 19:3-4,); but other experimentalists are said to have suceeded when this was not done. For the particulars stated in the text, and others cqually incredible, the reader may consult the work' of Trembley and Baker, passim. 
off it may safely be ingrafted on the body of any other which may chance to want one. You may slit the animal up, and lay it out flat like a membrane, with impunity; nay it may be turned inside out, so that the stomachal surface shall become the epidermous, and yet continue to live and enjoy itself. * And the creature even suffer's very little by these apparently cruel operations,

His wound,-"

_-" scarce seems to feel, or know

for hefore the lapse of many minutes, the upper half of a cross section will expand its tentacula and catch prey as usual; and the two portions of a longitudinal division will, after an hour or two, take food and retain it. "A polype cut transversely, in three parts, requires four or five clays in summer, and longer in cold weather, for the middle piece to produce a head and tail, and the tail part to get at body and head, which they both do in pretty much the same time. The head part always appears a perfect polype sooner than the rest." "And what is still more extraordinary, polypes produced in this manner grow much larger, and are far more prolific, in the way of theil natural increase, than those that were never cut. It is very common when a polype is divided transversely, to see a young one push out from one or other of the parts, and sometimes from both of them, in a very few hours after the operation bas been performed: and particularly from the tail part, two or three are frequently protruded in different places, and at different times, long before that part acquires a new head, and consequently whilst it can take in no fresh nomishment to supply them with : and yet the young ones proceeding from it, under these disadvantages, thrive as fast, and seem as vigorous as those produced by perfect and uncut polypes." +

When such things were first announced-when to a little worm the attributes of angelic beings were assigned + -it is not wonderful that

* Trembley had several by him " that have remained turned in this manner; their inside is become their outside, and their ontside their inside : they eat, they grow, and they multiply, as if they had never been turned."-Phil. Traus. Abridg. viii. 627 ; and his Mem. 253, \&c.

† Baker, lib. s. cit. 92,93 .

‡ "Vital in every part, not as frail Man

In entrails, heart or head, liver or veins,

Canıot but by annihilating die;

Nor in their liquid texture mortal wound

Receive, no more than can the fluid air,

All heart they live, all head, all eye, all ear,

— _ _ _ and, as they please,

They limb themselves, and colour shape or size

Assume, as likes them best."

Milton. 
the vulgar disbelieved, albeit credulity may be their besetting sin, when even naturalists, familiar with all the miracles of the insect world, were amazed and wist not what to do. "Il faut"-exclaimed Reaumur_." il fant porter la foi humaine plus loin qu'il n'est permis à des hommes eclairés, pour le croire sur le premier témoignage de celui qui le raconte, et assure l'avoir vu. Peut-on se resoudre à croire qu'il y ait dans la nature des animaux qu'on multiplie en les hachant, pour ainsi dire, par morceaux?" * But this illustrious naturalist was himself the first to promulgate, and experimentally to verify, the discoveries of Abraham Trembley, which have been fully confirmed by many subsequent inquirers, and are now made so familiar to us by their admission into elementary works and treatises on natural theology, that we read of them with little surprise and without incredulousness.

* Hist. des Insectes, vi. pref. 49. 


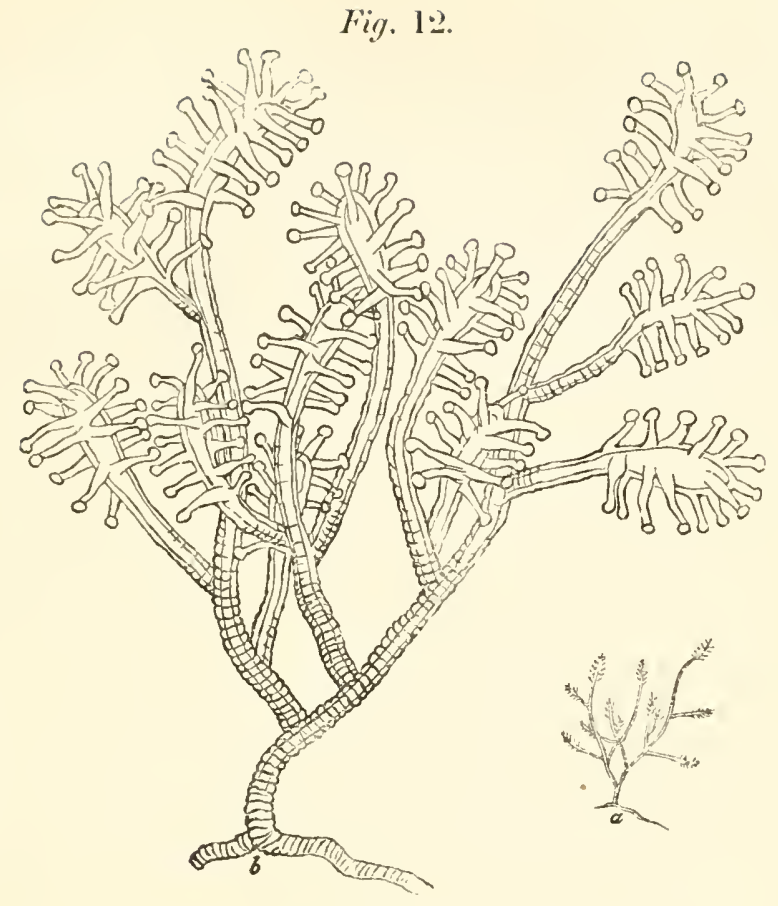

FAMILY II. TUBULARIADE.

2. Coryne, Grortner.

Character.-Polypes fixed, single, naked, cylindrical, or claviform but contractile, the head with scattered filiform smooth tentricula: mouth 0 ?

1. C. SQuamata, body more or less clavate; the tentaculo shorter than the body. Gærtner. $\uparrow$

Plate II.

Hydra squamata, Mull. Zool. Dan. prod. 230, no. 2786. Zool. Dan. tab. iv. fig. 1_3. Fabric. Faun. Groenl. 347.___Polyporum species margine conchie insidentes, Bast. Opuse. Subsec. i. 44, tab. 5, fig. 2, c.-Tubu-

* Coryne $=$ clava $=$ a club.

† Gartner, Joseph, M. D. a native of Wurtemburg, born in 1732; elected F. R. S. in 1761 ; died in 1791. Having visited England, he made several zoological discoveries on the southern coast, published in the Plil. Truns., and the Spicilegia Zoologica of Pallas. He is celebrated for his work "De Fructibus et Seminibus Plantarum." There is an interesting biographical sketch of him in Thomson's History of the Royal Society, p. 46-7. 
laria affinis, Turt. Gmel. iv. 668. Turt. Brit. Faun. 210. Stew. Elem. ii. 438. Bose, Ver. iii. 92._Coryne squamata, Jameson in Wern. Mem. i. 565. Lam. Anim. s. Vert. ii. 62, 2de edit. ii. 73. Bosc, Vers. ii. 279. Fleming in Edin. Phil. Journ. ii. 87. Flem. Phil. Zool. ii. 616, tab. 5. fig. 1. Flem. Brit. Anim. 553. Coldstream in Edin. New Phil. Journ. ix. 234. Stark, Elem. ii. 443._L_La Coryne écailleuse, Blainv. Actinolog. 471.__C. multicornis, Templeton in Mag. Nat. Hist. ix. 419.- $-\mathrm{Hy}-$ dra capitata, Mull. Zool. Dan. prod. 230.

Hab. Parasitical on sea weeds, corallines, stones and dead shells, at and within low-water mark. "On the shore of the island of Burra, and on the Holm of Cruster, in Bressay Sound, in Shetland," Jumeson. At Abercorn; and at the Isle of May, Rev. Dr Fleming. Island of Bute, Dr Coldstrectm. Maybole, Ayrshire, Rev. George Gray. "Found in great plenty on Fucus vesiculosus at the White House Point, Belfast Lough; Aug. 1807," J. Templeton, Esq. In Berwick Bay, not uncommon.

Polypes in general gregarious, fixed by a narrow disk, from two to six or eight lines in height; clavate or cylindrical with a knobbed head, rose-coloured or white, smooth, fleshy; the head or upper part furnished with from 5 to 25 scattered filiform tentacula, which are usually much shorter than the body, and not always of equal lengths. In gravid individuals the oviform gemmules hang from the bases of the tentacula in one or several clusters; they are of a round or elliptical figure, rose-coloured with a darker centre, and large in proportion to the animal.

Towards the roots of the tentacula we can frequently observe a reddish spot which probably indicates the position of the stomach; and a dusky line prolonged down the centre of the body appears to show that the latter is hollow, the canal being doubtless intestinal. The tentacula are also tubular, as I infer from their being marked with a similar line : unlike those of the Hydra they are smooth, or merely crenulate, but like them they are capable of being shortened and elongated at will, though to a less extent. The form of the body is also varied at pleasure, but all its motions are slow, and indicate a very inferior degree of irritability. I have never heen able to discover a mouth or aperture on the top on the body, but Dr Coldstream says, "after having been kept in small vessels of sea-water for some hours, without renewal of the water, some of the animals protrude the inner surface of the mouth, so as to present a convex disc, with the tentacula ranged round it."-The young are of a fine pink or rose colour : at first they resemble little smooth rounded tubercles, which grarlually elongate, and soon acquire one, then two, three or four tentaculi, and so on until the number of maturity is completerl, for these organs are developer in succession. 
The clavate rose-red specimens I have generally found between tille marks, and the white ones with a long filiform stalk on dearl shells dredged from leeper water. On the latter is undoubtedly founded the "HYDra capita Ta alba, pedunculo rugoso longo, cirris capritis longitudine" of Muller; while the former answer better to his $H$. stuamate, but although at one time disposed to consider them distinct, I am now satisfiel of their identity as species, for they graduate so insensibly into one another as to lose even the character of fixed varieties. I am also led to suspect that the $H$. brevicornis and minuticomis of Muller, Zool. Dan. prorl. p. 230, will be found to be modifications of this species.

The Hydra Tuba of Sir J. G. Dalyell probably belongs to this genus, and may be distinguished by its tentacula being much longer than the body. It inhabits the Frith of Forth near Edinburgh, where its natural abode seems the internal concavity of the upper oystershell. It extends "about two inches in whole, with its long white tentacula waving like a beantiful silken pencil in the water. it propagates by an external shapeless bud issning from the side of the parent, and withdrawing, though very long comnected by a ligament, on approaching maturity. In thirteen months a single specimen had eighty-three descendants. Singular and distorted forms appear from the successive and irregular evolution of the buds, during subsistence of the connecting ligament." Edin. New Phil. Journ. xvii. 411 ; xxi. 92. and Rep. Brit. Assoc. an. 1834, p. 599.

\section{Hermia, * Johnston.}

Character.-Polype fixed, sheathed in a thin horny membrane, clavate or branched and subphytoidal, the apices of the liranches clubbed and furnished with scattered glandular tentacnla: mouth 0 .

\section{H. Glandulosa, irregularly or dichotomously branched ;}

" I foumd the name in Shakspeare ;

"What wicked and dissembling glasse of mine,

" Made me compare with Hermia's sphery eyne."

When 1 defined this genus in the Mag. Zool. and Bot. V. ii. p. 326, I was not arare that the same had been instituted by Sars under the name of Stipula, and by Ehrenberg who called it Syncoryne. The latter designation is in direct opposition to the Linnæean axiom- " generic names, derived from others by the addition of a syllable, are disapproved ;"-and Sars' name seems to me even more inadmissible, since it is a descriptive term in Botany. The fancy that the glands which surround the heads were the guardians of the animal,-its "sphery eyne" - suggested the name here adopted. 
the tentacula shorter than the enlarged heads of the branches. Gærtner.

Vignetre, No. 12, and Plate IV. Fig 1, 2.

Tubularia Coryna, Turt. Gmel. iv. 668. Turt. Brit. Faun. 210. Stew. Elem. ii. 438. Bosc. Vers. iii. 91.—Hydra ramosa, Fabric. Faun. Gronl. 348.—Coryne Glandulosa, Lam. Anim. s. Vert. ii. 62. 2de edit. ii. 74. Fleming in Edin. Phil. Journ. ii. 87, and viii. 295. Flem. Phil. Zool. ii. 616, tab. v. fig. 2. Flem. Brit. Anim. 553. Encyclop. Method. tab. 69. fig. 15, 16. Johnston in Trans. Newc. Soc. ii. 253 ; and in Mag. Nat. Hist. v. 631. fig. 110_—C. glanduleuse, Blainv. Actinol. 47l. pl. 85, fig. 3,3 a.—Coryne, Lister in Pbil. Trans. an. 1834, p. 376. pl. 10. fig. 3.

$H a b$. On the under surface of stones between tide-marks; on old shells, and often parasitical on Tubularia indivisa. Isle of May ; and on the Bell Rock on the coast of Angus, Rev. Dr Fleming. Maybole, Ayrshire, Rev. Geo. Gray. Brighton, Mr Lister. Scarborough, Mr Bean. Berwick Bay.

Polypes adherent by a tubular fibre which creeps along the surface of the object on which they grow, seldom an inch in height, irregularly branched, the stem filiform, tubular, horny, subpellucid, wrinkled and sometimes ringed at intervals, especially at the origin of the branches, each of which is terminated with an oval or clubshaped hear of a reddish colour, and armed with short scattered tentacula tipt with a globular apex. The ends of the branches are not perforated, but completely covered with a continuation of the horny sheath of the stem. The animal can bend its armed heads at will, or give to any separate tentaculum a distinct motion and direction, but all its movements are very slow and leisured.

When parasitical on Tubularia this zoophyte surrounds the stalks, for the space of an inch or more, with a thick beard-like mossiness composed of entangled corneous fibres, not coarser than a sewing thread, and more irregularly branched than when the polypes have greater freedom to spread. This variety is figured on Plate IV. Fig. 1,2. The stem is filled with a pulpous medulla, enlarged in the heads and continued up the tentacula, the round tips of which appeared to be smooth and areolar under a magnifier, but Mr Lister says they are covered with "short projections like blunt hairs," " and it seems to be by their means that the polypi attach with a touch, or release at will, substances that drift within their reach." Mixed with the tentacula, on some heads, there are a few round and larger bodies of a deep red colour in the centre with a transparent albuminous envelope: these are supported on a very short stalk, and are evidently the gemmules by which this species is propagaterl. 
On examining a few tubes under the microscope I perceived in one of them, and only in one, a crowd of minute elliptical bodies which were in active motion, ruming up the tube on one side, and down on the other, but frequently crossing, nor was it uncommon to see one accelerate its pace and beat the others in the race. The tube had lost its head, and the moving bodies were evidently, as I think, infusory animalcules which had got admission into it; - the currents they created are therefore to be distinguished from those observed by $\mathrm{Mr}$ Lister, analogous to the circulation in the Tubularia and Sertulaliadæe.

\section{Tubularia, * Linnæus.}

Character.-Polypidom rooted, more or less plant-like, horny, fistular, simple or branched; no cells-Polypes protruding at the ends of the tubes or branchlcts, non-retractile, the head crested with one or two circles of tentacula.

\section{* Tubes undivided.}

1. T. INDIVISA, tubes clustered, simple, cylindrical, narrowed and interwoven at the base: head of the polype crested with two rows of tentacula. E. Lhwyd. $†$

\section{Plate III. Fig. 1, 2.}

Remarkable Sea-plant, Lhwyd in Phil. Trans. abridg. vi. 73, pl. 3, fig. 1. (pessima.) _ Adianti aurei minimi facie planta marina, Raii, Syn. 31, no. 4. Jussieu in Mem. Acad. Roy. des Sc. 1742, p. 296, tab. 10, fig. 2._-Tubular coralline like oaten pipes, Ellis in Phil. Trans. xlviii. tab. 17, fig. $D$. Ibid. abridg. x. 453 , pl. 10, fig. $D$. Corall. 31 , no. 2. tab. 16, fig. C.—Tubularia indivisa, Lin. Syst. 1301. Solnnd. Zooph. 31. Berk. Syn. i. 214. Turt. Gmel. iv. 666. Blumenb. Man. 272. Turt. Brit. Faun. 210. Stew. Elem. ii. 437. Wern. Men. i. 563. Lam. Anim. s. Vert. ii. 110. 2de edit. ii. 125. Lamour, Cor.

* Formed from tubulus - a little hollow pipe.

† Edward Lhwyd or Lloyd (as Dillenius spells the name) was born in 1670 and died in July 1709. He was keeper of the Ashmolean Museum, Oxford, and was distinguished atnong his contemporaries for knowledge in antiquities and natural history. "He is indeed," writes Archdeacon Nicolson, afterwards Bishop of Carlisle, and a very competent judge, " if I may judge of him, the greatest man (at antiquities and natural philosophy together) that 1 bave had the happiness to converse with." Letters to R. Thoresby, F. R. S. v. i. p. 206. Ray gratefully records his assistance in the Synopsis and Hist. Plantarum; and Petiver frequently mentions him as his "worthy," "curious," and "generous friend." Of his life and writings the reader will find an account in Pulteney's Skelches of Bolany in England, v. ii. p. 110-116: and some additional particulars in the "Analecta Scolica," especially in the Second Serics published at Edinburgh during the present yeat. 
Flex. ঐ30. Corall. 100. Cuv. Reg. Anim. iii. 299. Bosc, Vers, iii. 89, pl. 28, fig. 5. Flem. Brit. Anim. 552. Johnston in Trans. Newc. Soc. ii. 252. Dalyell in Edin. New Phil. Journ. xvii. 411; and xxi, 93; and in Rep. Brit. Assoc. an. 1834, 600. Lister in Phil. Trans. an. 1834, 366, pl. 8, fig. 1.—__ Tub. calamaris, Pall. Elench. 81._— Tub. gigantea, Lamour. Soland. 17, tab. 68, fig. 5.__ Tub. gracilis? Harvey in Proc. Zool. Soc. no. 41, p. 54._L La Tubulaire chalumeau, Blain. Actinolog. 470.

Hab. On shells and stones from deep water. Leith shore; Orkney and Shetland Islands, Professor Jameson. Scarborough, Mr Bean. Coast off Dunstanborough Castle, $M \cdot R$. Embleton. Cullercoats, Northmmerlant, Mr.J. Alder. Berwick Bay.

The tubes are simple or sometimes divided once at the base, where they are twisted and flexuous, fistular, even, continuous or sometimes wrinkled at distant intervals with a few anmulations, horn-coloured, from 6 to 12 inches in height, and ahout a line in diameter. Ellis's comparison of them to "part of au oat-straw, with the joints cut off," is very apt. They are filled with a soft almost fluid redlish-pink pulp in organic connection with the Polypes, which project from the open ends of the tubes, and are not retractile within them. The body, or naked portion, of the polype forms a globular knob of a scarlet colour, prodnced above into a sort of proboscis encircled with a series of numerons short tentacula of the same colour. Around the base of this body there is another circle of much longer tentacula from 30 to 40 in number ; and between their insertion and the body clnsters of oviform gemmules are prodnced at certain seasons. The neck of the polype is greatly constricted; and we find that the recent tube is marked with several longitudinal pale lines, placed at equal distances, and which are evidently caused by some structure of the interior pulp, for when empty the tubes exhibit no such appearance. What is their relation to the currents olserved by Mr Lister? - As the animal becomes weak when kept in a basin of sea-water, the head drops off, like a flower from its stalk; and if it is immersed, even when most vivacions, in fresh-water, the pulp is expelled from the tubes until these are almost emptied. If this is effected by a contraction of the tube (and the phenomenon is not otherwise easily explained), does not this imply a degree of irritalility in the polypidom inconsistent with the theory of its extravascular character?

I can find no characters either in the description or figure of $T u b$. gigante which warrant its separation as a listinct species. The character of Lamouroux is : "T. tubulis rectis, simplicissimis, ad basim attematis, gradatim dilatatis, deinde reqnali crassitie, lævibus nitidisque."-Neither do I find in Mr Harvey's description of his 
Tub. gracilis any essential specific character : the differences he points out between it and $\mathrm{T}$. indivisa seem to depend on the peculiar locality of the former, viz. on chains or woor exposed to a rapid current.

2. T. LARrxx, tubes clustered, slender, cylindrical, ringed at regular intervals: polypes with a double series of tentacula.

\section{Plate III. Fig. 3, and Plate IV. Fig. 3-5.}

Var. $a$. The tubes simple or undivided. Plate III. Fig. 3. Fucus Dealensis fistulosus, laryngæ similis, Raii, Syn. i. 39, no. 8. Petiv. Oper. iii. 39, no. 406. Ellis in Phil. Trans. abridg. x. 453, pl. 10, fig. c, and xi. pl. 5, fig. 3, young.—_-Tubulous Coralline wrinkled like the windpipe, Ellis, Corall. 30, no. 1. tab. 16, fig. $b$. Corallina tubularia laryngi similis, Bast. Opusc. Subs. 4I, tab. 2, fig. 3-4 ; and tab. 3, fig. 2-4.—_Tubularia muscoides, Pall. Elench. S2. Berk. Syn. i. 21 4. Turt. Gmel. iv. 667. Turt. Brit. Faun. 210. Stew. Elem. ii. 438. Bosc, Vers, iii.90. Flem. Brit. Anim. 552.-Tub. Larynx, Soland. Zooph. 31. Lam. Anim. s. Vert. ii. 110. Hogg's Stock. 34.—La Tub. muscoïde, Blainv. Actinolog. 470. Var. $b$. The tubes sparingly and irregularly branched. Plate IV. Fig. 3, 4, 5, and Plate V. fig. 3, 4. Tubularia muscoides ? Lin. Syst. 1302. Corall. 101. Fistularia muscoides? Mull. Zool. Dan. prod. 254, no. 3068. -Fistulana muscoides? Fabric. Faun. Groenl. 442.

Hab. On shelis, corallines, \&c. beyond low-water mark. (a.) "Found about Deal by the Reverend Mr Hugh Jones* and Mr James Cuninghame + " Peliver. "Found in great plenty in the sea, near the opening of the Thames, adhering to other marine bodies, and often to the bottoms of ships," Ellis. Stockton-on-Tees, J. Hogg, Esq. Scarborough, Mr Bean.-(b.) Berwick Bay, parasitical on Tubularia indivisa and ramea.

Polype-tubes, in var. a, clustered, about 2 inches in height, undivided and filiform, more or less entwined at the base, of a thin pellucid pale corneous texture, wrinkled and annulated at intervals, whence

* " A very curious person in all parts of Natural History, particularly in Fossils, some of which he hath sent me from Maryland, with several volumes of Plants very finely preserved; with divers Insects and Sliells. From this obliging gentleman, 1 am promised frequent remittances of whaterer those parts afford, as well Animals and Fossils as Vegetables."-Petirer.

+ Cuninghame was a Surgeon, probably in the East India Company's service, and had visited those places which lie in the course of its trade, whence he brought numerous plants, \&c. to enrich the museum of Petiver. The latter styles bim " that industrious promoter of Natural Philosophy, and my very ingenious friend ;"- " my very worthy filend;"-_ my liearty friend;" and the 20 th plate of Petiver's English Plants is gratefully dedicated to the memory of this " his curious friend," to whom he says he was " beyond expression obliged." Cuninghame is the author of a paper on the plants of the island of Ascension in Phil. Trans. no. 255 ; and seems to lave deserved the praises which his contemporaries bestowed. 
each tube assumes somewhat the appearance of the wind-pipe of a small bird. In $v a r . b$, the tubes are distinguished by being slightly branched, the branches coming off irregularly and at various angles. They rise to about 3 inches in height, and are smooth in a fresh state, but when dried exhibit the annulations distinctly, especially at the origin of the branches. The naked body of the polypes is rose-red, more or less deeply tinted, while the tentacula are milk-white, or sometimes faintly tinged with red. Of these there are two series: one round the oral aperture composed of short threads usually held in an erect position; the other forms a circle round the most bulging part of the body, and consists of more than 20 long filaments which spread like rays from a centre, or droop elegantly, being usually held still, or allowed listlessly to follow the undulations of the water. When the polypes are all displayed, they afford a very interesting and pretty spectacle, equalled by no other species I have seen, the crimscn heads contrasting finely with their white polypidoms, especially when loaded with the gemmules which pullulate from the inner side of the bases of the inferior tentacula. When few in number and immature these gemmules are sessile and separate, but in their progress to evolution they form grape-like clusters: each separate gemmule is of a roundish or oval shape, consisting of a white albuminous coat with a dark red cylindrical centre.-Plate IV. Fig. 5.

According to Agardh and Lamouroux the Tubularia muscoides of Linnæus is distinct from the T. Larynx of Ellis and Solander, but his specific character-." T. culmis subdichotomis, totis anmuloso-rugosis,"-answers sufficiently to our $b$ in a dried state to induce me to quote it as a synonyme, the more so as Linnæus refers to Ellis's figure for a representation of what he intended. The Tubularia polyceps of Sir J. G. Dalyell in Rep. Brit. Assoc. an. 1834, p 601, and Edin. New. Phil. Journ, xxi. 93, appears to be referable to the same variety. From the observations of this ingenious naturalist we must infer that the number of tentacula is an uncertain character : he says, " a specimen had originally 21 tentacula, hut only 16 were renovated with the second head; and with the seventh they had diminished to six."

* Tubes ramous. (Eudendrium, Ehrenberg.)

3. T. ramosa, tube single, irregularly branched, the lranches erecto-patent, ringed and rather narrower at their origins : polypes with a single series of tentacula. J. Ellis.

Small ramified tubular coralline, Ellis, Corall. 31, No. 3, tab. 16, fig. $a$; and tab. 17, fig. «, A.—Tubularia trichoides, Pull. Filench. 84.-T. 
ramosa, Lin. Syst. 1302. Soland. Zooph. 32. Berk. Syn. i. 214. Turt. Gmel. iv. 666. Turt. Brit. lanun. 210. Stew. Elem. ii. 437. Wern. Mem. i. 563. Lam. Anim. s. Vert. ii. 110. 2de edit. ii. 126. Bose, Vers, iii. 89. Lamour. Corall. Trans. 101. Flem. Brit. Anim. 552. Hogg's Stock. 34. Sturk, Elem. ii. 441, pl. 8, fig. 15 . Templeton in Mag. Nat. Hist. ix, 466._Fistularii ranısa, Mull. Zool. Dan. prod. 254, no. 3067. — Fistulana lamosa, Fabric. Faun. Groenl. 441.—Tubulaire rameuse et trichö̈le, Blainv. Actinolog. 470, pl. 30, fig. 3, $3 \alpha$, copied from Ellis.

Hab. On oyster's and other marine productions. "At W'hitstable on the Kentish shore ;" and "at Emsworth, on the borders of Sussex," Ellis. "Leith shore, found by the late Mr Mackay," Jameson. I'ery common on stones, muscle and oyster shells near Stockton-onTees, J. Hogg, Esq. "Found on the shore of Dublin Bay," Templeton.

Thongh said to be common, I am but imperfectly acquainted with this species, which it must be difficult to distinguish from the branched variety of the preceding except in a living state, when the polypes afford a certain means of discrimination in the arrangement of their tentacnla. In size and texture the two species seem to be nearly alike. Ellis says, " 1 have often met with specimens of this coralline that have been regularty branched in a doubly pinnated form ; and when I was at Emsworth, on the borters of Sussex, I found a specimen of this 'Tubularia, with its ovaries placed in a circle round the lower part of its heads." I have had small and imperfect specinens of Thoa halecina sent me as T. ramosa; nor is it impossible to mistake the variety of Hernia glandulosa which infests Tubularia indivisa for it. Lamouroux and Blainville make of Ellis' figure in Plate XVI. their Tub.trichoides, and they restrict the name ramosa to that figured in Plate XVII, but Ellis himself knew no difference, nor am I aware on what grounds these authors place the distinctions between them.

4. T. RAMEA, arborescent, the stem and branches formed of agglutinated filiform tubes irregularly branched: polypes with a single series of tentacula.

Plate V. Fig. 1, 2.

Tubularia ramea, Pall. Elench. 83. Bosc, Vers, iii. 90._-T. ramost, Johnston in Trans. Newc. Soc. ii. 253, pl. 30.__ Fistulaua ramosa? Fabric. Faun. Groenl. 441.—_Thoa Sarignii? Lamour. Corall. 93, pl. 6, fig. 2, malé.

Hab. On old shells and on stones from deep water. Shetland and Leith shore, $D$ r Coldstream. Frequent on the coasts of Northumherlanil and Berwickshire. 
This coralline so perfectly resembles a tree in miniature, deprived of its leaves, that persons unacquainted with the nature of zoophytes cannot be persuaded that it is not of a vegetable nature. It is from 3 to 6 inches high, rooted by a densely interwoven mass of tubular fibres, which by their cohesion and intertwining form the stem, which is sometimes as thick as the little finger. This is irregularly divided into many compound branches, formed like the stalk itself, but the ultimate branches consist of a single short tube, ringed at the base, and terminated by the non-retractile polypes. The separate tubes are filiform, not thicker than ordinary thread, of earthy brown colour, horny, wrinkled at intervals. The polypes placed at the extremities of the branches are of a reddish colour and appear indolent in disposition, contracting slowly under external irritations : they have about twenty whitish tentacula arranged in one row round a broad oral disk.

It is possible this may be a state of $\mathrm{T}$. ramosa, but its arborescent character and the complexness of its structure are so remarkable that I have willingly followed the example of Pallas, who has given a description of the species in his usual accurate and expressive style. I find it noticed by no other author, unless perhaps by Otho Fabricius, but his description is not sufficiently explicit to remove all douhts of the correctness of his synonyme. The Sertolara racemosa of Cavolini, Polip. Mar. p. 160, tav. 6, fig. 1, is a nearly allied species.

The Tubularia flabellfformis of Adams in Lin. Trans. $\mathrm{v}$. 12. (Turt. Gmel. iv. 669. Turt. Brit. Faun. 211. Stew. Elem ii. 438.) is a minute parasitical alga of the family Diatomacex. 


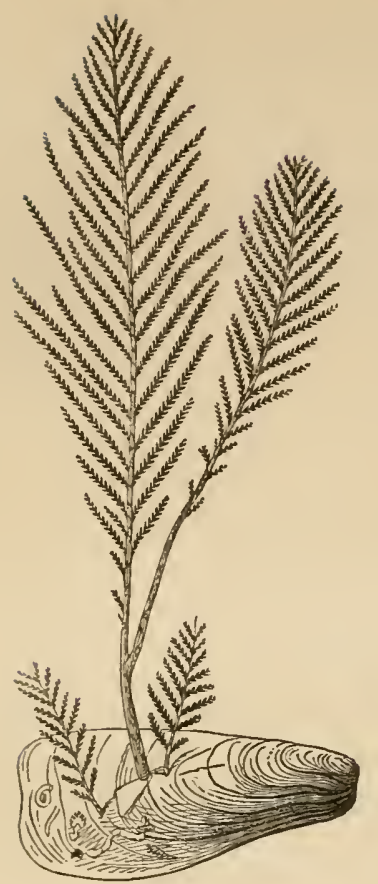

\section{FÄMILY III. SERTULARIADÆ.}

\section{5. Тнон, ${ }^{*}$ Lamouroux.}

Character.-Polypidoms rooted, arbuscular: the stem composed of aggregated subparallel capillary tubes; the branches alternate, spreading bifariously: cells tubular, indistinct, alternate : ovarian-vesicles irregularly scattered.-Polypes hydraform, scarcely retractile within their cells.

1. T. HALEcina, vesicles oval, the aperture shortly tubulous subterminal. Mr. Newton.†

$$
\text { Plate Vi. }
$$

* From $\theta$ cos, sharp ; or more probably a mispelling of Thoe-one of the Nereids.

+ Mr James Newton, a good practical botanist, contemporary with Ray, to whom he sent many contributions for the Synop. Stirp. Brit, and the Hist. Plantarum. He died before the publication of the $3 \mathrm{~d}$ edition of the Synopsis in 1724, but Dillenius acknowledges his obligations, and introduced several species into our Flora, for the first time, on Newton's authority, I am not aware 
Corallina scruposa pennata, cauliculis erassiusculis rigidis, Raii, Syn. i. 36, no. 15. - Herring-bone Coralline, Ellis in Phil. Trans. abridg. x. 454. pl. 10. fig. E, F, G. Coral. 17, 110. 15, pl. 10. Phil. Trans. xlviii, 506, pl. 17, fig. f, E.__ Sertularia lıalecina, Lin. Syst. 1308. Pall, Elench. 113. Mull. Zool. Dan. prod. 255. Fabr. Faun. Grœnl. 443. Ellis and Soland. Zooph. 46. Berk. Syn. j. 217. Turt. Gmel. iv. 678. Turt. Brit. Faun. 213. Wern. Mem. i. 564. Stew. Elem. ii. 442. Bosc, Vers, iii. 109. Lam. Anim. s. vert. ii. 119. 2de edit, ii. 146. Hogg's Stockton, 32. Flem. Brit. Anim. 542. Johnston in Trans. Newc. Soc. ii. 259, pl. 12, fig. 2. —Thoa halecina, Lamour. Cor. Flex. 211. Corallina, 93. Templelon in Mag. Nat. Hist. ix. 468.-La Thoa halecine, Blainv. Actincl. 488, pl. 84, fig. 4, $4 a$.

Hab. On old shells and stones in deep water, common. Common on oyster shells in the Frith of Forth, Prof. Jameson. Vicinity of Stockton-on-Tees, J. Hogg, Esq. Found on the shore of Belfast Longh, Mr Templeton. Cork Harbour, J. V. Thompson. Coasts of N. Durham and Berwickshire.

Polypidom from 4 to 6 inches high, fixed by numerous fibres " irregularly matted together like a piece of sponge," of an earthy-brown colour, stiff, brittle when dry, irregularly branched, the stem and principal branches composite, tapered upwards, pinnate; the pinnæ alternate, patent. Cells alternate, tubular, bi-articulate, the aperture even. Vesicles unilateral, scattered, of an oval shape "with a tube arising from the pedicle, and passing up on one side to a little above the top of each," Ellis.___Young specimens are often partially coloured a bright yellow, dependent apparently on the colour of the interior pulp. When the specimen is recent and clean the cells are seen to be divided by one or two wrinkles or joints, but in general they are obscurely marked.

2. T. BEaniI, vesicles calceoliform, the aperture subcentral, shortly tubulous. Mr William Bean.*

$$
\text { Plate VII. Fig. 1, 2. }
$$

$H a b$. "Near Scarborongh, in deep water, very rare," $M v$ Bean. Polypidom $\mathbf{3} \frac{3}{4}$ inch high, irregnlarly branched, the branches alternate, spreading, the principal composed of many parallel tubes, the ulti. mate of a single tube, with a joint between each cell, which is small,

that any genus of plarits has been dedicated to his memory,_an honour of which he seems not unworthy. He must not be confounded with another James Newton, author of a " Compleat Herbal," Lond. 1752.

* Hr B. of Scarborough, well known to naturalists generally by his numcrous discoveries in British Zoology, recent and fossil. To some of his new species the trivial name fabalis has been applied, but the justice of such a conceit or puzzle is questionable, since it veils the discoverer's name from those who are not good guessers. 
articulated, cylindrical or somewhat dilated at the aperture. Vesicles numerous, scattered or imperfectly clustered, large and shaped somewhat like the flower of a Calceolaria, with a short tubulous aperture in the middle of its concavity, which is on the superior and inner aspect.

I have named this curious and rery interesting species after its discoverer, to whose kindness I am indebted for the specimen that furnished our figure and description. In habit and structure it closely resembles Th. halecina, from which it is, however, at once distinguished by its remarkable ovaries.

3. T. muRICATA, vesicles roundish or ovate, echinated. Dr Darid Skene.

\section{Plate VII. Fig. 3, 4.}

Sertularia muricata, Ellis and Soland. Zooph. 59, pl. 7, fig. 3, 4. Turt. Gmel. iv. 681. Turt. Brit. Faun. 215. Stew. Elem. ii. 445. Jameson in Wern. Mem. i. 564. Flem. Brit. Anim. 543. Hogg's Stockton, 34. Bosc, Yers, iii. 115. L Laomedea muricata, Lamour. Cor. Flex. 209. Corallina, 92.—La Sertulaire muriquée, Blainv. Actinol. 480. La Campanulaire muriquée, lbid. 473.

$H a b$. On old shells in deep water. The sea at Aberdeen, Skene. Frith of Forth, Jameson. Seaton, J. Hogg. Near Scarborough, W. Bean.

Polypidom from 2 to 4 inches high, rooted by a fibrous entangled mass, irregularly branched, stout and rigid, yellowish-brown; the stem and branches composed of capillary tortuous tubes closely agglutinated, but the extremities of some of them become free and appear like simple fibres; branches erecto-patent, slightly tapered at the point. Cells visible only on the simple fibres, small, alternate, separated by an oblique joint, sessile, campanulate, with an entire even aperture. Vesicles rery numerous and often crowded, shortly stalked, roundish or ovate, somewhat compressed, and rough with prickles arranged in lines on elevated strix: when filled with ova the centre is of a deep chesnut-brown colour.

May not the obscure Sertularia echinata of Limneus be referable to this species?

\section{Sertularia, * Linnæus.}

Character. Polypidoms rooted, plant.like, variously branched, the divisions or branches formed of a single tube divided at regular intervals by imperfect septa: cells paired or arranged in

- From sertula, the dininutive of serta, a garland. 
two opposite rows, sessile, distinct and separated by a joint from the stem, short with everted apertures: vesicles scattered.-Polypes hydraform.

* Cells distinctly alternate.

1. S. Polyzonias, erect, subflexuous; cells ovate, with a wide somewhat uneven aperture; vesicles obovate, wrinkled across, the orifice contracted and plain. Mr Newton.

Plate VIII. Fig. 1, 2, 3.

Corallina minus ramosa, alterna vice denticulata, Raii, Syn. 35, no. 13, tab. 2, fig. 4, malé.—-Great Tooth Coralline, Ellis, Coral. 5, no. 3, pl. 2, fig. $a, A$. and pl. 38, fig. 1, A.—Sertularia polyzonias, Lin. Syst. 1312. Ellis and Soland. Zooph. 37. Berk. Syn. i. 219. Turt. Gmel. iv. 683. Blumenb. Man. 273. Turt. Brit. Faun. 216. Wern. Nem. i. 564. Stew. Elem. ii. 447. Lam. Anim. s. Vert. ii. 117. 2 de edit. ii 142. Lamour. Cor. Flex. 190. Corallina, 83. Risso, L'Europ. mérid. v. 130. Bosc, Vers, iii. 119. Hogg's Stockton, 31. Flem. Brit. Anim. 542. Johnston in Trans. Newc. Soc. ii. 256. Templeton in Mag. Nat. Hist. ix. 468._- S. ericoides, Pall. Elench. 127._-Sertolara polizonia, Cavol. Polip. Mar. 224, tav. 8, fig. 12-14.—La Sertulaire zonée, Blainv. Actinolog. 480.

Hab. On shells and other corallines, in deep water. Near Queenborough in the island of Sheppey, Ellis. Leith shore, Jameson. Coast of Ayrshire, $M \cdot P$. W. Maclagan. On the shore of Belfast Lough, Templeton. Cork Harbour, J.V.Thompson. Scarborough, Mr Bean. Coasts of N. Durham and Berwirkshire.-( $\beta$.) Cornwall, Pallas. Isle of Wight, Ellis. Berwickshire.

Polypidoms affixed ly a creeping tubular fibre, from 1 to 2 inches ligh, of a yellowish horn-colour, filiform and slender, scarcely zigzag, simple or sparingly branched in general, but specimens occasionally occur which are bifariously pinnated ; the pinnæ alternate, erecto-patent. Cells rather distant with an oblique joint in the stem above the origin of each of them, urceolate, smooth, the aperture wide and obsoletely tridentate. Polypes white or sometimes bright-yellow, with numerous tentacula. Vesicles large, sessile, ovate with a short tubulous apex, smooth or transversely wrinkled on the upper balf.

Pallas describes a variety $(\beta)$ worthy of notice, not unfrequent on the coast of Cornwall, 3 inches and upwards in height, with a compound stem, and branched in a pinnate manner similar to Thoa halecina, which this variety indeed very closely resembles. Ellis mentions that he had received specimens of the same from the Isle of Wight ; and I have found it on the coast of Berwickshire. In the collection of my friend Dr Coldstream there are specimens also, from 
the Cape of Good Hope, of a still greater size and more robust and shrubly habit, with numerous and compound branches,-evidencing the genial influence of climate on the growth and appearance of these corallines.

2. S. ElLisin, climbing, flexuous; the cells urceolate, bulged at the base, with a 4-toothed rim: vesicles with the opening 4toothed. Ellis.

Ellis, Corall. 6, pl. 2, fig. $b, B$. Sertularia Ellisii, M. Edwards in Lam. Anim. s. Vert. ii. 142,2 de edit.

Hab. Parasitical on other corallines.

Under the "Great-tooth Coralline" Ellis describes this shortly : "The other species, which is the climbing one, is more branched, the denticles are placed more asunder, and their mouths are wider: The vesicles of both species are wrinkled." It has been always considered a variety of the preceding until separated from it by MilneEdwards on what appear to be sufficient characters of distinction. I have seen no specimen.

3. S. Teupletoni, "stems simple; cells short and narrow." Mr Templeton.*

Sertularia Templetoni, Fleming in Edin. Phil. Journ. ii. 88. Flem. Brit. Anim. 543 -La S. de Templeton, Blainv. Actinolog. 480. Lan. Anim. s. Vert. ii. 15:, $2 \mathrm{~d}$ edit.

Hab. "Loch of Belfast, Mr Templeton," Fleming.

"Height about an inch; slightly branched; cells narrow, tubular, produced; the vesicles oval, lengthened, narrow at the base, covered towards the summit with lanceolate spines. This species is of a more delicate texture than the preceding, (Thoa muricata), the vesicles are of a different shape, and the stem is simple. It was given to me by an accomplished naturalist, the late Mr Templeton of Orange Grove, Belfast. It adheres apparently to a gramineous leaf, probably of a zostera, and therefore may be considered an inhabitant of shallow water." Fleming.

4. S. IUGOSA, cells ovate, wrinkled transversely, the mouth narrow with 3 or 4 small teeth on the rim. J. Ellis.

Plate VIII. Fig. 4, 5, 6.

Snail-trefoil Coralline, Ellis, Corall. 26, no. 23, tab, 15, fig. a, A.Sertularia rugosa, Lin. Syst. 1308. Pall. Elench. 126. Ellis and Soland.

- John Templeton, Esq. born in Belfast in 1766, where he died, I believe, in 1827. For an interesting memoir see the Mag. Nit. Hist. v. i. p. 403, and $\mathrm{v}$. ii. p. 305. 
Zooph. 52. Berk. Syn. i. 216. Fabr. Faun. Groenl. 443. Turt. Gmel. iv. 678. Wern. Mem. i.564. Turt. Brit. Faun. 213. Stew. Elem. ii. 442. Lam. Anim. s. vert. ii. 121. 2d edit. ii. 149. Bosc, Vers, iii. 108. Flem. Brit. Anim. 542. Hogg's Stockton, 32. Johnston in Trans. Newc. Soc. ii. 257, pl. 11, fig. 3.__Clytia rugosa, Lamour. Cor. Flex. 204. Corallina, 89. Templeton in Mag. Nat. Hist. ix 466._La Campanulaire rugueux, Blainv. Actinol. 473.

Hab. Parasitical on Flustræ, Sponges and Fuci at low water-mark, common. Brighthelmstone, Ellis. Near Hartlepool, common, $\boldsymbol{M} \boldsymbol{r}$ Hogg. Leith shore, Jameson. Shores of N. Durham and Berwickshire.

A small species not exceeding an inch in height, and well distin. guished by its strongly wrinkled cells which resemble a barrel in miniature. Polypidoms gregarious, the shoots united by a radical branching fibre, erect or creeping, obliquely twisted or ringed between the cells, simple or sparingly branched, the branches irregular, patent. Cells crowded, alternate, subsessile, ovate, coarsely wrinkled, especially when dried, contracted at the orifice which is obsoletely tridentate. The ovarian vesicles are sparingly evolved, and differ from the cells only in being a little larger, and in having three teeth in the opering at the top of each. As a parasite it does not confine itself to Flustra foliacea, as Pallas would have us to believe, but infests the roots and stems of many sea-weerls.

* *ells in pairs, opposite or semialternate.

5. S. ROSACEA, cells opposite, tubulous, the upper half free and divergent, the aperture entire, truncate; vesicles crowned with spines. Ellis.

\section{Plate IX. Fig. 1, 2.}

Lily or Pomegranate-flowering Coralline, Ellis, Corall. 8, no. 7, pl. 4, fig. a, A. Phil. Trans. abridg. x. 492, pl. 12, fig. 5, s.--H._- Sertularia rosacea, Lin. Syst. 1306. Ellis and Soland. Zoopl. 39. Berk. Syn. i. 215. Turt. Gmel. iv. 676. Turt. Brit. Faun. 212. Wern. Mem. i. 564. Stew. Elem. ii. 440. Lam. Anim. s. Vert. ii. 119. Bosc, Vers, iii. 105. Hogg's Stockton, 32. Johnston in Trans Newc. Soc. ii. 258. Templeton loc. cit. 468.__ Sert. nigellastrum, Pall. Elench. 129._Sert. abietina? Fabric. Faun. Grœnl. 442.-Dynamena rosacea, Lamour. Cor. Flex. 175. Corallina, 79. Flem. Brit. Anim. 544._L La Dynamène rosacée, Blainv. Actinol. 484.

Hab. Frequent on Corallines, and occasionally on old shells, from deep water. At Brighthelmstone adhering to oyster-shells, Ellis. Scarborough, $M_{v}$ Bean. A rare species near Hartlepool, Hogg. Coast at Dunstanborough Castle, $M r \boldsymbol{R}$. Embleton. Leith shore, Jameson. Shore of Belfast Lough, Templeton. Coast of Berwickshire and N. Durham. 
Polypidom from one to two inches in height, attached by a creeping tortnous tubular fibre, rery slender and delicate, of a white or pale horn colour, pellucid, varionsly branched, the branches bifarious, altemate, patent, similar to the stem. Cells opposite, with a joint between each pair, rather long, tubular, the upper half suddenly divergent with an oblique entire aperture. Ellis compares the vesicles to a "Lily or Pomegranate flower just opening," but Pallas asserts that the comparisons, as well as the figures of them in Ellis's work, are inaccurate, - a criticism the truth of which Ellis denies in his subsequent volume on zoophytes. They appear in fact to vary somewhat according to their age, and also from the manner in which they have been dried. They are large and pear-shaped, subsessile, puckered at the top where they are crowned with several spines;

Fig. 14.

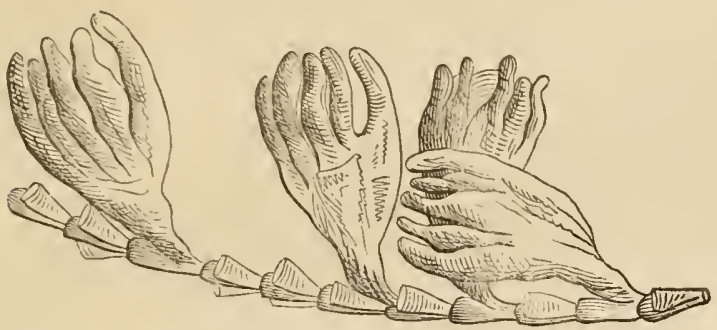

and though scattered over the polypidom, they appear to be produced from one side only, and are often arranged in close rows along the branches.-Our figure is the exact portrait of a beautiful specimen in the collection of Dr Coldstream ; and I have a similar one from $\mathrm{Mr}$ Bean, but in general the species is very small and sparingly branched.

\section{S. Punila, cells opposite, approximated, shortly tubular, the} top everted with an oblique somewhat mucronated aperture; vesi.cles ovate. Doody.*

$$
\text { Plate IX. Fig. 3, } 4 .
$$

- Doody, Samuel, an apothecary in London, contemporary with lay, Petiver and Sloane, admitted F. R. S. in 1695. He was chosen superintendant and demonstrator of the garden at Chelsea, an office which he held for some years before his death, which took place in 1706. Petiver characterises him as an "in. defatigable botanist," and "memorable naturalist." Jussieu speaks of him as " inter Pharmacopœos Londinenses sui temporis Coryphæus." Pulteney styles him, "the Dillenius of his time ;" and Brown has crowned his praise by bestowing his name on a genus of New Holland plants. "In memoriam dixi Samuelis Doody, Pharmacopei Londinensis, qui primus fere in Anglia plantas cryptoga- 
Corallina pumila repens, minus ramosa, Raii, Syn. i. 37, no. 19._-C. pumila erecta, ramosior, Ibid. 37, no. 20. pl. 2, fig. 1.-Muscus marinus lendigenosus minimus arenacei coloris, Morris. Plant. hist. iii, 650, tab. 9, fig. 2.— Reaumur in Mem. de l'Acad. Roy. des Sc. an. 1711, 394, pl. 11, fig. 4, M.—-Sea-oak Coralline, Ellis, Corall. 9, no. 8, pl. 5, fig $a$, A. Phil. Trans. xlviii. 632, pl. 23, no. 6. Phil. Trans. Ivii. 437, pl. 19, fig. 11. Phil. Trans. abridg. x, 493, pl. 12, fig. 6, F.—-Sertularia pumila, Lin. Syst. 1306. Pall. Elench. 130. Ellis and Soland. Zooph. 40. Berk. Syn. i. 215. Turt. Gmel. jv. 676. Wern. Mem. i. 564. Turt. Brit. Faun. 212. Stew. Elem. ii. 441, pl. 12, fig. 10, 11 , copied from Ellis. Lam. Anim. s. Vert. ii. 119. 2 de edit. ii, 145. Bosc, Vers, iii. 105. Hogg's Stockton, 32. Stark, Elem. ii. 440, pl. 8, fig. 14. from Ellis. Johnston in Trans. Newc. Soc. ii. 259. Lister in Plil. Trans. an. 1834,371 , pl. 8, fig. 3. Templeton, lib. cit. 468.

Sertolara pumila, Cavol. Pol. mar. 216, tav. 8, fig. 8-10.-Dynamena pumila, Lamour. Cor. Flex. 179. Corallina, 79. Flem. Brit. Anim. 544. La D. naine, Blainv. Actinol. 484.

Hab. Near low-water mark common, parasitical on various Fuci, particularly F. vesiculosus and serratus. Also on oyster shells.

The polypiferous shoots originate from a slender tubular thread which creeps along the surface of the fucus, and connects them all together. The shoots are very numerous, often covering a considerable space of the sea-weed, seldom more than half an inch in height, of a dusky horn colour, and thickish texture, sparingly branched, filiform, flattish, serrated with the cells, which are divided in pairs by a dissepiment or joint. The polypes have 14 tentacula, and when the animal displays them, it at the same time extrudes the body far beyond the rim of the cell. The vesicles are copiously produced during the summer months, and are irregularly distributed over the branches : they are subsessile, ovate with a short tubulous rim, smooth, or sometimes wrinkled circularly : in the centre a placentular column is at seasons obvious, and in June I have found them filled with innumerable pellucid granules floating in an amniotic liquor.

"This species, and probably many others, in some particular states of the atmosphere, gives out a phosphoric light in the dark. If a leaf of the above Fucus (serratus, with the Sertularia upon it, receive a smart stroke with a stick in the dark, the whole coralline is most beantifully illuminated, every denticle seeming to be on fire." Stewart.

"While thus with pleasing wonder you inspect

Treasures the vulgar in their scorn reject, See as they float along th' entangled weeds Slowly approach, upborne on bladdery beads;

micas investigavit." Prod. Flor. Nov. Holl. p. 7._- See also Pultency's Sketches, v. ii. p. 107-9. 
Wait till they land, and you shall then behold The fiery sparks those tangled fronds infold, Myriads of living points ; th' unaided eye

Can but the fire, and not the form desery."-Crabbe.

7. S. Evansir, "has opposite branches, and short denticles placed opposite to each other; the ovaries are lobated, and arise from opposite branches, which proceed from the creeping adhering tube." Mr John Evans.*

Sertularia Evansii, Ellis and Soland. Zooph. 58. Turt. Gmel. iv, 681.

Bosc, Vers, iii, 115. Lam. Anim. s. Vert. 2de edit. ii, 154. Turt. Brit.

Faun. 215. Stew. Elem. ii, 445. —_Dynamena Evansii, Lamour. Cor.

Flex. 177. Corallina, 78. Flem. Brit Anim. 545.—La D. d'Evan, Blainv. lib. cit. 484 .

Hab. "Among some sea productions brought from Yarmouth, in Norfolk, in the year 1767," Ellis.

"This coralline is about two inches high, very slender, and of a bright yellow colour. It creeps on fucus's. The ovaries differ from all the rest of the genus: they are lobated, and the lobes are placed opposite to one another: these appear to be full of spawn, of a deep orange colour, which is sent forth from holes at the end of the lobes." Ellis.

8. S. PINNATA, cells opposite, tubular, the upper part free and divergent, with an even patulous aperture; vesicles obconical, trituberculate on the top. Pallas. $\dagger$

\section{Puate IX. Fig. 5, 6.}

Sertularia pinnata, Pall. Elench. 136.__ S. fuscescens, Turt. Gmel. iv. 677. Turt. Brit. Faun. 213. Stew. Elem. ii, 442. Lamour. Cor. Flex. 195. Corallina, 85. Bosc, Vers, iii, 107.___Dynamena pimmata, Flem. Brit. Anim. 545. Dyn. tubiformis ? Lamour. Soland. Zooph. 12, 11. 66, fig. 6, 7.—La D. brunatre, Blainv. Actinol. 483.

Hab. "Oceanus ad Prom. Lacertæ, Cornubiæ," Pallas. "On oyster-heds, common," Fleming. Frith of Forth, plentifully, D, Coldstream.

Polypidom attached by tortuous tubular fibres, between two and three inches in height, pinnated with alternate branches, of a blackish or dusky horn colour, with a slight gloss on the surface, rather rigid

"Ellis calls him "a sca-officer in the East India Company's service." Probably the same Mr E., a surgeon, whom Petiver mentions amongst the contributors to his nuseum.

† Peter Simon Pallas, M. D. born at Berlin, Sept. 22, 1741 : elected F. R. S. in 1764: died Sept. 8, 1811. See Brewster's Edin. Encyelop. xvi, 278; Clarke's Trarels, i, 458, \&e. Pennant's Literary Life, p. 7 ; hut above all Cuvier's Memoir in Edin. New Phil. Journ. iv. p. 211, \&c. 
when dry, straight, flattish, jointed, with a pair of opposite cells on each interspace ; branches patent, mostly undivided, jointed like the stem. Cells tubular, the upper portion free, erecto-patent, with an even aperture often girded with two or three faint circular wrinkles. Pallas says that the cells inclirie to one side of the stem, a character which Dr Fleming failed to observe, and which is not perceptible in any of the specimens sent me by Dr Coldstream. "Ab eodem latere," says Pallas, " ovaria in pinnis plerisque mediis crebra, in seriem conferta, minuta, obverse conica, supra trituberculata, et inter tulercula osculo instructa."

9. S. HibeRNiCA, "greater and lesser branches alternately pinnated; denticles alternate, elliptical, with emarginate mouths; vesicles ovate, with a denticulate mouth and transverse undulated strice."

Sertularia pimnata, Templeton in Mag. Nat. Hist. ix, 468.

Hub. "Dredged up, with other marine productions, in the sound of Donaghadee. Received from Mr J. Gilles, Aug. 1805," Templeton.

"The branching of this species is somewhat peculiar, each of the primary and secondary branches springing out at an angle of $40^{\circ}$ or $50^{\circ}$. That part of the stem which bears the denticles is waved so as to bear earh denticle on the projecting part; the denticles are elliptic, and the mouth of each apparently a little hollowed inwards, perhaps arising from the extremity being fractured; the vesicles are ovate, with 4 or 5 blunt teeth surrounding the mouth, and divided into 6 or 8 portions by annulated undulating lines. It might be classed among the large and strong sertularias, the principal shoot being of the thickness of a sparrow's quill at its base, and $4 \mathrm{in}$. or 5 in. long. The branches shoot forth from opposite sides, the whole coralline thus assuming a flat form, to the extent of 4 in. or 5 in." Templeton.

10. S. NIGRA, cells nearly opposite, small, ovate, appressed, with a scarcely everted aperture; vesicles ovate or elliptical.-Pallas. Vignette, No. 13, page 119.

Sertularia nigra, Pall. Elench.135. Turt. Gmel. iv.676. Bosc, Vers, iii. 106. Turt. Brit. Faun. 212. Jameson in Wern. Mem. i. 565. Corallina, 86. -S. Lichenastrum, Lin. Syst. 1313. (exclus. syn.) —-Dynamena nigra, Flem. Brit. Anim. 545.-La D. noire, Blainv. Actinolog. 484.

Ilab. Lizard Point, Cornwall, Pallas. Coast of Aberdeenshire, Robert Broun. Scarlorough from deep water, $M I r$ Bean. Coast of Northumberland at Dunstanhorough Castle, $M r \cdot R$. Embleton. 
Polypidom 3 or 4 inches high, rigid, pinnate, lanceolate, dusky or blackish-brown, varnished. Stalk straight, compressed, jointed, with a series of alternate cells on each side: pinna alternate, close, bifarious, several originating from each space between the joints of the stalk, simple, narrow at their origins, filiform, often gangrened at the apex. The cells are arranged in a close row along each margin, and directed alternately to opposite sides (Fig. 15); they are small, ovato-tu bular, short and adnate with a wide month having a small tooth on the outer edge. Vesicles unilateral, superior, elliptical or orate, sub-pedicellate, smooth.

\section{Fig. 15.}

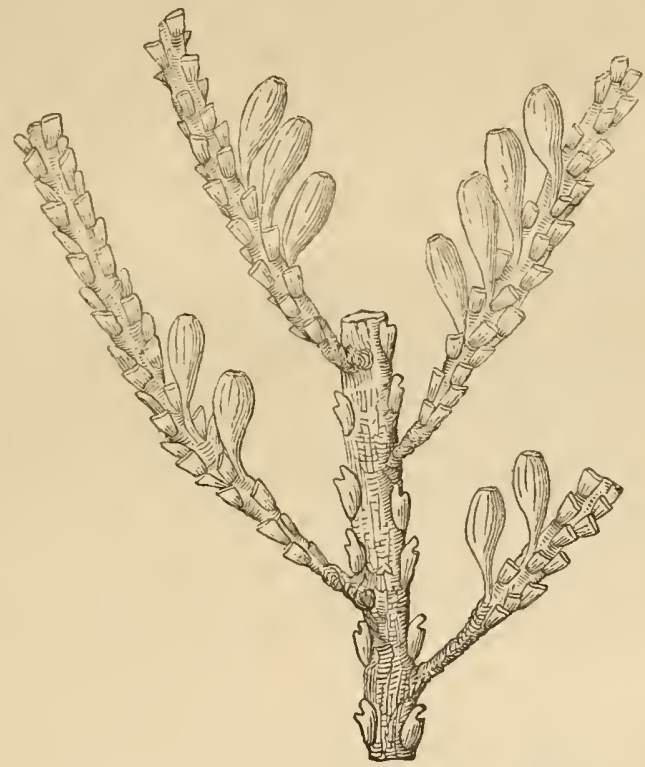

To this description, derived from specimens furnished by Messrs Bean and Embleton, I append that of Pallas, for Milne-Edwards denies the identity of his nigra with the British species (Lam. Anim. s. Vert. 2 de edit. ii. 155) ; for which in my opinion there are no sufficient grounds, but a comparison of the descriptions will enable every one to decide for himself. "Radices sunt tubi intestinuliformes, lutescentes, implexi, usque ad pinnarum originem assurgentes. Stirps ad summum quadripollicaris, simplex, pemnata, sublanceolata, testaceo nigra et tenuior molliorque quam tubuli radicantes. Rachis stirpis est tubulus crassitie fere calami avenacei, compressus, e planinsculis lateribus, et ipsis denticulatis, pinnas proferens. Pinnce s, ramuli 
teretiusculi, depressi, lineares, sæpe longissimi, tenuiter a scapo oriuntur, bifariam serrulati denticulis, uti ipse quoque scapus s. rhaclis. Denticuli (sic potius in hac specie vocandi) subtubulosi, exigui, simplices. Ovaria ab altero stirpis latere in ramulis crebra, secunda, parallela, versus rami extremitatem sensim minora, membranacea, stirpi concoloria, obovato-subquadrangula, clauşa."

11. S. TAMARISCA, cells opposite, tubular, the upper half divergent with a wide aperture sinuated on the margin; vesicles oval, truncate, with two small points at the corners and a tubulous mouth. Ellis.

\section{Plate X. Fig. 2, 3, 4.}

Sea Tamarisk, Ellis, Corall. 4, no. 1, pl. 1, fig. $a$, A.___Sertularia tamarisca, Lin. Syst. 1307. Pall. Elench. 129. Ellis and Soland, Zooph. 36. Berk. Syn. i. 216 . Turt. Gmel. iv. 676. Turt. Brit. Faun. 212. Stew. Elem. ij. 441. Bosc, Vers, iii. 106. Lamour. Cor. Flex. 188. Corallina, 82. Lam. Anim. s. Vert. 2de edit. ii. 153.—Dynamena tamarisca, Flem. Brit. Anim. 543.—La D. tamarisque, Blainv. Acti110l. 483 .

Hab. On old shells in deep water, not common. Near the island of Dalkey, t the entrance of the harbour of Dublin, Ellis. Near Aberdeen, Dr. Darid Skene. Frith of Forth, Dr. Coldstream. Very rare at Scarborough, $\lambda \boldsymbol{H}$ Bean.

Polypidom from four incles to " sometimes nearly a foot" in leight, rooted by a creeping vermicular fibre, stont and erect, denticulated throughout, bifariously branched, the branches alternate, rather distant, either simple or semipennated with secondary shoots, for these appear only to spring from the upper side of the branch, and are erect. The cells are of a thin transparent corneous texture, large, smooth, exactly opposite, in approximated pairs, the upper half free and divergent, and the margin of the aperture obsoletely tridentate. Vesicles large, unilateral, scattered, obcordate or pyriform with a tubular aperture. It seems that the little spine on each side is dependant on the age of the vesicle, and not perceptible when this is young. When mature it is filled with orange-coloured ova.-In the thin texture of the polypidom generally, and in the form of its cells, this species resembles Sert. rosacea; but its robust habit, and the manner of its branching, give it at least equal claims to affinity with the following.

12. S. ABIETINA, cells nearly opposite or subalternate, ovatotubular, the month entire; vesicles oval.

$$
\text { Plate X. Fig. 1, } 1 .
$$

Abies marina, Ger. emac. 1574, fig. Sibbald. Scot. ill. lib. quart. 55.-_ 
Corallina marina abietis forma, Raii, Syı. 35, no. 12. Bast. Opusc. Subs. 41 , tab. 2, fig. 6 ; and tab. 7, fig. 1-3, pessimx._-Muscus marinus major argutè denticulatis, Plunh. Phytog. tab. 48, fig. 5. Raii, Hist. i. 78. Mluscus maritimus filicis folio, Morris. Plant. Hist. iii. 650. tab. 9, fig. 1—. Se:a-fir, Ellis, Corall. 4, no. 2, pl. 1, fig. b. B. Sertularia abietina, Linn. Syst. 1307. Pall. Elench. 133. Mull. Zool. Dan. prod. 20̃5. Ellis and Solund. Zooph. 36. Berk. Syn. i. 216. Turt. Ginel. iv. 676. Blumenb. Man. 273. Wern. Mem. i. 564. Turt. Brit. Fanı. 212. Stew. Elen. ii. 441. Lam. Anim. s. Vert. ii. 116, 2 de edit. ii. 141. Stark, Elem. ii. 4ł0. Risso, L'Europ. mérid v. 311. Lamour. Cor. Flex. 189. Corallina, 81. Bosc, Vers, iii. 106. Hogg's Stock. 31. Johnston in Trans. Newc. Soc. ii. 256. Templeton in Mag. Nat. Hist. ix. 468.—Dynamena abietina, Flem. Brit. Anim. 543._L_La Sertularie sapinette, Bluinv. Actinolog. 480, pl. 83, fig. 6 .

Hab. On shells and stones in deep water, common.

"This elegant coralline is frequently found on our coast, adhering by its vermicular tubes to most kinds of slells : it grows very erect, ancl is frequently infested with little minute shells called Serpulas." Ellis. Polypidom from 4 to 6 inches high, of a yellowish horn co. lour, smooth and varnished, stout, regularly pinnate, the stem flattened, slightly zigzag; the branches rather close, linear, alternate, bifarious, simple, or sometimes pinnated. Cells generally semialternate, rather small, bellied at the base with a narrow everted neck and plain aperture, so as somewhat to resemble a Florence-flask. Vesicles scattered, sulısessile, proportionably small, smooth, ovate, with an eren shortly tubulous mouth : they are produced principally in the winter season, when they are sometimes " in such abundance as al. most to cover the denticles, but placed in a very regular order," $E$ lis, and always on the upper edge of the branch from which they oliginate.

13. S. FILICULA, cells of the form of a Florence-flask, opposite, a single one in the axilla of each pinna; vesicles pear-shaped, smooth, the aperture shortly tubulous, entire. Hudson.*

Plate XI. Fig. 1, 1.

Sertularia filicula or Fern Coralline, Ellis and Soland. Zooph. 57, pl. 6, fig. c, C. Turt. Gmel. iv. 681. Bosc, Vers, iii. 114. Turt. Brit. Faun. 215. Stcw. Elem. ii. 445. Jameson in Wern. Hem. i. 564. Lam. Anim. s. Vert. ii. 119. Lamour. Cor. Flex. 188. Corallina, 82. Johnston in Trans. Newc. Soc. ii. 257. Hogg's Stockton, 32._S.

* William Hudson, a Loudon apothecary, elected F. R. S. in 1761: the author of the "Flora Anglica," the publication of which, in 1762, " marks the establishment of Limnean principles of Botany in England, and their application to practical usc."-Sir $J$. E. Smith. 
abietina, $\beta$, Pall. Elench. 134.—Dynamena filicula, Flem. Brit. Anim. 544. La D. filicule, Blainv. Actinolug. 483.

$H a b$. Parasitical on sea-weeds, particularly on the entangled roots of Laminaria digitata. Coast of Yorkshire, Hudson. Scarborough, Ellis. Frequent about Seaton, Hartlepool, Whitburn, and other places on the coast of Durham, Hogg. Cullercoats, Northumberland, Jos. Alder. Dunstanborough, R. Embleton. Common on the shores of N. Durham and Berwickshire, $G_{\text {. }} J$. Frith of Forth, Jameson.

Polypidom arising from a creeping fibre, 1 to 4 inches in height, spreading bifariously, irregularly branched, slender and flexible, of a straw-yellow or brownish colour, homologous throughout; the racbis zig-zag, or "bent to and fro into alternate angles," closely pinnated, the pinnæ shooting from every bend alternately on opposite sides, linear, patent, simple or composite. Cells closely set, minute, giving a serrulated appearance to the ramifications of the polypidom, shaped something like a Florence-flask, smooth, the aperture oblique, entire. The vesicles are rarely produced, nor have I seen a specimen with them: they are represented by Ellis as of a pear shape with a short tubulous aperture.

This, like its ally the S. abietina, is often infested with Serpulæ, but it is a much more delicate species, and, notwithstanding the similarity of their specitic characters, perfectly distinct. "The sirgularity of its waved stem, with its erect single denticle at the insertion of the branches, together with the single pair of denticles on each part of the stem, that form the angles, make it a very distinct species from any of this genus." Ellis.

14. S. OPERCULATA, cells opposite, inversely conical, the aperture patulous, obliquely truncate, pointed on the outer edge, with two small lateral teeth; vesicles obovate. Mr Newton.

$$
\text { Plate XI. Fig. 2, } 2 .
$$

Muscus marinus denticulatus, procumbens, caule tenuissimo, denticulis bijugis, Raï, Hist. j. 79. Morrison, Plant. Hist. Oxon. iii. 650, tab. 9, fig. 3. Plukenet, Phytogr. tab. 47, fig. 11.___C Corallina muscosa denticulita procumbens, Raii, Syn. 36, No. 18._Sea-Hair, Ellis, Corall. 8, No. 6, tab. 3, fig. b. B.— Sertularia operculata, Lin. Syst. 1307. Ellis and Soland. Zooph. 39. Berk. Syn. i. 216. Turt. Gmel. iv. 676. Jameson in Wern. Men. i. 564. Turt. Brit. Faun. 212. Stew. Elem. ii. 441. Bosc, Vers, iii. 106. Lam. Anim. s. Vert. ii. 118. Hogg's Stockton, 32. Johnston in Trans. Newc. Soc. ii. 258, plate 11, fig. 2. Templeton, ut supra cit, 468.__. S. usneoides, Pull. Elench. 132.__ Dynamena operculata, Lamour. Cor. Flex. 176. Corall. 78. Flem. Brit. Anim. 544._La Dynamène opercul'e, Blainv. Actinolog. 483, pl. 83, fig. 5 . 
Hab. Near low-water mark on Fuci, particularly on the stalks of Laminaria digitata. Common on all parts of the British coast.

Grows in tufts from 2 to 4 inches high. The sloots are slender and neat, filiform, flexuose or wilely zig-zag, always erect, alternately hranched, the branches erect, and, like the first shoot, serrulated with the polype-cells which are exactly opposite, and less everted than is usual to the genus. The outer angle of the aperture of the cell is produced into an acute point, and there is a sharp tooth on each side, which is onitted in the otherwise admirable figure of Ellis, although it could not escape his lyncean eye.* The vesicles are irregularly scattered on the branches, large, smooth, egg-shaped, the top often covered with a sort of rounded operculum : they are produced abundantly in the winter season and in spring, when indeed, I think, the ovaries appear on the greater number of this order of corallines. It was from the great resemblance of these vesicular ovaries to the capsules of mosses, that the early botanists drew an additional argument in behalf of the vegetability of the corallines themselves ; $†$ and a Darwinian might be, perhaps, forgiven were he even now to feign how the Nereides stole them from the mossy lierbelets of Flora's winter and vernal shews, to deck and gen the arbuscular garnitures of their own coral caves : f

The shoots are usually so little waved that Pallas' term " subflexuosi" is very appropriate, but in the collection of Dr Coldstream there

* "Zoophytorum lynceus Ellisius," Lin. Syst. 1071.

+ "These vesicles appearing at a certain season of the year, according to the different species of corallines, and then falling off, like the blossoms or seeds of plants, has made some curious persons, who have not had an opportunity of seeing the animals alive in the vesicles, conclude them to be the seed-vessels of plants; and into this mistake I was led myself, in the account laid before the Royal Society in 1752 . In which account I had taken some pains to point out the great similitude between the vesicles, and denticulated appearance of some of these corallines; and the tooth-shaped leaves and seed-vessels of some species of land-mosses, particularly of the Hypnum and Bryum."-Ellis, Corall. Introd. ix.

$\ddagger$ " Nymphs! you adorn, in glossy volutes roll'd,

"The gaudy conch with azure, green, and gold.

"You thase the warrior shark, and cumbrous whale,

"And guard the mermaid in ber briny vale;

"Feed the live petals of her insect-flowers,

"Her shell-wrack gardens, and her sea-fan bowers;

"With ores and gems adorn her coral cell,

" And drop a pearl in every gaping shell."

Botanic Garden, Canto iii. 
is a large specimen, from the Frith of Forth, in which they are remarkably zig-zag or kneed, so as to give it a peculiar character and appearance. In the s.me collection are specimens from the Cape of Good Hope, which differ in no respect from those of our shores.

15. S. ARGENTEA, polypidom cauliferous; cells nearly opposite or subalternate, urceolate, acutely pointed, the upper half divaricated; vesicles oval. Merret.

\section{Plate XII. and Plate XI. Fig. 3, 3.}

Corallina muscosa, alterna vice denticulata, ramulis in creberrima capillamenta sparsis, Raii, Syn. i. 36, No. 17.___Muscus marinus denticulatus minor ramulis in creberrima capillamenta sparsis, Pluknet, Phytog. tab. 48, fig. 3._Muscus marinus minor denticulis alternis, Morris. Hist. Plant. Oxon. iii. 650, tab. 9, fig. 4.__ Squirrel's-tail, Ellis, Corall. 6, No. 4, pl. 2, fig. $c, C$.___ Sertularia cupressina, $\beta$, Lin. Syst. 130S._S. argentea, Ellis and Soland. Zooph. 38. Turt. Gmel. iv. 677. Wern. Mem. i. 564. Berk. Syn. i. 216. Turt. Brit. Faun. 213. Stew. Elem. ii. 442. Bosc, Vers, iii. 108. Lam. Anim. s. Vert. ii. 117. Lamour. Cor. Flex. 192, Corall. 84. Hogg's Stockton, 32. Templeton in lib. cit. 468. Johnston in Trans. Newc. Soc. ii. 258, pl. xi. fig. 4.—La S. argentée, Blainv. Actinol. 480. ——Dynamena argentea, Flem. Brit. Anim. 544.

Hal. In deep water. On oysters and other large bivalved shells, as also on the stalk of Laminaria digitata, common.

Polypidom from 6 to 18 inches high, cauliferous, the stem percurrent, filiform, waved or straight, smooth, of a dark brown colour, divided at rather wide but regnlar intervals by an oblique joint, clothed with short panicled dichotomous branches which spread out on every side, and being all of the same size or nearly so, (excepting at the bottom where they are less branched and smaller, and at the top where they also frequently become gradually shortened,) the whole coralline assumes somewhat of the shape of a squirrel's tail, and has given origin to its English name. Two branches usually arise from each internode of the stem, and they come off in such a manner that four or five of them complete a whorl. The polype-cells on the stem are alternate, appressed, and appear to be less than those on the branches, which are placed in two rows with their orifices inclined to one side; they are bellied like a Florence-flask with a narrow divaricated neck terminated with a small oblique aperture: on some of the branchlets every pair is separated by a joint or stricture, while on others several pairs occur in succession withont the interference of such a structure. Vesicles scattered, oval, smooth, attenuated at the base.

In young specimens of an inch or two in height the polypidom is simply pinnate, and as it rises the lranches gratually divide into more 
numerous segments. In Plate XI. Fig. 3, I have given a figure of such a specimen selected from many others on acconnt of its greater divergence from the usual character of the species. When, on the contrary, the polypidom attains a foot or more in height, the lower Lalf of the stem loses its branches and cells, and becomes entirely naked. I think it likely that such a specimen, of the unusual size of 3 feet, constitutes the Sertularia uber of Sir J. G. Dalyell in Edin. New Phil. Journ. xvii. 412.

16. S. CUPRESSINA, polypidom cauliferous ; cells nearly opposite, tubulous, adnate, the aperture scarccly contracted, bilabiate, with two minute spinous teeth; vesicles nearly oval.-Ellis.

\section{Plate XIII.}

Sea-Cypress, Ellis, Corall. 7, No 5, pl. 3, fig. a, A.—Sertularia cupressina, Lin. Syst. 1308. Ellis and Soland. Zooph. 38. Berk. Syn. i. 216. Turt. Gmel. iv. 677. Wern. Mem. i. 564. Turt. Brit. Faun. 213. Stew. Elem. ii. 442 Bosc, Vers, iii. 108. Lam. Anim. s. Vert. ii. 118. Lamour. Cor. Flex. 192. Corall. 84. Hogg's Stock. 32. Templeton in loc. cit. 468. Stark, Elem. ii. 440, pl. 8, fig. 12. Risso, L'Europ. mérid. ․ 311.—_La S. cyprés, Blainv. Actinol. 480.—Dynamena cupressina, Flem. Brit. Anim. 543.

$H a b$ "The Sea-cypress is chiefly found in deep water on the coast of Yorkshire, Scotland, and the north of Ireland," Ellis. Scarborough, $M v \cdot$ Bean. Frith of Forth, Jameson. Cork Bay, $M, J . V$. Thompson. On the shore of Magilligan Strand, County Derry, Templeton.

This is in general a larger and stouter species than the preceding, with longer branches more decidedly fan-shaped, the pinnæ being closer and more parallel to one another. The cells are in two rows, nearly opposite, smooth and pellucil, adnate, with the margin of the comparatively wide aperture sinuated so as to form two or sometimes three prominent denticles. The branches in some specimens are gracefully arched, bending as it were under the load of pregnant ovaries which they carry, and which are arranged in close-set rows along the upper sile of the pinnæ. They are of an oral shape, smooth, attenuated at the hase, with sometimes a sharp spine at each corner of the apex, but these are oftener absent.

This and the preceding have a distinct stem, in which they differ from all the other native species, which are pre-eminently frondose or homologous, the offsets and pinnæ being in all respects the same as the prinary shoot. Pallas maintains that they constitute but one species, his S. cupressina, Elench. 14I. - the characters assigned to them respectively heing far from specifical, since he found, on one 
and the same specimen, that the young vesicles had long spines at their tops, the more mature shorter ones, and on full-grown vesicles they were nearly or altogether obsolete; while bluntly tubulous and acutely pointed cells occurred promiscuonsly, on the same stalk, in specimens of every size and exterior habit. Linnæus, apparently swayed by these assertions, followed Pallas; but Ellis, in a later work, adhered to his first opinion, for, " besides the difference of their denticles (cells) and ovaries," which he evidently regarded as permanent, they have, he says, "quite a different habit and manner of growing:" All subsequent writers have assenterl to Ellis's views, most of them, at the same time, expressing a suspicion of their correctness, and my own limited observations have possesse $\mathrm{de}$ with the same dubiety. Specimens can be readily produced which, from habit and the figure of their cells, will be at once pronounced the representatives of distinct species, but a larger examination may lead to anther conclusion. I have seen no specimens of S. cupressina with the cells of S. argentea, * but I lave seen several which, from their habit, I would refer to the latter, with the cells and vesicles of the former. Such a specimen is figured in Plate XII. I can also state that on the same specimen I have observed cells that might be considered as belonging to either species; and with these facts I should, perhaps, have amalgamated the synonymes, had I not been aware that some of our best naturalists, for example Bean and J. V. Thompson, are opposed to the junction. "Besides," to adopt the words of Professor Lindley in a somewhat similar discussion, "our daily ex. perience shows us that excessive analysis is far preferable to excessive synthesis, especially for the purposes of students; the former leads to no other inconvenience, than that of increasing the degree of investigation which species must receive to be understood: the latter has a constant tendency to render investigation superficial, and characters confused," Syn. of the British Flora, Pref. p. ix.

Professor Jameson has inserted Sertularia cupressoides among those species found in the Frith of Forth, Wern. Mem. i. 564 ; and in the work entitled "Corallina," p. 83, the elegant Australasian S. ELONGATA and S. PECTinata are said to be found on the English coast. I believe there is some error in all these illstances.

I have repeatedly observed on oyster-shells, and among the roots

- It deserves to be remarked, in comection with this point, that the characters of $S$. argentea given by Lamarck are really those of $S$. cupressina; and this has ascribed to it the diagnostics of $S$. argentea. 
of corallines, a sessile vesicular body filled with milk-white granules, resembling very exactly the oviferous vesicle of a Sertularia, but of what species I am unalle to say, if indeed it belongs to any. It is rooted, snbsessile, rounlish, slightly flattened on the sides, smooth, with a short tubulous even aperture. Fig. 10, page 92. It has no attachment to any organized hody. Can it be the nidus of some minute Fusus or Purpura?

\section{Thuiaria, * Fleming.}

Character. Polypidom plant-like, rooted by a tubular fibre, erect, dichotomously branched or pimnated; the cells sessile, biserial, adnate to the rachis or "imbedded in the substance of the stem and branches ;" vesicles scattered.-Polypes hydraform.

1. 'Тн. Тнuгі, cells ovato-clliptical, rather acute; vesicles pear-shaped. Sir Robert Sibbald. $†$

$$
\text { Plate XIV. and XV. Fig, 1, } 2 .
$$

Planta marina equiseti facie, Sib. Scot. ill. ii. lib. iv. 55, tab. 12, fig. 1 .

Fueus equiseti facie, Ibid. lib. i. 56. Raii, Syn. 50, no. 47._- Bottlebrush Coralline, Ellis, Corall. 10, no. 9, pl. 5, fig. b. B._-Sertularia thuja, Lin. Syst. 1308. Pall. Elench. 140. Ellis and Soland. Zooph. 41. Berk. Syn. i. 217. Turt. Gmel. iv. 678. Wern. Mem. i. 564. Turt. Brit. Faun. 213. Bosc, Vers, iii. 109. Stew. Elem. ii. 442 . Lamour. Cor. Flex. 193. Corall. 84. Hogg's Stock. 32. Risso L'Europ. Merid. v, 311.__Cellaria thuia, Lam. Anim. s. Vert. ii. 339. Stark, Elem. ii. 439._ Thuiaria thuia, Flem. Brit. Arim. 545. Johnston in Trans. Newc. Soc. ii. 261._La Biseriare thuia, Blainv. Actinol. 482, pl. 81, fig. 3.

Hab. On shells from deep water. "They are found on the coast

" Formed from duix - a cedar. There is a Thuarea in Botany, so near to the zoophytical genus in sound as to render this name objectionable. The Thuarea is formed from the name of the botanist $\mathrm{A}$. du Petit-Tlouars.

† There is a very interesting life of Sir Robert, written by himself, in the Analecta Scotica, v. j. p. 126 et seq. It is printed in a separate form with the title "The Autobiography of Sir Robert Sibbald, Knt. M. D. ; to which is prefixed a short aceount of his MSS." Sro, published by Thomas Sterenson, Edin. 1833. The pamphlet forms the basis of his Life prefixed to the 20th rol. of the "Naturalist's Lihrary," with which a portrait is also given. Sir Robert was born 15th April 1641 ; graduated in 1662 ; was knighted in 1682; and died probably in 17:20, for the precise date has not been ascertained. See Pulteney's Sketehes of the Progress of Botimy, v. ii. p. 4-8. The following Elogium is from the Second Series of the Analecta Scotica, p. 153, Edin. 1837.

" Illustrata simul decorat, pariterque Sibaldum

" Seotia, scriptori lumine grata suo." 
of Scotland, and in the north of England, particularly about Scarborough, where the fishermen have given them the name of Bottlebrushes," Ellis. "Very frequently found on the coast of Durham," J. Hogg. Common on N. Durham and Berwickshire, G. J. Leith shore, Jameson.

This remarkable coralline is sometimes a foot in height, generally less, affixed by a tubular fibre, which is sometimes agglutinated to others from other shoots, so as to form a lichen-like crust concentrically wrinkled. Stem percurrent, erect, filiform, rigid, zig-zag, knotted, naked underneath, bearing on the upper part a cylindrical tuft of dichotomous short equal branches, coming off alternately and so disposed that four complete a whorl. The knots on the lower part are the remains of former branches which seem to drop off as the portion of the stem immediately beneath them successively loses its vitality. The stem has no cells, and neither it nor the branches are jointed. Cells close-pressed, arranged in two rows, sub-alternate, smooth, tapered from the base to a contracted orifice. Vesicles sul)pedicellate, pear-shaped, smooth, placed in clusters or solitary on the upper side and towards the base of the branches; they are produced mostly in the winter season, and are filled with a milk-white grumous fluid previous to the discharge of the ova.

Young specimens of this polypidom are simply pinnate, but these may be always distinguished from the following by the greater intervals between the origin of the pinnæ, and by the shape of the cells. The Fig. 1,2 of Plate XV. representsa specimen of this kind, which las been the more readily introrluced, since it exhibits the living polypes in an active state, and proves that the coralline has no relationship to Cellaria.-The Sertularia thuia of Fabricius in his Fauna Groenlandica, p. 444, I am inclined to refer to Sert. pumila.

2. Th. articulata, cells ovate, obtuse or truncate; ovarian vesicles elliptical. Ellis.

\section{Plate XV. Fig. 3, 4.}

Sea-Spleenwort or Polypody, Ellis, Corall. 11, no. 10, pl. 6, fig. $a, A .-$ Sertularia articulata, Pall. Elench. 137.__. Lonchitis, Ellis and Soland. Zooph. 42.__. Lichenastrum, Berk. Syn. j. 219. Turt. Gmel. iv. 683. Turt. Brit. Faun. 216. Stew. Elem. ii. 447. Bose, Vers, iii. 119.___Cellaria Lonchitis, Lam. Anim. s. Vert. ii. 139._— Thuiaria articulata, Flem. Brit. Anim. 545.__La B. articuléc, Blainv. Actinol. 482.

$H a b$. On shells and stones in deep water, very rare. In the harbour of Dublin, Ellis. At Scarborongh, Mr Bean.

Polypilom about 4 inches high, pinnate, lanceolate, corneous, suh- 
pellucid, the stem nearly equal in diameter throughout, compressed upwards, finely wrinkled when dry, divided by joints not regularly equidistant, naked on the lower half, pinnated above and celliferous: pinne simple, patent, rather close-set, not exactly opposite nor yet properly alternatc. Cells in a single series along each side, semialternate, ovato-tubular, short with a round plain aperture. Vesicles issuing from both sides of the pinne, most numerously from the upper, subpedicellate, clliptical, smooth, the orifice contracted and even.

,Through the liberality of $M r$ Bean, I am enabled to give a figure - the most perfect one which has been yet published-of this rare species. Its synonymes are somewhat confused. Pallas affirms, correctly in my opinion, that the Sea-Spleenwort of Ellis is not the Sertularia Lichenastrum of Linnæus as generally asserted, and he has described a different species considered by him as identical with the Linnean. The figure of Ellis is quoted by Pallas as an admirable representation of his own S. articulata, but in the description of this the branches or pinna are said to he opposite, whereas in Ellis's fi. gure, and in our own, although less deciledly, they are regularly alternate. Ellis notices uncler his S. Lonchitis a foreign variety with opposite cells and pimnæ, having " the joints both on the stem and branches much closer together "; and it will probably be found that this constitutes a distinct species, hitherto confounded with others nearly allierl.

\section{Antennularia, * Lamarck.}

Character. Polypidom plant-like, horny, simple or branched irregularly, the shoots fistular, jointed, clothed with hair-like verticillate lranchlets : cells small, sessile, campanulate, unilateral : vesicles scattered, unilateral-Polypes hydraform.

\section{A. Antennina.-Mrs Ward. +}

\section{Plate XVI.}

Lobster's.holn coralline or Sea-beard, Ellis, Corall. 15, no. 14, jl. 9, fig. a, b, A. B. C. Phil. Trans, xlviii. 630, tab. 22, no. 3. Phil. Trans. abridg. x. 491, pl. 12, fig. 3, C._- Sertularia antennina, Lin. Syst. 1310. Pall. Elench. 146. Ellis and Soland. Zooph. 45. Berk. Syn. i. 217. Turt. Gmel. iv. 679. Wern. Mem. i. 564. Turt. Brit. Faun.

* From Antennula, diminutive of antenna, a term applied to the feelers of insects.

† "Found on the rocks by Mrs Ward, an ingenious gentlewoman of Gisburgh in Cleveland, Yorkshire, and by her named Sea-beard; I suppose from its growing in a thick tuft; Mr Lawsolı."-Ray. 
214. Stew. Elem. ii. 443. Bosc, Vers, iii. 111.—Antennularia anten. nina, Flem. Brit. Anim. 546. Johnston in Trans. Newc. Soc. ii. 260.

Var. 1. The stem simple._Corallina astaci corniculorum æmula, Raii, Syn. i. 34, no. 10._Corallina affinis, non ramosa, Pluken. Almag. Bot. 119. -Muscus marinus s, coralloid. non ramosus, erectus, Pluken. Phytog. tab. 48, fig. 6.—_ertularia antennina, Hogg's Stock. 33.—-Nemertesia antennina, Lamour. Cor. Flex. 163, Corall. 71.__Antennularia, indivisa, Lam. Anim. s. Vert. ii. 123. 2de edit. ii. 156. Templeton in Mag. Nat Hist. ix. 468. L_Antennulaire simple, Blainv. Actinolog. 486, pl. 83, fig. 3.

Var. 2. The stem branched.-Corallina minima, Ger. Herb. emac. 1572, no. 4, quoad tig.___. ramosa cirris obsita, Raii, Syn. 35, no. 11._-_. Sertularia seticornis, Hogg's Stock. 33.—-Nemertesia ramosa, Lamour. Cor. Flex. 164. Corall. 71.--Antennularia ramosa, Lam. Anim. s. Vert. ii. 123. 2de edit. ii. 156. Stark, Elem. ii. 440. Templeton in lib. cit. 468.-L'A. rameuse, Blainv. Activolog. 486.

$H a b$. On shells and rocks in deep water, frequent. "In littore Dubrensi collegit D. Dare Pharmacopæus Londinensis," Ray. Sussex coast, Ellis. From deep water in the Frith of Forth, Jameson. Common on the coasts of Durham, Northumberland, and Berwickshire, G. J. Cork harbour, J. V. Thompson. (1.) "On the shore of Dublin Bay; (2.) Found on the shore of Belfast Lough," Templeton.

Stems clustered, rooted by numerous implexed tubular fibres, erect, straight, attaining a height of $S$ inches and upwards, cylindrical, of a clear yellowish-horn colour, irregularly branched or undivided, and in the latter instances resembling, when dried, the Lobster's antenna, to which they have been appropriately compared. The branches are exactly like the primary shoot, and are equally beset with hair-like branchlets arranged in numerous whorls. These are often broken short in specimens cast on shore after storms, but in recent ones dredged from their native sites they are as long as represented in our figures. They carry the polype cells, which are distant, small and campanulate with entire rims, and divided from each other by a joint. The ovarian vesicles are situated in the axils of the whorls, subpedicellate, ovate, smooth, with a subterminal aperture.

I can detect no essential difference between the two varieties, and I have had, through the kindness of friends, an opportunity of examining specimens from various parts of the coast.

\section{Plumularia ; * Lamarck.}

Character. Polypidom plant-like, rooted, simple or branch-

* Formed from Plumula, the dimin. of Pluma, a featber.-I have, in common with most French authors, adopted the generic names of Lamarck in prelerence 
ed, the shoots and offsets plumous : cells small, sessile, unilateral, usually seated in the axilla of a homy spine: vesicles scattered, unilateral. - Polypes hydraform.

\section{* Stem a single tube.}

\section{P. FALCATA, stem waved, branched; branches alternately} pennated; cells close-ranked, shortly tubulous with a plain rim; vesicles oblong.oval. Merret. *

\section{Plate XVII. Fig $1,2$.}

Corallina muscosa pennata, ramulis et capillamentis falcatis, Raii, Syn. i. 36, No. 16.— Muscus pennatus, ramulis et capillamentis falcatis, Pluken. Phytog. tab. 47, fig. 12.—Muscus maritimus pennatus ramulis et capillamentis falcatis, Morris. Plant. hist. Ox. iii. 650, tab. 9, fig. 2.__ Sickle Coralline, Ellis, Corall. 12, No. 11, pl. 7, fig. $a$, A. and pl. 38, fig. 6.— Sertularia falcata, Lin. Syst. 1309. Pall. Elench. 144. Ellis and Suland. Zooph. 42. Berk. Syn. i. 217. Turt. Gmel. iv. 679. Blumenb. Mau. 273. Wern. Mem. i. 564. Turt. Brit. Faun. 213. Stew. Elem. ii. 443. Bosc, Vers, iii. 110. Hogg's Stock. 32.—Aglaophenia falcata, Lamonr. Cor. Flex. 174. Corall. 77.__ Plumularia falcata, Lam. Anim. s. Vert. ii. 12j. 2de edit. ii. 160. Grant in Edin. New Phil. Journ. i. 155. Flem. Brit. Anim. 546. Johnston in Trans. Newc. Soc.

to those of Lamouroux, although aware that the claim of priority is generally allowed to the latter; but let us hear what Milne-Edwards says._- "Pendant que Lamarck préjarait le grand ouvrage dont le second volume est consacré aux Polypes, Lamouroux s'occupait du même sujet, et fit paraître à Caen un traité spécial sur les Polypiers coralligènes flexibles. D'après la date de la présentation de son manuscrit à l'Institut, on pourrait même lui attribuer l'antériorité sur Lamarck, et penser que ce derrier savant, nommé par l'Académie des Sciences commissaire pour l'examen du mémoire de Lamouroux, avait profité de cette circonstance pour s'approprier les résultats obtenus par ce zoologiste. Un atlteur récent semble porté à croire que les choses se sont passées de la sorte; mais les traditions du muséum prourent qu'il n'en est rien, et je me plais à rendre ici toute justice à la conduite de Lamarck. En effet, M. Valenciennes, qui était alors attaclı́ à Lamarck en qualité d'aide-naturaliste, m'a assuré que depuis long-temps toutes les divisions génériques établies par ce professeur daus la classe des Polypiers se trouvaieut indiquées dans la collection publique de muséum, et que pour faciliter le travail de Lamouıoux sur le même sujet, Lamarck a vait mis généreusement à sa disposition toutes les riclıesses de cet établissement déja denominées et classées par ses soins."-Ann. des Sc. Nat. Part. Zool. Tom. vi. second ser. p. 12 .

* For an account of Dr Christopher Merret see Pulteney's Sketches, v. i. p. 290, \&c ; and Thomson's Hist. of the Roy. Soe. p. 22. He was born in 1614 ; was one of the original members of the Royal Socicty; and died in 1695. Ray's character of lim in 1688 is,_- "annis et scientia gravis, de Professione sua deque Repub. Botanica optime meriti." Hist. Plant. ii. pref. Contrast this with the character in Sir J. E. Smith's Eng. Flora, i. pref. vii-viii. 
ii. 259. Templeton in Mag. Nat. Hist. ix. 466. Risso, L'Europ. merid. v. 313._I.a P. en faux, Blainv. Actinolog. 477.

$H a b$. On shells and rocks near low water-mark and in deep water. A common and very elegant species, generally from 4 to 6 inches in height, rising in wide spiral turns, and sending out from its filiform percurrent stem, at regulated intervals, alternate spreading plumous branches which are placed one above the other on the outer side. Pinnæ alternate, bifarious. In young specinens the branches are two-ranked and alternate, and I have seen this character remain in one specimen of considerable size. There are no cells on the spiral stem, but they occur on the branches as well as on the pinnæ, and are arranged in two rows pointing alternately to opposite sirles. There is a fine figure of the coralline in the centre of the curious frontis. piece to Ellis's Essay; and the magnified figure in tab. 38 is a more correct representation of the cells than that given in tab. 7, which has been drawn from a dried specimien. The ovarian vesicles are of uncertain occurrence, and I have seldom seen them; they are scattered irregularly on the branches, stalked, ovate or pear-shaped, with a short tubulous aperture, aud occasionally wrinkled longitudinally when dry.

" This species is very common in the deeper parts of the Frith of Forth; its vesicles are very numerous, and its ova are in full maturity at the beginning of May. The ova are large, of a light-brown colour, semi-opaque, nearly spherical, composed of minute transparent granules, ciliated on the surface and distinctly irritable. There are only two ova in each vesicle; so that they do not require any external capsules, like those of the Campannlaria, to allow them sufficient space to come to maturity. On placing an entire vesicle, with its two ova, under the microscope, we perceive through the transparent sides, the ciliæ vibrating on the surface of the contained ova, and the currents produced in the fluid within by their motion. When we open the vesicles with two needles, in a drop of sea-water, the ova glicle to and fro through the water, at first slowly, lut afterwards more quickly, and their ciliæe propel them with the same part always forward. They are highly irritable, and frequently contract their bodies so as to exhibit those singular changes of form spoken off by Cavolini. These contractions are particularly observed when they come in contact with a hair, a filament of conferva, a grain of sand, or any minute object; and they are likewise frequent and $r$ markablo at the time when the ovum is busied in attaching its borly permanently to the surface of the glass. After they have fixed, they become flat and circular, and the more opake parts of the ova assume a radiated appearance; so that they now appear, even to the naked eye, like 
so many minute grey coloured stars, having the interstices between the rays filled with a colourless transparent matter, which seems to harden into horn. The grey matter swells in the centre, where the rays meet, and rises perpendicularly upwarls surrounded loy the transparent horny matter, so as to form the trunk of the future zoophyte. The rays first formed are ohviously the fleshy central substance of the roots, and the portion of that substance which grows perpendicularly upwards, forms the Heshy central part of the stem. As early as I could observe the stem, it was open at the top; and, when it bifurcated to form two branches, both were open at their extremities, but the fleshy central matter had nowhere developed itself as yet into the form of a polypus. Polypi, therefore, are not the first formed parts of this zoophyte, but are organs which appear long after the formation of the root and stem, as the leaves and flowers of a plant." Professor Grant.

2. P. CRISTATA, shoots simple, plumous, the pinne alternate; cells in a close row, cup-shaped with a toothed margin and a short lateral spine; vesicles giblous, girt with crested ribs. Ellis.

Plate Xix. Fig. $1-3$, and Plate XX. Fig. 1.

The Podded Coralline, Ellis, Corall. 13, no. 12, pl. 7. fig. b. B.—Sertularia pluma, Lin. Syst. 1309. Pall. Flench. 149. Ellis and Solend. Zooph. 43. Berk. Sym. i. 217. Turt. Gmel. jv. 679. Turt. Brit. Faun. 214. Stew. Elem. ii. 443. Bose, Vers, iii. 111, pl. 29, fig. 1, pessima. Lister in Phil. Trans. an. 1834. 369, pl. 8, fig. 2. - Aglaophenia pluma, Lamour. Cor. Flex. 170. Corall. 75.__ Plumularia cristata, Lam. Anim. s. vert. ii. 125. 2de edit. ii. 161. Stark, Elem. ii. 440. Templeton in Mag. Nat. Hist. ix. 467. Risso, L'Europ. mérid. v. 313._Pl. pluma, Flem. Brit. Anim. 546. - La Plumulaire plume, Blainv. Actinol. 477.Sertolaria pluma, Cavol. Pol. mar. 210, tav. 8, fig. 5-7.

Hab. On Fuci, particularly Fucus siliquosus, and sometimes " on muscles and other shells." Common on the southern coasts of England. Picked up on the shore at Stevenston, Ayrshire, Rev. D. Landsborough. On the coast of Ireland near Dublin, Ellis. On the shore of Belfast Lough, \&c. $M T$. Templeton.

Attached to sea-weeds by a flexuous horny anastomosing tubular fibre, which throws up, at intervals, phumous shoots from one to one and a half inch high: these are very elegant and erect when in the sea, but when dry become curved in a falcate manner with all their pinnles, which are also frequently laid to one side. "Siccatione surculi sursum seu contrario modo quam fuerant, recurvantur, pinnulæque curvatæe ad invicem accedunt." Pallas. The polypilom is of a honey-yellow colour with a dark brown rachis, which is smooth, and divided by numerous ohlique septa or joints, there being one be- 
tween every pair of pinnæ. Pinuæ alternate, close, parallel, celluliferous on the upper side; the cells separated by a joint and set in a sort of indentation in the stalk. They have been aptly compared by Ellis to the flower of the lily of the valley, being of a campanulate form with the rim cut into eight equal teeth, while in front there is a stronger spinons process which does not project beyond the cell. The ovarian vesicles are large and remarkably curious : they are produced both from the main stalk and pinnæ, are shortly pedicellate, and resemble a swollen pod girded round with from 5 to 9 cristated ribs or bands proceeding from a dorsal tube, and rising into short spines on the anterior margin. When recent " they are translucent, and six or seven dark oval masses can be seen within each. These seemed to be ova. The vesicle being torn up, and the ova allowed to escape, they were seen to be in form irregularly oval, but contain. ing an opake elongated body in their centre. (Fig. 6, p. 48.) The form of this central body varied in different ova, but it was generally somewhat hanmer-shaped. Neither the general mass of the ovum, nor this central body were seen to move." $D$ r Coldstream, June 10, 1833.-Polypes " minute, delicate ; tentacula 10, annulated; mouth infundibuliform." Dr Coldstream.

"Each plume," says Mr Lister in reference to a specimen of this species, " might comprise from 400 to 500 polypi ;" and a specimen, of no unusual size, before me has twelve plumes, with certainly not fewer cells on each than the larger number mentioned, thus giving. 6000 polypes as the tenantry of a single polypidom! Now many such specimens, all united too by a common fibre, and all the offshoots of one common parent, are often located on one sea-weed, the site then of a population which nor London nor Pekin can rival ! But Pl. cristata is a small species, and there are single specimens of $\mathrm{Pl}$. falcata, or Sertnlaria argentea, of which the family may consist of 80.000 or 100,000 individuals. It is such calculations, always under-rated, that illustrate the "magnalities of Nature," and take us hy surprise, leaving us in wonderment at what may be the great objects of this her exuberant production of these " insect-millions peopling every way." But

"So He ordain'd, whose way is in the sea,

His path amidst great waters, and his steps

Unknown;--whose judgments are a mighty deep,

Where plummet of Archangel's intellect

Could never yet find soundings, but from age

To age let down, drawn up, then thrown again,

With lengthened line and added weight, still fails;

And still the cry in Heaven is ' $\mathrm{O}$ the depth' !"-Montgomery. 
I have a specimen of $\mathrm{Pl}$. cristata gathered in Cork Bay, and presented to me by J. V. Thompson, Esq., which is nearly 3 inches in height, spreading laterally, the rachis divided in a regular dichotomons manner, and rough or muricated on one side, wherever it is naked of pinn:e. The vesicles have from 7 to 9 crested ribs with a spinous dorsal keel. The roughness of the rachis is produced by the remains of the deciduous pinna. I give a figure of this specimen, (Plate XX. Fig. I,) as an additional proof that little reliance can be placed on external habit as a character in determining the species of this order.

3. P. pennatula, plumous, the pinuce opposite; cells in $\boldsymbol{a}$ close row, cup-like with an unequally crenated margin, supported on the under side by a lengthened incurved spinous process. Montagu.

\section{Plate XVIII. Fig. 1, 2.}

Sertularia permatula, Ellis and Soland. Zooph. 56, tab. 7, fig. 1, 2. Bose, Vers, iii. 114. Fleming in Edin. Phil. Journ. ii. 83.—_Aglaophenia pennatula, Lamour. Cor. Flex. 168. Corall. 74._-Plumularia penna. tula, Lam. Anim. s. Vert. ii. 128. 2de edit. ii. 165. Flem. Brit. Anim. 546. La P. pennatule, Blainv. Actinolog. 478.

Hab. Coast of Devonshire, rare, Mr.Montagu.

"This coralline is as remarkable for the elegance of its form, as its likeness to the feather of a pen." Specimens frum the seas of tropical climates are from 5 to 6 inches high, but my British specimen, which I owe to the liberality of J. E. Gray, Esq., is scarcely one inch and a half. The polypilom rises from implexed tubular fibres: the lower portion of the cylindrical jointed rachis is naked, the upper pennate and gracefully proportioned. The cells are small with a waved margin and a little spine on each side, and they are seated in the axil of a long tubular incurved process which rises much above them. Lamouroux has conjectured that the Pl. pennatula of Fleming is only a repetition of Pl. myriophyllum; and Milne-Edwards refers it to Pl. cristata. I cannot see the slightest foundation for these suspicions.

4. P. PINNAta, stem plumous, the pinne alternate; cells rather distant, one on ench internode, campanulate, leaning, the mouth entire; vesicles obpyriform, strongly toothed above. Dillenius.*

\section{Plate XVII. Fig. $4,5$.}

* Born in 1687 at Darmstadt in Germany ; came to England in 1721 ; and died at Oxford in 1747. He was the first Professor of Botany there, and has not been equalled in celebrity by any successor. It is unnecessary to give particulars of 
Fucoides setis minimis indivisis constans, Raii, Syn. i. 39, no. 7. tab. 2, fig. 2. lit. $a$, (injured and deprived of the pinne.) - Sea Bristles, Ellis, Corall. 19, no. 16, pl. 11. fig. a. A.—_Sertularia pinnata, Lin. Syst. 1312. Ellis and Soland. Zooph. 46. Berk. Syn. i. 219. Turt. Gmel. iv. 683. Turt. Brit. Faun. 215. Stew. Elem. ii. 446. Bosc, Vers, iii. 118. Aglaophenia pinnata, Lamour. Cor. Flex. 172. Corall. 76.Plumularia pinnata, Lam. Anim. s. Vert. ii. 127. 2de edit. ii. 164. Risso, L'Europ. merid. v. 313. Johnston, Trans. Newc. Soc. ii. 260, and in Mag. Nat. Hist. vi. 498.—La P. pinnée, Blainv. Actinolog. 477.

Hab. On shells, stones and other corallines in deep water. "In littore maris pone Sheerness," D. Dillenius. At Briglitelmstone and Whitstable, Ellis. Scarborough, $\boldsymbol{M} r$ Bean. Cullercoats, Northumberland, $M r J$. Alder. Common in Berwick Bay, G.J. Frith of Forth, Dr. Coldstream. Cork Harbour, J. V. Thompson, Esq.

In general about one inch and a lialf, but sometimes attains the leight of four inches, very delicate, simple, plumous, white, and pretty. The rachis is compressed, straight, jointed, the internodes abont six times longer than their diameter, and each giving origin to three pinnæ, in which character I find an invariable and ready distinction between this and the following species. There is a minute tooth-like spine, only visible under the microscope, between the cells, which are perfectly transparent, and admit a distinct view of the polypes. These have a reddish body and numerous tentacula. The vesicles are rarely produced, but then profusely, and the specimens on which I have seen them have lost almost all their polypiferous pinnox. At the base of the remnants they occur clustered, and are pear-shaped with an aperture cut into a circle of spinous teeth, or, as Ellis expresses it, "the tops of the ovaries are divided like a coronet."

5. P. SETACEA, pimnate, the pinna alternaie, one originating at each ringed joint of the rachis; cells very remote, campanulate, with an even margin; vesicles elliptical, smooth. Ellis.

Plate XVIII. Fig. 3-5.

Corallina setacea, Ellis, Corall. tab. 38, fig. 4._- Sertularia pinnata $\beta$, Lin. Syst. 1312. S. setacea, Pall. Elench. 148. Ellis and Soland. Zooph. 47. Turt. Gmel. iv. 683. Wern. Mem. i. 564. Turt. Brit. Faun. 216. Stew. Elem, ii. 446. Bosc, Vers, iii. 119. Hogy's Stock. 33. Lister in Phil. Trans. an. 1834, 371, pl. 8, fig. 4, but the vesicles

so eminent a man ; for his life 1 may refer the reader to Pulteney's Sketches v. ii. p. 154, \&e. ; Thom son's Hist. Roy. Society, p. 26; and Brewster's Edin. Encyclopsedia, v. vii. p. 742 ; a good article contributed by my worthy friend $\mathrm{Dr}$ Neill. Haller's notice of his friend is short, but interesting. Bib. Bot. v. ii. p. 124. 
belong to Pl, pinuata.___Aglaophenia setacea, Lumour. Cor. Nhex. 172. Corall. 76._Plumularia seticea, Lam. Anim. s. Vert, ii, 129. 2de edit. ii. 165. Flem. Brit. Anim. 547. Templeton in Mag. Nat. Hist. ix. 467. Starh, Elem. ii. 440. Risso, L' Europ. mérid. v. 313.La P. setacée, Blainv. Actinol. 477.

Hab. Parasitical on other corallines, not uncommon. At Brighton on flag, Lister. Frequent near Hartlepool, growing on the roots of the Palmated Fucus, Hogg. On scallop shells in the Frith of Forth, Jameson. Berwick Bay, G.J. Belfast Lough, Templelon. Cork Harbour, Thompson.

In favourable sites this coralline will sometimes attain a height of six inches, but in general it is smaller, more delicate, and less plumous than Pl. pinnata with which it has been confounded, althongh its luabit and minuter characters prove it to be quite distinct. Thestem is somewhat waved and regularly jointed, the joints consisting of two or three rings, and immediately under eacli joint the internode is somewhat enlarged in consequence of the pinna originating there, a single pinna only springing from under each joint, whereas in $\mathrm{P}$. pinnata, as already remarked, three pinnæ proceed from each interspace, the joints of which, moreover, consist of a single fracture. The pinnæe are jointed like the stem, celliferous, the cells small and distant. At the base of each there is a minute tubular process (abortive cell?), visible only with a high magnifier. The vesicles are elliptical, smooth, with a narrow plain orifice, and originate in the axils of the pinnæ.- "The ova within were opake and yellow. Its polypi had from sixteen to nineteen arms, sud when they were full blown it was an object of remarkable beanty." Lister.

6. P. Catharina, stem plumous, the pinnce opposite, bent invords; cells distant, campanulate with an even margin ; vesicles scattered, pear-shaped, smooth. G. J.

\section{Vignette, No. 8, page 79.}

Plumularia Catharina, Johnston in Mag. Nat. Hist. vi. 498, fig. 61, 62.

$H a b$. On old shells, corallines, and ascidia in deep water. At Scarhorough, rare, $\boldsymbol{M r}$ Bean. Frith of Forth, $D_{r}$. Coldstream. Frequent in Berwick Bay.

This equals Pl. pinnata in size and delicacy, but differs from it very obvionsly in having opposite pinnæ, which, instead of being arched, bend inwards, so as to render the general form of the coralline concave on a front view; an appearance produced by the pinnæ originating, not from the sides, but from the anterior face of the stem. The stem itself is straight or slightly bent, jointed, pellucid, filled with a granular fluid matter ; and, in which it differs from its congeners, bearing cells, there being always one at the base and between the insertion of the pinnæ, and generally another on the 
interval between them. Between the cells there is a series of minute tubular or tooth-like cells, visible only with a high magnifier. The ovarian vesicles are produced in summer : they are stalked, shaped like a pear or vase, solitary, scattered, and originating always at the base of a polype cell. From the intermediate cellules, particularly from the one next the polype-cell, there often grows up a small trumpet-like tube; and I have seen, in one specimen, all the ends of the branches terminated by four of these tubes divergFig. 16.

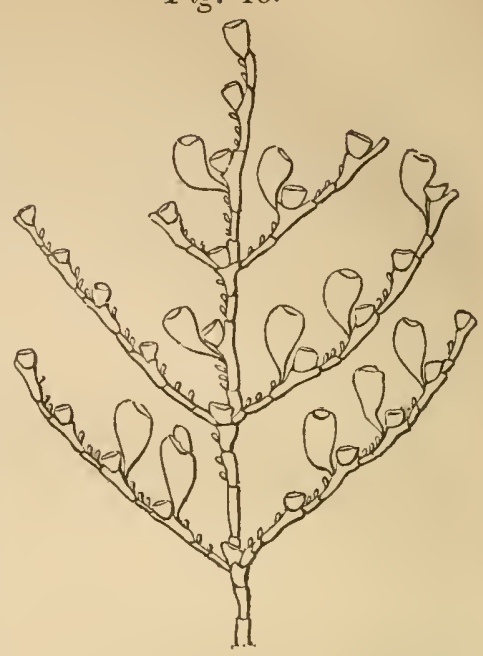
ing in pairs.-To this very distinct and elegant species $I$ have taken the liberty of assigning the Christian name of the lady to whom this work is indebted for nearly all its illustrations.

“ $\mathrm{O}$ quæ fontibus integris

Gaudes, apricos necte flores,

Necte meo Lamix coronam,

Pimplei dulcis ! nil sine te mei

Possunt honores." Hor. Carm. i. ode 26.

\section{* * Stem composed of many parallel tubes.}

7. P. mYRIOPHYLlum, clustered, the stems undivided, bellied at distant intervals, pinnate; pinne leaning to one side; cells shortly tubular, seated in the axil of a curved spinous process, the aperture wide and nearly even. Ellis.

\section{Plate XIX. Fig. 4, 5.}

Corallina fruticosa pennata, Petiv. Plant. Ital. tab. 2. fig. 11._-Pheasant's-tail Coralline, Ellis, Corall. 14, no. 13, tab. 8, fig. a. A.—-Sertularia myriophyllum, Limn. Syst. 1309. Pall. Elench. 153. Ellis and Soland. Zooph. 44. Berk. Syn. i. 217. Turt. Gmel. iv. 678. Turt. Br. Faun. 213. Stew. Elem ii. 443. Bosc, Vers, iii. 109. —-Aglaophenia myriophyllum, Lamour. Cor. Flex. 168. Corall. 74.—Plumularia myriophyllum, Lam. Anim. s. Vert. ii. 124. 2de edit. ii. 159. Flem. Brit. Anim. 547. Templeton in Mag. Nat. Hist. ix. 466. Stark, Elem. ii. 440. Risso, L'Europ. Merid. v. 312._L La P. myriophylle, Blainv. Actinolog. 477 , pl. 83 , fig. 4.

Hab. Deep water, rare. Near Dublin, Ellis. Coast of Devon. shire, Dr Coldstream. "Found by R. Brown, Esq, on the shore at Ballycastle. In Dublin Bay," Templeton. 
The roots are matted together with numerous entangled fibres. Stalks 6 inches in height or more, the largest as thick as a crow-quill, yellowish-lrown, straight or slightly curved, swollen at intervals on the back, and simple or once divided : they are each of them composed of a number of tubes hound together, as is easily seen on a transverse section, and the oblong dorsal knobs seem to be produced by a less close adhesion of the tubes at these places, "marking probably the stages of growth." The l,ranches or pinna spring from both sides beginning about the middle of the stalk, the lower part being naked, but they incline so much one way as to appear unilateral. The wide eylindrical cells are divided from each other by a joint, and are seaterl in the axil of a curved spinous process which projects far enough to form a short tooth at the under side of the aperture.When dry the stalk is twisted and more distinctly perceived to be composed of a bundle of tubes, and consequently furrowed. In each of the furrows there is a row of small holes with a raised brim as if punctures had been made by an instrument pushed from within. 'The holes are close-set, and regular in their size, form, and in the distances between them.

8. P. FRUTESCENS, stem branched, the branches piunate; pinnce alternate, bifid; cells infundibuliform, leaning, rather distant, the mouth plain. Ellis.

$$
\text { Plate XX. Fig. 2, } 3 .
$$

Sertılaria Gorgonia, Pall. Elench. 15s.__. S. frutescens, Ellis and So. land. Zooph. 55. pl. 6, fig. a, $\Lambda$, and pl. 9. fig 1, 2, encrusted with a Gorgonia. Turt. Gmel. iv. 680. Turt. Brit. Faun. 214. Stew. Elem. ii. 445. Bosc, Vers, iii. 113. Hogg's Stock. 33._- Aglaophenia frutescens, Lamour. Cor. Flex. 173. Corall. 76.__ Plumularia frutescens, Flem. Brit. Anim. 547. Lam. Anim. s. Vert. 2de edit. ii. 166._LLa P. frutescente, Blainv. Actinolog. 477.

Hab. Found at Scarborongh in Yorkshire, Ellis, -whence I have specimens from $M r$. Bean, who states that it inhabits deep water, where it grows attached to stones and shells by a fibrous base, and is very rare. Hartlepool, Durham, J. Hogg, Esq.

Polypidom between four anıl five inches in height, firm and woody, black or dusky-brown, varnished, irregularly branched. Stem and branches tapered, composed of many parallel twisted capillary tubes, the branches erecto-patent, spreading laterally, pinnate ; pinnæ rather close, alternate, two or three from each space hetween the joints, and each divided into two hranches. Cells rather distant, arhate, cylindrical widening outwarls, smooth, with an entire slightly everted margin: there is a small cell in the axils of the pimma, and a den- 
ticle at the base of all the cells, each of which occupies a joint. Vesicles scattered, small, pear-shaped, the rim of the opening plain.

\section{LAonedeA.* Lamouroux.}

Character. Polypidom rooted by a creeping fibre, plantlike, erect; jointed at regular intervals, the joints ringed, incrassated, giving origin, alternately on opposite sides, to the shortly pedicled cells; cells campanulate : vesicles axillary.-Polypes hydraform.

1. L. Dichо'тома, stem filiform, branched dichotomously; cells alternate, campanulate, the rim even. Ellis.

\section{Plate XXII. Fig. 1, 2.}

Sea-thread Coralline, Ellis, Corall. 21, no. 18, pl. 12, fig. a, A.—Sertularia dichotoma, Lin. Syst. 1312. Ellis and Soland. Zooph. 48. Berk. Syn. i. 218. Turt. Gmel. iv. 682. Wern. Mem. i. 564. Turt. Brit. Faun. 215. Stew. Elen. ii. 446. Bosc, Vers, iii. 118. Hogg's Stock. 33.__ S. longissima, Pall. Elench. 119._-Sert. volubilis, Fabric。 Faun. Gronl. 444.—Laomedea dichotoma, Lamour. Cor. Flex. 207. Corall. 91. Risso, L'Europ. Merid. v. 314. La Laomédée dichotome, Blainv. Actinol. 474.-Campanularia dichotoma, Lam. Anim. s. Vert. ii. 113. Flem. Brit. Anim. 548. Stark, Elem. ii. 441. Risso, L'Europ. Merid. v. 309. Grant in Edin. New Phil. Journ. i. 151. Grant in Cyclop. Anat. and Phys. i. 108, fig. 30. Grant, Comp. Anat. 10, fig. 5. Johnston in Trans. Newc. Soc. ii. 255. Templeton in Mag. Nat. Hist. ix. 469. Kister in Plil. Trans. an. 1834, 372, pl. 8, fig. 5.

Hab. On old shells in deep water, common. "This is found in great alundance on the south-west coast of England, and seems most curiously contrived, from its structure, to resist the violence of the waves, all its joints being furnished with springs," Ellis. Scarborongh, $M r$ Bean. Dunstanborough Castle, Mr R. Embleton. Berwick Bay, G.J. Leith shore, Jameson. Found on the shore of Dublin Bay, \&c. Templeton.

Polypidom confervoid, rooted by a creeping flexuous fibre, from fonr to six inches high, slender, filiform, smooth, of a blackish colour, wavy, branched in a dichotomous or alternate manner, the branches ringed at their origins, simple or divided like the primary stem. The cells are bell-shaped, on ringed stalks, transparent and very tender, so that specimens gathered amongst the rejectamenta of the sea are mostly deprived of them. Polypes reddish. Vesicles ovate, smooth, axillary, filled with ova in spring. These are numerous, "amount. ing to twenty or thirty in each vesicle," and like the ova of zoophytes

* $\Lambda x o \mu$ sf $s x$, - the name of our of the Nereids, according to Hesiod's Thengolly. v. 257 . 
in general, clothed with cilia and moveable. Every three of them are inclosed, while in the vesicle, within a thin transparent motionless capsule, presenting at its free extremity several stiff, straight, diverging pointed processes, which Ellis mistook for the tentacula of a young polypus. Dr Grant.

Sir. John G. Dalyell has made some singular observations on this species, which seem irreconcileable with those of Professor Grant and Cavoliai. He tells us that it rarely produces vesicles. When present they contain from 20 to 30 greyish corpuscula with a dark central nucleus. "At first, all are immature and quiescent, but motion at length commences : the corpuscula become more distinct; several slender arms protrude from the orifice of the vesicle, which are seen in vehement action, and, after many struggles, an animated being escapes. But this has no relation either to the planula of the Sertulariæ, or the corpusculum of the Flustra, Alcyonium, or Actinia. It might be rather associated with the Medusarix. Before ascertaining its origin, I had named it Animalculum tintinnabulum, from its general resemblance to a common hand-bell, for the purpose of recognition. This creature is whitish, tending to transparency, about half a line in diameter ; the body is like a deep watch glass, surmounted by a crest rising from the centre, and fringed by about twenty-three tentacula pendant from the lip below. These are of muricate structure, or rough, and connected to the lip by a bulb twice their own diameter. The summit of the crest unfolds occasionally into four leaves, and four organs prominent on the convexity of the body, appear at its base. When free, the animal swims by jerks, or leaps through the water, or drops gently downwards; it is invited to move hy the light, and it has survived at least eight days. Then it disappears, at least I have not been able to pursue its history longer. No other product has ever issued from the vesicles of the Sertularia dichotoma." Edin. New Phil. Journ. xxi. 91-2.

2. L. GENICULATA, stem zig-zay, simple or sparingly branched; cells on annular stalks from the joints, alternate, campanulate, the rim plain; vesicles ovate. Doody.

Plate XXI. Fig. 1, 2.

Corallina confervoides gelatinosa alba, geniculis crassiusculis pellucidis, Raii, Syn. j. 34, no. 7.— Fucoides setaceum tenuissime alatum, lbid. 38, 110. 6, pl. 2, fig. 2. Ellis, in Phil. Trans. abridg. x. 491, pl. 12, fig. 1, a, A. - Knotted-thread Coralline. Ellis, Corall. 22, no. 19, pl. 12. b. B.—Sertularia geniculata, Lin. Syst. 1312. Pall. Elench. 117. Mull. Zool. Dan. tab. 117, fig. I-4. Ellis and Soland. Zooph. 49. Berk. Syn. i. 218. Turt. Gmel. iv. 682. Wern. Mem. i. 564. Tur\%. Brit. Fan, 215. Stew. Elem. ii, 44f, Bosc, Vers, iii. 117. Lam. Anim. s 
Vert. ii. 120. 2 de edit. ii. 149. Hogg's Stock. 33.—Laomedea geniculata, Lamour. Cor. Flex. 208. Corall. 91. Templeton in Mag. Nat. Hist. ix. 466. La L. geniculéc, Blainv. Actinol. 474._-Campanularia geniculata, Flem. Brit. Anim. 548. Johnston in Trans. Newc. Soc. ii. 255.

Hab. Parasitical and gregarious on sea weeds that grow near lowtide mark, especially on the frond of Laminaria digitata, very common.

Polypidom attached by a creeping tubular thread, erect, about an inch in height, simple or sparingly branched, regularly zig-zag, slender and flexile, of a clear white colour, often tinted more or less with rose-red, and filled with a dusky granular pulp : at every flexure, the stem is divided by a single joint and incrassated, a twisted pedicle originating from the incrassated part alternately from opposite sides; the pedicle consists of $4-6$ nearly equal rings, is erecto-patent, tapered slightly and terminated with a bell-shaped cell, perfectly transparent and entire. The vesicles are matured in spring: they originate from the incrassation of the joints at the side of the cells, and resemble an elegant Greek rase or urn, being of an elliptical or ovate shape, with a very short tubular opening on the flattened apex. The ova are comparatively large.

The polypidom is occasionally tinted of a pink or rose-red colour, -an accident which is not unfrequent with the Sertulariadx in general, especially with Sert. abietina and pumila. On what the colour depends has not been ascertained. Some specimens so tinted retain the colour after being dried, while others lose it. The nature of the habitat has apparently no influence on it, for I have often observed coloured and colourless specimens on the same stone or sea-weed.

\section{L. GELATINOSA, "6 subordinate branches dichotomonsly} branched; cells on twisted footstalks, campanulate, with even margins." Ellis.

Plate XXI. Fig. 3, 4. and Plate XXIII. Fig. 1.

Corallina filiformis ramosa pedunculis calyculorum contortis, Ellis, Corall. pl. 38, fig. 3, and p. 23, pl. 12, fig. c, C._Sertularia gelatinosa, Pall. Elench. 116. Stew. Elem. ii. 444. Bosc, Vers. iii. 112. Fleming in Edin. Phil. Jourı. ii. 84. Flem. Phil. Zool. ii. 616. pl. 5, fig. 3. Campanularia gelatinosa, Flem. Brit. Anim. 549. Johnston in Trans. Newc. Soc. ii. 254. Sertularia dichotoma, in part, Lister in Plil. Trans. an. 1834, 372, 375, pl. 10, fig."1.-Laomedea gelatinosa, Corallina, 92. La L. gélatineuse, Blainv. Actinol, 475._La Sertolara dictoma, Cavol. Pol. mar. 194, tav. 7, fig. 5-8.

Hab. On stones hetween tide marks. "Very common in the Tay above Balmerino, towaris Flisk heach," Fleming. In Berwick Bay, ahundantly, G.J. 
This species, in its most perfect state, rises to the height of 8 or 10 inches. The stem is as thick as small twine, straight, opake, and composed of many tubular threads twisted together. It does not properly diride itself, but sends off branches from all sides, which are either opposite or alternate, and much ramified into diverging branchlets, each of them marked with three or four rings at its base, and terminated with a bell-shaped polype-cell of a very thin corneous texture. A specimen of this description from Shetland, in the collection of my friend Dr Coldstream, is figured in Plate XXIII.

But more commonly Laom. gelatinosa is found in a much humbler condition, and under a guise that requires for its discrimination from Laom. geniculata, a careful examination. It occurs thus in Berwick Bay, growing gregariously on the sides and under surface of stones lying in shallow pools between tide-marks, and seemingly giving a preference to those that contain an impure or brackish water. The shoots are all connected with one another by the radicle fibre which creeps in an irregular manner along the rock; they are rarely above an inch in height, simple or sparingly branched, consisting of a single tube of a light corneous colour and texture, ringed above the origins of the long twisted filiform pedicles on which the polype-cells are raised. These cells are deeply cupped, transparent, with a wide even margin. Vesicles urn-shaped, smooth, shooting from the axils of the pedicles. They are matured during the summer months, when we find them filled with ova of a circular flattish form, marked with a dark speck in the centre. At first they fill not more than half of the vesicle, but by their increase in size they soon come to occupy the whole cavity, and are ultimately extruded from the top, after which the empty resicle soon disappears. The ova while in the vesicle are arranged round a central placentular column, and the lid which closes the vesicle is a mere dilatation of this column, which appears to be composed of two pieces soldered together, and bulged at intervals, where perhaps the ova are more immediately affixed in their immature state.

The Polypes have ahout twenty long filiform tentacula roughened with minute tubercles placed in whorls. In their centre is the mouth, which assumes the shape sometimes of a rounded projecting tubercle, sometimes of a narrow column, and sometimes of a broad flat disk with a stricture under it simulating a neck. It leads directly to the stomachal cavity which is large and undivided, and I have occasionally witnessed within it currents of a fluid filled with minute granules, as has been more fully noticed by Mr Lister and Dr Fleming.

Milne-Edwards, in the belief of there being a specific difference between the zoophytes described by Pallas and Fleming, has propos- 
ed to call the latter Campanularia Flemingii, distinguished by the cells having an even rim, whereas it is stated to be serrulated in the other. I have preferred following the judgment of Fleming, who has very carefully studied the species.

\section{Campanularia, * Lamarck.}

Character. Polypidom rooted, creeping or when compound erect, the main tube filiform, continuous, giving off its pedunculated cells irregularly or in whorls; pedicles ringed, usually long; cells campanulate; vesicles scattered, sessile.-Polypes hydraform.

* Stem a single tube.

1. C. volubilis, stem creeping, filiform; cells on long slen. der annular pedicles, campaniform with a serrated rim; vesicles ovate, wrinkled concentrically. Ellis.

Fig. 17.
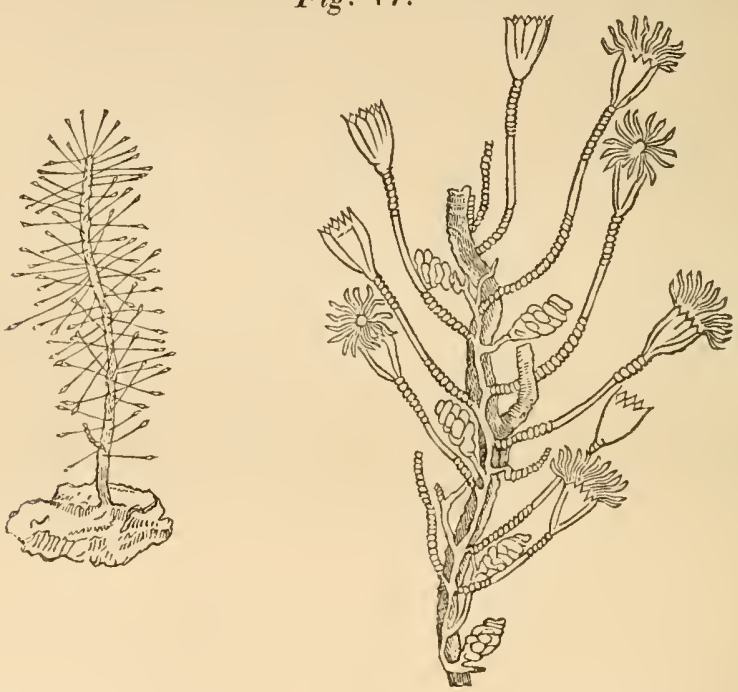

Small climbing Coralline with bell-shaped cups, Ellis, Corall. 24, no. 21, pl. 14, fig. a. A. Phil. Trans. xlviii. 629, pl. 22, no. 2. Phil. Trans. abridg. x. 491, pl. 12, fig. 2, B.—_ertularia volubilis, Lin. Syst. 1311. Ellis and Soland. Zooph. 51, pl. 4, fig. e, $f, E . F$. copied into Kirby's Bridgew. Treat. i. pl. 2, fig. 2. Berk. Syn. i. 218. Turt. Gmel. iv. 680. Fabric. Faun. Gronl. 444. Wern. Mem. i. 564. Turl. 13rit Faun. 2l4. Stew. Elem. ii. 444. Bosc, Vers, iii. 112. Ifogy's Stork. 
34,-S. uniflora, Pall. Elench. 121. Ellis, in Phil. Traus. Ivii. 437, pl. 19, fig. 9.—Clytia volubilis, Lamour. Cor. Flex, 202. Corall. 88. Campanularia volubilis, Lam. Anim. s. Vert. ii. 113. 2de edit. ii. 132. Flem. Brit. Anim. 548. Risso, L'Europ. mérid. v. 309. .Johnston in Traus Newc. Soc. ii. 255. Templeton, in Mag. Nat. Hist. ix. 466._La Campanulaire grimpante, Blainv. Actinolog. 472, pl. 84, fig. 2.

IIab. Parasitical on other corallines, frequent. Brighthelmstone, on the coast of Sussex, Ellis. Frith of Forth, adhering to Flustræ and Fuci, Jumeson. Berwick Bay, G. J. Found in Belfast Lough, Templeton. On specimens of Sertularia tamarisca, \&c. from Scarhorough, Bean.

A minute species, and a beantiful object for the microscope. I have seen the antenmæ of a crab (Lithodes spinosa) so profusely invested with this zooplyte as to resemble hairy brushes. The coralline in this instance had chosen a station by which it obtained all the benefits of locomotion. Our figure represents a specimen which had adorned in a similar manner the remnant of a Plumularia falcata. The stem is a capillary corneous tube which creeps and twists itself upon its support, throwing out, at alternate intervals, a long slender stalk twisted thronghout or only partially, that supports a bell-shaped cup of perfect transparency and prettily serrulated round the brim. The ovarian vesicles arise from the creeping tube, are sub-pedicellate, orate, coarsely wrinkled, and contain each several ova. Polypes with numerous slender white tentacula.

2. C. SYRINGA, stem creeping, capillary; cells on shorter twisted pedicles, tubulous, with a plain margin. Ellis.

Fig. 18.

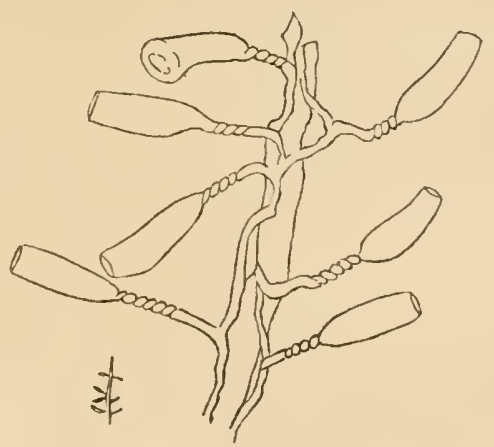

Creeping Bell-Coralline, Ellis, Corall. 25, pl. 14, fig. b. B.—_Sertularia syringa, Lin. Syst. I311. Berk. Syn. i. 218. Turt. Gmel. iv. 680. Turt. Brit. Faun. 214. Steu, Elem. ii. 444. Bosc, Vers, iii. 11:3. S. volubilis, Pall. Elench. 122.___ S. repens, Ellis and Soland. Zooph. 
52. Hogg's Stock. 34.—Clytia syringa, Lamour. Cor. Flex. 203. Corall. 89.—Campanularia syringa, Lam. Anim. s. Vert. 113. 2de edit. ii. 132. Flem. Brit. Anim. 548. Johnston in Trans. Newe. Soc. ii. 256. Blainv. Actinolog. 472.

Hab. Parasitical on other corallines and the lesser fuci, less common than the preceding.

This is only to be distinguished from C. volubilis by the aid of the micloscope. The two species frequently grow intermixed, and their habit is the same, but the syringa is easily distinguished by its denser corneous structure, its cylindrical tubular cells, and the shortness of the pedicles which support them. Polypes with 8 filiform equal tentacula.-Pallas describes a branched variety from the coast of Cornwall, which, however, undoubtedly belongs to C. dumosa. His words are-_" Nuper ex Oceano Cornubiam alluente, ubi hæc Sertularia in testaceis et Zoophytis omnibus abundat, accepi ramescentem eandem, seu vegetantem; dum tubuli plurimi proprii simul assurgentes efficiunt stirpes sponte erectas, sæpe sesqui-pollicares, ramumque unum vel alterum exserentes, tutas ab imo ad summum calyculis tubuliformibus, sine ordine, quaquaversum muricatæ."

* * Stem composed of many parallel tubes.

3. C. verticillata, erect, branched; cells on verticillate pedieles, campanulate with a servulated rim. Dr Brownrigg.*

Plate XXII. Fig. 3, 4.

Horse-tail Coralline with bell-shaped eups, Ellis, Corall. 23, no. 20, pl. 13, fig. a, A.— Sertularia verticillata, Linn. Syst. 1310. Pall. Elench. 115. Ellis and Soland. Zooph. 50. Berk. Syn. i. 218. Turt. Gmel. iv. 679. Turt. Brit. Faun. 214. Stew. Elem. ii. 444. Bosc, Vers, iii, 112. Hogg's Stock. 34___Clytia verticillata, Lamour. Cor. Flex. 202. Corall. 88.—Campanularia verticillata, Lam. Anim. s. Vert. ii. 113. 2 de edit. ii. 131. Flem. Brit. Anim. 550. Templeton in Mag. Nat. Hist. ix. 466. Stark, Elem. ii. 441._L_La Laomédée verticillée, Blainv. Actinolog. 475, pl. 84, fig. 3.

Hab. "Near Whitehaven, in Cumberland," Dr Brownrigg. Near Hartlepool, Durhan, not very frequent, J. Hogg, Esq. Not uncom. mon on the coast at Scarborough, adhering to shells, \&c. Mr Bean. Cullercoats, Northumberland, Mr. Joshuce Alder.

* Dr William Brownrigg, born at High Close Hall, Cumberland, March 24, 1711 ; graduated M. D. at Leyden in 1737 ; elected F. R. S. in 1742 ; in 1748 published his valuable work on the art of making common salt; received the Copley medal for the year 1765 ; continued to prosecute with zeal his ehemieal and philosophieal experiments, and to enjoy his literary taste, until the period of his death, which took place at Ormathwaite, January 6,1800 , aged 88 years. For an able biographical account of this learned and excellent physician, see the Aunals of Philusophy, Vol. x. p. 321, Sc. 
Polypidon alhering by creeping tubulons fibres, erect, irregularly branched, the stem and branches composed of many closely applied parallel tuhes; branches erect or erecto-patent, cylindrical, straight, hirsute from the capillary pedicles of the cells which originate in whorls at stated intervals: the pedicles are ringed at top and bottom but generally smooth alout the middle, patent, simple : the cell itself campanulate, thin and transparent with a serrated brim. Vesicles scattered, arising from the branches, solitary, very shortly stalked, oval, smooth, with a narrow aperture.

\section{C.? Dunosa, ereet or climbing, irregularly branched, hirsute} with the cells, which are long, tubular, patent, almost sessile, the aperture entire. Rev. Dr Fleming.

$$
\text { Plate XXIII. Fig. 2-5. }
$$

Coralliua astaci corniculorum æmuli, Petiv. Plant. Ital. pl. 2, fig. 10.Sertularia dumosa, Fleming in Edin. Phil. Journ. ii, 83._- Tubularia tubifera, Jolnston in Edin. Phil. Journ. xiii. 2222, pl. 3, fig. 2, 3.——Lafea cornuta, Lamour. Soland. Zooph. 5, pl. 65, fig. 12-14_Campanularia dumosa, Flem. Brit. Anim. 548. Johnston in Trans. Newc. Soc. ii. 254. pl. 11, fig. 1._—La Laomédée touffue, Blainv. Actinol. 474.

Hab. On rocks, shell-fish, and other corallines, in deep water. On the shores of Devonshire, Montagu. At Newhaven in the Frith of Forth, at Aberbrothick and in Zetland, Fleming. Berwick Bay, very common, $G$. $J$.

There are two varieties of this species : the first is from 2 to 4 inches in height, hushy, irregularly branched, the branches straight, square, slightly tapered upwards, and formed of several parallel tubes; (Fig. 4.) the second is a single thread-like tube which climbs up the stalks of other flexible corallines, giving off on all sides its long spreading trumpet-shaped cells, which are not unlike those of C. syringa, but are to be distinguished by their thicker and much more horny texture, and by being almost or altogether sessile (Fig. 2, 3.) Small specimens of the first variety are very common on some sorts of crabs, but the larger specimens have their roots or base almost in variably immersed in the snbstance of a sponge, the Halichondria panicea or papillaris. Neither the resicles nor polypes have been observed, and there is something in the babit, and in the form of the cells, which renders it very donbtful whether this species belongs to this order.

This appears to be the proper place to notice two doubtful zoophytes which have been referred to the genus 


\section{CYMOdoceA, * Lamouroux.}

Character." "Plant-like; cells cylindrical, varying in length, filiform, alternate or opposite; stem fistular, marked with rings below, plain above, and without interior division."

1. C. SIMPLEX, stems simple, slightly undulated, twig-like; cells long and filiform, alternate. Dawson Turner.†

Cymodocea simplex, Lamour. Cor. Flex. 216, pl. 7, fig. 2. Corallina, 95, pl. 7, fig. 2.—La Cymodocee simple, Blainv. Actinolog. 487. pl. 81, fig. 4.

Hab. The sea near Yarmouth, and in Ireland, Turner.

Height nearly three inches : colour a yellow-fawn.

2. C. comata, stems straight, cylindrical, almost simple; branchlets capillary, whorled, mumerous, flexuous, jointed and celliferous. Dr Leach.f

Cymodocea comata, Lamour. Ellis and Soland. Zooph. 15, pl. 67, fig. 12, 13. Flem. Brit. Anim. 551._La C. chevelue, Bluinv. Actino$\log .487$.

Hab. Coast of Devonshire, Leach.

Height about one decimetre : colour yellowish. At each joint of the branchlets there is a short cell ringed at its base, and almost invisible to the naked eye.

I have seen no authentic specimen of either species, the above descriptions being translated from the works of Lamouroux. IYe says that Cymodocea has the closest relations with Tubularia, from which, however, it differs in the position of the polype-cells which are placed, not at the top of the branches, but upon these branches or upon their divisions. From this circumstance Lamouroux classes the genus amongst the Sertulariadæ, to which alliance the absence of ovarian vesicles seems opposed, nor can we hope to locate the genus with any certainty until the polypes have been discovered. The very existence of the genus has in fact been ques-

* The name of one of the sea-nymphs into which the ships of Eneas were changed by Cybele.

+ D. Turner, Esq. of Yarmouth, F. L. S. :-very eminent for his knowledge of cryptogamic botany, and for his skill in antiquities. He is the author of a beautiful work on the Fuci. The genus Dawsonia of Robert Brown is a just tribute to his merit.

\$ William Elford Leach-a naturalist of most indomitable enthusiasm and very extraordinary acquirements. He died in ltaly in 1836, of cholera. "We may say, with respect to the extent and effect of his zoological labours, -Nihil non tetigit, et omnia quae tetigit ornavit."-Kirby. 
tioned. Mr J. E. Gray, a high authority in matters of this kind, says, " the Cymodocex appear to be only Sertulariæ which have lost their ceils," (Synop. of Brit. Mus. p. 75); and Blainville makes the same assertion in reference to the above species.* Dr Fleming is of opinion that $C$. simplex has been established from an individual of Campanularia dichotoma in a depauperated state ; (Brit. Anim. 548,) while again Mr Hogg informs me that he is almost satisfied that this Cymodocea is Plumularia pinnatı with its pinnæ rubbed off by the waves or tide on the beach; and the specimens he has sent me in confirmation of this supposition are certainly very exact to Lamouroux's figure, nat. size, - for it must be observed that his magnified figure represents the polypidom as unjointed or continuous, whereas it is regularly jointed both in the Campanularia and Plumularia. But I make this remark not to invalidate the opinions either of Dr Fleming or $\mathrm{Mr}$ Hogg, for that of the latter I am disposed to adopt; but it gives me an opportunity of warning the student against an implicit reliance on the figures of Lamouroux, which we are assured by Blainville, who has compared them with the specimens from which they were male, are in many instances vely erroneous.

* Milne-Edwards also adopts this riew. Lam. Anim. s. Vert. 2de edit. ii. 157.

"All the works of the LoRD are exceeding good: and none may say, What is this? Wherefore is that? for at time convenient they shall all be sought out._-_ All the works of the LORD are good: So that a man cannot say, This is worse than that; for in time they shall all be well approved."-Ecclesiasticus. 



\section{B RI TISH Z O O PHY'TES.}

\section{PAR'III.}

\section{\%OOPHYTA ASTEROIDA.}

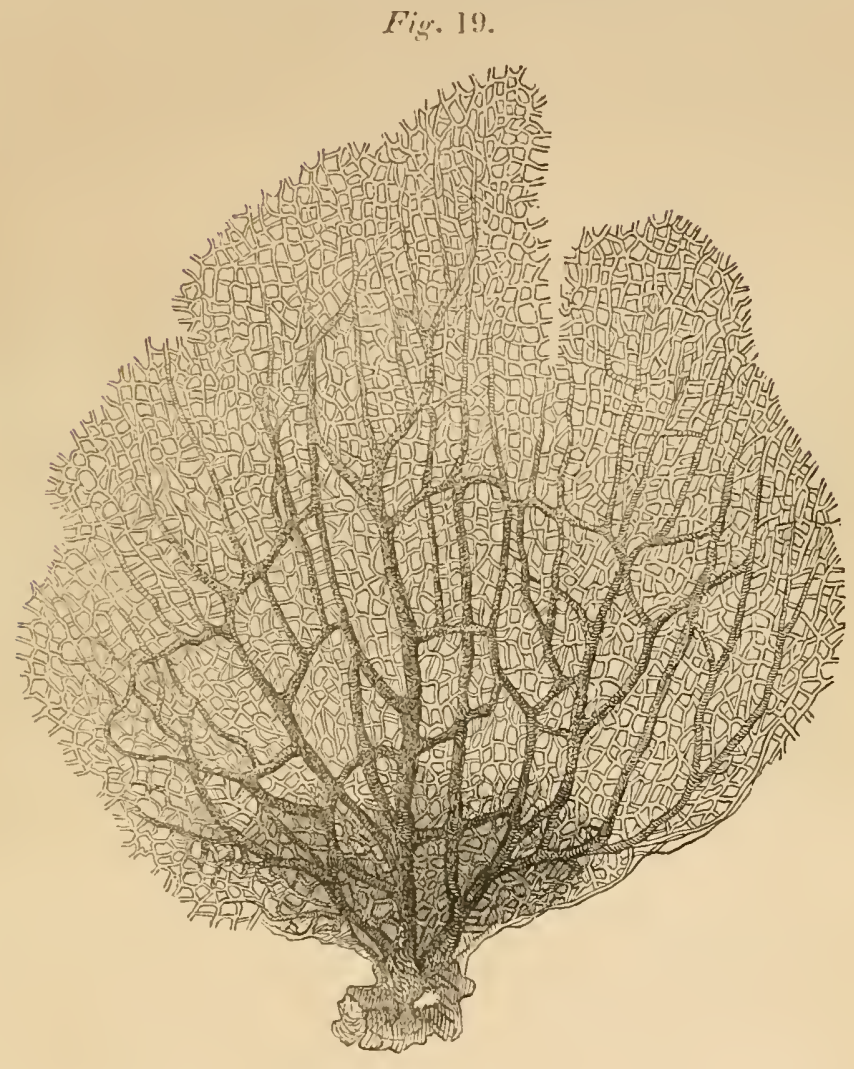

(iorgonia Frabfirtoy.

" - _ - - all the firmament

"Was throng'd with constellations, and the seil

"Strown with their images "-James Montgomery.

L 
" Nicostratus in Elian, finding a curious piece of wood, and being wondered at by one, and askerl what pleasure he could take to stand as he did still gazing on the picture? answered, Hadst thou mine eyes, my friend, thou wouldst not wonder, but rather be ravished as I am at the inimitable art of this rare and admirable piece. I am sure no picture can express so much wonder and excellency as the smallest insect: but we want Nicostratus his eyes to behold them.

"And the praise of God's wisdom and power lies asleep and dead in every creature, until man actuate and enliven it. I cannot, therefore, altogether conceive it unworthy of the greatest mortals to contemplate the miracles of nature, and that as they are more visible in the smallest and almost contemptible creatures, for there most lively do they express the infinite power and wisdom of the great Creator, and ereet and draw the minds of the most intelligent to the first and prime Cause of all things, teaching them as the power, so the presence of the Deity in the smallest insects."___ Samuel Purchas. 


\section{ZOOPHYTA BRITANNICA.}

\section{ORDER II.}

\section{Z. ASTEROIDA.}

\section{Character.}

Polypes compound, the mouth encircled with 8 pectinate tentacula; stomach membranous with dependant vasculiform appendages; intestine 0 ; anus 0 ; reproductive gemmules produced interiorly.—Polype-mass variable in form, free or permanently attached, carnose, generally strengthened with a horny or calcareous axis enveloped with the gelatinous or creto-gelatinous crust in which the polype-cells are immersed, and which open on the surface in a starred fashion with 8 rays.

\section{Observations.}

On a cursory view the Polypidoms of the three families enbraced in this order appear very dissimilar, and accordingly, by many recent authors, they have been scattered over the class, and placed widely asunder. The affinity between them, however, is generally acknowledged, and had been distinctly perceived by some of the earliest zoophytologists. Thus Bohadsch found so much in common between the typical Pennatulæ and a species of Alcyonium, that he has not hesitated to describe them as members of the same genus; and although the more systematic character of Pallas prevented him falling into this error,-if error it can indeed be called,- - he did not the less recognize the relationship between the genera or families. Pal-

- "Pennatulæ Alcyoniis specierum gradatione ita propinquæ sunt et tamen simul structura, habitu, vitæque sensitivæ gradı discrepant, ut exemplum majoris simul affinitatis et discordantiæ inter duo genera in rerum natura vix dari existimem. Certo respectu Pennatulæad Alcyonia sunt, quod Hydræ ad Sertularias." Elench. p. 362. In $^{\circ}$ relation to this paragraph consult also p. $370,343,162$, 191:-and Misc. 7ool. p. 177. 
las also tells us that his Pennatula cymomorium differs from the Alcyonium only in this, that the former is a moveable, and the latter a fixed polypidom; and he saw with equal clearness, the connection which exists between these genera and the shrublike Gorgonia. Of the Pennatula mirabilis he had entertained doubts whether it was not rather a species of Gorgonia until he perceived that the stem was attenuated at each end and free; and of the Sea-Pens generally, Ellis remarks, that they are "a genus of zoophytes not far removed from the Gorgonias, on account of their polype mouths, as well as having a bone in the inside, and flesh without." On the other hand the Gorgoniæ, says Pallas, seen, with the exception of their horny skeleton, to be nearly similar in structure to the Alcyonia; but as there are species of Gorgonia which are suberose internally and almost of a uniform medullary consistence, even this mark of distinction fails to separate the tribes, and we have little left to guide us in arranging these osculant species excepting their external habit, or, if we may so express ourselves, their physiognomy. Gorgonia Briareus has been described by some authors as an Alcyonium; and Pallas would have enumerated the Gorgonia radicata in the same genus, had not its gorgon-like habit interfered. I am satisfied that no zoophytologist can examine Ellis's figure and description of Gorgonia suberosa without being convinced that it pertains rather to the congenerous family, or holds at least very debateable ground between them.

The names which the fishermen have conferred on the polypidoms of this order will convey to the student a better idea of their general appearances than any laboured description. The Pennatulie in their language are Sea-Pens; the Virgularia are Sea-Rushes; Sea-Paps, Deadman's hand or Dead-man's toes, if not agreeable, are yet expressive names for the Alcyonia; and the Gorgonix are Sea-shrubs when they branch away irregularly, but when the branches inosculate and form a sort of net, they become Sea-Fans, which some naturalist, of more than our usual fancy, has appropriated to the use of Venus-Flabellum Veneris.*

- Ray has especially called attention to the fan-like growth of submarine bodies. - "That the motion of the water descends to a good depth, I prove from those plants that grow deepest in the sea, because they all generally grow flat in manner of a fan, and not with branches on all sides like trees; which is so contriv- 
In every polypidon of this order there are three parts which require notice, - the polypes, the fibro-fleshy calcarcous crust in which they are placed, and the internal axis. The connection between these parts is indissoluble, and although we may treat of them scparately, and as if they were somewhat independent, yet we must guard against the entertainment of any such opinion. * It was once indeed a debated question whether each polypidom might not rightly be consiclered a mere aggregation of separate animalcules, but all that we know of their habits and structure goes to prove the contrary, so that no one probably now disputes that the polypidom with its polypes constitute but one body, the latter being in the place of as many mouths and stomachs scattered over the surface. The whole mass, with the exception at most of the axis in those which possess a stony or horny one, is living and organized, receiving the material of its nourishment and growtl from the food captured and digested by the polypes; and as they have not only an organical union with the irritable flesh in which they are immerser, but are many of them more intimately associated together by means of canals and intestines, so they participate in every benefit and every evil. When, therefore, one pinna of a Sea-Pen is lacerated or cut away, the remaining pinnæe gradually shrink, the polypes withdraw, and the whole body contracts in every dimension; or if a portion of the Alcyonium be subjected to irritation, the gradual collapse and contraction of the polypidom renders it obvious that the irritation has been communicated and felt through the entire mass. $\dagger$ On the con-

ed by the providence of nature, for that the edges of them do in that posture with most ease cut the water flowing to and fro ; and should the flat side be objected to the stream, it would soon be tumed edge-wise by the force of it, beeause in that site it doth least resist the motion of the water: whereas did the branches of these plauts grow round, they would be thrown backward and forward every ticle. Nay, not only the herbaceous and woody submarine plants, but also the lithophyta themselves affect this manner of growing, as I bave observed in various kinds of cornls and pori."-The Wisdom of God in the Creation, p. 77.

* Tiedemann has inadvertently asserted that the polypes "are able to leave the crust and return to it." Comp. Phy. 306.

† " Unknown to sex the pregnant oyster swells,

And coral-insects build their radiate cells;

Parturient sires caress their infant train,

Ind hearen-born Storge weares the social chain 
trary, when at rest and undisturbed, the polypes protrude their tentacula and a portion of the body, and, imbibing the circumfluent water, this percolates into the interior through numerous anastomosing canals, and distends the polypidom so much that it will more than double or treble its former size. In this respect the Zoophyta asteroida show an affinity to the Helianthoida, and differ from the hydraform and more especially from the ascidian orders.

The axis of the Alcyonidæ is imperfect, but exists nevertheless in the form of calcareous or siliceous spicula diffused through the gelatinous interior, or more or less densely clustered at the centre; and the appearance of these spicula is such that we are almost tempted to believe they may possibly be the products of crystallization rather than of any regular secretion.* It might not be difficult, but it is beyond my province, to trace the gradual increase and consolidation of these spicula through many intermediate species to the horny flexible axis of Gorgonia, where it has become such an efficient support to the whole soft envelope as to claim not improperly the name of its skeleton; thence to the stony axis of the coral; and having there reached its maximum of developement, I might, on the other hand, have marked its progress towards degeneration until it became again only a partial support, such as we find it in the naked middle portion of the Pennatulidæ, more especially in some of the foreign and less typical species of that family.

According to Lamarck, this axis, under all its modifications, is inorganic, containing neither vessels nor any portion of the body of the polypes, but formed of matter excreted by them, and afterwards thickened, solidified and depurated by affinity. $†$ Although this is rather, on Lamarck's part, the de-

Successive births her tender cares combine,

And soft affections live along the line."

Darwin's Temp. of Nature, canto ii.

* They may be compared with the Raphides found in the intercellular pas. sages of certain monocotyledonous plants. See Lindley's Introd. to Botany, p. 29. Mr Children found in the ashes of a piece of the axis of Gorgonia Flabellum, a distinct trace of pure silica, sufficient to form a globule before the blow-pipe.-Ann. of Philosophy, New Series, Vol. ix. p. 431.

$f$ " L'observation constate que l'axe central de ces polypiers, quoiqu' offrunt quelquefois des conches concentriques, ne fut jamais organisé, n’a contenu ni vaisseaux quelconques, ni aucune portion du corps des polypes; qu'il est le résultat de matières excrétécs par ces polypes, matic̀res qui se sont épaissies, 
duction of theory than of observation, yet the opinion is in the main correct, and in correspondency witl what had been long previously maintained by Ellis. In the spicula of Alcyonidæ certainly, we can find no traces of organism, and they lie seemingly unconnected with the adjacent parts. The axis of Pennatula is a solid bone formed of lamina laid over each other, softer and cartilaginous at each extremity where it seems to be organically connected with the soft surrounding flesh : it is evidently secreted, and deposited successively in layers, from the inner surface of a thin pellucid membrane which Bohadsci has described as investing it in the manner of a periosteum,* and probably is endowed with that low degree of vitality which preserves the horns, hairs and feathers of the higher animals in that elastic and fresh condition which they have only when in connection with living parts. The horny axis of Gorgonil, notwitlıstanding some observations of Ellis which apparently tend to a different conclusion, + is not more distinctly organized, and is doubtless formed in the same manner as the axis of Pennatula, for it is also of a lamellated structure, and, according to Lamouroux, is invested with a similar periosteum. $\ddagger$ A cross section of the stem or of a principal branch will show the layers to be disposed concentrically round a central medulla, the layers

condensées, épurėes par l'affinité, réunies, juxta-posées successivement, et ont formé, par leur réunion, l'axe central et longitudinal dont il s'agit. Aussi cet axe est-il d'une substance continue, non poreuse."-Anim. s. Vert. V. ii. p. 294. See also p. $78-80$; and p. 311 .

* "Totum os membrana tenuis, lutescens, pellucida cingit, atque in utroque extremo in ligamentum contorquetur, quod ex ura parte in apice trunci pinnati, ex altera vero in apice trunci nudi inseritur."-De Anim. mar. p. 104. See also Corall. p. 214, 218, 224 .

+ "Proceeding thus far, I was led on to observe, what kind of communication there was betwcen the suckers (or polypes) and the bone of the animal; for this end I examiued several specimens, both dry, as well as those that were preserved in spirits, with good magnifying glasses, and could distinctly trace an infinite number of ninute winding canals, that lead from the suckers through the flesh into those parallel longitudinal tubes, which closely surround the bone or solid part on all sides ; perhaps these may not improperly be called the periosteum; for all along that side of those tubes by which they adhere to the bony part, I could discover the pores very plainly from whence the juices flow, that supply it with proper materials to answer this great end."-Soland. Zooph. 69.

‡ “L'écorce des Gurgoniées ne se lie pas immédiatement à l'axe, elle en est sépasée par une membrane d'une naturc particulière, si inince dans lc genre Forgonia, qu'il est très-difficile de l'apercevoir; elle cst plus apparente dans les Plexaures et les Eunicées."-Polyp. Corall. Flex. p. 391. 
more or less compactly pressed according to the nature of the species. (Fig. 21.) The whole section presents a certain resemblance to a similar section of a dicotyledonous tree: (Fig. 20.) the medulla in position and outward appearance is a pith; the horny axis is the wood; and the fleshy crust has been denominated the bark; ${ }^{*}$ - nor perhaps could fault be found with this language, since it is sufficiently illustrative, had it not been the mother of some very erroneous notions, and a great means of their propagation and continuance. Thus Linnæus, in his definition of Gorgonia, calls the axis a regetating stem; and as if this was not sufficiently explicit, we find Pallas entering into detail and telling us that the concentric circles are produced by successive transmutations of the fleshy crust, in the same manner that the circles of the wood of trees are formed by transformations of the inner layers of the bark. $t$ And this opinion, if we may judge from their language, has been adopted by many, and even recent, authors, though Ellis had previous to its promulgationf, Fig. 20. Fig. 21.
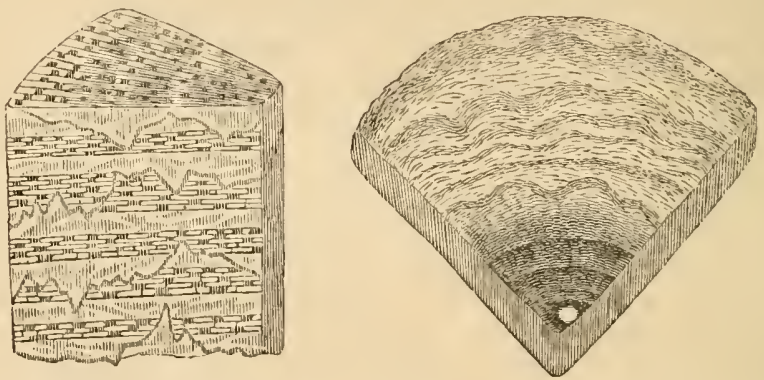

and also shortly afterwards, demonstrated that there was not on ly no real resemblance, but such remarkable differences as rendered the hypothesis altogether untenable. $\S$ The pith of

* Lin. Syst. 1289.

† Elench. p. 162. He seems, however, to have had his suspicions that the theory was questionable, for he adds_-" Quanquam diversissima corticis natura, ejusdemque facilis a ligno separatio, suggerere possent: hujus strata potius ex deposito intus succo fieri, aut lignum, prout ossa animalium sanguineorum intra periosteım, generari, augeri, durescere."

$\ddagger$ Coral. 65. Lin. Corresp. i. 225. Phil. Trans. (an. 1776) abridg. xiii. 721.

\$ What then could induce Blumenbach, so late as in 1825 , to write thus?"The stems appear to he really regetables (the woody nature of which in the larger ones cannot be mistaken) incrusted with corals."-Nan. of Nat. Hist. Trans. p. 271 
the Gorgonia is not continued, as in the tree, from the trunk throngh the branches, but is interrupted at their origins by several intervening layers of fibres, so that they are rather, as it were, inserted upon the stem than propagations of it; the axis possesses none of that curions complexity of structure,-of fibres, of sap and air vessels and utricular cells, - which renders the wood so beautiful an object under the microscope; and lastly there is between the bark and the crust of the zoophyte nothing but contrasts and discrepancies.*

The axis of a Gorgunia, at least of our native species, resembles a tree in this, that the stem always bears a certain proportion in thickness to the size of the polypidom, being slender in the small, and thicker in the larger specimens: it tapers from the rock or dilated base, and becoming gradually more gracile and attenuated, disappears at the extreme points of the branches. It is covered throughout with the flesh, which is the same in structure at all points, but thicker and more loaded with polypes towards the ends of the branches than on the stem or near their base, whence the former generally assume a cylindrical form. 'This flesh when dry is earthy and friable, a considerable proportion of carbonate of lime entering into its composition; but in a recent state it is soft and fleshy, and excavated with numerous cells for the lodgement of the polypes. When a portion of a branch is macerated in a weak acid, the lime is entirely removed, but the branch retains its original size and figure, and shows the frame-work to be an irregular close tcxture of corneous fibres, the interstices of which had been probably filled in part with a gelatinous fluid. And this is much the same structure that we find in the Alcyonium. The skin is coriaceous, strengthened with calcareous particles, but the interior offers a fibrous net-work containing a transparent jelly in the squares, and permeated with a certain number of longitudinal cartilaginous tubes. The soft part of Pennatula seems more uniformly fleshy or gelatinous, and its polypes are placed only on certain wings or appendages of the polypidom, but the skin is also coriaceous, and has moreover in its substance a great number of calcareous spicula placed parallel to one another, and which must greatly add to its consistency and strength. 
The polypes are placed in this external fleshy crust, which, indeed, is but a continuation of their tunic, and serves as a connecting medium to the whole assemblage. Their position in it is marked by an orifice on the surface distinguished by its being cut into eight rays in a starred fashion, and which open when the superior portion of the body is forced outwards. * This exsertile portion, in a state of expansion, resembles a cylindrical bladder or nipple crowned with a fringe formed by the eight short thick pectinated tentacula which encircle the mouth. (Plate xxvi. Fig. 1.) Under this orifice we perceive the stomach, readily distinguished through the transparent parietes by its opacity, occupying the centre of the cylinder, and itself of a cylindrical figure. The space between it and the outer envelopes is divided into eight equal compartments or cells by as many thin ligamentous septa, which, originating in the labial rim, between the bases of the tentacula, descend through the cylinder, attached on the one side to the inner tunic of the body, and on the other to the stomach, which is by this means suspended and retained in its position. The canals or cells formed by these septa communicate freely with the tubulous tentacula above ; and they have a still wider communication with the abdominal cavity underneath the stomach, into which we may observe the septa are also continued for a certain way, adhering still to the tunic, but free on their inner edges, for now instead of septa, they form only the same number of plaits of more or less prominence and width. Attached to them, and indeed forming a part of them, there are an equal number of twisted somewhat glandular filaments, which, originating round a small aperture in the base of the stomach, appear to be suspended in the cavity, gradually losing themselves in its depth. By most authors these have been mistaken for ovaries, + but though this assignation of function to

* See on this part of zoophytology Milne-Edwards Memoires "sur les Alcyons" in Ann. des Sc. Nat. part. Zool. iv. p. 333, \&c. an. 1835 : and in the 2de edit. of Lam. Anim. s. Vert. ii. p. 465.

† Cuvier, Reg. Anim. iii. p. 309, 310, 319. Lamarck gives us Savigny's opinion in the following passage : "Les buit intestins d'un Polype semblent de deux sortes, car ils ne se ressemblent pas tous par la forme, ni vraisemblallement par les fouctions. Deux d'entre eux descendent distinctement jusque an fond du corps du Polype, et n'arrivent it aucun oraire. Les six antres, phus 
them is easily proved to be erroneous, their true office remains conjectural. Milne-Edwards says they have great analogy with the biliary ressels of insects; and they probably secrete some fluid subservient to digestion and to the more complete assimilation of the food.

As already remarked the protrusile portion of the polype is very delicate, the intemal viscern being as it were enclosed in a serous bladder so transparent as to permit a view of their disposition. This envelope is itself, however, composed of two very thin membranes in intimate union : at the base of the body the outer of these assumes a considerable thickness, and in coalescing with that of the adjacent polypes, constitutes the common cortical portion into which each animalcule retreats at will by a process of invagination, which we have had occasion already to compare to that by which a snail shortens its horns. (Pl. xxvi. Fig. 2.) In the greater number of the Asteroida this common portion secretes carbonate of lime, which is deposited in the meshes of its tissue either in granules or in crystalline spicula, and imparts more or less of consistency to the whole. The inner tunic on the contrary continues unaltered, and prolonged within the polypiferous mass, it lines the cell, the abdominal cavity, and the longitudinal canals which permeate the mass, as well as the very fine tubular net-work with which the spaces between these canals is occupied, (Fig. 5.) for Milne-Edwards has shewn that there is a free communication between these parts through the medium of numerous minute apertures perforated in the sides of the abdominal cavity. ${ }^{*}$ It is probably in this tenuous inner tunic that the buds or gemma by whose increase and evolution the polypemass is enlarged are generated, the shape and size of the mass depending upon the manner, or pre-ordained fashion, in which the buds are evolved, for in some, as in Pennatula, determinate spots only have the appropriated organization; while in others, as in Alcyonium, the generative faculty appears to be undefined and diffused. These buds are produced in the net.work of the crust; while the gemmules or ova by which the species is pro-

variés dans leur forne, selon les gcures, paraissent s'arrêter à six grappes de gemınules oviformes qui imitent six ovaires."-Anim. s. Vert. ii. p. 4115-7; 417.

* Lam. Anim. s. Vert. ii. 465. 2de edit. 
pagated are the peculiar products of the lining of the abdominal cavity. The ova sometimes originate in its lamellæ, sometimes from the interspaces, and in other cases from the walls of the permeating canals. In Pennatula we first detect them between the membranes of the polypiferous pinnæ; in Alcyonium in the cartilaginous canals which are traced through the polype-mass, or in the abdominal sac sprouting from the plaits; and in Gorgonia, Cavolini informs us, they germinate in eight distinct "ovaria at the base of each polypus." They first appear like a minute smooth wart which gradually rises up from the surface, enlarging itself at the same time, and when a certain size has been attained, the wart becomes constricted at its base, then shortly pedicelled, and at lastit separates a free egg by the absorption of this retaining neck or umbilical cord. (Plate xxvi. Fig. 6.) The eggs now at liberty to move, gradually approach the base of the stomach, which, as already mentioned, is perforated with an opening that can be made wider or closed by means of its sphincter muscle. After several approaches and as many repulsions, the aperture at length allows the egg to pass through into the stomach, whence it is ejected through the mouth into the open sea. Professors Grant and Milne-Edwards lıave witnessed this process in the Alcyonia, and the former also in the Pennatula and Virgularia; but in the Gorgonia, according to Cavolini, the ova pass upwards " through eight small oviducts," and are discharged, by as many apertures, "between the bases of the eight tentacula." *

The structure of the ova has been well described by Cavolini, and more especially by Professor Grant. Before their detachment they seem, in general, to be white, but when mature they are almost always vividly coloured, globular, and apparently smooth, but clothed, as the microscope shews, with short ciliæ, which by their vibration cause them to move to and fro as if they were actuated by volition. They are membranous capsules filled with a gelatinous matter composed of very minute transparent globules similar to those which compose almost all the soft parts of animals, or like the sporules of the lower cryptogamic plants. The investing capsule is soft and irritable, for during their motions the ova are seen frequently to contract themselves 
and alter their form. "When placed under the mieroscope," says Professor Grant,* " and viewed by transmitted light, they appeared as opaque spheres surrounded with a thin transparent margin, which increased in thickness when the ova began to grow, and such of the ova as lay in contact united and grew as one ovum. A rapid eurrent in the water immediately around each ovum, drawing along with it all loose particles and floating animalcules, was distinetly seen flowing with an equal veloeity as in other ciliated ova, and a zone of very minute vibrating eiliæ was pereeptible, surrounding the transparent margin of all the ova. 'The progressive motion of the ova, always in a direction contrary to that of the eurrent ereated by their eiliæ, was very obvious, though less rapid than in any other zoophyte in which I have observed the same remarkable phenomenon. The specimen suspended in a glass jar filled with pure sea-water I now brought so close to the transparent side of the vessel, that I could exanine throngh it, with the assistance of a powerful lens, and without disturbing the animal, the motions and progress of the groups of ova passing through the colourless bodies of the polypi. To the naked eye at first sight all appeared motionless. The deep vermilion hue of the small round ova, and the colourless transparency of the outer covering of the polypi, formed a beautiful contrast with the pure white colour of the delicate longitudinal folds, the central open eanal, and the slender filaments which wind down from its sides towards the clusters of white ova at the base; but the living phenomena discovered within were even more admirable than the beautiful contrast of colours, the elegant forms, and the exquisite strueture of all the parts. When observed with a lens the ova were seen to be in constant motion, and quite free within the bodies of the polypi. They moved themselves backwards and forwards, and frequently contracted their sides, as if irritated or capable of feeling. I could observe none passing upwards between the stomach and the sides of the polypi. They never assumed the appearance of a string of beads inclosed in a narrow shut eurved tube, as represented by Spix, but swam freely in the water which distended the polypi, as figured by Ellis. Their motions in the

- Dr Graut's observations, quoted in the text, were made on Alcyonium di. gitatum, but the generalities may be safely applied to the other families, agreeing as they do with the observations of Cavolini on Gorgonia. 
polypi, though circumscribed, were so incessant, that by watching attentively I could observe them with the naked eye, and they became more conspicuous as the ova advanced to the open base of the stomach. From their restlessness, as they approached that last passage which separates them from the sea, they seemed to feel the impulse of a new element, which they were impatient to enjoy, and by following the direction of that impulse they appeared to find their way into the lower open extremity of the stomach, without any organic arrangement to lead them into that narrow canal. In their passage through the stomach, which was effected very slowly, the spontaneous motions of the ova were arrested, unless some imperceptible action of their ciliæ, or some contractions of their surface, might tend to irritate the sides of that canal, and thus direct or hasten their escape."

The native species referable to the Order are not well ascertained. They are apparently few in number, but belong to three distinct families.

\section{Family I. PENNATULIDÆ.}

Polype-mass free, pennated, carnous, the skin spiculiferous, the axis bony, simple, continuous: Polypes arranged along the margin of the pinnce.

12. Pennatula. Polype-mass plumous.

13. Virgularia. Polype-mass linear-elongate.

Family II. GORGONIADE.

Polype-mass fixed, arborescent, the axis covered with a thick cretaceo-gelatinous celluliferous crust: Polypes scattered over the whole surface.

14. Gorgonia. Polype-mass arborescent with a horny continuous flexible axis: "cells for the polypi sessile."

Family III. ALCYONIDÆ.

Polype-mass fixed, coriaceous or somewhat carnous, without any distinct axis but strengthened by variously disposed calcareous or siliceous spicula: polype-cells subcutaneous, scattered over the surface.

15. Alcyonium. Polypes scattered over the whole surface: the spicula calcareous.

16. Cydonium. Polype-mass tuberous: the spicula siliceous. 


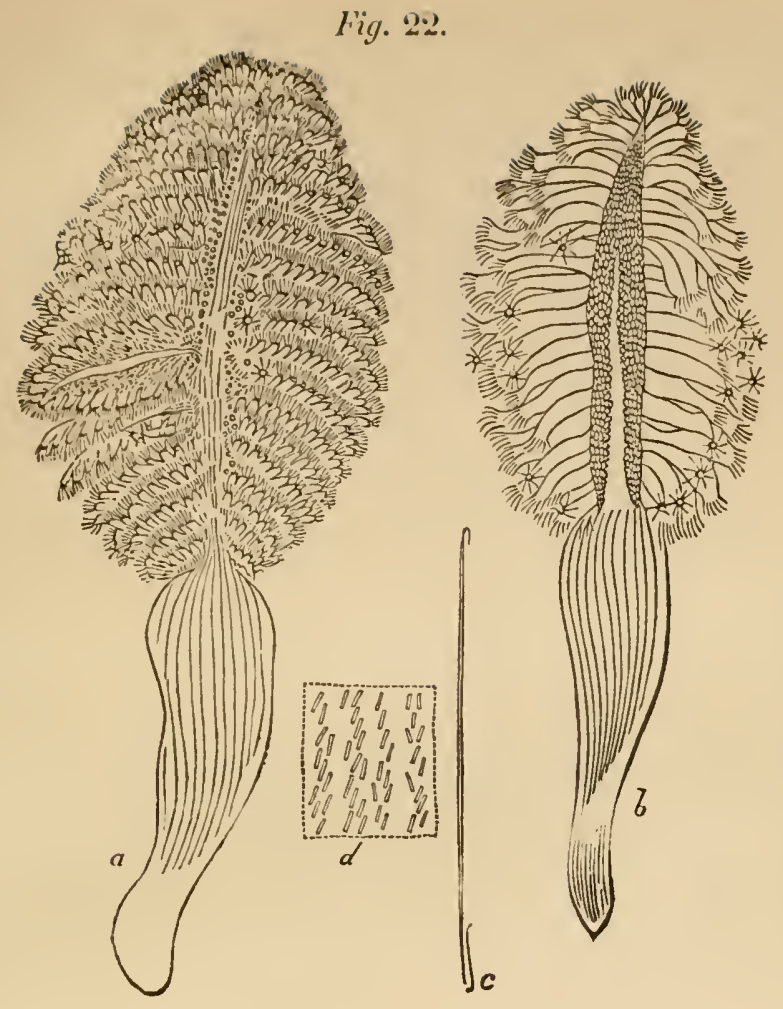

\section{FAMILY IV. PENNATULIDA.}

\section{Pennatula, * Linnæus.}

Character. Polype-mass free, plumous, the shaft subcylindrical, naked beneath, pennated above; pinne two-ranked, spreading, flattened, and polypiferous along the upper margin.

1. P. PHoSPHOREA, purplish-red, the base of the smooth stalk pale; rachis roughened with close set papillce and furroved down the middle; pinnce close; polype-cells uniserial, tubular, with spinous apertures. Sir R. Sibbald.

\section{Vignette, Fig. 22.}

- Formed from Penna, a quill-which the species so remarkably resemble that we may say in the words of Lamarck-" Il semble, en effet, que la nature, en formant ce corps animal composé, ait voulu copier la forme exterieure d'une plume d'oiseau."-Anim. s. Vert. ii. 425. 
Penua marina, Sib. Scot. ii. lib. tert. 28.—P. rubra, Bohad. Anim. Mar. 101, pl. 8. fig. 1-6-__Pennatula phosphorea. Lin. Syst. 1332. Ellis in Phil. Trans. liii. 420, pl. 19. fig. 1-5. Mull. Zool. Dan. prod. 255, no. 3075. Turt. Gmel. iv. 688. Wern. Menı. i. 565. Turt. Brit. Faun. 217. Stew. Elem. ii. 450. Blumenb. Man. 274. Lam. Anim. s. Vert. ii. 426. 2de edit. ii. 643. Cuv. Reg. Anim. iii. 318. Bosc, Vers, iii. 62, pl. 28, tig. 3, 4. (pessima) Flem. Brit. Anim. 507. Stark, Elem. ii. 420. Johnston in Trans. Newe. Soc. ii. 248, pl. 7. Roget, Bridgew. Treat. i. 174, fig. 71, 72. (bal.)__P. rubra, Pall. Elench. 368._P. Britannica, Ellis and Suland. Zooph. 61._L La Pennatule luisante, Blainv. Actinolog. 517.

Hab. Deep water. "It is found in great plenty sticking to the baits on the fishermen's lines, round the coasts of this kingdom; especially when they make use of muscles to bait their hooks. Great numbers have i)een taken on the coast of Scotland, especially near Aberdeen," Ellis. Frith of Forth, Jameson. Coast of Berwickshire, abundant, $G, J$

Our fishermen call this zoophyte the Coch's-comb, a name which is not unapt, but less expressive of its general form than that of Seapen conferred hy naturalists. It is from two to four inches in length, and of a uniform purplish-red colour, except at the tip or base of the stalk, where it is pale orange-yellow. The skin is thickish, very tough, and of curious structure, being composed of minute crystalline cylinders, densely arranged in straight lines, and held together by a firm gelatinons matter or membrane. 'These cylinders are about six times theil diameter in length, straight and even, or sometimes slightly curved and bulged, closely compacted yet distinct, and of a red colour, for the colour of the zoophyte is derived from them, and they are accordingly less numerous where the purple is faint or defective. They are apparently inorganic and calcareous, being dissolved, with effervescence, in the mineral acids.* Their form and arrangement is the same in every part of the skin ; and the papillæ on the back of the rachis, as well as the polype-cells, are constructed of them, but none can be detected in the suljcutaneous uncoloured gelatinous flesh.

The stalk is hollow in the centre, and contains a long slender bone, which is white, smooth, square, and tapered at each extremity

* Dr Coldstream, of Leith, on whose observations I place a greater reliance tban on my own, writes me thus_-"The spicula of the Pennatula appear to me to be solid. I have examined them with high powers, after having exposed them to a high temperature, and have not been able to see any evidence of a cavity within;--whether viewed with reflected or transmitted light they seemed to be opaque. When comnected with the body of the animal, they certainly spem to be red, but a slight degree of heat is sufficient to bleach them." 
to a fine point. It seems intenled to stiffen the polypidom, but it does not extend the whole length of the stalk, for before it reaches either end, the point is bound down and bent backwards like a shepherd's crook. It consists, according to Sir E. Home, of phosphate and carbonate of lime, naking thus a near approach to the bone of vertebrate animals. Lect. Comp. Anat. i. p. 59.

The papillæ on the back of the rachis, and between the pinnæ, are disposed in close rows, and do not differ from the polype cells except in size. 'The latter are placed along the upper' margin of a flattened fin; they are tubular, and have the aperture armed with eight spinons points, which are moveable, and contract and expand at the will of the animated inmates. These are fleshy, white, provided with eight rather long retractile tentacula beautifully ciliated on the inner aspect with two series of short processes, and strengthened moreover with crystalline spicula, there being a row of these up the stalk, and a series of lesser ones to the lateral ciliæ. The mouth, in the centre of the tentacula, is somewhat angular, bounded by a white ligament, a process from which encircles the base of each tentaculum, which thus seems to issue from an aperture. The ova lie betveen the membranes of the pinnæ; they are globular, of a yellowish colour, and by a little pressure can be made to pass through the mouth.

Bohadsch says that the Pennatulæ swim by means of their pinnæ which they use in the same manner that fishes do their fins. Ellis says it " is an animal that swims freely about in the sea," " many of them having a muscular motion as they swim along ;" and in another place he tells us that these motions are effected by means of the pinnules or feather-like fins, - " these are evidently designed by nature to move the animal backward or forward in the sea, consequently to do the office of fins."-Phil. Trans. abridg. xii. 42. Pallas adopted, with some reservation, $\ddagger$ the opinion of Bohadsch; but Bosc, in an effort to be original, fancied that these remarkable zoophytes lay during the winter at the bottom, concealed among seaweed and in the crevices of rocks, while in summer they often swam at the surface! Cuvier tells us that they have the power of moving by the contractions of the fleshy part of the polypidom, and also by the combined action of its polypes; and, to adopt the words of Dr Grant, " a more singular and beautiful spectacle could scarcely be conceived, than that of a deep purple Pen. phosphorea, with all its delicate transparent polypi expanded and emitting their usual brilliant phosphorescent light, sailing through the still and dark ahyss by the 
regular and syuchronous pulsations of the minute fringed arms of the whole polypi." And Bohadsch asserts that he has been a witness of this spectacle. "Deget nostrum Zoophyton in altiori mari, ubi interdum cum aliis piscibus capitur. Dum versus maris superficiem fertur, bullulæ innumeræ corpus ejus circumdant, quæ stellarum instar de die splendent; id quidem non hac occasione, sed anno 1749, dum Liburno Marsiliam versus per mare proficiscerer, observavi. Quo tempore in historia naturali minime versatus corpus bullulis nitens ad quatuor circiter pedes infra superficiem maris conspiciens e nautis quæsivi, quidnam rei esset? qui Pennam esse pro responso dedere." An. Mar. p. 107.-Linnæus had therefore some grounds for inserting the "phosphorescent Sea-Pens, which cover the bottom of the ocean, and there cast so strong a light, that it is easy to count the fishes and worms of various kinds sporting among them"-amongst the most memorable productions in Nature. See Smith's Tracts relating to Nat. History, p. 43. But some authors, as Lamarck and Schweigger, reasoning from what is known regarding other compound animals, have denied the existence of this great locomotive power in a zoophyte placed so low in the scale, as contrary to every analogy, and not necessary to the existence or wants of the animal. And there is little doubt these naturalists are right, for, when placed in a basin or plate of sea-water, the Fennatulæ are never observed to change their position, but they remain on the same spot, and lie with the same side up or down just as they have been put in. They inflate the body until it becomes in a considerable degree transparent, and only streaked with interrupted lines of red ; they distend it more at one place and contract it at another; they spread out the pinnæ, and the polypes expand their tentacula, but still they never attempt to swim or perform any effort towards locomotion. Our fishermen believe that they are fixed at the bottom with their ends immersed in the mud, and the paleness of the base, when viewed in connection with the preceding observations, go far, in my opinion, to prove this statement to be correct. " Si les pennatules nagent aussi," says Blainville, "ce dont je doute un peu, quoiqu'elles rampent trés-lentement, c'est peut-être en chassant le fluide qui est entré dans leur système acquifère, plutôt qu'à l'aide des pinnules polypifères." $-A c$ tinolog. p. 83.

As the name imports, this Pennatula is a phosphorescent animal, but the light, of a faint blue colour, is emitted only under circumstances that tend to shew that the polypes have felt some painful ir. ritation which they would drive away hy the dread influence of their tiny lamps. I have repeatedly kept living specimens for several days 
in sea water, and have observed then at all hours, without once de-tecting them in a voluntary emission of the flame. It proceeds solely from the polypes themselves, and can only be elicited by mechanical irritations, which have no sooner ceased than the phosphorescence declines and dies away.

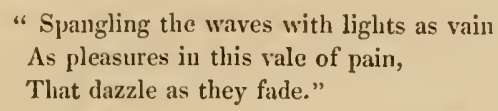

Sir W. Scort.

\section{Virgularia, * Lamarck.}

Character.-Polype-mass free, linear-clongate, "supporting, towards the upper extremity, sessile lunate lobes embracing the stem obliquely, and bearing a row of cells on their margin."

1. V. MiRABILIS, stem filiform, with alternate lobes transversely ridged." Mr Simmons. +

\section{Plate XXIV.}

Pennatula mirabilis, Lin. Syst. 1322. Mull. Zool. Dan. prod. 255, no. 3074.-Zool. Dan. tab. 11, fig. 1-3. Ellis and Soland. Zooph. 63. Sowerby, Brit. Misc. 5I, pl. 25. Turt. Brit. Faun. 217. Jameson in Wern. Mem. i. 565. Stew. Elem. ii, 450. Bosc, Vers, iii. 62.Virgularia mirabilis, Lam. Anim. s. vert. ii. 430 , 2de edit. ii. 647. Flem. Brit. Anim. 507. Grant in Edir. Journ. of Science, no. 14. Stark, Elem. ii. 420._- Scirpearia mirabilis, Templeton in Mag. Nat. Hist. ix. 470._L La Virgulaire à ailes laches, Blainv. Actinol. 51 4, pl. 90, fig. 3 .

Hab. Dredged up by Mr Simmons off Inch-Keith, Sowerby. Prestonpans Bay, Jameson. "On the east and north coast of Scotland, where it is believed by the fishermen to have one end lodged erect in the mud; in Zetland it is called the Sea-rush," Fleming. Dredged up in Belfast Lough, Templeton.

"Seems to represent a quill stripped of its feathers. The base looks like a pen in this as in the other species, swelling a little from the end, and then tapering. The upper part is thicker, with alternate semicircular pectinated swellings, larger towards the middle, tapering upwards, and terminating in a thin bony substance, which passes through the whole." Sowerby.__ "From 6 to 10 inches in length." "They perfectly correspond in form and external appearance with the elegant coloured figure given by Muller. Their axis is calcareous, solid, white, brittle, flexible, cylindrical, of equal

* Formed from Virgula, the diminutive of Virga-a rod.

+ "A young man who has since fallen a sacrifice to his zeal for Natural History in the West Indies."-Leach. He was, I believe, a native of Edinburgh. 
thickness throughout, and exhibits no mark of attachment at either end. When broken, it exhibits a radiated surface, like the broken spine of an echinus. The axis appears to have little connection with the fleshy part, and to consist of concentric layers deposited by the soft parts surrounding it. When a portion of the axis is broken off from either extremity, the animal retracts at that part, so as continually to expose a fresh naked portion of the axis : hence we can take out the axis entirely from its soft sheath, and we always find the lower pinnæ of the animal drawn up closely together, as if by the frequent breaking of the base. These very delicate and britthe animals seem to be confined to a small circumscribed part of the coast which has a considerable depth and a muddy bottom, and the fishermen accustomed to dredge at that place believe, from the cleanness of the Virgulariæ when brought to the surface, that they stand erect at the bottom with one end fixed in the mud or clay. Muller's specimens were likewise found on a part of the Norwegian coast with a muddy bottom. The Polypi, much resembling those of the common Lobularia digitata, are long, cylindrical, transparent, marked with longitudinal white lines, and have eight tentacula which pre. sent long slender transparent filaments or cilix on each of the lateral surfaces when fully expanded. The polypi are easily perceived extending throngh the lateral expansions or pinnæ, to near the solid axis, where we observe two transverse rows of small ronnd white ova placed under each pinna, and contained within the fleshy substance. These ova appear to pass along the pinnæ, to be discharged through the polypi, as in the Lobularia, Gorgonia, Caryophyllea, Alcyonia, \&c." Grant.

The figures in our plate were drawn from specimens with which I was favoured by Dr Coldstream, and which had been preserved for some time in spirits; but to shew the difference between the animal in this contracted condition and when alive, 1 have placed beside them Figures 5 and 6, copied from Muller. The dissimilarity between figures taken in these different states has rendered the synonymy of the species perplexed and almost inextricable. According to Cuvier, Lamarck, and Blainville, the species delineated by Muller, and which is certainly identical with the British one, is not synonymous with the Linnæan; but this opinion rests solely upon the circumstance of Linnæus having quoted a figure in the " Mus. Ad. Fr."-belong. ing confessedly to another Zoophyte-as a representative of the species be intended, which may have been done from the then uncertainty of the limits of the species, or from having seen specimens in spirits only. His character is very applicable to our animal,- 
"P. stirpe filiformi, rachi distiche pennata: pinnis lunatis remotis alternis ;" and the habitat "in $O$. Norvegico," seems to confirm the reference.

Virgularia differs from Pennatula remarkably in this that no spicula enter into the composition of its soft parts. The polypiferous pinnules are secund, leaving the posterior part naked, and this is marked with a deep furrow extending from one end to the other, dividing the polypidom into two symmetrical halves.

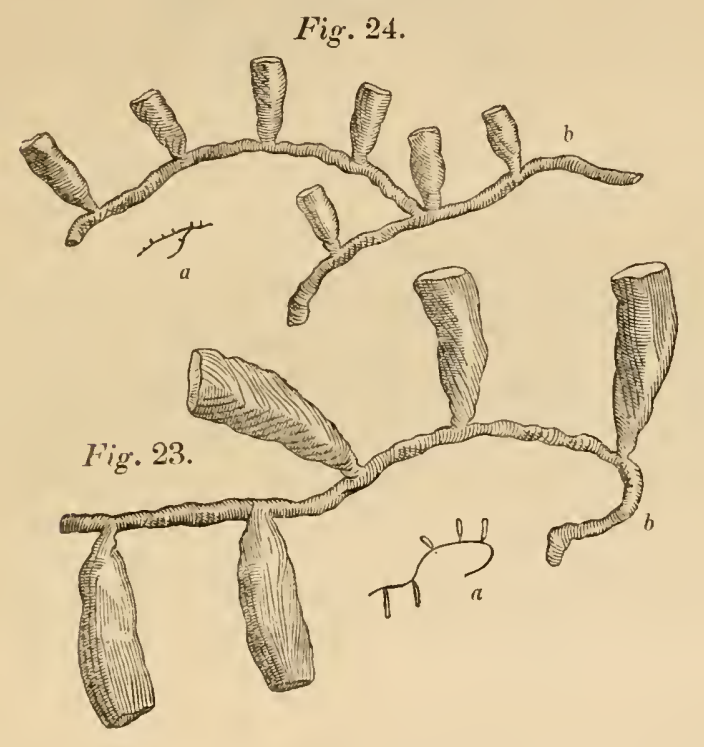




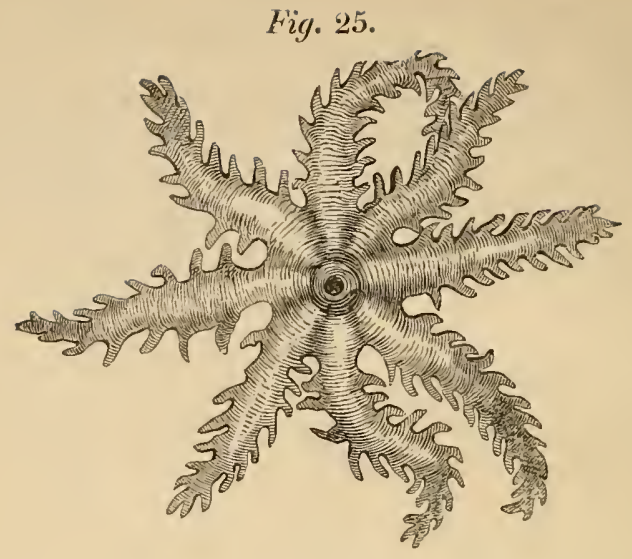

FAMILY V. GORGONIADÆ.

\section{Gorgonia, ${ }^{*}$ Linnæus.}

CHARACTER.-Polype-mass rooted, arborescent, consisting of a central axis barked with a polypiferous crust: the axis horny, continuous and flexible, branched in coequality with the polypemass: the crust when recent soft and fleshy, when dried porous and friable: the orifices of the polype-cells more or less protuberant.

1. G. verrucosa, much and irregularly branched, the branches spreading laterally, cylindrical, flexuous, barked when dry with a white warted crust: segments of the cells unequal, obtuse. Cole. $†$

\section{Plate XXV. Fig. 1.}

Frutex marinus flabclliformis, Raii, Hist. Plant. iii. 7. Sir H. Sloane in Phil. Trans. abridg. (an. 1746) ix. 198, pl. 4, fig. 4._Keratophyton flabelliforme, cortice verrucosa obductum, Raii, Syn. 32._- Erica marina alba frutescens, Petiv. Mus. cent. prim. 9, no. 50.__-Warted Seafan, Borl. Cornw. 238, tab. 24, fig. 1.__-Gorgonia verrucosa, Lin. Syst. 1291. Pall. Elench. 196. Ellis and Soland. Zooph. 89. Turt.

* From Gorgon-the name of a daughter of Phorcys, whose locks of lair were changed into serpents by Minerva.

$\uparrow$ Ray, in his Historia, mentions Mr, afterwards Dr, Cole of Bristol as the finder of this zoophyte on the coast of Cornwall. Cole is well known to naturalists by his ingenious enquiry into the purple liquor of the Purpura lapillus. 
Gmel. iv. 648. Turt. Brit. Faun. 206. Cavol. Polyp. Inar. 29, tav. 1, fig. 1-11, and tav. 4, fig. 1-16. Lam. Anim. s. Vert. ii. 315. 2de elit. ii. 491. Bosc, Vers, iii. 36. Lamarck in Mém. du Mus. ii. 82. Corill. 207. Stew. Elenı. ii. 430. Flem. Brit. Anin. 512. Risso, l'Europ. Merid. v. 327._-Gorg. viminalis, Sower. Brit. Misc. 81, pl. 40. Jameson in Wern. Mem. i. 560. Turt. Brit. Faun. 206.—La G. verruqueuse, Blainv. Actinol. 505 , pl. 87, fig. 3.

Hab. Deep water. "Mount's Bay in Cornwall," Mr Batten. Plentiful on the Devonshire coast, Montcrgu. Said by Dr Walker to occur in Scotland, Jameson. "I have also received it from Scot. lind," Souerby.

Polype-mass more than 12 inches in height, and 15 or 16 in breadth, fixed to rocks by a broad circular fibro-corneous disk, shrub-like, branched from near the base, the branches expanded laterally, cylindrical, erect or erecto-patent, warty. Axis black, smooth and somewhat glossy, round or a little conpressed, compact and corneous, with a snow-white pith in the centre, irregularly cellular and very like the pith of a rush; near the extremities of the branches the axis appears to be a single tube striated longitudinally, but this appearance is produced by drying, for when steeped in water the strix are removed; it is often bulged or knotted at uncertain intervals, but no pores can be letected in its parietes. Crust white, cretaceous, friable, warted with numerous polype-cells and wrinkled in the small spaces between them; thickest towards the ends of the branches which it covers over. Cells partly filled with a yellowish fibrous substance being the remains of the polypes, their orifices closed with eight converging obtuse smail segments, one of which is so much larger than the others as to occupy a half or a third of the whole circumference.

2. G. PLACONus, irregularly branched, the branches disposed in a dichotomous order and a flattish form, cylindrical, warty; cells protuberant, conical, surrounded at top by little spines. Ellis.

\section{Plate XXV. Fig. 2.}

Warted Sea-fan, Ellis, Corall. 67. no. 1. t. 27. fig. a, A. 1, 2, 3.—Gorgonia placomus, Pall. Elench. 201. Lin. Syst. 1290. Mull Zool. Dan. prod. 254. no. 3061. Ellis and Soland. Zooph. 86. Turt. Gmel. iv. 649. Lamarck in Mém. du Mus. ii. 83. Turt. Br. Faun. 206. Berk. Syn. i. 212. Lam. Anim. Vert. ii. 316. 2de edit. ii. 492. Bosc, Vers, iii. 31. Corall. 207. Stew. Elem.ii. p. 430. Flem. Brit. Anim. 512. La G. placome, Bluinv. Actinolog. 505.

Hab. Coast of Cornwall, Ellis. 
"This Sea-Fan is of a reddish brown colour ;" "has its branches disposed in a dichotomous order and a flattish form; they bend irregularly towards one another, but rarely unite. Their mouths are conical, project, and are surrounded at top by little spines. The bone or support is nearly of the substance of wood." Ellis.

3. G. ANCEPS, branched, subdichotomous; branches with the flesh flat on each side, with a row of little mouths along both the margins. Mr Dale. *

\section{Plate XXV. Fig. 3.}

Keratophyton dichotomum; caule et ramulis leviter compressis, Raii, Syn. 82. —-Sea Willow, Ellis, Corall. 68. no. 2, tab. 27, fig. g. —-Gorgonia anceps, Pall. Elench. 183. Ellis and Soland. Zooph. 89. Berk. Syn. i. 212. Lin. Syst. 1292. Turt. Br. Faun. 206. Lam. Anim. s. Vert. ii. 317. 2de edit. ii. 494. Lamour. Cor. Flex. p. $395 . \quad$ Turt. Gmel. iv. 649. Bosc, Vers, iii. 37. Lamarck in Mém. du Mus. ii. 84. Corall. 200. Stew. Elem. ii. p. 430. Flem. Brit. Anim. p. 512. La Gorgone gladiée, Blainv. Actinol. 505.

$H a b$. Deep water, very rare. Found by Mr Dale growing near Margate, Dillenius. Now and then found on the coast of Great Britain and Ireland; but not frequently, Ellis.

"This Gorgon is branched nearly in a subdivided manner." "The bone is roundish, and small at the ends, of a horny nature, inclining to leather." Specimens recent from the sea "are of a fine violet colour; but when we receive them, some are yellow, others white." Ellis. The claims of this species to be considered a British native are doubtful.

The following species, referable to this family, have been indicated as British, but neither figures nor descriptions of any of them, derived from native specimens, have been as yet published:

Gorgonia Flabellum, "grows in form of a net, with its branches compréssed inwardly : the flesh is yellow, sometimes pur.

* " Samuel Dale, Medicus et Pharmacopœus vicinus et familiaris noster, Bantriæ in Essexia degens," one of the four botanists to whom Ray acknowledges his greatest obligations in the compilation of lis "Historia Plantarum." Pref. 1686. - He died in 1739 , æt. 80 . Petiver affectionately styles him " my very kind friend," and " our curious brother."- In the latter pei iod of his life he set. tled as a plysician at Bocking. He is the author of a "Pharmacologia," and of a History of Harwich,- both works of merit, and once of repute. See Pulteney's Sketches, Vol. ii. p. 122-8. Pulteney says he was a F. R. S., but I do not find his name in the list of Fellows given by Dr Thomson. 
ple, with small mouths placed irregularly, having polypes with eight tentacles : the bone is black, horny, and slightly striated on the large branches."

\section{Vignette, No. 19, Page 161.}

Flabellum Veneris, Ellis, Corall. 61. pl. 26. fig. A-M. (foreign). Borl. Cornw. 238.__ Gorgonia Flabellum, Lin. Syst. 1293. Mull. Zool. Dan. prod. 253. Ellis and Soland. Zooph. 92. Berk. Syn. i. 212. Turt. Gmel. iv. 65l. Turt. Brit. Faun. 206. Jameson in Wern. Mem.

i. 561. Flem. Brit. Anim. 511 .

$H a b$. "The Flabellum veneris has been found on the shores of Mount's Bay after a storm, but whether from a wrecked vessel, or tor'n off by the violence of the waves from some rock in the Bay, is not to be asserted positively," Borlasse. "Leith Shore, found by the late Mr Mackay," Jameson. " Mr Neill informs me that he saw Mr Mackay's specimen shortly after it was found, and that it had all the aspect of being fresh and recent," Fleming.

Gorgonia Lep'adifera, "this Gorgon is dichotomous: it is almost covered with mouths, which are placed close together, hanging over one another; they are bell-shaped, bent downwards, and full of small scales: the flesh is covered with minute whitish scales. The bone in the larger branches is testaceons, or rather like bone, and in the smaller ones horny."

Gorgonia lepadifera, Lin. Syst. 1289. Mull. Zool. Dan. prod. 254. Ellis in Phil. Trans. abridg. xiii. 728, pl. 12, fig. 12. Ellis and Soland. Zooph. 84. tab. 13, fig. 1, 2. Wern. Mem. i. 560. Stew. Elem. ii. 430._Primnoa lepadifera, Flem. Brit. Anim. 513.

Hab. "Found on the coast of Aberdeenshire, and coasts of Shetland islands," Jameson.

Isis Hippuris, "has a jointed stony stem, which rises into many loose branches. The bone or support of the animal consists of white, cylindrical, stony, channelled joints, connected together byblack contracted horny intermediate ones. The flesh is whitish, plump and full of minute vessels; the surface of it is full of the little mouths of the cells, which are disposed in a quincunx order, covering the polypes with eight claws."

Isis Hippuris, Lin. Syst. 1287. Ellis and Soland. Zooph. 105, tab. 3, fig. 1-5. Jameson in Wern. Mem. i. 560. Stew. Elem. ii. 429. Stark, Elem. ii. 427 , pl. 8. fig. 7,8 .

$H a b$. "Said by the late $\mathrm{Dr}$ Walker to occur on the east coast of Scutland, and also in the Orkney islands," Jameson. 
Drayton, in the Poly-olbion, mentions the Isis as a product of Portland isle, but his Isis is probably the Corallina officinalis. I gladly quote the lines:

" Upon whose moisted skirt, with sea-weed fring'd about, The bastard coral breeds, that, drawn out of the brack, A brittle stalk becomes, from greenish turn'd to black; Which th' ancients for the love that they to Isis bare (Their goddess most ador'd) have sacred for her hair. Of which the Naiads and the blue Nereids make Them taudries for their necks : when sporting in the lake, They to their secret bowers the sea-gods entertain."

Song 2.

The Isis Entrochus of Turt. Brit. Faun. 206, is a fossil species of Pentacrinus.

Fig. 26.

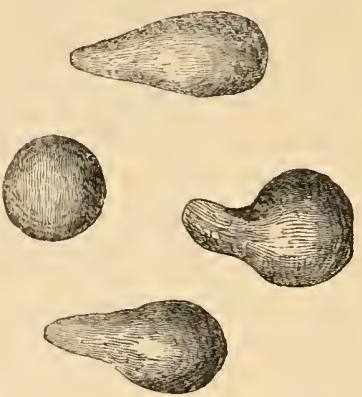

Ora of the Gorgonia. 


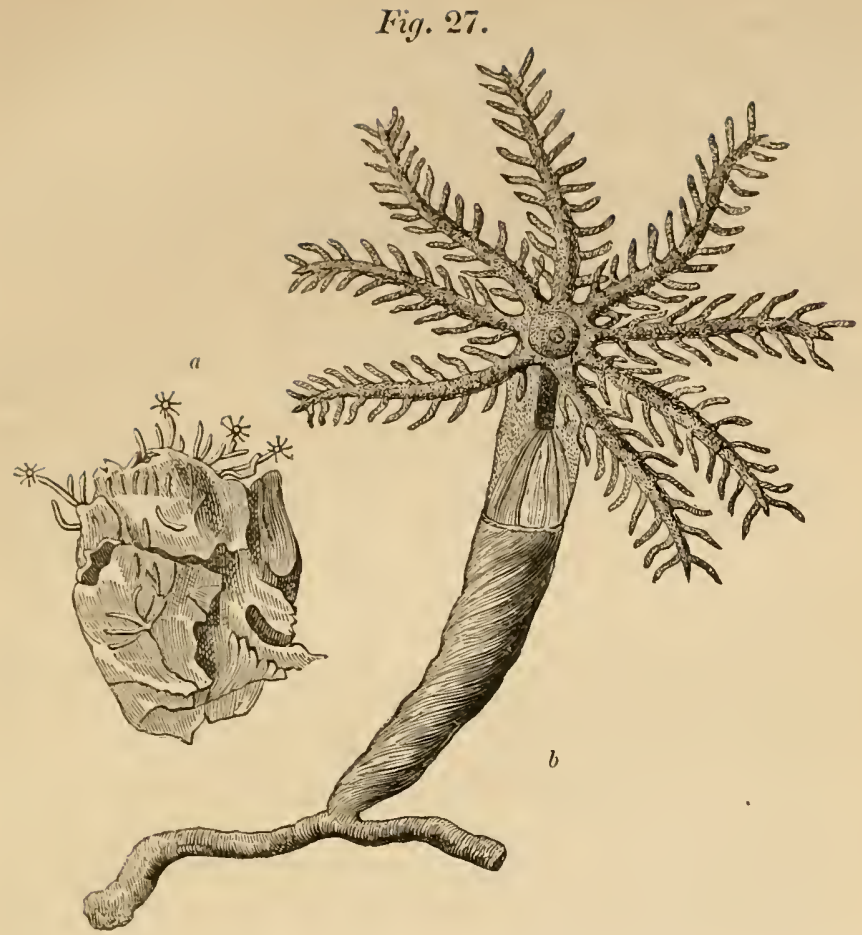

FAMILY VI. ALCYONIDÆ.

\section{Alcyonium, *innæus.}

ChaRACTER.-Polype-mass lobed or incrusting, spongious, the

"From Alcynn-the King's-fisher : the word itself signifies "sea-foam" of which the Halcyons were supposed to make their nests. See Lib. Entert. Knowl. "The Architecture of Birds ;" p. 45, \&c.

"And every thing dispos'd it to my rest,

"As on the seas when th' Halcyon builds her nest.

"When those rough waves, which late with fury rush'd,

" Slide smoothly on, and suddenly are hush'd:

"Nor Neptune lets bis surges out so long,

"As nature is in bringing forth her young."

Drayton's Heroical Epistles.

To the reasons adduced by Milne-Edwards for retaining the name Alcyonium to this group, I would add that Lobularia is inadmissible, having been preoccupied by the botanists. The Alcyonium of Lamarck is composed of certain sponges, of which the true character remains unknown. 
skin coriaceous, marked with stcllated pores; interior gelatinous, netted with tubular fibres and perforated with longitudinal canals terminating in the polype-cells, which are subcutaneous ancl scattered.—Polypes exsertile.

1. A. Digitatum, polymorphous, greyish-white or orange-coloured, the skin somewhat wrinkled, studded over with stellated pores even with the surfice. Dillenius.

\section{Plates XXVI. and XXVI*.}

Alcyonium ramosa-digitatum molle, astericis undiquaque ornatım. Raii, Syn. 31, no. 2. Breynius in Ephemerid. Acad. Leopold. cent. 8, app. 159. Bast. Opus. Sub. i. 24. tab. 3. fig. 6, 7. pessima. Main de mer, Jussieu in Mem. Acar. Roy. des. Sc. an. 1742, 294, tab. 9, fig. 1.Dead Man's hand or Dead Man's toes, Ellis, Corall. 83, no. 2, pl. 32, fig. a, A. A. 2. Alcyonium manus marina, Ellis in Phil. Trans. liij. 431. tab. 20, fig. 10-13._A. digitatum, Lin. Syst. 1294. Mull. Zool. Dan. prod. 255, no. 3078. Fabric. Faun. Gronl. 447. Ellis and Soland. Zooph. 175, pl. 1, fig. 7. Berk. Syn. i. 212. Turt. Gmel. iv. 652. Jameson in Wern. Mem. i. 563. Turt. Brit. Faun. 207. Stew. Elem. ii. 431. Bosc, Vers, iii. 156, pl. 30, fig. 4, 5. Fleming in Edin. Pbil. Journ. ix. 251. Cuv. Reg. Anim. jii. 321. Hogg's Stock. 38. Templeton in Mag. Nat. Hist. ix. 470. Harvey in ibid. new series, i. 475, fig. 56. 57, (very inaccurate).___Alc. lobatım, Pall. Elench. 351. Lamour. Cor. Flex. 336, pl. 12, fig. 4, and pl. 13, fig. omn. Corall. 243, pl. 12, fig. 4 ; pl. 13, and pl. 14, fig. 1.——Lobularia digitata, Lam. Anim. s. Vert. ii. 413. 2de edit. ii. 631. Flem. Brit. Anim.515. Grant in Edin. Journ. of Science, no. 15. Stark, Elem. ii. 421. Johnston in Trans. Newc. Soc. ii. ${ }^{2} 250$, pl. 8. Roget, Bridgw. Treat. i. 162, fig. 56. — Le Lobulaire digité, Blainv. Actinol. 521.

$H a b$. On stones, old shells, \&c. in deep water.

This is one of our most common marine productions, so that, on many parts of the coast, scarce a shell or stone can be dredged from the deep that does not serve as a support to one or more specimens. It appears often in the form of a mere crust about the eighth of an inch in thickness when removed from the sea and in a state of constriction, but more commonly it rises up in conoid masses of various sizes and lobed in a very irregular manner. Sometimes the polypidom is a simple obtuse process, very much resembling the teat of a cow's udder, whence our fishermen have happily named it Cow's-paps: other polypidoms are more or less divided into fingerlike lobes, and assume figures that have suggested the names of Dead Man's toes or Dead Man's hands. The outer skin is tough and coriaccous, stulded all over with stellate figures which, if attentively 
examined, are seen to be divided into eight rays, indicating the numher of the tentacula of the polypes, which issue here. The body of the polypes is as it were enclosed in a transparent vesicular membrane, dotted with many minute calcareous grains, and marked with eight white longitudinal lines or septa which, stretching between the membrane and the central stomach, divide the intermediate space into an equal number of compartments. These lines not only extend to the base of the tentacula, but run across the oral disk, and terninate in the central mouth. The tentacula are short, obtuse, ciliated on the margins, and strengthened at their roots by numerous linear straight crystalline spicula. From the base of the white longitudinal lines an equal, number of white tortuous glandular filaments depend, banging loose in an abdominal cavity placed underneath the fleshy cylindrical stomach, and continuous with the aquiferous canals.* The Polype-cells are oval, placed just under the skin, and are the terminations of the long aquiferous canals which run through the whole polypidom. These canals divide in their course into branches that diverge towards the circumference where they dilate into the cells; they have strong cartilaginons, perhaps muscular, coats; and are filled with a much less consistent matter than that of the body of the polype itself. It appears, from this disposition of the tubes, that many polypes communicate together and form a compound animal, but that all the polypes of the same polypidom do not communicate directly by their medium. The space between the tubes is occupied by a loose fibrous net-work, and the threads being a little more crowded at particular places, they form lozenge-shaped compartments within which are smaller meshes; and the interstices of the whole are filled with a transparent gelatine, in which numerous crystalline irregular spicula lie immersed. These spicula are mostly in the form of a cross and toothed on the sides, but they have no organic connection either with the reticular fibres or with the tubes: they are calcareous, for if a portion of the zoophyte is immersed in a mineral acid, a strong effervescence immediately takes place, and spicula are no longer discernible.

* A classical friend on seeing the specimen from which our figure was taken in full expansion, when it is translucent and permits a view of the interanea, was reminded of the following lines:

" lu liquidis translucet aquis; ut eburnea si quis

" Signa tegat claro, vel candida lilia, vitro."

"_._salientia viscera possis

"Et perlucentes numerare in pectore fibras."

Orid. Met. ri. 354 and 390. 
The ova are placed in the polype-tubes; they are white at first, but ultimately become of a scarlet colour, opake, globular, and about the size of a grain of sand. Each ovum is filled with a mass of extremely minute pellucid granules, and is ultimately discharged through the mouth. They seem to be produced in spring and summer, for in June and July $I$ have seen many specimens with not more than three or five polypes developed, and these are as large and perfect as the polypes of the oldest specimens.

Dr Fleming is of opinion, that the Alcyonium lobatum of Lamouroux, whose figure $I$ have quoted without any mark of doubt, is a perfectly distinct species, because its tentacula "are sub-cylindrical, rounder at the extremity, and covered above and on the margin with blunt tubercles;" whereas of the British Alcyonium "the tentacula in Ellis's figures (and, having compared these with nature, we can pronounce on their accuracy,) are pinnate and pointed." But of these figures of Ellis's, it may be observed that the one he bas given in his essay on Corallines* is very unlike the figure of the same parts in his Nat. Hist. of Zoophytes; and I must acknowledge that neither of them correspond with what 1 have myself seen. When a specimen of Alcyonium digitatum is placed in a vessel of sea.water, the polypes protrude themselves amazingly, and extend their tentacula, which are thick, obtuse, grooved along the centre, and not longer than the diameter of the oral disk, being in fact very like what they are represented to be by Lamouroux; but when these organs are removed and slightly pressed between plates of glass, they become so much elongated that I can readily believe they may, when the animal is active and in its native site, assume the shape and appearance of Ellis's latter figure. And I am thus drawn to the conclusion that the differences in the different figures will not justify the establishment of distinct species, but are to be attributed to the animal being in different states when observed, - a conclusion which a writer in the Encyclop. Method. Supp. p. 497, has also come to. "Les figures données par Ellis, Spix et Lamouroux ne se ressemblent guére; je pense neammoins que cette difference ne peut être rapportée à aucune inexactitude, mais dépend de l'état du polype à l'instant ou il a été dessiné."

The Alcyonium rubrum of Muller defined to be "crustaceum, molle, miniatum, punctis sparsis saturatioribus,"-Zool. Dan. prod. 255 , no. $3081,-$ is, moreover, surely nothing else but this species in its primary crustaceous condition, and of a reddish-orange colour, as

* This figure it appears, was taken from specimens which had been immersed in spirits. Introd. to Corall. p. xii. 
I have occasionally met with it. I have not seen the original figure, but the copy of it given by Blainville, Man. d'Actinol. pl. 88, B, fig. 7, does not diminish the strength of my suspicion, which, however, some may deem a very vague guess, when they observe that it has been referred even to a different genus, and forms the Arthelia rubra of the author just mentioned, Actinolog. p. 524 ; and the Sympodium rubrum of Ehrenberg. Lam. Anim. s. Vert. 2de edit. ii. 625.

\section{Cydonium, * Fleming.}

Character.- "A coriaceous skin, internally carneous, with mumerous straight ridged spicula, perpendicular to the surface. Polypi with a central opening, and an orifice at the base of each of the cight pinnated tentacula."

\section{C. MULLER1, "skin ycllowish, with numerous stellate pores;} internally brown." Jameson.

Alcyonium cydonium, "Mrull. Zool. Dan. tab. 81, fig. 3, 4, 5." Fabric. Faun. Groenl. 448, no. 464. Jameson in Wern. Mem. i. 563. Stew. Elem. ii. 432._— Lobularia conoidea, Lam. Anim. s. vert. ii. 413. Cydonium Mulleri, Flem. Brit. Anim. 516. Grant in Edin. New Phil. Journ. i. 195.——La Cydonie de Muller, Blainv. Actinolog. 525, pl. 92. fig. 2.

Hab. " Island of Fulah and Unst," Janeson.

"Base of adhesion narrow, body massive, surface irregular" the skin consists of animal matter cementing innumerable round siliceous grains; the cells leading from the stellate pores are indistinct; the spicula, which converge towards the centre, are fusiform, grouped in small bundles, and many of them at the skin are tricuspidate. In a dried specimen from Zetland, which I have had an opportunity of examining through the kindness of Professor Jameson, the surface is slightly villous, owing probably to the contraction of the skin, leaving the extremities of the fibres free. With the exception of the stellate pores, it agrees with the Alcyonium primum Dioscoridis of Donati (Adriat. 56. t.ix. f. 1.) in the villous skin and the simple and tricuspidate spicula."-Fleming.

In the $\cong d$ edit. of Lamarck's Anim. s. Vert. ii. 632 , I find it stated that Ehrenberg considers the Alcyonium cydonium of Muller as founded on a young individual of Alcyonium digitatum, of which, indeed, it has much the appearance; but the zoophyte which Dr Fleming has had in view, seems to be different.

* Cydonium-a quince, in allnsion to the figure of the Zoophyte. 
In the "Annals of Natural History" for May 1888, Mr J. E. Gray has inserted the following notice.- " Miss Attersoll has lately discovered, on the coast of Sussex, the Cornularia rugosa of Cavolini, growing on a Tubularia, and has communicated specimens of these interesting zoophytes to the British Museum. This genus has hitherto been believed to he confined to the Mediterranean. It differs from most other horny zoophytes in the tentacles being pinnate like those of Gorgonia." V.i. p. 238.

To enable the student to identify this species-certainly among the most singular of its order-I have given a copy of Cavolini's figure, (Vignette, No. 27, p. 187); and it may be useful to add the generic character : "Polyparium basi affixum, corneum ; surculis simplicibus, infundibuliformibus, erectiusculis, polypum unicum singulis continentibus.-Polypi solitarii, terminales : ore tentaculis octo dentato-pirnatis, uniserialibus." Lam. Anim. s. Vert. ii. 128, 2de edit.

On the eve of the preceding remarks being sent to press, I received from Mr J. E. Gray a specimen of the Cornularia from "Wey mouth." I agree entirely with this sagacions naturalist in his opinion of the identity of the zoophyte with Cavolinis. In textmre it accords with Sertularia. The root-like fibre is filiform and tubular, creeping in a flexuous manner, along the stem of Tubularia indivisa, and putting ontat irregular intervals, tubular vase-like cells from two to three lines in height. 'The cells are smooth, with a narrow base and a wide even aperture. (Fig. 23, $a$ and $b$, p. 181.)

The examination of it has thrown new light on the Polypidom described at p. 157, under the name of Campanularia dumosa. I have there expresser my donbts as to the real position of that species, and $I$ had indeed a suspicion of its being an ascidian zoophyte allied to the Vesicularia. Now, however, there can be little doubt that it is a Cornularia, probably identical with the C. rugosa, for its comparatively smaller size may depend on peculiarity of habitat. To slew their similarity, 1 place a figure of it beside the other. (Fig. 24, $a, b$. p. 181.) 


\section{BR I T ISH Z OOPHY'TES.}

\section{PART IV}

\section{ZoOphyta Heliantholda.}

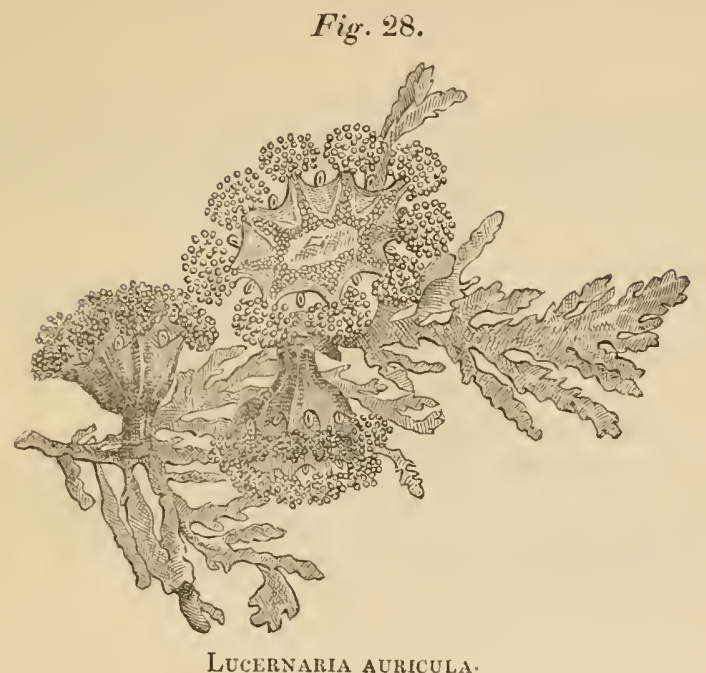

Lucernaria auricula.

" _ in the waters we may see all creatures, Even all that on the earth are to be found, $A s$ if the world were in deep waters drown'd. For seas have As well as earth_Vines, Roses, Nettles, Melons, Mushrooms, Pinks, Gilliflowers, and many millions Of other plants, more rare, more strange than these, As very fishes, living in the seas."

\section{Du Burtas.}


" Mihi firme persuadeo, eum, qui plantas marinas et insecta marina perscrutari velit, magna perfusum iri voluptate : est enim hic novus microcosmus, cujus incolæ parum innotuerunt, sed qui propter proprios propagandi modos, ritus, œconomiam, aliasque qualitates, attentione Naturæ venatoris sunt dignissimi."-J. Basterus.

"—_ and made their beauties known,

"Not without moral compliment."

\section{Crabbe.}

" Still life was theirs, well pleasing to themselves,

"Nor yet unuseful, as my song shall show.

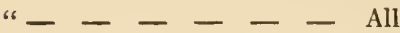

" Life's needful functions, food, exertion, rest,

"By nice economy of Providence

"Were overruled to carry on the process,

"Which out of water brought forth solid rock."

Montgomery. 


\section{ZOOPHYTA BRITANNICA.}

\section{ORDER III.}

\section{Z. HELIANTHOIDA.}

\section{Character.}

Polypes separate or compound, free or attached, flosculous; the body regular with a circular periphery, contractile, internally divided into numerous spaces by perpendicular muscular septa: mouth superior and central, encircled with one or more series of tubular tentacula : stomach membranous: anus 0 : ovaries and creca placed in the septa between the stomach and skin.

\section{Observations.}

I borrow the name of this order from Latreille, * but give to it a wider application than it has in the classification of that illustrious naturalist, that it may embrace the madrepores and starred stones, which the observations of Le Sueur, confirmed as they have been by subsequent voyagers, demonstrate to be the products of zoophytes similar, in all essential points, to the naked Actinix. The order thus corresponds to the class "Zoantha" of De Blainville,-a namẽ which has the claim of priority, and might have been adopted by me, had not its conjunction with zoophyta appeared inappropriate, as involving a tautology. The term preferred expresses the resemblance which the animals it designates liave to the compound or syngenesious flowers,-a resemblance which has been very generally remarked, and the source of the name-Sea Anemonies_by which the typical species are known in this country. When speaking of these Ellis says,_- " their tentacles, being disposed in regular circles, and tinged with a variety of bright lively colours, very nearly represent the beautiful petals of some of our most

\footnotetext{
- Fan. du liegue Animal, p. 535.
} 
elegantly fringed and radiated flowers, such as the Carnation, Marygold, and Anemone." The language of Le Sueur in respect of the tropical coral-bearing tribes is still warmer. The little polypes of Porites astroïdes, when in blow, remind him of a field enamelled with small flowers; and of them in general he says,__ "Quand la mer est calme, c'est un spectacle admirable que de voir les belles couleurs velontées qu'ils étalent: elles imitent les tapis les plus riches et les plus variés. Près d'eux se montrent des gorgones et des serpules dont les houpes blanches, jaunes et rouges, brillent de l'éclat le plus vif, et des amphitrites qui élèvent au-dessus de l'eau leur tête couronnée de palmes enrichies des teintes les plus variées. Je ne pouvois me lasser d'admirer avec quelle profusion ces animaux sont groupés et enlacés: c'étoit à regret qu'après m'être promené long-temps au milieu d'eux je me déterminois à les arracher du sein des eaux, et à en mettre des fragments dans un baquet, que je faisois de suite transporter chez moi pour examiner a loisir les animaux particuliers à chacun des polypiers." *-It is only, however, when they lie with their upper disk expanded and their tentacula displayed, that they solicit comparison with the boasts of Flora, for when contracted the polypes of the madrepores conceal themselves in their calcareous cups, and the Actiniæ hide their beauty, assuming the shape of an obtuse cone or hemisphere of a fleshy consistence, or elongating themselves into a sort of flabby cylinder that indicates a state of relaxation and indolent repose.

The Actinia gemmacea is the only species which the anatomist has yet examined with care, + but it may safely be chosen as the representative of its order, the probability being that the deviations from its structure in the other species and genera are only of secondary consequence. Of the species mentioned $\mathrm{Mr}$ Teale has given a very elaborate anatomy, $\ddagger$ more correct and minute than any hitherto published, but the sketch to suit our design, must be of a more general character.

* Memoires du Muséum, Tom. vi. p. 272 and 287.

+ M. Delle Chiaje has, it seems, anatomized several other species, but $J$ have no access to bis works. Bull. des. Sc. Nat. xvii. 470.

$\ddagger$ "On the Anatomy of Actinia coriacea, by Thomas Pridgin Teale," in Transactions of the Leeds Philosoplical and Literary Society, Vol. i. 
The body of the Helianthoïla may be compared to a truncated cone or short cylinder, seated on a flat plain base, while the opposite end is dimpled in the centre with the oral aperture, and garnished with variously figured tentacula which originate from a space between the proper lip and the free somewhat thickened border of the disk. In a state of contraction the mouth is closed, the tentacula are shortened, and the whole concealed by this border, being drawn like a curtain over them, leaving a mere depression on the top. The mouth leads by a very short and wide passage into a large stomach, which is a membranous bag puckered internally with numerous plaits, and divided in a perpendicular direction into two equal halves, by a deep smooth furrow with cartilaginous sides, as was first remarked by Reaumur.* There is no intestine, nor any other visible exit from the stomach than the mouth, by which the undigested remains of the food are ejected, always enveloped in a large quantity of a clear glairy fluid. But in a state of expansion and of hunger, many kinds of Helianthoïda can protrude the stomach beyond the lip in the form of large bladder-like lobes, which often hang over the sides and almost conceal the rest of the body; and amidst them there are very frequently extruded at the same time some white filaments, like liundles of ravelled thread, which have escaped either through a rupture, or a circular opening in the bottom of the stomachal membrane. 'The space between the walls of this organ and the outer envelope is divided into numerous narrow compartments by perpendicular and parallel lamellæ of a musculo-tendinous texture, which extend from the oral disk to the base, and radiate to the centre like the gills of a mushroom to its stalk,--a comparison the more exact as some only of the lanellæ reach and touch the stomach, the rest coming more or less short, and forming consequently imperfect interseptal spaces. "The breadth of the leaflets va-

* " They (the furrows) are produced on each side by the firm adherence of the gastric membrane to a pair of very dense, fleshy, but narrow leaflets, throughout their whole extent, or, in other words, from the top to the bottom of their internal border. These depressions divide the animal into two lateral halves, constituting a bilateral symmetry in Actinia, as has been obserred by M. Agassiz in other supposed radiated animals." Teale in loc. cit. 102._-But in Actinia Dianthus the channel or furrow exists on one side only: 
ries considerably, some extending scarcely a line from their external attachment, others reaching as far as the stomach, being nearly half an inch in breadth. The height generally corresponds with the height of the animal; a few, however, of the narrowest leaflets extending upwards from the base, terminate obliquely in the sides, without being prolonged as high as to the lip or roof."* These lamellæ are of a muscular character, and by their actions cause the body to assume its various forms. The spaces between them are filled, 1st, with the ovaries attached, in elnngated masses, to the inner border of most of the leaflets; and $2 d l y$, with the "verniform filaments" which, as already mentioned, are often extruded at the mouth. These filaments are capillary, greatly convoluted, smooth and of a white colour, with a sort of mesentery extended along one side. Their appearance naturally suggests the idea of their being either the intestines or the oviducts of the creature, but they perform no function of the kind; and probably they are creal, analogous to the filaments which hang from the stomach of the asteroid zoophytes. They have been often described as ovarian, even by late authors, $\uparrow$ but $\mathrm{Mr}$ Teale has fully shewn the improbability, if not the erroneousness of this opinion. He believes the filament to be tubular, though he acknowledges he has not been able to obtain any evidence of the fact, and " under the microscope it appears simply as a round, solid, translucent chord." Such also has it always appeared to me, so that I can scarcely hesitate to pronounce Dicquemare's description of its structure to be altogether incorrect. "I have observed," he says, "that there grows or comes out of their body and mouth a sort of threads about the size of a horse-hair, which being examined with a solar microscope of five inches diameter, appear as if made up

* Teale in Trans. Leeds' Soc. i. 96.

$\dagger$ " Entre ce sac intérieur (the stomach) et la peau extérieure, est une organisation assez compliquée, mais encore obscure, consistant surtout en feuillets verticaux et fibreux, auxquels adhèrent les ovaires, semblables à des fils tres entortillés." Cuvier, Reg. Anim. iii. p. 290. Delle Chiaje in Bull. des Sc. Nat. xvii. 471. See also J. R. Jones in Cyclop. of Anat. and Physiol. ii. 409.Sharpey describes them as oviducts. Cyclop. cit. i, 614. Dicquemare had it singular notion that they contained certain bulbs or buds "which open in time and cleaving to the bodies on which these threads are extended, produce small anemonies." Phil. Trans, abridg. xiii. 639. 
of a prodigious number of vessels, wherein a liquor is seen to circulate. 'The largest of these unite together, much in the same manner as the optic nerves do in man."*

The external envelope of the naked Hydroinda is a thick firm fleshy or coriaceous skin consisting of a corium and epidermis, - the former layer constituting the chief organ of support, and giving to the animal its peculiar form. "A circular horizontal portion forms the base or foot; a cylindrical rertical portion constitutes the sides, and is inflected at the superior border, so as to form a thick rounded lip. The corium is afterwards prolonged over the tentacula, giving investment and form to these organs, and is then extended horizontally to form the roof, near the centre of which it again becomes folded upon itself, forming an internal lip or mouth, at which part it is continuous with the digestive sac." †-" 'The epidermis forms a thin layer of unorganized matter spread over the whole extent of the corium, and may be traced into the stomach. The external surface of the epidermis is dense and membranous ; intermally, when examined by the lens, it appears as a pulpy substance. Intimately intermixed with it, in irregular patches, and not constituting a distinct or separate layer, is a pigment varying in colour in different parts of the same animal, and in different individuals. This colouring matter is extensively distributed over the base, sides, tentacula, and roof, but I have never observed any trace of it in the stomach." + The surface is either smooth or studded over with glandular warts, which, having an adhesive quality, enable the creatures the more completely to conceal themselves by induing the body with an extraneous coat formed of the sand, gravel, and broken shells which lie around their peculiar localities. This is exchanged in the madrecolous tribes for the more perfect defence which a hard coral affords, into which the soft parts are withdrawn at will. "This coral is calcareous, and the cells which are inhabited by the animals are furnished with more or less distinct longitudinal lamellæ, placed in a radiating position round the central axis, so as to give the cavity a star-like appearance." $\$$ Its structure is in fact a model cast in lime of what may be called the skeleton of the Actiniæ,-the parts on

* Phil. Trans. abridg. xiii. 639.

$\$$ Teale in loc. 95 .

$\dagger$ Teale in lib. supra cit. 93.

§ Gray in Synop. of British Museum, 70. 
which the support depends being converted into stone by a deposition of calcareous matter in their texture,-the corium in this manner becoming a solid polypidom, and the muscular leaflets partitions of limestone.*

When a Helianthoid Polype is at rest and unalarmed, it can dilate the body to fully twice its ordinary bulk by imbibing water through the mouth or tentacula, $f$ the bases of which open in the spaces between the perpendicular lamellæ. These spaces being filled, the water is then made to permeate the rim of the oral disk, which is full of cavities and cells for its reception; and the tentacula are in the same manner distended, the water being forced into them from behind while the little opening on their tips is held close. The whole animal is thus distended to a wonderful degree, and every organ stretched and displayed; - the tentacula spread out in quest of prey,-the skin rendered almost clear from very fulness; and the stomach, pushed beyond its natural bounds, lies over the sides in swollen diaphanous lobes. The water thus introduced is doubtless subservient to the purposes of respiration, and to aid this, the vermiform filaments, and the internal surface of the stomach and tentacula are clothed with vibratile cilia, exciting and directing currents over the surfaces. $f$ Since too the contents of the stomach must be fully exposed to the influence of the water, the

" “Dans cette classe d'animaux, le polypier ou la partie solide qui reste quand le partie animale a été desséchée et enlevée, est done une sorte de réseau calcaire d'un tissu plus ou moins compacte, qui remplissoit les mailles, les vacuoles de celle-ci. La proportion de ces deux parties est en rapport avec l'âge du zoanthaire : plus il est jeune, plus il y a de matière animale; plus il est âgé, et plus il y a de matière inorganique : aussi la base de ces polypiers, le plus souvent morte, est-elle fort dure, tandis que le sommet ou les bords essentiellement vivans sont entièrement mous." Blainville, Actinolog. 311.-_See also Harvey in Mag. Nat. Hist. n. s. 1. 474.

+ "It has not, so far as I know, been clearly shewn by which of the communicating orifices the water enters. Though I took considerable pains, I have not been able satisfactorily to ascertain this point ; l may remark, however, that 1 have repeatedly noticed water entering at the mouth." Sharpey in Cyclop. Anat. and Phys. i. 614.-Delle Chiaje asserts that it enters by the tentacula. Bull. des Sc. Nat. xvii. 471. He adds, "Il est curieux d'observer le courant d'eau qui, lorsque l'Actinie se relâche, pénètre par quelques tentacules, et dès qu'elle se contracte, sort par d'autres tentacules précisément opposés aux premiers. Ce phénomène s'observe sur toutes les espèces d'Actinies."

‡ Sharpey in lib. cit. i. $614-15$. 
nutrient parts may be by its means fitted for more immediate assimilation, for as there is neither circulating nor lymphatic systems, the absorption of the nutrient fluids must be made directly from the stomach itself. By the contraction of the periphery of the body, this water is again expelled at pleasure through the tentacula in a continuous stream or in jets, and if the contraction is sudden and strong, the water may be thrown out with such force as to rise to the height of at least a foot. It is remarkable that the water does not escape from all or the greater number, but only from a few of the tentacula. Whether any part escapes by the mouth is doubtful.

All the native species are single, viz. every individual is isolated and complete in itself, and not organically associated with others, as the polypes of the preceding orders are. They are also all oviparous, the ova being generated in appropriated organs. According to Spix the ova, in the Actinia, form several grape-like clusters, situated in the interseptal spaces, with ducts which open into the base of the stomach by several apertures, and hence the ova are presumed to gain their freedom by traversing the stomach and mouth.* Blainville doubts this, being led from analogy to believe it more probable that the oviducts may open in the labial rim, as they do in the asteroid zoophytes. + Delle Chiaje says that they terminate in the tentacula of the Actinix ; and Cavolini states, that in the Caryophyllia the ova are discharged through small distinct openings between each of the tentacula. $\S$ Their natural passage of egress may be considered to be undetermined, but it seems to be ascertained that they do, under certain circumstances, escape from the body sometimes through the tentacula, or in apertures between them, and sometimes through the mouth. Mr Teale, after vainly attempting to discover any proper oviduct, thinks it probable that the ova, when sufficiently matured, " actually burst their membranous envelope, and becone lodged in the interseptal spaces where they are exposed to the free access and continued supplies of sea water, the grand stimulus to their further develope-

- Carus, Comp. Anat. Trans. ii. 308, pl. i. fig. $x$.

+ Nan. d'Actinologie, 79.

$\ddagger$ Bull. des Sc. Nat. xvii. 471 .

$\$$ Edin. New Phil. Journ. i. 153. 
ment."* The supposition readily explains some facts which have given rise to an opinion of their viviparous generation, for the young will be born alive if the easy arlmission is made that some of the ova may have their egress delayed until they have passed through their first stages of evolution. That many ova, and probably by much the greater number, escape previously to this is now well ascertained.

Mr Teale's description of the ovaries varies also from Spix's, and is very accurate. In Actinia gemmacea he tells us they form " elongated masses attached along the inner border of most of the leaflets. Each ovary is composed of several horizontal folds or plaits, which, when unfolded, show this structure to be about three times the length it assumes when attached to the leaflet. By carefully spreading out these folds, the ovary, with the assistance of a lens, is seen to consist of two very delicate layers of membrane, enveloping a closely compacted layer of ova. After enveloping the ova, the membranous layers are placed in apposition, and form a kind of mesentery, by which the ovary is attached to the internal border of the leaflet. The two layers afterwards separate to pass one on each side of the leaflet, thereby lining the interseptal spaces from which this membranous investment is prolonged into the tentacula, as well as into the cavities within the structure of the lip and mouth. At the summits of the tentacula, and of the tubular eminences of the lip, the membrane becomes continuous with the common integument, whilst at the inferior part of the interseptal spaces it is continuous with the digestive sac. The breadth of the ovaries is nearly uniform from the top to the bottom. Some irregularities are occasionally observed in their attachment to the leaflets. Sometimes one leaflet supports two ovaries, and not unfrequently two neighbouring ovaries are continuous with each other at their inferior extremities." +

The period of propagation is probably, in most Helianthoida, not limited to any particular season. According to the observations of Cavolini the Caryophyllia matures its ova in spring; and it is only at this season that $I$ have found the Lucernariæ on

* Leeds Phil. and Lit. Soc. Trans i. 111. † Lib. supra cit. p. 104. 
our northern shores, when they are big with numerous eggs. But in the Actinix, ova in every state of developement may be seen in the same individual throughout the year; perhaps, however, they are most abundantly laid in autumn. They are usually of a roundish figure, and, like the gemmules of polypes in general, contractile and motive, being carried about from the action of the cilia that clothe the surface. "Under the microscope they prove of diversified form, many resembling flattened pease, some elongated or exhibiting irregular prominences, some almost spherical, others as if composed of two or even of three unequal spheres, and some which cannot be referred to any particular figure." After moving about for several days, during which their forms suffer some slight change, they insensibly relax in their activity, the cilia disappear, and, having become stationary, each rapidly runs through the stages of developement that lead it up to the similitude of its parent.

Every one has read of the coral islands of tropical seas; how they grow from the fathomless profound, and how they rise to day by the operations of puny insects, which, in countless numbers, and in untold generations, effectuate changes on our glohe superior, perhaps, to what all other animals united do, and compared to which the greatest achievements of "intellectual man," sink to insignificance.* Geology teaches us that with these worms the great work of creation began; and from that uncer-

* “ Their plants are made of stone, and they build dwellings. Dwellings ; they construct islands and continents for the habitation of man. The labours of a worm, which man can barely see, form mountains like the Apennines, and regions to which Britain is as nothing. The invisible, insensible toil, of an ephemeral point, conspiring with others in one great design, working unseen, unheard, but for ever guided by one volition, by that One Volition which cannot err, converts the liquid water into the solid rock, the deep ocean into dry land, and extends the dominions of man, who sees it not and knows it not, over regions which even his ships bad scarcely traversed. This is the Great Pacific Ocean; destined, at some future day, to be a world. That same power which has thus wrought by means which blind man would have despised as inadequate, by means which he has but just discovered, here too shows the versatility, the contrast of its resources. In one hour it lets loose the raging engines, not of its wrath, but of its benevolence; and the volcano and the earthquake lift up to the clouds, the prop and foundation of new worlds, that from those clouds they may draw down the sources of the river, the waters of fertility and plenty."

Dr Macrulloch, Ilighlands and West. Islands, Vol. iv. p. 14. 
tain date even to the present day, their amazing labours have been continued, the product remaining in the extensive ranges of limestone rocks which lie buried in our northern regions, as well as in those islands of new formation with which they threaten to convert the equatorial seas into dry land. "They that sail on the sea tell of the danger thereof; and when we hear it with our ears we marvel thereat."*

"Millions of millions thus, from age to age,

With simplest skill, and toil unwearyable,

No moment and no movement unimproved,

Laid line on line, on terrace terrace spread,

To swell the heightening, brightening gradual mound,

By marvellous structure climbing tow'rd the day.

Each wrought alone, yet all together wrought,

Unconscious, not unworthy, instruments,

By which a hand invisible was rearing

A new creation in the secret deep.

Omnipotence wrought in them, with them, by them;

Hence what Omnipotence alone could do

Worms did. I saw the living pile ascend,

The mausoleum of its architects,

Still dying upwards as their labours closed :

Slime the material, but the slime was turn'd

To adamant, by their petrific touch;

Frail were their frames, ephemeral their lives,

Their masonry imperishable." $\dagger$

By much the greater number of those wonder-working zoophytes belong to this order. In former ages the geologist tells us that they were numerous and varied in our seas, - their remains, entombed in limestone and marble, constituting the models by which he decyphers their forms and species; but this ancient host is now represented by two or three species only, and these so small and rare, that it would be giving them a disproportionate importance to make them more than the subject of a passing allusion to the labours of their races.

The British species may be arranged under the following genera;

* Ecclesiast. chap. xliii. v. 24.

† Montgomery's Pelican lsland, canto ii. p, 27. 


\section{Family I. MADREPHYLLLIAA.}

Body cased with a solid calcarcous cupped polypidom, lamellated internally.

17. Turbinolia. Polypidom turbinate, becoming free by age. 18. Caryophylia. Polypidom cylindrical, always attached.

\section{Family II. ACTINIID $Æ$.}

Body naked, fleshy, contractile, locomotive.

19. Actinia. Body conoid or cylindrical; the tentacula retractile. 20. Antrea. Body cylindrical; the tentacula non-retractile.

21. Lucernaria. Body somewhat campanulate; the tentacula in tufts disposed at distant intervals round the margin.

Fig. 29.

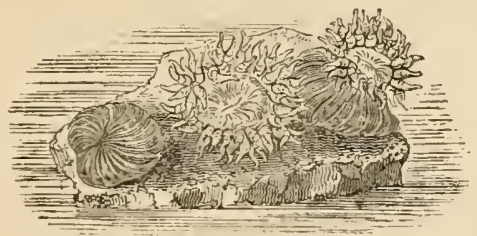

ACTINIA VIDUATA. 


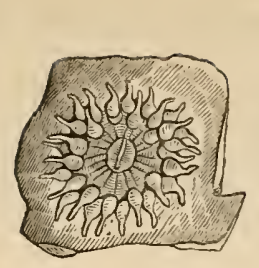

Fig. 30.
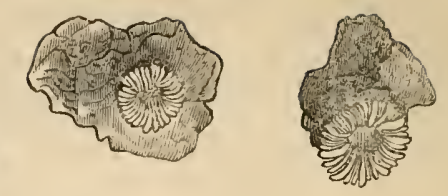

\section{ZOOPHYTA HELIANTHOIDA.}

\section{FAMILY VII. MADREPHYLLIÆA.}

\section{Turbinolia, ${ }^{*}$ Lamarck.}

Character. Animal like the Actinia, single: Polypidom fixed when young, becoming detached in the progress of its growth, simple, inversely conical, furrowed on the outside, pointed at the base, and terminating above in a lamellated stellular cell.

1. T. Bonealis, " widely conical, slightly bent." Rev. D. Fleming. $\dagger$

Fungia turbinata, Fleming in Weru. Mem. ii. 250.—Turbinolia borealis, Flem. Brit. Anim. 509._La Turbinolie boréale, Blainv. Actinolog. 341.

Hab. "Zetland," Fleming.

"This species occurred in the same boat in which I picked up the Caryophyllea cyathus. Though greatly defaced, it still exhibits proofs of its recent origin. It is inversely conical, pointed, subarcuated, with a concave disc and a prominent centre; the plates appear to have been equal. It is about five-tenths of an inch in height, and nearly the same in breadth across the star." Fleming.

Lamouroux maintains, in opposition to Lamarck, that the Turbino . liæ are fixed, and says that in well preserved specimens a distinct pedicle, with the point broken off, is obvious. I The fact seems to be, as stated

* From turbo, a top.

t The anthor of the "Philosophy of Zoology," and the "History of British Animals." He, for many years, discharged the duties of a minister of the Church of Scotland; and is now Professor of Natural Philosophy in King's College, Aberdeen. To his labours and writings I am inclined to ascribe a considerable share in diffusing that taste for natural listory which is now abroad.

‡ Soland. Zooph. new edit. p. 51 . 
by $\mathrm{Mr}$ J. E. Gray, * that they are fixed in their first stage of existence, but become detached by age. Dr Fleming, to his description of the species, adds, "From its shape, it appears probahle, that it grows with its base fixed in the sandy bottom of the sea, as Pallas formerly conjectured."

\section{Caryophyllia, $†$ Lamarck.}

Character. Animal like the Actinia: Polypidom permanently fixed, simple, cylindrical or conoid, striated externally in a longitudinal direction, the top hollowed into a lamellated stellular cup.

1. C. Sмгтні1, polypidom cylindrical; lamella entive, arched, faintly crenate, from 3 to 5 smaller ones between the larger; centre tubercular. Rev. Dr Fleming.

Vignette, No. 30, page 206.

Caryophyllia cyathus, Fleming in Wern. Mem. ii. 249 ; and in Edil. New Phil. Journ, viii. 70. Broderip in Ibid. viii. 312. Flem. Brit. Anim. 508. -C. Smithii, Stokes and Broderip in Zool. Journ. iii. 486, pl. 13, fig. 1-6. and in Bull. des Sc. Nat. xvii. 157. Buckland, Bridgew. Treat. ii. 90, pl. 54 fig. 9-11. Harvey in Proc. Zool. Soc. 1834, part ii. 28 : and iu Mag. Nat. Hist. New Series, i. 474, fig. 55 .

Hab. "From deep water off Foulah, in Zetland," Fleming. Southern coast of Devonshire, Thomas Smith, Esq. Cornwall, Mr Coutch.

The Polypidom is firmly attached to the rock so as apparently to make a part of it: it is cylindrical, whitish stained with brown, striated or finely grooved on the exterior, internally cupped and lamellar. The lamellæ are of three kinds, a larger and more prominent, between every pair of which there are generally three, but sometimes five lesser ones, of which the central one differs from the others in being divided into two portions, the imnermost half projecting beyond the others towards the centre and forming an inner series. $\neq$ All

* Syn. of Brit. Museum, p. 70. See also in relation to this point Mr Stutchbury's observations on the growth of young Corals of the genus Fungia, in Lin. Traus. xvi. p. 493.

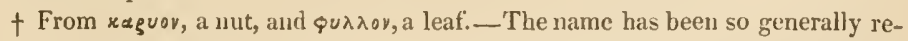
ceived that it might be difficult to substitute another for the genus, and yet it is very objectionable. There is a Caryoplyllceus amorg the intestinal worms; and the Caryophyllece are familiar to all botanists.-The following generic cha. racter of Caryophyllia is given by Mr Stokes: "Polyparium simplex, basi affixum. Corona laminis duplici serie dispositis, exterioribus majoribus, regulariter inæequalibus, maximis inter seriei intcrnæ laminas interpositis. Discus lamellis erectis, prominulis foliatis."

† Dr Fleming describes the plates thus: "The lamellie are disposed in fours, 
the lamellæ are arched, entire, striated on the sides, whence the margin appears somewhat crenulate: they terminate about half across leaving a plain centre which is rongh or tubercled. In one specimen before me the primary lamellæ are 14 in number; in another they are 20 ; but Dr. Fleming gives about 40 as the number in his Zetland specimen. Height from two-tenths to half an inch; diameter threetenths to one inch.

My friend Dr Coldstream has furnished me with the following account of the animal of this interesting zoophyte, which he watched for several successive weeks during his residence at Torquay. "When the soft parts," he writes, " are fully expanded, the appearance of the whole animal resembles very closely that of an Acrinia. When shrunk they are almost entirely hid amongst the radiating plates. The specimens I have seen have varied in size from threeteriths to one inch in diameter, and from two-tenths to half an inch in beight. They are found pendant from large boulders of sandstone just at low water-mark; sometimes they are dredged from the middle of the bay. Their colour varies considerably; I have seen the soft parts white, yellowish, orange-brown, reddish, and of a fine apple green. The tentacula are usually paler. During expansion, the soft parts rise above the level of the calcareous lisc to about twice its height. The tentacula are pushed forth very slowly, but sometimes are as long as the whole height of the body. They are terminated by a rounded head. * The mouth has the appearance of an elongated slit in the centre of the disc: it is prominent, and the lips are marked with transverse striæ of a white colour. When a solid body is brought into contact gently with the tentacles they adhere pretty strongly to it, just as the Actiniæ do; but when they are rudely touched, they contract very quickly, and if the irritation

and may be distinguished into three different kinds. The first are the highest and the broadest at the margin, but as they descend into the disc they become narrower before they join the central plate. The second kind are narrower than the preceding at the margin, but towards the middle they suddenly enlarge and join the middle plate. The third kind are the smallest and terminate before reaching the middle plate. The space included between a pair of the first kind of plates, contains one of the second kind in the middle, with one of the third kind in each of the lateral spaces. Those on the sides are rough, with small scattered tubercles, and their margins are curled. This last circumstance occasions the roughness externally, where the longitudinal striæ are the remains of the gills. The plate which occupies the bottom of the cavity is smooth, variously twisted, and connected with the base of the lateral plates."

* "They are nearly transparent except at the termination, which is a little ball, white and opake." De la Beche. 
be continued, the whole soft parts sink within the calcareous cup." 5 th April 1833.

Pocillopora interstincta. Madrepora interstincta, Mull. Zool. Dan. prod. 252.-Dr Fleming (Brit Anim. 511) has seell a specimen "probably of this species," obtained by Dr Hibbert in Zetland, but I am not aware that any description of it has been yet published.

Madrepora musicalis, Lin. Syst. 1278. Berk. Syn. i. 211. Turt. Gmel. iv. 625. Turt. Brit. Faun. 204.-Said to be sometimes cast on the Irish coast; but without the slightest claim to denization.

MAdREPORA PORPITA, Turt. Gmel. iv. 616.-A fossil confounded with the M. porpita of the Indian seas.

Millepora truncata, Stew. Elem. ii. 426. Marked erroneous. ly as British.

Millepora lichenoides, Turt. Brit. Faun. 204. Turt. Gmel. iv. 635. - I an not aware on what authority this has been introduced into our native Fauna by Dr Turton. Ellis says nothing that can lead one to suppose that his specimen was British. 


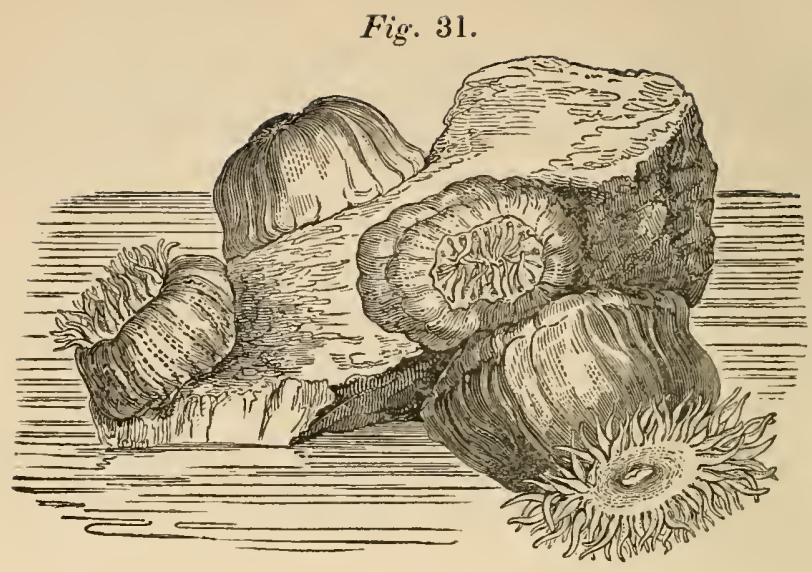

\section{FAMILY VIII. ACTINIIDÆ.}

\section{Actinia, * Linnæus.}

Character. Body conoid or cylindrical, adhering by a broad base: the space between the mouth and the rim of the upper disk occupied by one or more uninterrupted series of conical undivided tubular tentacula which are entirely retractile.

1. A. mesembryanthemum, body conoid, smooth; tentacula numerous, multiserial; margin of the oral disk ornamented with a circle of azurc-blue tulercles.

Var. $\alpha$. Body and tentacula of a uniform liver-brown or olivaceous colour, rarely streaked with bluish or gree $₫$ lines.

\section{Vignette, No. 31.}

Ortie de mer, Reaumur in Mem. de l'Acad. Roy. des Scienc. 1710, pl. 10. fig. 22.—Priapus equinus, $L$ Lin. Syst. edit. 10. 656.—Hydra disciflora, tentaculis retractilibus, extimo disci margine tuberculato, Gartner in Phil. Trans. lii. 83, pl. 1. fig. 5._Actinia equina, Lin. Syst. 1088. Dicquemare in Phil. Trans. lxiii. 364, pl. 16, fig. 1-7.t Mull. Zool.

* From $\alpha x \tau \iota v$, a ray.

† Dicquemare himself uses no specific names: they were applied to his figures by Dr Solander, who, it is to be presumed, was well acquainted with the Linnæan species. 
Dan. prod. 231, no. 2793. Turt. Gmel. iv. 104. Flem. Brit. Anim. 497. Cuv. Reg. Anim. iij. 292. Bosc, Vers, ii. 255. Jolinston in Trans. Newc. Soc. ii. 243. Dalyell in Edin. New. Phil. Journ. xvii. 41] ; and in Proc. Brit. Assoc. 1834, 599. Templeton in Mag. Nat. Hist. ix. 303._A Mesembryanthemum, Ellis and Soland. Zooph. 4. Turt. Brit. Faun. 131. Rapp, Polyp. 52, taf. 2, fig. 1. Johnston in Mag. Nat. Hist. viii. 81, fig. 12.— 1 . hemispherica, Pen. Brit. Zool.

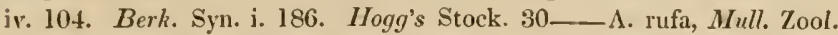
Dan. prod. 231. Zool. Dan. tab. 23, fig. 1-5. Pen. Brit. Zool. iv. 10J. . Jameson in Wern. Mem. i. 558. Stew. Elem. i. 393. Lam. Anim. s. Vert. iii. 67. Stark, Elem. ij. 412. Rapp, Polyp. 53. Royet, Bridgew. Treat. i. 198. fig. 86, 87.—A. Anemone, Pen. Brit. Zool. iv. 106. Hogg's Stock. 30._-A. coralkina, Risso, L'Europ. Merid. v. 285.—A. margaritifera, Templeton in Mag. Nat. Hist. ix. 304, fig. 50.——Common Actinia, Buckland, Bridgew. Treat. ii. 89, pl. 54, fig. 4.-Hydra mesembryanthemum, Stew. Elem. ii. 451. Small red Sea-Nettle, Wallis, Hist. of Nortlumb. i. 374 .

Var. ß. Body paler striped longitudinally with white ; tentacula annulated with white.

Vignette, No. 29, page 205.

Actinia viduata, Mull. Zool. Dan. prod. 231, no. 2799. Zool. Dall. pl. 63, fig. 6-8,-copied in Encyclop. Method, tab. 72, fig. 4, 5. Johnston in Mlag. Nat. Hist. viii. 82, fig, 13. Turt. Gmel. iv. 101. Lam. Anim.

s. Vert. iii. 68. Bosc, Vers, ii. 256.

$H a b$. On rocks between tide-marks, very common.

Body one or one and a half inch in diameter, hemispherical when contracted, when relaxed forming a short cylinder with a breadth greater than the height, of a uniform liver-colour or often olive-green, and sometimes streaked with blue or greenish lines, either continuous, or in spots : the base generally of a greenish colour encircled with an azure-blue line, but it is often also streaked with red, and the blue marginal line is wanting. The tentacula, when fully extended, are nearly equal to the height of the body, and of the same colour. The tubercles within the margin of the oral disk are formed by papillary projections of the parenchyma of the body, covered over on the top with a thick layer of dense blue matter : in it, as well as in the skin generally, minute fusiform calcareous spicula, some slenderer than others, may be detected in abundance with the microscope.

In its young state, A. mesembryanthemum is liable to greater variations in colour than when mature. One of these varieties, as it seems to me, constitutes the A. viduata of Muller, distinguished by its light olive body striped with white; while the tentacula are prettily ornamented with white and olive-green rings. This variety usually attaches itself to shelving rocks, where it is covered over aud concealed by a layer of sand, protruding the tentacula through a small aperture at the surface opposite the mouth. On the recess of 
the tide, nothing of the animal can be seen, and its presence in a locality is only to be gnessed at by the holes in the sand, which, how. ever, are exactly like the holes of many arenicolous worms.

Actinia mesembryanthemum lives between tide-marks, and is most plentiful near that of high water. It is consequently often left exposed to the open atmosphere, but it expands only when covered with water. It never, so far as I have observed, emits from the mouth, like the other species, any thread-like tangled filaments; nor does it seem to have the porver of protruding the membrane of the stomach in the form of vesicular lobes. Gærtner says that " the colour of its body is always red in the summer, but changes into a dusky green, or brown, towards the latter end of antumn," - a remark which certainly does not hold good on the northern shores of Britain, where the red and dusky green varieties may be found intermingled at all seasons.

\section{A. BELLIS, "body lengthened, the lower part narrow,} smooth, the upper enlarged and glandularly; warty; oral disc expanded, lobed ; tentacula in several rows, variegated." Grertner.

Hydra calycitlora, tentaculis retractilibus variegatis; corpore verrucoso, Gærtner in Phil. Trans. lii. 79. tab. 1, fig. 2._-Actinia Bellis, Ellis and Soland. Zooph. 2. Turt. Gmel. iv. 103. Turt. Brit. Faun. 131. A. pedunculata, Pen. Brit. Zool. iv. 102. Berk. Syn. i. 186. Lam. Anim. s. Vert. iii. 70. Bosc, Vers, ii. 258. Stark, Elem. ii. 412. Flem. Brit. Anim. 498. Templeton in Mag. Nat. Hist. ix. 303._- Hydra bellis, Stew. Elem. ii. 451.

$H a b$. "Frequently found in the pools about the Mount's Bay," Cornwall. "It is rare to meet with a single one in a place, there being most commonly four or five of them living so near together in the same fissure of the rock, which they constantly inhabit, that their expanded calyces form a row of flower-like bodies, that seem to grow upon the cliffs under water," Gartner. "Found in a pool on the rocks at the north end of the Island of Rathlin, August 1795," 'iempleton.

"From its small basis rises a cylindric stalk, which supports the roundish body of the animal, from whence afterwards the calys, being a continued membrane of the body, draws its origin. The stalk, or the pedunculus of the polype, is quite smooth, and its colour inclines towards the carnation. The outside of the calyx, and the body of this animal, are marked with a number of small white protuberances, resembling warts, to which fragments of shells, sand-grains, \&c.adhere, and hide the beautiful colour of these parts, which, from that of carnation, is insensibly changerl towards the border of the calyx first into purple, then violet, and at last into a dark brown. The inside of the calyx is covererl witl the feelers, that grow in several ranges 
upon it: they differ considerably in length; those that are near the edge of the calyx being but small papillx, in proportion to those that surround the disk, or the central part of the body. They are almost transparent; and some of them are of a pale ash colom, with brown spots; others, on the contrary, are of a chesnut colour, marked with white spots. The disk is formed like a star, which, accorling to the figure that is traced ont by the innermost row of the feelers, consists of many angles. 'The colour of this part of the hody is a beautiful mixture of brown, yellow, ash-colour and white, which together form variegated rays, that from the centre, or the mouth of the animal, are spread over the whole surface of the disk._- This polype contracting itself, changes its body into an irregular hemisphere, which is so covered with the several extraneous bodies that stick to it, that it is extremely difficult to know the animal in this state, and to discem it from the rubbish, that commonly surrounds it." Gcertner.

Perhaps a variety of the A. gemmacea.

3. A. InteStinalis, "body cylindrical, the upper half suddenly contracted and narrou." Dr Fleming.

Actinia intestinalis, Fabr. Faun. Grœnl. 350, no. 342, pl. I, fig. 11. Flem. Brit. Anim. 498.

Hab. "Adheres to rocks at low water-mark, Zetland," Fleming.

"When contracted, the bolly seems like two broad rings, of near. ly equal breadth, and about half an inch in diameter; when expanded to nearly two inches, the hody consists of two cylindrical portions of different dimensions, smooth, pellucil, yellowish; a few longitudinal white streaks under the skin; oral disk not expanded, surrounded with about 18 filiform tentacula in two alternate rows." Fleming.

4. A. GEMMACEA, body conoid, variously coloured, rough with glandular warts or sometimes smooth; tentacula numerous, in 3 or 4 series, shorter than the diameter of the oral dish, thick, and generally variegated with red and white rings.

\section{Platexivii.}

Actinia senilis, Flem. Brit. Anim. 498. Johnston in Trans. Newc. Soc. ii. 244.

Var. a. Body warty, the warts large and arranged in vertical rows. _- Ortie de mer, Reaumur in Mem. de l'Acad. Roy. des Scicnc. 1710, pl. 10, fig. 21, 23-26. Hydra disciflora, tentaculis retractilibus subdiaphanis; corpore cylindrico, miliaribus glandulis longitudinaliter striato, Gartner in Phil. Trans. lii. 82, tab. 1, fig. 4.__Hydra gemmacea, Stew. Elem. ii. 451 - Actinia gemmacea, Ellis and Soland. Zooph. 3. Turt. Gmel. iv. 104. Turl. Brit. Faun. 131. Wern. Men. i. j58.—A. verrucosia, Penn. Brit Zool. iv. 1C3. Berk. Syn. i. 186. Lam. Anim. s. Vert. iii. 70. Stark, Elcm. ii. 412. Rapp, Polyp. 1. 50._-A. glumdulosa 
Bosc, Vers, ii. 259.__ A. monile (the young, Templeton in Mag. Nat. Hist. ix. 303, fig. 49.—A. Bellis, Rapp, Polyp. 50. tab. 1, fig. 1, 2.

Var. $\beta$. The body warted, the warts equal, distinct, but scattered without order over the surface._- Act. senilis, Dicquemare in Phil. Trans. lxiii. 367, tab. 16, fig. 10; and tab. 17, fig. 11, 12. Penn. Brit. Zool. iv. 105. Blumenb. Man. 246. Templeton in Mag. Nat. Hist. ix. 303. - A. coriacea, Cuv. Reg. Anim. iii. 291. Rapp, Polyp. 51, tab. 1, fig. 3, 4. Teale in Trans. Leeds Soc. i. 91, pl. 9, 10, 11.

Var. $\gamma$. Borly warted, the warts distant, equal, and sometimes obscure.Act. equina, Sowerby, Brit. Misc. 7, pl. 4. Turt. Brit. Faun. 130. Penn. Brit. Zool. iv. 106. - A. effoeta? Rapp, Polyp. 54, taf. 2, fig. 2. Templeton in Mag. Nat. Hist. ix. 303.

Var. \&. Body quite smooth, irregularly clouded with scarlet, tentacula annulated with red and white.__ Priapus sive Actinia proboscidibus crassis rotundis, Bast. Opusc. Subsec. i. lib. 3. 143, tab. 13, fig. 1.—_Act. feli na, Lin. Syst. 1088. Barbut, Gen. Verm. 53, tab. 5, fig. 6. Bosc, Vers, ii. 255. A. coccinea, Mull. Zool. Dan. prod. 231, no. 2792. Zool. Dan. tab. 63, fig. 1-3. (young.) Bosc, Vers, ii. 255. Lam. Anim. s. Vert. iii. 68. A. crassicornis, Mull. Zool. Dan. prod. 231. Adams in Lin. Trans. iii. 252. Penu. Brit. Zool. iv. 105. Turt. Gmel. iv. 100. Turt. Brit. Faun. 130. Stew. Elem. i. 393. Lam. Anim. s. Vert. üi. 67. Stark, Elem ii. 412. Fabric. Faun. Grœnl. 348, no. 341. Jameson in Wern. Mem. i. 558.—A. truncata, Jameson in Wern. Mem. i. 558. Penu. Brit. Zeol. iv. 106. Turt. Gmel. iv. 101. Turt. Brit. Faun. 131.

$H a b$. In crevices of rocks between tide-marks, and on shells, \&c. in deep water, very common.

Body usually rather more than two inches in diameter, hemispherical when contracted, covered witl glandular warts, arranged sometimes in regular perpendicular lines, sometimes irregularly, and sometimes they are scarcely or not at all obvious. The tentacula are disposed within the circunference of the oral disk, in 3 or 4 close rows; they are thick, short, obtuse, somewhat compressed, almost always annulated or variegated with white and red, but when the body is of a uniform pale, flesh, or cream colour, the tentacula are of the same colour and without rings. The animal protrudes from the mouth at pleasure four or five vesicular, pellucid, scored lobes, which vary in size according to their degree of evolution, and often liang over the sides. When kept for a few days in a basin of sea-water, it becomes much larger in all its parts, paler and almost diaphanous; and the tentacula elongate themselves, swell out, and are distinctly seen to be iubular. These adhere tenaciously to foreign bodies, for their apices act as suckers, and carry prey to the mouth in spite of all its struggles.

This species is liahle to great variation in colour and size. The 
littoral varieties, or such as are alternately submerged and exposed by the recess of the tides, are always strongly warted, generally orangecoloured with dusky blotches, and coated with particles of broken shells, small gravel and pieces of sea-weed, by which means, when contracted, they are detected with difficulty in the recesses or sandy places which they prefer. This foreign covering adheres to the glands with great tenacity, and cannot be removed by any natural causes to which the Actinia is exposed; but what is surely worthy of our admiration, and seems to prove the existence of an instinct even in these lowest creatures, the individuals which are placed in deep water, as if aware they did not require such a mode of concealment, form no extraweous covering, but leave the surface clean, and this acquires then more vivid and varied tints, while at the same time the warts become smaller or disappear. Of these pelagic sorts there are some eminently beautiful : one is of a uniform bright scarlet studded over with pale warts like ornamental beads; another is of a pale sulphur yellow, or greenish with orange-coloured stripes, the oral disk and vesicular lobes borrowing the hues of the wild rose; but they vary in this respect so much that no description can do justice to them or define their limits.

1 have little doubt that all the synonymes quoted under this species truly belong to it. Gærtner's figure represents it of a more cylindrical shape than $I$ have ever seen it assume, and with only a single row of rather slender tentacula, which, he says, vary from 18 to 36 in number. Hence the figure we may suppose to have been taken from a young individual, which is certainly the case in the Ac. tinia monile of $\mathrm{Mr}$ Templeton.

Dicquemare says - "Of all the kinds of sea-anemonies, I would prefer this for the table; being boiled some time in sea water, they acquire a firm and palatable consistence, and may then be eaten with any kind of sauce. They are of an inviting appearance, of a light shivering texture, and of a soft white and reddish hue. Their smell is not unlike that of a warm crab or lobster." Phil. Trans, abridg. xiii. 637 .

Ehremberg divides the family Actiniidæ into two sections, - the second embracing such genera as have glandular pores in the skin. The genus "Cribrina," in this section, has Act. gemmacea for its type, which is thus far sundered from the species with which it is here associated. Ehrenberg seems to me to have been peculiarly unfortunate in his choice of a character, for if I have studied the animal rightly, so far from being of sectional or generic value, it serves not even to discriminate a species, which may have its smooth and 
glandular varieties, passing too into one another by such " unperceived shades" that the limits cannot be distinctly defined. Nay, as Mr Teale has also noticed, I have seen specimens which were glandular on one-half of the body and smooth on the other, illustrating in a striking manner the inconstancy of the structure, and its subordinate value.

In most systematic works on British Zoology there is an Actinic effota, which is referable sometimes to this species, and sometimes to Act. maculata. The Act. effoeta of Linnæus, Syst. 1088, is founded on the "Tertia Priapi marini sive Actiniæ species" of Baster, Opus. Subsec. 143, tah. 14, fig. 2. This figure is very unlike any variety of Act. gemmacea, or any other species with which I am acquinted. All the description Baster gives is this: "Directas illa habet in corpore strias, et inferne basin, sive marginem, qua se affigit."

5. A. DinNthus, body cylindraceous, smooth; oral dish marked in the centre with clavate radiating bands; tentacula numerous, irregular, the outer small and forming round the margin a thick filamentous fringe. Ellis.

\section{Plate xxviii.}

Priapus sive Actinia proboscidibus tenuibus brevibus, Bast. Opusc. Subsec. i. lib. 3, 143. tab. 13. fig. 2-4. (bene)_Actinia senilis, Lin. Syst. 1089. * _ Actinia Dianthus, Ellis in Phil. Trans. 1vii. 436. tab. 19. fig. 8. Ellis and Soland. Zooph. 7. Shaw, Nat. Misc. xiii. pl. 539; (copied from Ellis and coloured from the description !) Turt. Gmel. iv. 104. Turt. Brit. Faun. 131. Stew. Elem. i. 394. Flen. Brit. Anim. 498.Fourth species of Anemony, Dicquemare in Phil. Trans. abridg. xiii. 638. pl. 12. fig. 9.-A pentapetala, Penn. Brit. Zool. iv. 104. Berk. Syn. i. 187. Lam. Anim. s. Vert. iii. 71. Bosc, Vers, ii. 259. Actinolobe œillet, Blainv. Actinol. 322.-A A. plumosa, Mull. Zool. Dan. prod. 230. no. 2791. Zool. Dan. tab. 88. fig. 1. 2. (drawn when the animal has been in a very relaxed and half expanded condition.) Turt. Gmel. iv. 100. Turt. Brit. Faun. 130. Stew. Elem. 1. 394. Lam. Anim. s. Vert. iii. 68. Bosc, Vers, ii. 256. Stark, Elem. ii. 412. Cuv. Reg. Anim. iii. 291. Rapp, Polyp. 55, tab. 3. fig. 1. (good) Johnslon in Trans. Newc. Soc. ii. 246. La Métridie plumeuse, Blainv. Actinol. 321.A. senilis, Barb. Gelı. Verm. 53. tab. 5. fig. 5. Adams in Liı. Trans. v. 9. Lam. Anim. s. Vert. iii. 68. Stark, Elem. ii. 412.-Hydra Dianthus, Stew. Elem. ii. 451.

$H a b$. On rocks and shells in deep water or within low tide-mark.

* Linnæus quotes two distinct figures of Baster for his senilis, but as he subsequently refers to onc of these figures for lis effoeta, the other (tab. 13. fig. 2.) unst be considered as representing the true senilis. 
At Hastings in Sussex, Ellis. Tenbigh, Wales, Adams. Frith of Forth, Dr Coldstream. Berwick Bay, common.

When contracted the body is of a thick short subcylindrical form, deeply wrinkled in two or three places, about three inches long, and one-half of that in diameter, but when fully expanded about five inches : the skin is quite smooth, and of a uniform whitish, cream or flesh-colour. The centre of the oral disk is ornamented with a circle of white bands radiating from the mouth, and the transparency of the skin here permits us to see the lamellæ running across the circumference with their narrow colourless interspaces. From these interspaces the tentacula originate; the largest about one inch long, watery, white, tapered, smooth, irregularly dispersed, and very numerous. They are all placel between the mouth and the margin, which is encircled with a dense fringe of inimitable beauty, composed of innumerable short tentacula or filaments forming a thick furry border.

I have seen specimens of this species, which is certainly as Muller says " actiniarum pulcherrima," from the size of a split pea to fully five inches in diameter, and have found it, in all the intermediate sizes, uniform in shape and colour, but others have found it variable in these respects. It is strictly gregarious, and the larger individuals are generally surrounded by a multitude of small and middle-sized ones, which form very pleasing groups. From this gregarious habit it is subject to monstrosities, two or three occasionally uniting and coalescing into one body, of which Dicquemare has described an example.

"This species is good to eat," according to Dicquemare; and his testimony may be strengthened by the authority of Plancus, who says of his "Urtica soluta caryophyllum referens,"-a synonyme probably of A. Dianthus, *- " hæc more ostrearum coquitur, et una cum ipsis, quibus, ut dixi, frequentissime hæret, comeditur." Planc. de Conch. min. not. 43 , tab. 4 , fig: $6 . \dagger$

No one who bas studied the species but will, I think, assent to the conjecture of Cuvier that the A. Dianthus of Ellis is a mere variety of the $A$. plumosa of subsequent authors, the former having had the oral disc deeper lobed than is usual from peculiarity of position or

* If this opinion is correct, and to me the thing scems indisputable, theu the Actinia JUDAICA, Lin. Syst. 1088, and of all other systematists who have followed him, must be added to the aliases of A. Dianthus.

$\dagger$ In reference to these edible Actinia 1 may here remark that the Anemonia edulis of Risso, which, according to Rapp, is synonymous with the Anthea Ce.reus of this work, furnishes the dish called Rasiegna, a favourite in Provence. "Nostrates vero hoc ribo delectari noudum comperi." Baster. 
from the mere will of the creature, which has great powers of contractility. This being assumed, we are entitled to say to Oken, who makes one genus of the Dianthus, and another genus of the plumosa, - "Generis falsa est ea fabula vestri."

Mr Templeton under the name of "A. DiAnthus ?" describes a species which appears to be distinct.- "Conic, rounded alove, of a green or greenish-yellow colour, with a few scattered warts in longitudinal rows; disk light blue, often divided into 11 lobes; tentacula numerous, pale, in from 5 to 7 fasciculi, variegated with dark annuli. In the hollows of the rocks at Ballyholm Bay, Bangor." Mag. Nat. Hist. ix. 304 .

\section{A. MACULATA, base fixed to a thin horny expansion attached} to the apertures of various dead shells; body longitudinally sulcated, marked with purple spots; tentacula numerous, rather short, arranged in three or four irregular rows. Mr Adams.

\section{Fig. 32.}

$a$

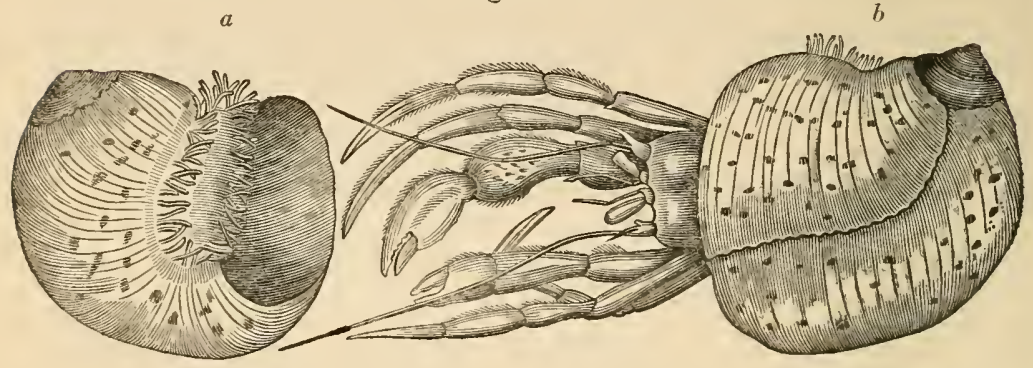

Actinia maculata, Adams in lin. Trans. v. p. 8. Turt. Gmel. jv. 105. Penn. Brit. Zool. iv. 104. Coldstream in Edin. New Phil. Journ. ix. p. 236. t. 4. f. 6. 7. and in Edin. Journ. Nat. and Geog. Sc. iii. 49._A. carciniopados, Otto in Nov. Act. Acad. C. L. C. Nat. Cur. xi. 288. pl. 40._- Parasite Actinea, Landsborough in Scottish Christian Herald, ii. 333.—A. effœta, Turt. Brit. Faun. p. 131. Turt. Gmel. iv. 101.

Hab. Milford Haven, surrounding the apertures of deserted shells of the Murex despectus, Adams. Torbay; and in Rothesay and Kames Bays in Bute, either thrown ashore after easterly gales, or drawn in by flounder-nets, $D r$ Coldstream. Stevenston, Ayrshire, Rev. D. Landsborough.

"This beautiful species is longitudinally sulcated, having the edges of the base crenated: the lower part is an obscure red, and the upper part is transparent white marked with fine purple spots; the outer circumference of the aperture has a narrow stripe of pink. 
When expanded, the superior division of the body seens formed of fleshy bars placel in a reticulated manner, and lined with a fine membrane. From perforated warts, placed without order on the outer coat, issued white filamentose substances variously twisted together : I have observed a similar body ejected from the moutlis of all the species of this genus which have fallen within my notice." Adams. - The following more detailed description of this very interesting species is by Dr Coldstream. "General mass of the animal flattened and extended; thickness at the oral disc three-tenths of an inch, diminishing towards the circumference of the base; longest diameter of the base about three inches; margin minutely crenated; colour of the body, near the base, reddish brown, passing gradually into a light cream colour towards the oral disc; whole surface striated longitudinally with alternate opaque white, and translucent bluish lines, and marked irregularly with bright reddish-purple spots. These spots are confined to the outer coat, which is easily peeled off. That below it is of a pink colour, and is marked with the striæ, which shine through the outer coat. Oral disc of an elongated oval form, white, and bearing on its onter margin numerous rather short tentacula arranged in three or four irregular rows : tentacula shorter than the hody, acuminated, white, each marked with a faint streak of brown; mouth large, oval; lips white, contracted into folds; internal surface of the stomach marked with numerous white striæ. Base fixed to a thin horny expansion attached to the apertures of various dead shells, such as Trochus cinerarius and T. Magus, and forming, as it were, an extersion of the body-whorl of the shell in a spiral form. Over this, the Actinea is spread entirely, and covers also more or less of the shell. Its oral disc is uniformly situated close to the inner lips of the horny case. The aperture of the case is accurately surrounded by its body, the margins of the opposite sides of which meet, and are closely applied to one another at the middle of the outer lip of the aperture, whence they run upwards towards the old shell, where they generally separate again, leaving its apex uncoveled." "The horny membrane to which the Actinia is "attached, cover's, for the most part, nearly the whole of the external surfare of the old shell to which it is fixed, and from the circumference of its aperture, is prolonged into a large hollow expansion, resembling in form, and occupying, relatively to the shell, the place of, a ventricose body-whorl. Its substance is of a uniform thickness throughout its whole extent, of a greenish-brown colour, translucent, having both surfaces irregularly wrinkled transversely. In a recent state it is quite flexible, but when dried it is brittle. It takes fire and burns readily, leaving a very small residuum, which does not ef- 
fervesce with acids. It is insoluble in boiling water and in alcohol, but dissolves slowly in acids, and in solutions of the alkalies. Its general appearance may be compared to that of the cases of Tubularia indivisa, except in point of colour."

"The case thus formed by the old shell and the horny membrane, and covered by the Actinia, I have always found inhabited by a variety of the hermit-crab." "I Its natural history is perhaps doubtful. Is the horny case secreted by the Actinia? Or is it the deal axis of some zoophyte, like that which covers old Buccina (Alcyonium echinatum, Fl.), and which I have found forming an extension of the body-whorl of the Turbo littoreus, also inhabited by the $\mathrm{Pa}$ gurus? Or, is it likely that the old shell, with a young crab in it, may have been swallowed by the Actinia; that the crab may have forced its way through the walls of the stomach, and the integuments of the latter, and that, the Actinia then secreting a peculiar membrane to defend its base, the crab may have found itself provided with a habitation suited to its wants? To this last supposition an objection is found in the fact, that the full grown shell of Trochus Magus forms sometimes the base of the horny case, and this shell is too large to enter the mouth of the Actinia. It seems to be probable that the horny membrane is produced by the Actinia; and that its formation presents a striking instance of the operation of that beautiful law of Nature which makes the habits of one animal subservieut to the wants of another."

Bohadsch, in his work de Animalibus marinis, has describer a species nearly allied, if not identical with the above, under the name of Medusa palliata, p. 135 t. 11. f. I : which is probably identical with the Actinia picta of Risso, L'Europ, Merid. v. 286. See also a no. tice by Professor Jameson in Edin. New. Phil. Journ. July 1830, p. 332 .

\section{Anthe A, Johnston.}

Character. Body cylindraceons, adhering by a broad base : tentacula disposed in circles round the mouth, elongated, tapered and incapable of being retracted within the body.

* From divos - a flower : the name borrowed from Drayton-

"Antheu, of the flowers, that hath the general charge,

"And Syrinx of the reeds, that grow upon the marge."

The genus was first proposed, and indifferently characterized by Risso under the name of Anemonia, which being the same as Anemone must be rejected, for if new generic uames formed by the mispelling of old ones were tolerated, confusion and barbarism wonld soon be the result. 
1. A. Cereus, bolly somenthat cylindrical, furrowed lengthways ; tentacula numerous, longer than the body, smooth. Dr Gartner.

IIydra tentaculis denulatis, numerossimis; corpore longitudinaliter sulcato, Gertner in Phil. Traus. lii. 78, tab. 1. fig. 1.__ Act. Cereus, Ellis and Soland. Zooph. 2. Turt. Gmel. iv. 103. Turt. Br. Faun. 131. Rapp, Polyp. 56, tab. 2, fig. 3._-Act. sulcata, Pen. Brit. Zool. iv. 102. Berk. Syn. i. 186. Stew. Elem. i. 394. Flem. Brit. Anim. 498. Lam. Anim. s. Vert. iii. 69. Bosc, Vers, ii. 257.__Hydra Cereus, Stew. Elem. ii. 451.

Hab. "Very frequent upon the sea-coasts" of Cornwall, Gartner. Anglesey, Pennant. Torquay, Dr Coldstream.

"The body of this polype is of a light chesnut colour, and feels perfectly smooth, though it be lengthways sulcated by a number of sulci, that are frequently divided into three smaller ones, and are continued into the dentated margin that surrounds the upper periphery of the body, just beneath the insertion of the feelers. These feelers, arising from the disk of the polype, are, according to the age of the animal, between 120 and 200 in number ; they exceed the body, when expanded, by more than an inch in length, and are of a beautiful sea-green colour, except towards their extremities, which are coloured with a lively red, like that of the rose. The disk is of the same brown colour with the rest of the body, and contains in its centre the mouth of the animal, which is an aperture of various shape and diameter.—-The two varieties of this species, which I met with, differ hut little from the already described animal. The feelers of the one, instead of being green, are throughout of a red colour, like that of the mahogany wood. The other variety has pale ashcoloured feelers, marked with a small white line running along their back; its body is of the same chesnut colour with that of the first species; but the sulci are not divided, nor has it a dentated margin surrounding its upper periphery." Gartner.—The Act. sulCAT A of Templeton, which he says is "most probably the young" of Actinice effecta, Mag. Nat. Hist. ix. 303, can scarcely belong to this species.

2. A. Tuedi玉, body somewhat cylindrical, smooth or wrinkled with circular folds; tentacula numerous, shorter than the body, longitudinally striate. G. J. 


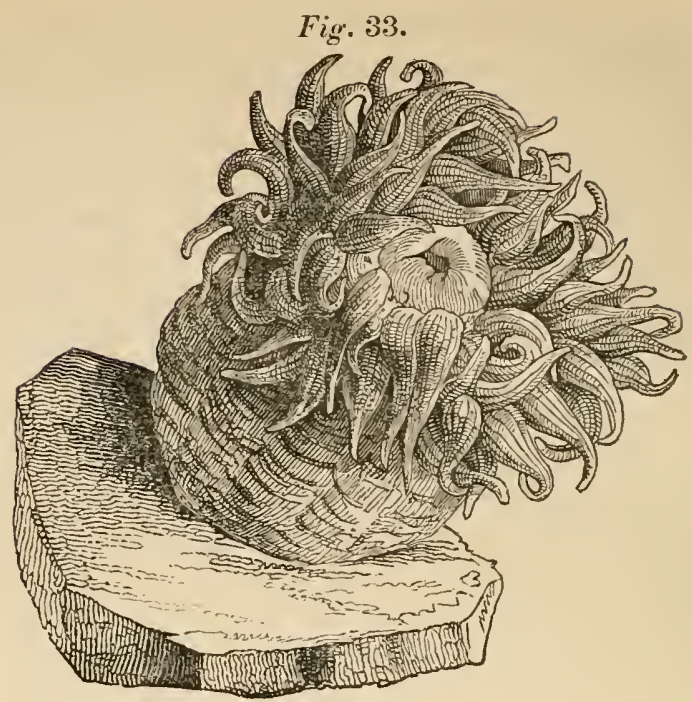

Actinia Tuediæ, Johnston in Mag. Nat. Hist. v. 163, fig. 58; and Traus. Newc. Nat. Hist. Soc. ii. 246.—Anemonia edulis, Risso, L'Europ. Merid. v. 289.

Hab. Coast of Berwickshire, in deep water.

Anthea Tuediæ is amongst the largest of our species. The body, when relaxed, generally measures three inches in length, and about the same in diameter; it is of a uniform reddish or brownish-orange colour, and either smooth or contracted at pleasure into circular folds. The base is smooth and orange-coloured, with a thin areolar skin. The mouth is ever varying in size and form, and there are often protruded from it vesicular-like lobes of a reddish colour scored with fainter lines. When fully expanded, the oral disk is not less than four inches across; there is a smooth space between the mouth and tentacula, which are very numerous, and placed in several rows around the circumference; those of the inner row are larger than the others, measuring frequently two inches in length, and they become gradually shorter in the exterior series. They are of a chesuut or reddish flesh colour, often darker coloured towards the bases, but never variegated with rings of different hues, thick and clumsy, tapered to an obtuse point, marked longitudinally with distinct lines or impressed striæ, tubular, perforated at the ends, and constricted at their insertions. The creature has no power of withdrawing them within the oral aperture, nor does it seem capable even of shortening them in any considerable degree, but it twists them in a wreathed or spiral form, or gives the whole circle a greater or less degree of expansion. 
The trivial name which I have bestowed on this species is intended to indicate the place of its first discovery, Tuedia being, according to Sir Robert Sibbald, the ancient name of the maritime parts of Berwickshire. It is not uncommon on that coast, but is found only in deep water, whence it is dragged up by the fishermen. I have often found the tentacula, in a separate state, adhering to their lines; and as these retain their irritability and motion for a long time, they are apt to be mistaken for independent and perfect worms, which they much resemble.

Dr Turton las introduced into his Compendium of the British Fauua, p. 131, two species which I purposely omit. These are, I. Actinia Caryophillus, * for which "Martin's Marine Worms" is quoted, a work apparently very rare, and which $I$ have not been able to procure ; 2. A. Anemonoides, $\dagger$ quoted from Shaw's Naturalist's Miscellany, tab. 26, 27. The plates referred to I bave not seen, but $I$ have looked over some volumes of the work, and I entirely agree with $\mathrm{Dr}$ Leach in thinking it contemptible and unworthy of citation: the figures are in general copies from others, coloured from the descriptions, without a single hint being given that this is the case, and the colours are laid on in a patched and gaudy manner, only to be rivalled in the pictures which adorn the toy-books of children.

\section{OBSERVATIONS.}

The Actiniæ adhere to rocks, shells, and other extraneous bodies by means of a glutinous secretion from their enlarged base; but they can leave their hold and remove to another station whensoever it pleases them, either by gliding along with a slow and almost imperceptible movement, $\ddagger$ as is their usual method; or by reversing the body and using the tentacula for the purpose of feet, as Reaumur asserts, $\S$ and as I have once witnessed ; or lastly, inflating the borly with water to render it more buoyant, they detach themselves and are driven to a distance by the random motion of the waves. They feed on shrimps, small crabs, whelks, and similar shelled mollusca, or, probably with indifference, on whatever animals are bronght within their reach, and whose strength or agility is insufficient to extricate them from the grasp of their numerous tentacula, for as these organs can be inflect-

* Stew. Elem. i. 394. Turt. Gmel. iv. 103. Pen. Brit 7ool. iv. 106.

† Turt. Gmel. iv. 101. Act. anemone, Pen. Brit. Zool. iv. 106.

$\ddagger$ Reaumur found that they require an hour to advance one or two inches; but $I$ have seen $A$. Mesembryanthemum advance at a rate considerably quicker -half an inch in about five minutes.

\$ Mem. de l'Acar. Roy. des Sc. 1710, p. 621. 
ed in any direction and greatly lengthened, they are capable of being applied to every point, and adhere by suction with considerahle tenacity. * The food is retained in the stomach for ten or twelve hours, when the undigested remains are regurgitated, enveloped in a glairy fluid, not unlike the white of an egg. The size of the prey is frequently in unseemly disproportion to the preyer, $\dagger$ being often equal in bulk to itself. I had once brought me a specimen of Act. gemmacea, that might have been originally two inches in diameter, and that had somehow contrived to swallow a valve of Pecten maximus of the size of an ordinary saucer. The shell, fixed within the stomach, was so placed as to divide it completely into two halves, so that the body, stretched tensely over, had become thin and flattened like a pancake. All communication between the inferior portion of the stomach and the mouth was of course prevented, yet instead of emaciating and dying of a hytrophy, the animal had availed itself of what undoubtedly had been a very untoward accident, to increase its enjoyments and its chances of double fare. A new mouth, furnished with two rows of numerous tentacula, was opened up on what had been the base, and led to the under stomach:- the individual had indeed become a sort of Siamese twin, but with greater intimacy and extent in its unions!

The existence of nerves in the structure of the Actiniæ is still doubtful. Spix tells us, that he detected near the base and centre of the body some small nodules or ganglions placed in pairs, from which filaments emanate towards the circumference, constituting, as he believes, their nervous system. Blainville asserts, however, that in numerous dissections made with every possible care, he could see nothing like what Spix has described and figured; and the only part that he can regard as nervous, is a sort of grey pulpy cord in the margin of the labial rim. Delle Chiaje, and Mr Teale agree with Blainville.f Be the fact as it may, we know that every part of the

* According to Gærtner the animal fixes the tentacula by throwing out of their whole surface " a number of extremely minute suckers, which, sticking fast to the small protuberances of the skin, produce the sensation of a roughuess, which is so far from being painful, that it even cannot be called disagreeable." Phil. Trans. v. 52. p. 76.--No such structure can be discovered.

$\dagger$ " Fauces hæc animalia, subtus sacci instar penitus clausa, superne habent pro libitu tam patulas, ut mytulos satis magnos aliasve conchas ingurgitent, e quibus, modo nos fugiente, pisces extrahere, et evacuatas testas per eandem aperturam, ejicere rursus valent. Quæ testre, si majores sint, et ægre per fuuces transituræe essent, Priapus non solum fauces late expandit, sed easdem, ut solemus tibialia, quasi invertit, quo spatium brevius et apertura fit latior." Basteri Opusc. Subsec. i. lib. iii. 122.

\& But Dr Grant says_ " The nervous system has been long known in the 
borly is very sensible to external irritations: no point of the skin, the tentacula, nor the membrane of the stomach can be touchel, but immediately the creature evidences its sense of the injury hy contractions and other motions of the part. They are said also to be very sensible of atmospherical changes: they shrink under a glare of light; * but in a calm and unclouded sky expand and disclose every beauty, while they remain contracted and veiled in cloudy or stormy weather. Dicquemare has even found, from several experiments, that they foretell clanges in the weather as certainly as the barometer: when they remain naturally closed there is reason to fear a storm, high winds, and a troubled sea; but a fair and calm season is to be anticipated when they lie relaxed with spread-out tentacula. $\dagger$

Actinia."- "Nervous filaments surround the muscular foot of the Actinia, beneath the stomach, and present minute ganglia in their course, from which nerves pass out to the circumference, and to the muscular folds which here possess great power of eontraction. The same system probably exists in many other elosely allied forms of polypi." Outl. of Comp. Anat. p. I8.2.

* It has been suggested that their perception of light may be communicated through the tentacula, on the tips of which, Bosc assures us, there is a black point or eye. Vers, Vol. ii. p. 247. This black point, as well as the other parts of Bosc's description of the tentacula, is wholly imaginary; nor is there a necessity of an eye to explain the phenomena, for there can be "little doubt that a diffused sensibility to light and sound exists in animals which present no special organs of vision or hearing." Brit. and Foreign Med. Rev. v. p. 491.

† Dicquemare's observations seem of sufficient interest to justify their insertion at length. He says, "My very earliest observation showed that the sea ane. monies feel and prognostieate, within doors, the different changes of temperature in the atmosphere. I had not leisure at that time to form tables of their varions indications, but I lave since done it. This fact, if applied to practice, might be of use in the formation of a sea-barometer, an object of no small importance, which several ingetious men have hitherto enteavoured in vain to furnish us with. I should prefer the anemonies of the third speeies for this pur. pose, their sensation being very quiek; they are also easily procured, and may be kept without nourishment. Five of them may be put in a glass vessel, four inches wide and as many in depth, in which they will soon cleave to the angle formed by the sides and the bottom. The water must be renewed every day, and as they do not require a great quantity of it, as much may be fetched from the sea (if they be kept on land) as will supply them for several days; its settling some time will only improve it. If the anemonies be at any time shut or contracted, I have reason to apprehend an approaching storm, that is high winds, and an agitated sca. When they are all shut hut not remarkably contracted they forebode a weather somewhat less boisterous, but still attended with gales and a rough sea. If they appear in the least open, or alternately and frequently opening and closing, they indicate a mean state both of winds and waves. When they are quite open I expect tolerable fine weather and a smooth sea. And lastly, when their 
That the Actiniæ are viviparous is very commonly alleged, and almost every naturalist who has paid attention to their habits may be quoted as a witness of the escape of the young from the stomach through the oral aperture.* Some have maintained that these young may have been swallowed accidentally by the supposititious mother, and being found unfit for digestion are consequently rejected, quoting in favour of this not very feasible conjecture, an experiment of Dicquemare, who, offering several small individuals to a larger one of a different species, found that it swallowed them readily, "but threw them up again alive within eight, ten, or twelve hours, or even later." Dicquemare himself, although he expresses himself in dubious terms, evidently believed them to he viviparous, having seen several bring forth even in his hand, eight, ten, or twelve young ones like to their parents in all but size, and which immediately affixed themselves, and began to stretch their tentacula as if in quest of prey. Ellis was of the same belief ; and Sir J. G. Dalyell, the best authority on the subject, also says that they are viviparons. "The embryos, one or more, appear firstin the tentacula, from whence they can be withdrawn and transmitted to others by the parent, and are at last produced by the mouth. In the conrse of six years, a specimen preserved by the author, produced above 276 young; some pale, and like mere specks, with only eight tentacula, others florid, and with twenty. They are frequently disgorged along with the half-digested food, thirty-eight appear-

bodies are considerably extended, and their limbs divergent they surely prognosticate fixed fair weather and a calm sea. There are times when some of the anemonies are open and others shut; the number must then be consulted, the question is decided by the majority. The anemonies used as barometers should not be fed, for then the quantity of nourislinent might influence their predictions. Anemonies of this and of the first species live and do well for several yeas without taking any other food but what they find disseminated in the sea water; but should a respite of some days be granted them, they might then be fed with some pieces of muscles of soft fish, and thus restored to their original vigour. Whenever the vessel is sullied by the sediments of salts, slime, the first shoots of sea plants, \&c. it may on changing the water be cleansed by wiping it with a soft hair pencil, or even with the finger, carefully avoiding to rub or press bard on the anemonics. Should any of them drop off during this operation, they may be left at liberty, for they will soun of their own accord fix themselves to some other place. Should any of them die, which will soon be discovered by the milky colour of the water, and an offensive smell on changing it, it must be taken out, and on the first opportunity another of the same species be put in its place; those of a moderate size are the most eligible." Diequemare in Phil. Trans, abridg. xiii. 642-3.

" "Leur génération ordinaire est vivipare. Les petites actinies passent de l'ovaire dans lestomac et sortent par la bouche." (uvier, Reg. Anim. iii. 291.

$\dagger$ Phil. Trans. lvii. 429 . 
ing thus at a single litter. An embryo extracted artificially from the amputated tip of a tentaculum, began to breed in fourteen months, and survived nearly five year's. Monstrosities by excess are not uncommon among the young: one produced naturally, consisting of two perfect bodies, and their parts sustained hy a single base, exhibited embryos in the tentacula at ten months, bred in twelve, and lived above five years. While one body was gorged with food, the other continued ravenous." * These facts are to be explained on the supposition that the ova have been detained and developed in the interseptal spaces, for it is very well ascertained that the creatures are truly oviparous. The ovum, under ordinary circumstances, is recognizahle as the young of an Actinia about twenty days from the Fig. 34.

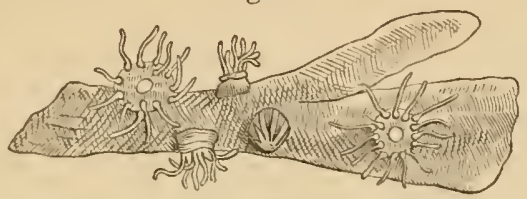

time of its separation. $\dagger$ It has at first very few tentacula,-from four to twelve, arranged in a single row, but they gradually germinate in greater numbers, and arrange themselves in two or more imperfect circular series ; $\neq$ - a fact which strikingly illustrates the futility of that classification which mainly rests the distinction of its genera upon the number of these circles. $\S$

The Actinix are very patient of injuries, and rival the IIydra in their reproductive powers. They may be kept withont food for upwards of a year; they may be immersed in water hot enough to blister their skin, or frozen in a mass of ice and again thawed; and they may be placed within the exhausted receiver of the air pump, without being deprived of life, or disabled from resuming their usual functions when placed in a favourable situation. If the tentacula are clipped off they soon begin to bud anew, and if again cut away they grow again, so that " it seems these reproductions might extend as far, or be as often repeated as patience and curiosity would admit." If cut transversely through the middle, the lower portion of

- Rep. Brit. Assoc. an. 1834, p. 599 ; and Edin. New Phil. Journ. xvii. p. 411.

+ Dalyell in Edin. New Phil. Journ. xxi. p. 89, 90.

$\ddagger$ Dalyell in Edinburgl Encyclopredia, art. "Animal Flower," p. 132. Templeton in Mag. Nat. Hist. i.. 303; and Harvey in ibid. n. s. i. p. 474.

$\$$ Branlt. A Synopsis of his System is given by Blainville. Actinologie; p. 666 . 
the body will after a time produce new tentacula " pret ty near as they were hefore the operation ;" while the upper portion swallows food as if nothing had happened, permitting it indeed at first tu come out at the opposite end, "just as a man's head being cut off, would let out at the neck, the bit taken in at the month," but which it soon learns to retain and digest in a proper manner. In an experiment of this kind, the upper half, instead of healing up into a new basis, actually produced another mouth and tentacula, so that an animal was formed which canght its prey, and fed at both ends at the same time! If again the section of the body is made in a perpendicular direction so as almost to divide it into two halves, these halves unite again in a few days. If the section is complete, two perfect individuals is the result; and to complete the wonder, if the body is torn away and only a portion of the base remain, from this fragment a new offspring will sometimes rise up to occupy the place of its parent!* Yet these creatures, almost indestructible from mutilation and injury, may be killed in a few short minutes, by immersion in fresh water.

\section{Lucernaria, $†$ Muller.}

Character. Body somewhat campanulate, fixed when at rest ly a narrow disk or stalk: mouth quadrangular, in the centre of inn umbrellar expansion : tentacula disposed in widely separate tufts on the margin.

1. L. FASCICULARIS, "peduncle of the body produced: tuft of tentacula in pairs, about a hundred in each." Rev. Dr Fleming. Lucernaria fascicularis, Fleming in Wern. Mem. ii. 248, pl. 18, fig. 1, 2. Flem. Brit. Anim. 499. Templeton in Mag. Nat. Hist. ix. 304. Blainv. Actinolog. 664._-Lucernaire fasciculaire, Lamouroux in Mém. du Mus. ii. 470.

Hab. Common in Zetland, where "it is chiefly found on the leaves of Fucus digitatus and F. esculentus, which grow in deep water," Fleming. "Found on the coast at Donaghadee, after a strong easterly gale, adhering to a fragment of Fucus serratus," Templeton.

"Colour dark brown; peduncle cylindrical, flexuous, wrinkled, with a narrow base; body bell-shaped, subquadrangular, concave; margin divided into four pairs of arms, concave within; mouth central, tubular, consisting of a loose membrane, four notched at the tip,

* Dicquemare in Plil. Trans. abridg. xii. 640, \&c. ; xiv. 129. Yet, according to the same excellent naturalist, a wound or rent of the basis of an Actinis often proves fatal. xiii. 637.

† From Lurerna, a lamp. 
and also expanded, circular, or striated at the pleasure of the animal ; the inside with numerous white filaments." - "The animal contracts itself into various shapes. It moves the tentacula very quiclily, especially if mudly water is poured upon it. Although I have kept it alive several days, I have never observed it in an upright position. It in general hangs downwards, as expressed in the figure, sometimes, however, it is nearly horizontal." Fleming.___ "When at rest, it assumes very much the form of a common drinking-glass, and is exceedingly conspicuous from its heautiful rose tint." Templeton.

2. L. AURICULA, body sessile, campanulate; tufts of tentaculn 8 , equidistant, with a marginal tubercle between each pair. G. Montigu.*

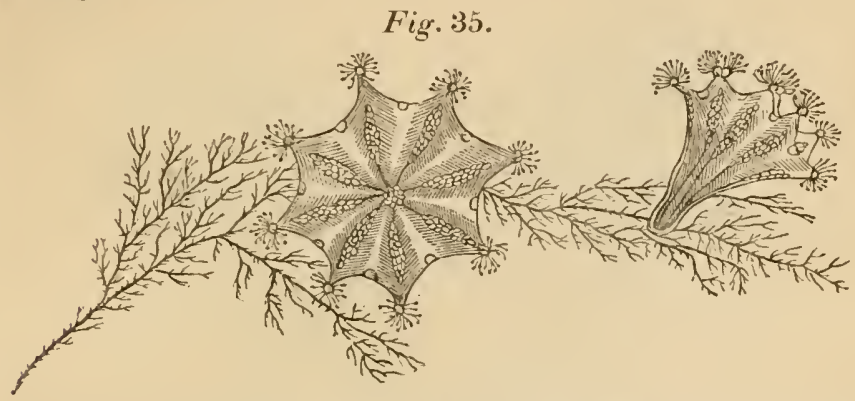

Holothuria lagenam referens tentaculis octonis fasciculatis, Mull. Zool. Dan. prod. 232, no. 2812._Lucernaria auricula, Fabric. Fam. Grœnl. 341. Turt. Gmel. iv. 121. Montagu in Lin. Trans. ix. 113, pl. 7, fig. 5. Penn. Brit. Zool. iv. 110. Flem. Brit. Anim. 499. Johnston in Mag. Nat. Hist. v. 44, fig. 29 ; and in Trans. Newc. Soc. ii. 248. Templeton in Mag. Nat. Hist. ix. 304. L L. octoradiata, Lam. Anim, s. Vert. ii. 474. L- L. auricule, Lamour. in Mem. dis Mus. ii. 471.

Hab. Coast of Devonshire, Mrontagu. Adheres to Fuci, near lowwater-mark, on different parts of the coast, Fleming. "Found adhering to the Fuci on the shore at Ballycastle, and in the cave near

" George Montagu, Esq. F. L. S. the author of "Testacea Britannica," and of a much valued Ornithological Dictionary. His contributions to the history of invertebrate animals were also numerous, and alwys interesting: the best, perhaps, is his Essay on Sponges in the Wernerian Memoirs. He is often styled Colonel Montagu, probably being the commander of some voluuteer corps. He died at Knowle House, his residence, near Kingsbridge, Devonshire, on Jume 19, 1815 , in the 76 th year of his age, from tetanus produced hy a wound in his foot from a mail. Annals of Philosophy, vi. p. 77. His collections are now in the British Museum. For an ustimate of his tharacter see Fleming's Brit. duimals, Pref. p. $x$. 
Dunluce Castle, county Antrim, in great numbers ; July 18I5," Templeton. Berwick Bay, rare.

Our figures represent this beautiful animal in its natural size. The individuals from which they were drawn were of a clear pinkish red colour, but Montagu says that it is " pellucid, green, brown, purple, red, or yellow, and all the intermediate shades in different subjects." It adheres by a short stalk, cupped in its base and variable in its degree of distinctness, dilating into a sort of campaniform blossom, the margin of which is set round usually with eight short processes or ar'ms, each of them terminated with a globose tuft of about sixty glanduliferous filaments, (Fig. 36, a.) The arms are mottled with two rows

Fig. 36.

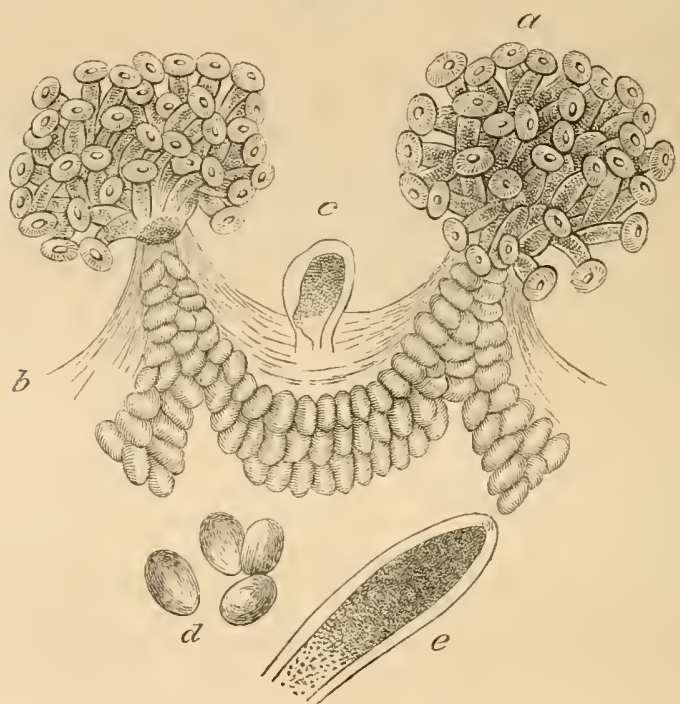

of spots, occasioned by the ova $(b)$; and they are counected together by a thin transparent membrane. Between each pair there is an oval vesicle $(c)$ placed on the edge of this membrane. Lamouroux asserts, apparently on the authority of $\mathrm{Ch}$. Muller, that this vesicle appears only at certain seasons, and again disappears, - a statement which requires confirmation. The mouth forms a slight quadrangular projection in the centre of the cupped expansion, exactly opposite the contracted base.

In the specimens which furnished the vignette to this order (Fig. 28,) there were nine glanduliferous tufts ; and Montagu's figure represents a monstrosity with seven only, but as there is no appearance of marginal tubercles in it, the figure may belong to the following 
species. Otho Fabricius tells us-"Vescitur oniscis, præesertim onisco alyssino, quem semper fere solum in ventriculo ejus inveni; raro in majoribus squilla lobata occurrit. Hi miseri in aperturam corporis dilatatam offendentes, statim tentaculis conclndentibus capiuntur et ingurgitantur.-Sxpe in uno verme plures oniscos invenire contigit, interioribus corruptis, exterioribus adhuc integris."-Otho Fabricius.

3. L. CaMPANULATA, body subsessile, campanulate; tufts of tentucula 8, equidistant, without intermediate marginal tubercles. Dr John Coldstream.**

Fig. 37.

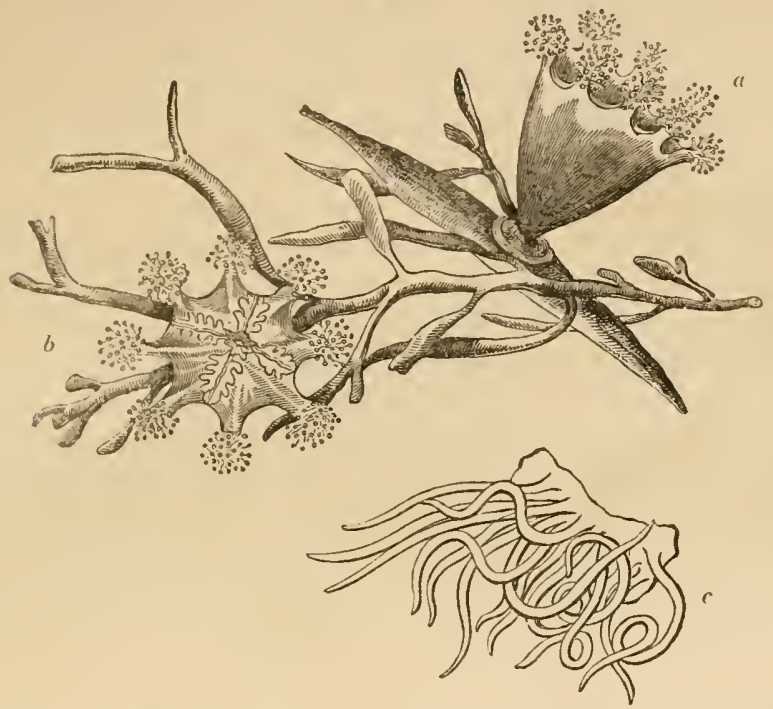

Lucernaria campanulata, Lamouroux in Mem. du Mus. ii. 472, pl. 16, fig. I-7._L L. Convolvulus, Johnston in Mag. Nat. Hist. viii. 59, fig. 3. -Lucernaire auricule, Blainv. Actinolog. pl. 50, fig. 4.

II $a b$. On sea-weed near low-water mark. Torbay, $D r$ Coldstream. Berwick Bay, G. J.

About an inch in height; of a uniform liver-brown colour, smooth, adhering by a circular disk, above which there is a deep stricture or short peduncle: the disk even, strengthened by an interior cartila-

* A native of Leith, where he is now settled as a physician. Dr C. is an alumnus of the University of Edinburgh, and graduated M. D. in 1827; his Thesis being "de Indole Morborum periodica." He early distinguished himself by researches in Mcteorology and Zoology, more particularly by his essays on the chromophorous globules of the Cephalopoda, and on Limnoria terebrans. 
ginous lamina which rises up the short peduncle, and forms a minute hollow firm centre. The margin of the oval expansion is somewhat thickened, and divided into eight equal arms, each furnished with a tuft of numerous short tentacula tipped with a gland, and brighter coloured than the body. The interior is hollowed like the blossom of a flower, the square extensible mouth projecting in the centre ; and in the space between the arms there is a complicated structure composed apparently of two series of foliaceous processes arranged on each side of a white line that seems to spring from the sides of the mouth. These processes are formed by the complicated foldings of a thin membrane attached by one side in the manner of a mesentery; there are no vessels in the membrane, but some portions of it exhibit, when magnified, a kind of net-work of irregular cells, and the outer and free erge is bounded by a thread-like line. The white cen. tral line which divides them is formed of small roundish bodies arranged in two or three close series; and some of these ova can at times be traced along the margin of the circumference to the tentacula. The latter are cylindrical and terminated with a globular head, which is seemingly imperforate. The stomach is a loose thin plaited extensible bag, having attached to its inner surface numerous fili form cra, (Fig. $c$ ) that, after their removal from the body, retain their irritability for a long time, and writhe themselves like a knot of worms.-Dr Coldstream has favoured me with the following observations on the habits of this Lucernaria.- " I find the animal very hardy. It is constantly in a state of expansion, and does not contract excepting when very rudely handled. One specimen has lived with me for three weeks although the water bas not been very often changed. When $I$ first procured it, the two rows of spots running from the mouth along each arm were prominent, and of a dark reddish-brown colour. Since that time they have increased in size, and have become studded with numerous white oval bodies which I sul. pose to be ova. I see some of these have made their way into the web connecting the arms, but I liave not observed any expelled from the body."-5th April 1833.

\section{OBservations.}

The Lucernarix are of a gelatinous consistence. The skin or corium is smooth and thickish. After covering and giving form to the hody it is reflected over the oral disk, and encloses, within the duplicature formed by this reflection, the internal viscera. The body is more or less distinctly campanulate, and is prolonged inferiorly intn a pedicle, very variahle in length, which has its hottom conformed into a small sucker From this point four ligaments, probably of a 
muscular nature, rise up within the peduncle, dividing at the expansion of the loody, into cight distinct fasciculi, one proceeding to each arm. These fasciculi are composed of long parallel fibres, are analogous to the lamella of the Actinia, and like them divide the hody into cight equal compartments, for the inner fold of the corium is intimately connected with them on both sides. The vermiform crea lie in these compartments; and the ova appear also to be generated in them, but whether they have an appropriate ovary is loubtful. $\Lambda$ specimen which had undergone a certain degree of putrefaction and dissolution exhibited these ova forming a complete circle round the mouth with rows running up the arms to the base of the tentacula. (Fig. 36.) The ova were proportionably large, roundish or oval (Fig. $36, d)$, and irregularly grouped. The change produced in the appearance of the tentacula was considerable, for the globular apex had disappeared, and all had assumed a linear or conical figure (Fig. $e$ ), - the centre filled with an opake gramular matter forming a dark speck at the apex, and covered with a clear mucous skin. The vesicle presented precisely the same structure, but no aperture was visible in either part.

'The Lucernarix can swim with some rapidity in the water by alternate dilatations and contractions of the body, but they are usually found adherent to sea-weeds, the first species in a dependent position, the two latter invariably erect, so that Lamarck is in error when he describes the mouth as being inferior. When in a state of expansion, few marine worms exceed them in heauty and singularity of form; when contracted they are shapeless and easily overlooked. They feed on small crustaceous animals brought within reach by the tide or their own destiny,* and to arrest them more certainly the ten-

* Lamouroux asserts that L. campanulata perceives its prey when witlin a short distance and pursues it. His words are-" J'avois la précaution de chaulger l'eau de mes Lucernaires deux fois jar jour; dans un vase qui ne contenoit qu'un de ces animaux, ce dernier exécuta des mouvements qui me parurent extraordinaires dans uı être d'un consistance aussi molle, immédiatement après que j'y eus de l'eau nouvelle; avec la loupe je m'aperçus que ces monvennens étoient causés par la présence l'un animalcule que la Lucernaire sembloit pursuivre en se portant à droite et ì gauche, pour tacher de le saisir; toutes les fois qu'il s'éloignoit à la distance d'environ un pouce, la Lucernaire cessoit tout mouvement; s'il se rapprochoit, la chasse recommençoit de suite, et les mouremens étvient vifs et prompts : l'animaleule fut enfin saisi par les tentacules d'uı des rayons, qui ì l'iustant se replic vers la bouche; les autres restérent toujours étalés; ce rayon reprit peu à peu sa position ordinaire, M'étant procuré d'autres animalcules, je les donnai à mes Lucernaires, et j'cus le plaisir de voir leur's mouvemens se répéter avec les mêmes circonstances." Mèn. dı . Ius. ji. 4 (iil. 
tacula are widely displayed; but no sooner have they felt the prey than they instantly contract, envelope it in their joint embrace, and carry it to the mouth by an involution of the whole marginal circumference. I have found that the glands with which the tentacula are tipped perform the office of suckers, as Lamarck conjectured, and thus retain their captives with greater certainty ; but if Dr Fleming's figure of $\mathrm{L}$. fascicularis is correct, its tentacula are not glanduliferous.

"O Lord, how manifold are thy works! in wisdom hast thou made them all : the earth is full of thy riches : so is this great and wide Sea, wherein are things creeping innumerable, both small and great beasts."-Psalmist. 


\section{BRITISH Z OOPHY TES.}

\section{PART V.}

\section{Zoophyta Ascidioida.}

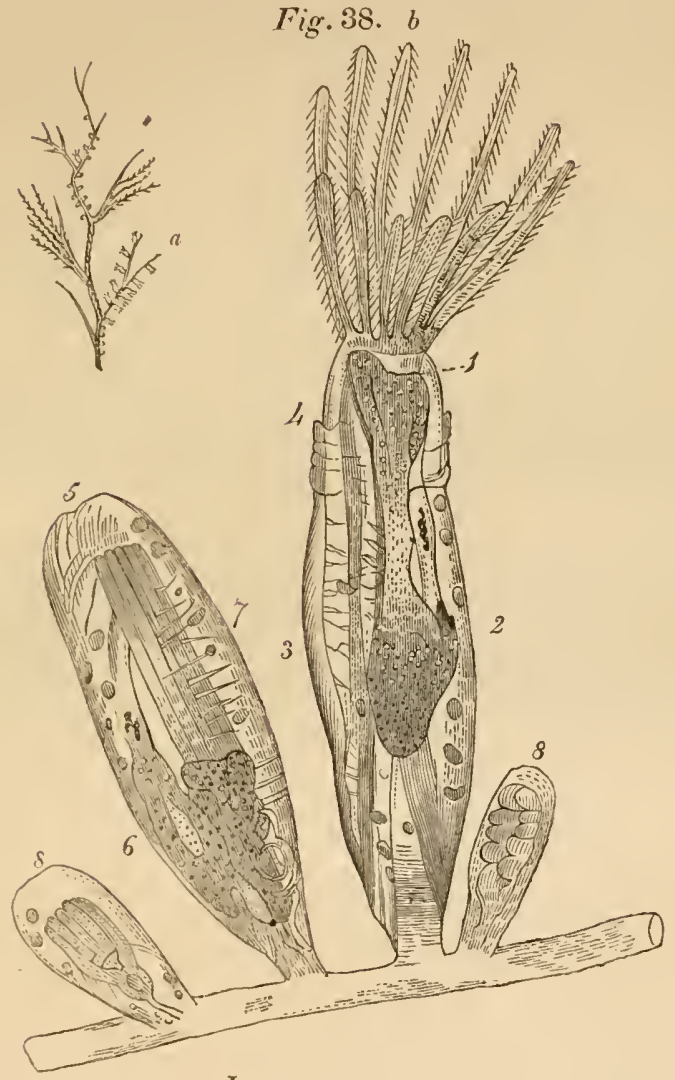

Lagenella REPENS.

" How many animals, whose middle part

"The sharpest eye

"Can't see?

"How subtle then the guts, the heart, the eye !

"How thin each little member of the whole !" 
"Ainsi pour l'espèce humaine on peut dire que les Zoanthaires ne sont utile's que comme moyen philosophique. Ce sont en effet des auimanx fort remarquables sous ce rapport, et dont la connoissance a introduit des considerations très intéressantes dans la science de la vie."- H. M. D. De Blainville.

"Combien on a eu tort de négliger, dans la recherche des lois de la vie, l'étude de ces êtres microsoopiques que l'on se contentait de reléguer dans le domaine des amusemens et des petites récréations physiques, comme si, dans les profondeurs de la nature, il existait de petit autre chose que les petits esprits "' -M. Raspail.

"O low desirable are all His works ! and that a man may see even to a spark. All these things live and remain for ever for all uses, and they are all obedient. All things are double one against another: and He hath made nothing imperfect. One thing establisheth the good of another : and who shall be filled with beholding His glory."-Ecclesiasticus. 


\title{
ZOOPHYTA BRITANNICA.
}

\author{
ORDER IV. \\ Z. ASCIDIOIDA.*
}

\section{Character.}

Polypes aggregate, the mouth cncircled with fliform ciliated retructile tentacula; a distinct stomach, with a curved intestine terminuting in an anus near the mouth; ova internal.-Polypidoms very variable, - cither horny fistular and confervoid, or calcareous, membranous, or fibro-gelatinous, formed of cells connected and arranged in a determinate and usually quincuncial manner.

\section{Observations.}

Is the preceding orders we found reason to conclude that the polypidom of the Hydroida was a sheath disconnected, or at least not in organic union, with the soft pulpous matter which it invests and protects ; that the corresponding part in the Asteroida, become an interior skeleton or axis, lield the same relation to its polypiferous crust; nor was this relation altered when the polypictom had again, in the Helianthoida, assumed an external position, forming an integral part of the epidermis. In all these instances the polypidom appears to be unorganized, and when once formed, beyond the reach of change from either the polypes or its own inherent powers; $\uparrow$ but in the present

- This order corresponds with the PoLyzoA of Thompsoll, the Bryozoa of Ehrenberg, the Bryozoaires of Milne-Edwards, and the Ciliobrachiata of Farre. Our order Hydrojda Farre designates Nudidrachiata, thereby indicating the absence of cilia on the tentacula; and Milne-Edwards les SERtulaIRIENs. His Alcroniens is symonymous with our Asteroida; and the ZoANTAIRES with Helianthoida, but Farre unites these under the name of ANTHoZOA, borrowed from Elirenberg.

† "Unorganized non-vascular parts are produced by an organized matrix, and grow by the continued deposition of new matter on one surface." Mïller's Elements of Physiology, p. 384. 
order, the cell, althuugh pre-eminently entitled to the name of polypidom from its appearance and use, is a living portion of the animal which it seemingly contains. The cell is in fact the outer tunic of the polype, analogous to the envelope of the compound mollusca, endowed certainly with no very sensible or active properties of life, yet in organic connection with the interior parts and liable to organic changes. The relationship in which they stand to one another is nearly, if not precisely, the same as that which the fleshy crust of the Asteroida bears to its polypes, as a comparison of the Alcyonium with the Alcyonidium or Alcyonella will render sufficiently plain; and it is not less real even in those genera where the cells, when dried, have hard calcareous and apparently impermeable parietes. For the proof of this fact,-a very important one in their physiology, and in any question touching their rank in the animal kingdom,-naturalists are principally indebted to Milne-Edwards, and I cannot do better than lay his arguments in its behalf before the reader in a translation of his own words. * The connection is effected by means of an inner tunic which, after enclosing the polype's body as in a pouch, is afterwards reflected over the aperture of the cell, - the reflected portion becoming exterior and solidified either by calcareous depositions in its texture, or by a mutation of its thin membranous character into a hurny investment better suited to the office it has now to perform of protecting the sentient body from a too rough contact of the medium in which the animals live, and from worser foes. From this mode of connection it results that when the polypes retire within, they at the same time must close the aperture to their cells, for that portion of the inner tunic which is pushed outwards by their exit, in their withdrawal follows the body by a process of invagination, becoming at one and the same time a sheath for the column of tentacula, and a plug to the aperture, which, when of a flexible material, has its margins also drawn tighter and closer together.

The polype which endues itself with this cell is widely different from any previously described; and in a system that should pretend to arrange animals according to their agreements in organization, could not be placed in one common class. Be- 
tween the polypidoms there is an apparent affinity. The Crisiadie are not unlike the Sertulariadae, and it is still disputed whether some Gemmicellarixe appertain to this family or to the Flustra; the resemblance between the Sertularixe and the Vesiculariadxe misled even Lamarck to their union under one genus; and their names would seem to imply that the framers of the genera Alcyonidium and Alcyonella believed them to be in a family relationship to Alcyonium. These are examples which prove the fallacy of outward characters; and how darkly the naturalist must grope his way who would walk through Nature's labyrinth without the ariadnaean thread that the anatomist alone can give him! In the instance before us he has demonstrated that the resemblances indicated above imply no propinquity in their objects. The ascidian polypes the Creator has cast in the mould - not of the radiata-but of the mollusca, _ yet with such a considerable variation as to mark their ordinal distinctness; for the Mollusca Tunicata-their nearest allies - are not protrusive from their cells as these polypes are; and this seeming slight discrepancy connects itself, perhaps of necessity, with a total change in the position and nature of their respiratory organs. Interior and immotive in the one tribe, they line, in a reticular pattern, the parietes of a sac capacious enough to contain a sufficiency of the aërating fluid; while in the other they clothe the exsertile tentacula in the form of cilia which must be placed outwards amid the circumfluent waters before they can play and fulfil their functions.

Notwithstanding the great diversity in the forms of the polypidoms of this order, there appears to be a very remarkable uniformity in the habit and structure of the polypes. The body lies doubled up in the cell (Fig. 39, $a, b$.), its oral extremity crowned with a circle of long filiform ciliated tentacula.* From the centre of this circle the mouth opens into a sort of pharyox (Fig. 39, a, 1.) which begins the œsophageal tube, generally of

* At page 34 the tentacula of the Ascidioida are stated to be solid: an error which Dr Farre enables us to correct. In Alcyonidium, "with an amplifying power of 200 linear," "they are secu to be tubular throughout, and to have an aperture at each extremity; that at the base apparently communicating with a fine canal round the oral rim, which probably uxites the tentacular canals into one circle." Phil. Trans. an. 1837, p. 406. This is a structure very like that in the two preceding orders. 
considerable length, and studded, especially at the upper part, with minute oval spots arranged in close contact with each other. The whole tube appears to be highly irritable, and contracts vigorously when food is introduced into it._- At the termination of the esophagus is a distinct cardiac orifice $(a, 2$.$) that$ opens into a small globular cavity of singular construction, which appears to perform the office of a gizzard. ( $a$ and $b, 3$.) The parietes of this organ are thicker than in any other part of the alimentary canal. They contain two dark round bodies placed opposite to each other, from each of which dark lines are seen radiating." In the space between these bodies may be seen a number of scales gronped in a close, regularly tessulated manner, which line the inner surface of the cavity, and probably serve the office of gastric teeth, having their motions regulated by the muscular fibres whose disposition is indicated by the dark radiating lines.

The gizzard, * or when it is absent (which proves to be the case in many genera), the osophagus, opens downward into the true digestive stomach, $(a, 4$.) from which it is separated only by the contraction of the parietes. This stomach is usually of an oblong shape, and its walls are thickly studded with spots of a rich brown colour,-apparently hepatic follicles that secrete a fluid which often tinges the whole organ, as well as its contents, of a similar hue._" From the upper part of the stomach, and by the side of the entrance from the gizzard, arises the intestine $(a, 6$.$) by a distinct pyloric orifice (a, 5$. $)$ that is surrounded by vibrating cilia. The intestine passes up straight and narrow by the side of the osophagus, from which it is entirely separate and free, and terminates by a distinct anal orifice $(a, 7$.$) in the deli-$ cate parietes of the body, close to the outer side of the tentacular ring. The parietes of the intestine are marked with pale spots, something like those of the pharynx, and the whole tube, like the rest of the alimentary canal, possesses a high contrac. tile power. Thus the alimentary canal consists of pharyux or vesophagus, gizzard, stomach and intestine, with subsidiary se-

* Compare this with a somewhat similar structure in the planarian worms which 1 have placed in the gemts Nemertes. Mag. of Zool. and Bot. Vol. i. p. 5:30. pi. 17 , fig. 5 . 


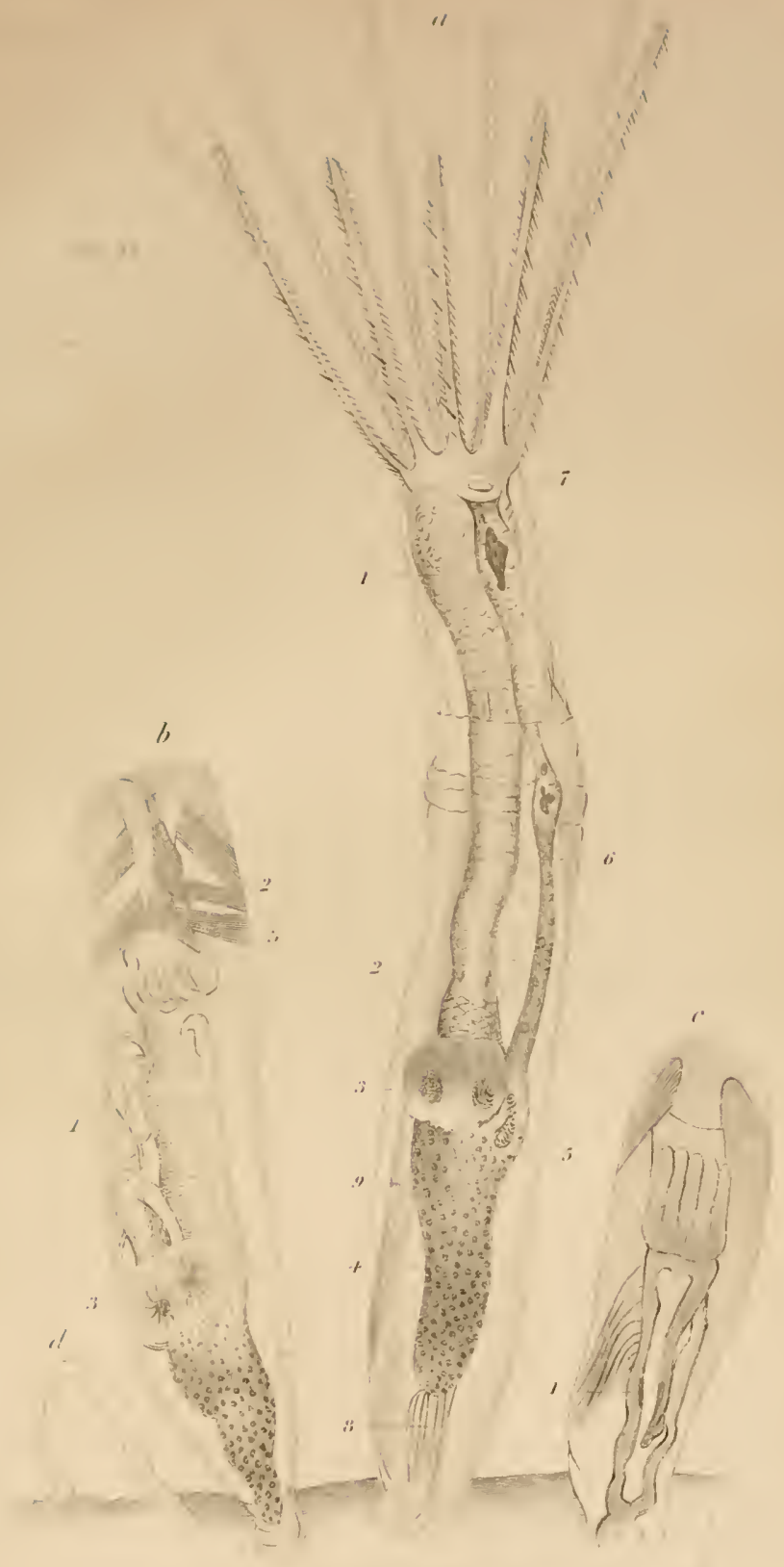



ereting follicles, and distinct oral, cardiac, pyloric, and anal orifices. The whole floats freely in a visceral cavity, the boundaries of which are formed by the delicate transparent parietes of the animal; the space between the alimentary canal and the parictes being occupied by a clear fluid, and by the museles whicl act upon the animal."**

Let us now suppose that the polypes are in a state of extrusion and fully expanded, as represented in Fig. 39, $a$; all the cilia in play, and the water whirling in rapid streams up and down the opposite sides of the tentacula, carrying with them nutriment and the breath of life. All is quietness and security around, and the little creatures are evidently in a state of happiness and enjoyment: no one who has witnessed the microscope scene, - the myriads of the little flosculous heads that pullulate and blossom over the entire polypidom, as thickly peopled as the swarming hive, can have any doubt of this, $f$ especially when he remarks the acuteness and vivacity of their sensibilities and actions, for, under his eye, one will ever and anon suddenly sink out of view, hide itself within the cell, again on a sudden emerge and expand, or, it may be, lay itself down in repose and concealment, until digestion has freed it from a state of repletion, or forgetfulness has removed the alarm of an enemy. $f$ These positions are assumed with such a rapidity that the eye cannot trace the steps of the process; and large glasses and minute skill are required to reveal to us its mechanism.

- Farre in lib. cit. p. 393.

$\dagger$ " The heart is hard in nature,

With sight of animals enjoying life,
Nor feels their happiness angment his own."

Couper.

\$ "No trace of either nerves or ganglia could be detected; yet the attributes of a nervous system were so clearly exhibited as to leave no doubt but that this must exist, and probably in some degree of perfection. Not only was the delicacy of their sense of touch very strongly marked, but the operations also consequent upon the enjoyment of such a sense were sometimes singularly striking. This is seen in the instant retiring of the animal on the slightest alarm, and the caution which it sometimes shows before emerging again from its cell; in the obrious selection of its food; and in the pertinacity with which it refuses to expose itself to water that has become in the least degree deteriorated,"-Farre in Phil. Trans. an. 1837, p. 414. 
The polype then is expanded and wishes to sink within its cell. To answer this wish two distinet sets of muscles are provided, the one acting upon the animal, and the other upon the flexible part of the cell, or, in other words, on that portion of the inner tunic which has been carried outwards in the polype's egress. The former set originate from the bottom of the cell $(a, 8$,$) and$ from the sides near the bottom $(a, 9)$; whence trending upwards, they are inserted into the stomach, and into the pharynx and tentacular ring. It is obvious from this position, that their contraction will draw the whole body down in the cell, where it lies doubled up in the form of a letter $\mathrm{S}$, that all its parts may be brought within the compass of its house. The other set of muscles for the retraction of the flexible portion of the cell, or operculum, have their origin from the inner surface and near the top of the fixed immotive part, and are inserted into the piece on which they act; (Fig. $b, 2,3$,) so that when the first set have partially done their duty, the second follow up the process by pulling after the sinking body the flexible membrane, inverting it at the same time as we undo a stocking from the leg; and as the last result, closing the aperture or fixing the operculum down upon it.

To replace the polype in its external relations a very different mechanism is brought into play. The inner tunic of the cell, or that which immediately invests the body and encloses the viscera as in a sac, appears to be susceptible of changes in its capacity from the action of some muscular fibres that run in a transverse direction through it. When the polype lies perdue, the sac is distended and the muscles relaxed, but on their contraction the capacity of the sac is reducerl; and the body, pressed upon on all sides, must of necessity rise upwards in that direction in which it is most free to move. At the same time the little creature appears to have the power of straightening the alimentary canal; and by its pressure against the bottom of the cell, the extrusion of the body is aided and completerl.*

* It would appear as if muscular fibre were here reduced to its simplest condition. The filaments are totally disconnected, and are arranged the one above the other in a single series. They pass straight and parallel from their origin to their insertion, and have a miform diameter thronghont their course, execpt that each filament generally presents a small knot upon its centre, which is most 
The cell tenanted by this polype is of a tubular, an elliptical, oval, or hexangular figure, circumscribed by distinct walls which apparently separate it from those that lie in juxtaposition, and linder any intercommunity. The isolation, however, I believe to be more apparent than real. In Vesicularia the cells are apart from each other, and rise from a common tube, - the zoophyte affording by this disposition of them a very favourable object for observing their true connection. Now Ellis states that while a branch of this species was in a watch-glass of sea-water, on the stage of the microscope, he " could plainly distinguish that the internal hollow part of the whole coralline was filled with the substance of the parent polype, which appeared to be of a tender gelatinous nature; and upon the least extension or contraction of the young polypes, this tender fleshy substance was visibly affected; for each one was united to it by their lower part or tail.", I think I have also noticed a distinct thread of communication between the polypes of the Flustra; and though the closeness of their proximity, and their opacity, may prevent the demonstration in other genera, yet a like union may be probably inferred, for other conclusion seems incompatible with the mode of increase of the polypidoms, and the regularity of their patterns.

The polypidom, formed in some species of a congeries of many thousand cells, begins with one only. This original or seminal cell has no sooner been completed, or even in many instances previous to its perfection, than another begins to shoot out from a fixed point of its parietes, the bud gradually enlarging and developing itself until the form and size of the primary one has been attained. $\uparrow$ This process can most easily be

apparent when it is in a state of contraction, at which time the whole filament also is obviously thicker than when relaxed. The filaments have a watery transparency and smooth surface, and under the highest powers of the microscope present neither an appearance of cross markings nor of a linear arrangement of globules." Farre in Phil. Trans. an. 1837, p. 394.

* Essay on Corallines, p. 21.

+ Of Lafling's observations on Membranipora pilosa, Pallas says_ " Vidit propagari seu augeri, per gemmas a marginalibus seu extremis cellulis protrusas, in perfectas cellulas effingendas, c quibus polypus dein exseritur. Interdum 2 proles ab eadem cellula, at non simul exseri, sicque series duplicari atque in latitudinem pandi crustam vidit." Elench. Zooph. p. 51. See also p 34. 
traced in the Vesiculariadæ, and in our common Flustræ and Escharinæ, where round the margin of the crust, cells can at all seasons be observed in every stage of their evolution;-one just jutting out, another half-formed, and others again nearly complete. They never begin their original in the body of the polype, but always from the parietes, or rather the connecting medium ; ${ }^{*}$ nor indeed is the embryo distinguishable within until the cells have made considerable advances to maturity. Then the softer parts begin to assume a shape, and gradually to limb themselves after the similitude of their antecedent copartners, when having reached their term and ready for a partial independency, they burst their outward cerements, always at a fixed point, prepared for their exit by the same Power which has moulded the whole.

From this mode of increase there would seem to be no natural limits set to the magnitude and duration of the polypidom, except what arise from accident or extrinsic causes. The original polype and its immediate successors may grow old, languish and die; but the solid cells remain in their connection as a root and fixture, while the newer races, which have sprung up towards the outskirts, continue their work, - generation following generation in rapid and ever-multiplying successions. The polypidom in this respect resembles a tree in its growth : the trunk and main branches have stood years and centuries, but the increase has been made by annual shoots and renewals, and the last know only vigour and jurenescence. And as the form of the tree depends on the fashion of its ramifications, so that of the polypidom on the mode of evolution of its cells, for every part of the axis is not equally organized to produce buds, nor the same parts in all. Hence if the primitive cell has only one point fitted for this gemmation, the polypidom will be builded up in a catenated chain; if the cell has two points, two series

* They, in this respect, are formed the same as the Asteroida, of which MilneEdwards says:- "On voit done qu' ici la partie qui dome naissance aux bourgeons reproducteurs est précisément la partie qui n'appartient en propre à aucun des Polypes réunis en masse, mais qui leur est commune à tous. Le tissu générateur entoure ces petits êtres comme une sorte de gangue vivante et produit dans la profondeur de sa substance de nouveaux polypes sans qu'aucuu de ceux déjà existans paraissent intervenir l'me manière directe dans l'acte de la reproduction." Amu, des Sc. Nat. iv. p. 310.1835. 
of cells are formed, and in several the multiplication goes on in at regular arithmetical progression; but in others the cells are heaped together without apparent regularity, as in Alcyonella and Alcyonidium, where the softuess of all the parts seems to allow of a non-regulated succession of buds. The general disposition of the cells, however, in this order is certainly after the quincunx, affording examples which the learned Sir Thomas Browne would have gladly adduced in proof that "Nature geometrizeth and observeth order in all things, and of the generality of this mystic figure." Nor indeed were they entirely overlooked by this observant physician. "The spongy leaves of some seawracks," he says, "Fucus, Oaks, in their several kinds, found about the shoar, with ejectments of the Sea, are over-wrought with net-work elegantly containing this order (the quincunx): which plainly declareth the naturality of this texture; and how the Needle of Nature delighteth to work, even in low and doubtful regetations."*

Whilst the composite individual is thus increased by gemmules or buds, the species is propagated and diffused by means of ciliated ova, of which the source has been a matter of some difference of opinion among naturalists. There appear at certain seasons, on many of these zoophytes, round pearly testaceous bodies which are placed on or above the mouths of the cells. Ellis beliered these to be their matrices or ovaries "which, in time," he says, "may unfold and extend themselves into those many beautiful tree-like forms that we find them in." $\dagger$ This opinion was also adopted by Pallas, because of the seasonal appearance of the bodies in question, and because they are found only over full-grown and matured cells. $\neq$ No one after this seems to have held other belief, $\S$ until recent discoveries, demonstrating the complexity of the organization of this order, rendered the exis-

* The Garden of Cyrus, p. 33. Lond. 1686. folio.

† Essay on Corallines, p. xi.-Ellis's earlier conjectures, which, being erro- rreous, it is unnecessary to detail, may be seen in Phil. Trans. abridg. (an. 1753) x. p. 346.

† Elench. Zoophytorum, p. 36.

\$ " I am inclined to consider them as ovaria enclosing the germs of future individuals; having observer that these vesicular bodies are sometimes whole, and in this case I have always found them filled with small globular bodies." Lamouroux, Corall. p. 58. 
tence of an internal separate ovary probable; and some have asserted its discovery. $\mathrm{Mr}$ Thompson, for example, maintains that the organ suspended from the bend of the body of the Vesiculariadæ is " an ovum or ovarium," because it is "quite analogous in situation with the same organ in the lately discovered compound Ascidiæ ;"* and when treating of the Cellariæ MilneEdwards assigns to this organ a similar function, + but in other places he tells us that it is connected with the biliary secretion. + Previously however to the researches of either Thompson or Edwards, Professor Grant had told us that the ova were generated exterior to the body of the polype and disjunct from it, pullulating from the common connecting medium, for the ova and gemmules have the same origin, but the ova sprout from its inner surface, whereas the gemmules grew from the exterior side on. $\mathrm{ly}$, and in consequence are capable of being developed without separation. The correctness of this opinion seems to be proved by the observations of Dr Grant on the Flustra, in which he saw that the ova were developed from the sides of the cell, which they gradually filled by their increase in size, the body of the polype being at the same time absorbed; by the observations of Raspail on the Alcyonella in which no ovary could be detected, and in which the ova are evidently the produce of a part disconnected with the animal viewed abstractedly; and by the researches of Dr Farre, who has equally proved that there is no ovary in the Vesiculariadx, the organ which had been so considered being in fact the proper stomach.

The following synopsis exhibits the genera arranged under their respective families, but at the same time it ought to be remembered that as, of many of the species and of some genera, the polype remains unknown, their true position in the class is only conjectural.

- Zool. Researches, p. 96.

† “ On remarque aussi au bas de l'anse, formé par l'intestin, un organe particulier qui pourrait bien être un ovarie destiné à produire des gemmes reproducteurs." Lam. Anim. s. Vert. ii. p. 175. 2de edit.

‡ "- - Ine anse à laquelle est comme suspendu un appendice crecal gros et court." Ibid. p. 214. This opinion is also that of Professor Grant. Outlines of Comp. Anat. p. 314. 
* Natres of thes sea. (Tentacula forming a perfect circle.) Polypiaria infundibnlati, P. Gervais.

Family I. VESICULARI $\triangle \mathrm{D} /$.

Polypidoms corncous, fistular, confervoid: cells vesiculur, deciduons, non-operculate.

22. Vesicularia. Cells ovate, disjunct, uniserial, unilateral.

23. Serialaria. Cells tubulons, adjacent, uniserial, unilateral.

24. VALKERIA. Cells ovate, clustered, or in pairs.

25. Bowerbankia. Cells elliptical, irregularly scattered, unilateral.

\section{Family 11. CRISIADR.}

Polypidom calcareous or subealcareous, branched, confervoid, jointed: the cells linked together in one or more series, distinct, tubular or clliptical, with a terminal or subterminal aperture, never closed with an operculum.

26. Crisia. Cells tubular, catenated in one or two alternating series, the aperture round and terminal.

27. Notamia. Cells ovate, geminate, opposite, the aperture subterminal.

28. Hippotios. Cells elliptical, linked together, the aperture superior and literal.

29. AxGuiniria. Cells spathulate, separate, the aperture lateral.

Family 1II. TUBULIPORID

Polypidoms calcareons, variable in shape but never confervoid : cells tubular, rowed, rising from a base and projecting, the aperture. terminal and non-operculate.

30. Tubulipora. Cells tubular, rowed, with distinct parietes.

31. Discopora. Cells tubular, quincuncial, confluent.

\section{Family IV. CELLEPORIDÆ.}

Polypidoms calcureous or membrano-calcarcous, lobed, ramous or crustaceous, formed of an agyregation of cells disposed usually in quincunx: cells utricular, in juxta-position, with " contracted terminal aperture, often covered with an opereulum.

32. Cellepor.1. Polypidom lobed or ramons; cells heaperl.

33. Lepratia. l'olypidom crustaceous; the cells in a single larer, rowed, suhalternate, with a contracted orifice. 
34. Membranipora. Polypidom membranous; the cells distinct, membranous with an ossified rim to the aperture which is patulous.

\section{Family V. ESCHARID曆.}

Polypidoms calcareous, membrano-calcareous or membranous, very variable in form, composed of cells usually disposed in quincunx; the cells oblong, pentagonal or hexagonal, conjunct, immersed or horizontal to the plane of axis, with a subterminal or lateral aperture usually covered with an operculum.

35. Flustra. Cells quadrangular or hexagonal, on one or two planes, forming mat-like expansions, free and foliaceous or incrusting.

36. Cellularia. Cells oblong with a terminal aperture, in two sublaternate rows on a single plane, forming a dichotomously divided narrow subcalcareous polypidom.

37. AсAmarchis. Cells oblong with a wide lateral aperture, in two subalternate rows, forming a dichotomous confervoid polypidom.

38. Farcinia. Cells rhomboidal, immersed; the polypidom dichotomous, with jointed cylindrical branches.

39. Retepora. Cells immersed, quincuncial, on the upper side of a frondescent, netted, calcareous polypidom.

40. Eschara. Cells immersed, quincuncial, in a double layer placed back to back like the cells in honey-comb, forming a frondescent membrano-calcareous polypidom.

\section{Family VI. ALCYONIDULA.}

Polypidoms sponge.-like, fleshy, polymorphous; the cells inegular in disposition, immersed and concealed, with a contractile non-nperculate aperture.

41. Alcyonidium. Cells immersed, irregular, with a contractile aperture, forming a fleshy lobed polypidom.

42. Cliona. Cells amorphous, perforated in a sponge-like polypilom strengthener with siliceous spicula.

* Lacustrine. (Tentacula in the form of a horse-shoe.) Polypiaria hippocrepia, P. Gervais.

\section{Family VII. LIMNIADES.}

Polypidoms fleshy or spongy or corneous, polymorphous, the polypes placed in tubes with angular or round orifices, closed when the animals recede.

43 Cristatella. Polypidom fleshy or sponge-like, massive.

44. Prumatella. Polypidom horny, fistular, confervoid. 


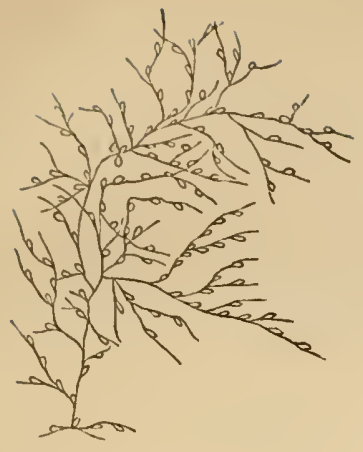

Fig. 40.

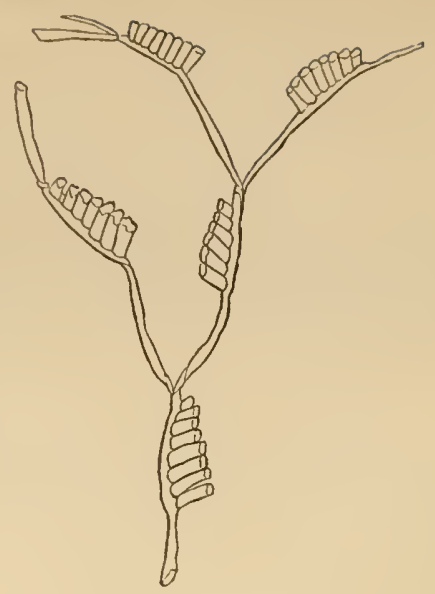

IV. ZOOPHYTA ASCIDIOIDA.

\section{FAMILY IX. VESICULARIADÆ.}

Since we profess to be guided, in the classification of zoophytes, by similarity in the structure of the polypes considered independently of their polypidoms, the Vesiculariadre, notwithstanding their apparent dissimilarity, must be issociated in the same order with Alcyonidium and Flustra. They have been hitherto united with the Sertulariadæ, and previous to our knowledge of their polypes, this seemed a very natural unior, for the polypidoms of both are slender and plant-like, horny, fistular and flexible, and furnished with somewhat similar cells on their branches. But the differences between them even in outward aspect are not inconsiderable, and although it may be difficult to point out these by any description, they are nevertheless not the less obvious to one familiar with the objects. The polypidoms of the Vesiculariadæ are more flexible and of a thinner texture, less arboreal and more confervoid, not so regularly jointed, nor ramified in the same determinate and fixed manner. They are all inarine productions, generally not more than an inch or two high, and are found attached only to sea-weeds or other corallines.

For a knowledge of the animated temants of these structures we are indebted to Cavolini, the Rev. Dr Fleming, J. V. Thompson, Esq. and more particularly to Dr Farre, of whose researches a summary has been given in the preliminary observations. The following is his description of the cells in the prescut family :

"The transparent horny cell which closely embraces the body of the animal is nearly unyielding in its lower two-thirds, but terminates above by a flexible portion, which serves to protect the upper part of the body when the whole is 
expanded, in which state it is of the same diameter as the rest of the cell; but when the animal retracts is folded up and drawn in after it, and completely closes the mouth of the cell.

" The flexible part consists of two portions, the lower half being a simple continuation of the rest of the cell ; the upper consisting of a row of delicate bristle-shaped processes or setæ, which are arranged parallel with each other round the top of the cell, and are prevented separating beyond a certain distance by a membrane of excessive tenuity, which surrounds and connects the whole. This mode of termination of the cell is one of constant occurrence, as will be described in other species, and is evidently a provision for allowing of the freest possible motion of the upper part of the body in its expanded state, to which it affords at the same time support and protection." Phil. Trans. an. 1837, p. 393.

\section{Vesicularia, * Thompson.}

Chanacter. Polypidoms rooted, confervoid, fistular, horny, dichotomously branched, jointed at the divisions: cells ovate, disjunct, uniserial and unilateral. Polypes ascidian.

\section{V. spinosa. Dillenius.}

Plate xxix. Fig. 1-4.

Conferva marina cancellata, Raii, Syn. i. 59, no. 11. Dill. Hist. Husc. 24, no. 22, pl. 4, fig. 22,_fide $D$. Turner in Lin. Trans. vii. 106._-Con.ferva cancellata, Lin. Syst. ii. 720. With. Bot. Arrang. iv. 131.Silk Coralline, Ellis, Corall. 20, no. 17, pl. 1], fig. $b, B, c, D$.__ Sertularia spinosa, Lin. Syst. 1312. Ellis and Soland. Zooph. 48. Turt. Gmel. iv. 682. Jameson, in Wern. Mem. i. 564. Bosc, Vers, iii. 118. Stew. Elem. ii. 446. Berk. Syn. i. 219. Turt. Brit. Faun. 215. Lamarck, Anim. s. Vert. ii. 120. 2de edit. ii. 148. Hogg, Stock. 33.Sert. sericea, Pall. Elench. 114.__LLomedea spinosa, Corall. 91. Templeton in Mag. Nat. Hist. ix. 466._Valkeria spinosa, Flem. Br. Anim. 551.___ Vesicularia spinosa, Thomp. Zool. Ill. 98, pl. 3. fig. 1-8. Farre in Phil. Trans. an. 1837, 401, pl. 22._-La Laomédee epineuse, Blainv. Actinolog. 474.

Hab. In deep water, not uncommon. "Junio et Julio mensilus pone Sheerness in insula Shepey copiose observavi," Dillenius. "At the Nore, near the entrance of the Thames," Ellis. Leith shore, Jameson. "Rarely found near Hartlepool," J. Hogg. "Found on the shore of Belfast Lough : common," Templeton. Liverpool, Rev. D. Landsborough.

Polypidom affixed by a fibrous base, very slender, confervoid, of it thin membranous pellucid texture, much branched, erect, sometimes as much as 8 inches in height, usually about 4 ; main branches composed of intertwined capillary tubes, tapered, zigzag; branchlets arising from the bends, either solitary or in pairs, short, much diviled dichotomonsly, the apices pointel and closed ; all the hranches are joint-

* From resicula, diminutive of e'esica, a bladiler. 
ed under each bend, and the branchlets at each division, and they are perforated with a single series of rather distant holes with a raised rim as if they had been hored from within outwards: cells three between each joint, deciduous, oval, transparent._" The animals are very easily seen in all their cletails in this species, from the great transparency of the resicles, and are provided with eight tentacula," Thompson, which "are ciliated but not armed with spines." Farre.

The holes in the sides of the capillary branches mark the places whence the polype-cells have fallen. The spine-like points in which the divisions of the branchlets terminate have suggested the Linnean specific name; and that of Ellis and Pallas expresses the silky appearance which dried specimens exhibit. Ellis has well marked the distinctions which separate the species from the Sertulariadæ. "The motion of the intestines of the young Polypes was very distinguishable till the water became putrid; and then hoth vesicles and polypes dropped off, like blighted blossoms off a tree; and the substance of the parent polype, though seeming to fill the whole cavity of the branch before, as soon as the water became improper for its support, shrivelled up immediately so as scarce to be visible."

\section{Serialaria, * Lamarck.}

Character. Polypidom confervoid, horny, the shoots slender, filiform, fistular and branched: cells tubulons, uniserial and unilateral, disposed in close parallel companies at stated intervals. - Polypes ascidian.

1. S. LENDIGERA, much branched, the branches spreading, subdichotomous; cells in isolated groups, erect, with wide uneven apertures.-Doody.

Vignette, No. 40 , page. 249.

Fucoides lendigerum capillamentis Cuscutæe instar implexis, Raii, Syn. 38. no. 3.— Nit Coralline, Ellis, Corall. 27, 110.24 , pl. 15, fig. $b . B$. Sertularia lendigera, Lin. Syst. 1311. Pall. Elench. 124. Ellis and Soland. Zooph. 52. Turt. Gmel. iv. 682. Berk. Syn. i. 218. Stew. Elem. ii. 445. Wern. Hem. i. 564. Turt. Brit. Fauı. 215. Bosc, Vers, iii. 117. Hogg's Stock. 33. Lister in Phil. Trans. an. 1834, 384. —-La Sertolara lendinosa, Cavol. Polip. Mar. 229, tav. 9, fig. 1, 2._ Serialaria lendigera, Lam. Anim. s. Vert. ji. 130. 2de edit. ii. 169. Risso, L'Europ. Merid. v. 315. Flem. Brit Anim. 547 Stark, Elem. ii. 439. Templeton in Mag. Nat. Hist. ix. 467. - Anathia lendigera, Lamour. Cor. Flex. 159. Corall. 68._La Serialaire lendigère, Blaine. Actinol. 476 , pl. 8.3, fig. ?.

- From serialr, diminutive formed from series, a row. 
$H a b$. At the roots of Fuci about low-water mark. "In Sussexiæ littore supra Fucos siliquosum et lumbricalem frequentem hanc speciem observavi," Pallas. Leith shore, Jameson. "Found in Belfast Lough, and Dublin Bay, \&c." Templeton.

"This extremely small climbing coralline arises from very minute tubes, by which it adberes to Fucus's, and other marine bodies; and is so disposed from its jointed shape, that it climbs np and runs over other corallines and Fucus's, as Dodder does over other plants." Ellis. The tufts thus formed resemble a flock of hair with clusters of nits scattered over it, and though the comparison is an ugly one, it is yet expressive. The filaments are capillary, smooth, pellucil, kneed and jointed at their dichotomies, immediately under which the cells are usually placed in a short row containing from four to eight or nine cells, growing gradually shorter outwards, and so arranged as to resemble a Pan's-pipe in miniature "with cylindrical reeds varying in their length." - That the Polypes are ascidian is satisfactorily proved by Cavolini ; and Lister informs us that they have eight ciliated arms.

\section{VALKERIA, * Fleming.}

Character. Polypidom confervoid, horny, fistular, irregularly branched; the cells ovate, clustered or scattered.-Polypes ascidian, without a gizzard.†

\section{Cuscuta, branches opposite; "cells usually in pairs, op-} posite." Ellis.

C'limbing Dodder-like Coralline, Ellis, Corall. 28, no. 26, pl. 14, fig. c. C. Sertularia Cuscuta, Lin. Syst. 1311. Pall. Elench. 125. Ellis and

* “This genus is dedicated to the late Dr John Walker, Professor of Natural History in the 'University of Ediuburgh, a laborious and an accomplished naturalist." Fleming. Sir J. E. Smith characterises him as "a most amiable, worthy and ingenious man." Sir James visited Moffat in the autumn of 1782, of which parish Dr W. was the minister. "I spent that day," he says, "and the next very happily with the Doctor; he is a very agreeable man: the life and soul of Moffat; his loss will be equally felt by the gay, the industrious, and the unhappy,"-alluding to his approaching removal or translation to Collington, near Edirburgh. His posthumous "Essays on Natural History," Edin. 1812, 8 vo. is an interesting volume, which I have had occasion to regret was not more noticed in our Faunas and Floras.

+ The animal of Valkeria differs from that of Vesicularia and Bowerbankia, " in the entire absence of the manducatory organ; a difference which it is of great importance to observe with reference to a natural arrangement of the class" Furre. 
Soland. Zooph. 53. Berk. Sym. i. 218. Turt. Gmel. iv. 680. Turt. Brit. Faum. 214. Wern. Men. i. 564. Bosc, Vers, iii. 113. Stew. Elem. ii. 444. Fleming in Wern. Mem. iv. 485, pl. 15, fig. 1._-Valkeria cuscuta, Flem. Brit. Anim. 550. Furre in Phil. Trans. an. 1837, 402, 11. 23. —-Vesicularia Cuscuta, Thomp. Zool. 11l. 97, pl. 2, fig. 14.__Lal Cuscutaire cuscute, Blainv. Actinol. 497, pl. 82, fig. 2.

Hab. On Fuci and corallines. West coast of England, Ellis. In the Frith of Tay, Rev. Dr Fleming. Leith shore, Jameson.

"The main stems originate from tubular creeping roots, which invest marine plants in shoal water: these stems are often jointed at un. equal distances, and give off a number of short branches, which originate in pairs from its opposite sides, frequently just above a visible joint; these branches support the vesicles, which are scattered over their surface in an irregular manner, and do not differ except in size and number of tentacula, from those of $\mathrm{V}$. imbricata: the tentacula being 8 in number." Thompson.-" Height seldom above two inches; several stems usually arise from the same base, filiform, jointed, waved, and support the branches and cells bifariously; branches opposite, nearly perpendicular to the stem, with a joint immediately above their insertion : cells oval, sessile, upwards of ten times the breadth of the stem, in pairs, at remote distances, projecting, and are probably ultimately converted into branches: sometimes they occur in pairs or crowds in the axillæe of the branches; polypi extend considerably beyond the margin, tentacula with hairs, which, by their motions, cause the water to ascend in a current on one side, and descend on the other, acting, probably, as aërating organs." Fleming.

2. V. UvA, "stem creeping, irregularly branched; cells scattered." Ellis.

Grape Coralline, Ellis, Corall. 27, no. 25, pl. xv. fig. c. C, D. Sertularia uva, Lin. Syst. 1311. Ellis and Soland. Zooph.53. Berk. Syn. i. 218. Turt. Gmel. iv. 682. Turt. Br. Faun. 215. Stew. Elem. 445. Jumeson in Werm. Mem. i. 564. Bose, Vers, iii. 117. Hogg's Stock. 34. Clytia uva, Corall. 89. Templeton in ${ }^{{ }^{\prime}}$;. Nat. Hist. ix. 466._- Valkeria uva, Flem. Brit. Anim. 551.___ La Campanulaire ovifere, Blainv. Actimol. 473.

Hab. "Growing on Fucus's and other corallines, on the British coast," Ellis. Leith shore, Jameson. "Found on Fucus nodosus, on the coast at Kirkubbin, county Down, July 1806," Templeton.

"This exceeding small coralline creeps on the broad-leafed hornwrack" (Flustra foliacea;) "and sends ont clusters of vesicles from several parts of its creeping tube, each of which has a black spot in it, like the spawn of frogs: Or rather, these look when they are magnified, like a bunch of full ripe transparent oval-shaperl grapes with 
the stones in them"- "A mong many other marine substances received fresh from the sea, in September 1753, this object happened to present itself under my magnifying glasses; when, to my surprise, I found those grape-like bodies were a cluster of polypes, each having eight claws or tentacula, very lively, extending themselves about in pursuit of prey; and upon their dying, the animals contracted themselves into their vesicles, which closed at the top: What we discover as a spot, is only the intestines of the polype with its food in it." Ellis.

3. V. Imbi ICATA, cells in dense chusters irregularly scattered on the polypidom. Adams.

Plate xxix. Fig. 5, 6.

Sertularia imbricata, Adams in Lin. Trans. v. xi. pl. 2. fig. 5-11. Turt. Gmel. iv. 683. Turt. Br. Faun. 216. Stew. Elem. ii. 450. Thomp. Zool. Ill. 94. pl. 1. fig. 1-4._-Valkeria glomerata, Coldstrean in Edin. New Phil. Journ. ix. 235. pl. 2. fig. 1, 2 : and in Edin. Journ. Nat. and Geog. Se. iii. 53.—Serialaria imbricata et S. verticillata, Templeton, iı Mag. Nat. Hist. ix. 467, fig. 66.

Hab. Parasitical on various littoral Fuci. On Fucus nodosus in Milford haven, Adams. In small pools, at low-water, near Leith, Dr. Coldstream. "On the Fuci and Conferva, on the shore of Belfast Lough, near White-House Point," Templeton. In the harhour of Cove, one of the most obvious and common species, J. Thompson.

"Stem simple, slightly branched, partly creeping, partly erect : cells ovate, lengthened, with the mouths slightly compressed quadrangularly, scatterel over the stem in irregular gromps. Before the polype is evolved, the cell is closed at the distal extremity by a conical covering. Polypi with ten tentacula, finely ciliated: they extend considerally heyond the mouths of the cells, to the margins of which each is attached by a membrane, which is protruded before the tentacula when the polype is abont to expand itself. When alarmed, it contracts very rapidly." $\mathrm{Dr}$. Coldstream.--According to $\mathrm{Mr}$ Thompson this species creeps over the surface of the Fuci by means of its tubular ramifying roots, and throws off numerous flaccid irregularly branchet shoots to the length of from one inch to one and a half or more, often so densely clustered as entirely to cover the plant on which it grows.

4. V. pustulosa, vesicles clustered, unilateral. Ellis. Plate xxix. Fig. 7-9.

Dichotomous tubular Coralline, Ellis, Corall. 54. pl. xxrii. fig. $b$. $B-$ Sertularia pustulosa, Ellis and Soland. Zooph. 54. Turt. Gmel. iv. 680. Bosc, Vers, iii. 113. Stex. Elem. ii. 444. Turt. Brit. Kan. 
214. Flem. Brit. Anim. 551._-Vesieularia pustulosa, Thomp. Zool. Ill. 99, pl. 1, fig. 5-11.

Hab. Parasitical on Fuci. Isle of Wight, Ellis. Cove Harloour, J. I. Thompson.

This " arises from the surface of marine fuci with a straight flexnose stem, to the height of two or three inches, giving off at each flexure a spreading luanch, which in like manner gives off secondary ones, all however, both primary and seconlary, lying in the same plane, they are hence what hotanists term distich; each flexure of the stem and branches and each terminal branchlet is composed of a ristinct joint, each of which are perforated by a double row of holes from 6 to 18 with elevated margins, on all of which in perfect specimens are placed oval transparent vesicles, furuished with animals having $S$ tentacula: the rows of perforations having a spiral tendency, the clusters of vesicles hence present themselves in every direction." Thompson.

\section{Bowerbankia, * Farie.}

Character. Polypidom confervoirl, homy, creeping; the cells sessile, unilateral, irregular, the inflected portion with a spinous or filamentous rim :-Polypes ascidian.

1. B. DENSA, matted; stem creeping; cells from the sides and upper surface, thickly set, elliptical: Polypes with 10 tentacula about one-third the length of the body, sparingly lispid along the outer side. Farre.

Bowerbankia densa, Farre in Phil. Trans. an. 1837, 391, pl, 20 and 21.

$H a b$. "Found commonly on Flustra foliacea thickly aggregated in masses of half of an inch to ore inch diameter." Isle of Sheppey, Farre.

"The animal when fully expanded is about one-twelfth of an inch in length. In its retracted state it is completely inclosed in a delicate horuy cell, sufficiently transparent to admit of the whole structure of the contained animal heing seen through its parietes. The cells are connected together by a cylindrical creeping stem, upon which they are thickly set, and sessile, ascending from its sides and upper surface."

* "Believing it to be new I have named it after my friend $\mathrm{Mr}$ Bowerbank, whose zeal displayed on this as on many other occasions where the study of natural history may be promoted, was mainly instrumental in inducing me to follow up these investigations, on account of the many supplies that I received from him, and I gladly therefore take the opportunity of acknowledging and recording the obligation that 1 am under to him." Dr Furre. 


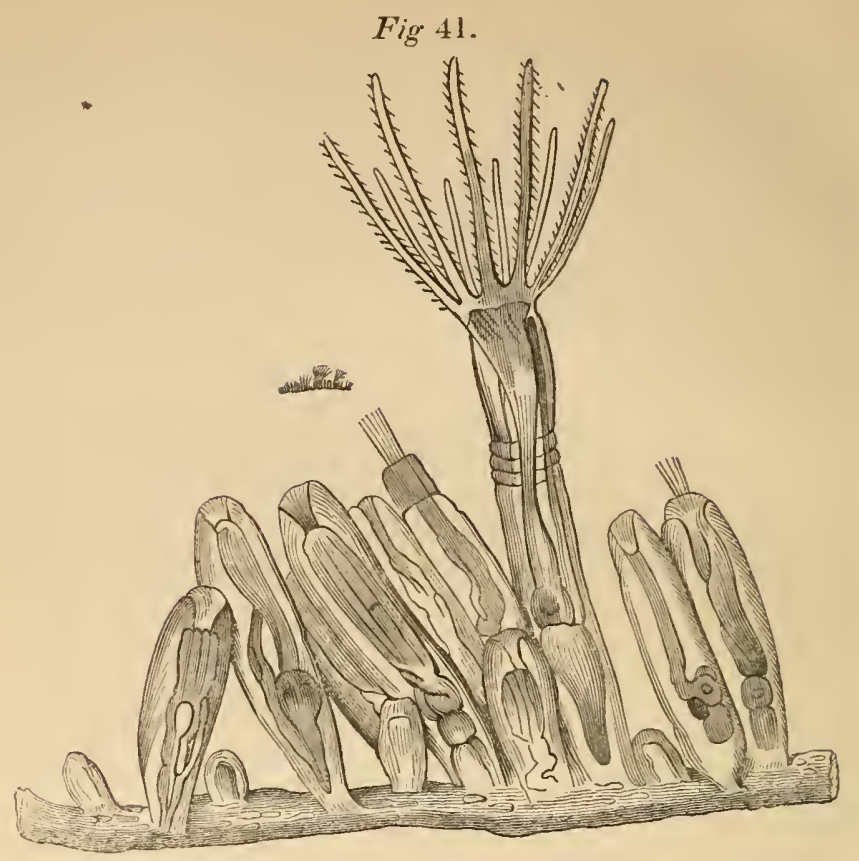

"The animal when completely expanded is seen to possess ten arms of about one-third the length of the whole body, each arm being thickly ciliated on either side, and armed at the back by about a dozen fine hair-like processes, which project at nearly right angles from the tentacula, remaining motionless, while the cilia are in constant and active vibration."

2. B. REPENS, stem creeping; cells irregularly disposed or scattered, elliptical. Polypes with 12 tentacula. Farre.

Vignette, No. 38, page 235.

Lagenella repens, Farre in Phil. Trans. an. 1837, 403, pl. 24.

Hab. "Parasitic, with a creejing stem, on Sertnlaria and on Halodactylus diaphanus. Not very common," Favre.

"This species has twelve ciliated arms, not spiny. The alimen. tary canal is short and stont, and whilst the animal is expanded remains high up in the body. During retraction the stomach is never brought down to the bottom of the cell, but remains suspended from the upper part of it by the intestine, which appears to have some attachment at this point. The upper part of the tube, however, is generally brought down lower than the stomach, in order that the 
tentacles may be completely drawn in. By this suspension of the stomach from the upper part of the cell a fixed joint is obtained, from which the retructed flexed portion of the tube may erect itself with the same effect as if the stomach were in contact with the bottom of the cell. This is a point which it would be important to observe in generic distinctions; but here, as with many other points in this species, my observations were not carried to the extent that they have been in others, as this was one of the specimens with which my investigations were commenced, and I have never since had an opportunity of confirming them."

"The cells have an oblong form, and are connected to their narrow creeping stem by a short peduncle. The opercular portion terminates in a notched margin, and is very short. (It is possible that this notched margin may be formed by the extremities of short and broad setæ, but this was not determined.) The cells spring from the sides and upper surface of the stem, and tum upwards as in Bowerbankia. They are set at some distance apart." Farre.

Dr Farre considers this species as forming a distinct genus, but I bave not been able to seize upon characters, in his description, of value sufficiently high to justify its separation.

In the Philosophical Transactions for 1834 , p. 385, pl. 12, fig. 5, Mr Lister has figured a zoophyte which he refers to the genus TıвıANA of Lamouroux, but erroneously in the opinion of Milne-Edwards.* It seemingly belongs rather to this than to any other family of its order, but the polypes, instead of being contained in distinct deciduous cells, issue from one continuous with the common stalk. "This is represented as slender, alternately branched, the branches simple, erect, forming a long tubular cell. The polypes appear to have eight tentacula. It was found at Brighton. (See wood-cut No. $42, a, b$.)

"A zoophyte allied to the above was found upon the same marine plants, which seems to be that imperfectly represented by Ellis, $\mathrm{pl}$. xxxviii. 5. F."†

- Ann. des Sc. Nat. Part. Zool. vi. second. ser. p. 18. He refers it to his genus Lucra, slightly indicated in the 2 de edit. of Lan. Anim. s. Vert. ii. 72 , and says it should stand near to Crisia. lbid. p. 185. I an not aware that any more detailed account of the genus or of its species has been published.

+ The Hydra coronata of Fleming, Brit. Anim. 554. Ellis's specimens were parasitical on Plumularia falcata. Professor Sharpey has given a figure and 


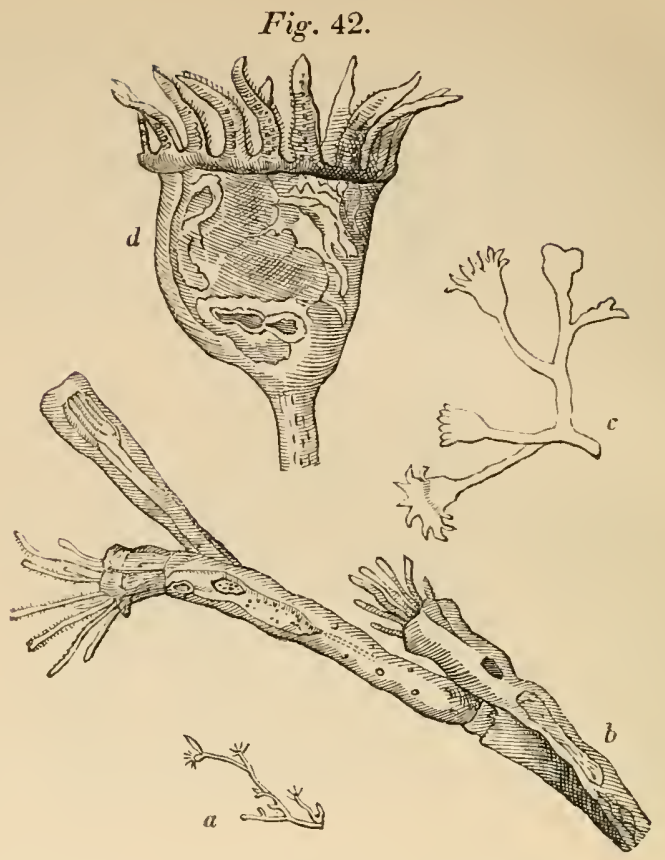

"It consists of a creeping tube and a number of stems branching from it, each ending in an animal that is shown (not very distinctly) at fig. $42, d$. The stems, though commonly still, have free power of motion; and when one is disturbed it bends quickly to and fro, so as to strike one or two more; these again strike upon others, and thus for a few seconds all are in action : but they soon returu to quietness, and the arms, which during the commotion had been doubled in, open again. (Fig. 42, c.)

"The arms are placed on the elge of a pretty transparent tunic, and have granulations on their back. They are fringed with cilix possessing the same action as those of Ascidiæ and Flustræ; and in the specimen drawn, small substances were occasionally seen carried downwards along them. As in Flustra, a part of the intestine had within it a revolution of particles and dark matter round its axis, and this part communicated with an ascending rectum. The arms at the part of the circle opposite to the rectum appeared to be con.

description of what appears to be the same species in the Cyclop. of Avat. and Physiology, i. 610, fig. 293; for a mere difference in the ramification can scarcely be considered specifical in this tribe. 
tinued below the edge of the tunic, and the current produced in the water, and the food it brought, flowed into a cavity there, at the bottom of which was active indistinct motion as if of filaments. A connexion was thought to exist between that part and the place where the revolution was going on, but no act of deglutition was perceived.

"No current of blood was visible in the stem, nor any circulation either in the body or the arms. Much of the space within the tunic was occupied by a darkish appearance, the nature of which was not ascurtained. I had not opportunity to inspect other individuals, but the species seemed to be intermediate between such animals of Flus. tra as I had met with, and the pedunculated compound Ascidia; more nearly related to the former, but approaching the latter in the form of the lower part of the body, the position of the rectum, and the absence of all apparent effort of swallowing : and if with the help of imagination we could counect the ciliated arms together by cross bands at intervals and unite their ends in a circle, extending the tunic to meet that circle, and leaving an opening for the funnel where the rectum is placed, the organ would not be mnlike the branchiæ of some Ascidia. Indeed the affinity appeared to me not very distant between Ascidia and Flustra; while, to the Sertularix, except in the resemblance given by their projecting arms, I can discover no more analogy in the Flustræ than in the Ascidiæ themselves." Lister. 
Fïg. 43.

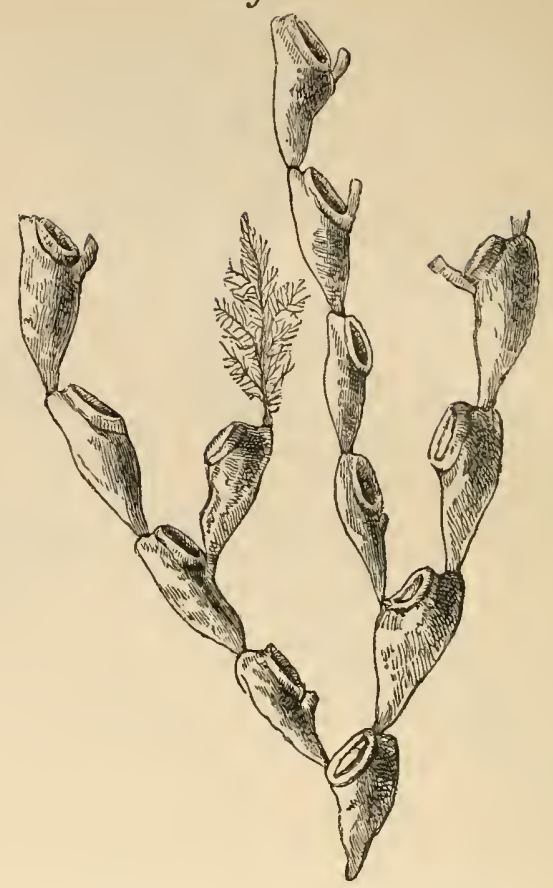

FAMILY X, CRISIAD无。

26. Crisia, * Lamouroux.

Character. Polypidom confervoid, rooted by tubular fibres, dichotomously branched; the cells long and tubular, catenated together in one or two series, the apertures round, terminal, and all inclined to one side.-Polypes ascidian.

* Cells linked in a single series. (Eucratea.)

1. C. CORNUTA, cells tubulous, curved, the aperture divaricated, with a long bristle at the bend. Ellis.

\section{Plate xxx. Fig. 1, 2.}

Goat's-horn Coralline, Ellis, Corall. 42, no. 10, pl. 21, fig. c, C.—-Sertularia cormuta, Lin. Syst. 1316. Berk. Syn. i. 220. Turt. Gmel. iv. 686. Turt. Brit. Faun. 217. Stew. Elem. ii. 449._Cellularia falcata, Pall. Elench. 76 . C. cornuta, Hogg's Stock. 35.—Cellaria coruuta, Ellis and Soland. Zooph. 25. Bosc, Vers, iii. 134. Lam. Anim. 
s. Vert. ii. 139. 2de edit. ii. 187.——Eucratea cornuta, Lamour. Cor. Flex. 149. Corall. 64. Risso, L'Europ. Merid. v. 319. Flem. Brit. Anim. 541. Templeton, in Mag. Nat. Hist. ix. 469.—L'Unicellaire corrue, Bluinv. Actinol. 462.

Hab. Parasitical on other corallines, and "adhering to Fuci beyond low water-mark, not common," Fleming. Very rare at Scarborough, $M r$ Bean. Occasionally found in tufts of Crisia eburnea on the coast of Berwickshire, G. J. "Found in the pools on the rocks below Bangor, very common," T'empleton.

Polypidom sometimes half an inch in height, very slender, erect, confervoid, white and brittle when diy, rooted by a few tubular fibres, alternately branched, the secondary branches unilateral, secund. The coralline consists of a series of cells placed one above another. the upper cell originating from the one below near the middle, at its point of divarication from the straight line; and a long tubular spine, which overtops the cell, rises from the same place. The cells are curved, tubular, smooth, the upper half everted, with a plain circular aperture. In some specimens oval-shaped vesicles are found scattered over the polypidom : they originate from the base of a cell, are specked, and have a small tube at the back.

2. C. CHELATA, cells in the form of a horn; the aperture oblique, marginated, with a spinous process beneath the rim. Ellis. Vignette, Fig. 43, page 260.

Bull's-horn Coralline, Ellis, Corall. 42, no. 9, pl. 22, fig. b,B._-Sertularia loricata, Lin. Syst. 1316. Berk. Syn. i. 220. Turt. Gmel. iv. 686. Turt. Brit. Faun. 217. Stew. Elem. ii. 449.—Cellularia chelata, Pall. Elench. 77.—Cellaria chelata, Ellis and Soland. Zooph. 25. Bosc, Vers, iii. 134. Lam. Anim. s. Vert. ii. 140. 2 de edit. ii. 189. -Eucratea chelata, Corall. 64, pl. 3, fig. 5.—E. loricata, Flem. Brit. Anim. 541._L L'Unicellaire cornet, Blainv. Actinolog. 461, pl. 77, fig. 2__Loricula loricata, Tentpleton, in Mag. Nat. Hist. ix. 469.

Hab. Parasitical on Fuci, rare. On stones at very low tides, very rare at Scarborough, $\boldsymbol{M}$ r Bean. "Common on the coast" of Ireland, Templeton. Cork Harbour, J. V. Thompson.

Smaller and more distinctly catenulated than the preceding. Ellis's description is very good. "This beautiful coralline is one of the smallest we meet with. It rises from tubuli, growing upon Fucus's; and passes from thence into sickle-shaped branches, consisting of single rows of cells, looking, when magnified, like bull's horns inverted, each one arising out of the top of the other. The upper branches take their rise from the fore part of the entrance of a cell, where we may observe a stiff short hair, which seems to be the beginning of a 
branch. The opening of each cell, which is in the front of its upper part, is surrounded by a thin circular rim; and the substance of the cells appears to consist of a fine transparent shell, or coral-like substance."

* Cells paired, with a joint between each pair. (Crisia.)

3. C. EBURNEA, "cells loosely aggregated, cylindrical, bent, tubular orifices free." Ellis.

Plate xxx. Fig. 3, 4.

Tufted Ivory Coralline, Ellis, Corall. 39, no. 6, pl. 21, fig. a, A.—Cellularia eburnea, Pall. Elench. 75. Hogg's Stock. 35._- Sertularia eburnea, Lin. Syst. 1316. Berk. Syn. i. 220. Turt. Gmel. iv. 686. Wern. Mem. i. 565. Turt. Brit. Faun. 217. Stew. Elem. ii. 449._La Sertolara d'avorio, Cavol. Pol. Mar. 240, tav. 9, fig. fig. 5, 6.Cellaria eburnea, Ellis and Soland. Zooph. 24. Bosc, Vers, iii. 133. Lam. Anim. s. Vert. ii. 138. 2de edit. ii. 184. Johnslon in Trans. Newc. Soc. ii. 262, pl. 11, fig. 5.—Crisia eburnea, Lamour. Cor. Flex. 138. Corall. 60. Flem. Brit. Anim. 540. Templeton, in Mag. Nat. Hist. ix. 468._L_La Crisie ivoire, Blainv. Actinolog. 460, pl. 78, fig. 3. Risso, L'Europ. Merid. v. 318.

Hab. Parasitical on the roots of sea-weed, and on other zoophytes, very common. "Alibi pollicarem et ultra inveni, in Sussexiæ v. gr. littore, ubi in Fuco pinastroide, una cum C. falcata et anguina abundabat," Pallas.

Grows in little bushy tufts of ivory whiteness, frequently tinted with rose-red, from a quarter to fully an inch in height, attached by a few capillary fibres dilated at their points of insertion into minute calcareous bulbs. Polypidom much branched, the primary divisions alternate, spreading; the secondary from one side only and bending inwards with a slight curve. Cells in two rows, nearly opposite or semi-alternate, with a joint between each pair, adnate, frosted, the aperture circular, somewhat oblique, even and entire. Vesicles obpyriform, roughish or granulated, sparingly and seldom produced.

4. C. LUXATA, " cells closely aggregated, cylindrical, nearly straight, with short tubular orifices; joints black." Rev. J. Fleming.

Plate xxx. Fig. 5, 6.

Crisia luxata, Flem. Brit. Anim. 540.—La C. luxée, Blainv. Actinolog. 460.

Hab. "On corallines, not rare, from various parts of the coast," Fleming. Cullercoats, Northumberland, $\mathbf{M r}$ Jos. Alder. Berwick Bay, very rare.

Polypidom erect, about an inch in height, white and calcareous, 
bushy, dichotomously divided, the branches inclining inwards; the joints jet-black; the internodes narrow at their origin, widened upwards ; the cells entirely adnate, tubulous, semi-alternate, with round even apertures. This, though in many respects similar to the preceding, is yet essentially different, and has been well characterized by Dr Fleming. It is of a denser texture; the branches, or rather the spaces between the joints, are longer, broader and thicker in the middle ; the cells are more closely connected; their orifices are not detached from the sides, and the joints are black, so that the polypidom appears dotted to the naked eye.

*** Cells ternate, with a joint above and below.

(Tricellaria.)

5. C. ? TERNATA, "cells lengthened, rounded at top, with spinous processes." Dr David Skene.

Cellaria ternata, Ellis and Soland. Zooph. 30.-_ Seltularia ternata, Turt.

Gmel. iv. 687. Stew. Elem. ii. 449. Turt. Br. Faun. 217. - Crisia ternata, Corall. 61.-Tricellaria ternata, Flem. Br. Anim. 240. La Tricellaire ternée, Blainv. Actinolog. 458.

Hab. From Aberdeen, Skene. Zetland, Fleming.

"Height scarcely an inch, dichotomously branched; the cells enlarge gradually in breadth towards the top, which is armed with two or three spines; when the outermost one is short, the cell externally has an angulated appearance; at the joints the stem is narrow." Dr Fleming.

\section{Notania, Fleming.}

Chamacter. Polypidom plant-like, subcalcareous, rather soft and flexible when dry, much branched dichotomously: cells geminate, exactly opposite, united back to back with a thick dissepiment, a joint above and below each pair.-Polypes ascidian.

\section{N. Loriculata, cells subcylindrical and obliquely truncated,} the aperture plain. Doody.

\section{Plate xxxi. Fig. 12, 13.}

Muscus coralloides mollis elatior ramossissimus, Doody in Raii, Syn. 1 . 34, no. 6. - Coat of Mail Coralline, Ellis, Corall. 40. no. 7, pl. xxi. fig. $b, B$._- Sertularia loriculata, Lin. Syst. 1314. Turt.Gmel. iv. 684. Berk. Syn. i. 219. Turt. Br. Faun. 216. Wern. Mem. i. 564. Stew. Elem. ii. 447._-Cellularia loriculata, Pall. Elench. 64.__Hogg's Stock. 35. Cellaria loriculata, Ellis and Soland. Zooph. 24. Bosc, Vers, iii. 133. Lam. Anim. s. Vert. ii. 136. 2de edit. ii. 179. Johnston in Trans.

" From "varos, dorsum, and rausiov, cella," Fleming. 
Newc. Soc. ii. 262.-Crisia loriculata, Corall. 61.—_Loricaria europæa,

Lamour. Zooph. 7._-Notamia loriculata, Flem. Br. Anim. 541. Fárre in Phil. Trans. an. 1837, 413, pl. 27, fig. 6-9.-- Gemicellarialoriculata, Blainv. Actinol. 461, pl. 78, fig. 4 .

Hab. "A few fathoms beyond low water-mark," common on all our coast.

Polypidom attached by capillary roots, from 2 to 4 inches lorig, very bushy, " in cupressi formam elongata," greyish-white, flaccid even when dry ; the branches cloșe, erect, dichotomous, filiform, consisting of a series of paired cells divided by a simple joint. Cells arluate, smooth, obliquely truncated, placed back to back, "so that the pair together resemble a coat of mail, or pair of stays ; and the entrances of the cells look like the places for the arms to come out at." Ellis. The Polypes have 10 tentacula: they have no gizzard, but in other respects the alimentary canal presents the usual details. Farre.

2. N.? BURSARIA, cells compressed, keel-shaped, "with a little tube, swelling at top like a tobacco-pipe, that appears to come out of them." Ellis.

Shepherd's-purse Coralline, Ellis, Corall. 41, no. 8, pl. 22, fig. $a, A$.Sertularia bursaria, Lin. Syst. 1314. Turt. Gmel. iv. 684. Berk. Syn. i. 219 . Stew. Elem. ii. 447.__. S. Bursa, Turt. Brit. Faun. 216. Cellularia bursaria, Pall. Elench. 65. Ellis in Phil. Trans. 1vii. 437, pl. 19, fig. 12.—Cellaria Bursaria, Ellis and Soland. Zooph. 25. Bosc, Vers, iii. 134. Lam. Anim. s. Vert. ii. 140. 2de edit. ii. 189._-Dynamena bursaria, Corall. 79. Blainv. Actinol 483. - Notamia bursaria, Flem. Brit. Anim. 541._-Gemicellaria bursaria, Blainv. Actinolog. 461 .

Hab. Parasitical on sea-weerls, very rare. " Mare anglicum, in cujus fucis crescit parasitica," Pallas.

"This most heautiful pearl-colourer Coralline adheres by small tubes to fucus's, from whence it changes into flat cells; each single cell like the bracket of a shelf, broad at top, and narrow at bottom : these are placed back to back in pairs, one above another, on an extremely slender tube, that seems to run through the middle of the liranches of the whole coralline. The cells are open at top. Some of them have black spots in them: And from the top of many of them, a figure seems to issue out like a short tobacco-pipe; the small end of which seems to be inserter in the tube that passes through the middle of the whole.

"The cells in pairs are thought by some to have the appearance of the small pods of the Shepherd's Purse: By others, the shape of the seed-ressels of the herh Veronica or Speedwell." Ellis. 
Milne-Edwards refers this species to Sertularia, section Dyname$n a$, but there is something in the habit to render this reference very doubtful, unless it is founded on an examination of the polype, which it is not mentioned to be. Lam. Anim. s. Vert. 2de edit. ii. 180.

\section{Hiрротніо ,* Lamouroux.}

Character. Polypidom confervoid, adherent and creeping, calcareous, irregularly branched, the branches frequently anastomosing, formed of elliptical cells linked to each other at the extremities; aperture lateral, near the distal end._Polypes ascidian.

\section{H. CATENULARia, "cells rounded anteally, tapering to the} other extremity, aperture oval." Jameson.

\section{Plate xix. Fig. 9, 10.}

Tubipora catenularia? Jameson, in Wern. Mem. i. 561. T. catenulata? Stew. Elem. ii. 425.—Hippothoa catenularia, Flem. Br. Anim. 534. -H. Elliotæ, Gray, Zool. Misc. 34.

Hab. On shells in deep water, not uncommon, Dr Fleming. Orkney and Shetland Islands, Jameson. Attached to Pinna ingens in the harbour of Kinglade near Cork, Miss Elliot.

Polypidom closely arlherent, much and irregularly branched in a confervoid manner, white, smooth, glossy, calcareous, the branches spreading, frequently anastomosing, sometimes parallel and coalescing, formed of a series of cells connected like a string of bugles; cells oval, widest and rounded anteally, the aperture oval with a plain thickish rim, placed near the top.-In its mode of ramification this coralline resembles many of the plant-like figures in marble or agate. "The branches proceed nearly at right angles, issuing from the margin beside the mouth," and will spread, on a favourable site, to such all extent as will cover an inch or two square surface. When alive it " appears like dew drops, and is easily separated from the shell by a pin; but is strongly attached when dry." Gray. In this state the aperture of the cells is sometimes closed by a membrane, the remains of the polype, which remains undescribed.

2. H. LANCEOLATA, cells slender, ovate-lanceolate, the aperture sunall and round. Miss Elliot.

Hippothoa lanceolata, Gray, Zool. Misc. 35.

- A Nereid :-Hesiod. Theog. 251.

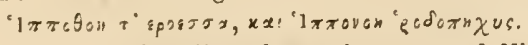

The charming Hippothoa and rosy-armed Hipponoe. 
Hab. On Pinna ingens in the harbour of Kinglade, near Cork, Miss Elliot.

" Coral attached, slender, dichotomously and divaricately branched, pearly white; cells slender, linear, ovate, base filiform, generally emitting a cell at right angles from the middle of each side; mouth small, round, with a raised margin, placed near the top of the cell."

"This species is very like $H$. divaricata, t. $10, \mathrm{f}$. 15, 16, Lamouroux, Expos. but he describes and figures the cells as fusiform, and not ovate, lanceolate, and his is from a Fucus." Gray.

\section{Anguinaria, * Lamarck.}

Character. Polypidom calcareous, creeping, adnate, slender, fistular, the cells scattered, erect, free, spathulate, with a lateral aperture near the apex.-Polypes ascidian.

\section{A. spatulata.-J. Ellis. \\ Plate xxx. Fig 7, 8.}

Snake Coralline, Ellis, Corall. 43, no. 11, pl. 22, fig. $c, C$. D.—_ertularia anguina, Lin. Syst. 1317. Turt. Gmel. iv. 686. Berk. Syn. i. 220. Turt. Brit. Faun. 217. Stew. Elem. ii, 449._Cellularia anguina, Pall. Elench. 78. Ellis in Phil. Trans. Ivii. 437, pl. 19, fig. 10. Hogg's Stock. 35.—Cellaria anguina, Ellis and Soland. Zooph. 26. Bosc, Vers. iii. 135. — Anguinaria spatulata, Lam. Anim s. Vert. ii. 143. 2de edit. ii. 196. Stark, Elem. ii. 439. Templeton in Mag. Nat. Hist. ix. 466.___ Ang. anguina, Flem. Brit. Anim. 542. Lister in Phil. Trans. 1834, 385, pl. 12, fig. 4.-Aetea anguina, Corall. 65, pl. 3 , fig, 6 . $L a-$ mour. Soland. 151__L'Anguinaire serpent, Blainv. Actinolog. 467, pl. 79, fig. 3.

Hab. Parasitical on the smaller Fuci, rare. Brighton, Mr Macgillivray. Scarborough, $M I r$ Bean. "Found on the shore at Carrickfergus, on the sand," Templeton.

This remarkable coralline creeps along the stalks of the sea-weed it prefers in a wavy line, the capillary tube swelling out at irregular intervals, and sending up numerous clavate processes or cells, which are from one to two lines high, more or less bent at the top, of a pale pink or flesh-colour or white, smooth, glossy, calcareous; the aperture inferior, subterminal, oval, with plain margins.

Lamouroux suspected that this might prove different from any polypous production, and he felt inclined to class it near to or with the Vorticellæ, but the conjecture has been shewn to be groundless by Mr Lister's discovery of its polypes, which are truly ascidian, and nearly allied to those of the Flustra. 


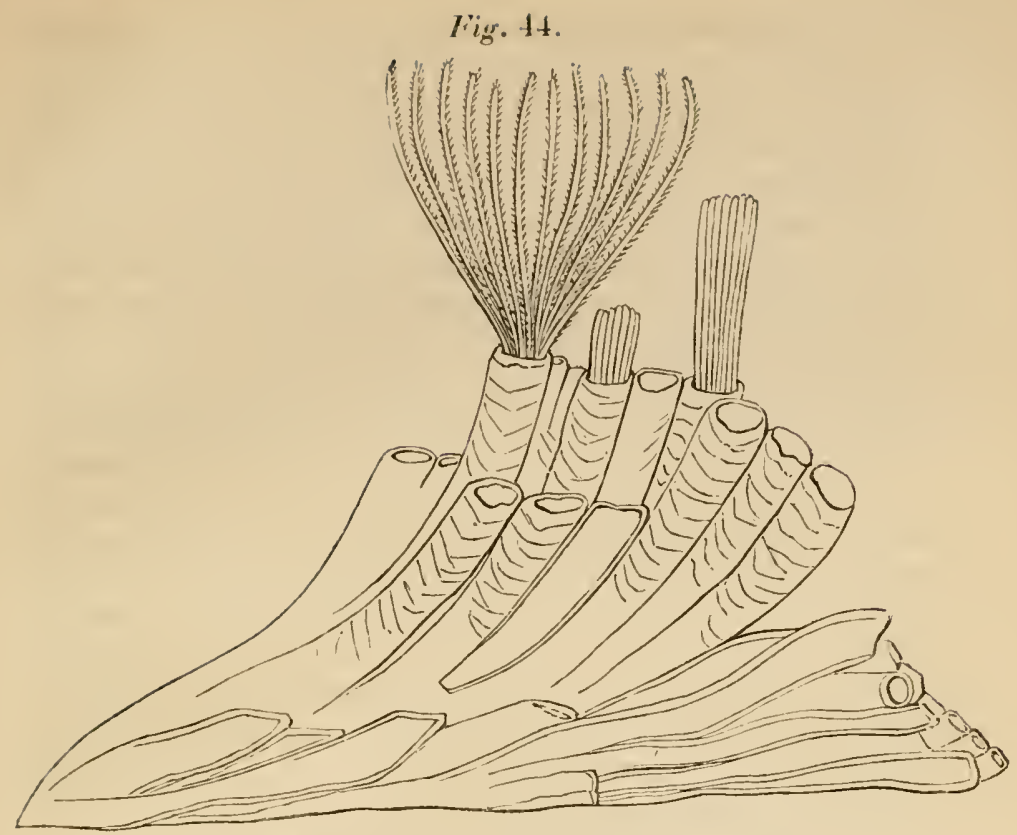

FAMILY XI. TUBULIPORIDÆ.

30. Tubulipora,* Lamarck.

Character. Polypidom attached by a partial adhesion of the base, sometimes crustaceous : cells placed on a calcareous basis, arranged in rows, long and cylindrical, separate, with a round erect aperture.-Polypes ascidian. $\dagger$

* Base subcircular, cupped. (Discopora, Fleming.)

1. T. PATina, aperture of the cells round and toothless. Pallas. Plate xxxi. Fig. 1-3.

Caryophyllus sive Fungites minimus tubulosus littoris Ariminensis, Planc. de Conch. min. not. 26, tab. 2, no. 9.-Madrepora verrucaria, $\mathrm{Lin}$. Syst. 1272. Pall. Zooph. var. B. 281. Turt. Gmel. iv. 616. Turt. Brit. Faun. 204. Stew. Elem. ii. 426. Hogg's Stock. 38. Millepora verrucaria, Ellis and Soland. Zooph. 137.-Tubulipora patina, Lam. Anim. s. Vert. ii. 163. 2de edit. ii. 244. Risso, L'Europ. Merid. v, 338. Johnston in Trans. Newc. Soc. ii. 269, pl. 9, fig. 8.-T. patené, Blainv.

* From tubulus-a tube, and $\pi$ ofos-a passage.

$\dagger$ See "Memoire sur les Folypes du genre des Tubulipores, par M. H. MilneEdwards," in Anu. des. Sc. Nat. Part. Zool. viii. 321. 
Actinol. 425. Milne-Edwards in Ann. des. Sc. Nat. Part. Zool. viii. 329 , pl. 13, fig. 1-Discopora verrucaria, Flem. Brit. Anim. 530.

Hab. On shells and corallines from deep water, frequent. "Minuta specimina ad Angliam in Fucis Escharisque observavi," Pallas.

Polypidom like a little saucer, calcareous, white, about half an inch in diameter; the base thin, subcircular, forming a shallow cup crowded with cells in the centre, the margin plain, entire, scored with faint lines; central cells shorter than those towards the circumference and frequently closed, most of them laid obliquely, but some erect, tubulous, with a round even aperture.-In its perfect state this zoophyte has been aptly compared to a compound flosculous flower; but specimens sometimes occur without any free margin to the base, when the congeries of cells forms a mere wart-like crust. It is to specimens of this kind, which are not unfrequent and variable, (some with erect cells forming a minute fluted column, that I feel inclined to refer the Madrepora verrucaria of Otho Fabricius, (Faun. Groenl. 430, no. 432,) and the Tubulipore verruqueux of Milne-Edwards, so well described and figured in Ann. des. Sc. Nat. Part. Zool. viii. 323, pl. 12, fig. I : remarking at the same time, however, that this celebrated naturalist refers it to the following, of which heconsiders the Obelia tubulifera of Lamouroux to be another variety.

* Base ramous. (IDMonea, Lamouroux.)

2. '1'. serPens, "creeping, prostrate, in obtuse linear divisions, with tubular pores on the upper surface disposed in transverse rows." Ellis.

\section{Plate xxxi. Fig. 4-6.}

Small purple Eschara, Ellis, Corall. 74, no. 6, pl. 27, e, E.-Tubipora serpens, I.in. Syst. 1271. Fubric. Faun. Gronl. 428. Turt. Gmel. iv. 614. Jameson in Wern. Mem. i. 561. Stew. Elem. ii. 426. Bosc, Vers, ii. 351._Millepora liliacea, Pall. Elench. 248. Turt. Gmel. iv. 639. Turt. Brit. Faun. 205. Bosc, Vers, ii. 345.-M. tubulosa, Ellis and Soland. Zooph. 136. Turt. Gmel. iv. 639. Turt. Brit. Faun. 205. Stew. Elem. ii. 428. Bosc, Vers, ii. 345. Hogg's Stock. 37.—Tubulipora transversa, Lam. Anim. s. Vert. ii. 162. 2de edit. ii. 242. Stark, Elem. ii. 437. Lamour. Zooph. 1, pl. 64, fig. 1. Risso, L'Europ. Merid. v. 338.Jolunston in Trans. Newc. Soc. ii. 269._- Tubulipora transversa, Blainv. Actinolog. 424. T. pourpre, Ibid. Atlas, pl. 72, fig. 3.—-T. serpens, Flem. Brit. Anim. 529.

Hab. Attached to corallines, old shells, \&c. especially to Plumularia falcata. Common on all parts of the coast. "Ex mari Cornubiam alluente allatæ Sertulariæ eandem crebram, in piso majores glomeres convolutam aut laciniosos passim et revolutos flosculos 
mentientem exhibuerunt," Pallas. Orkney and Shetland islands, Jameson.

Polypidom adherent by a narrow base, calcareous, of a faint purple colour or white, depressed, irregularly divided, the segments flat, bifid, spreading, more or less revolute, obtuse, the under surface even and striate, the upper rongh with the tubulous cells arranged in transverse rows, but divided by a central groove, which winds along the branches: the cells are generally placed in close apposition, sometimes they are disjunct, and the walls are minutely frosted.-The entire polypidom rarely exceeds half an inch in length.

Milne-Edwards is of opinion that the $T$. serpens of $O$. Fabricius is not synonymous with the Linnæan species, but with the T. fimbriata of Lamarck, in which opinion a re-perusal of the description, in the Fauna Gronlandica, does not induce me to coincide. MilneEdwards refers our polypidom to the genus Aulopore. Ann. des Sc. Nat. Part. Zool. viii. 331 .

3. T. TRUNCATA, "stem round, branched, ending with enlarged globular heads, radiated with plates of united vertical cells." Jameson.

Tubulipora truncata, Flem. Br. Anim. 529.__-Millepora truncata? Ja . meson in Wern. Mem. i. 560.—T. tronqué, Blainv. Actinol. 425.

Hab. "In deep water, Zetland," Dr Fleming. Shetland Islands,

\section{Jameson.}

"About an inch in height, the branches scarcely exceeding oneeighth; the branches are short, pierced by numerous pores, the openings of cells converging towards the centre; the head is stellate, the rays are highest in the middle of their course, diminishing towards the centre and lower margin of the head; each ray is compressed, and consists of two rows of tubular cells, united, crowded, with subangular orifices; the tubes have a central direction, and give to the sides of the plates a striated appearance. This species has probably been referred to as an inhabitant of the north seas, under the title of Millepora truncata,* but it differs widely from the Myriozoos of Donati, to which the term was restricted by Pallas." Fleming.

$$
\text { *** Crustaceous. (Obelia, Lamouroux.) }
$$

4. Т. ОвеLIA, crustaceous, the cells in rows, tubular, with an oblique even rim. Miss Elliot.

Plate xxxi. Fig. 7, 8.

* Stew. Elem. ii. 426, pl. I2, fig. 7. 
Obelia tubulifera? Blainv. Actinolog. 424, pl. 71, fig. 1. Lam. Anim. s. Vert. 2 de edit. ii. 246.__ O. tubifera? Gray, Zool. Misc. 35.

Hab. In the harbour of Kinglade near Cork, parasitical on a Pinna, Miss Elliot. In deep water at Scarborough, on Modiola vulgaris, rare, $M r$ Bean.

Crust rather thin, entirely and very closely adherent, chalk-white, even, spreading in somewhat circular expansions : the cells alternate, rather distant, rowed, radiating from several centres, divided by paler lines, horizontal, tubulous, mostly immersed, the mouths raised with a wide round oblique plain aperture.

This description is taken from a specimen in the collection of $\mathrm{Mr}$ Bean. It adheres to the shell of Modiola vulgaris, and is six-tenths of an inch in one direction and nearly five-tenths in another. The resemblance between it and Obelia tubulifera is fully sufficient to warrant the conjecture of their identity, for the differences which the sturlent will detect between our figure and that of Lamouroux, copied by Blainville, are probably the mere peculiarities which mark the individuals of a variable species. Of Obelia as a genus, Blainville remarks that it is truly unimportant, scarcely differing from Tubulipora; and the merging of them into one seems therefore a natural union, while at the same time we get quit of a name that has been also applied to some Medusæ.

Of Obeliæ generally Mr Templeton says, “ There are at least five native uncharacterised species, on small corallines and shells, very common in protected bays" of the Irish coast. Mag. Nat. Hist. ix. 470. To determine these will be the pleasant duty of the naturalists of that country.

\section{Dis copora, * Lamarck.}

Characrer. Polypidom calcareous, adherent throughout; the bisse a circumscribed crust ; the cells coalescent, indistinctly quincuncial, tubular, erect, with a round patulons terminal aperture without an operculum.-Polypes unknou:n.

1. D. HISPIDA, crust spreading subcircularly, roughish, voavy or ridged; the cells erect, obscurely rowed, with one larger and two minute denticles on the side of the apertures.-Dr Fleming.

P'LATE xxxi. Fig. 9-11.

Discopora hispida, Flem. Brit. Auim.530._Le discopore hérissé, Bluinv. Actinolog. 446 .

IIab. " On Corallines from deep water. Zetland," Fleming.

\footnotetext{
- From discus, a Hat plate or disk, aud ropos.
} 
Cuast of Devoushire, Dr. Coldstream. Stevenston, Ayrshire, Rev. D. Landsborough.

"Breadth nearly an inch, hispid; the cells seem distributed over the whole surface, and more vertical than the preceding ( Tub. patina); there are, lhowever, waved porous grooves, and the cells seem disposed on each side of these in irregular transverse rows, united or free, short, with expanding oritices dividing into irregular spinous processes." Fleming.-I have two specimens of a polypidom, given to me by Dr Coldstrean, which agree very well with this description, and are figured in the plate referred to, but they adhere to a piece of sandstone, and were found in sitn at low-water mark. The crust is half an inch or a little more in diameter, and scarcely a line in thickness, circumscribed by the thin very narrow edge of the basilar layer. It is hard, calcareous, entirely adherent, of a greyish white colour, with lighter slightly elevated roundish spots on the surface, or raised into transverse ridges, conforming in this respect, perhaps, to the form of the rock over which it spreads. The cells are barely visible with the naked eye, erect, very close or coalescent, and not arranged distinctly in any order. Their apertures are even with, or raised somewhat above, the surface, circular, and armed on one side with three small teeth, of which the central one is larger than the other. Many of the cells are destitute of these, which are only perceptible when the polypidom is viewed obliquely.

The genus Discopora differs from Tubulipora in having cells in such close and intimate union that they seem almost to be rather immersed or excavated in the crust than separate tubes; while from Lepralia it estranges itself by the erect position of its cells, their tubular form and non-constricted aperture, which, moreover, are at no season closed with ovaries. The British species answers so well to Lamarck's definition of Discopora verrucosa, Anim. s. Vert. ii. 165; Stark, Elem. ii. 436 ; that at one time I had concluded their identity to be scarcely doubtful, but Blainville's figure (if correct) of the latter proves the contrary, and represents a species with oblique ventricose cells, similar in all apparent respects to those of a Lepralia, The figures I give of the natural size are very exact to nature,-that drawn under the microscope is perhaps less characteristic, but there was no possibility of communicating to it a greater verisimilitude.

Pherusa tubulosa, Lamour. Corall. 53, pl. 2, fig. I. Blainv. Actinolog. 453, pl. 80, fig. 1.-Flustra tubulosa, Ellis and Soland. 
Zooph. 17. - According to Mr Templeton this is "found affixed to Sertulariæ, \&c." on the coast of Ireland. Mag. Nat. Hist. ix. 469.

Tubipora musica, Lin. Syst. 1270. Marked as British by $M r$ Stewart, Elem. ii. 425, -without doubt erroneously.

Filipora filograna, Fleming, Brit. Anim. 530 : Tubipora fascicularis, Stew. Elem. ii. 426; Jameson in Wern. Mem. i. 561 ; is a species of Serpula, as it was properly described by Linnæus and Pallas, Elench. Zooph. 240. The most accurate description of the species is given by the Rev. M. J. Berkeley in Zool. Journ. iii. 230. 
Fig. 45.

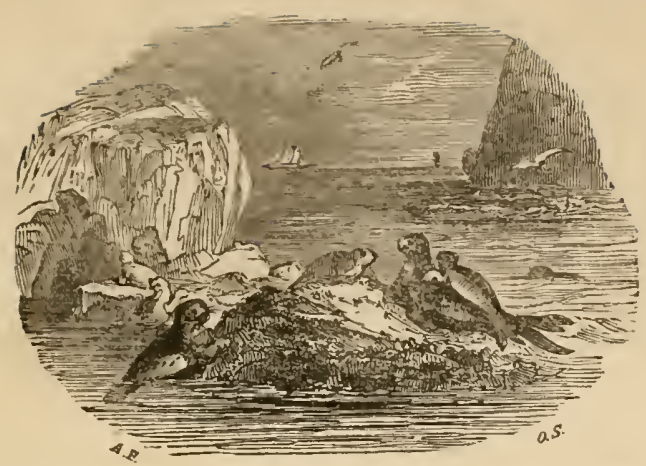

FAMILY XII. CELLEPORIDA.

\section{Cerllepora, * Otho Fabricius.}

Character. Polypidom calcareors, cellular, irregularly lobed or ramous, formed of urceolate cells heaped together or arranged in quincunx.-Polypes ascidian.

1. C. PUnicosa, glomerous, rough, porous ; cells suborbicular, the mouth round with a produced marginal process. J. Ellis.

Plate xxxii. Fig. 1, 2, 3.

Porous Eschara, Ellis, Corall. 75, no. 7, pl. 27, fig. $f, F$, and 72, pl. 30, fig. $d, D$.— Tubipora verrucosa, $L$ in. Syst. edit. 10, 789.— Cellepora pumicosa, Lin. Syst. 1286. Mull. Znol. Dan. prod. 253. Turt. Gmel. iv. 640. Berk. Syn. i. 212. Wern. Mem. i. 560. Turt. Brit. Faun. 206. Stew. Elem. ii. 428, pl. 12, fig. 16, 17, copied from Ellis. Lam. Anim. s. Vert. ii. 170. 2de edit. ii. 256. Corall. 40. Busc, Vers, iii. 147, pl. 3, fig. 3. Flem. Brit. Anim. 532. Hogg's Stock. 37. Stark, Elem. ii. 436. Johnston in Trans. Newc. Soc. ii. 267. Templeton in Mag. Nat. Hist. ix. 469._C. verrucosa, Lin. Syst. 1286. Fabric. Faun. Gronl. 434.—C. spinosa, Turt. Brit. Faun. 205. -Millepora pumicosa, Pall. Elench. 254. Ellis and Soland. Zooph. 135. Turt. Gmel. iv. 639. Wern. Mem. i. 560. Stew. Elem. ii. 428. _Flustra bullata? Ellis and Soland. Zooph. 16. Stew. Elem. ii. 436. Turt. Gmel. iv. 664 Le cellepore pouce et C. verruqueux, Blainv. Actinolog. 443-4.

$H a b$. Found on the stems of various corallines, on stones, and on the roots of Fuci, common.

The cells, by their conglomeration, form a porous friable calcareous

* lirom cella a cell, and $\pi$ søs. 
mass, encrusting submarine bodies, rarely exceeding an inch in length, usually round when small, more or less oblong and knobbed when large. It is rough, when quite recent of a pinkish colour, dirty-white when dry, rarely tinted with purple. The aperture of the cells is often toothless, but in a perfect condition a short mucro projects from the superior margin, and often a lesser one on each side.Linnæus' description under C. pumicosa is scarcely applicable, but his quotation of Ellis's figure determines the species he had in view. There can be little doubt that his C. verrucosa-cellulis subrotundo-glomeratis ovatis ore subtridentato"-belongs to the same species, although Blainville considers it synonymous with the Discopora verrucosa of Lamarck.

2. C. Ramulosa, dichotomously branched, the branches cylindrical, rough; cells irregularly clustered, with a mucro on the outer edge of the aperture. Pallas.

\section{Plate xxxii. Fig. 4, 5.}

Cellepore ramulosa, Lin. Syst. 1285. Mull. Zool. Dan. prod. 253, no. 3049. Bosc, Vers, iii. 148. Flem. Brit. Anim. 532. Johnston in Trans. Newc. Soc. ii. 267, pl. 12, fig. 3, 4 . Lam. Anim. s. Vert. 2 de edit. ii. 258 La C. rameux, Blainv. Actinol. 443.

Hab. In deep water, attached to old shells, " not rare," Fleming. Lizard Point, Cornwall, Pallas. On Serpula tubularia from the coast at Dunstanborough Castle, Mr R. Embleton. Coast of Berwickshire, occasionally, G. J.

Polypidom attached by a spreading base, calcareons, white, light and porous, rising to the height of between 2 and 3 inches, branched from the base, the branches bifid, spreading, cylindrical, the ultimate ones a little attenuated at the apex, very rough with the mucronate cells, which are urceolate, without any very regular arrangement, the aperture contracted, the mucro about as long as its diameter.-Pallas (Elench. 255,) and Ellis (Soland. Zooph. 136, con. sidered this a variety of the preceding. - The polypes are of a faint red or flesh colour, with two darker spots indicating the position of the stomach and ovary; tentacula numerous, filiform.

3. C. Skenei, much compressed, divided in a bifid manner, rough; cells rowed, with a strong mucro on the outer edge of the round aperture. Dr David Skene.*

$$
\text { Plate xxxii. Fig. 6, 7, } 8 \text {. }
$$

" “Dr David Skene-after a short time of study at Paris, in addition to the more ordinary preparations-cettled as a medical practitioner in Aberdeen, where 
Millepora Skenei, Ellis and Soland. Zooph. 135. Turt. Gmel. iv. 635. Turt. Brit. Faun. 204. Stew. Elem. ii. 427._Cellepora palmata, Flem. Brit. Auim. 532._- C. Skenci, Johnston in Trans. Newc. Soc. ii. 267._L_Eschare palmée, Blainv. Actinol. 428.

Hab. In deep water, attached to shells and corallines. Near Aberdeen, Skene. "A single specimen from deep water, Zetland," Fleming. Coasts of Nortbumberland and Berwickshire, not rare.

Polypidom attached by a spreading base, calcareous, erect, from half an inch to an inch high, much compressed, divided in a palmate manner, the segments truncate, the surface very rough with the mucronate cells, which are immersed, arranged in regular rows, and have a roundish aperture guarded by a strong divaricate mucro, and in some of the cells there are one or two shorter spines at the base of this. From these spines being worn away the base of the polypidom

his father and grandfather had heen physicians of reputation; and he soon became eminent in his own profession, as well as in literature and science. To Botany he was particularly devoted; and he frequently herborized in company with Principal Campbell and Dr Reid, who were both fully aware of his merits. The former is said to lave often lamented that his observations on plants had never been given to the world; while Dr Reid, in a letter addressed to him, observes, regarding his extensive acquirements- ' But is it all to die with you, and to be buried in your grave? This, my dear sir, ought not to be. Stultum est periture parcere charte. Can you find no time either when you are laid up in the gout, or when the rest of the world is in good health, to bequeath something to posterity? Think seriously of this.' I find the same distinguished philosopher in another of his letters from Glasgow, urging the physician to present himself as a candidate for one of the medical chairs of that place, about to become vacant by the removal of Dr Black to Edinburgh, particularly as this might become a step towards the University of Edinburgh, to which Dr Reid thought his ambition shonld extend. Nor was this a mere partiality derived from previous personal intimacy; for more than one seem to have been anxious that the Scottish metropolis should become Dr D. Skene's place of abode. Thus Lord Kames, a frequent and attached correspondent, says in one of his letters (dated Blair Drummond, II th January 1769,) 'I have a most hearty resentment at you for refusing the offer made you by Dr Hope, which would have settled you in the town of Edinburgh, much to your profit I am certain; but no particulars till $I$ see you in the Harrest circuit ;' and in another, 'I wish from my heart to have you settled here, and cannot but regret a good opportunity you missed.'" Dr Skene was also the correspondent of Pennant, Ellis, Walker, and of Linnæus, sereral of whose letters to him are still preserved. He died in December 1771, aged 36, learing behind him numerous manuscripts; and a museum, consisting of plants, minerals and shells, which might well have been called immense. Taking him all in all he was " probably as extraordinary a man as the north of Scotland ever produced ;" and it is hard to believe that, even in his native city, his name should now be entirely forgotten. See the "Northern Flora," hy Alexander Murray, M. D. pref. p. x. 
is generally smooth and more or less rounded: it is sometimes of a yellowish-brown colour, but commonly white, and when dry appears "as if covered over with a silver varnish."

Notwithstanding the apparent dissimilarity in habit of the three preceding Celleporæ, I cannot but suspect that they are merely different states of the same species : for in these productions the "fronti nulla fides" receives many an apposite illustration.

4. C. CERvicorNis, much and irregularly branched; branches compressed, palmate, truncate; surface roughish or even, compact, with simple circular pores disposed in quincunx. Borlasse.* Plate xxxiii.

Porus cervinus, Borl. Cornw. 240, tab. 24, fig. 7.-Millepora cervicornis, Stew. Elem. ii. 427. Turt. Brit. Faun. 204._-M. compressa, Sowerby, Brit. Misc. 83, pl. 41, Turt. Brit. Faun. 204. Jameson in Wern. Mem. i. 560._Cellepora cervicornis, Flem. Brit. Anim. 532.

Hab. "In deep water, not rare," Fleming. Cormwall, Borlasse. Devonshire, Dr Coldstream. Shetland Islands, Jamesnn.

A single specimen of this coral is about 3 inches in height and somewhat more in breadth. It rises from a broad flattened base, and begins immediately to expand and divide into kneed branches or broad segments, many of which anastomose so as to form arches and imperfect circles. The extreme segments are dilated and variously cut, truncate. Both sides are perforated with numerous pores just visible to the naked eye, and arranged in regular rows: the pores are circular, even with the surface on the smooth and newly formed parts, but on the older they form the apertures of urceolate cells which appear to be formed over the primary layers of cells, and give to the surface a roughish or granular appearance. The orifice is simple, contracted, with a very small denticle on one side. The thickness of the branches varies from a half to two lines; the interior cellular; the new parts formed of two layers of horizontal cells, but the older parts are thickened by cells superimposed on the primary layers._-This species certainly treads closely upon the genus Eschara, but Dr Fleming and Milne-Edwards, who had examined an authentic specimen in the York Museum, both agree in making it a Cellepora. It is entirely distinct from Eschara cervicornis, with wbich it has been confounded.

* Borlasse, William, of Ludgvan in Cormwall, D. D., born Feb. 2, 1695-6; elected F. R. S. in 1750 ; died Aug. 31, 1772: the author of a History of Cornwall still held in estimation; and characterized by biscontemporaries as an "able and worthy man." See Pennant's Literary Life, p. 1. 
5. C. LEVIS, " dichotomously branched, cylindrical, the prores wide, with simple mouths." Rev. Dr Fleming.

Cellepora læris, Flem. Brit. Anim. 532.—L'Eschare lisse, Blainv. Actinol. 4 -28.

Hab. "A single specimen from deep water, Zetland," Fleming.

"Height an inch and a quarter, diameter one-tenth; the branches are smooth, with the orifices of the cells smooth and concave; towards the extremities the branches are rough with the forming cells, and the orifices are more declining, circumscribed, a little prominent, with a blunt process at the proximal margin." Fleming.

\section{Lepralia, Johnston.}

Character. Polypidom calcareons or membrano-calcareous, adnate, crustaceous, spreading circularly, formed of a layer of urceolate cells in juxtaposition, horizontal, and arranged in quincunx; aperture terminal, often covered with an opercular ovary. -Polypes ascidian.

* Margin of the aperture plain.

1. B. HYALINA, " diaphanous, the cells forming an even smooth crust, with tubular simple mouths." Rev. Dr Fleming.

Cellepora hyalina, Lin. Syst. 1286. Fabric. Faun. Grœnl. 435. Bosc,

Vers, iii. 148.—Berenicea hyalina, Flem. Brit. Anim. 533.—La

Berenice byaline, Blainv. Actinol. 445 .

Hab. "On stones, shells, and corallines from deep water," Fleming. "The crust is semitransparent, the divisions of the narrow cells indicated by whitish lines, and the orifices are narrow, cylindrical, simple tubes. The crust is not circumscribed, otherwise it resembles the genus Discopora." Dr Fleming.

2. L. NITIDA, cells ovate, prominent, transversely ridged, or, when dry, fissured. Dr Fleming.

Plate xxxiv. Fig. 7.

- Lepralia_" sea-scurf"-derived from $\lambda \varepsilon \pi \rho x$, leprosy, and $\dot{\lambda} \iota\llcorner$, marine : an expressive name for the genus suggested by my friend, the Rev. Thomas Riddell. It is synonymous with the "Berenicea" of Dr Fleming, but not of Lamouroux, and the name belongs of right to the latter ; the more readily yielded up since we find a "Berenicea" also amongst the Medusæ. Milne-Edwards names the genus "Escharoides," but neither this nor Escharina, another of his names, can be adopted, since some naturalists use the terminations oide and ina as family appellatives. Moreover what saith Linnæus?- "Generic names including other generic names are unworthy of a scientific nomenclature." And again - "Generic names ending in oides are prohibited." See Young's Med. Literature, I. 28. 
Cellepora nitida, Fabr. Faun. Gronl. 435. Bosc, Vers, iii. 148. Lam. Anim. s. Vert. 2de edit. ii. 259. Corall. 38.—Berenicea nitida, Flem. Brit. Anim. 533. ' La B. brillante, Blainv. Actinol. 445.

Hab. On shells, rare, Dr Fleming. In Berwick Bay on Patella cærulea, G. J.

Crust spreading circularly, closely adherent, rather thin, greyishwhite, calcareous ; cells contiguous, in radiating rows, large, subalternate, ovate, ventricose, silvery, the walls fissured with 6 or 7 cross slits which meet on the mesial line; aperture subquadrangular, depressed, terminal ; anterior to it there is often found a globular smooth pearly oviferous operculum with a round even aperture.-C The remarkable structure of the cells renders this one of the most interesting species under the microscope. There is sometimes an appearance of a spine on each side of the lower angle of the mouth, which is merely the commencement of the walls of the next cell.

3. L. COCCINEA, cells ovate, granulous, the aperture with \& short tooth-like process above the superior margin. G. J.

Plate xxxiv. Fig. 1, 2, 3.

Cellepora coccinea, Corall. 40.—Berenicea coccinea, Lam. Anim. s. Vert. 2 de edit. ii. 259. Johnston in Trans. Newc. Soc. ii. 267, pl. 12, fig. 5 .

Hab. On rocks near low water-mark, and on the roots of Laminaria digitata, common on the coast.

The spots formed by this species are often an inch or upwards in. diameter, the crust closely adherent, thin, roughish to the naked eye, generally of a flesh-red or purplish colour, but sometimes pure white. The cells are disposed in adjacent rows, either opposite or subalternate, and lie upon the crust; they are ovate, granulated or froster, and, when dry, sometimes appear to be perforated with minute holes. Above the aperture, and a little removed from the margin, there rises up a blunt white tooth or mucro, but the margin itself is not toothed : the aperture is roundish, emarginated above, terminal, and on each side of many of them, in some specimens, there is a small triangular slit, which seems to be the aperture of an abortive or partially developed cell. Many of the cells are usually covered with a large pearly-white striated operculum.

4. L. VARIOLOSA, crust punctured or sometimes frosted only; the cells immersed, cylindraceous, raised anteriorly, with a plain semioval aperture. G. J.

Plate xxxiv. Fig. 4 .

Hab. On shells and stones in deep water. Scarborough, Mr. Bean. Berwick Bay. 
Crust spreading, rather thick, adherent, even, often roughened in the centre, greyish-white, dull, the space between the cells closely punctured like the end of a thimble; cells immersed, cylindraceous or somewhat ventricose, arranged in regular rows divided by a raised line very obvious in recent specimens, the apertures roundish or semioval, plain or with a small tooth on the upper edge, and in some cells two short blunt teeth are visible on the upper lip. Opercu. la pearly, globular, smooth._-When dry the crust can in some instances be separated from its foreign base in small pieces, but in general it is very firmly adherent, and has a decided tendency to grow in a circular form. In a very fine specimen which Mr Bean submitted to my examination, the space between the cells was not punctured, but merely rough or frosted, which I attribute rather to accident, or to a difference produced in drying, than to any specific character in the zoophyte.

* * Margin of the aperture spinous.

4. L. cILIATA, cells ovato-globose, frosted, the aperture contracted, circular, armed with from 5 to 7 long spines. Pallas.

Plate xxxiv. Fig. 6.

Eschara ciliata, Pall. Elench. 38.—Cellepora ciliata, Lin. Syst. 1286.

Fabric. Faun. Groenl, 434. Bose, Vers, iii. 147. Corall. 41.

Berenicea utriculata, Flem. Br. Arim. 533. Johnston in Trans. Newc. Soc. ii. 268 , pl. 12, fig. 6, (not good.)

$H a b$. On shells and stones from deep water, common.

The crust is always white, sprearling circularly, thin and closely adherent, so that it cannot be removed entire from its foreign base. "The cells appear as unconnected though adjacent," and their apertures look upwards. The aperture is encircled, for about two-thirds of its circumference, with from 5 to 7 spines almost as long as the cell itself, but they are of unequal lengths, and are so easily broken off that it is rare to find them perfect (very often no vestige of them is visible) excepting near the margin of the crust, or when this lies protected by some inequality of the surface which it grows upon.

I have seen many specimens of this species in the form of a calcareous compressed mass hispid on both sides with the teeth of the cells, which were aggregated in a double layer. These masses resemble some specimens of Cellepora pumicosa, or rather of Membranipora pilosa, and are proof that the distinctions between the genera are but of secondary importance, as Blainville has properly remarket. 
5. L. TRISPINOSA, cells radiating from a centre, the aperture armed below with 3 long spines. G. J.

Plate xxxiv. Fig. 5.

Discopora trispinosa, Johnston, in Edin. Phil. Journ. xiii. 222._-Berenicea trispinosa, Jolnston, in Trans. Newc. Soc. ii. 268.

$H a b$. On shells from deep water, rare. Berwick Bay.

Crust thin, circular, adherent, yellowish, or of a silvery white colour with minute yellow dots : cells in rows radiating from the centre, horizontal, immersed, the apertures raised, round, cleft, but not deeply, above, and below armed with three spines of which the middle one is the longest.- The margin of the crust is a thin pellicle marked with the raised lines which are to form the partitions between the future cells.

6. L. IMMERSA, crust spreading irregularly, the cells immorsed with small round apertures, having a tooth on the proximal and several spines on the distal margin. Fleming.

Plate xxxiv. Fig. 8.

Berenicea immersa, Flem. Brit. Anim. 533._-B. flava, Johnston, in Trans.

Newc. Soc. ii. 268._La B. immergée, Blainv. Actinolog. 445.

$H a b$. On stones and shells from deep water, frequent.

Crust rather thick, spreading irregularly, ochre-yellow, or sometimes cream.yellow, roughish and punctured to the naked eye by the apertures of the cells which do not radiate from a centre, though arranged in regular series. They are immersed in the crust so that their divisions are indistinct; the apertures contracted with a tooth on the upper edge and several spines on the lower margin which are very brittle and liable to be broken off, but when entire are longer than the diameter of the cell.

\section{Membranipora,* Blainville.}

Character. Polypidom encrusting, membrano-calcareous, spreading irregularly, formed of a single loyer of alternating approximated cells; cells oval, horizontal, membranous, the aperture patulous with a hard calcareous rim.-Polypes ascidian.

1. M. PILOSA, aperture of the cells with one long hair and several spinous denticles. J. Ellis.

Plate xxxiv. Fig. 10-12.

Irregular spongy foliaceous Coralline, Ellis, Corall. 73, no. 4, pl. 51._-

* From membrana-a thin skin or film, and ropos. 
Eschara pilosi, Pall. Elench. 50._-Flustra pilosa, Lin. Syst. 1301. Mull. Zool. Dan. prod. 253. Ellis and Soland. Zooph. 13. Berk. Syn. i. 214. Turt. Gmel. iv. 663. Werı. Mem. i. 563. Turt. Brit. Faun. 209. Stew. Elem. ii. 436. Bose, Yers, iii. 140. Lam. Anim. s. Vert. ii. 159. 2de edit. ii. 224. Grant in Edin. New Phil. Journ, iii. 111. Flem. Brit. Anim. 537. Hogg's Stock. 36. Risso, L'Europ. Merid. v. 335. Johnston in Trans. Newc. Soc. ii. 265, pl. 9, fig. 5. Lister in Phil. Trans. an. 1834, 3\&4, pl. 12, fig. 2. Templeton in Mag. Nat. Hist. ix. 469._L_La F. pileuse, Blainv. Actinol. 450.

Var. f. The long bristle abortive or destroyed._E Ellis, Corall. pl. 29, fig. D. Ellis in Phil. Trans. abridg. x. 492, pl.,12. fig. 4, D.—Flustra dentata, Ellis and Soland. Zooph. 15. Turt. Gmel. iv. 664. Turt. Brit. Faun. 209. Stew. Elem. ii. 436. Lam. Anim. s. Vert. ii. J58. 2 de cdit. ii. 224. Bosc, Vers, iii. 142. Sturk, Elem. ii. 437. Hogg's Stock. 36. Templeton, loc. s. cit. 469__L La Flustre dentée, Blainv. Actinolog. 450. Membranipora pilosa, Farre in Phil. Trans. an. 1837, 412 , pl. 27, fig. $1-5$.

Hab. On the lesser sea-weeds most abundant, and not uncommonly on old shells.

Polypidom incrusting, membrano-calcareous, irregular, following the shape and form of the objects it grows upon, straw-yellow, thickish, porous, hairy: cells short, somewhat tubulous, with large roundish apertures ossified and toothed on the margin, the teeth short, sharp and rigid, and behind the mouth of each cell there is a very long tubular bristle which issues from a hollow base like a hair from its bulb.-Polypes with 12 tentacula, long in proportion to the body, thick and rather clumsy. Fav'e. "Polypus-tentacula circiter 20, rqualia et corpus æquantia, in campanæ formam expandit." Pal. las.

When the polypidom encrusts the broad-leaved fuci or shells the texture is thinner and the cells more completely developed, and then their surface is perceived to be finely frosted. The small spines of the aperture are omitted in the figure of Ellis; and that referred to for the variety dentata is imperfect and unfinished. Many believe this variety to be distinct in species, and specimens, sufficiently characteristic, can easily be produced in favour of the opinion, which, however, 1 am satisfied is erroneous.

M. pilosa often rises into small sponge-like fronds, cellular and hirsute on each side. "In frondes lubenter assurgit, utrinque cellulosas crassiusculas, spongiosas; primo simplices, lineares, ol,tusas; deinde ramosas; imo pinnato-multifidas fere nunquam pollice longiores." Pallas. 
2. M. SPONGIOSA, aperture of the cells with several long setce. Robert Brown.*

Flustra spongiosa, Templeton, in Mag. Nat. Hist. ix. 469.

Hab, "Found by Robert Brown, Esq. on the coast of Ballycastle," Templeton.

"Allied to the preceeding: the mouths of the cells with several long setæ. In pilosa the mouths of the cells are surrounded by several very short teeth, with only one hair-like appendage. In this species the teeth appear lengthened into long setaceous bristles." Templeton.

* The author of the "Prodromus Flore Novæ Hollandiæ." 
Fig. 46.
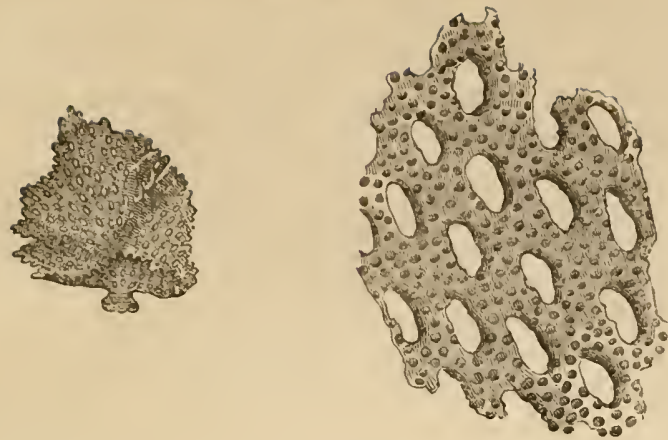

FAMILY XIII. ESCHARIDÆ.

\section{Flustra,* Linnæus.}

Character. Polypidom plant-like, membranaceous, flexile, frondose or crustaceous, formed of cells arranged quincuncially in several series and in one or two layers: cells in juxtaposition, more or less quadrangular, flat, with a distinct border; the aperture transverse, semilunar, valvular, subterminal. $+-P o l y-$ pes ascidian.

* Foliaceous, with cells on both sides.

1. F. FOLIACEA, cells narrow at the proximal and arched at the distal extremity, with scattered marginal denticles.

\section{Plate xxxv. Fig. 1, 2.}

Fucus marinus scruposus albidus telam sericeam textura sua æmulans, Morris. Hist. Plant. iii. 646, tab. 8, fig. 16. (bona.)___Fucus telam lineam sericeamve textura sua æmulaıs, Raii, Syn. 42, no. 9. Jussieu in Mem. Acad. Roy. des. Sc. 1742, 298, pl. 10, fig. 3.__Broad-leaved Hornwrack, Ellis, Corall. 70, no. 2. pl. 29, fig. $a, A$. B, b._Curious sea. weed, Hooke, Microg. 140, pl. 9, fig. 2; and pl. 14, fig. 1.__Eschara foliacea, Lin. Syst. edit. 10, 804. Pall. Elench. 52._-Flustra foliacea, Lin. Syst. 1300. Mull. Zool. Dan. prod. 253. Fabric. Faun. Groenl. 436. Ellis and Soland. Zooph. 12, pl. 2, fig. 8. Berk. Syn. i. 214. Turt. Gmel. iv. 663. Wern. Mem. i. 563. Turt. Brit. Faun.

- From the Saxon Flustrian, to weave : hence Flustra applied by Linneus to these sea-mats.

+ "The aperture of the cells is formed by a simicircular lid, convex externally and concave internally, which folds down when the polypus is about to arlvance from the cell. The opening of this lid in the F. truncata, where it is very long, appears through the microscope like the opening of a snakc's jaws, and the organs by which this motion is effected are not perceptible. The lid of the cells opens and shuts in Flustre, without the slightest perceptible syuchronous motion of the Polypi," Grant in Edin. New Phil. Journ. iii. 339. 
209. Blumenb. Man. 272. Stew. Elem. ii. 435. Corall. 44. Lam. Anim. s. vert. ii. 156. 2de edit. ii. 219. Grant in Edin. New Phil. Jonrn. ii. 111 and 337. Flem. Brit. Anim. 535. Hogg's Stock. 56. Stark, Elem. ii. 437. Johnston in Trans. Newc. Soc. ii. 263. Mag. Nat. Hist. iii. 483, fig. 120. Templeton in Ibid. ix. 469. Risso, L'Europ. merid. v. 333.—La Flustre foliacée, Blainv. Actinolog. 450, pl. 75 , fig. 1 .

Hab. Common on hard ground, in a few fathoms water.

Polypidom corneous, frondose, arising from a spreading base with a single plane of cells, about 4 inclies high, of a uniform wood-brown colour, thickish, deeply divided into numerous broad segments generally somewhat narrowed at their origin, often bifid or trifid, sometimes palmate near the apex which is slightly rounded; the surface roughish, minutely reticulated : cells small, in semialternating rows, narrow at the base, dilated and arched at the top, the superior margin armed with four stout conical processes shorter than the diameter of the cell. The top of the cells is sometinies covered with a small hollow globular pearly operculım opening downwards.

The segments vary very much in lireadth, but are rarely, if ever, proliferous. "Varietas vulgatior frondibus latiusculis, dilatatis, extremitate lata laciniosa. Rarior frondibus longis atque angustis. Perrara extremis frondium angustiorum latis et palmatis, Rarissima subpiunatis aut latissimis margineque tantum divisis frondibus." Pallas._Hooke, in his celebrated "Hicrographia," says, "for curiosity and beauty, I have not among all the plants or vegetables I have yet observed, seen any one comparable to this sea-weed." When recent it exhales a pleasant scent, which Pallas compares to that of the orange, Dr Grant to that of violets, and which a friend tells me smells to him likea mixture of theodour of roses and geranium.

\section{F. CHARTACEA, "cells slightly enlarged distally; margins} smooth." J. Ellis.

Eschara papyracea utrinque cellefera, summitatilous securis aciei instar truncatis, Ellis, Corall. pl. 38, fig. 8._Flustra papyracea, Ellis and Soland. Zooph. 13. Flem. Brit. Anim. 535. Lister in Plil. Trans. an. 1834, 384, pl. 12, flg. 3. Edwards in Lam. Anim. s. Vert. 2de edit. ii. 220. —La F. papyracée, Blainv. Actinolog. 451._-F. chartacea, Turt. Gmel. iv. 663. Turt. Brit. Fauı. 209. Stew. Elem. ii. 436. Bosc, Vers, iii. 141. Corall. 45. Risso, L'Europ. Merid, v. 333.

Hab. Coast of Sussex, Ellis. Brighton, Lister.

"The cells of this sea mat are of an oblong square figure, swelling out a little in the middle of each side. The openings of the cells are defended by a helmet-like figure; from hence the polype-shaped suckers extend themselves. This sea mat is of a slender and deli. cate texture, like thin semitransparent paper, of a very light straw 
colour._ It was first found on the coast of Sussex, adhering to a shell. I have since met, on the same coast, about Hastings, in the year 1765, with several specimens, whose tops were digitated, and other's that were very irregularly divided." Ellis.

As this is very certainly distinct from the F. papyracea of Linnæus, I have preferred the name of Gmelin. Dr Fleming seems inclined to consider the species as a variety of the preceding. For my own part I know not how it is to be distinguished from that which follows.

3. F. TRUncata, cells linear-oblong, with smooth margins.

Plate xxxv. Fig. 3, 4.

Fucus marinus scruposus albidus angustior compressus, extı emitatibus quasi abscissis, Raii, Syn. 43, no. 10 . Morris. Hist. Plant. Oxol1. iii. 646, tab. 8, fig. 17, opt.— Narrow leaved Hornwrack, Ellis, Coral. 69, no. 1, tab. 28, fig. 1, a. A, B.—_ Eschara foliacea $\beta$, Lin. Syst. edit. 10, 804 . -E. securifrons, Pall. Elench. 56.—- Flustra truncata, Lin. Syst. 1300. Mull. Zool. Dan. prod. 253. Ellis and Soland. Zoopl. 11. Berk. Syn. i. 214. Turt. Gmel. iv. 663. Wern. Mem. i. 563. Turt. Brit. Faun. 209. Stew. Elem. ii. 436. Lam. Anim. s. Vert. ii. 157. 2de edit. ii 219. Corall. 44. Bosc, Vers, iii. 140. pl. 30, fig. 1. Risso, L'Europ. Mend. v. 334. Grant. in loc. cit. 111 . Flem. Brit. Anim. 535. Hogg's Stock. 36. Johnston in Trans. Newc. Soc. ii. 264. pl. 12, fig. 1. Templeton in M.ag. Nat. Hist. ix. 469.—La Flustre tronquée, Bluinv. Actinolog. 450

IIab. In deep water, very common.

Attains a height of four or five inches, very bushy, of a straw-co. lour, smooth, varnished when dry, rather thin in texture, originating from a matted base formed of capillary fibres, which, by their union, compose a short stem that divides, after a dichotomous manner, into numerons flat narrowish segments, either linear or dilated upwards. From the edges of these there often sprout out wedgeshaped leaflets, affixed by a small pedicle, simple at first, but afterwards deeply bifid: the ends of all the segments are abruptly truncate. Cells linear-oblong, their septa unarmed, usually marked with a black dot towards the centre, which seems to be the remains of the shrivelled polype, and at some seasons covered with a hood-like operculum.

* Foliaceous, with cells on one side only.

4. F. CARBASEA, cells oblong, narrouced and truncate below, the margin toothless. Dr Skene.

Plate xxxvi. Fig. I, 2.

Flustra carbasea, Ellis and Soland. Zooph. 14, pl. 3, fig. 6, 7. Turt. Gmel. iv. 663. Wern. Mem. i. 563. Turt. Brit. Faun. 209. Stew. Elem. ii. 436. Lam. Anim. s. Vert. ii. 157. 2de edit. ii. 221. Bosc, 
Vers, iii. 141. Corall. 45. Flem. Brit. Anim. 535. Hogg's Stock. 36. Grant in Edin. New Phil. Journ. iii, 111. Stark, Elem. ii. 437. Joln ston in Trans. Newc. Soc. ii. 264, pl. 9, fig. 4 . Templeton ut. sup. cit. 469. Roget, Bridgew. Treat. i. 165, fig. 63, 64 ; and 172, fig. 69, 70. Dalyell in Edin. New Phil. Journ. xvii. 413; and in Rep. Brit. Assoc. an. 1834, 603._L_La F. voile, Blainv. Actinolog. 451.

Hab. On shells from deep water. From Aberdeen, Skene. Leith shore, Mr Parsons. Not unfrequent at Seaton, Hartlepool, Whitburn, and other places on the coast of Durham, J. Hogg. Coast of Berwickshire, not uncommon, $G$. J. Ireland, Templeton.

Polypidom frondose, fixed by a small disk, narrow at the base with thickened margins, dilating upwards and becoming very broad in proportion to the height, which at most is about two inches, thin, yellowish brown, deeply divided, the segments broad and somewhat rounded on the apex. Cells on one side only, large, and smooth. Polypes with about 22 tentacula, which are " nearly a third of the length of the body, and there appear to be about 50 ciliz on each side of a tentaculum, making 2200 cilia on each polypus. In this species there are more than 18 cells in a square line, or 1800 in a square inch of surface, and the branches of an ordinary specimen present about 10 square inches of surface; so that a common specimen of the F. carbasea presents more than 18,000 polypi, 396,000 tentacula, and $39,600,000$ ciliæ." Grant.

5. F. SETACEA, cells in 2 or 3 rows, oval, with a setaceous bristle. Rev. Dr Fleming.

Elustra Ellisii, Fleming in Wern. Mem. ii. 25l, pl. 17, fig. 1-3.- F. setacea, Flem. Brit. Auim. 536.__La F. setacée, Blainv. Actinolog. 451.

Hab. "Along with Cellepora cervicornis, from deep water, Zetland," Dr. Fleming.

"Height nearly two inches; branches linear, not the tenth of an inch in diameter; substance firm, brittle; the base consists of small tubes, which by their union, form the branches, dorsally carinated by the union of the tuhes, which, diverging to each side and dividing form two denticles and a long bristle, the latter serrated on one side ; cells oblique." Dr Fleming.

6. F. Avicui.ARIS, cells in 4 or five rows, oblong, with a strony conical spine at each side of the aperture. J. Ellis.

Plate xxxvi. Fig. 3, 4.

Corallina cum appendiculis lateralibus avium capitum forma, Ellis, Corall. pl. 38, fig. 7.—Cellularia avicularia $\beta$, Pall. Elench. 68.—Flustra avieularis, Soverby Brit. Mise. ii. 21. pl. 71. Turt. Brit. Faun. 210. Flem. Brit. Anim. 536. Johnston in Trans. Newc. Soc. ii. 265._L La 
F. avieulaire, Blainv. Actinolog. 451.—F. angustiloba, Lam. Anim.

s. Vert. ii. 158. 2de edit. ii. 222.__ F. capitata, Hogg's Stock. 36. Crisia flustroides, Lamour. Corall. Flex. 141. Corall. 61.

Hab. Attached to other colallines and old shells in deep water. Torbay, Dr Coldstream. Cullercoats, Northumberland, Mr Alder. Berwick Bay, G.J. Cork harbour, J. V. Thompson.

Usually about an inch in height, cæspitose and fan-like, or spread out circularly, of a cinereous colour, membrano-calcareous, brittle when dry, deeply divided in a dicliotomous manner into narrow thin plane segments, truncate at the end, formed of four or five series of oblong cells, capped with a hollow globose pearly operculum seated between the spines, of which there is one on each side of the circular aperture. The opercula are so nimmerous that they give to the upper surface the appearance of being thickly strewn with orient pearls: the under surface is even and longitudinally striated, the number of strix corresponding to the number of rows in which the cells are disposed.

7. F. MURRAYANA, cells multiserial, ovate, the margin armed with 6 or 8 spines shorter than the diameter of the cell. $\mathrm{Mr}$ Bean. Plate xxxvi. Fig. 5, 6.

Flustra Murrayana, Bean, MSS. named "after Dr Murray, a scientific and zealous naturalist of Scarborough."

$H a b$. In deep water. Scarbolough, very rare, $\boldsymbol{M r}$ Bean.

This pretty species grows in entangled spreading masses which are rooted to the object of attachment by numerous long thread-like tubular fibres, wrinkled when dry, and apparently always pullulating from the side or inferior surface of a marginal cell. Polypidom scarcely an inch in height, of a light colour and thin membranous texture, dichotomous, spreading, the segments plane, narrow wedgeshaped, truncate, the upper surface roughish with the cells, which are disposed in the usual quincuncial manner, but are more elevated than in any other species; the under surface glistening, striate : cells unilateral, so large that their figure is perceptible to the naked eye, ovate, truncate above with a short hollow spinule at each angle, and there are from 4 to 6 rather longer spinules protecting the margin of the elliptical aperture.-I have seen only Mr Bean's fine specimen, which is accurately delineated in our figure. The species is very distinct from any hitherto described.

** Crustaceous.

8. F. MEMBRANACEA, cells oblong, with a short llunt spine at. each corner. J. Ellis.

Plate xxxvii. Fig. 1, 2, 3. 
Flustra membranacea, Lin. Syst. 1301. Fabric Faun. Groenl. 437, no. 446. Mull. Zool. Dan. prod. 253. Ellis and Soland. Zooph. 18. Turt. Gmel. iv. 665. Wern. Mem. i. 563. Turt. Brit. Faun. 2]C. Stew. Elem. ii. 437. Bosc, Vers, iii. 144. Corall. 47. Hogg's Stock. 36. Flem. Brit. Anim. 536. Johnston in Trans. Newc. Soc. ii. 265. La F. membraneuse, Blainv. Actinol. 450._-Fl. telacea, Lam. Anim. s. vert. 2 de edit. ii. 223. Grant in loc. s. cit. iii. 111._La membranipore membraneuse, Blainv. Actinol. 447.

$H a b$. On the frond of Laminaria digitata: common.

Polypidom forming a gauze-like incrustation on the frond of the sea-weed, spreading irregularly to the extent of several square inches, in general, thin, and closely adherent, but sometimes becoming thickish, and then capable of being detached in considerable portions ; cells very obvious to the naked eye, oblong, quadrangular with a blunt hollow spine at each angle. In many specimens there are some anomalous processes, a quarter of an inch in height, scattered over the sur. face : they arise from within the cells, are simple, borny and tubular, but closed at top. Ellis conjectured they were ovaries, but the conjecture is certainly unfounded. - When the polypes are all protruded they form a beautiful object under the microscope, from their numbers, their delicacy, the regularity of their disposition, and the vivacity of their motions, now expanding their tentacula into a beautiful campanulate figure, now contracting the circle, and ever and anon retreating within the shelter of their cells. The tentacula are numerous, filiform, white and in a single series.

9. F. LINEATA, cells oval, separate, the margin armed with several short equal spinous denticles. Professor Jameson.

Plate xxxvii. Fig. 4.

Flustra lineata, Lin. Syst. 1301. Mull. Zool. Dan. prod. 253. Fabric. Faun. Groenl. 437. Turt. Gmel. iv. 665. Corall. 46. Jameson in Wern. Mem. i. 563.—La F. linéée, Blainv. Actinol. 450.—_F. spinifera, Johnston in Trans. Newc. Soc. ii. 266, pl. 9, fig. 6._-F. hirta? Bosc, Vers, iii. 144. Risso, L'Europ. Merid. v. 334. Corall. 49.

$H a b$. On stones at low-water mark in Berwick Bay, G. J. Orkney Islands, Jameson.

Polypidom membranous, of a horny texture, yellowish-brown, rough, closely adnate, thin, sprearling irregularly : cells scarcely visible to the eye, separate hy a space not equal to the cell in breadth, the marginal teeth stout and somewhat inclined inwards.

10. F.? CARnOSA, "substance fleshy; cells remote, aperture contracted, armed at the top with spmous processes." Jameson. Plate xxxvii. Hig. 5. 
Flustra hispida, Fabric. Faun. Groenl. 438 Jameson in Wern. Men. i. 563. Flem. Brit. Anim. 537. Jolnston in Trans. Newc. Soc. ii. 266, pl. 9, fig. 7._La F. hispide, Blainv. Actinolog. 450.

$H a b$. "Investing Fucus serratus; everywhere common," Fleming. Leith shore, Jameson. Berwick Bay, at low water mark.

"Substance thick, tough, full of mucus, brown; base of the cells, where attached, contiguous and angular; at the surface the cells are ovate, the aperture lunate. Polypi with an enlarged head, and from 20 to 30 tentacula," Fleming.-As the Flustra hispida of Pallas is unquestionably a different species, it has become necessary to adopt another specific name.

11. F. TUBERCULATA, membrano-calcareous; cells oval with two short spines at the sides of the aperture and one above it. Fleming.

Plate xxxiv. Fig. 9.

Flustra tuberculata? Bosc, Vers, iii. 143._" F. dentata? Mull. Zool. Dan. iii. tab. 95, fig. 1, 2."___ unicornís ? Fleming, in Edin. Phil. Journ. ii. 87. Flem. Brit. Anim. 536. Johnston, in Trans. Newc. Soc. ii. 266. Fl. memtranacea? Lam. Anim. s. Vert. 2de edit. ii. 225. Le Membranipore unicorne? Blainv. Actinolog. 447.—-La Flustre uni. corne, Ibid. 450.

Hab. On stones within low water-mark, Fleming. Frequent in Berwick Bay.

Polypidom in the form of a thin closely adherent greyish-white subcalcareous crust, reticulated like a piece of gauze to the naked eye, spreading circularly : cells quincuncial, short, oval, with a large ovate aperture armed with two short spinous teeth inclined inwards, the margin somewhat thickened: in the space between the cells and above the aperture there is a conical process which appears to be perforated on the top.

This is more calcareous in its texture than any of the preceding species, and herice assumes a white colour when dried. When perfect and young, the denticles to the aperture are very evident, (Fig. $a$ ), but in old or exposed specimens no vestige of them can be discovered. (Fig. b.) At one time I had nearly concluded that these specimens belonged to different species, but the timely possession of a perfect polypidom prevented the commission of the error, for in it the cells towards the margin have all the characters of $\alpha$, and those near the centre the character of $b$. I have not seen Muller's figure, but the description of F. tuberculata given by Bosc agrees with the the first state of the species; and it appears to be probable that on the second state is founded the F. unicornis of Fleming. 
Flustra arenosa, Ellis and Soland. Zooph. 17. Stew. Elem. ii. 437. Bosc, Vers, iii. 142._Millepora arenosa anglica, Raii, Syn. i. 31.— English Sandy Millepore, Ellis, Corall. 74, no. 5, pl. 25, fig. e.Eschara lutosa, Pall. Elench. 37. Alcyonium arenosum, Turt. Gmel. iv. 564. Turt. Brit. Faun. 207._According to Mr Boys this "is un . doubtedly the nidus of some marine animal, as I bave found the cells entire, with eggs in each." Lin. Trans. v. 231. Mr J. Hogg bas proved that it is the nidus of Nerita monilifera. Lin. Trans. xiv. 318, \&c.

\section{Cellularia, ${ }^{*}$ Pallas.}

Character. Polypidom calcareous or membrano-calcareous, confervoid, divided subdichotomously, the divisions narrow, composed of two alternating series of oblong sessile cells on a single plane; the apertures terminal, oblique, facing one way, and usually covered with an operculum.-Polypes ascidian.

1. C. ciliata, erect, dichotomous; cells alternate, turbinate, with an oblique open aperture armed on the outer edge with 4 or 5 long spines.-Ellis.

Plate xxxviii. Fig. 1-2.

Ciliated Coralline, Ellis, Corall. 38, no. 5, plate 20, d, D._-_. Sertularia ciliata, Lin. Syst. 1316. Berk. Syn. i. 220. Turt. Gmel. iv. 685. Turt. Brit. Faun. 217. Wern. Mem. i. 565. Stew. Elem. ii. 448.—Cellılaria ciliata, Pall. Elench. 74. Flem. Brit. Anim. 540. Hogg's Stock. 35._-Cellaria ciliata, Ellis and Soland. Zooph. 24. Bosc, Vers, iii. 133. Lam. Anim. s. Vert. ii. 139. 2de edit. ii. 186.—Crisia ciliata, Corall. 60. Templeton in Mag. Nat. Hist. ix. 468._-La Bicellaire eiliée, Blainv. Actinolog. 459.

$H a b$. Parasitical on corallines and the roots of Fuci, not uncommon. "Mare Anglicum; ubi, in Fucis, Spongiis, Sertulariis, parasitica crescit," Pallas. Leith shore, Jameson. Scarborough, Mr. Bean. Rare on the coast of Berwickshire, G. J. "Found on Fucus siliquosus, and on other corallines" in Ireland, Templeton.

Tufted, abont half an inch in height, very slender and delicate, hispid, pellucid white, calcareous, dichotomously branched. The cells are rather widely alternate, turbinate, with the apertures everted, patnlous, and armed with long spines which are apt to be broken off. The spines appear to be tubular. A sacate pearly lid covers the month of many cells; and at or near the base there is, on some of them, a small anomalous appendage something like a bird's head. The pellucidity and delicacy of this species, with its pearly lids scat-

* From cellula, diminutive of cella, a cell. 
tered over the branches, render it a remarkably beautiful object under the microscope.

2. C. SCRUPOSA, creeping, dichotomous; cells alternate with a plain aperture, "an angle projecting on the outwurd side of each." Ellis.

Plate xxxviii. Fig 5, 6.

Creeping stony Coralline, Ellis, Corall. 38, no. 4. pl. 20,c, C._Celliferous Coralline with angular edges to its cells, Ellis, in Phil. Trans. xlviii. pl. 13, no. 7. Phil. Trans. abridg. x. 493 , pl. 12 , fig. $7, K, L$._- Sertularia scruposa, Lin. Syst. 1315. Turt. Gmel. iv. 686 . Berk. Syn. i. 220. Turt. Brit. Faun. 216. Wern. Mem. j. 565. Stew. Elem. ii. 448. Cellnlaria scruposa, Pall. Elench. 72. Flem. Brit. Anim. 539._- Cellaria scruposa, Ellis and Solund. Zooph. 23. Bosc, Vers, jii. J32, pl. 29, fig. 7. Lam. Anim. s. Vert. ii. 141. 2de edit. ii. 192. Johnston ju Trans. Newc. Soc. ii. 261, pl. 11, fig. 5._C Crisia scruposa, Corall. Templeton in lib. cit. ix. 469._La. B. raboteuse, Blainv. Actinolog. 459.

Hab. On the roots of Laminaria digitata, on Flustræ, corallines and old shells, common.

This frequently covers a space about an inch square, the branches diverging and creeping along the surface or the entangled roots of sea-weed, to which they are attached by simple tubulous root-like fibres pullulating from the plane inferior surface. The branches are rather broad, dichotomous, of an earthy brown colour, hrittle when dry. Within the cells I have occasionally seen one, or sometimes two, nearly globular orange-coloured ova.

3. C. REPTANS, creeping, dichotomous; cells alternate with an oblique aperture armed with short spines at the top.-Ellis.

Plate xxxviii. Fig. 3-4.

Creeping Coralline, Ellis, Corall. 37, pl. 20, no. 3, fig. b. B. - Sertularia reptans, Lin. Syst. 1315. Fabric. Faun. Grœnl. 445, no. 459. Turt. Gmel. ir. 685. Turt. Brit. Fann. 217. Steu. Elem. ii. 448._S. repens, Berk. Syn. i. 220.—Cellularia reptans, Pall. Elench. 73. Flem. Brit. Anim. 540. Hogg's Stock. 35._Cellaria reptans, Ellis and Soland. Zooph. 23. Bosc, Vers, iii. 132. Lam. Anim. s. Vert. ii. 141. 2de Edit. ii. 191. Stark, Elem. ij. 439. Johnston in Trans. Newc. Soc. ii. 262._Crisia reptans, Coral. 60. Risso, l'Europ. Merid. ․ 318. Templeton in Mag. Nat. Hist. ix. 469.-La Bicellaire rampante, Blainv. Actinol. 459.

Hab. On Flustra foliacea and other submarine bodies, common.

Similar to the preceding in form and mode of growth, but its spreading tufts cover in general a larger space, and are more densely matted: 
The radical tubes are flexuous, corneous, and divided at the extremity into two or three small knob-like processes. Branches linear, plane, jointed at their origins, composed of two rows of semialternate oval cells, with an oblique terminal aperture level with the surface, and armed with several short brittle spines. Ellis represents only two spines to each cell, and Pallas follows him in his description, but they are commonly more numerous. Stretched across the mouth of the cells there may occasionally be observed, in dried specimens, an irregularly veined pellucid membrane, undoubtedly the remains of the polype's sac or tunic. Opercula are also to be seen over some cells, but these are not common.

\section{C.? Avicularia, erect, dichotomous; the cells with two} spines at the aperture. Ellis.

\section{Plate xxxvi. Fig. 7, 8.}

Bird's-head Coralline, Ellis. Corall. 36, no. 2, pl. 20, fig. a, A. Cellularia avicularia, Pall. Elench. 68. Hogg's Stock. 35. Sertularia avicularia, Lin. Syst. 1315. Berk. Syn. i. 220. Wer1. Mem. j. 565. Turt. Brit. Faun. 216. Stew. Elem. ii. 448. Cellaria avicularia, Ellis and Soland. Zooph. 22. Bosc, Vers, iii. 131. Lam. Anim. s. Vert. ii. 141. 2de edit. ii. 191. Johnston in Trans. Newc. Soc. ii. 262._-Crisia avicularia, Lamour. Cor. Flex. 141. Corall. 61. Templeton, in Mag. Nat. Hist. ix. 468.

Hab. Parasitical on other corallines in deep water. From the sea-coast near Dublin, Ellis. "Mare inter Angliam et continentem terram," Pallas. Not very uncommon at Hartlepool, J. Hogg. Leith shore, not common, Jameson. Scarborough, on stones \&c. at low water, not urrommon, $M r$ Bean. Ireland, Templeton.

Polypidom caulescent, erect, bushy, from one to two inches in height, membrano-calcareous, silvery or glassy greyish-white, brittle when dry, attached by a fibrous root, the stalk composed of numerous interwoven fibres; primary branches alternate, flabellate, divided dichotomously into many narrow linear flat segments, which are rough and cellular on the upper or inner side, but smooth and longitudinally striate underneath. Cells in two semialternating rows, coalescent, opening on one plane, oblong, flat, their parietes thin and pellucid, a strong spine at each of the superior angles, the aperture subterminal, transverse, generally covered with a large globular pearly operculum placed between the spines; and at the external side there is in many a curious appendage which Ellis has aptly com. pared to a "bird's head, with a crooked heak, opening very wide." These appendages, of unknown use, are about one fourth the size of the cell, and, when the coralline is in a living state, are continually 
moved upwards and downwards with the regularity of a peridulum. The polypes have apparently twelve tentacula.

The cells have the characters of Acamarchis or Flustra rather than of Cellularia. Many naturalists make the zooplyyte a variety of Flustra avicularia, but Mr Bean and Milne Edwards dissent from this association. The principal distinction between them lies in the dissimilarity of their habit : in the shape of the cells I do not perceive auy noticeable difference, but in this I have never seen more than two spines at the top of each cell, while in the Flustra I have seen four on some cells, though certainly many of them are armed with two only.

5. C. HоокеRI, "cells rounded, diverging, projecting."-Sir W. J. Hooker.

Cellularia Hookeri, Flem. Brit. Anim. 539.__La Bicellaire de Hooker, Blainv. Actinol. 460.

Hab. "Found by Dr Hooker at Torquay, 1812," Fleming.

" Heighth upwards of an inch, dichotomously branched, branches straight, stiff, brittle, divaricate; the cells are protuberant dorsally, and their rounded top is nearly free, projecting laterally, giving the edge a remarkably jagged outline, and the pearly ovaria are rounded." Fleming.-This is probably syonymous with Cellaria denticulata of Lamarck, Anim. s. vert. ii. 137.

\section{ACAMARCHis, * Lamouroux.}

Character. Polypidom plant-like, subcalcareous, attached by fibrous radicles, bushy, dichotomously branched, the branches composed of a double series of semialternate oblong cells whose apertures occupy nearly one side and face one voay, usually protected by an operculum.-Polypes ascidian.

1. A. NERITINA, "cells quadrangular, lengthened, with a truncated summit, the outer angle projecting." - Miss Blackburne. Remarkable Coralline, Ellis in Phil. Trans, abridg. x. 345 , pl. 8, fig. $a, A$. - G. Ellis, Corall. 35, pl. 19.__ Sertularia neritina, Lin. Syst. 1315. Turt. Gmel. iv. 685. Stew. Elem. ii. 448._-Cellularia neritina, Pall. Elench. 67. Flem. Brit. Anim. 539.—Cellaria neritina, Ellis and Soland. Zooph. 22. Bosc, Vers, iii. 131. Lam. Anim. s. vert ii. 140. 2 de edit. ii. 190_-Acamarchis neritina, Corall. 58, pl. 3, fig. 2. Risso, l'Europ. Merid. v. 318. Blainv. Actinolog. 459, pl. 77, fig. 3. Templeton in Mlag. Nat. Hist. ix. 469.

Hab. On the English coast, very rare. "I possess a specimen

- The name of one of the daughters of Oceanus. 
from the collection of the late Dr Walker, which he received from Miss Blackburne from the coast of Cheshire," Fleming. "Found in Dublin Bay and Belfast Lough," Templeton.

"Height several inches, dichotomonsly divided, spreading; the cells are narrow, rather diverging, and more than the half of the outer summit is free; the pearly helmet-shaped ovaria opening transversely, were at one time considered by Ellis as the young of Neritæ." Fleming.

2. A. PLUmos , cells linear-oblong, with a spine at the outer and upper angle; the aperture elliptical, entire. Doody.

\section{Plate xxxix.}

Corallina pumila erecta ramosior, Raii, Syn. i. 37 , no. 20 , tab. 2 , fig. 1 . Ellis, in Phil. Trans. abridg. x. 346 , pl. 8, fig. $b, B-D$. _- Soft feathered coralline, Ellis, Corall. 33, no. 1, pl. 18, fig. a, A.——Sertularia fastigiata, Lin. Syst. 1314. Fabric. Faun. Grœenl. 445. Turt. Gmel. iv. 684. Berk. Syn. i. 219. Turt. Brit. Faun. 216. Wern. Mem. i. 565. Stew. Elem. ii. 448.—Cellularia plumosa, Pall. Elench. 66. Hogg's Stock. 35._C C. fastigiata, Blumenb. Man. 273. Flem. Brit. Anim. 539._C Cellaria plumosa, Ellis and Soland. Zooph. 21. Bosc, Vers, iii. 131. Lam. Anim. s. Vert. ii. 140. 2de edit. ii. 190.--Crisia plumosa, Corall. 62.—C. fastigiata, Templeton in Mag. Nat. Hist. ix. 468. La Bicellaire plumeuse, Blainv. Actinolog. 459.

$H a b$. "Not uncommon beyond low water-mark," Fleming. Leith shore, Jameson. In deep water at Scarborough, common, Mr Bean. Rare in Berwick Bay, G.J. "Common on the coast" of Ireland, Templeton.

Polypidom attached by fibrous roots, subcalcareous, caulescent, erect, from 2 to 4 inches high, very much branched, the branches panicled, dichotomous, with linear or filiform segments; cells oblong with a short pointed spine on the superior outer angle, smooth, pellucid or somewhat crystalline, marked always with a black or orangecolonred dot near the centre, the remains of the dried polype; ovaries pearly, globular or pear-shaped, placed over the apertures.

In habit this fine species is sometimes like Sertularia argentea, but in general it is more tufted and bushy. Specimens occur without all ovary on any cell, while others are loaded with them; and in one of the latter sort I found some of the segments of the branches composed of a triple series of cells. The whole polypidom is often coloured of a pink or purplish hue. In an old condition the cells become obsolete, and the habit of the species so altered, as to render its detection in this guise somewhat difficult to the inexperienced.

Dr Fleming cioes not adopt this genus, which Blainville is also of 
opinion differs too little from Cellularia to be admitted. There is certainly much sameness in the characters of these genera, but there is a recognizable difference in the form of the cells, more particularly in the aperture, liker in Acamarchis to that of Flustra than of Cellularia, which warrants us in laying hold of it as a line of separation in a case where the dissimilarity in habit is very obvious. The agreement in this respect between the species seems no less patent, although it has not been hitherto perceived.

\section{Farcinia, * Fleming.}

Character.-Polypidom rooted, plant-like, calcarıo's, dichotomous; the branches cylindrical, regularly jointed, with immersed rhomboidal cells diverging from the axis, disposed in quincunx, and opening on the surface; the apertures lateral, plain, non-operculate.

1. F. SALICORNIA, articulations nearly cylindrical; the cells rhomboidal, plain.

Plate xxxvii. Fig. 6, 7.

Corallina fistulosa fragilis, Raii, Hist. i. 65.—Corallina fistulosa fragilis, iuternodiis prælongis lævibus, albis, farciminum modo catenatis, Pluken. Phytog. pl. 26, fig. 2.___Bugle Coralline, Ellis, Corall. 46, no. 1, pl. 23. —Eschara fistulosa, Jin. Syst. edit. 10, 804.—-Tubularia fistulosa, Lin. Syst. 1302. Berk. Syn. i. 214. Turt. Gmel. iv. 666. Turt. Brit. Faun. 210. Stew. Elem. ii. 438. Cellularia Salicomia, Pall. Elench. 61.-Cellularia farciminoides, Ellis and Soland. Zooph. 26. -C. salicornia, Lam. Anim. s. Vert. ii. 135. 2de edit. ii. 176. Stark, Elem. ii. 439. Bosc, Vers, iii. 129, pl. 28, fig. 6, Corall. 55. Lamour. Zooph. 5. Risso, L'Europ. merid. v. 317.—La Cellaire salicorne, Blainv. Actinol. 455, pl. 77, fig. 1.—_- Farcimia fistulosa, Flem. Brit. Anim. 534. Johnston in Trans. Newc. Soc. ii. 266._- Salicorniaria fistulosa, Templeton in Mag. Nat. Hist. ix. 469._- Isis hippuris? Fabric. Faun. Grœenl. 427.

$H a b$. On corallines and old shells from deep water, not uncommon. Torquay, Dr Coldstream. Cullercoats, Northumberland, Mr Jos. Alder. Dunstanborough, Mr Embleton. Coast of North Durham and Berwickshire, occasionally, G.J.

One of the finest of British zoophytes. Polypidom from 1 to 3 inches high, white, calcareous, fibrous at the base, erect, regularly dichotomous; branches erecto-patent, straight; joints constricted,

* From Farcimen-a sausage, in allusion to the manner in which the internodes are joined. The genus is synonymous with the Cellaria of Lamouroux, and with the Salicornaria of Cuvier, Reg. Anim. iii. 303. 
often blackish and emitting fibrous radicals; the intervening spaces long, cylindrical, frequently swollen near the upper end, covered all round with lozenge-shaped immersed cells, disposed in quincunx, and radiating from the centre.

In a weak mixture of muriatic acid and water, the calcareous portion of the polypidom is entirely removed without any other alteration in its form and structure, and we learn from the experiment that the joints are connected together by capillary corneous tuhes, equal in number to the series of cells. These tubes cannot be traced through the immediate spaces, but from the circumstance of their being hollow, it seems not unreasonable to infer that they may naturally be filled with an irritable pulp, and be the medium of communication between the cells and polypes of the different interspaces. The branches are not tubulous or fistular, as Blainville has properly remarked; whence the impropriety of the Linnæan trivial name, the retention of which only tends to the perpetuation of error.

Under this species Pallas has the following interesting observation: "Celerrime hanc Cellulariam crescere, saltem celerius embryone Squali, docuerunt ova Squali Promontorio merid. Africes allata, in quibus plăintulas plures semipollicares observavi, quanquam fœtum adhuc immaturum continerent."

\section{Retepora, * Lamarck.}

Char.cter.-Coral foliaceous, stony, fragile, netted: cells opening only on the upper or inner side, short and not prominent. -Polypes ascidian.

1. R. RETICULATA, polypidom latticed, wavy and convolute, the upper side warty and very porous. Rev. William Borlasse.

Mlillepora retepora, Borl. Cornw. 240 , pl. 24, fig. 8._-Millepora reticulata, Lin. Syst. 1284. Fabric. Faun. Grœnl. 433. Ellis and Soland. Zooph. 138._M. frondipora, Pall. Elench. 241._-Retepora reticulata, Lam. Anim. s. Vert. ii. 182. 2de edit. ii. 275. Risso, L'Europ. Merid. v. 343. Flem. Brit. Anim. 531. Stark, Elem. ii. 435.—Rétépore reticulée, Blainv. Actinolog. 633.___Frondipore réticulé. Ibid. 406 , pl. 69, fig. 1.

Hab. Deep water, rare. Cornwall, Borlasse.

" Expanding to the extent of 2 or 3 inches; more or less cupshaped, waved, uniting; the lobes are oval, regular, the intervening spaces supporting two or three pores in oblique rows. 'This species

"From Rete and $\pi \circ \xi \circ$, i. c. al " a porous net-work." 
is very distinct from the R. cellulosa, with which it has been confounded." Fleming.

2. R. Cellulosa, polypidom retivulated, umbilicate, funnelshaped, wavy, celluliferous on the inner side; the pedicle short, subtubular. Ellis.

Vignette No. 46 , page 283.

Retepora eschara marina, Fer. Imperal. Hist. Nat. 630, c. fig. Ellis, Corall. 72, pl. 25, fig. $d, D, F$.__ Millepora retepora, Pall. Elench. 243._M. cellulosa, Lin. Syst. 1284. Turt. Gmel. iv. 637. Turt. Brit. Faun. 205. Jameson in Wern. Mem. i. 560. Stew. Elem. ii. 427. Bosc, Vers, ii. 343, pl. 25, fig. 5. Cavol. Polyp. mar. 73, tav. 3, fig. 12-14. Blumenb. Man. 270.-M. foraminosa, Ellis and Soland. Zooph. 138. j). 26, fig. 2.——-Retepora cellulosa, Lam. Anim. s. Vert. ii. 182. 2de edit. ii. 276. Stark, Elem. ii. 435. Risso, L'Europ. Merid. v. 343. Johnston in Mag. Nat. Hist. vii. 638, fig. 69.—L La Retejore dentelle de mer, Blainv. Actinolog. 433, pl. 76, fig. I.

$H a b$. Deep water, rare. Shetland islands, and in the island of Fulah, Jameson. Scarborough, Mr. Bean.

Polypidom about an inch in height, affixed by a hollow, thick, and very short stalk, which expands into a shallow cup with unequal waved and sinuous margins; pure white, calcareous and beautifully reticulated, the meshes about a line in length, oval, subequal, regular and divided by celluliferous spaces, rather wider than their own shortcst diameter; the cells immersed, quincuncial, leaning, with the apertures looking upwards, a little prominent, round, with a small tooth on the distal edge; they open only on the superior or inner aspect, for the under surface of the polypidom is imperforate and almost. smooth.

\section{Eschara, * Ray.}

Character. - Polypidom membrano-calcareous, inflexible, brittle, expanding in the form of foliaceous porous lamella, variously folded and anastomosing, and consisting of two layers of opposite cells : cells immersed, coalescent, horizontal to the plane of axis, opening on both surfaces in quincuncial pores protected with an operculum.-Polypes ascidian.

1. E. Foliacea, plates foliaceous, winding, uniting irregularly and forming sinuous cavities. Dillenius.

Plate xl.

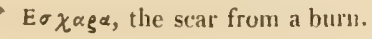


Eschara retiformis, Raii, Syn. i. 31. Flem. Brit. Anim. 531.— Stony foliaceous Coralline, Ellis, Corall. 71, no. 3, pl. 30. fig. a, A. B. C. Borl. Cornw. 239, pl. 24, fig. 6._-Millepora fascialis, Lin. Syst. 1283. Stew. Elem. ii. 427._-M. foliacea, Ellis and Soland. 133. Turt. Gmel. iv. 636. Turt. Brit. Faun. 205. S'tew. Elem. ii. 427. Hogg's Stock. 37. Bosc, Vers, iii. 341, pl. 25, fig. 4._-_Eschara fascialis, Pall. Elench. 44.——E. foliacea, Lam. Auim. s. Vert. ii. 175. 2 de edit. ii. 266. Risso, L'Europ. Merid. v. 341. Stark, Elem. ii. 436. Blainv. Actinolog. 428, pl. 75, fig. 3. Milne Edwards in Ann. des. Sc. Nat. Part. Zool. vi. 36 , pl. 3, fig. 1.

$H a b$. On various parts of the English coast in deep water. "Conchis testisve adnascitur" et circa Cockbnsh in Sussexia sæpe reperitur," Dillenius. Isle of Wight, Ellis. Cornwall, Borlasse. Devonshire, $\mathrm{Dr}$ Coldstream.

This curious polypidom attains a large size being often 3 or 4 inches high, and from 12 to 20 in its greatest diameter. It may be described as a broad membrane twisted into winding folds, leaving large sinuosities and cavernous interstices : it is very light and floats in water, crisp when dry, membrano-calcareons, cellular, of a yellowish-brown colour, roughish and punctured with the numerous pores which open on both sides. The membrane is less than a line in thickness, and consists of two layers of cells separated behind from one another by a thin plate down the middle. The cells open ob. liquely by contracted roundish apertures disposed in a quincunx order on the surface, and which, more especially when recently formed, are often covered by a small operculum. When a portion is macerated in diluted muriatic acid, it retains the original form, but becomes soft and flaccid from the subtraction of the carbonate of lime. The cells are liable to all the changes of form which have been indicated, in an appended note, as the results of age upon these polypidons in general.

2. E. FASCIALIS, ": expansions narrow, compressed, branched, occasionally united." Pallas.

Italian Coral, Ellis, Corall. 72, pl. xxx. fig. b.__Eschara fascialis var. $a$, Pall. Elench. 42. Lam. Anim. s. Vert. ii. 175. 2de edit. ii. 267. Flem. Brit. Anim. 531._-_Millepora tænialis, Ellis and Soland. Zooph. 133. M. fascialis, Turt. Gmel. iv. 636. Berk. Syn. i. 211. Turt. Br. Faun. 204._L L'Eschare à bandelettes, Blainv. Actinolog. 428 . Milne-Ed. wards in Anı. des. Sc. Nat. Part. Zool. vi. 43. pl. 4, fig. 1.

Hab. Deep water. Isle of Wight, Pallas.

"This Millepore grows in very irregular masses, but always preserves the same habit of growing; that is, the branches are flat, narrow, and regularly subdivided: they coalesce, twist, and branch out 
again, leaving certain hollow spaces between them; their cells are much smaller, though of the same shape with the cells in the foliaceous Millepore" (E. foliacea). Solander.-Pallas maintains that it is merely a variety of the preceding; but Milne-Edwards thinks it ought to be retained distinct, for its peculiarity of ramification, and the narrowness of the divisions, do not depend on age, and seem to indicate a specifical difference. The cells in both are alike. 


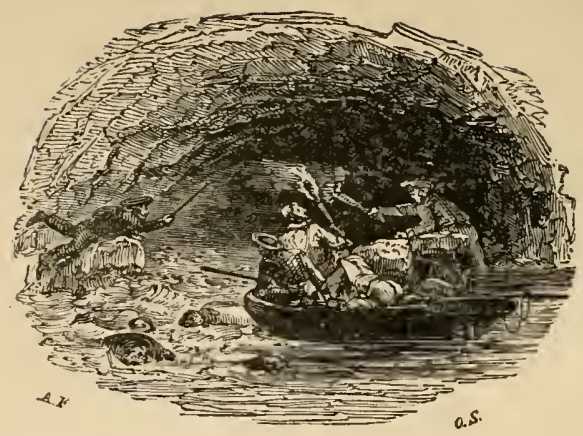

\section{FAMILY XIV. ALCYONIDULF.}

\section{Alcyonidiun, * Lamouroux.}

Chanacter. Polypidom fleshy, lubed or crustaceots ; cells immersed, pentagonal, with fibro-corneous parietes, the aperture terminal, simple, contractile. $†-P o l y p e s$ ascidian.

1. A. Gelatinosum, polypidom variously lobed or branched, subcylindrical or somewhat compressed, the surface smooth and even. Johnson. +

Plate xli. Fig. 1-3.

Fucus spongiosus nodosus, Ger. Herb. emac. 1570, no. 10, fig. Raii. Syn. i. 49 , no. 42.—Alcyonium, seu fucus nodosus et spongiosus, Ellis Corall. 87. no. $5, \mathrm{pl} 32$, fig. $d$. D._- Alcyonium ramosum molle, multis polypis obsessum, Bart. Opusc. Subs. i, 40, tab. 1, fig. 5, A. B.Alcyonium gelatinosum, Pall. Elench. 353. Lin. Syst. 1295. Mull. Zool. Dan. prod. 255, no. 3082. Ellis and Soland. Zooph. 176. Turt. Gmel. iv. 633. Jumeson in Wern. Mem. i. 563. Turt. Brit. Faun. 207. Stew. Elem. ii. 432. Bosc, Vers, iii. 157. Flem. Brit. Anim. 517. Lamour. Cor. Flex. 350. Corall. 249._L L'Alcyon gélatineux, Blainv. Ac-

* From Alcyonium, to which the name implies a resemblance.

+ According to Dr Farre the retractile portion of the cell, or that which constitutes the base of the polype, is composed of a series of stout short setæ.

$\ddagger$ Johnson, Thomas, born at Selby in Yorkshire; a Lieut. Colonel in the royal army during the civil wars, created M. D. Oxon, in 1643, in consideration of his loyalty and learning; killed in 1644, " at which time his worth did justly challenge funeral tears ; being then no less eminent in the garrison for his valour and conduct as a soldier, than famous through the kingdom for his excellency as an herbalist and Physician." See Pultency's Sketches, i. p. 128. \&c. 
tinolog. 525, pl. 92, fig. 1.—Ulva diaphana, Eng. Bot. pl. 263. With. Bot. Arrang. iv. 1:21. Hull, Brit. Fl. ii. 312. Lam. and Decand. Flor. Franç. ii. 6._Alcyonidium diaphanum, Lamour. Soland. Zooph. 71. Gray Brit. Pl. i. 353. Hook. Fl. Scot. ii. 75. Loud. Encycl. Pl. 928, no. 15045 . Al. flavescens, Loud. Encyclop. Pl. 928, no. 15046.

Halodactylus diaphanus, Farre in Phil. Trans. an. 1837, 405, pl. 25 and 26.

Hab. Deep water, attached to old shells and stones. "Margate in the island of 'Tanet," Johnson. " Prope Margate in insula Thanet Cantio adjacente primum observavit Johnsonus, postea D. Dale in insula Mersey, and D. Doody in insula Shepey," Ray, "Satis copiose reperitur posteriore insula, sed longe copiosius observatur in insula Thamesis ostio altius arljacente, Grain vocata," Dillenius. "In the month of August 1752, there was so great a quantity of it driven near Sheerness, in the Isle of Sheppey, as to clog the fishermen's nets, and interrupt their fishing," Ellis. Isle of Anglesea and Walney, Hudson. Lowestoffe, Woodward. Leith shore, Jameson, where $D r$ Coldstream tells me it is sometimes very abundant. Very rare in Berwick Bay, G.J. Orkney islands, Dr Pat. Neill.

The polypidom is attached by a narrow base to the substance from which it grows, and rises to the height of from 6 to 12 inches, "sometimes attaining the length of two or three feet." It resembles a compact sponge, but is more pellucid and gelatinous; sometimes simple and entire, usually branched ; the colour, as is well observed in English Botany, varying from a very pale brown, almost like that of wet sea-sand, to a clear yellow; in the latter case the polypidom has exactly the appearance of barley-sugar of the paler kind. The surface is smooth and speckled with minute dots produced by the dark bodies of the inhabitant polypes, which protrude their tentacula through angular apertures, and are all placed immediately underneath the skin, for the centre of the polypidom is a clear transparent jelly traversed with corneous fibres forming a very wide and irregular net-work. The polypes are so intimately connected with their cells that it is almost impossible to remove them without mutilation. They have 16 filiform tentacula, disposed in a single circle, which are capable of being retracted within the cell. "The tentacula are sixteen in number, (occasionally fifteen,) fully two-thirds the length of the body of the animal, and extremely slender and flexible. When expanded they are frequently seen to roll up closely upon themselves, even down to their base, the revolution taking place either inwardly or outwardly, and in one or more arms at the same time. Their full expansion affords a more perfect campanulate form than is usually met with in this class, each of the arms having 
a slight curve outwards towards its extremity, which gives to the whole a very elegant appearance. It is remarkable that in some specimens the arms are much shorter on one side of the body than on the other." Farre.

"The stomach is not furnished with a gizzard in this species. The intestine forms a considerable elbow at its origin, and is short and wide, terminating not as in other cases near the tentacular ring, but about midway up the body, at a point opposite the base of the setæ.

"A very singular organ was frequently observed, consisting of a little flask-shaped body situated between the base of two of the arms, and attached to the tentacular ring by a short peduncle. The cavity in its interior is lined with cilia which vibrate downwards towards the outer, and upwards towards the inner side; it has a narrow necks and a wide mouth, around which a row of delicate cilia are constantly playing. No flow of fluids could ever be detected through it, nor did the use of carmine assist in showing with what parts the cavity in its interior might communicate. From the circumstance that it is more frequently absent than present, it cannot be an organ of vital importance to the animal: and it is too intimately blended with the sides of the tentacula, and too constant in its position to be regarded as a parasite. Does it indicate a difference of sex ?" Farre.

This production was first described by Johnson, the editor of Gerarde's Herbal. His description, which is characteristic enough, is as follows: "This is a very succulent and fungous plant, of the thicknesse of one's thumbe ; it is of a dark yellowish colour, and buncheth forth on everie side with many unequal tuberosities or knots : whereupon Mr Thomas Hickes being in our companie did fitly name it Sea ragged Staffe."-It was afterwards observed on the southern coasts of England by Dale and Doody ; and Ray introduced it into his synopsis of British Plants as a fucus. Ellis at first suspected it to be the spawn of some shell-fish, but (whether relying on the authority of Pallas, who had seen the polypes, or upon subsequent original observations, is uncertain,) he ultimately came to a correct conclusion, for in his history of Zoophytes he says, "This is found at particular seasons full of minute papillæ which send forth polypes." The fact was overlooked; and on the authority of Ray and Hudson, botanists continued to rank it in the vegetahle kingdom, where it remained until very recently. Even Lanouroux considered it at first as a sea-weed, but he had the fortune afterwards to detect the polypes which he describes as having a cylindrical body and 12 tentacula ; and the description which Dr. Fleming has given is essentially the same. If no error has crept into their calculation, the speries must 
be distinct from ours, for a very careful examination has satisfied me that the tentacula are 16 in number.

D'Orbigny says that the Ulva diaphana of the Flore Française " n'est autre chose qu'un amas de séries d'œufs d'une espèce de gas. téropode nu." Mém. du Museum, vi. 181. The description, however, so evidently belongs to the Alcyonidium before us, as to make it almost certain that this remark has originated in some misapplication of it.

2. A. HIRSUTUM, polypidom variously divided, compressed, the surface covered with minute conical papilla or polype-cells. Fleming.

\section{Plate xlii. Fig. 1, 2.}

Alcyonium gelatinosum, Fabric. Faun. Groenl. 447._- A. hirsutum, Flem. Brit. Anim. 517. Johnston in Zool. Journ. iv. 418. and in Trans. Newc. Soc. ii. 251, pl. 9, fig. 1. L'A. velu, Blainv. Actinolog. 525.

Hab. Parasitical on various sea-weeds, at low-water mark, very common on the coasts of Scotland and North of England. Coast of Devonshire, Mr Jos: Alder.

Polypidom variously divided, often proliferons, sometimes sub-cylindrical, commonly flattened and palmate, of a dirty straw-yellow colour, often partially stained with red, and marked with numerons yellowish circular spots irregularly disposed. It is thickish, somewhat cartilaginous, and to the naked eye resembles a compact sponge. When viewed through a common magnifier, the surface is seen to be covered with close-set conical transparent papillæ, each of which is a cell containing a polype with $16 \mathrm{long}$ filiform tentacula, and in its structure resembling the polype of a Flustra. The yellowish spots, mentioned in the description, are produced by clusters of ova lying. imbedded in the cellular texture. These are opaque milk-white, large enough to be easily visible to the eye, of a roundish figure, but not all of them alike, for some are ovate, and others incline to a heart-shape, rather compressed, the surface uneven. The egg is not clothed all over with cilia, but there is a fringe of cilia encircling it; these cilia appear to be of a yellowish colour, and to be hooked near the apices, (wood-cut No. 7, page 51.) They are of equal size and shape, and all inclined in one direction, moving with a uniformity and quickness which is admirable and very pleasing to the beholder. When the egg is at rest, their velocity is not diminished, excepting at the will, so to speak, of the ovum, for it may be seen to become slower and less constant, to cease entirely for a moment, and again be renewed with its former force. The egg at rest will at once start 
from its place, and swim about hither and thither as it were endowed with volition, turning on its axis frequently, moving sometimes on one side, sometimes on its edge, when the cilia become invisible. I have seen the cilia, when the ovum was at rest, suddenly disappear, withdrawn as it seemed within themselves, or under the opaque margin, and again be quickly protruded. By their motion they drive a current of water over the surface, but this current has certainly not an uninterrupted circular motion-it is rather a flowing to the surface, and a current from it, or as Raspail would express it, an inspiration and expiration of water-When lying still, I have seen the eggs exhibit the most unequivocal signs of irritability, contracting and lilating themselves. The ovum appears to be formed of a firm elastic coat or shell filled with a granular matter ; it is opaque, excepting on the margin, under which the cilia appear to originate.

3. A. Echinatum, polypidom incrusting dead univalve shells, the surface muricated with rough prominent papillae or cells. $\mathrm{Mr}$ Montagu.

\section{Plate xlii. Fig. $3,4$.}

Alcyonium echinatum, Flem. Brit. Anim. 517. Johnston in Trans. Newc. Soc. ii. 251, pl. 9, fig. 2._—L'A. hérissé, Blainv. Actinolog. 525.

Hab. Parasitical on Buccinum undatum and similar univalve shells; not uncommon. Stevenston, Ayrshire, Rev. D. Landsborough. Berwick Bay.

"This species incrusts dead univalve shells exclusively; and is about the one-twentieth of an inch in thickness. When first taken out of the water, it is soft and spongy, but becomes rigid on drying." The surface in this state is muricated with spinous papillæ, somewhat less than a line in height aud rough with minute prickles pointing upwards and arranged in rows. The poly pes appear to have only 12 tentacula.

4. A.? PARASITICUM, incrusting corallincs, earthy, the surface even and porous. Rev. Dr Fleming.

$$
\text { PцA те xli. Fig. } 4,5 .
$$

Alcyonium parasiticum, Flem. Brit Anim. 518.--L'A. parasite, Blainv. Actinol. 525.

Hal. Parasitical on Sertulariadæe and old shells. Hartlepool, .J. Hogg. On the valve of an old Venus islandica dredged from deep water at Scarborough, Mr Bean. Berwick Bay, rare.

This production spreads up the stem and hranches of various flexible corallines coating them with an incrustation of an earthy appearance, from a line to the eighth of an inch in thickness. The sur- 
face is porous or cellular, even, ronghish, the pores roundish or pentagonal, distinct and separate, but not arranged in rows, or in any regular fashion; the interior is irregularly cellular, and earthy.-None of the mineral acids have any effect on this substance, nor does it absorb water like a sponge, but when dropt into a glass of water, it sinks to the bottom and lies there unaltered. No siliceous nor calcareous spicula enter into its structure, but it seems to be entirely composed of particles of sand cemented together with mud or clay. It has therefore no character of a proper polypidom, although the conformation and regularity of its cells prove it to be the work of some gregarions animal.

\section{Cliona, * Grant.}

Challacter. Polypidom amorphous, fleshy, containing siliceous spicula and perforated with ramified canals.-Polypes minute, retractile, placed in tubular papille.

\section{C. celata. R. E. Grant. + \\ Plate xlii. Fig. 5, 6.}

Cliona celata, Grant in Edin. New Phil. Journ. i. 78 - ii. 183, pl. 2, fig. 7, (the spiculım.) Flem. Brit. Anim. 516. Stark, Elem. ii. 421.La Clione cacheé, Blainv. Actinolog. 527.

Hab. In perforations of the shell of the oyster (Ostrea edulis): abundantly in the oyster beds at Prestonpans, off Inchkeith, and in the roads of the Firth of Forth, Grant.

This sponge-like zoophyte inhabits and fills up the worm-like holes in old oyster-shells. The part which projects beyond the orifice of the hole is papillary, about a line in height and about the same in breadth, of a yellowish colour, tubular, and either closed or widely open at the apex. In texture it resembles the Halichondria papil-

" "I have termed this genus Cliona, (from $\times \lambda \varepsilon i \omega$, claudo), from its most obvious and remarkable property of retracting and shutting the papillæ when irritated; and the above described species, the only one I have met with, is named celata, from its concealed and secure liabitation within the substance of oystershells." Grant.

$+\operatorname{Dr}$ G. is a native of Edinburgb, where he received his education, and graduated M. D. in 1814, when he was President of the Royal Medical Society. His 'Thesis was "de Circuitu Sanguinis in Fœtu." Shortly afterwards his attention was turned to natural history; and his researches into the nature of sponges and zoophytes laid the foundation of that reputation which readily secured him the chair of Zoology and Comparative Anatomy in the London University, on its first establishment, - a chair which he continues to fill witl the most distinguished ability. 
laris, and, like it, is almost entirely composed of siliceous spicula, which are straight and in shape like a pin, but from their brittleness few can be separated from the mass in an entire state, and we seldom observe one with the enlargement that takes the place of the head. I have examined specimens in oysters brought to market, and having placed these in sea water, other fellow parasites of their own class soon gave evidence of their being yet living and active, but I had never the pleasure of seeing the polypes of this production.

"The Cliona in the living state consists of a soft, fleshy, granular and distinctly irritable substance, of a greenish yellow colour, traversed, like many other zoophytes, with minute and regularly formed spicula. Its form depends on that of the cavities which it fills; it insinuatesitself into their minutest ramifications, and alheres so closely to their smonth parietes, that it cannot be separated without tearing. The parts of the Cliona which project through the holes on the surface of the shell are tubular; and on removing the outer layers of the shell, we can perceive several empty canals winding and ramifying from these tubular papillæ, through the body of the zoophyte. During the months of March and April, when these observations were made, numerous small yellow ova were seen in the vicinity of the canals, agreeing much in their form, colour, size, and mode of distribution with those of the Spongia papillaris and Spongia panicea, which were then nearly in the same stage of advancement. The projecting tubular papillæ possess a complicated structure, and a high degree of contractile power, and exhibit a singular series of appearances, when the zoophyte is attentively examined while at rest in pure sea water. When under water, the papillæ are seen projecting from the apertures of the shell, sometimes to the length of a line and a half; they present a wide circular opening in their centre, and a rapid current of water issues constantly from them, conveying occasional flocculi of a grey membranaceous matter. But on being tonched with a needle, or withdrawn from the water, the opening gradually closes, the current ceases, and the whole papilla continuing slowly to contract, is withdrawn completely within the aperture of the shell. The papillæ, viewed in their contracted state, present a smooth, rounded, shut extremity; but when they begin to advance beyond the surface of the shell, their extremity becomes flat and slightly dilated, assumes a villous appearance, with open fissures, radiating from the centre to the margin of the papillæ, and at length a minute circular opening is perceived in the centre of the villous surface. The papilla advances from the shell, and its central opening enlarges in proportion to the healthy state of the zoophyte, and the purity and stillness of the wa. 
ter; its flat downy radiated surface gradually diminishes loy the widening of the central opening, till only thin margins are left around the orifice, and the current is again seen to play briskly from it. In recent speeimens of the Cliona dredged from an oyster-bed near the shore at Prestonpans, and examined under the most favourable circumstances on the coast, I have twice observed polypi of extraordinary minnteness and delicacy placed around the margin of the orifice, and which kept in constant motion, advancing and withdrawing themselves into the substance of the papilla, while the current flowed from its central opening. The polypi were perfectly invisible to the naked eye in an ordinary light and position; but by suspending the Cliona in a crystal jar with clear water, and placing it between the eye and a candle, or the sun, they were seen like filaments of silk or asbestus constantly rising and sinking on the margin of the papilla. On cutting off a papilla, and plaeing it under a microscope in sea.water, the polypi continued their motions, and were seen to consist of a long, slender, transparent, cylindrical, tubular fleshy body, at the farther extremity of which were placed about eight short broad tentacula, slightly dilated at their free ends, which were constantly inflecting and extending themselves irregularly, while the polypi advanced or retreated. In two entire and fresh specimens, the polypi continued visible and in motion for more than twenty-four hours in a jar of water at Prestonpans; but $I$ have not yet succeeded in perceiving them in any of the numerous specimens which $I$ have preserved alive in the water procured from Newhaven." Professor Grant. The spicula " are about the fourth of a line in length, and appear through the microscope as minute curved pins spread irregularly through the whole fleshy substance of the animal :" they are " slender, cylindrical, tubular, slightly curved, shnt at both ends, a little fusiform in the middle, acutely pointed at one end, and terminated by a small hollow round head at the other." Grant.

Dr Coldstream writes me that, judging from the form of the spicula, he believes he possesses another species of Cliona from Bute, perforating the walls of the limpet (Patella vulgata.) 


\section{FAMILY XV. LIMNIADES.}

\section{Cristatella, ${ }^{*}$ Cuvier.}

Character. Polypes with about 60 tentacula, affixed within a floating membranaceous sac, variously aggregated; a separate orifice to each; gemmiparous or oviparous, the ova spiniferous.

\section{C. Mucedo. Sir John Graham Dalyell. $†$ Plate xliii.}

Cristatella mucedo, Cuv. Reg. Anim. iii. 296. Gervais in Ann. des Sc. Nat. part. Zool. vii. 77, n. s. Turpin in ibid. vii. 65 , pl. 2 and 3, fig. 1-7._C. vagans, Lam. Anim. s. Vert. ii. 97. 2de edit. ii. 110. Blainv. Actinolog. 489 and 678 , pl. 85, fig. 7. Bosc, Vers, iii. 180, pl. 30, fig. 9. Stark, Elem. ii. 442._C. mirabilis, Dalyell in Edin. New. Phil. Journ. xvii, 414 ; and in Rep. Brit. Assoc. an. 1834, 604.

Hab. "An inhabitant of the fresh waters of Scotland," Sir J. G. Dalyell.

"Perfect specimens occur from six lines to twenty-four in length, by two or three in breadth, of a flattened figure, fine translucent green colour, and fleshy consistence. Some of the shorter, tending to alt elliptical form, may be compared to the external section of an ellipsoid; but those of the largest dimensions are linear, that is, with parallel sides and curved extremities." - "The middle of the upper and the whole of the under surface are smooth; the former somewhat convex, occasioned by a border of 70 or 80 , or even of 350 individual polypi, disposed in a triple row. Their number depends entirely on the size of the specimen,-increasing as long as it grows."

"This product is endowed with the faculty of locomotion, either extremity indifferently being in advance, but its progression, uncommonly slow, seldom exceeds an inch in twelve or twenty-four hours. Each of the numerous polypi, though an integral portion of the common mass, is a distinct animal, endowed with separate action and sensation. The body, rising about a line by a tubular fleshy stem, is crowned by a bead which may be circumscribed by a circle as much

* The diminitive of cristata-crested.

+ The author of a very interesting work on the Planariæ. 
in diameter, formed as a horse-shoe, and bordered by a hundred tentacula. Towards one side the mouth, of singular mechanism, seems to have proje zting lips and to open as a valve, which folds up within, conveying the particles which are absorbed to the wide orifice of an intestinal organ which descends, perhaps in a convolution, below, and returns again to terminate in an excretory canal under the site of the tentacula. Probably the whole race of Cristatellæ is distinguished by a similar conformation."

"The polypus is a very vivacious animal, quickly retreating for security when alarmed, and rising to expand in activity. Though each be enilowed with independent life, sensation, and all the motions that can be exercised without actual transition, the whole are subjected to the rolition of the slnggish mass in respect to progression: -they arc borne along with it." - " A specimen having been cut transversely asunder, each portion seemed to recede by common consent; but both survived, as if sustaining no injury. Neither is any polypus affected by the violence offered in its vicinity.

"Twenty, thirty, or more lenticular substances, of considerable size and in the most irregular arrangement, imbedded in the flesh, are exposed through the translucent green of the animal. Its death and decomposition towards the end of autumn liberate them to float in the water. Suljected to the microscope, or, indeed to the naked eye, their convex surfaces prove brown, the circumference yellow, and begirt with a row of spines terminating in double hooks. Each is an ovim of the Cristatella with a hard shell, and occupied by yellowish fluid contents." “ "In 5 or 6 months the ovum gapes at one sile to allow the protrusion of an originating polypus, which by a remarkable provision of nature now floats reversed, with the head downwards, to ensure absorption of the liquid element below. On quitting the ovim it attaches itself to some solid substance by the base, then disproportionately large, from which a second polypus quickly rises, then a third, and a fourth; and thus with others. In earlier stages the Cristatella mirabilis seems to be of a circular figure, and in its most mature state there is a margin projecting beyond the root of the polypi." Dalyell.

To illustrate this description of Sir J. G. Dalyell, the only naturalist who has observed the species in Britain, I have given copies of the beautiful figures of M. Turpin in Plate xliii, for there can surely be scarce a question of the identity of the continental and British zoophyte. Turpin's figures, it is to be noticed, were drawn from young or slightly developed specimens; a mature polypidom with its 300 individuals must indeed present 
to the naturalist a spectacle of such singular curiosity and beauty as perhaps can meet its superior or rival in no other creature. I am unwilling to borrow, from the memoirs of the foreign authors, any additions to Sir J. G. Dalyell's short history, for I am aware of the confusion to which such a practice has occasionally led, but no harm can arise from the mention of some particulars which are evidently generical. I may state then, that the tentacula are ciliated like those of other ascidians; the intestine has an oral and anal aperture, the latter with a medial position; and there is no trace of any organ like what, in some other families of the order, has been reckoned an ovary. The egg, according to M. Turpin, forms a small flattened sphere with a papillous surface slightly incrusted with calcareous matter. The centre is of a dark reddish-brown or vinous colour, the margin more transparent and yellowish, proving that the egg is vesicular, - the exterior circle marking out the thickness of the cocoon or shell, and the more opake disk the part occupied with the embryotic fluid. About 16 rough spines radiate stiffly from the circumference : they are tubular, yellow, terminated with from two to four crotchets, and apparently vary in length, for they arise alternately from the edge and from the surface a little behind this.* The egg is filled with an albuminous granular fluid analogous to the vitellus or yolk, for in it the fotus is perfected after a period which probably depends, in a great measure, on the temperature of the season in which they are laid. The time of birth having arrived, the shell opens in two gaping halves, as an oyster opens its valves, to permit the escape of the young polypus, which enters on its existence complete in all respects, either a single individual, or with one or two others, less mature, pullulating from the sides.

One of the most interesting facts ascertained by M. Turpin is that the eggs kefore exclusion, and immediately after, are oval or lenticular, and entirely free of the spines which roughen them at a later stage. Hence an easy solution of a question touching the manner of escape from the mother, which, before this discovery, seemed incapable of being effected without a painful laceration from their bristling armature. This alteration in the structure of the egg is very remarkable, although not singular, for the eggs of several mites

* According to M. P. Gervais this is not the case,-the spines orignate solely from the line of junction between the marginal band and the dise;-" du point de contact de cet anneau et du corps disciforme partaierut sur l'une des faces les crochets dont j'ai parlé. Je reconnus depuis que l'autre face présentait aussi les appendices en crochets, mais qu'ils y étaient moins allongés." 
are known to undergo somewhat similar changes. The eggs float in the water from their lesser specific gravity, but often they become attached by their spines to the filaments of confervæ, \&c. where they float until the young are hatched and afford to them an immediate place of rest.

M. Turpin has ascertained that some varieties of silex contain immense numbers of the ova of the Cristatella and Alcyonella, preserved in entire perfection. Ann. des Sc. Nat. Part. Zool. vii. 120, plates 6 and 7.

\section{Alcyonella, * Lamarck.}

Character. Polypidom fixed, incrusting, or floating, in the form of an irregular sponge-like mass composed of vertical aggregated membranaceous tubes opening on the surface.-Polypes ascidian, the mouth encircled with a single series of fliform tentacula depressed or incomplete on one side: eggs coriaceuns, smooth.

\section{A. stagnoruir.}

\section{Plate xliv.}

Variation $\alpha$. Sponge-like, massive.-Alcyonium fluviatile, Bosc, Vers, iii. 159. Corall. 250.—Ephydatia Gibbsii, Gray, Brit. Pl. i. 353.Alcyonella stagnorum, Lam. Anim. s. Vert. ii. 102. 2de edit. ii. 116. Stark, Elem.ii. 442. Lamour. Soland. tab. 76, fig. 5-8. (bad.) Teale in Trans. Leeds Phil. and Lit. Soc. i. 116, pl. 12, and in Mag. Zool. and Bot. i. 293.—A. fluviatilis, Raspail in Mém. de la Soc. d'Hist. Nat. de Paris, iv. 130, pl. 12_16._L'Alcyonella des étangs, Blainv. Actinolog. 491, pl. 85. fig. 8.

Variation $\beta$. Polypidom lobed or stellate.-Polypes à panache, Tremb. Mem. 210, pl. 10, fig. 8-9. Reaum. Mem. des lnsect. vi. pref. lxxvi._-The Bell-Flower-Arimal or plumed Polype, Baker, Employ. Micros. 306, pl. 12, fig. 15-22.___Hydra campanulata, Lin. Syst. edit. 10,817._ Tubularia crystallina, Pall. Elench. 85._-T. campanulata, Lin. Syst. 1303. Berk. Syn. i. 215. Shaw Nat. Misc. x. pl. 354. Turt. Gmel. iv. 668. Turt. Brit. Faun. 211. Adums on the Microscope, 449, pl. 22, fig. 32. Bosc, Vers, iii. 92. Blumenb. Man. 272._- T. reptans, Bosc, Vers, iii. 93.—Plumatella cristata, Lam. Anim. s. Vert. ii. 107. 2de edit. ii. 122. Stark, Elem. ii, 441. Blainv. Actinol. 490. Pl. campanulata, Risso, L'Europ. Merid. v. 308._-Naisa reptans, Corall. 99, pl. 6, fig. 4._C Cristatella campanulata, Flem. Brit. Anim. 518. _ C. paludosa, Dalyell in Rep. Brit. Assoc. an. 1834, 606.

$H a b$. Stagnant waters, especially in such as are tinctured with iron

" A diminutive from Hulcyon. The sponge-genus Alcyonellum of Quoy and Gaymard, being of subsequent creation, cannot be retained. 
in solution: their developement chiefly in autumn. Habitat ad Angliam, Linnceus. About Chelsea, Dr Shaw. Not uncommon in Hyde-park, and Green-park, in the centre of London, J. E. Gray. Near Leeds, $\boldsymbol{M} \boldsymbol{r}$ Teule. Near Howick, Northumberland, $\boldsymbol{M} \boldsymbol{r} \boldsymbol{R}$. Embleton. On leaves in ponds in Scotland, Sir J. G. Dalyell.

Polypidom, when at maturity, in large amorphous compact masses, soft, compressible, and somewhat elastic, of a blackish green colour, irregularly lobulated or sinuous on the surface, which has a lubricous appearance, and is more or less apparently porous. The mass is composed of subcylindrical tubes rising from the base to the surface, nearly parallel, connected by, or permeating, a transparent firm jelly-like substance, with which the tubes appear to be also partially filled. The tubes are simple or unbrancbed, and open outwardly by a roundish or pentagonal aperture, which is closed by a thin membranous cover. The walls of the tubes are of the same thin membranous character, pellucid, colourless, or tinted with green, and without any visible vessels; they contain innumerable lenticular ova of a dark brown colour, about half a line in their longest diameter, very hard and incompressible, but in drying the centre becomes depressed and more transparent than the edges. These singular ova are quite smooth,* and arranged in rows in the tubes, though not very regularly : they are more abundant near the surface than at the base of the polypilom, and exist in such amazing numbers as to excite surprise at the seening productiveness of an animal which appears to be very partially diffused, and is very capricious in its appearance even in ponds favourable for its growth,_swarming in one season, of rare occurrence in the next, and perhajs then for years lying dormant until some undiscovered cause batches the egg and renews its pristine fertility. When freed from the mass, the greater number of the ova swim on the surface of the water, but some sink to the bottom.

To this description, derived from specimens in a recent, but not living condition, sent me by $\mathrm{Mr}$ Embleton, I add the following particulars derived from Mrr Teale's valuable paper. A good idea of the polypes will be obtained by reference to figures 5, 6, of Plate xliv, which are reduced copies of Raspail's. It is organically connected with the mass, the tube forming its tunic, from which the animated body issues by a process of evolution similar to that which developes the horn of a suail. When developed, the head projects a short way,

* M. Meyen says, on the contrary, that the envelope of the ovum is covered with very fine vibratile eilia. Bull. des Sciences Nat. xviii, 313. Has not Neyen mistaken the ova or seeds of the Spongilla for those of the Aleyonella? for uudoubtedly the ova of the latter are smooth. 
and is crowned with a " beautiful expansion of tentacula, about fifty in number, arranged in an unbruken circle, which is, however, depressed into a deep concavity on one of its sides, so as to produce the appearance of a double row of tentacula in a horse_shoe form. About one thousand six hundred polypes are sitnated on a square inch of surface of the mass, consequently the number of polypes" in one specimen which weighed 17 ounces, and measured $14 \frac{1}{2}$ inches in circumference, "may be computed at one hundred and six thousand, and the tentacula at five millions three hundred and twenty thousand!" The mouth is, as usual, in the centre of the crater formed by the tenta. cula, and is the entrance to an alimentary canal that, descending in the body, swells out into a stomach, and then bends to gain an upward course, having its termination exterior to and underneath the indenture in the tentacular circle. "The lower portion of the stomach is of a bright brown colour, longitudinally striated. The colour appears to depend upon the alimentary materials which it contains, and the vertical striæ are probably produced by folds in the organ. On lacerating the stomach, the brown matter escapes in the form of innumerable minute granules. A sort of vermicular motion is sometimes observed in the stomach."

The ova are generated in that portion of the polype-tubes which is prolonged from the stomach through the common mass, (fig. 2,) not germinating in any certain point, but from all the gelatinous sides. "Those which are perfectly matured are of a dark reddish-brown colour. Others of the same size have their external envelope opaque and white; others are somewhat smaller and translucent, whilst some are very ninute and perfectly transparent. The mature and immature ova appear scattered indiscriminately throughout the tube. The uvil are stated by Raspail to occur in a double series; I have, however, almost invariably found them in a single row. M. Raspail also says he has been able to see the small filament which connects the ova to their containing membranous tube."- - There appears to be no duct or aperture through which the ova can escape, their liberation being apparently dependent on the decomposition of the body. 'This is of two kinds: "In the first, the papilla which during life closes the tube, dies and becomes softened, ragged, and flocculent, and in this state no longer forms a harrier to the exit of the ova. In November, many of the specimens were seen in this condition. On exanining the surface of the polypiferous masses, they were seen corered with ragged shreds of membrame instead of the well-defined conical papillæe or expanded polypes. In the second stage, air is disengaged from decomposition of the contents of the horny tube or 
ovary. If a recently dead specimen in which the papillæ are reduced to the state above described, be examined with the lens, a succession of air-bubbles are seen frequently escaping from the horny tubes. By the successive formation and ascent of these bubbles, the ova which at this period are loose and floating in the tubes, are gradually elevated and couveyed to the exterior. In November, many of the specimens were seen with air-bubbles and ova successively escaping, and the external surface was covered by ova thus conveyed to the exterior. Those specimens which were black and putrid, and appeared to have been dead some time, exhibited the horny tubes nearly devoid of ova. After a time the horny basis itself becomes softened, and appears to undergo decomposition. During the following spring, according to the evidence of Vaucher and Raspail, the horny envelope of each ovum separates into two lateral halves adhering on one side as by a hinge. From these valves a small gelatinous tubercle projects, which soon expands into a distinct polype, and gradually becomes elongated into a tubular form. From the sides of this tubular polype, small gelatinous buds soon appear, and these again become developed into distinct polypes; the tubular parietes gradually become consolidated, and form the lorny basis of the mature Alcyonella."

Fig. 48.

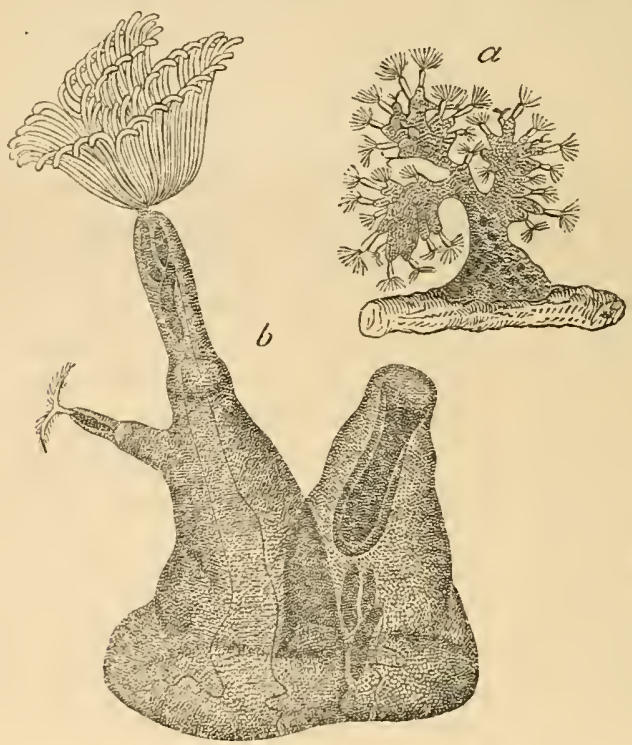


The Alcyonella, if $I$ have correctly sorted the synonymes, was discovered by Trembley in the spring of 1741 . It seems necessary to give a copy of his figures here, (wood-cut, No.48,) since on them is founded the second variation of the species, and they exhibit it in a guise very different from that represented in our Plate xliv. His history of the animal is marked with much of that excellence which distinguishes the inquiries of this naturalist. He correctly describes the connection and relationship between the polype and the common mass; the arrangement of the tentacula, and the structure of the alimentary canal, although he failed to detect the anus. He overlooked the cilia of the tentacula from employing magnifiers of too low a power, and attributed the whirlpools created in the water by their play to the motion of the tentacula themselves, which he says were also used separately to force the animalcular prey into the mouth. He knew that the polypes were not contractile, and believed their retraction within the tubes was dependant on the play of a muscular thread which descended from the body in the common mass. The gemmiparous mode of increase in the polypidom is also detailed with some minuteness, but he had not seen the ova, at least in a state of maturity.*

Immediately after Trembley's discovery, Reaumur and Bernard de Jussieu found this animal in the neighbourhood of Paris, and detected its ova, from which they saw the young issue. Reaumur's account of the growth of the compound animal appears to me to corroborate the opinion of the sameness of the Plumatella and Alcyonella. He says that while the polypes à panache are still very young, they increase in the same manner that the locomotive polypes do, with one difference only which it is essential to note, since it explains clearly the formation of those polypidoms that resemble plants. The tube of a newly evolved polype continues as it were permanently grafted upon the tube of that which has given birth to it: from the polype tube he has seen germinate by little and little another which contained a nascent polype; he has seen this tube elongate itself, and the polype tenant at length show itself outwards to follow out the destined tenor of its life. Scarcely had a few days passed until this again gave birth to a young one whose tube was in connection with

* It is even loubtful whether the bodies he took for immature ova were really so. "J'ai vu dans plusieurs des Polypes à panache, sur lesquels j'ai fait mes observations, de petit eorps sphériques de diffèrentes grandeurs, blanes et transparens. J'ai seulement soupçonné que ces petits corps étoient des oeul's, mais je nai pas cu occasion d'examiner si ece soupçon étoit fondé, ou nou." p. 219. 
the parent's, and continued so. In this manner he has seen files of tubes and polypes formed, grafted the one on the other; he has seen these unite in polypidoms which there would have been no hesitation in regarding as plants, if he had not followed them in the progress of their growth, and if he had not had the opportunity of convincing himself that the whole was but the assemblage of cells constructed and developed one after another, and inhabited by animalcules.

Baker next described the animal in what Raspail considers its second stage of developement; and as his descriptiun is derived from native specimens, $I$ insert it entire, anxious to give as much completeness as possible to the history of a zoophyte which appears under so many phases, and regarding which there still exist considerable doubts. "I was first informed," Baker says, "of this creature by my industrious friend Mr William Anderson, towards the end of the year 1743, as his letters shew : and in the year 1744, it was taken notice of by Mr Trembley, who gave it, in his Memoirs, the name of the Polype a Panache, or the Plumed Polype. My friend, who discovered it in bis searches for the Polype, called it the Bell-Flower Animal; and after favouring me with his own observations, sent me some of the ereatures themselves, which, living with me for several months, I had sufficient time and opportunity to examine and consider them. And as there seems some little difference between those in my keeping, and what $\mathrm{Mr}$ Trembley describes, they may possibly be of another species, though of the same genus.

"This is one of the many kinds of water animals which live as it were in societies; of which some sorts hang together in clusters, but can detach themselves at pleasure ; whilst others are so intimately joined and connected together, that no one seems capable of moving or changing place without affecting the quiet and situation of all the rest. But this creature forms as it were an intermediate gradation between the other two, dwelling in the same general habitation with others of its own species, from whence it cannot entirely separate itself; and yet therein it appears perfectly at liberty to exert its own voluntary motions, and can either retire into the common receptacle, or push itself out from thence and expand its curious members, without interfering with or disturbing its companions.

"They dwell together from the number of ten to fifteen, (seldom exceeding the latter or falling short of the former number, in a filmy kind of mucilaginous or gelatinous case, which out of the water has no determined form, appearing like a lump of slime, but when expanded therein, resembles nearly the figure of a bell with the mouth upwards ; and is usually about the length of half an inch, and one quar- 
ter of an inch in breadth or diameter. This case being very traus . parent, all the motions of its inhabitants may be discernel through it distinctly. It seems divided internally into several apartments, or rather to contain several smaller Sacculi, each of which encloses one of these animals. The openings at the tops of these Sacculi are but just sufficient to admit the creature's head, and a very small part of its body, to be thrust out beyond them, the rest remaining always in the case. The animal can, however, when it pleases, draw itself entirely down within the case, which is an asylum to secure it from its enemies, (for it is not unlikely many of the larger aquatic insects prey upon it,) and a safe and agreeable retirement wherein to perform the functions of digestion, sleep, and the other necessary calls of nature. This case it can, I say, retire into at pleasure; and it never fails to do so when any sudden motion of the water or of the vessel it is in disturbs it: as also when it has seized with its arms any of the minute insects which serve for its food.

"The arms are set round the liead to the number of forty, having each the figure of a long $f$, one of whose hooked ends is fastened to the head; and all together when expanded compose a figure somewhat of a horse-shoe shape, convex on the side next the body, but gradually opening and turning outwards, so as to leave a considerable area within the outer extremities of the arms. And when thus extended, by giving them. a vibrating motion, the creature can produce a current in the water, which hrings the animalcules, or whatever other minute budies are not beyond the sphere of its action, with great velocity to its mouth, whose situation is between the arms: where they are taken in if liked, or else by a contrary current, which the creature can excite, they are carried away again: whilst at the same time other minute animalcules or substances, that by lying without-side the inclosure made by the arms are less subject to the force of the stream, are frequently seized by them : for their sense of feeling is so exquisite, that on being touched ever so slightly by any such little body, it is caught immediately and conveyed to the mouth. Howerer, one may observe the creature is sometimes disappointed in its acquisition, for after drawing down one of the arms suddenly inwards towards the mouth, it may be perceived slowly extending itself again without the creature's retiring into its case; which it fails not to do on meeting with anything worth the while.

"The food is conveyed immediately from the mouth or opening between the arms, thrungh a very narrow neck, into a passage seemingly correspondent to the osophagus in land animals; down which 
it passes to the stomach, where it remains for some time, and then is voided upwards in small round pellets, (which at first I imagined to be its eggs, ) through the gut, whose exit is near a neck, where it was first taken in.

"The body of this animal consists of three parts or divisions, in the uppermost whereof all the aforementioned intestines are contained, though they are not to be distinguished when the creature is hungry; but after it has eaten they become distended and opake, and may very plainly be discovered. The other two divisions (the lowermost of which I take to be fixed to the bell or outward case,) seem of no other service than to give the creature power of contraction and extension.

"The arms seem not able like those of the common Polype to contract or shorten themselves; but instead thereof, when the animal retires into his case, they are brought together in a close and cu. rious order, so as easily to be drawn in. Their general figure when expanded is that of a cup, whose base and top are of an horse-shoe form; but they present sometimes a very different appearance, by separating into four parts, and ranging themselves in such sort as to represent four separate plumes of feathers.

"I could never discover any eyes they have, and yet find some reason to believe they see: for on being set in the light of the sun, or a candle, or brought out of the dark into dayliglit, though contracted before and retired into the bell, (as indeed they generally are when in the dark, ) they constantly extend their arms for prey, and shew evident signs of being pleased.

"Besides the particular and separate motion each of these creatures is able to exert within its own case and independent of the rest, the whole colony has together a power of altering the position, or even of removing from one place to another the bell or common habitation of them all. Hence this bell is seen sometimes standing perfectly upright, sometimes bending the upper part downwards.

"It has been mentioned already, that between ten and fifteen of these animals dwell together, as it were a little community, in one bell-like case or common habitation: but their number increasing, this bell may he observed to split gradually, beginning from about the middle of the upper or anterior extremity, and proceeding downwards towards the bottom, till they separate at last entirely, and form two complete colonies, independent of each other; one of which sometimes removes itself to another part of the vessel. The manner how the single animals propagate I have not heen able to discover, though 
there is some reason to conjecture it may be by the means of eggs ; as small opake bodies of a constant and determinate figure are sometimes seen lying in their bells : and unless they are eggs I know not what to make of them. Their shape is nearly that of a weaver's shuttle, being composed of two circular arcs, whose concave parts are towards each other. The breadth is about two-thirds of the lengtl, and in the middle of each a circular spot appears more opake than the rest, which possibly may be the embryo. But as I never saw any of them come to perfection, I can make no farther judgment of them than what their situation and form suggests.

"The bells or colonies of these animals are to be found adhering to the large leares of duckweed and other aquatic plants; and may easiest be discovered by letting a quantity of water with duckweed in it stand quietly for three or four hours in glass vessels, in some window or other place where a strong light comes; for then, if any are about the duckweed, they will be found on careful inspection extending themselves out of their cases, spreading their plumes, and making an elegant appearance.

"They are extremely tender, and require no little care to preserve them : their most general disorder is a kind of slime or mouldiness, which will sometimes envelope them in such a manner as to prove mortal. The best way of curing this is by gently pouring a large quantity of water (perhaps two or three quarts) into the vessel where they are kept, and letting it run off slowly: by which means the sliminess will gradually be loosened and carried away with the water.

"As to food, if fresh water be given them daily they will find sufficient for themselves; and it is dangerous to try any other way of feeding them, for the smallest worms or other visible insects one can think of giving them will tear their delicate frame in pieces."

Pallas has added nothing to the history of this polype, which he had, nevertheless, personally examined.-Bosc having collected, in ponds near Paris, a polypidom of a massive character, apparently unknown, sent it to Bruguiere, who described it as a new species of Alcyonium. The same production having come under Lamarck's inspection, he formed of it the genus Alcyonella, which was immediately adopted by all naturalists, for Brugniere's description of the polypes (the accuracy of which was vouched for hy Lamouroux!) differed in so many obvious particulars from Trembley's, that no one could suspect their identity, the more especially as the figures of the polypidoms were equally dissimilar. Bosc's polypidom was therefore catalogued in our systems as an Alcyonella, and Trembley's as a spe- 
cies of Plumatella. Thus matters stood when Raspail was led, in 1826 and 1827, to examine the subject, and the result of his ingenious labours has been very curious, though some of his conclusions, notwithstanding the boldness of their enunciation, seem to me unproved, and one of them, which identifies the Cristatella with the Alcyonella, has already been shewn to be erroneous. He has, however, demonstrated very satisfactorily the entire sameness of the Polypes à panaches of Trembley, the Bell-flower animal of Baker, and the Alcyonella of Lamarck,-the variations in the polypidom, which had deceived all others, being produced by age, or by external and fortuitous circumstances, as for example by peculiarities in its site: when this is the floating leaves of Lemnæ, or the upper or under side of a stone, the developement is diffused, or lobed, or arborescent, or creeping, or massive and spongy, according as the polypidom has freedom to spread, or is restrained by its position, or is irfluenced by the mere gravitation of one part against another. I can find, however, in the beautiful series of figures which illustrate his Memoir, none to make me assent to Raspail's opinion that all the Plumatellæ are certainly mere variations of this zoophyte : at present the facts appear rather of an opposite tendency;-while, on the contrary, subsequent observations bave shewn that he is right in considering as embryo Alcyonellæ the Leucophra heteroclita and Trichoda floccus of Muller, as well perhaps as the Diffugia protæiformis of Leclerc, although Ehrenberg declares against this conclusion.

Raspail's description of the zoophyte is admirable, and is rendered peculiarly interesting from the generalizations in physiology which the author ever and anon boldly hazards on certainly a very narrow basis; and the curious experiments detailed in it. He has fully recognized the merits of Trembley, and has confirmed his accuracy in most particulars; he has explained the cause which led Trembley erroneously to ascribe a retractor muscle to the body, the appearance being the result of a fold or plait in the tunic in certains positions of the body ; he ascertained the position of the anus; gave a complete view of the tentacular apparatus, and an inimitable anatomy of the ova, which we shall transcribe at least in part. 'The ova, he says, are in general one-third of a millimetre in their longest diameter. On each of the two parallel faces we distinguish a shield, a little convex, and of the same shape as the egg itself, surounded with a rim of the same colour and consistence. (Fig. 49, a.) In drying, these two faces approximate and become concave, while the rim remains unaltered. A section perpendicular to the two faces shews that the rim has no communication with the shield, (Fig. 49,b.); that it is distended with a cel- 


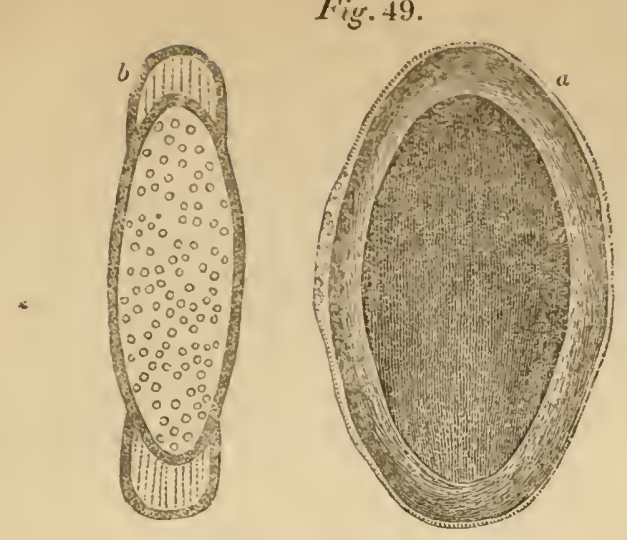

lular tissue of the same substance as the parietes; and that the shield incloses, under a shell of the same nature as the rim, a glutinous cellular tissue, the cells of which are filled with transparent, apparently amylaceons, granules, spread in my iads over the olject-glass when the perisperm is torn. The most minute observation has been employed without success in finding any indication of an organ analogous to the embryo.

By a section parallel to the two faces the difference which exists between the structure of the rim and shield is made apparent. Of the former the coat, deprived of the tissue which it contains, is seen to be transparent and divided into cellules arranged in rays which point towards the centre of the organ; while the resinous and woody thickness of the shield presents a great number of small globular yellowish cells disposed in quincunx. (Fig. 50.) This arrangement becomes still more apparent on boiling the ovum in alcohol, which however, no otherwise than ether, does not seem to discolour it much. Its brown colour is not owing to the presence of iron, for a long soaking of the eggs in prussiate of potass sharpened with sulphuric acid has not communicated the slightest tint of blue to their surface, even when they

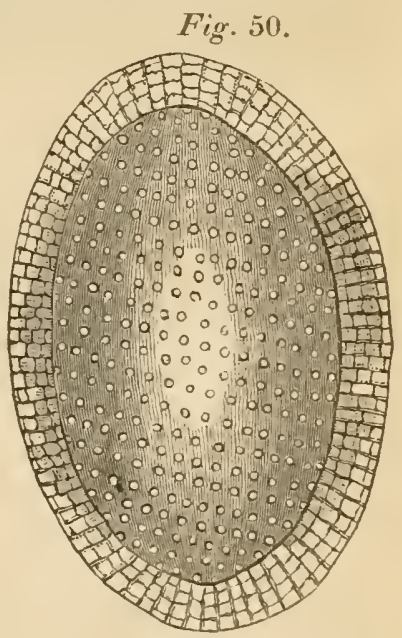
have been bruised previous to the maceration. Alcohol changes to a golden yellow the original brown colour of the shield. Iodine 
does not colour at all, if not a yellow, the granules of the perisperm which their appearance suggested to be amylaceous, but alcohol separates from them a fatty substance, for, in spontaneous evaporation, this menstruum deposits on the object-glass a white layer over which water glides without raising any thing from it.

On examining by refraction one of the eggs with a magnifier of 100 diameters, very often another transparent narrow margin becomes visible, which overlaps all the circumference and indicates an external envelope of extraordinary delicacy. On one side of this there is to be distinguished an evident trace of the old adhesion of the egg to the walls of the tubes which enclosed them, - a point which may be called the hilum. Very often, however, this delicate tunic may be sought for in vain on other eggs.

\section{Plumatella, * Bosc.}

Character. Polypidom fixed, membranaceous, confervo id, slender, tubular, irregularly branched; the polypes issuing firom the apices of the branches.-Polypes ascidian, crowned with a single series of ciliated tentacula.

1. P. REPENS, "stem adhering; tentacula disposed in a crescent." Rev. Dr Fleming. Fig. 51.

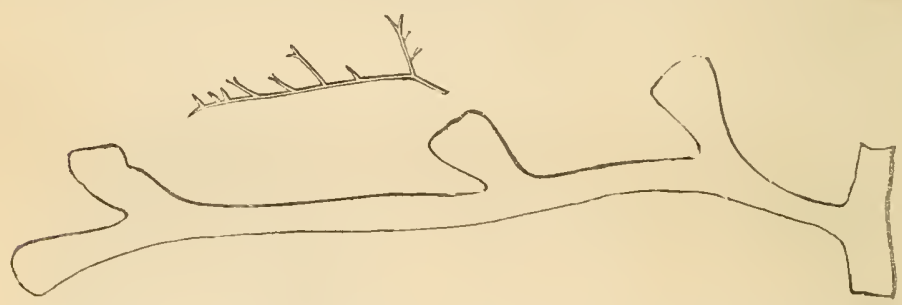

Tubipora repens, Lin. Syst. edit. 10, 790._- Tubularia repens, Mull. Verm. i. ii. 16. Zool. Dan. prod. 254. Bosc, Vers, iii. 93.—Tub. reptans, Turt. Gmel. iv. 669._- Plumatella repens, Lam. Anim. s. Vert. ii. 108. 2 de edit. ii. 123. Flem. Brit. Anim. 522. Stark, Elem. ii. 441._-Naisa repens, Coral. 98._L La Plumatella rampante, Blainv. Actinolog. 490. †

* The diminitive of plumata-plumed.

+ To this synonymy it may be useful to add the following, communicated to me along with a dried specimen of the polypidom, by J. Hogg, Esq. " $\Lambda$ small piece of it is figured in $S_{c h a f f}$. Armpolyp. tab. i. fig. 1, 2, published in 1754 . The next representation of it is in tab. 19, fig. 1-5, in the Bulletin Philomatique 
Hab. "On the under side of stones, Lochmill-loch, Fife," Fleming. "Not unfrequent in a rivulet of beautifully clear water, at Norton, in the county of Durham," John Hogg, Esq.

"Stem extending several inches, irregularly branched, slightly enlarging towards the aperture, dilatable; tentacular margin divided into two lobes, tentacula ciliated in opposite directions. Besides a gullet, stomach, and gut, there is a distinct rectum, terninating in a tubular orifice seated externally to the tentacular margin, out of which I have witnessed the remains of the foorl swallowed but a short time before forcibly ejected." Fleming.

2. P. Gelatinosa, "free, branched ; tentacula circularly disposed." - Rev. Dr Fleming.

Tubularia gelatinosa, Pall. Elench. 85._-_Plumatella gelatinosa, Flem. Br. Anim. 553.

Hab. "Found along with the preceding," Fleming.

"Height about two inches, tufted, shrubby ; stem dichotomously branched, scarcely enlarging at the extremity; polypi with a bellshaped disk, the tentacula regularly disposed, and appearing as if webbed at the base ; mouth with a valve." Fleming.

3. P. sultana, irregularly branched ; tentacula campanulate. J. G. Dalyell.

Tubularia sultana, Blumenb. Man. 272. pl. 1. fig. 9. Bosc, V'ers, iii. 93.

Hab. Fresh water. Near Foulden, Berwickshire, Dalyell.

Polypidom irregularly branched, about an inch in height, earthy brown, roughish and opaque, the tubes short, cylindrical and unjointed ; polypes entirely retractile, with abont 20 slender white tentacula, assuming when expanded a regular campanulate figure. Blumenbach says they are ciliated at the base.

As I have already stated, Raspail considers the Plumatellæ (with the exception of P. sultana, which he does not mention,) to be merely states of the Alcyonella,*-an opinion which future inquiries may shew to be true, but at present there are some difficulties in the way of its adoption. Pallas had examined both the Polypes-à-panache of

(not Bull. des. Sciences Nat.) p. 137, no. 81, an 12 (de la Republique) $=1804$, belonging to an extract from a memoir by Vancher on the fresh-water Tubularix: there fig. I. much resembles the polypary in its natural state, but the animal magnified is not near so like as that figured in the former work: however neither plates do justice to the polypes."

- Mr J. E. Gray, in 1832, says, "It is probable that the Plumatellæ may be only the young of the Alcyonellie." Syn. of Brit. Mus. p. 75. 
Trembley, and his Tubularia gelatinosa, in a living state, and he asserts that the latter-a Plumatella - differs from the former-an Alcyonella-not solely in habit,* but in having fewer, shorter, and more recurved tentacula. "Interaneis quoque" he adds, " a præcedenti differt et distinctissima est hac species, quæ interdum in iislem cum præcedenti (semper rariore, adeoque, ut videtur, ninus prolifica) reperitur aquis." Muller's description of Plumatella repens certainly affords nothing in opposition to Raspail's theory, but on the contrary may be deemed favourable to it, since he tells us that it is intermediate between the very species which Pallas considered so widely different, possessing many of the characters of both, and differing principally in the appearance of the polypidom. Lamarck perceived the affinity of the genera, which be nevertheless kept separate, resting the distinction on the massive and ramous forms of the polypidoms. Baër, apparently speaking from personal examination of the productionsin question, has expressed his conviction of the perfect distinctness of Alcyonella and Plumatella, and this subsequent to his knowledge of Raspail's Memoir : and Milne-Edwards has still more recently shown that this essay had at least not conveyed perfect conviction to his mind, otherwise he would scarce have expressed himself in this manner: "Il nous paraît en effet probable que ces Polypes, observés à des périodes diverses de leur développement, ont été pris pour des animaux differens et décrits sous des noms particuliers. Mais il serait possible aussi que les formes transitoires de l'Alcyonelle décrites par M. Raspail se rencontrassent d'une manière permanente chez l'autres Polypes, et par conséquent, on ne peut encore rayer des catalogues zoologiques la longe suite d'espèces mentionnées ci-dessus." Lam. Anim. s. Vert. 2de edit. ii. 116.-Under these circumstances 1 have deemed it the best course to keep the genera separate, as least likely to perplex the student.

Of the P. Sultana little is known. 1 have seen a living specimen in the possession of Sir John G. Dalyell, but had no opportunity of making an examination of it. Naturalists wait with some impatience the publication of a work from this ingenious observer, on which, it is understood, he has been long engaged, and which will disappoint expectation if it does not disclose many novel facts, and illustrate many present obscurities, and give additional respect and permanence to his name and reputation as a naturalist.

* "Mrabit is a general agreement in growth and appearance." Limncus. 


\section{ADDITIONAL NOTES.}

\section{The Nature of Sponges. Page 29.}

I may fortify my opinion of the vegetable nature of these productions by the following quotation from the "Elements of Physiology" by Muiller, the celebrated professor of anatomy in the university of Berlin.-_" If, therefore, it is still a matter of doubt whether certain simple organized beings, sueh as the sponges and several so called alcyonia, are animal or vegetable, the absence of all voluntary motion in these bodies, whether of the whole or of individual parts of it, must determine the question, and they must more properly be numbered among the vegetable marine structures. It may certainly be said that the embryo of sponges, as Dr Grant has shown, like the embryo of polypes and corals, moves by means of cilia; lut the distinetive marks between the embryo of sponges and marine infusoria are by no means certain, and similar motions have been many times observed in the embryo of true vegetables, - of the alga, for example." p. 42. Lond. 1837.

Mr J. Hogg, in a letter dated June 25, states that the green colour of the fresh water sponge (Spongilla fluviatilis) depends upon the action of light, -as he has prover by experiments which shewed that pale coloured specimens beeane green when they were exposed, for a few days, to the light and full rays of the sun; while on the contrary green specimens were blanched by being made to grow in darkness or shade. Hence Mr H. infers the vegetability of this sponge; but he still leans to the opinion that the sea sponges are animals.

Dujardin, again, is a new advoeate for the animality of all sponges! " $\mathrm{Ml}$. Dujardin having repeated his observations on spongillæ or fresh water sponges, as well as other's on marine sponges, thinks he has proved, that these ambiguous beings are positively groups of animals, capable of contraction and extension. If a pieee be detached from a living sponge, and submitted to a mieroscope, it will be seen to groupe itself into irregularly rounded masses, and change the form of its edges incessantly : isolated portions, detached from the general mass, move slowly in the liquid, and creep along by means of their alternate contraction and expansion." Athenxum, June 16, 1838, p. 430._-I may remark on these experiments, that locomotion is no proof of animality. Several alga are locomotive.

2. The asexual character of Zoophytes. Page 46.

This is contrary to the opinion of Professor Wagnes. He says that doulbleness of sex appeurs to be an invariable condition of all animals; and when the sexes are not separate individuals, there always exists a hermaphroditical organzation. Ile has discovered maseuline organs in the Aetinice. "I found, last Antumn," he says, " in the isle of Heligoland, "pon the Actinia lolsatiea and rufa 
testicles formed by numerous canals twisted around one another : they were much developed and placed along-side the ovaries, which they equalled in number." Their real nature was ascertained by the detection of spermatic animalcules in them; and these were also found in the Act. effœta.-Ann. des Sc. Nat. tom. viii. p. 283 , \&c.

\section{Structure of the Hydra. Page 99.}

Augustus Josephus Corda has recently published a memoir on the anatomy of Hydra fusca, where he shews that this is greatly more complicated and curious than has hitherto been imagined. According to Corda each tentaculum forms a slender membranaceous tube filled with an albuminous nearly fluid substance intermixed with some oleaginous particles : this substance swells out, at certain definite places, into denser wart-like nodules which are arranged in a spiral line. These are the tubercles noticed by all observers, but no one had hitherto developed their structure. Corda says that each nodule is furnished with several spinigerous vesicles used as organs of touch, and with a very singularly constructed organ for catching the prey. The organ of touch consists of a fine sac enclosing another with thicker parietes, and within this there is a small cavity. From the point where the two sacs coalesce above, there projects a long cilium or capillary spine which is non-retractile, and apparently immoveable. Surrounded by these cilia, and in the centre of the nodule, is placed the captor organ, called the hasta. This consists of an obovate transparent sac, immersed in the nodule, with a small aperture even with the surface. At the bottom of the sac, and within it, there is a saucer-like vesicle, on whose upper depressed surface is seated a solid ovate corpuscle that gives origin to, or terminates in, a calcareous sharp sagitta or arrow, that can be pushed out at pleasure, or withdrawn till its point is brought within the sac. When the Hydra wishes to seize an animal, the sagitta are protruded, by which means the surface of the tentacula are roughened, and the prey more easily retained : and Corda believes that a poison is at the same time injected, which will explain the remarkable fact of the almost instant death of the prey.

The nodules of the tentacula are connected together by means of four muscular fibres or bands which run up forming lozenge-shaped spaces by their intersections. These are the extensor muscles of the tentaculum. They are again joined together by transverse fibres, which Corda believes to be adductor muscles, and to have also the power of shortening the tentacula. Corda states that there is no communication between the tube of the tentaculum and the cavity of the body.

The lip of the mouth is armed with hastce and cilia similar to those of the tentacula, but the rest of the body is destitute of them.

The skin consists of two strata, the exterior largely cellular, the inner with cells of a much smaller size. In the latter the gemmules lie. Under it there is a layer consisting of densely aggregated cells, filled and coloured with minute granules. This layer Corda regards as muscular; and within it there is another layer which, from its texture and position, he says may be called the villons coat. From the inner surface of this, numerous villi project into the stomachal cavity, collected into masses which are divided from each other by passages destitute of villi. Each of the villi is in the form of a cylindro-conical pellucid vesicle filled with the nutrient matter; and most of them are perforated on the tip while 
others arc closed, though equally filled with nourishment. The digestion of animal matter is very rapid; the pacliydermatous larva of an insect being rendered irrecognisable in four minutes. Vegetable matter is an inappropriate food, and secmingly indigestible. See Ann. des Sciences Nat. Part. Zool. tome viii. p. 363, \&c.-It were well that this anatomy of Corda was confirmed, for the fallacy of the microscope is almost proverbial, and powers of very high intensily must have been uscal in this demonstration.

\section{The nature of the Cells of the Escharida. Page 238.}

" If the stony cells of the Escharidse were formed by the exudation of a calcareons matter which moulded itself on the surface of the secreting membrane, it is evident that the first layer thus formed must be the external one, and that the addition of new quantities of this carthy matter could only augment the thickness of the parietes of the cell, and modify the disposition of its interior cavity, with out at all changing the exterior configuration of the first formed layer ; for here the solid ccll completely envelopes the animal, and is not overlapped by the secreting organ, as in the Mollusca gasteropoda, whose shell changes its form with age, because the leposit of new matter, taking place on the border of the part already consolidated, continually lengthens it, and is moulded on the soft parts whose configuration is liable to change.

"To throw some light on the mode of formation and on the nature of the cells of the Eschares, it became consequently interesting to examine these cells at different ages, and to see if their exterior form ehanged or remained always the same. This study, indispensable for the anatomical and physiological history of these little beings, may also lead to a knowledge useful to zoology and to geology; for the determination of the species, recent and fossil, rests principally on the characters furnished by these cells; and we are still ignorant whether or not they can be nodified in the progress of age.

"This examination can be made more easily than one might at first inagine; for neither the observation of the same individual, at different stages of $\mathrm{jts}$ developement, nor the collection of a series of specimens so as to represent all the phases through which these little creatures pass successively, is required. Indeed, since these polypes spring from each other, and do not separate from their parents, each polypidom must present a long series of generations enchained to each other, and in cach of these series, the relative age of living individuals must be indicated by the place which they occupy. To resolve the question which we have put, it is sufficient therefore to study comparatively the cells situated near the base of the polypidom, in its middle, in its young branches, and towards the extremity of the latter; for we are certain that it is not only in this last place that living polypes are found, as some authors affirm, but that they exist over almost the entire extent of the polypidom.

"After cxamining in this manner, with a sufficient magnifying power, the cells of the Eschara cervicomis, I am quite convinced that the mode of developement of these stony cells is not that which is usually admitted.

"Indeed, I have seen that not only does the gencral conformation of the cells change with age, but also that these changes operate in a great measure on the extcrior surface, - that is to say, on that side of their parietes, which, in the hypothesis of their formation by layers, must exist from the first, and once consolidated, onght to change no more, unless from exterior and accidental frictions. 
"In the young cells, whose partitions, although thin, bave already acquired a stony consistence, the exterior surface is quite convex, and the margin of their apertures jut out so that they are easily distinguished; but by the progress of age their appearance changes; their free surface rises so as to efface the deep depressions which marked originally their respective limits, and to raise to the level of the surface the border of the openings. The result of this is that the cells cease to be distinct, or even distinguishable without, and that the polypiclom seems to be formed of a stony continuous mass, in the substance of which are excavated certain holes slightly widened interiorly, and disposed in quincunx.

"But differences of this nature cannot be formed by the simple juxtaposition of new calcareous layers under those primitively formed; for the soft parts of the animal, the only ones which can be the seat of a secretion of this calcareons matter, do not extend over the surface which is thus modified; and the position of the cells thus immersed in the apparently common mass of the polypidom is often such that we cannot attribute their change of form to any operation or friction of foreign bodies.

"It appears evident to us that these facts indirate the presence of life in the substance which composes the parietes of these cells, and can only be explained by the existence of a nutritive movement; like to that which, in the configuration of bones, effects analogous modifications.

"To know better the nature of these cells, I submitted to the action of nitrous acid diluted with water, a part of a polypidom recently taken from the sea. A brisk effervescence was visible immediately, and in some minutes the cells became flexible, and separated from one another. Before treating them thus, no distinct membrane was seen on the internal wall of these cells; and when the nitrous acid had destroyed all the calcareous carbonate on which their rigidity depended, these same parietes still existed and had not changed their form much : only they were formed now of a soft and thick membrane constituting a bag, in the interior of which we perceived the digestive apparatus of the polype. The opening of this bag was no longer truncated, as it appeared when the texture of the membrane was thickened by the stony deposit from which we had just freed it, but the membrane was continued uninterruptedly with the tentacular sheath.

"We see then that in the Eschares, the cell in which it is said the polype retires as into a shell, is a component part of the animal itself, in which it conceals itself, if we may use the comparison, as the hedgehog enters into the thorny skin of his back. It is not a calcareous crust which is moulded on the surface of its body, but a portion of the general tegumental membrane,- of the skin of the polype,-which, by a molecular deposit of eartly matter in the meshes of its tissue, ossifies as the cartilages of superior animals ossify, witbout ceising to be the seat of a nutritive movement.

" We see also that that which is consideredgenerally, as being the body of these polypes, constitutes in reality only a small portion of it, and consists of little but the digestire, and probably breathing organs, of these little animals.

"The tegumental bag, freed from its carbonate of lime, seems to me formerl of a tomentose membrane covered, particularly without, with a multitude of cylindrical filaments, disposed perpendicularly to the surface, and pressed close to one another. It is in the spaces left between these fibres that the calcareous matter appears to be principally deposited, for if we examine, with the micro- 
scope, a transverse cut of the polypidom iu its natural state, we distinguish in it an analogous conformation, the external wall of the cells being not composed of layers, but rather of cylinders or irregular prisms placed perpendicularly to its surface.

" As to the operculum, which scrves to shut the entrance of the tegumental cell of the Eschara, when the animal is wholly concealed in it, it is but a labial fold of that which we may call the skin of the polype, and of which the projecting margin has acquired a horny consistence, whilst that portion continuous with the general envelope, preserves sufficicnt softness to remain flexible, and to obey the action of the muscles whose tendons are inserted in its thickness.

"The changes which we have indicated above in the external formation of the cells of the Fschares are not the only ones effected by the progress of age in the stony integuments of these zoophytes. The form of their opening is modidified considerably, as may be seen by the figures which accompany this memoir : the sinus or emargination situated under the operculum disappears by degrees, and their interior carity becomes filled up so as not to occupy more than about the quarter of their original diameter. This thickening changes even a little the general appearance of the polypidom; for as it is more considerable in the cells situated farthest from the extremities of the branches, it results that these, at first almost flat, become more and more cylindrical. Lastly, it is not without surprise that we have seen these same cells when they are arrived at extreme old age, lose altogether the opening from which the polype extended its tentacula. In fact, the margins of this opening swelling more and more outwardly come at last to touch and to close, so that no trace of its existence is left : but the cell, now a shut cavity, still exists towards the axis of the polypi. dom.

"Thus, then, the last external mark of the individual existence of these collected polypes, disappears before that life is extinct in the interior, and the most remarkable character of the polypidom is lost without hope of recovery.

"Reflecting on the fact we bave just noticed, we are naturally led to ask how the nourishment necessary for the support of the secretions on which the pro. gress of consolidation depends, can continue when the cell containing the digestive apparatus of the animal is shut up in this manner. Is it from its neighbours that it receives its nutritive matters, or can it continue to absorb them directly from without through these stony integuments? The nature of this solid shell seems at first sight to oppose great obstacles to this imbibition, particularly to that which would take place by the free surface of the polypidom, but an experiment which is, so to speak, the counterpart of that which has been already detailed, shows that it is otherwise.

"On boiling a fragment of the solid polypidom of an Eschara in a solution of caustic potash, I have extracted the major part of the substances which comfose the organized part of its tissue, and I have then seen that the appearance of the polypidom is considerably changed. The extcrnal parietes of the cells bad become of an almost spongy texture, and its surface, instead of being simply granular, presented a great number of very distinct pores, which were before concealed by the soft parts with which they were filled.

"We may understand, then, that the organized tissue of the old polypes finding itself without covering in different points of the cxternal surface of the cells, 
the absorption may continue to be effected directly from without, although the opening by which the nutritive matters penetrate usually into the digestive cavity, is obstructed and obliterated."-Ann. des Sciences Nat. Part. Zool., Vol. i. p. 25-31.

"And now, should it be asked, granting all this to be true, to what end has so much labour been bestowed in the demonstration? I can only answer, that as to me these disquisitions have opened new scenes of wonder and astonishment, in contemplating how variously, how extensively life is distributed through the universe of things : so it is possible, that the facts here related, and these instances of nature animated in a part hitherto unsuspected, may excite the like pleasing ideas in others; and in minds more capacious and penetratiug, lead to farther disccveries, farther proofs (should such be wanting,) that One infinitely wise, good, all-powerful Being has made, and still upholds, the whole of what is good and perfect; and hence we may learn, that, if creatures of so low an order in the great scale of nature are endued with faculties that enable them to fill up their sphere of action with such propriety ; we likewise, who are advanced so many gradations above them, owe to ourselves, and to Him who made us and all things, a constant application to acquire that degree of rectitude and perfection, to which we also are endued with faculties of attaining."-Ellis. 


\section{EXPLANATION OF THE PLATES.}

PLATE I. Fig. 1. Hydra vulgaris, var. $b$, natural size: specimens from Yetholm Loch, Roxburghshire. Fig. 2. H. vulgaris, var. $a$, nat. size and maguified.

PLATE II. Fig. 1. Coryne squamata, nat. size and magnified. Fig. 2. C. squamata, loaded with reproductive gemmules. Fig. 3 . The same magnified. Fig. 4. Vuriety of C. squamata, Fig. 5. The same magnified.

PLATE III. Fig. I Tubularia indivisa, nat. size. Fig. 2. Head of the same magnified. Fig. 3. Tub. Larynx, nat. size.

PLATE IV. Fig. 1. Hermia glandılosa, var, nat. size. Fig. 2. The same magnified. Fig. 3. Tubularia Larynx, var. nat. size. Fig. 4. The same magnified. Fig. 5. Gemmules, magnified.

PLATE V. Fig. 1. Tubularia ramea, nat. size. Fig. 2. A portion of the same magnified. Fig. 3. Tubularia Larynx, var. nat. size. Fig. 4. A portion of the same magnified.

PLATE VI. Fig. I. Thoa halecina, nat. size. Fig. 2. A small variety of the same. Fig. 3. A piece of the stalk magnified. Fig. 4. A piece of the polypidom magnified.

PLATE VII. Fig. 1, 2. Thoa Beanii, nat. size and magnified. Fig. 3, 4. Thoa muricata, from a specimen communicated by Mr Bean.

PLATE VIII. Fig. 1. Sertularia polyzonias. Fig. 2. A variety of the same. Fig. 3. The same magnified. Fig 4, 5. Sertularia rugosa. Fig. 6. A creeping var. of Sert. rugosa, magnified.

PLATE IX. Fig. 1. Sertularia rosacea, of the nat. size. Fig. 2. A portion magnified. Fig. 3, 4. Sertularia pumila. Fig, 5, 6. Sertularia pinnata.

PLATE X. Fig. 1, 1." Sertularia abietina, of the nat. size and magnified. Fig. 2. Sertularia tamarisca. Fig. 3. A portion magnified. Fig. 4. The ovarian resicle, copied from Ellis.

l'LATE XI. Fig. I, 1. "Sertularia filicula, nat. size and magnified. Fig. 2, 2.* Sert. operculata. Fig. 3, 3. * Sert. argentea, var. in a young state.

PLATE XII. Fig. l. Sertularia argentea. Fig. 2. The same in its young state. Fig. 3, 4. Portions of two different specimens of the same magnified, to shew the variations of the cells.

PLATE XIII. Fig. 1, 2. Sertularia cupressina, from a specimen presented to me by J. V. Thompson, Esq.

PLATE XIV. Fig. 1, 2. Thuaria thuja, nat. size and magnified.

PLATE XV. Fig. 1, 2. Thuiaria thıja, in its primary state. Fïg. 3, 4. Th. articulata, from a specimen in the collection of Mr Bean.

PLATE XVI. Antennularia antennina. Fig. 2. represents the branched variety. 
PLATE XVII. Fig. 1, 2. Plumularia falcata. Fig. 3. The resicle mannified. Fig. 4, 5. Pl. pinnata, of the natural size and magnified.

PLATE XVIIl. Fig. 1, 2. Plumularia pennatula, from a specimen presented to me by J. E. Gray, Esq. Fig. 3, 4, 5. Fl. setacea, 4, is from specimens sent from Cork by Mr Thompson.

PLATE XIX. Fig. I, 2, 3, Plumularia cristata. Fig. 4, 5. Pl. myriophyllum, from a Devonshire specimen given to me by Dr Coldstream.

PLATE XX. Fig. 1. A variety of Plumularia cristata. Fig. 2, 3. Plum. frutescens : speeimen from Mr Bean.

PLATE XXI. Fig. 1, 2. Laomedea geniculata. Fig. 3, 4. Laomedea gelatimosa.

PLATE XXII. Fig. I, 2. Laomedea dichotoma, nat. size and magnified. Fig. 3, 4. Campanularia verticillata.

PLATE XXIII. Fig. 1. Laomedea gelatinosa, variety, from a specimen in the collection of Dr Coldstream. Fig. 2. Campanularia? dumosa, variety. Fig. 3. The same magnified. Fig. 4. C ? dumosa. Fig. 5. The same magnified.

PLATE XXIV. Fig. 1, 2, 3, 4. Virgularia mirabilis, from specimens sent to me by Dr Coldstream. Fig. 5, 6. The same, copied from Muller.

PLATE XXV. Fig. 1. Gorgonia verrucosa, redueed one half. Fig. 2. Gorg. placomus, copied from Ellis. Fig. 3. Gorg. anceps, also copicd from Ellis.

PLATE XXVl. Alcyonium digitatum, nat. size, with its polypes fully expanded.

PLATE XXVI.* Alcyonium digitatum. Fig. 1. The Polype as it appears when fully extruded and seen through a magnifier. Fig. 2. The Polype when about to derelope-itself, and about one-third protruded. Fig. 3. A view of the oral disk after the animal has been killed by immersion in fresh water, and the piece placed between two plates of glass. Fig. 4. A view of the upper part of the body compressed between plates of glass. Fig. 5 . A view of a transverse section of the polypiciom, highly magnified, shewing the longitudinal eanals cut aeross, and the ova in them. Fig. 6. A cell still more highly magnified to shew the developement of the ova. Fig. 7. The spicula.

PLATE XXVII. Actinia gemmacea, natural size.

PLATE XXV1lI. Actinia Dianthus.

PLATE XXIX. Fig. 1. Vesicularia spinosa, a small and perfect specimen. Fig. 2. Specimens of the same as they are found wlicn cast on the shore. Fig 3. A portion of the same magnified; the cells have fallen off. Fig. 4. A portion with the cells remaining : copied from Thompson. Fig. 5, 6 . Valkeria imbrieata. Fig. 7, 8, 9. Valkeria pustulosa. For the specimens which furnished these figures I am indebted to Mr Thompson.

PLATE XXX. Fig. 1, 2. Crisia comuta. Fig. 3, 4. Crisia cburnea. Fig. 5, 6. Cr. luxata. Fig. 7, 8. Anguinaria anguina. Fig. 9, 10. Hippothoa catenularia.

PLATE XXXI. Fig. 1, 2, 3. Tubulipora patina. Fig 4, 5, 6. Tubulipora serpens. Fig. 7, 8. Tubulipora Obelia. Fig. 9, 10, 11. Discopora hispidi. Fig. 12, 13. Notamia loriculata.

PLATE XXXll. Fig. 1, \&. Cellepora pumirosa, mat. sizc. Fig. 3. The same 
magnified. Fig. 4. Cellepora ramulosa, nat. size. Fig. 5. $\Lambda$ cross section of a branch cularged. Fig. 6. Cellcpora Skenci, nat. size. Fig. 7. The same magnified. Fig. 8. A transverse section.

PLATE XXXIII. Fig. 1. Cellepora cervicornis, nat. size. Fig. 2. A magnified view of old or mature cells. Fig. 3. The cells from near the edge of the divisions. Fig. 4, 5. Transverse sections of the branches.

Pl.ATE XXXlV. Fig. 1, 2, 3. Lepralia coccinea, 1, nat. size; 2, a few of the cells magnified; 3 , the cells with their ovarian opercula. Fig. 4. Lepralia variolosa. Fig. 5. Lep. trispinosa. Fig. 6. Lep. ciliata. Fig. 7. Lep. uitida. Fir. 8. Lep. immersa. Fig. 9. Flustra tuberculata. Fig. 10, 11, 12. Menbranipora pilosa. 10, nat. size; 11 , cells of, magnified; 12, cells of varicty $\beta$.

PLATE XXXV. Fig 1, 2. Flustra foliacea. Fig. 3, 4. Flustra truncata.

PLATE XXXVI. Fig. 1, 2. Flustra carbasea. Fig. 3, 4. Fl, avicularis Fig. 5, 6. Fl. Murrayana. Fig. 7, 8. Cellularia avicularia.

PLATE 'XXXV1I. Fig. 1, 2, 3. Flustra membranacea, nat. size and magnified. Fig. 4. Flustra lineata. Fig. 5. Fl. carnosa. Fig. 6, 7. Farcimia salicornia.

PLATE XXXVHI. Fig. 1, 2. Cellularia ciliata, nat. size and magnified. Fig. 3, 4. Cell. reptans. Fig. 5, 6. Cell. scruposa.

PLATE XXX1X. Acamarchis plumosa, of the natural size and magnified.

PLATE XL. Eschara foliacea, reduced one lalf, with portions magnified to shew the cells.

PLATE XLI. Alcyonidium gelatinosum. Fig. 1 and 2, specimens of the natural size to shew the variations to which the species is subject in outward form. Fig. 3. The polype removed. This figure was made in the year 1833 ; and is less accurate than that of Dr Farre's. 'Fig. 4, 5. Alcyonidium parasiticum.

PLATE XL1I. Fig. 1. Alcyonidium hirsutum, of the natural size; and Fig. 2, a portion of the surface as seen through a magnifier. Fig. 3, 4. Alcyonidium echinatum. Fig. 5. Cliona celata. Fig. 6. The spicula of the same.

PLATE XL1II. Cristatella mucedo, copied from Turpin. Fig. 1. The polype at the period of its birth, magnified. Fig. 2. The same when fully developed : $a$, the transparent margin; $b$, the disk of the polypidom; $c$, the holes whence the polypes protrude; $d$, the neck of the polypes and anus; $e$, the tentacular arms, with the mouth at their base ; $f$, the filameuts which fringe the tentacula: the arrows mark the direction of the currents of water. Fig. 3. The tentacular filaments very much magnified to show their cilia.

PLATE XLIV. Alcyonella stagnorum. Fig 1. natural size and appcarance. Fig. 2. A longitudinal section. Fig. 3. A portion of the surface magnified. Fig. 4. A transverse section. Fig. 5. A front view or the polype. Fig. 6. A lack view of the same: copied from Raspail. 



\section{INDEX TO THE WOOD-CUTS.}

No. 32. Actinia maculata

Page 31. mesembryanthemum

34.

29. viduata

49. Alcyonella, ovum of,

50. ㄴ - ovum of,

7. Alcyonidium, ovum of.

5. Alcyonium digitatum, section of,

33. Anthea Tuediæ

39. Bowerbankia densa

41.

24. Campanularia dumosa

18. syringa

17. volubilis

30. Caryophyllia Smithii.

23. Cornularia rugosa

27.

43. Crisia chelata

2. Flustra membranacea

10. Fusus, the capsule of ?

21. Gorgonia, section of the stem of,

19. Flabellum

25. verrucosa, animal of,

26. ova of,

12. Hermia glandulosa

42. Hydra coronata. Fig. $c, d$.

11. - fusca

4. - viridis

38. Lagenella (Bowerbankia) repens

The animal is after De la Beche. 206

9. Laomedea gelatinosa, polype and cell

28. Lucernaria auricula

35.

36. tentacula and ova of,

37. campanulata

12. Lucia? Fig. $a, b$.

22. Pennatula phosphorea

G. J. 181

Cavolini. 187

G. J. 260

G. J. 34

G. J. 92

Ellis. 168

G. J. 161

Cavolini. 182

Do. 186

G. J. 109

Lister. 258

Baker. 93

G. J. 37

Farre. 235

Lister. 83

G. J. 193

G. J. 229

G. J. 230

G. J. 23]

Lister. 258

G. J. 175

G. J. 32으 


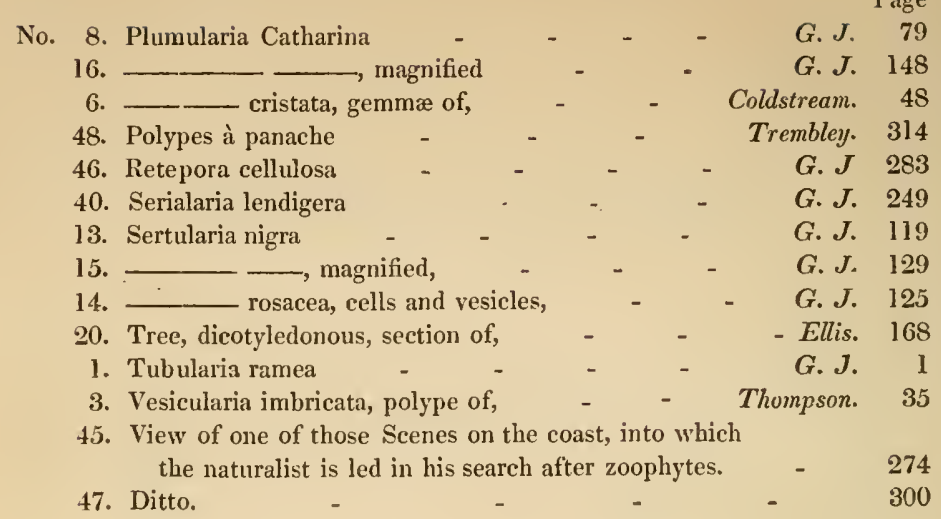




\section{$1 \mathrm{~N} D \mathrm{E} X$.}

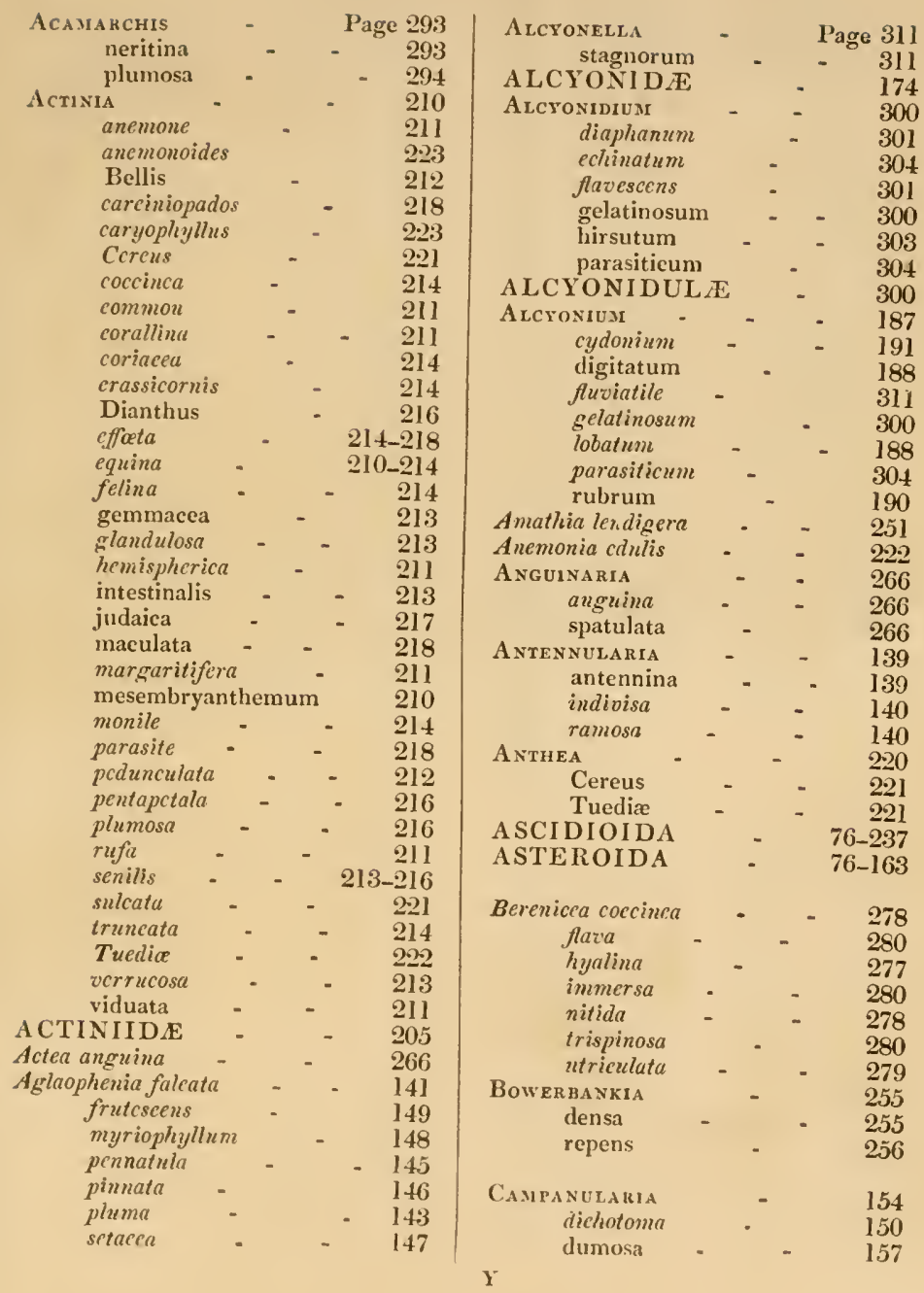




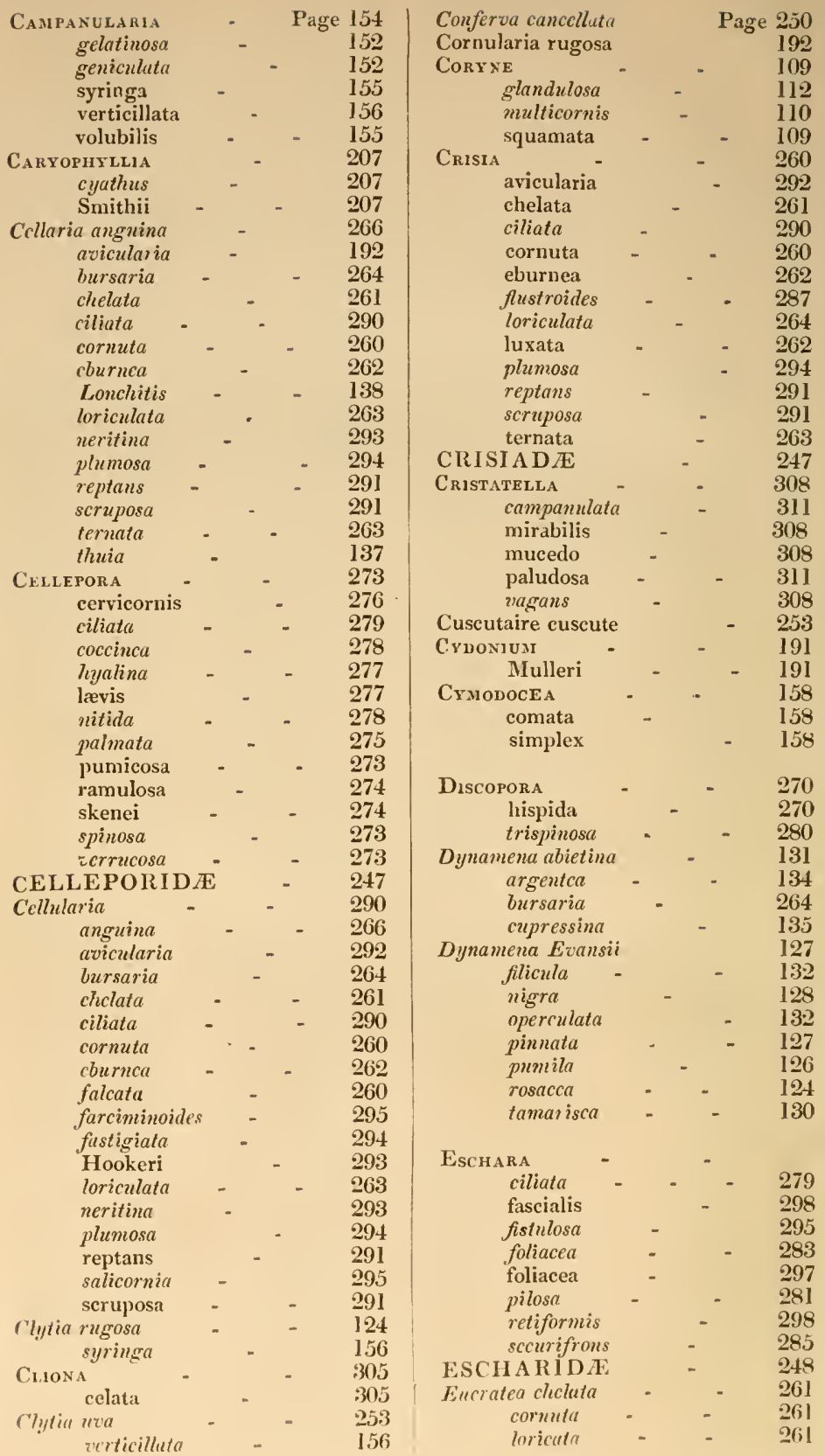




\begin{tabular}{|c|c|c|c|c|c|c|c|}
\hline FARCIMAA & & & Pinge 295 & HYWRA & - & & Page 93 \\
\hline fistulosu & - & & $-\quad 295$ & corynaria & - & & 98 \\
\hline salicornia & - & & 295 & Dianthus & - & & 216 \\
\hline Filipora filograni & & - & 272 & fusca & - & - & 96 \\
\hline Fislularia muscoides & & - & 115 & gremmacea & & - & 213 \\
\hline ramosa & - & - & 117 & grisca & - & - & 95 \\
\hline Flabellum veneris & - & - & 185 & littoralis & - & - & 98 \\
\hline Flustra & - & - & 283 & lutea - & - & - & 98 \\
\hline angustiloba & - & - & 287 & mescmbryanth & themum & & 211 \\
\hline avicularis & - & - & $2 \varsigma 6$ & oligactis & - & - & 96 \\
\hline bulluta & - & - & 273 & ramosa & - & - & 112 \\
\hline capitata & - & - & 287 & squamata & - & & 109 \\
\hline carbasea & - & & 285 & verrucosa & - & - & 97 \\
\hline carnosa & - & - & 288 & viridis & - & & - 93 \\
\hline chartacea & - & - & 284 & viridissima & & - & 94 \\
\hline denluta & - & - & 281 & vulgaris & - & - & 95 \\
\hline Ellisii & - & - & 286 & HYDRAIDE & - & - & 91 \\
\hline foliacea & - & & 283 & HYDROIDA & - & & $75-81$ \\
\hline hirta & - & - & 288 & & & & \\
\hline bispida & & & 289 & Isis entrochus & - & - & 186 \\
\hline lineata & - & & 288 & Hippuris & & - & 185 \\
\hline membranacea & & - & 287 & & & & \\
\hline Murrayana & & - & 287 & Lagcuella repens & - & & 256 \\
\hline papyracca & - & - & 284 & IEDEA & - & & 150 \\
\hline pilosa & - & & 281 & dichotoma & - & - & 150 \\
\hline setacea & & - & 286 & gelatinosa & - & - & 152 \\
\hline spinifera & - & - & $-\quad 288$ & geniculata & & & 1 l l \\
\hline spongiosa & - & & 282 & muricata & - & - & 121 \\
\hline telacca & - & & 288 & spinosa & - & & 250 \\
\hline tuberculata & & - & 289 & LEPRALIA & & - & 277 \\
\hline truncata & - & & 285 & ciliata & - & - & 279 \\
\hline tubulosa & & - & 271 & coccinea & - & - & 278 \\
\hline unicornis & & - & 289 & liyalina & - & - & 277 \\
\hline Fungia turbinala & - & & 206 & immersa & - & & 280 \\
\hline & & & & nitida & - & - & 277 \\
\hline Gcmiccllaria bursuric & & - & 264 & trispinosa & - & - & 280 \\
\hline loriculata & - & - & 264 & variolosa & - & & 278 \\
\hline GORGONIA & & - & 182 & LIMNIADES & - & & 248 \\
\hline anceps & - & & 184 & Lobularia conoidea & - & . & 191 \\
\hline flabellum & & - & 184 & digitata & - & & 188 \\
\hline lepadifera & & - & -185 & Loricaria curopea & - & & 264 \\
\hline placomus & - & - & I8:3 & Loricula loricata & - & - & 261 \\
\hline verrucosa & & - & 18 & RARIA & - & - & 228 \\
\hline viminalis & - & - & 183 & auricula & - & - & 229 \\
\hline GORGONIADE & & - & 17 & campanulata & - & & 231 \\
\hline & 1 & 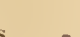 & 301 & $\begin{array}{l}\text { conzolvulus } \\
\text { fascicularis }\end{array}$ & - & - & $\begin{array}{l}231 \\
2228\end{array}$ \\
\hline $\begin{array}{l}\text { Halodactylus diapha } \\
\text { HELI A N'THOID }\end{array}$ & DA & & $76-195$ & $\begin{array}{l}\text { fascicularis } \\
\text { octoradiata }\end{array}$ & - & & 229 \\
\hline HerMia - & & - & 111 & 1. $\mathrm{UCIA} \longrightarrow \square$ ? & - & - & 257 \\
\hline glandulosa & & - & & & & & \\
\hline Hippotiea & - & & 265 & MADREPHYLL & I EA & & 205 \\
\hline catenularia & & - & 265 & ERORA intersti, & incta & & 209 \\
\hline Elliotce & - & & 265 & musicalis & - & & 209 \\
\hline lanceolata & & - & 265 & porpita & - & - & 209 \\
\hline IIYDRA & & - & 93 & truncata & - & - & 209 \\
\hline Bcllis & - & & 212 & verrucaria & - & - & 267 \\
\hline brunnca $\because$ & - & - & 95 & MEMibraniroka & - & & 280 \\
\hline campanulin (is. & & - & 311 & pilosa. & - & - & 280 \\
\hline capilata & & - & & spongiosa & - & . & 282 \\
\hline $\begin{array}{l}\text { Corcus } \\
\text { coronatil }\end{array}$ & - & - & 2.21 & Metridium plumosun & & - & 216 \\
\hline coronatal & & & & & & & 23 \\
\hline
\end{tabular}




\begin{tabular}{|c|c|c|c|c|c|c|c|}
\hline Millepora cervicomis & & Pag & с 276 & Salicornaria fistulosa & & & Page 295 \\
\hline compressa & - & - & 276 & Scirpearia mirabilis & & - & 179 \\
\hline fascialis & & & 298 & SERIalaria - & - & - & 251 \\
\hline foliacca & - & & 298 & imbricata & - & - & 254 \\
\hline foraminosa & & - & 297 & lendigera & - & & 251 \\
\hline frondipara & & - & 296 & verticillala & & - & 254 \\
\hline lichenoides & & - & 209 & SERTULARIA & - & - & 121 \\
\hline liliacea & & - & 268 & abietina & - & - & 130 \\
\hline pumecosa & & - & 273 & anguina & - & & 266 \\
\hline retepora & & - & 296 & antennina & - & - & 139 \\
\hline reticulata & & - & 29 & argentea & & - & 134 \\
\hline Skenei & - & - & 275 & articulata & - & - & 138 \\
\hline toenialis & & - & 298 & avicularia & & - & 292 \\
\hline truncata & & - & 269 & bursa. & - & - & 264 \\
\hline tubulosa & - & - & 268 & bursaria & - & - & 264 \\
\hline verrucaria & & - & 267 & $\begin{array}{l}\text { ciliata } \\
\text { cornuta }\end{array}$ & & - & $\begin{array}{l}290 \\
260\end{array}$ \\
\hline Naisa reptans & - & & 311 & cupressina & - & & 135 \\
\hline repens & - & & 322 & cuscuta . & & - & 252 \\
\hline Nemertesia antennino & & - & 140 & dichotoma & - & - & 150 \\
\hline ramosa & - & - & 140 & dumosa & - & - & 157 \\
\hline Notania & & - & 263 & eburnea & - & - & 262 \\
\hline bursaria & - & & 264 & Ellisii & - & - & 123 \\
\hline loriculata & - & - & 263 & ericoides & - & - & 122 \\
\hline & & & & Evansii & - & - & 127 \\
\hline Obelia tubifera & - & - & 270 & falcata & & - & 141 \\
\hline tubulifera & - & & 270 & fastigiata & & - & 294 \\
\hline Penna marina & - & - & 176 & filicula & - & - & 131 \\
\hline rubra & & - & 176 & frutescens & - & - & 149 \\
\hline Pennatula & & $\cdot$ & 175 & fuscescens & & - & 127 \\
\hline Britannica & & - & 176 & gelatinosa & - & & 152 \\
\hline mirabilis & - & & -179 & geniculata & - & - & 151 \\
\hline phosphorea & - & - & 175 & Gorgonia & - & - & 149 \\
\hline PENNATULID $A$ & & - & 174 & hatecina & - & - & 120 \\
\hline Pherusa tubulosa & - & - & 271 & Hibernica & - & - & 128 \\
\hline Plumatella & - & - & 322 & imbricata & - & - & 254 \\
\hline campanulata & & - & 311 & lendigera & - & - & - 251 \\
\hline cristata & & & & Lichenastru? & & - & $128-138$ \\
\hline gelatinosa & & - & & Lonchitis & - & - & 138 \\
\hline repens & - & - & & longissima & - & - & 150 \\
\hline sultana & - & - & & loricata & - & - & 261 \\
\hline PLUMULARIa & & - & 140 & loriculata & & - & 263 \\
\hline Catlıarina & - & - & & muricata & - & - & 121 \\
\hline cristata & & - & & myriophyllun & & - & 148 \\
\hline falcata & - & - & & nigcllastrum & & - & 124 \\
\hline frutesceus & - & - & 149 & neritina & & - & 293 \\
\hline myriophyllun & & - & 148 & nigra & - & - & 128 \\
\hline pessnatula & & - & & operculata & & - & 132 \\
\hline pinnata & - & - & & pennatula & - & - & 145 \\
\hline pluma & - & - & & pinnata & - & & $128-146$ \\
\hline setacea & - & - & & pluma & - & - & 143 \\
\hline l'ocillopora interstin & neta & - & & polyzonias & - & - & 122 \\
\hline Polypes à panache & & - & 31 & pumila & - & - & 125 \\
\hline Polypes verds - & & - & 9 & pustulosa & - & - & 254 \\
\hline Polypus, fresh-woater & $r \quad$ & & 93 & repens & - & & $155-291$ \\
\hline Porus cervinus & - & . & 276 & reptans & & - & 291 \\
\hline Primnoa lcpadifera & & & 185 & rosacea & - & - & 124 \\
\hline RETEPORA & & - & 296 & $\begin{array}{l}\text { rugosa } \\
\text { scruposa }\end{array}$ & - & - & $\begin{array}{l}123 \\
291\end{array}$ \\
\hline & - & - & $\begin{array}{l}29 \\
29\end{array}$ & scricea & - & - & 250 \\
\hline & & & 296 & sctacca & - & - & 146 \\
\hline
\end{tabular}




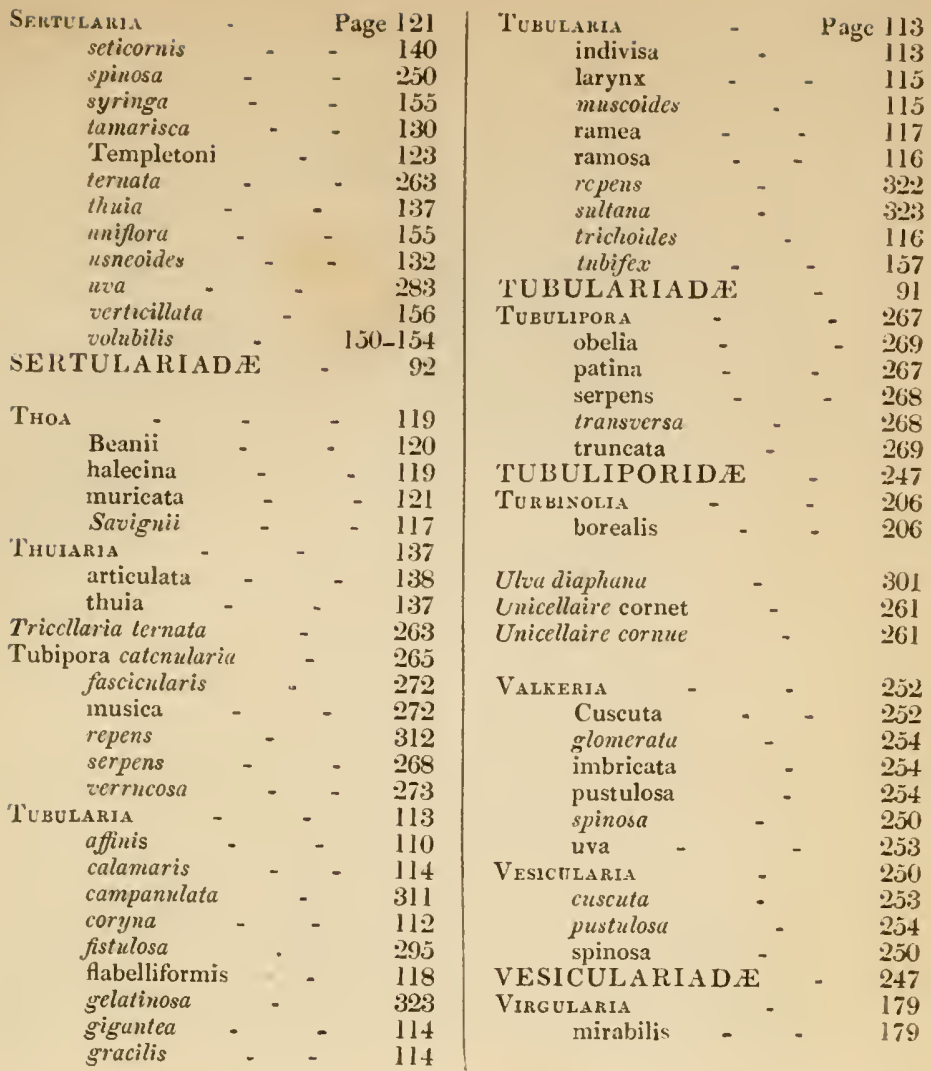




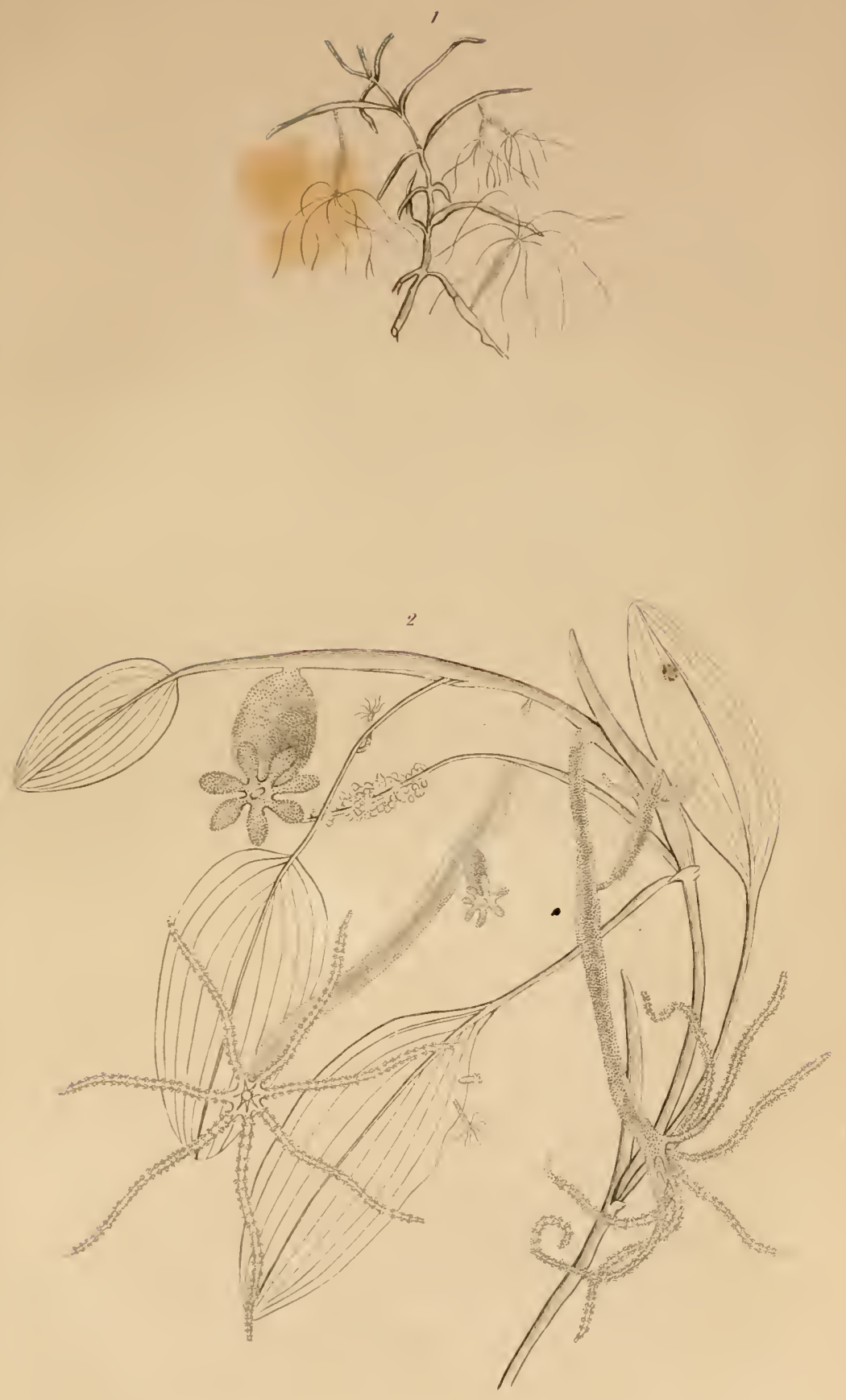


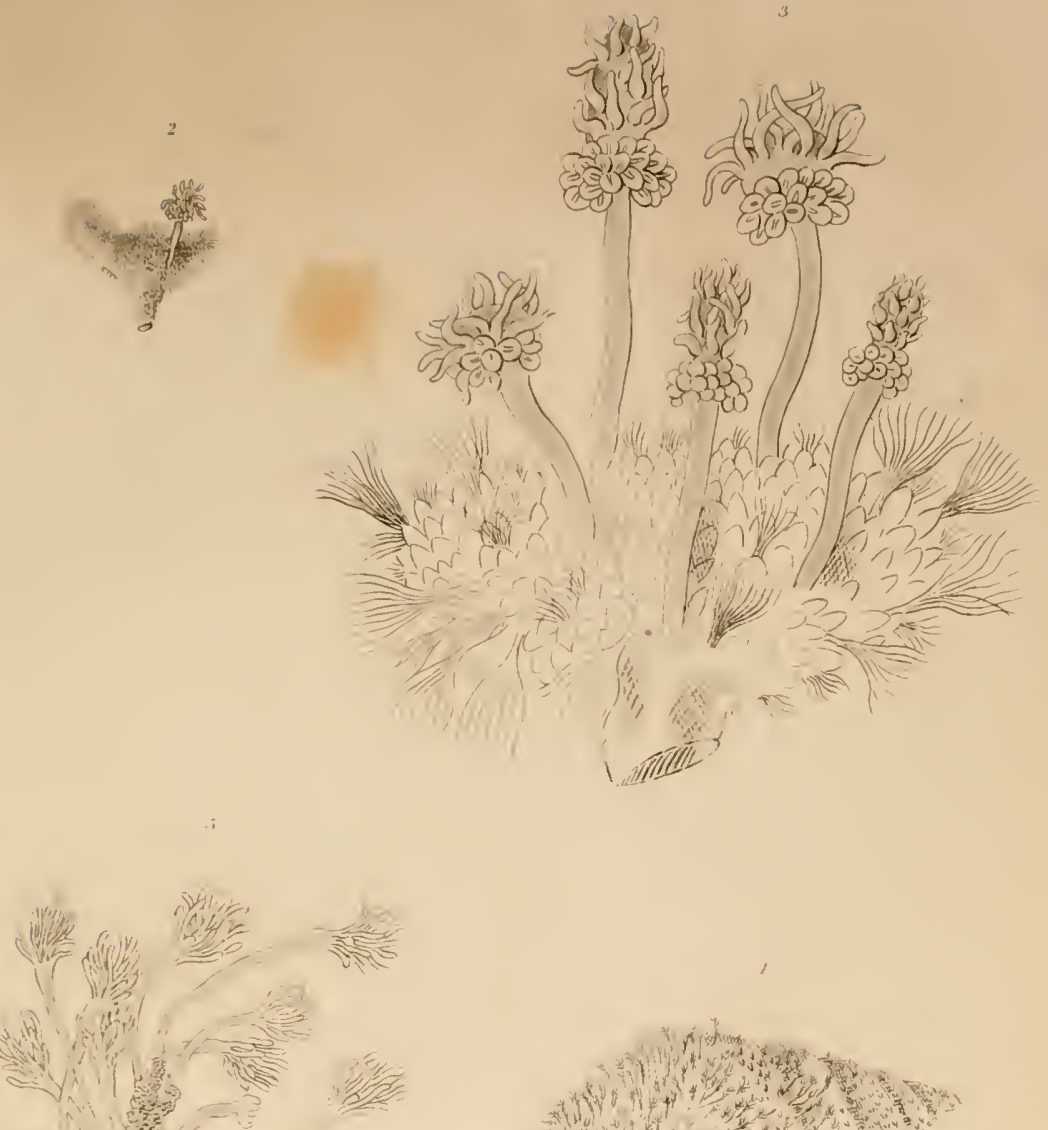

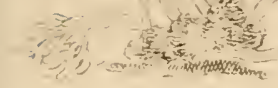
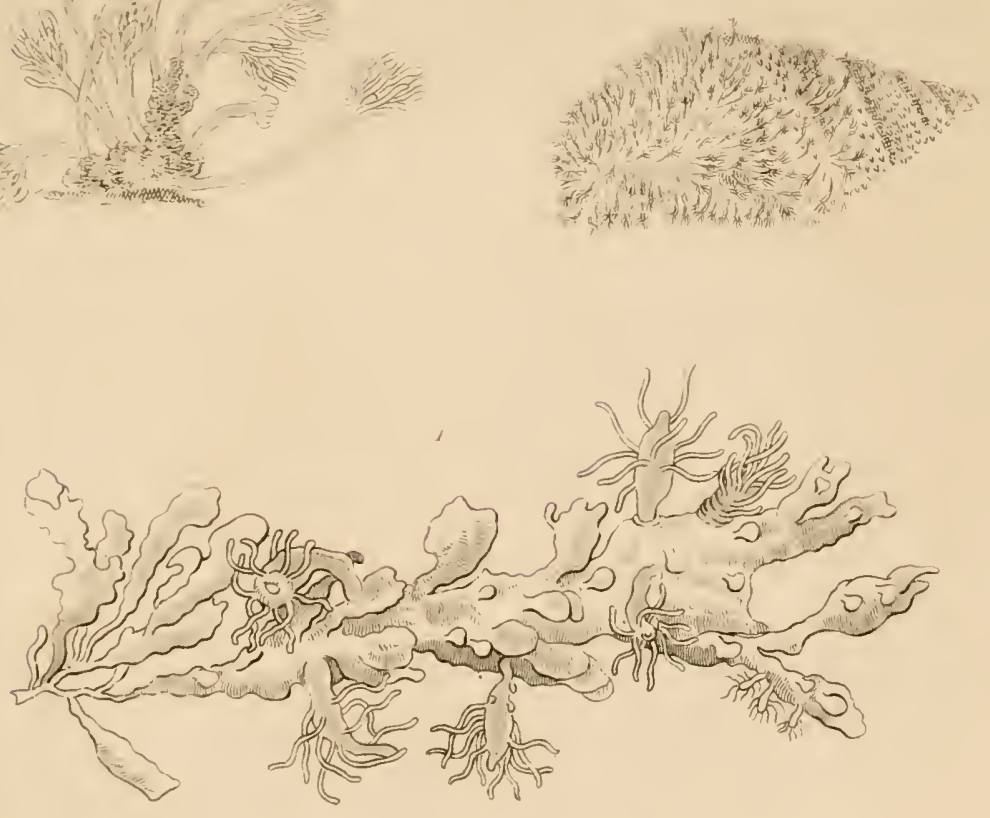

PLATE III

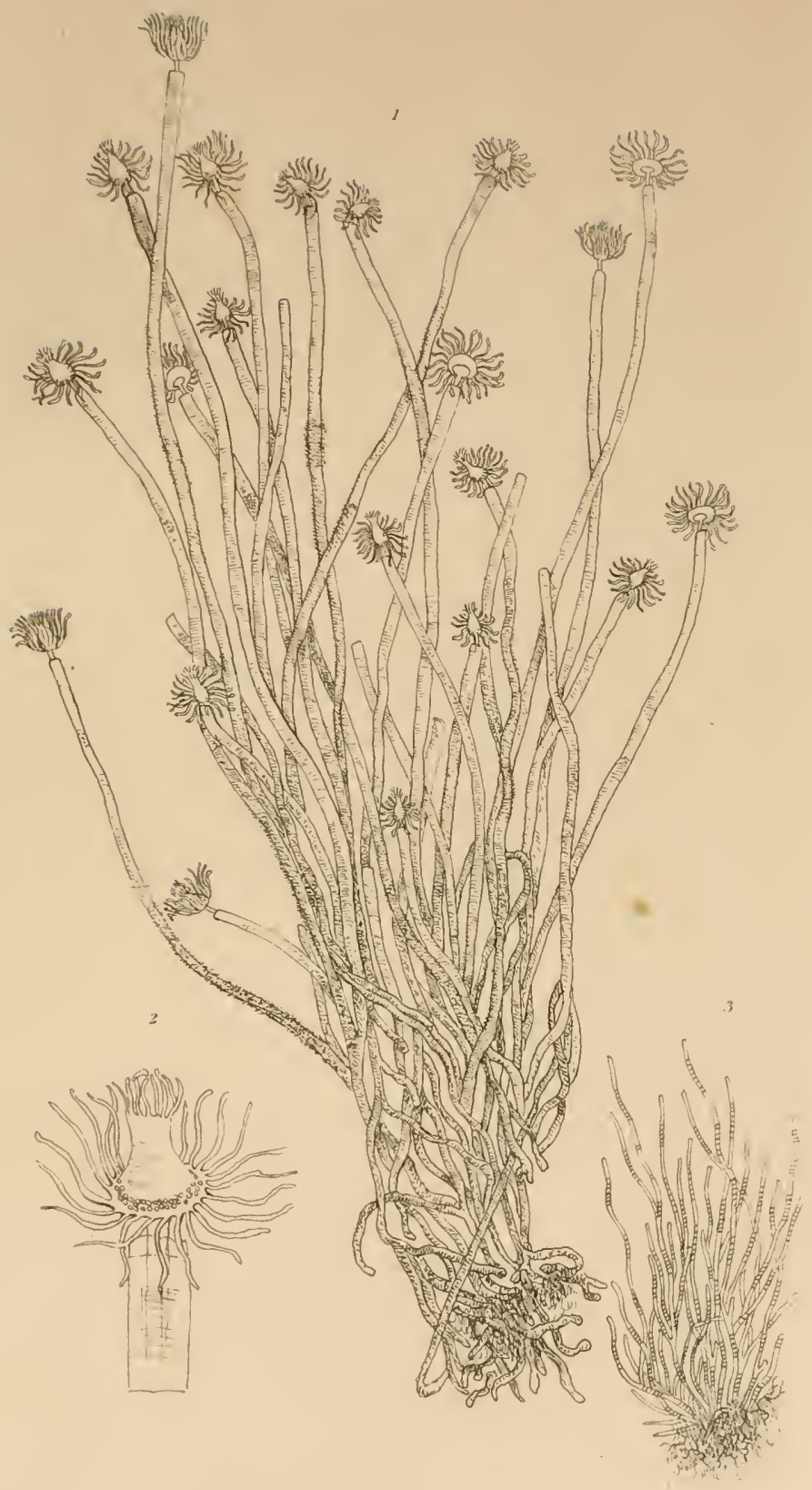





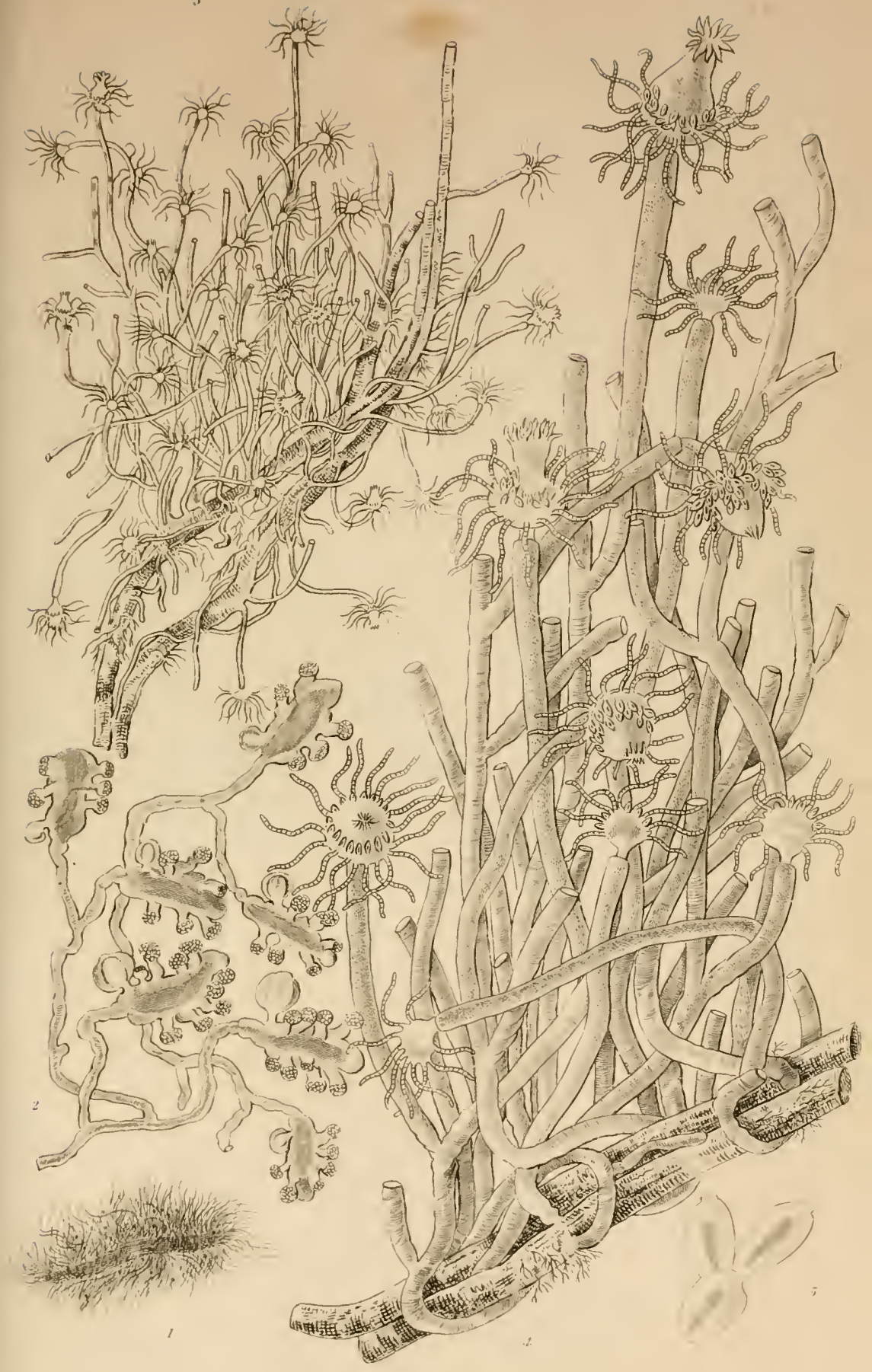





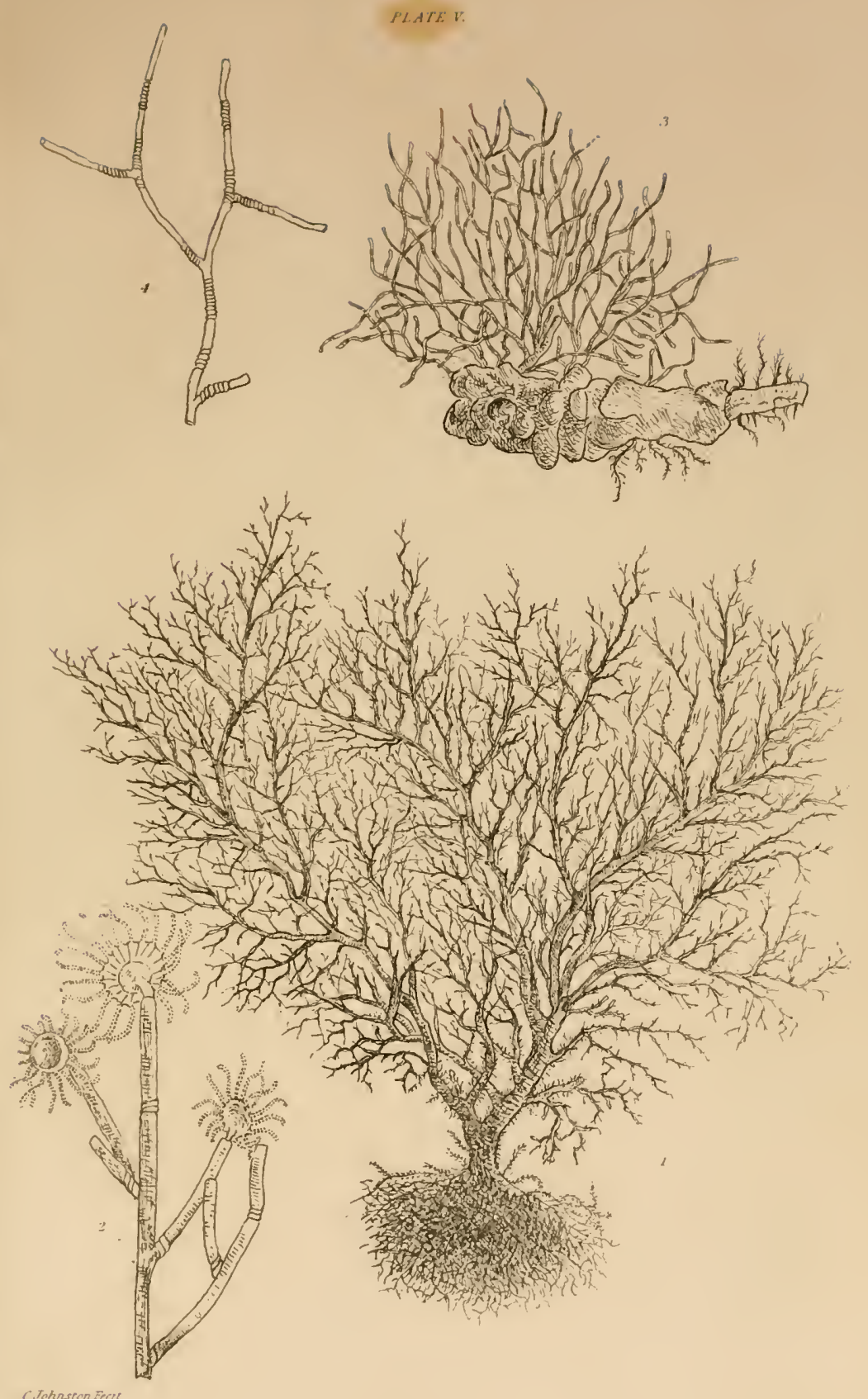





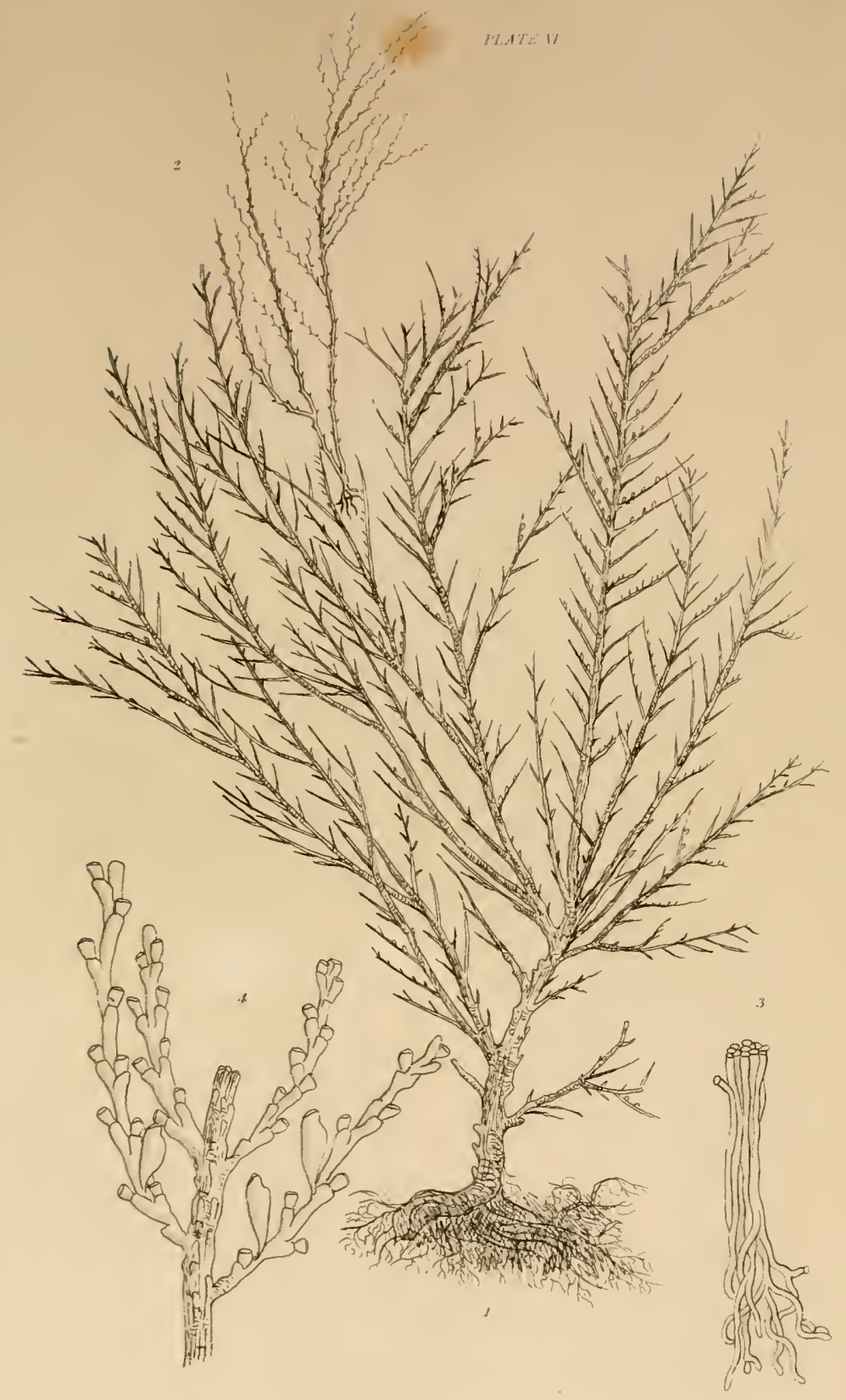




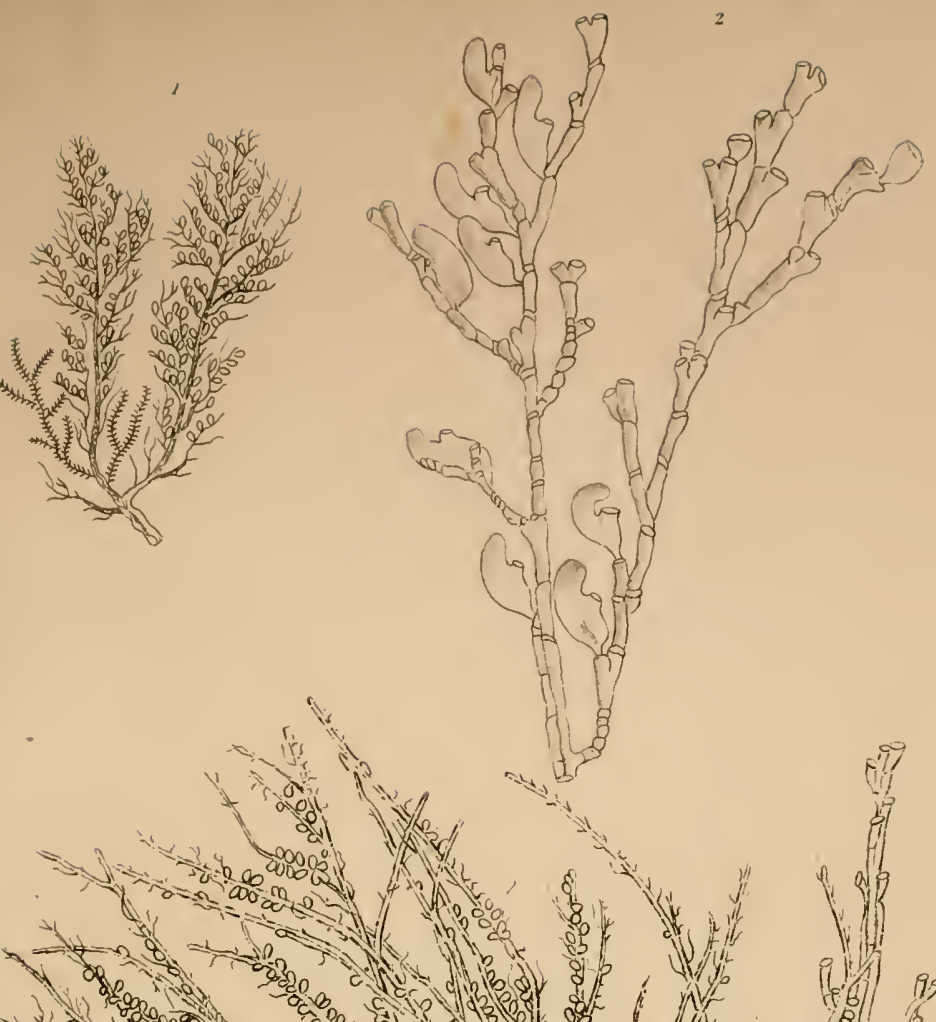

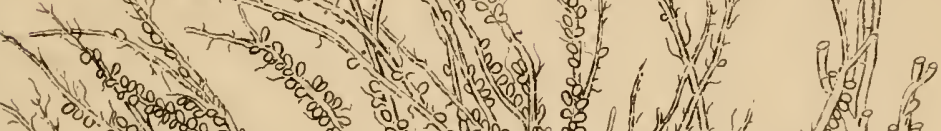

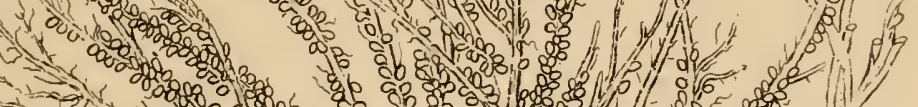

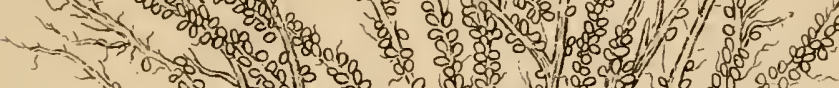

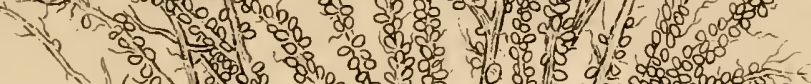

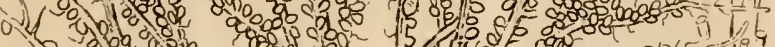

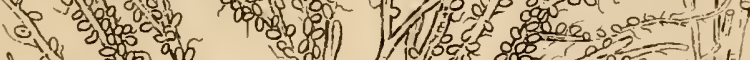
1.12 aी 90

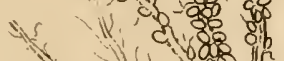
- iv v

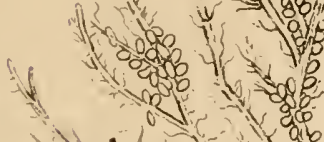
that तe s.
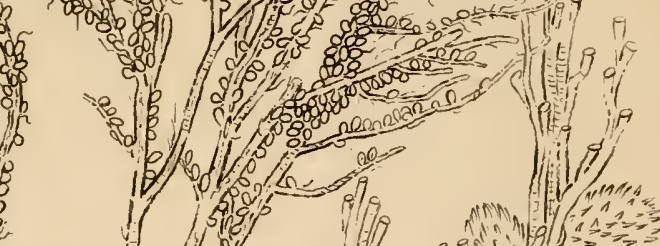



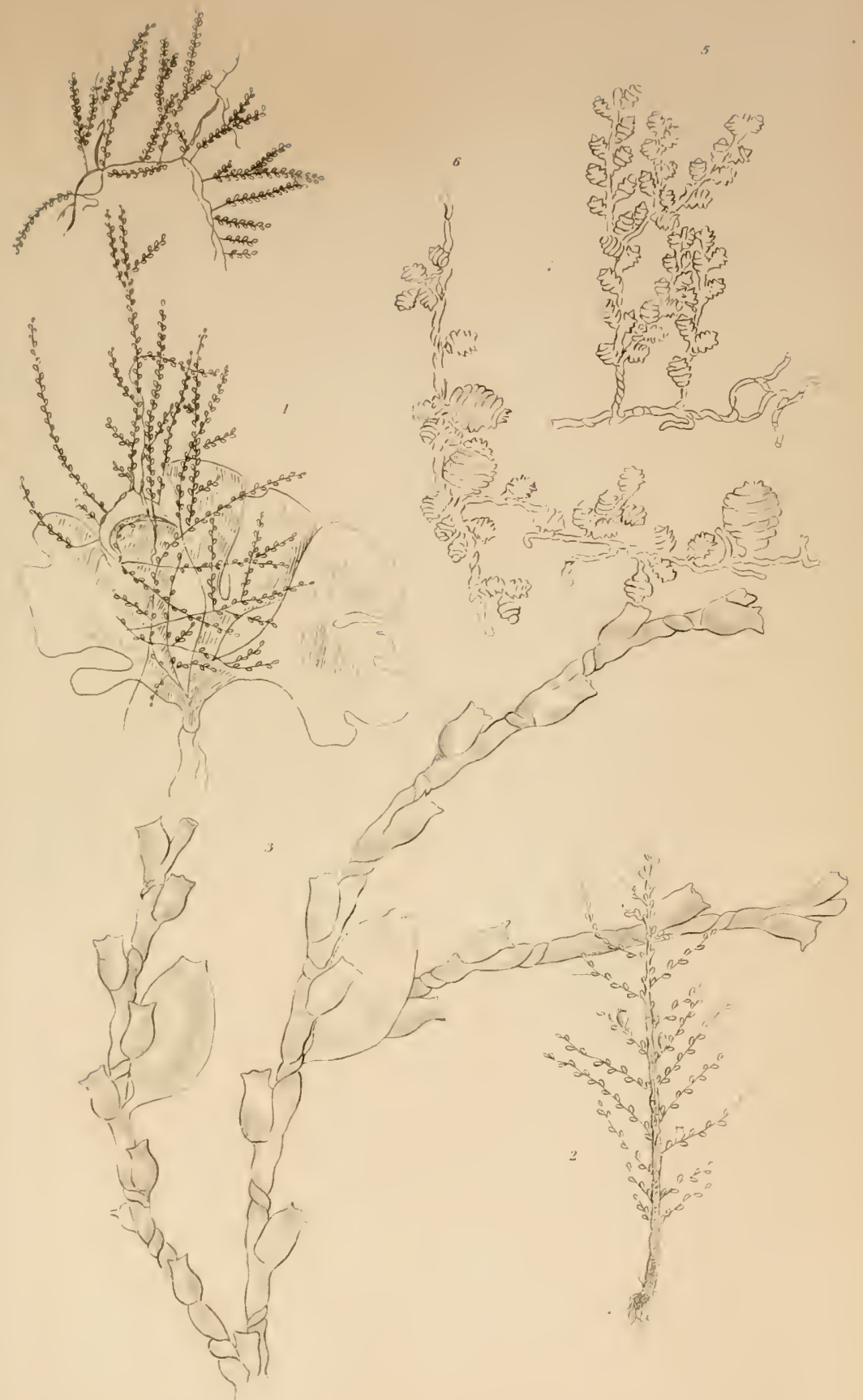



7 ,

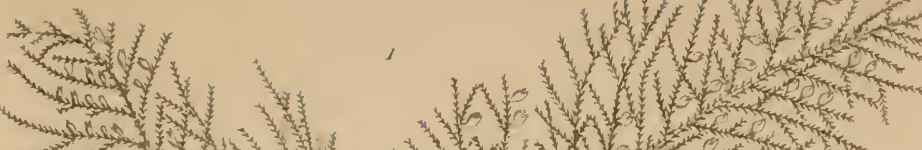

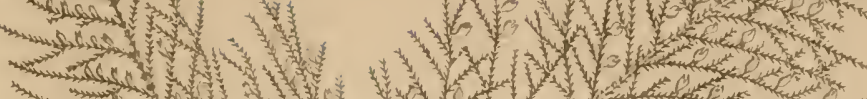

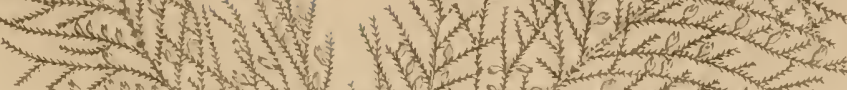

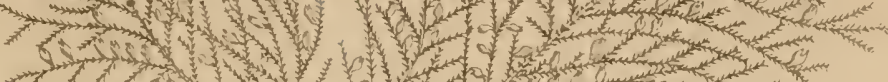

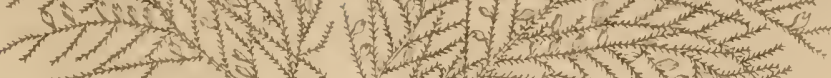
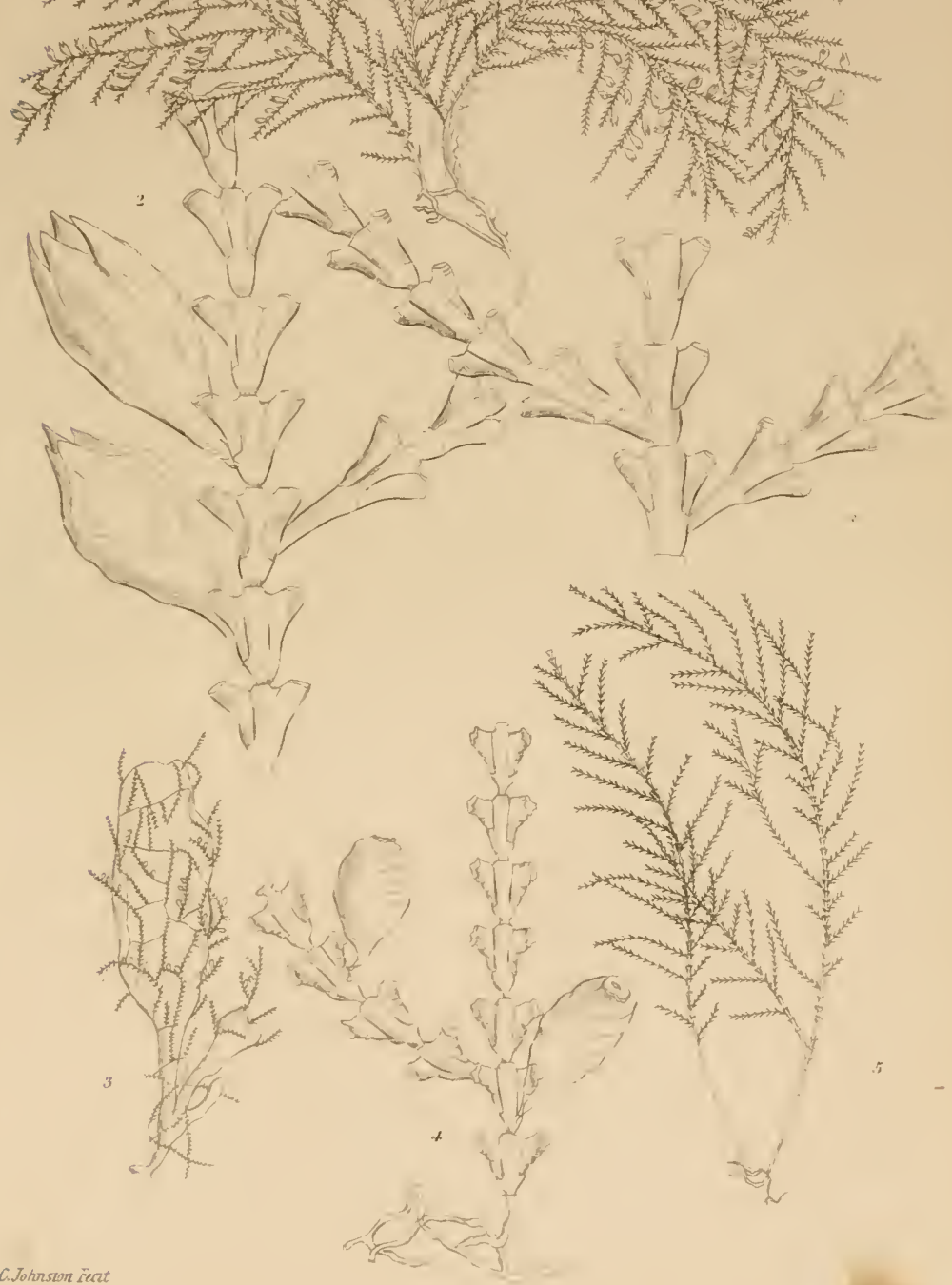

c. Johrston Eert 



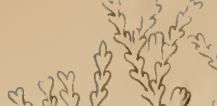

रुरीक ती है?

i) 10015

कै तै है। त)

है? है? $3(3,5$

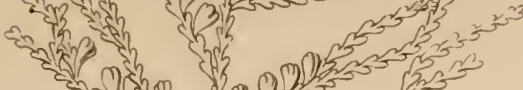

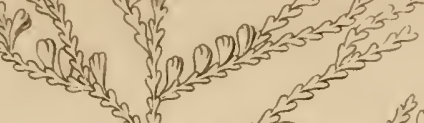

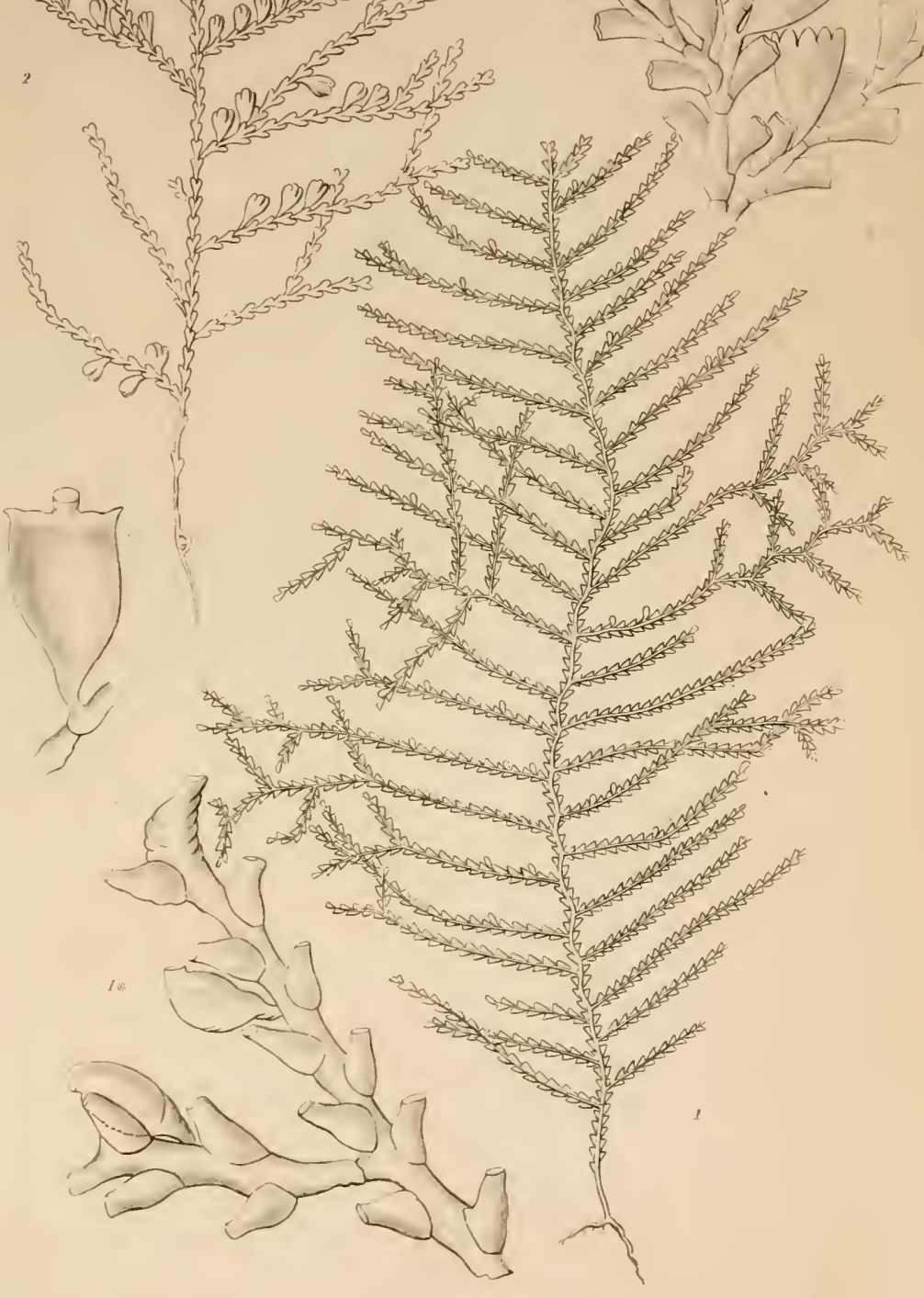





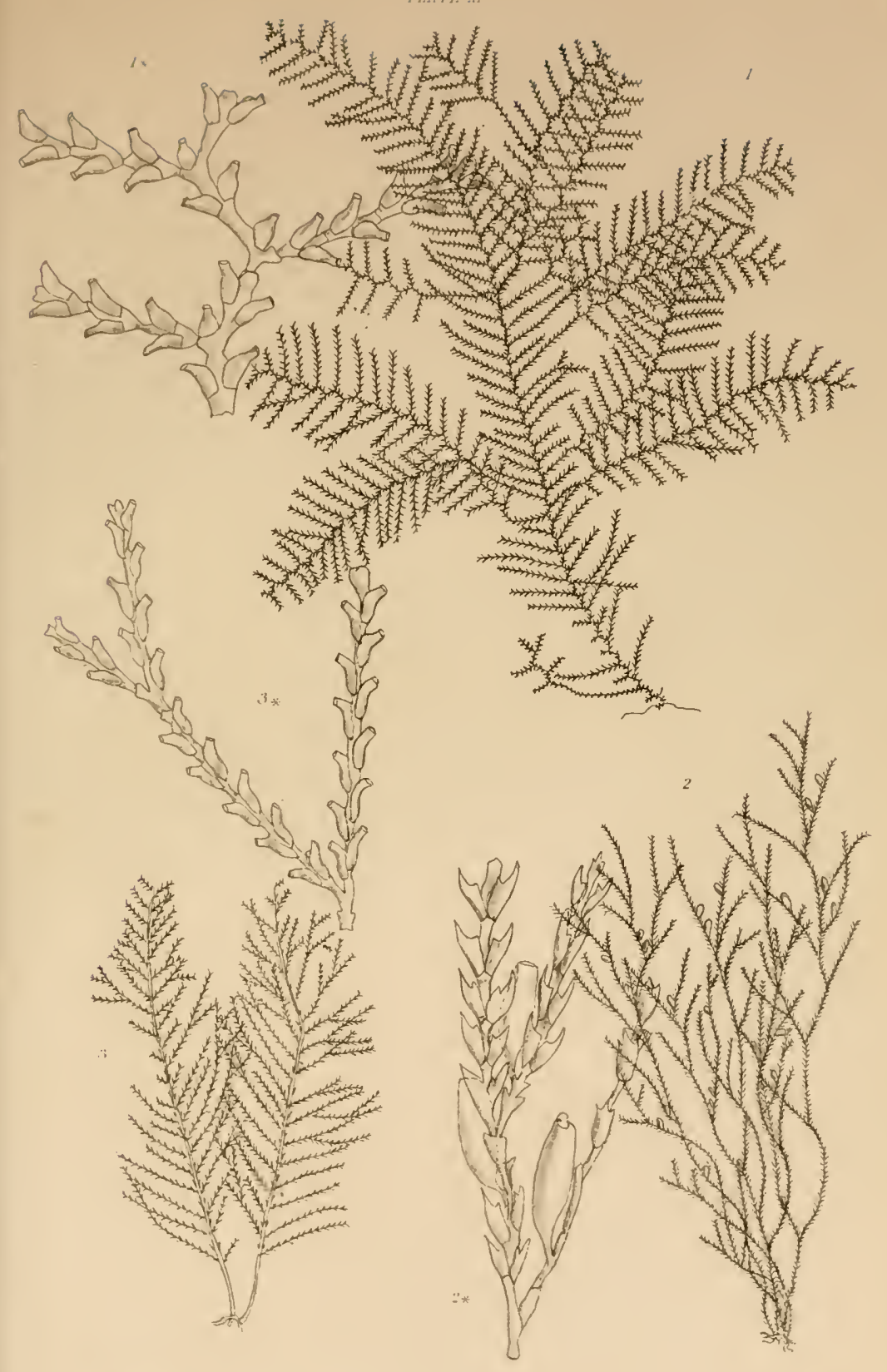





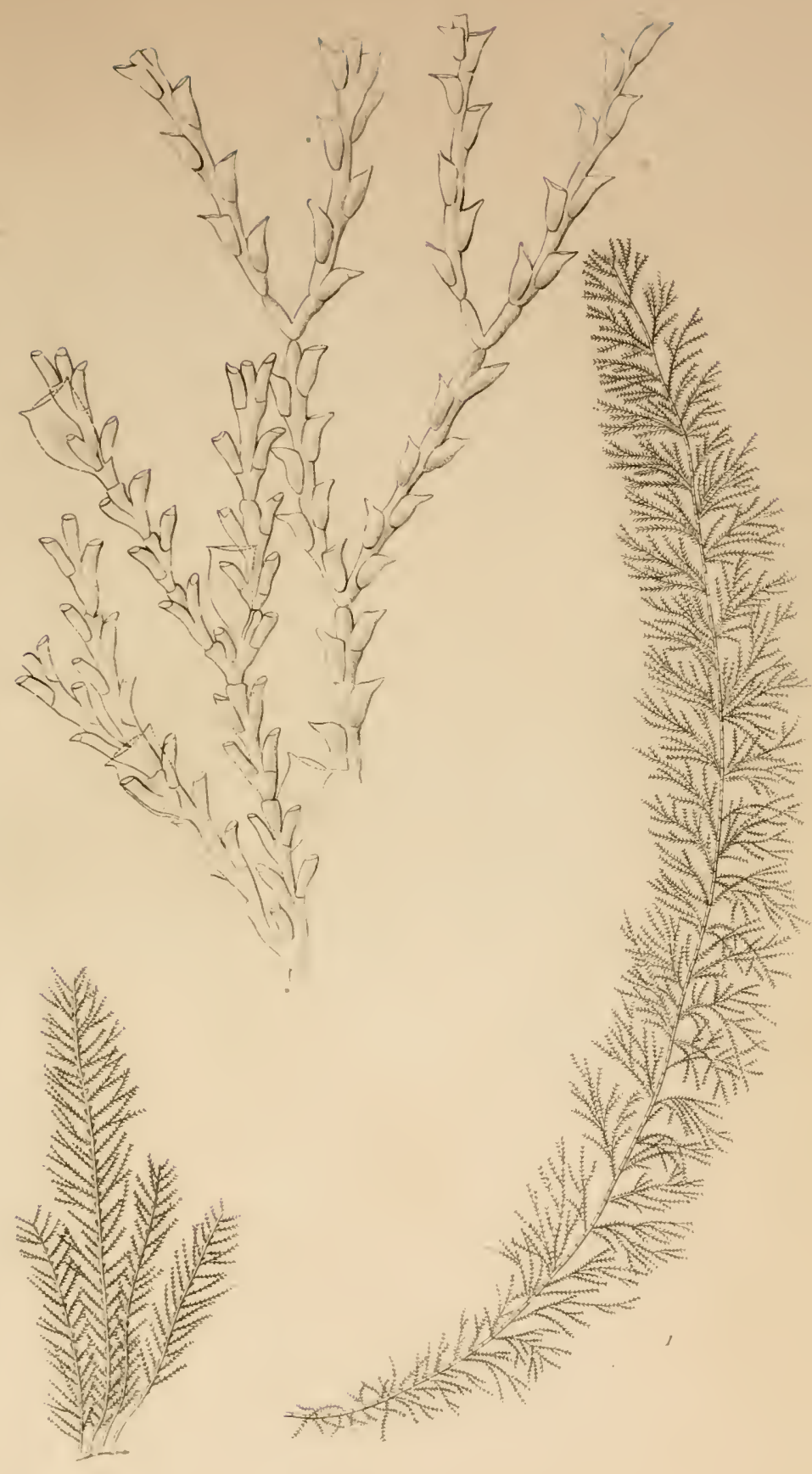





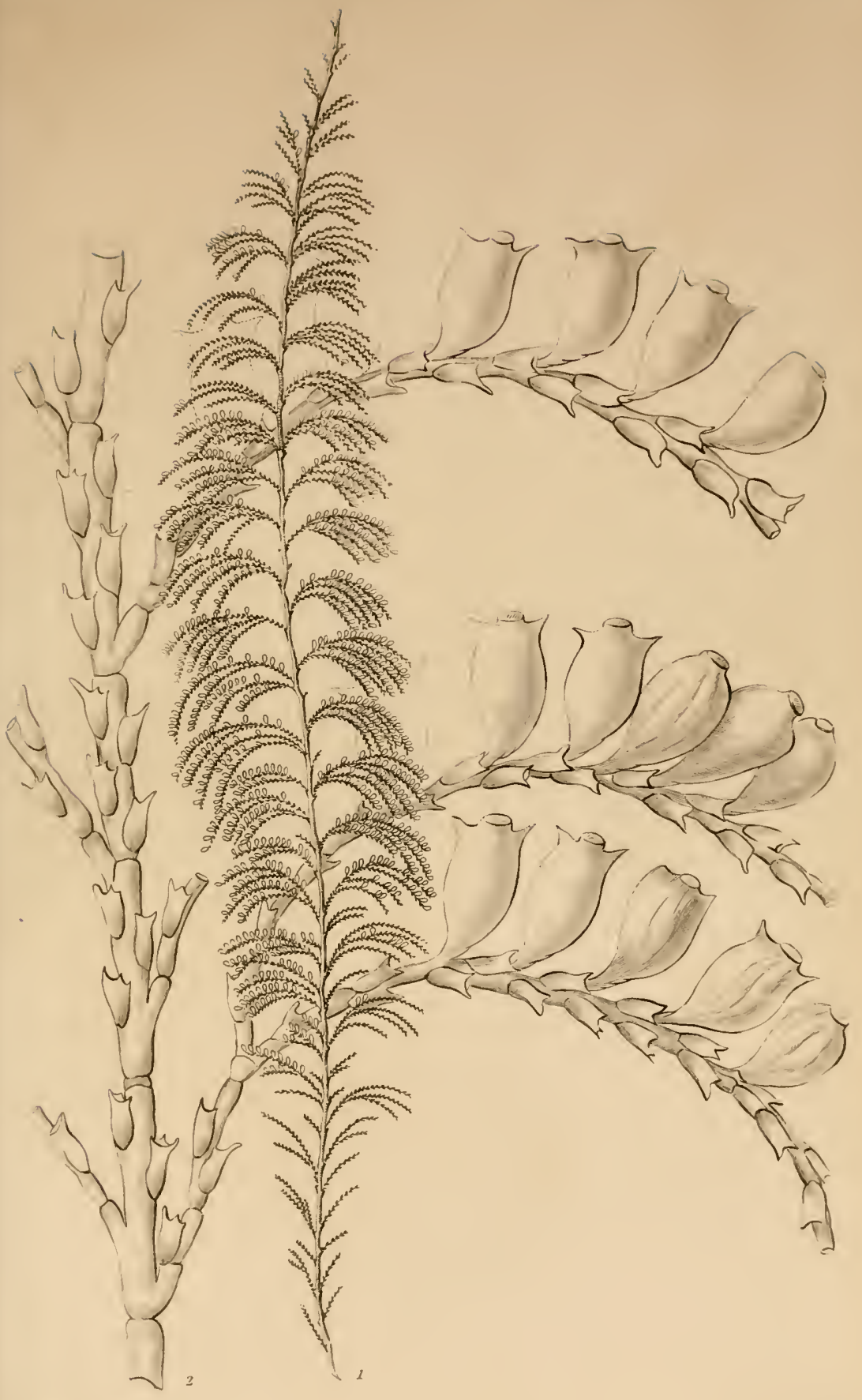





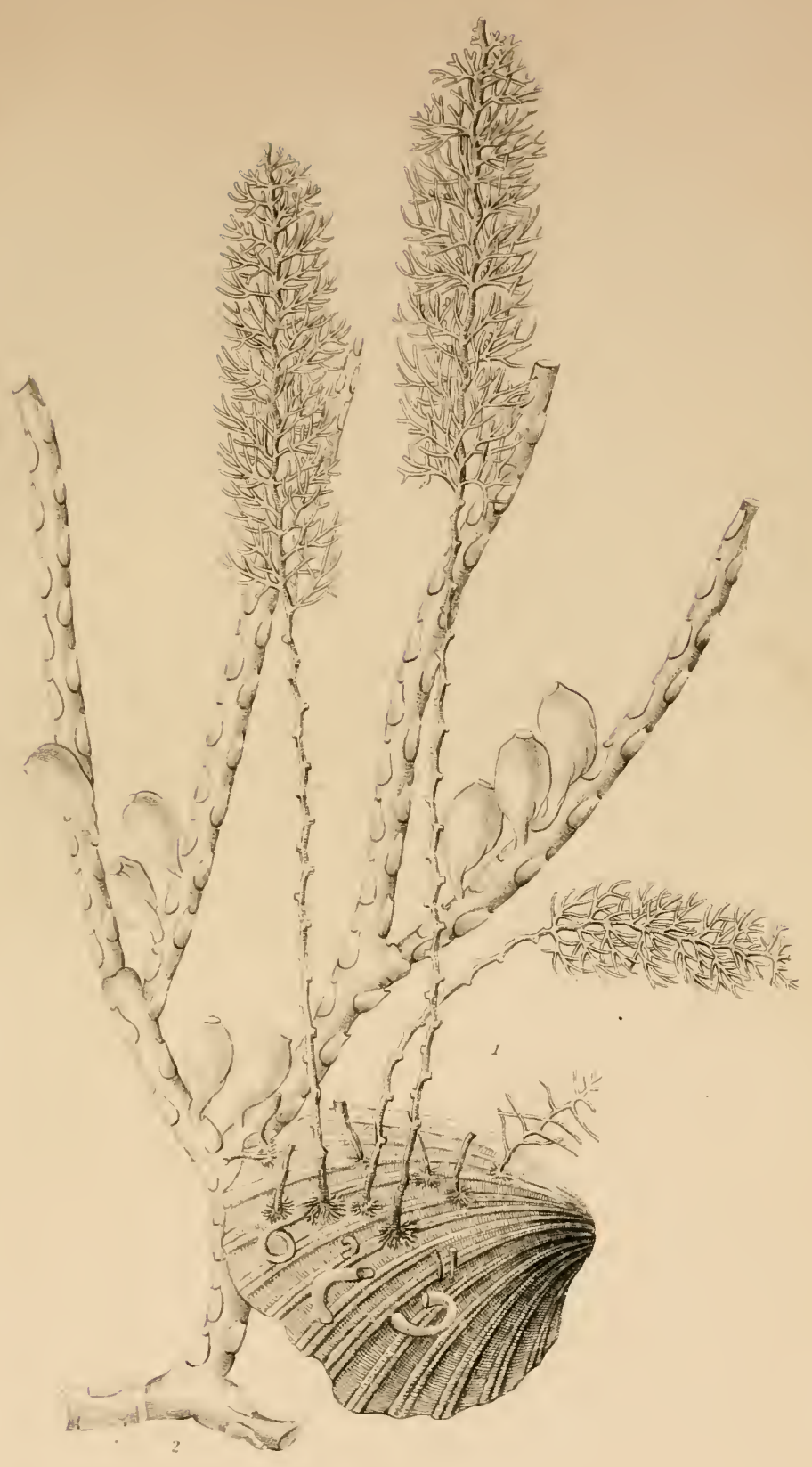





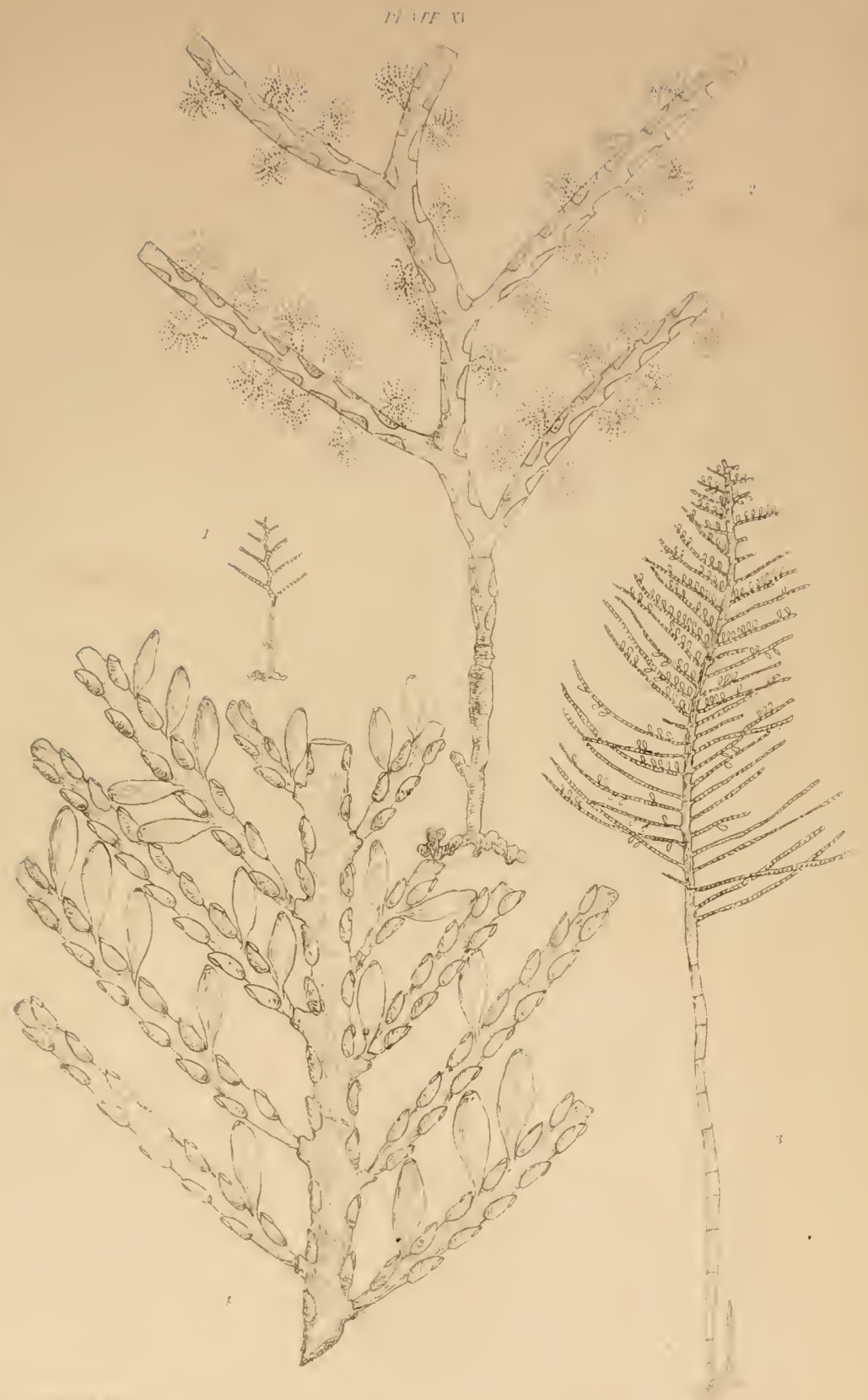





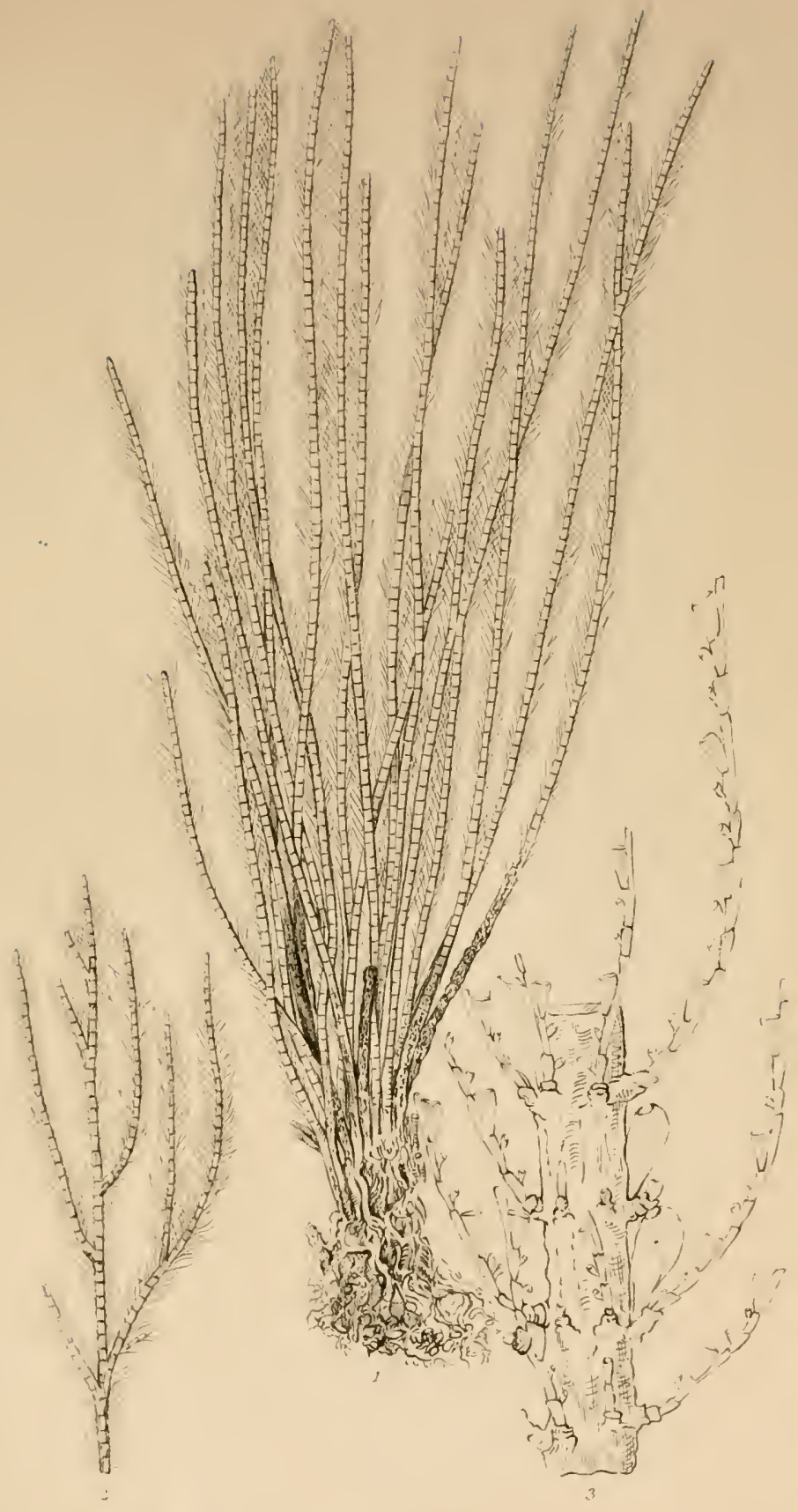





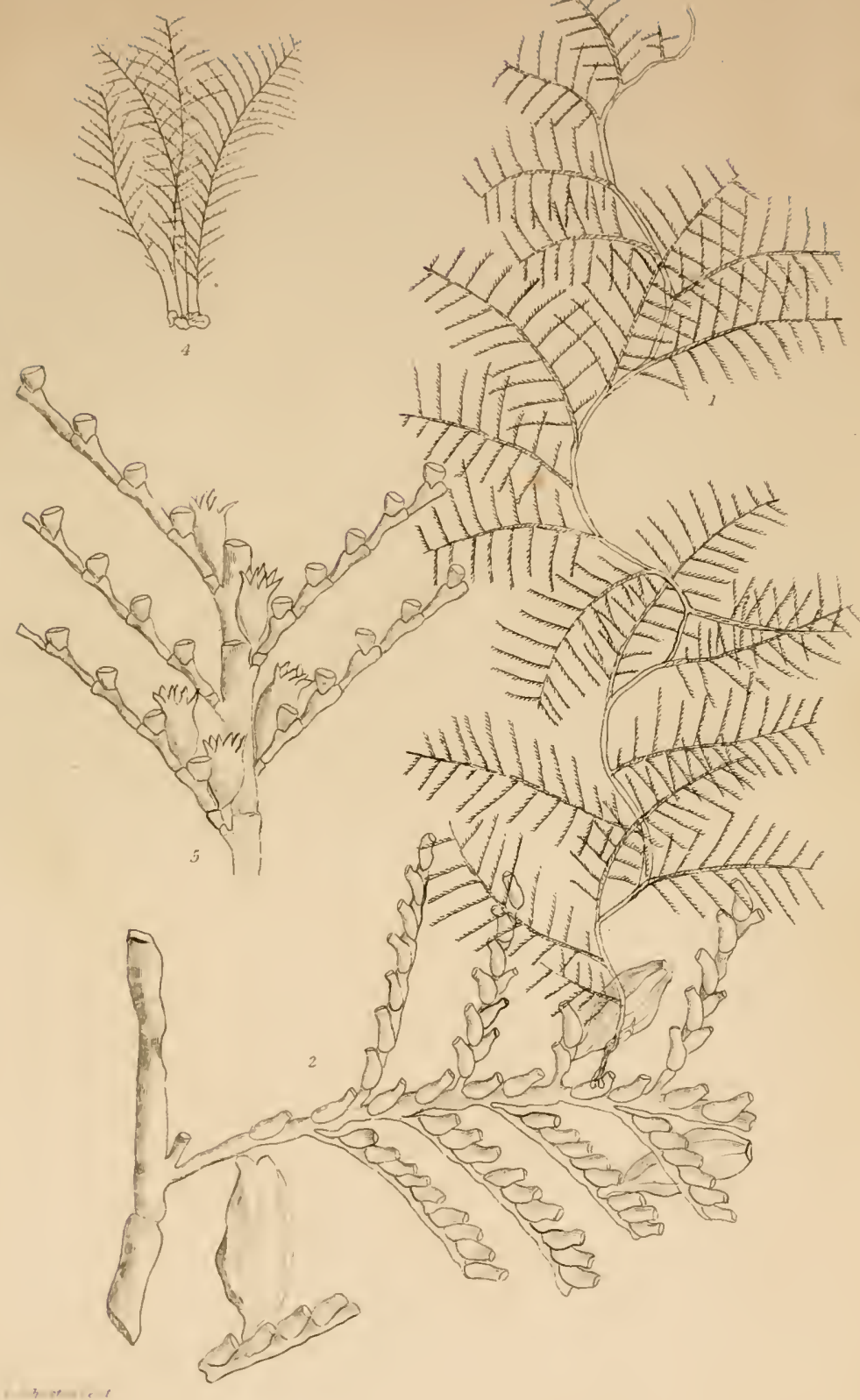



PI.ITE XILI

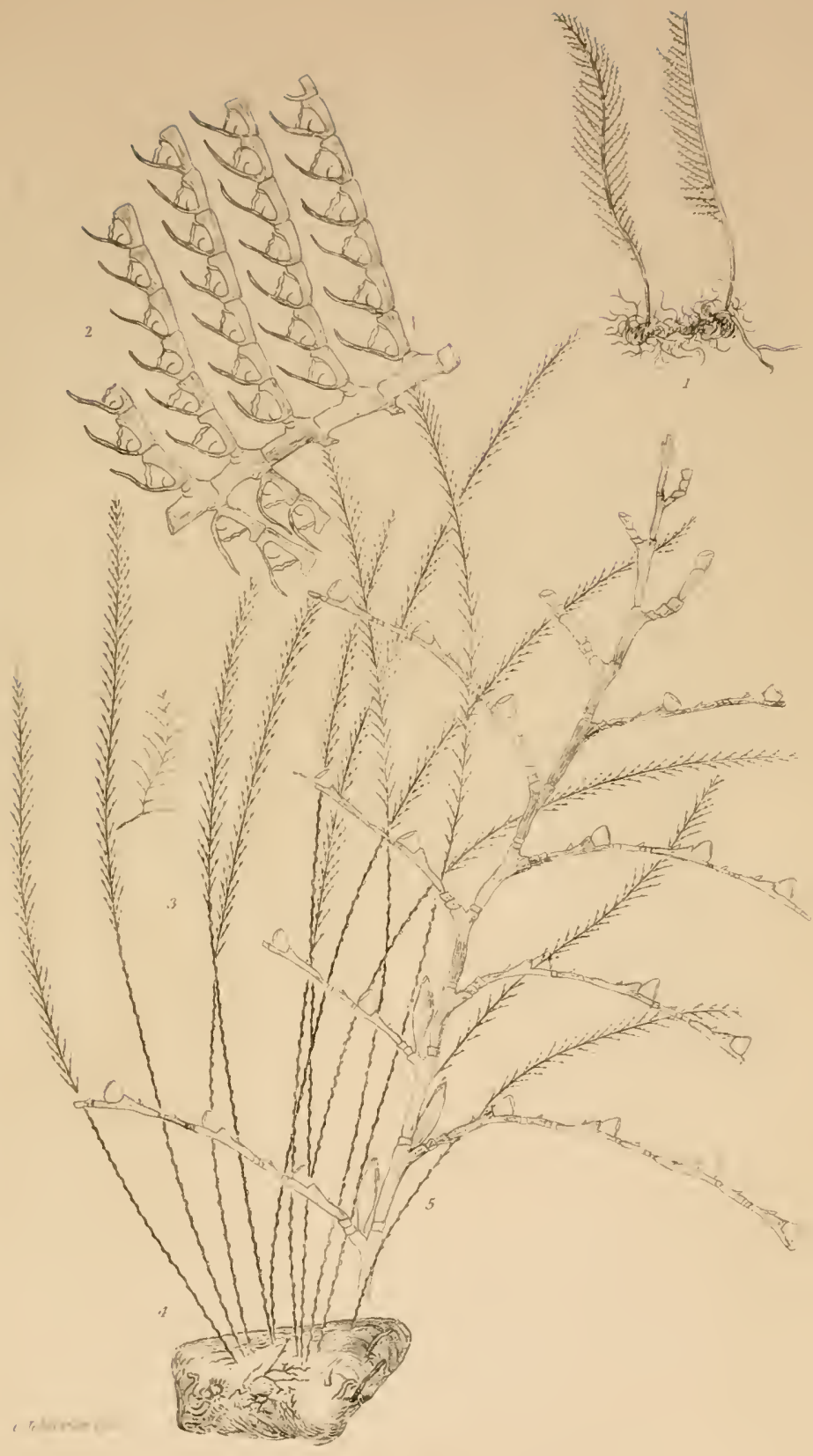



PLATE $X Y X$

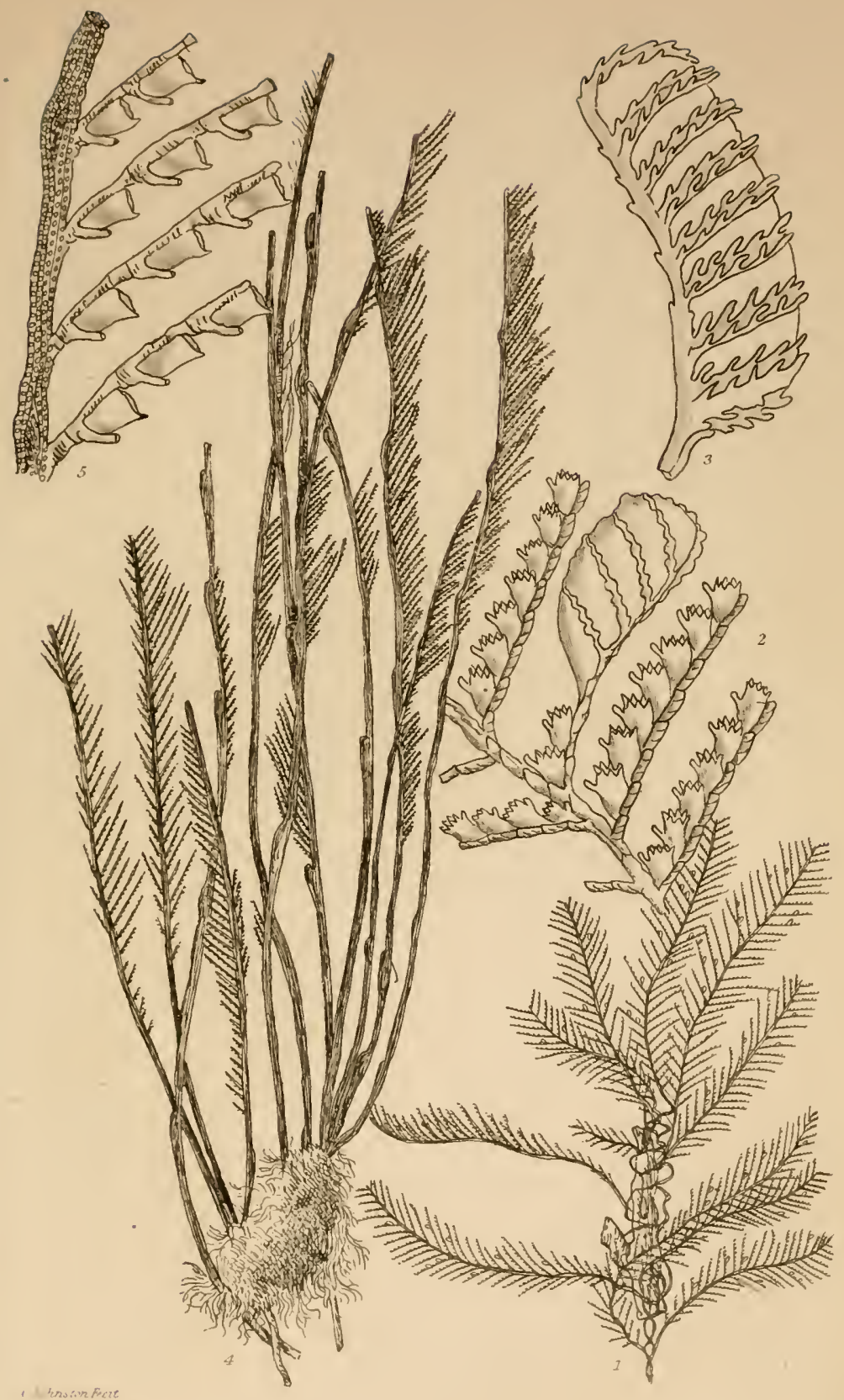




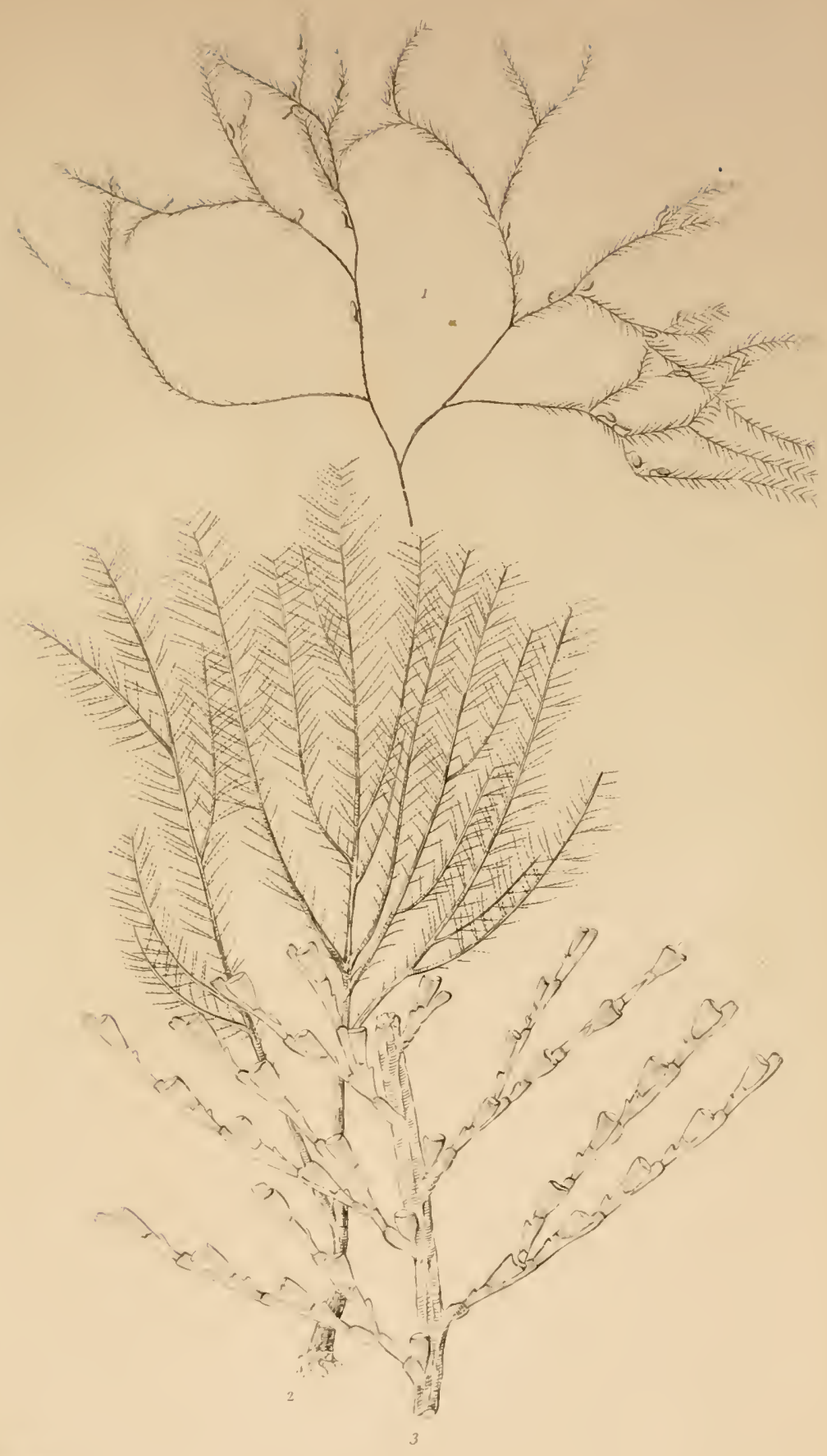



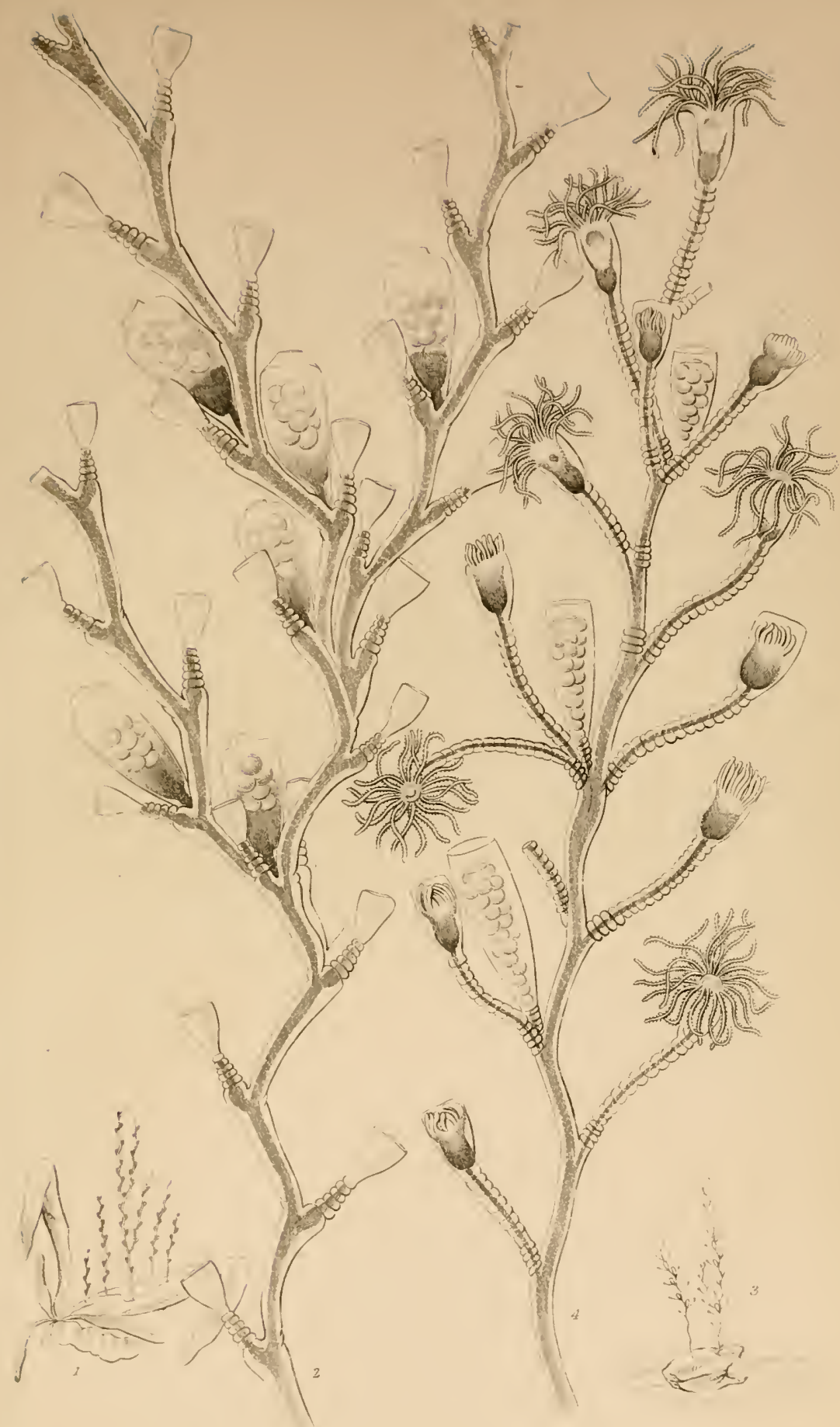





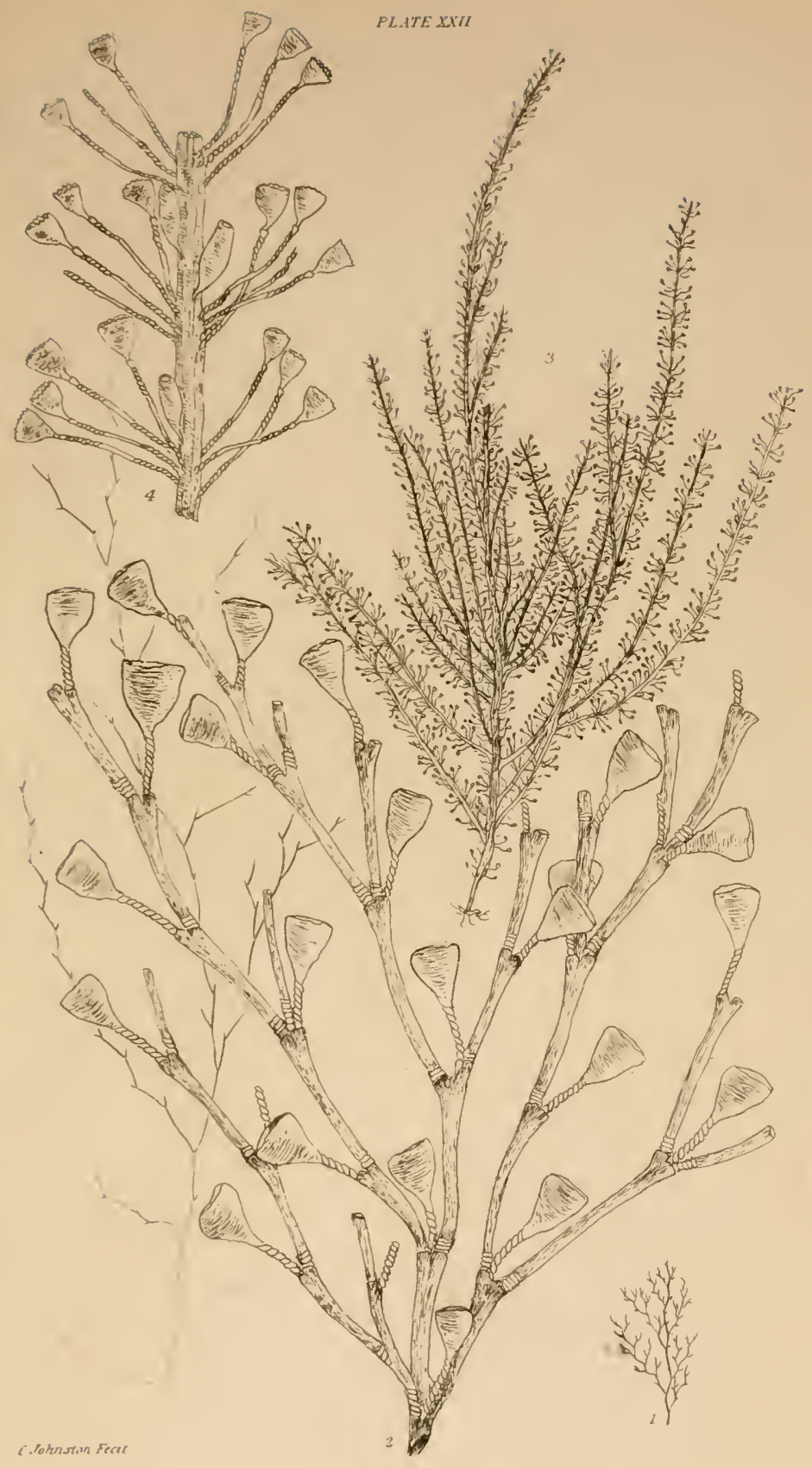





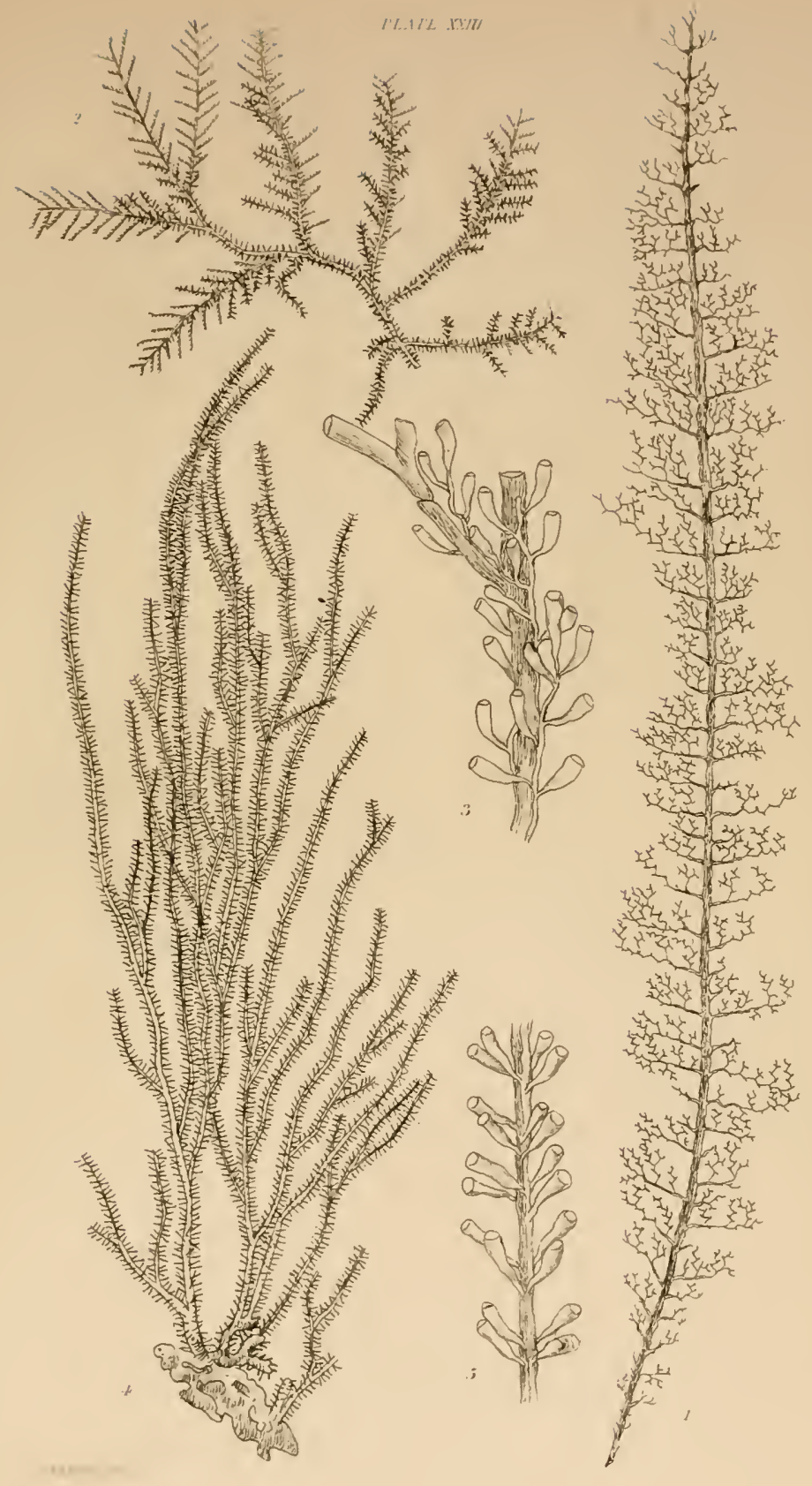





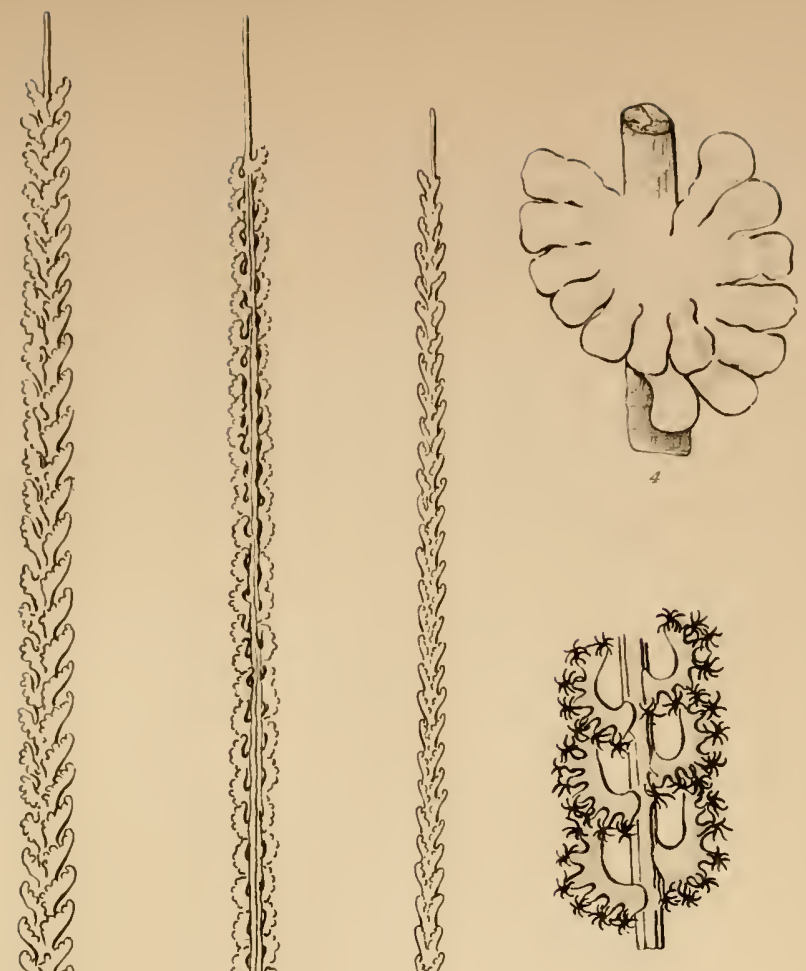

(अ)

(3)!?

()

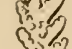

करी?

तi?

Sis?

हis?

S?

ज?

डी?

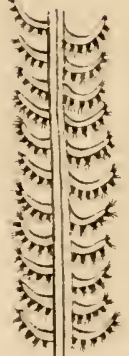





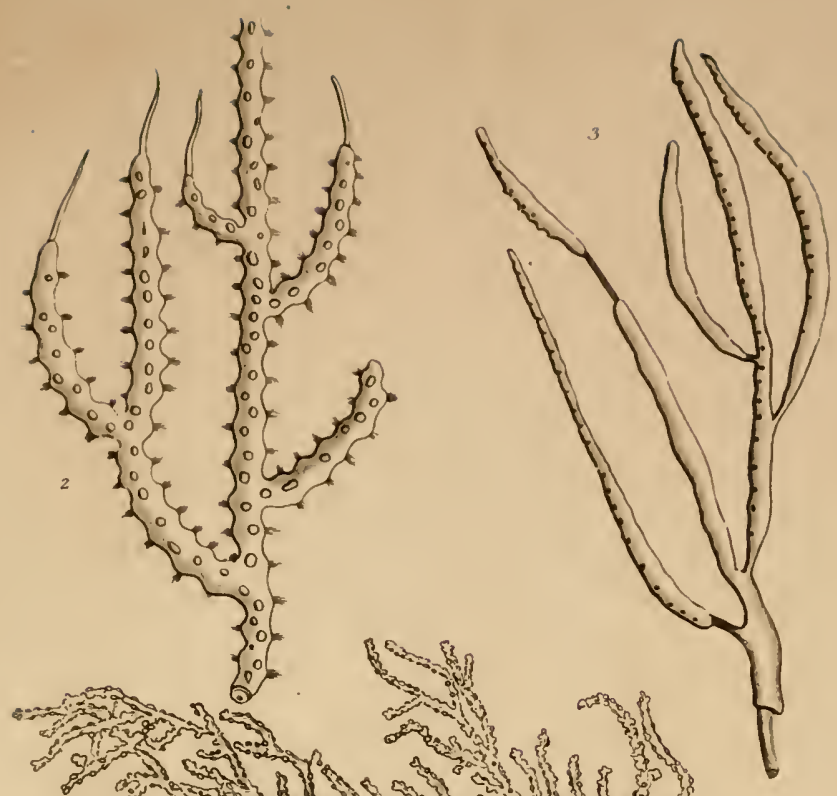

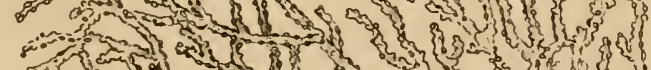

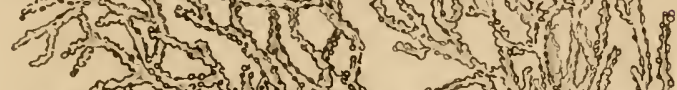

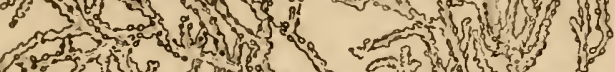
A 3 की \& 15 2 की

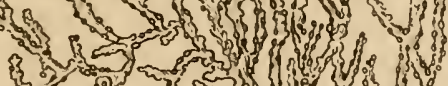
\{ 190 .

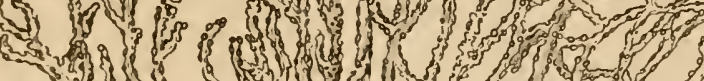

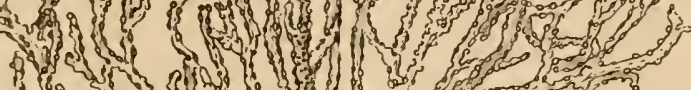

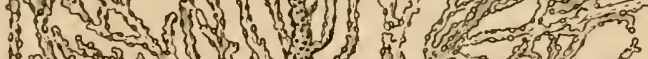
3 ros 6.

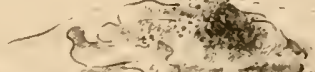

1 . Serces

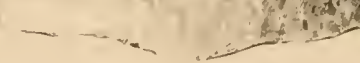





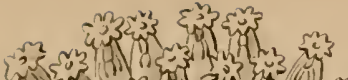

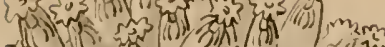

तn

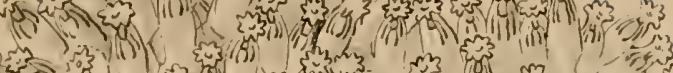
, हn ? सुत ins

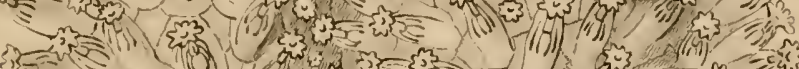
5.

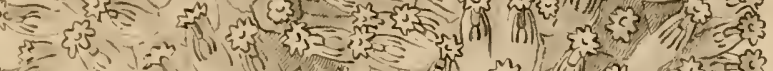

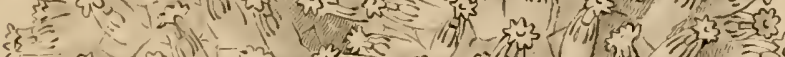
क है

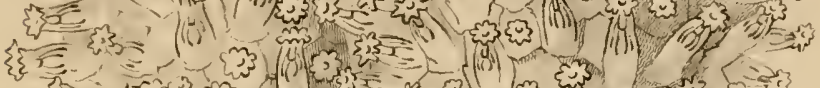
है

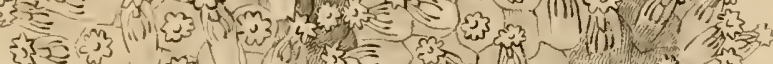

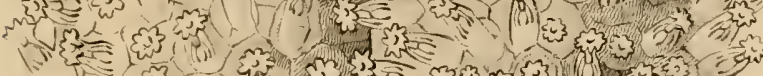

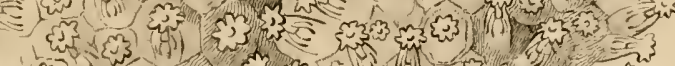
है है

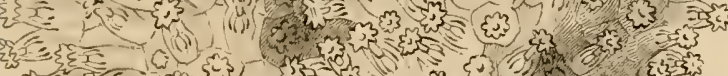

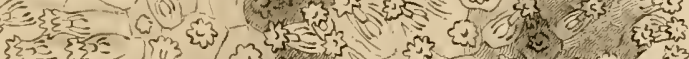
, Es

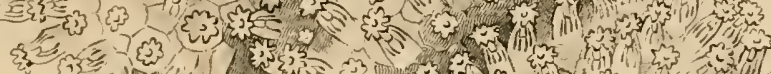

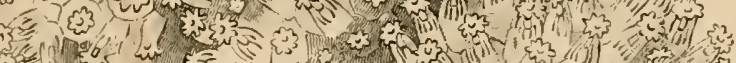
Es (1) $19(9)$
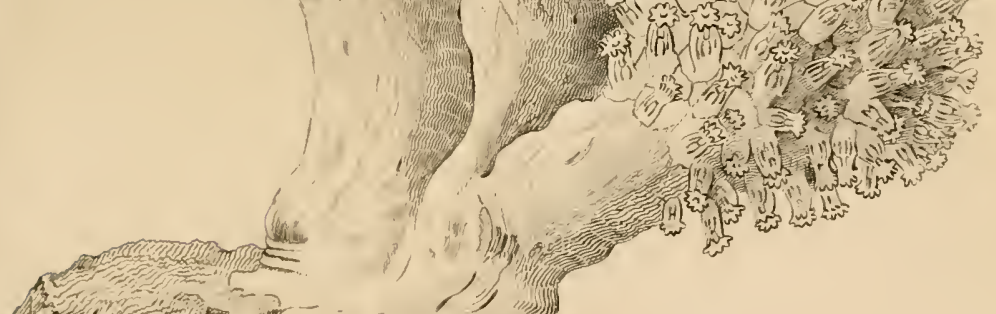


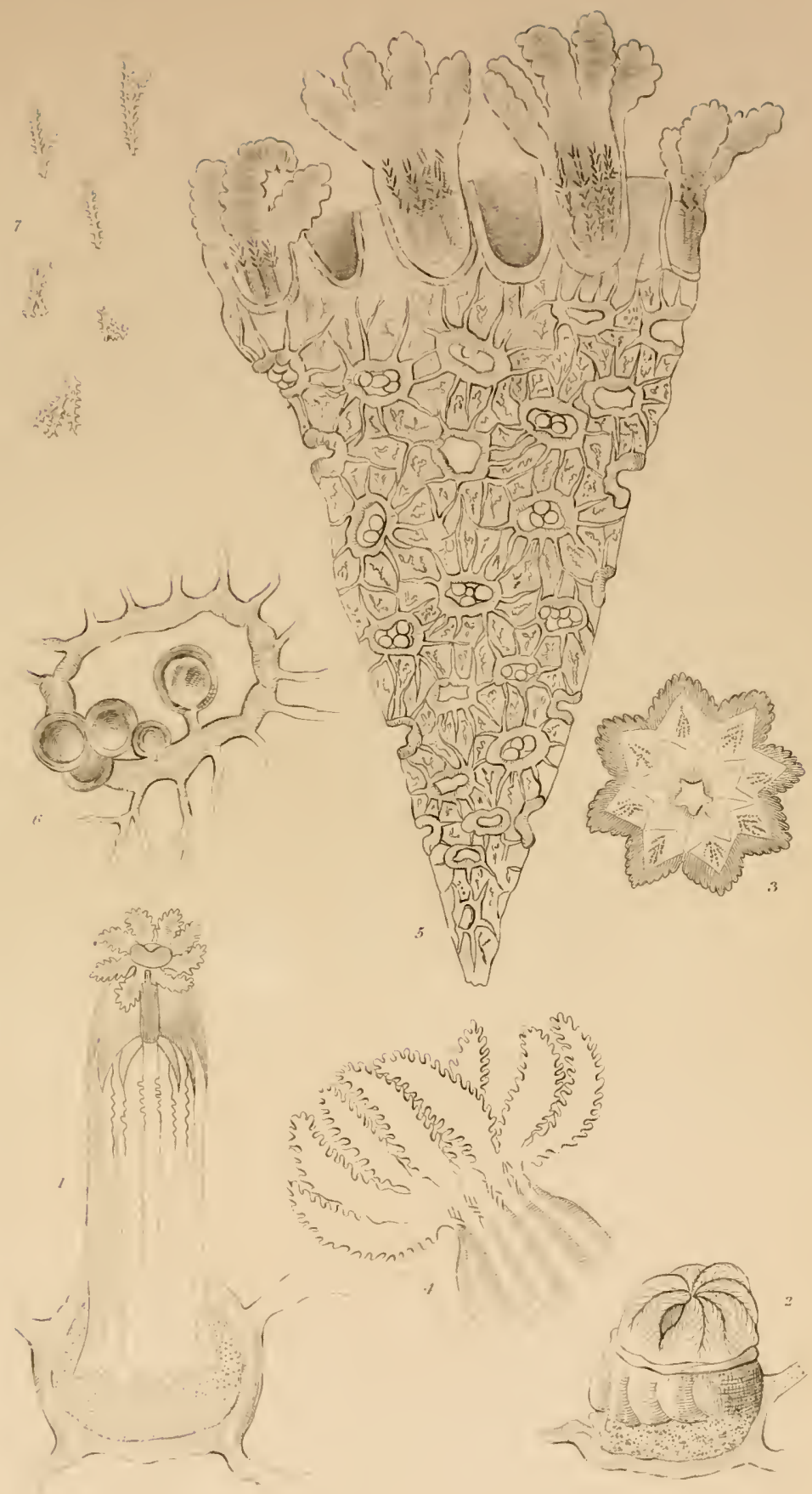


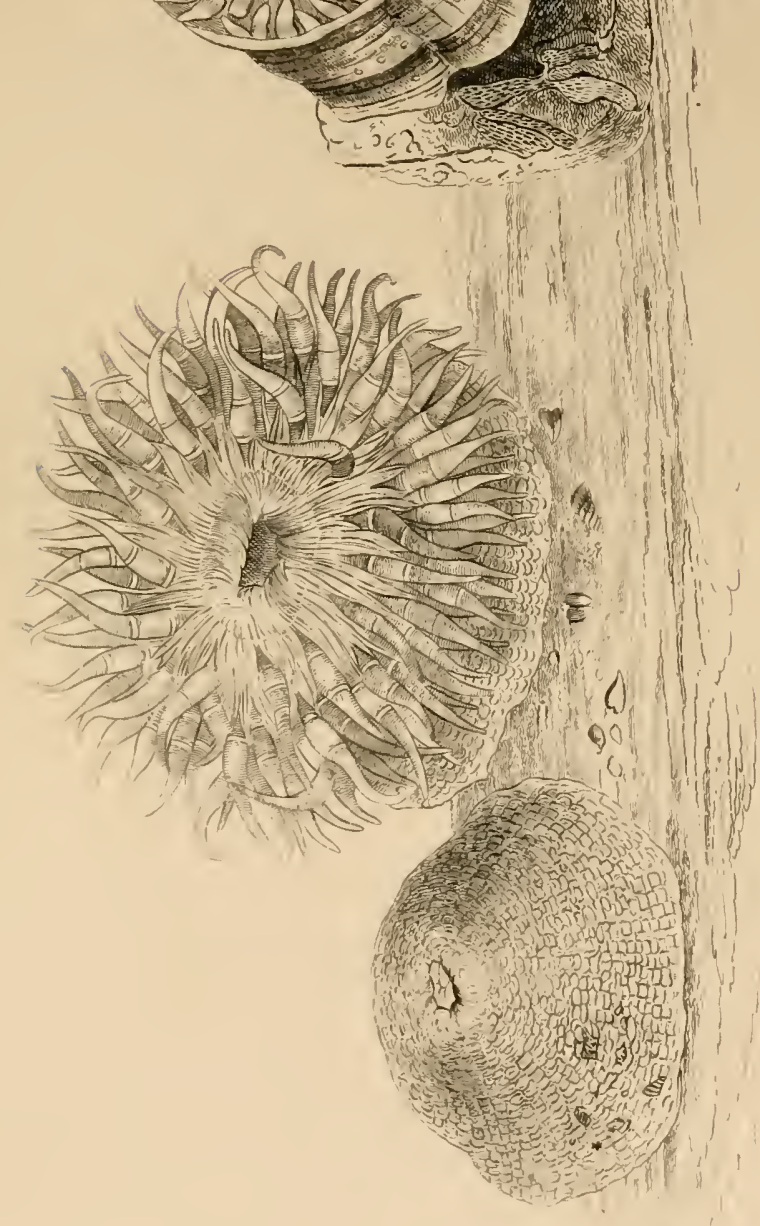



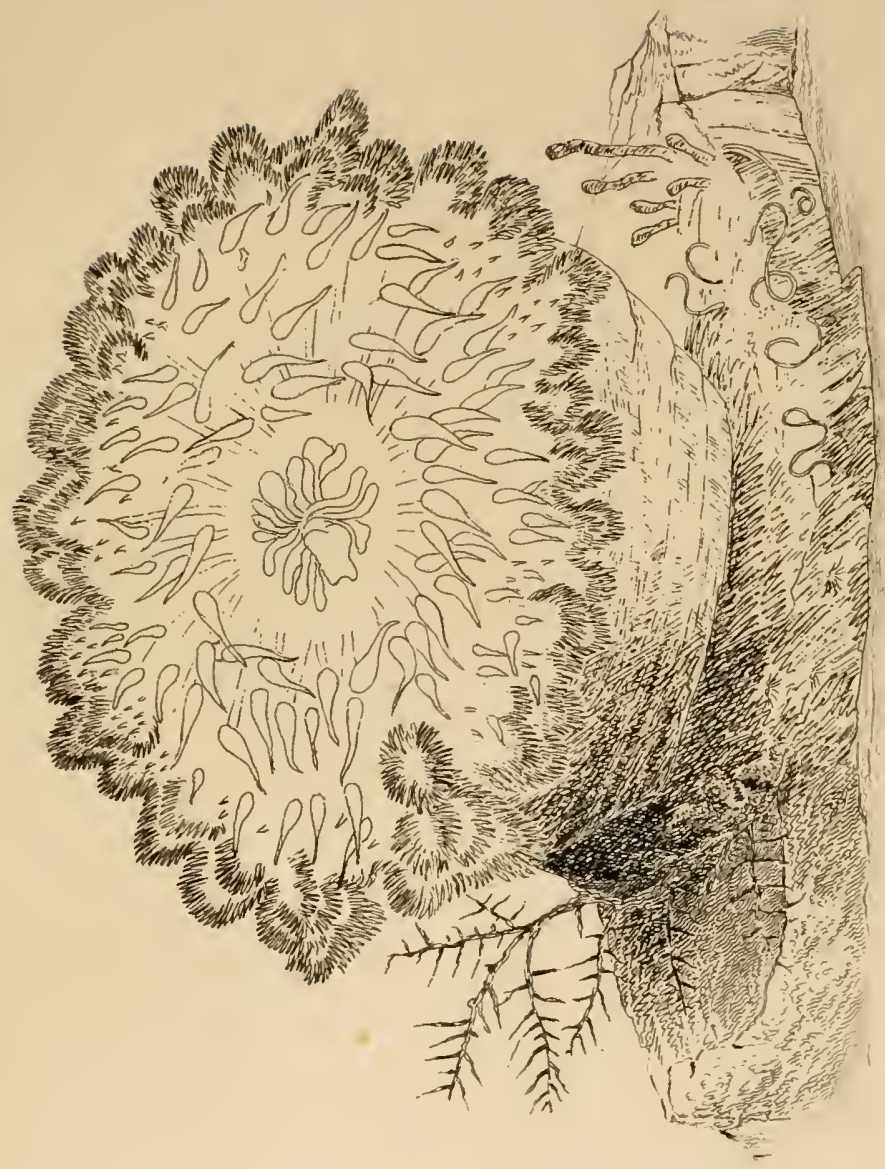





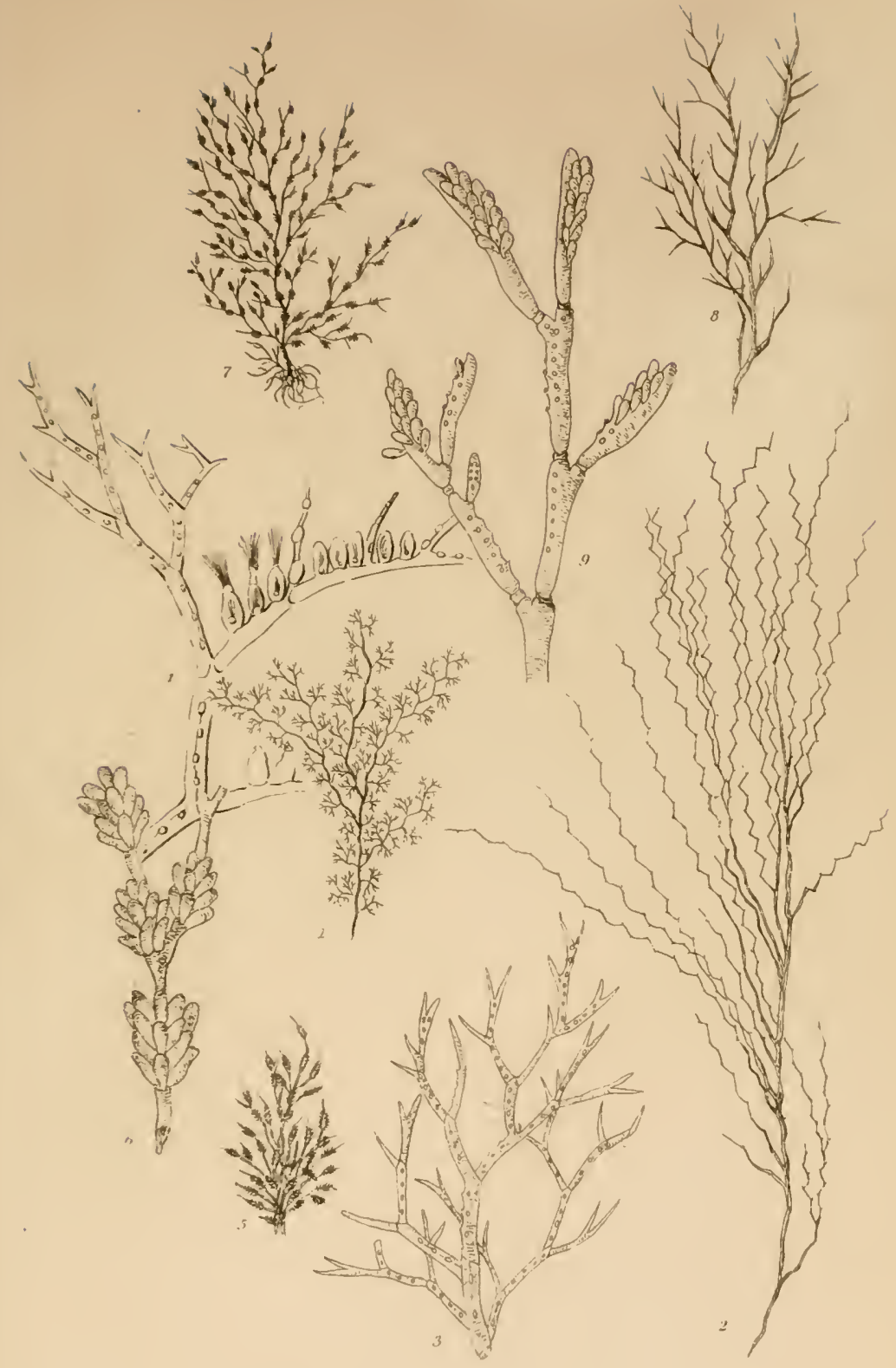




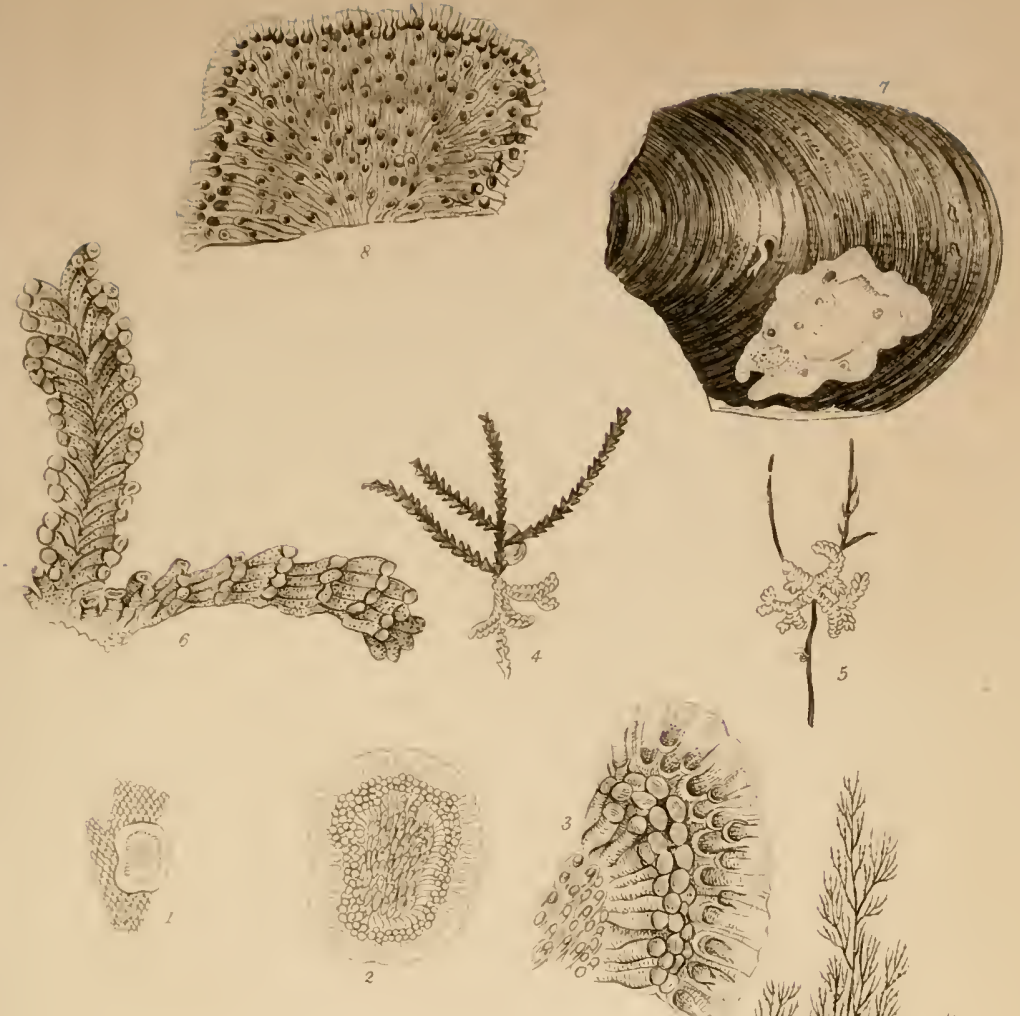

2
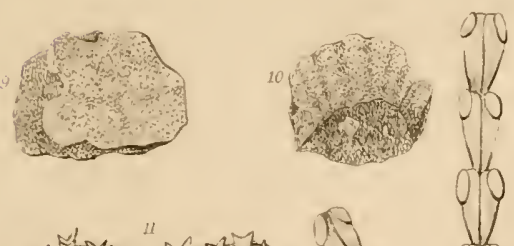

लón "म

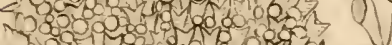

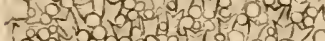

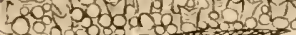
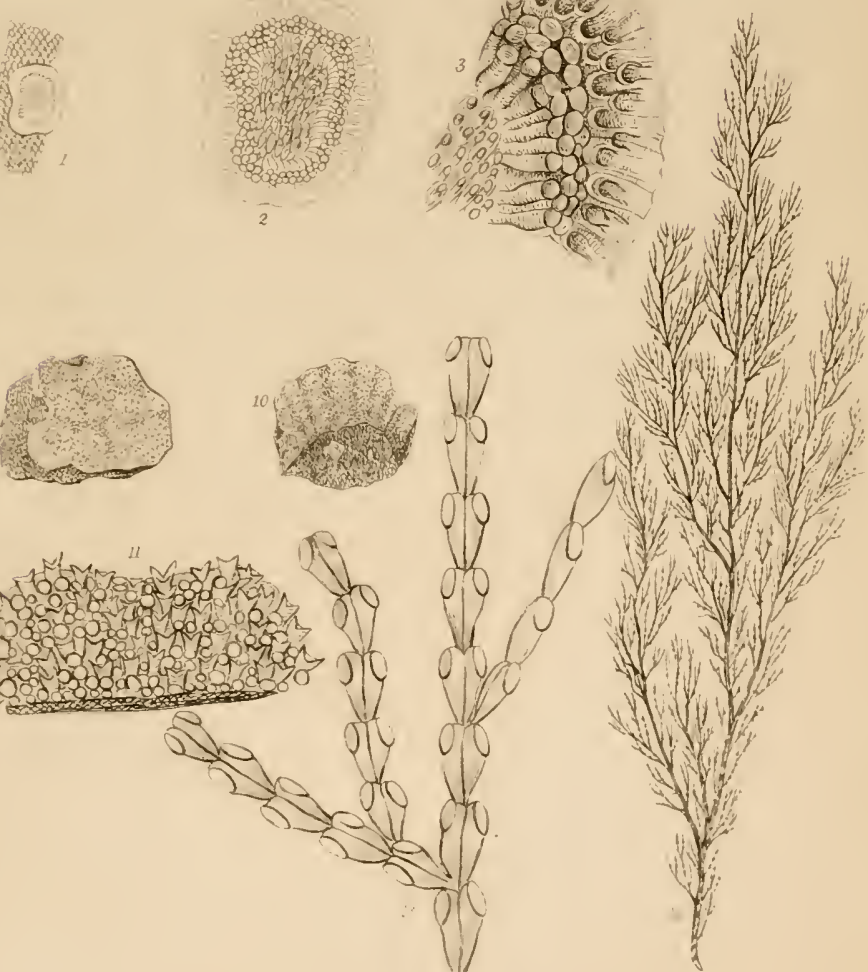

PL..TE II.Y
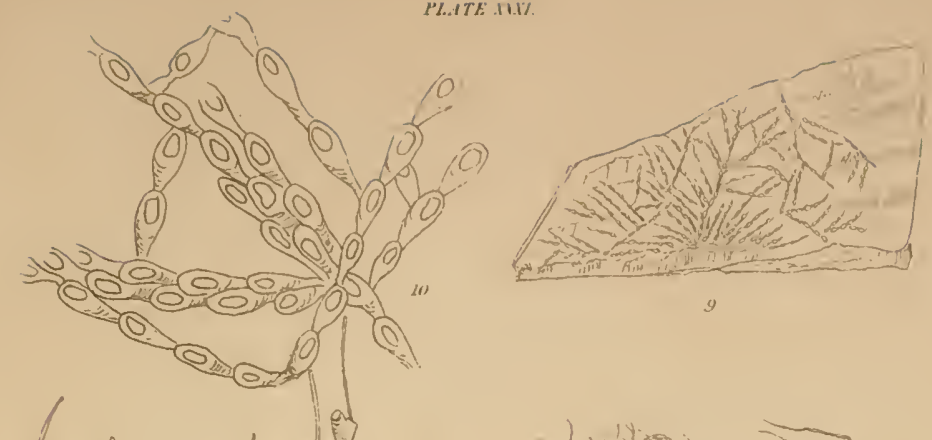

9
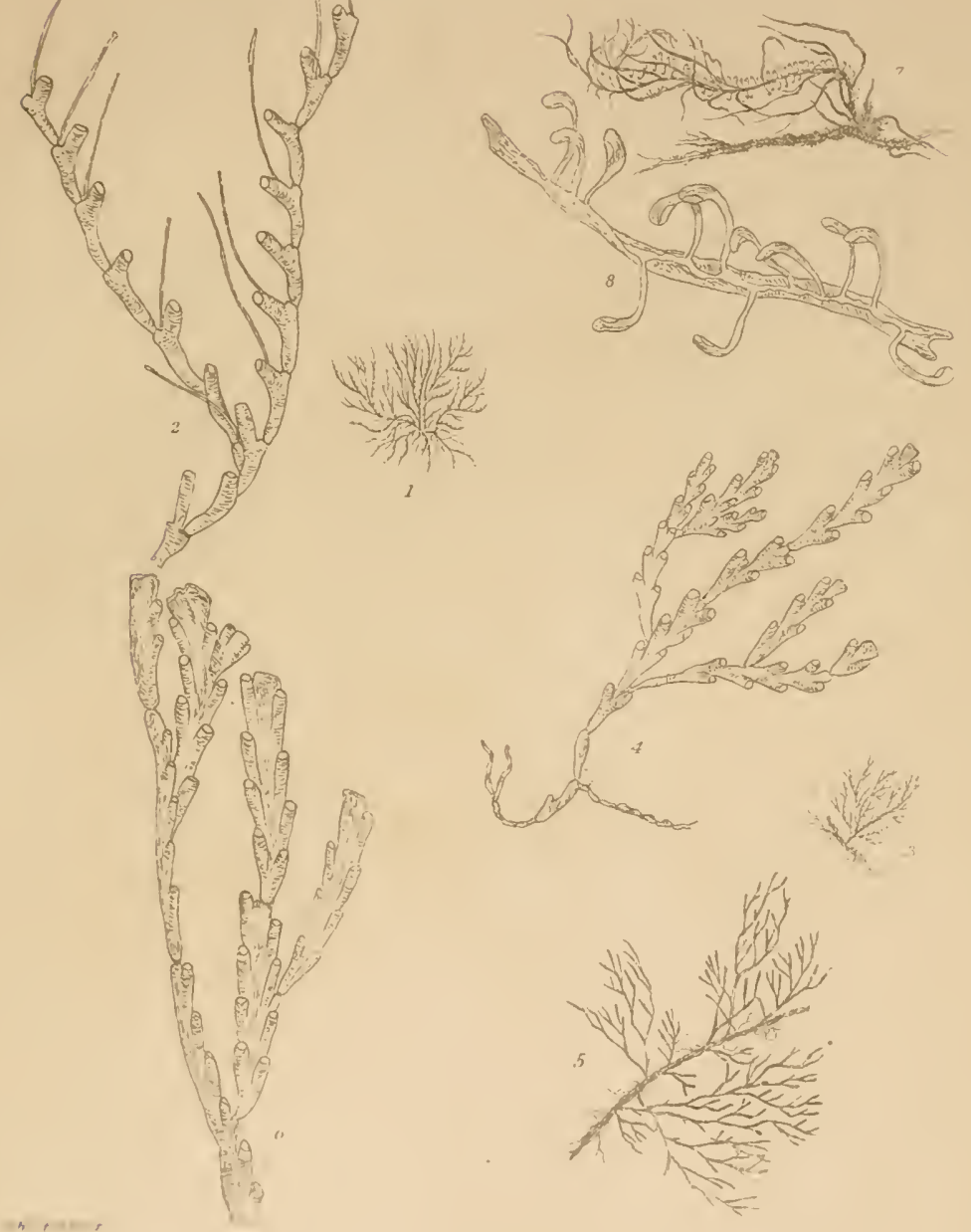



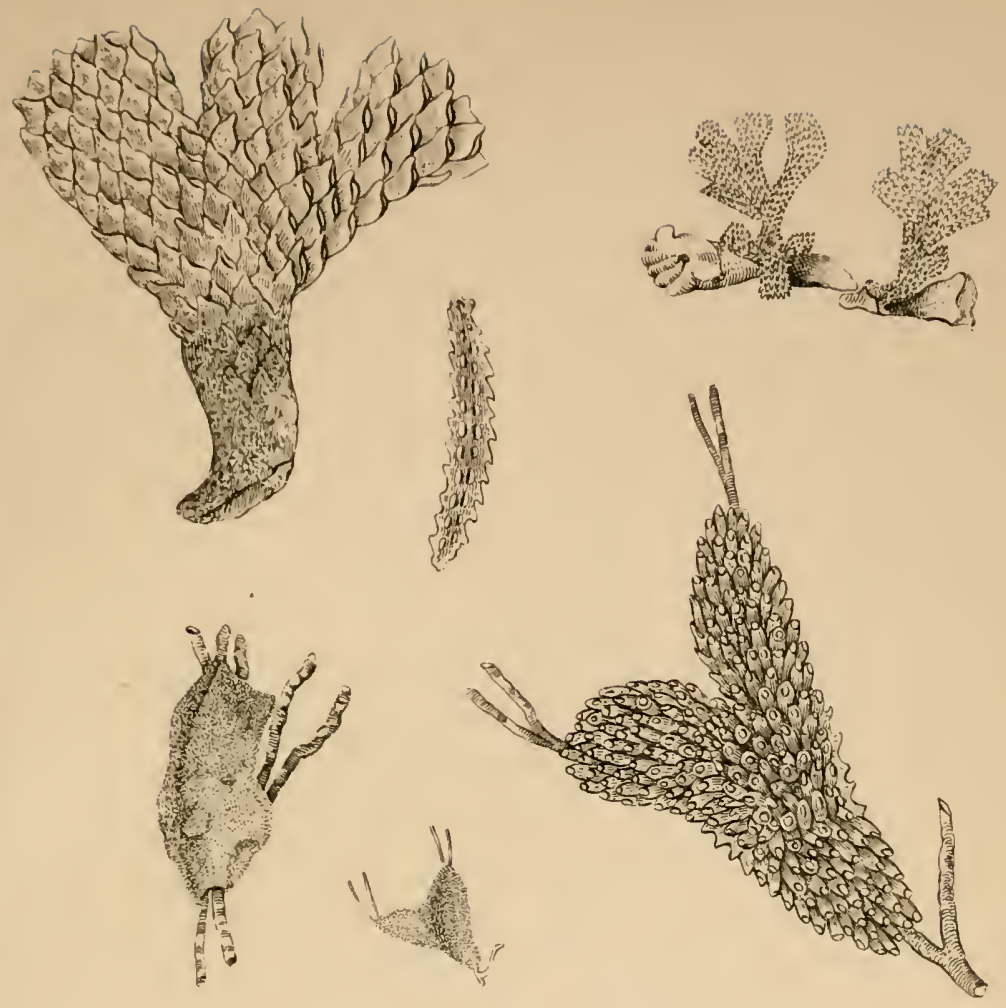

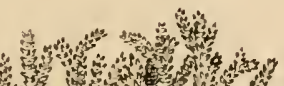

*

3.

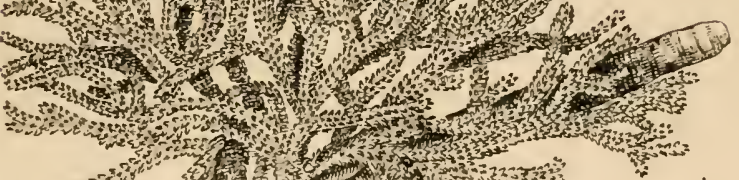

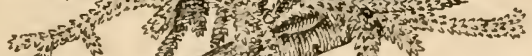

慗

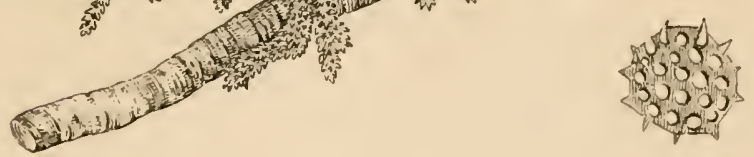





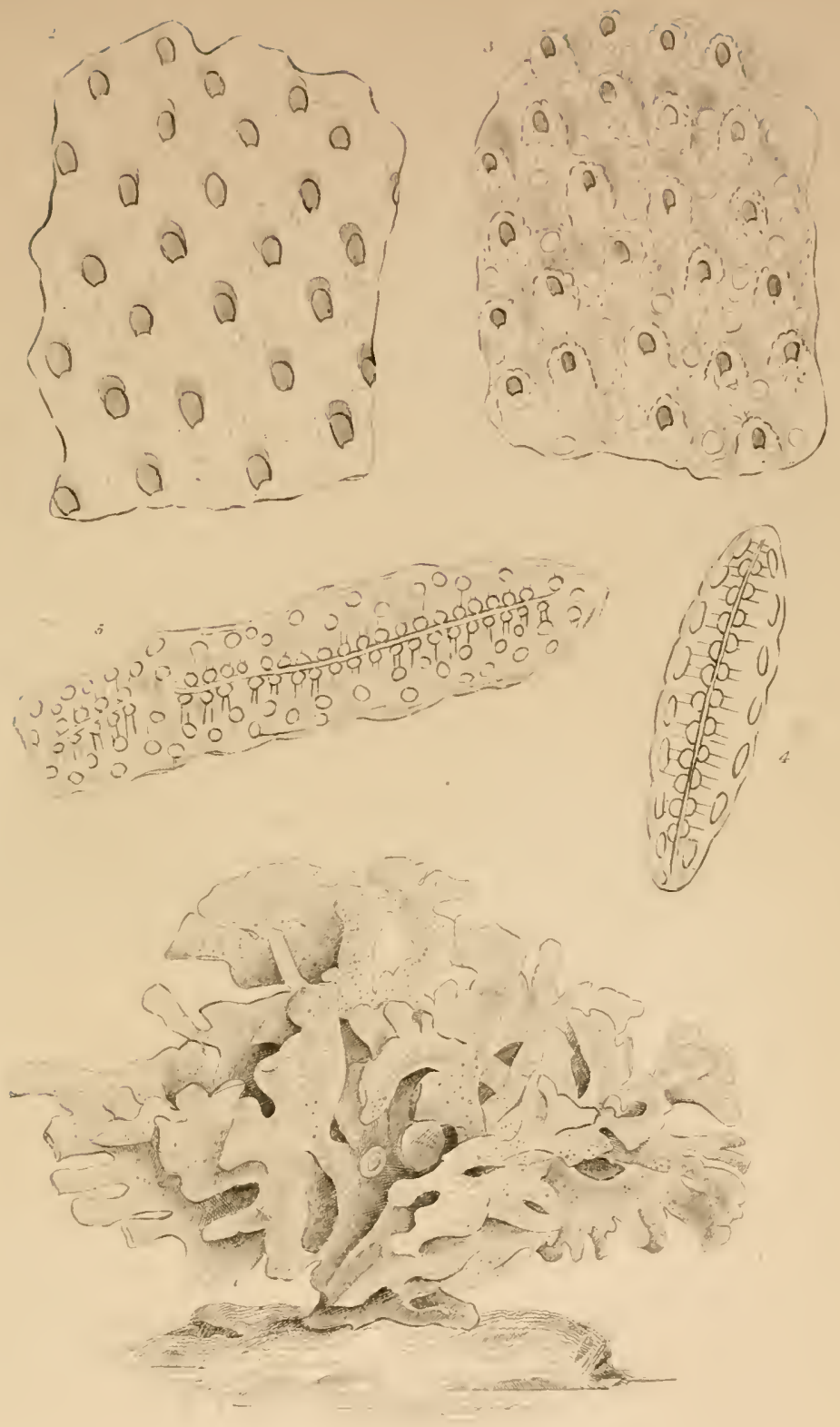





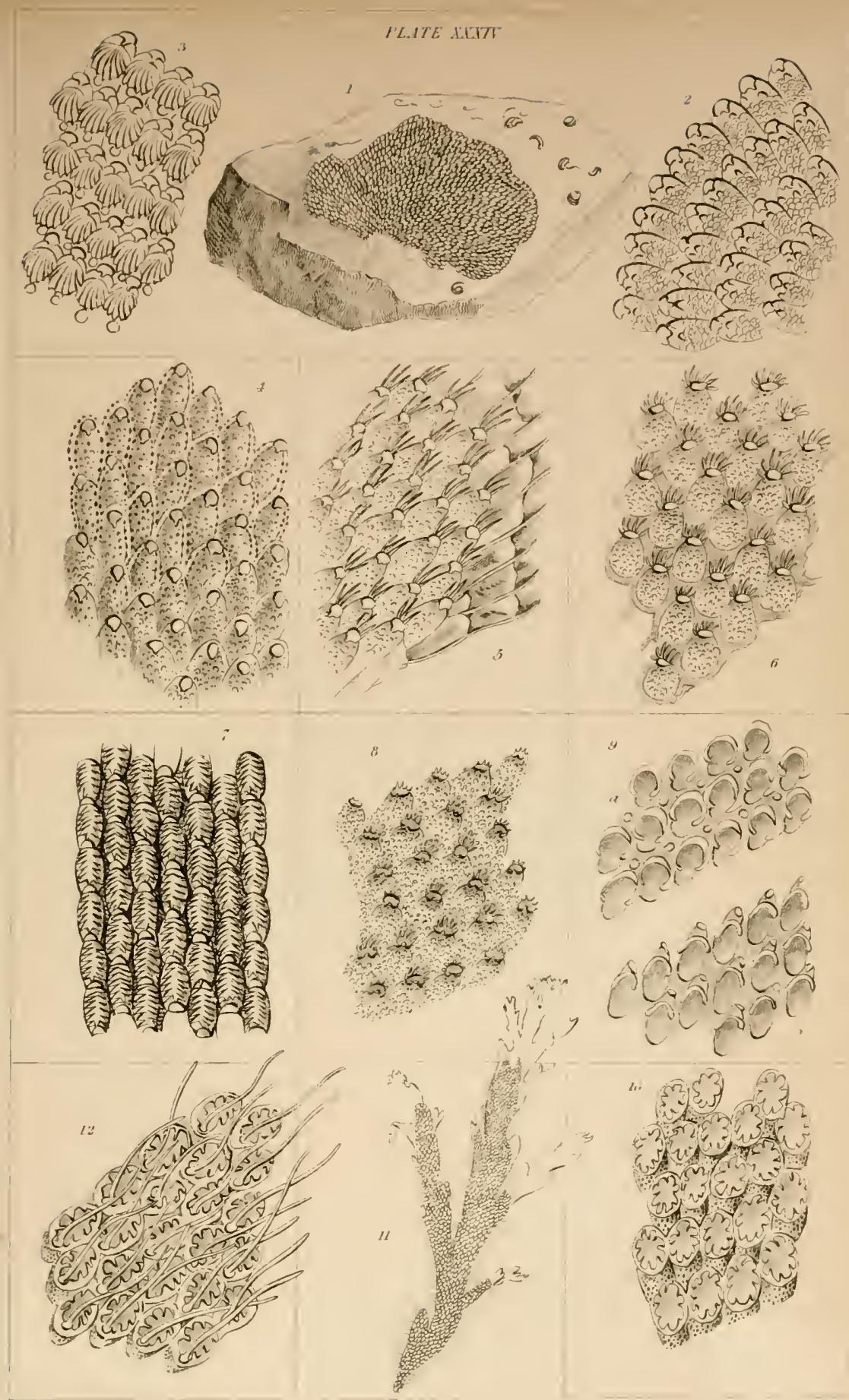





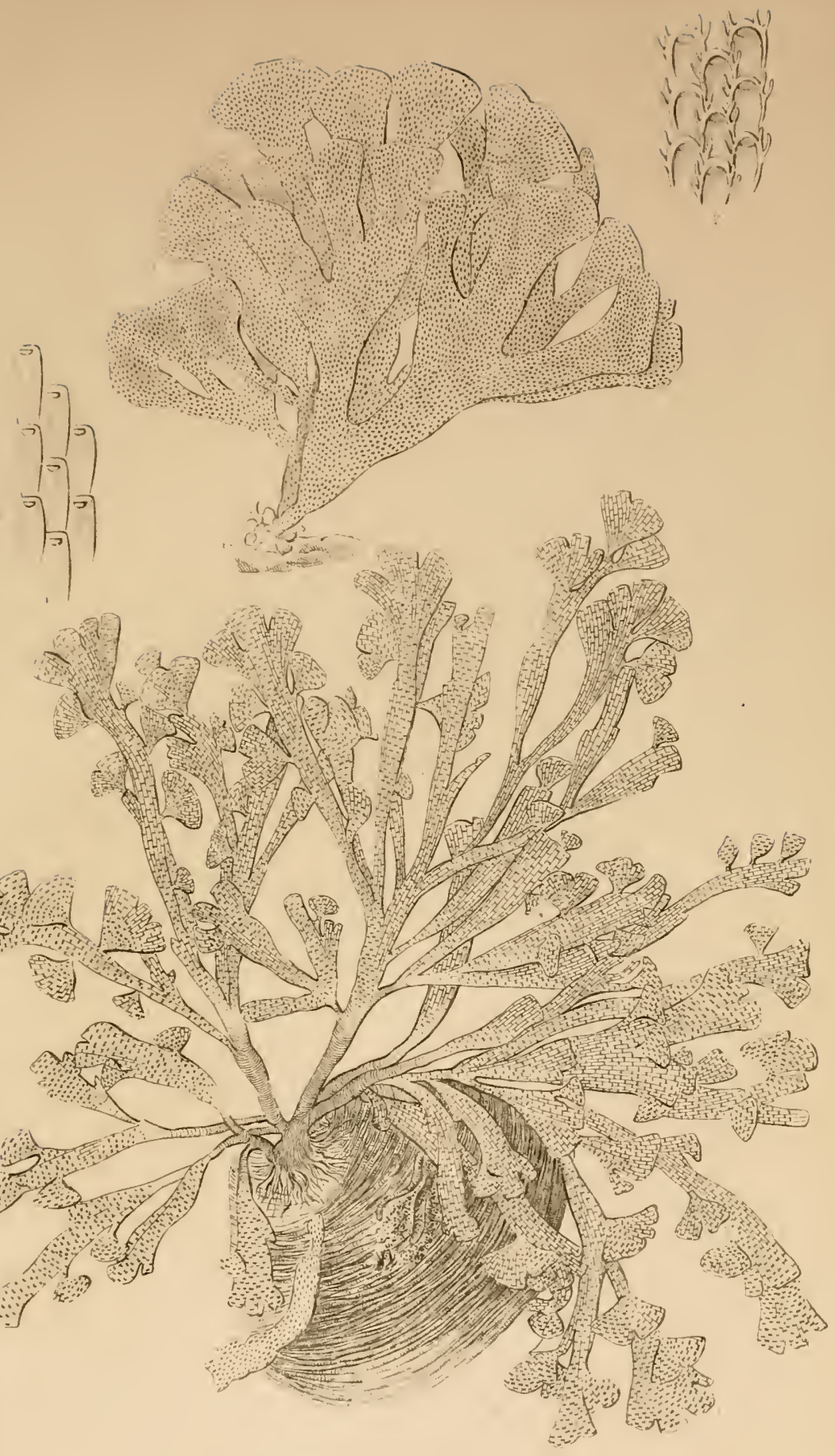




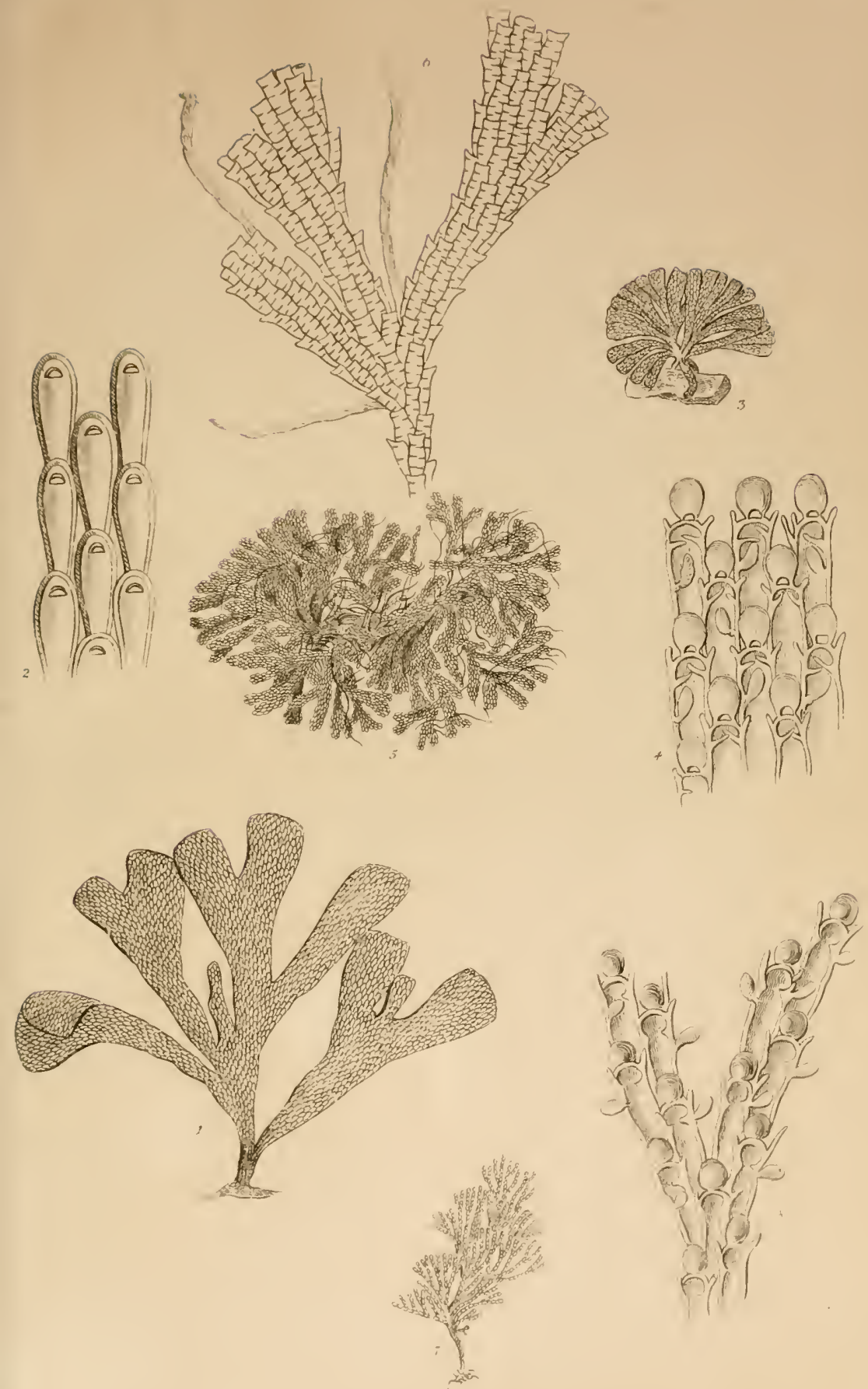



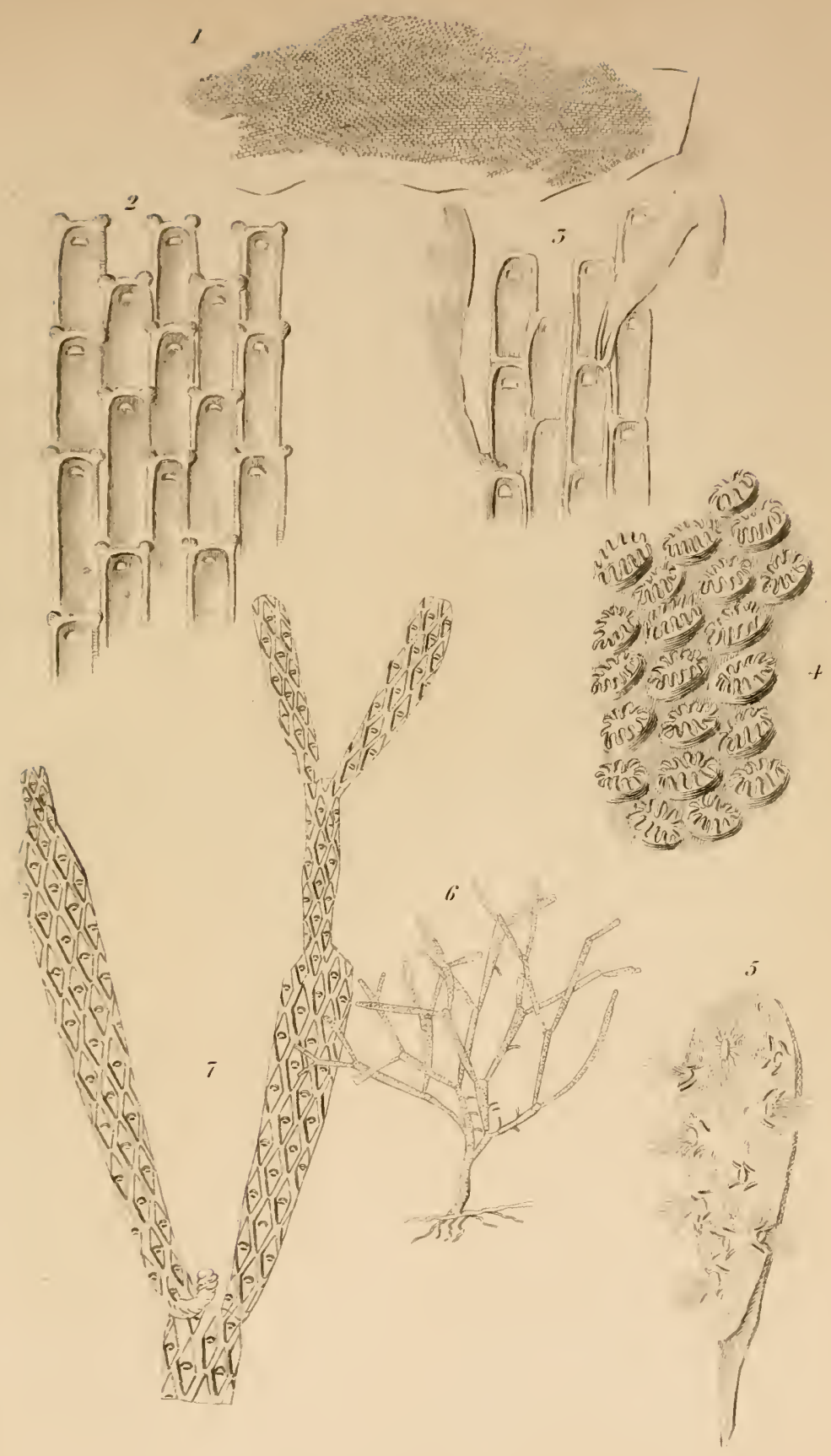





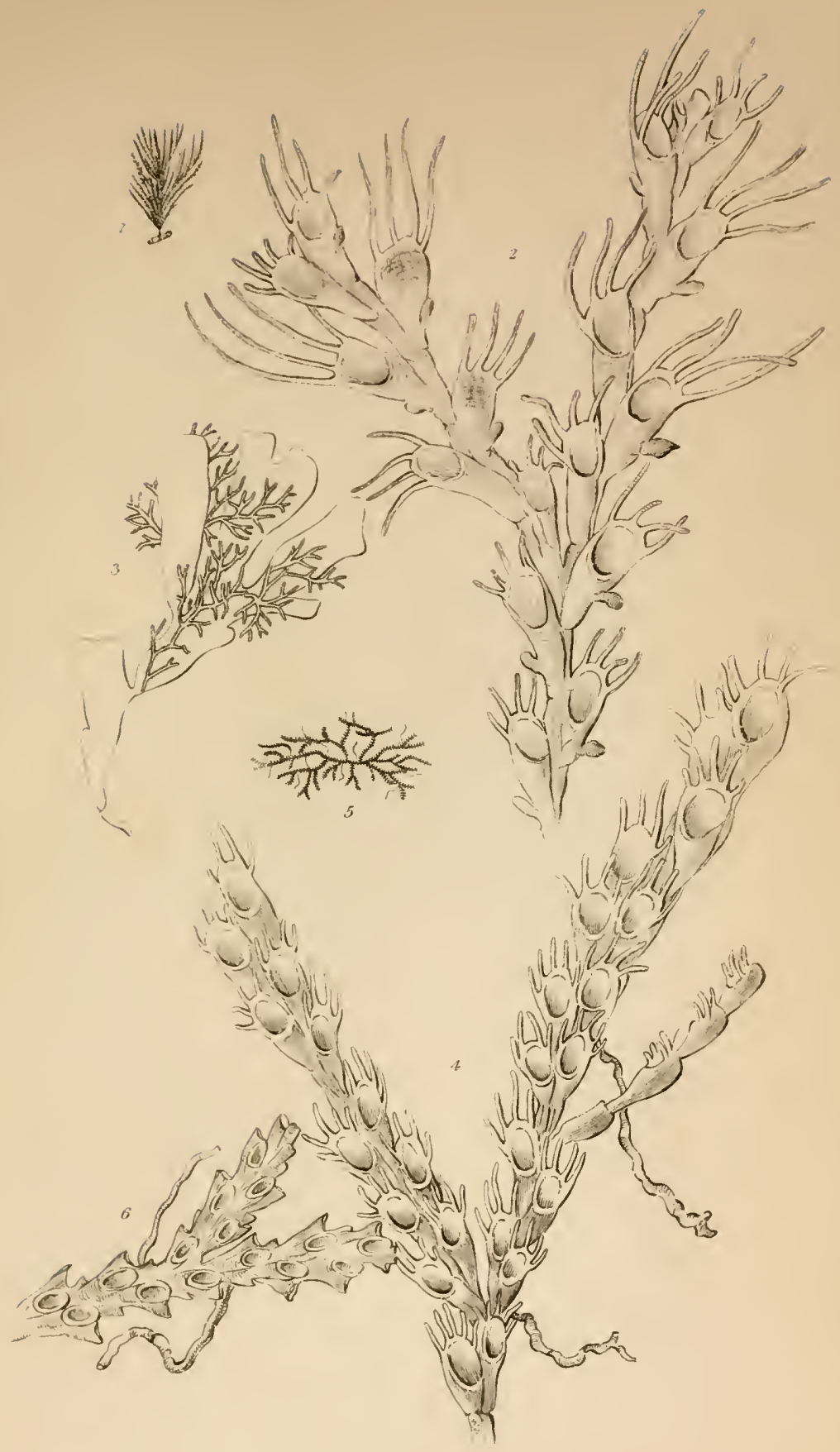





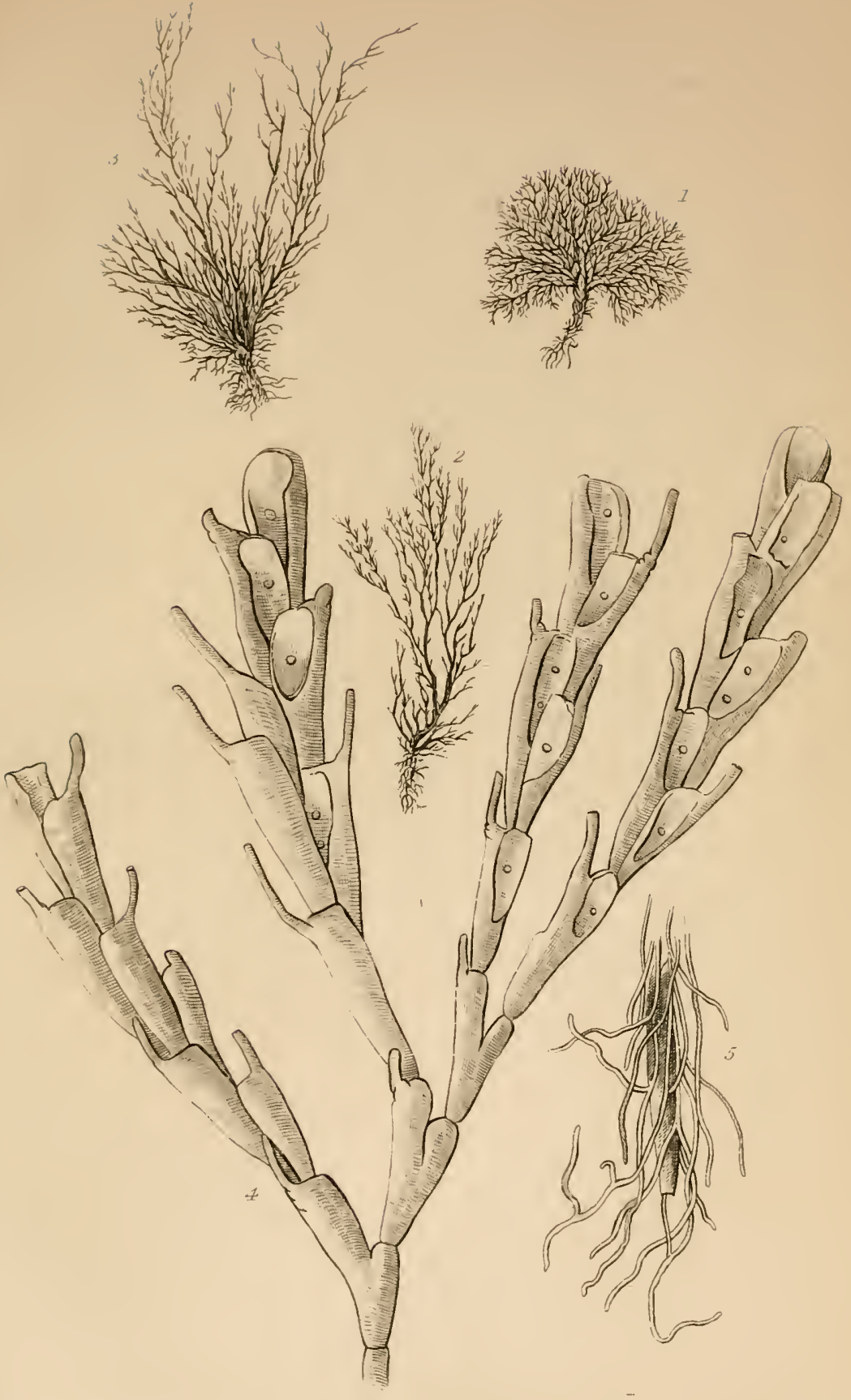




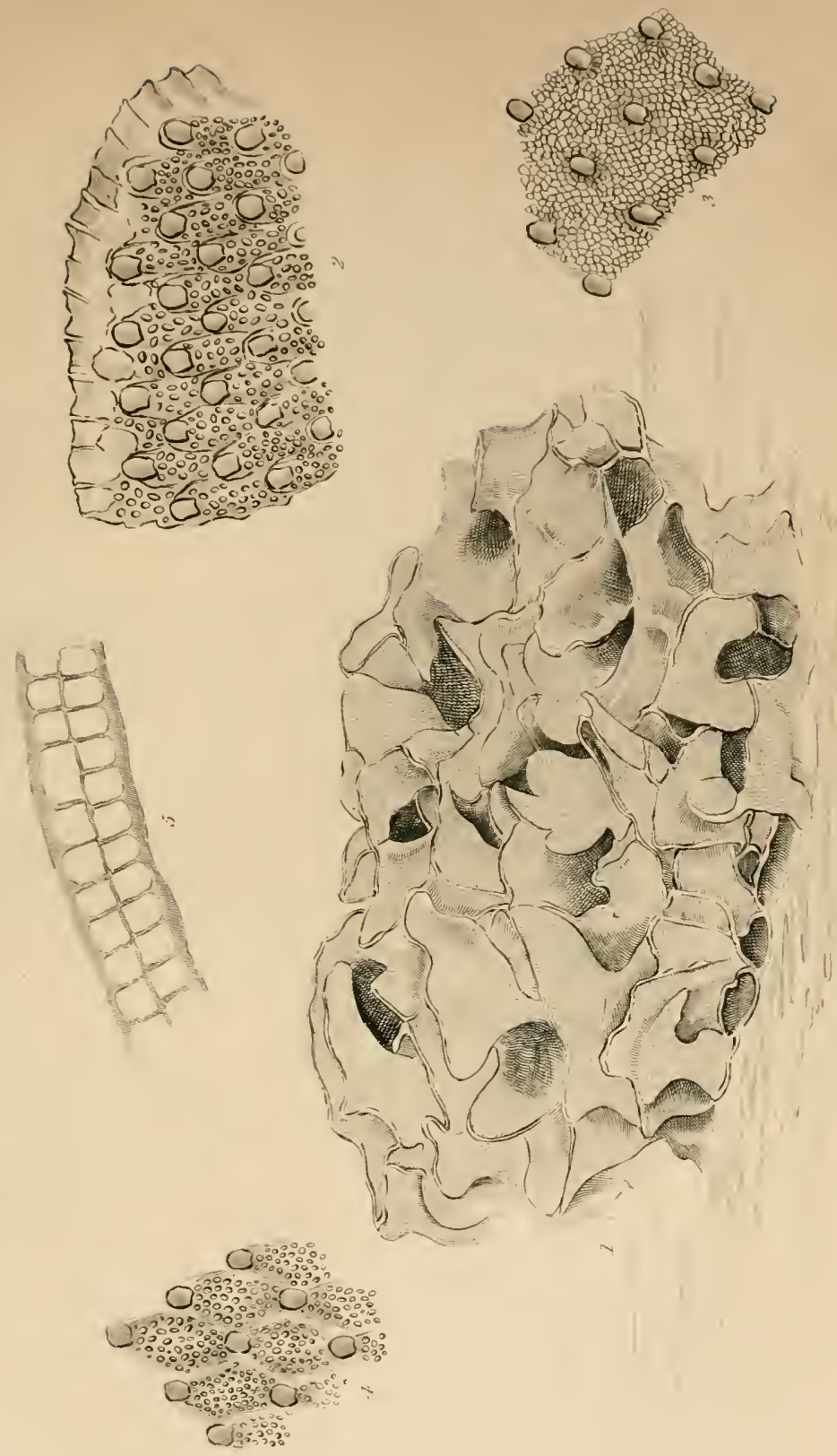



$$
\frac{6}{4}+4
$$

$$
a^{2}+5
$$
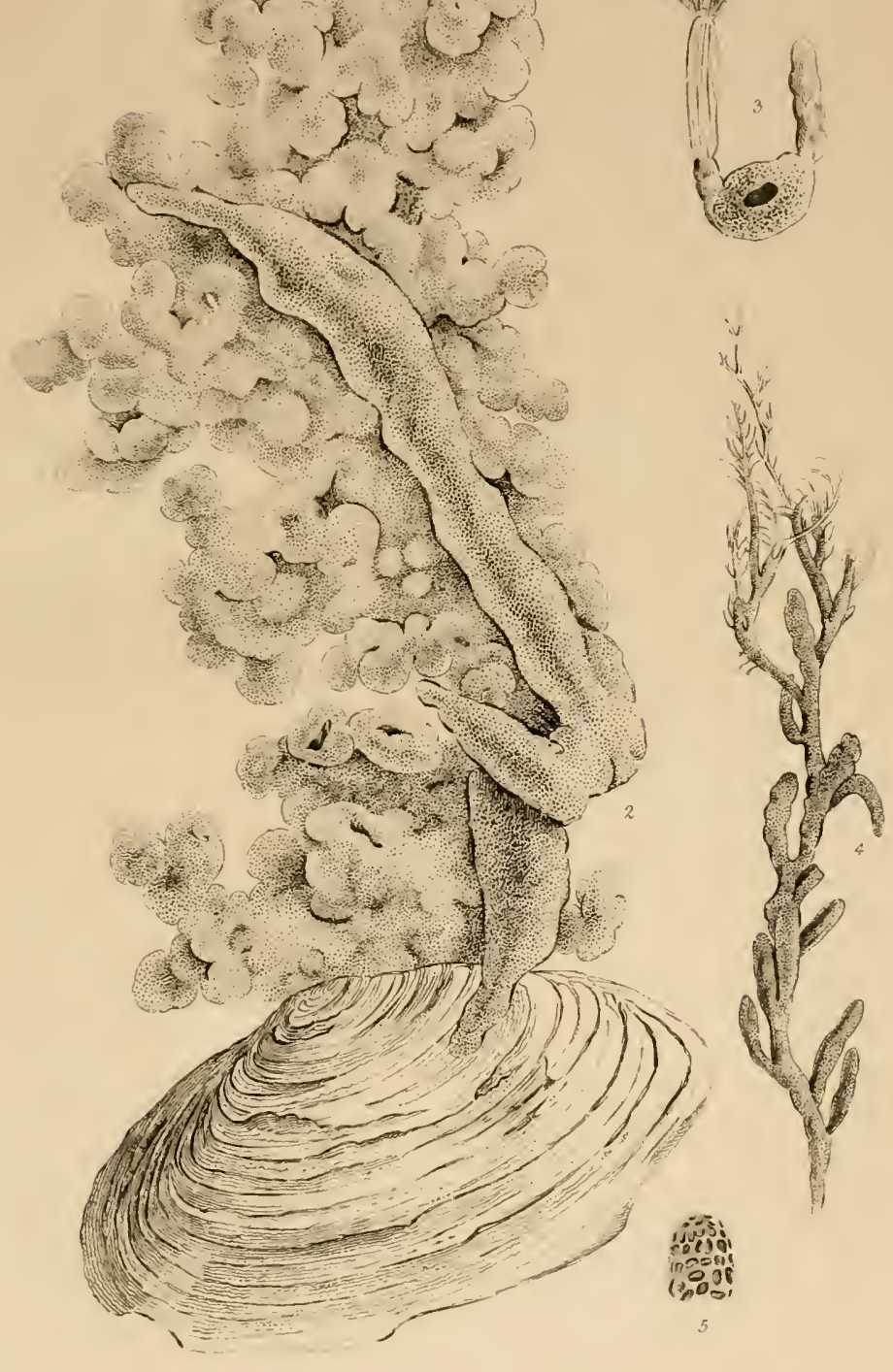


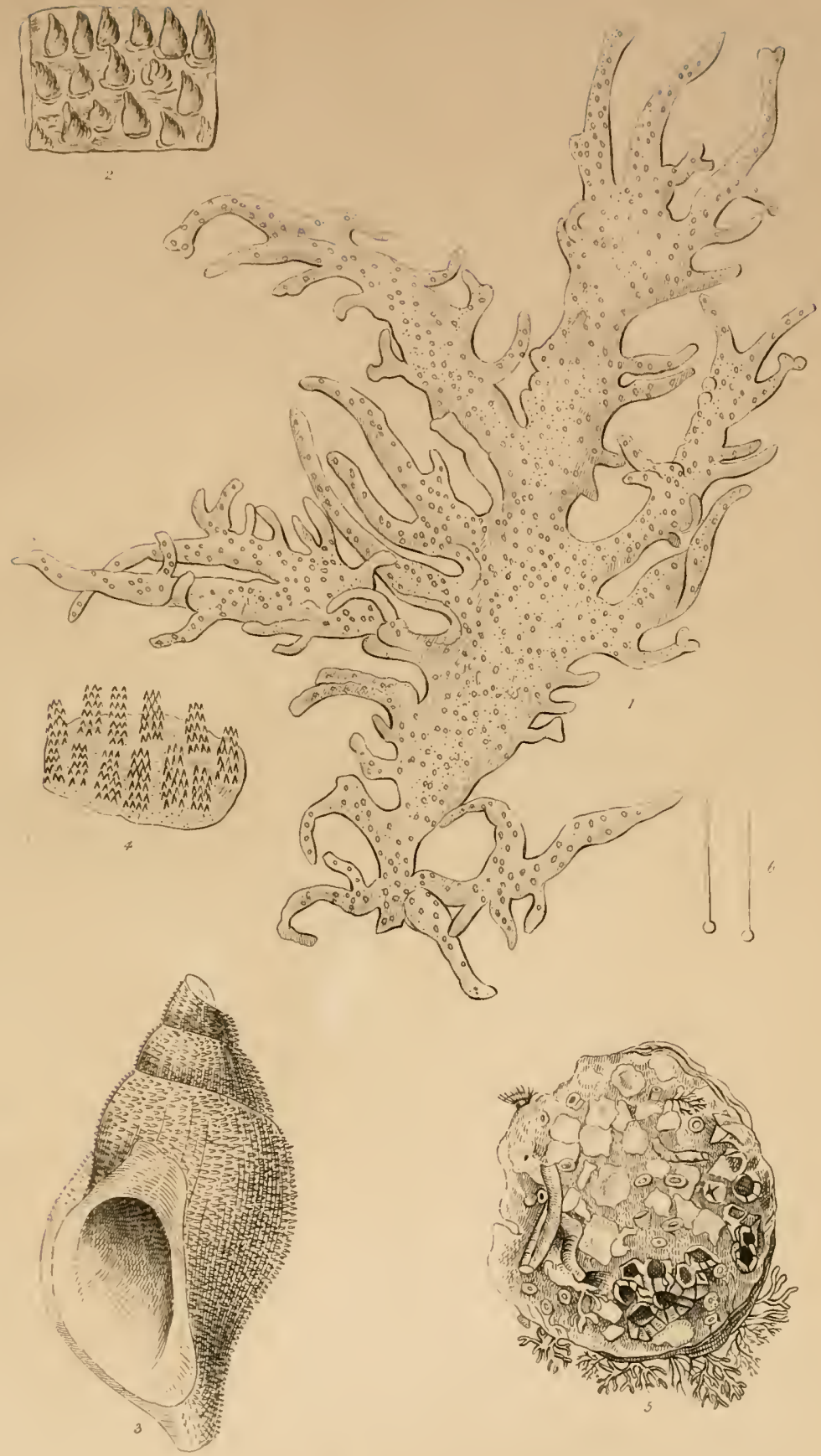


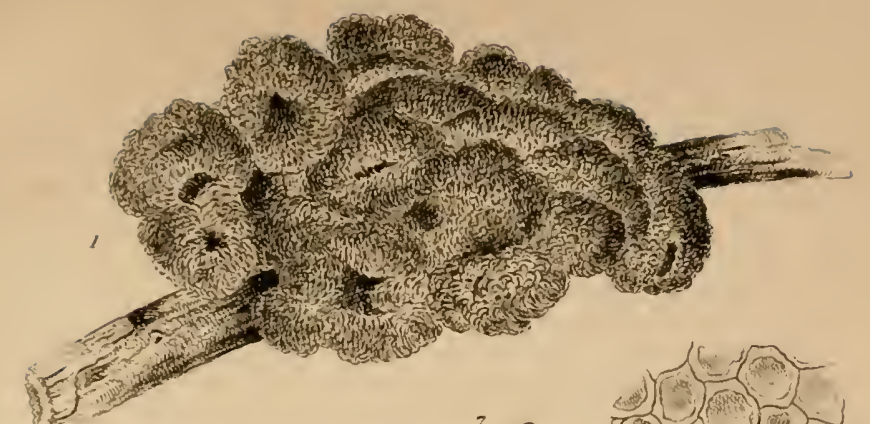

$$
\text { 100 }
$$
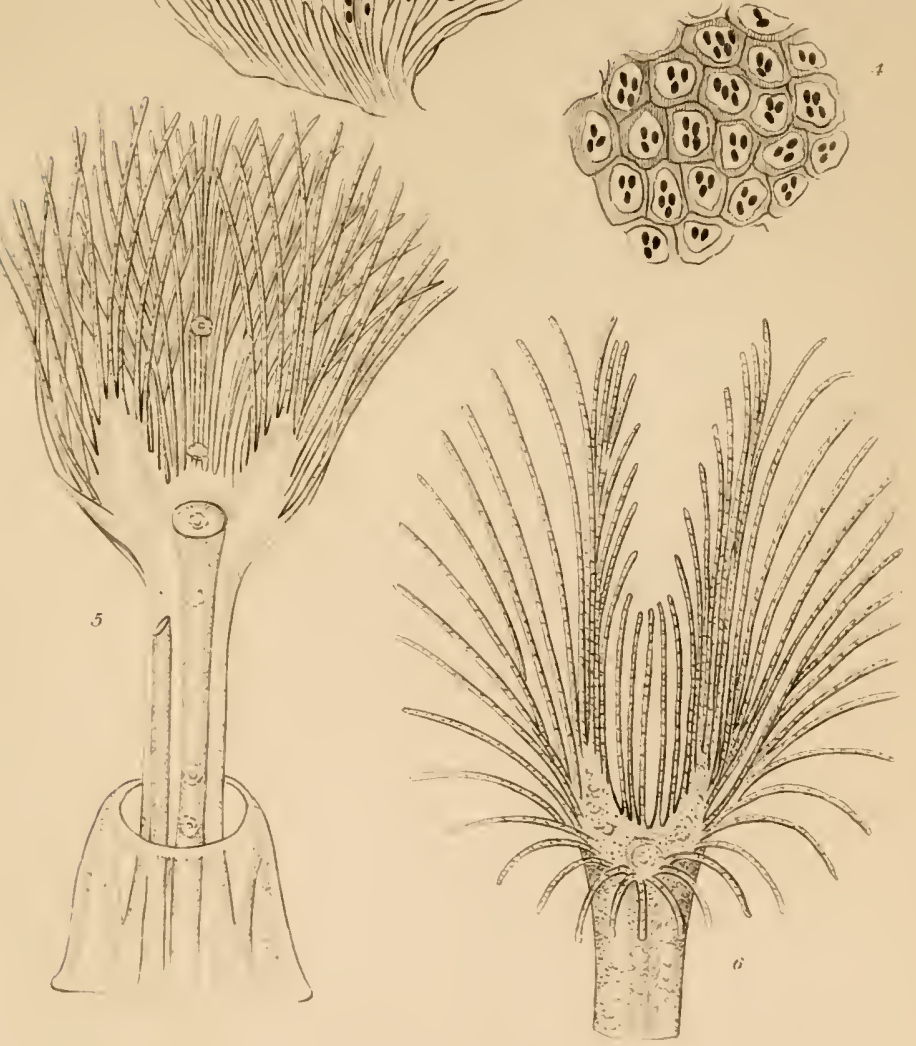






